HNF-SP-1234

Revision 0

UC-900

\title{
Facility Stabilization Project Fiscal Year 1998 Multi-Year Work Plan (MYWP) for WBS 1.4
}

Date Published

September 1997

Prepared for the U.S. Department of Energy

Assistant Secretary for Environmental Restoration

Project Hanford Management Contractor for the

U.S. Department of Energy under Contract DE-ACO6-96RL13200

Approved for public release; distribution is unlimited 


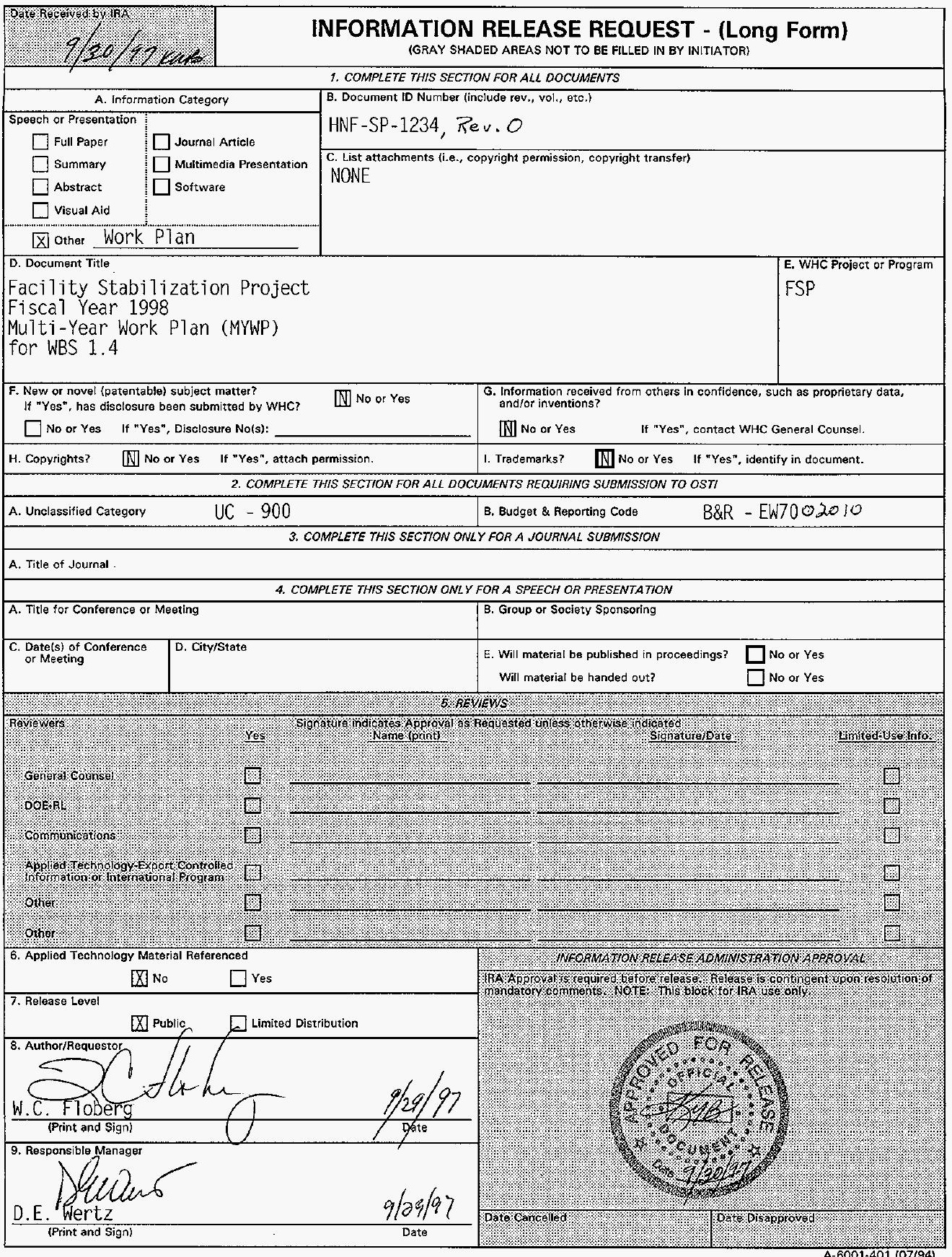




\section{HNF-SP-1234}

\section{ERRATA SHEET}

Please make the following changes to the attached document:

1. Remove existing pages "B.5-9/B.5-10, B.6-19/B.6-20, and B.6-21/B.6-22," and replace with new pages "B.5-9/B.5-10, B.6-19/B.6-20, and B.6-21/B.6-22."

2. Page B.5-2, paragraph 10, second bullet: Change "FY 1999" to read "FY 2000"

3. Page B.6-2, first new paragraph: Change "October 1, 1997" to read "February 16, 1998"

4. Page B.6-10, first paragraph: Change "May 7002" to read "May 2002" 


\section{PFP Deactivation Work Breakdown Structure}

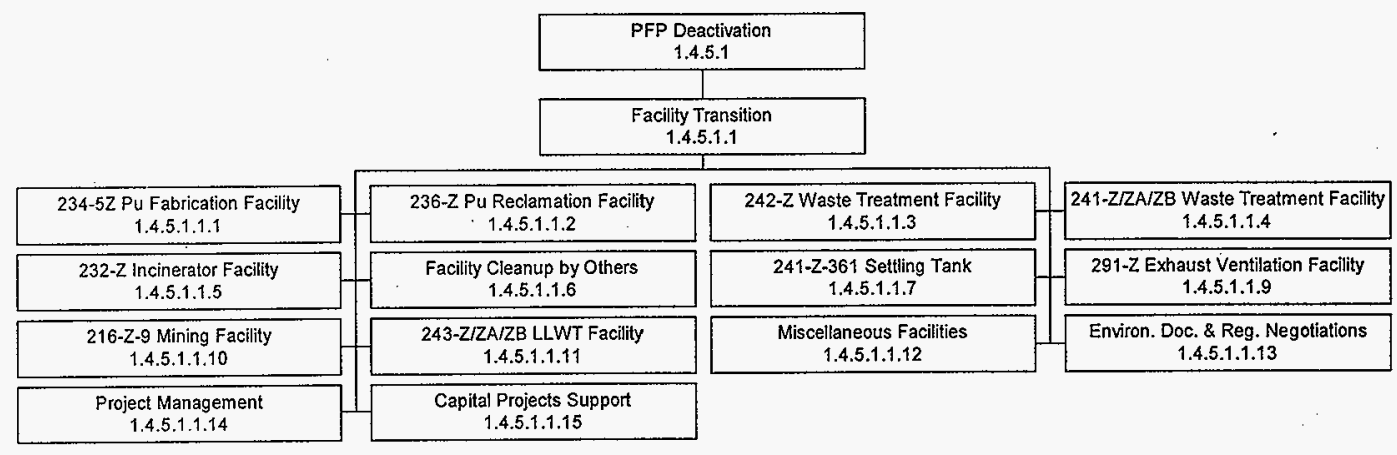




\section{PHMC \\ MILESTONE DESCRIPTION SHEET}

Tit7e: COMPLETE CEMENTATION/DISCARD OR DISP. OF 1.269 KG BULK PU RESIDUE

Assigned To: FSP/PFP

CIN:

Program WBS Designator: 1.4.5.2

Due Date: $9 / 30 / 98$

PBS No: RL-TP06

MC \#: TRP-97-409

MILESTONE

LEVEL:

DOE-HQ

$X$ DOE-RL

DOE-FO

CONTRACTOR

\begin{tabular}{||l||l||l||}
\hline MILESTONE & DNFSB STATUS: & DELIVERABLE: \\
TYPE: & & \\
EA & DNFSB $(Y / N):$ & Report \\
PEG & COMMIT \#: & X Letter \\
OTHER & RECOMM \#: & Drawing(s) \\
& & \\
& & \\
& &
\end{tabular}

Rev: 1

TPA No:

ADDRESS TO:

DOE-HQ

$X$ DOE-RL

Other (Specify)

Milestone Description:

The cementation/discard or disposition of 1,269 Kg Bulk Pu Residues (total combined for FYs 1997 \& 1998) out of a total of $3.765 \mathrm{Kg}$ Bulk will be completed to the applicable discard criteria.

Description of what constitutes completion of this milestone:

The cementing, packaging for discard, or dispositioning of the PFP's inventory of miscellaneous Pu-bearing residues will be performed to criteria acceptable to Hanford's Central Waste Complex and the applicable regulatory agencies. Also included is all necessary stabilization. shipping, packaging and/or waste disposal tasks necessary to support the cementation/discard or disposition.

This milestone provides for the cementing, packaging for discard, and acceptable packaging for shipment to Hanford's Central Waste Complex of approximately 1,050 (1,269 total) $\mathrm{kg}$ Bulk Pu-bearing residues in FY 1998 out of a total $3.765 \mathrm{Kg}$ of residues currently stored in the PFP vaults. A letter will be issued to DOE-RL documenting completion of this milestone. also indicating the plutonium inventory of the material dispositioned and its packaging configuration. 


\section{PHMC \\ MILESTONE DESCRIPTION SHEET}

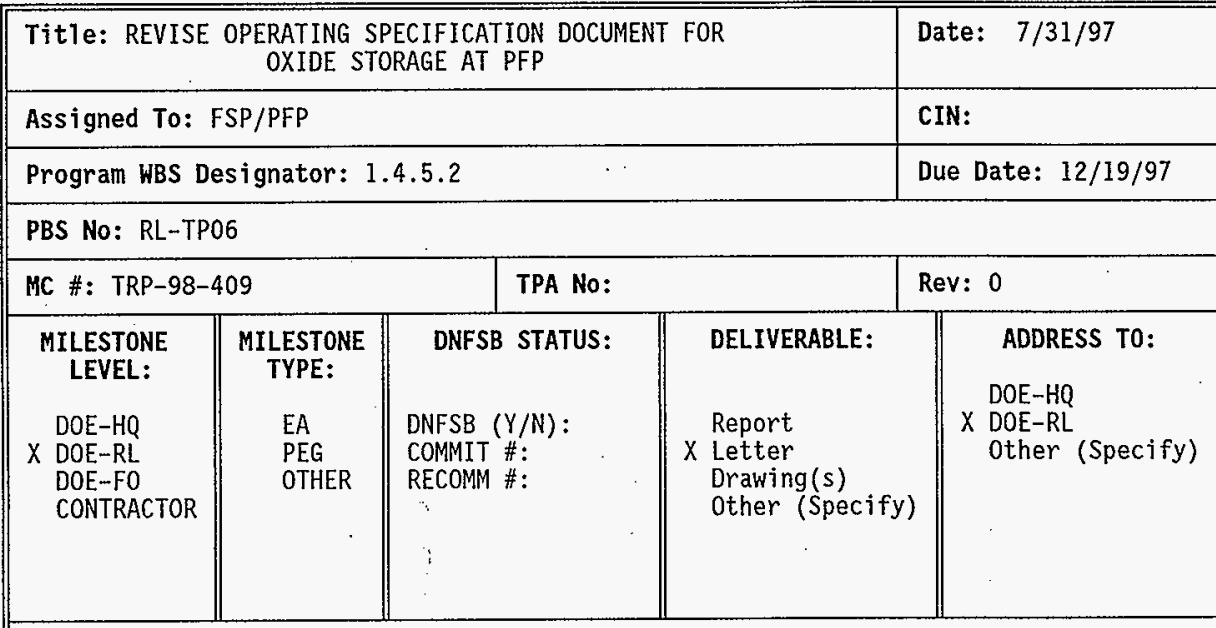

MiTestone Description:

Revise operating specification document (OSD) for oxide storage at PFP.

Description of what constitutes completion of this milestone:

Revise the operating specification document (OSD) for plutonium oxide storage at PFP consistent with technical basis documentation. The purpose is to insure that the PFP vault storage OSD provides a can configuration so that plutonium dioxide, generated either by direct denitration, oxalate conversion, or thermal stabilization can be safely stored in PFP vaults consistent with accepted technical justification.

A letter will be issued to DOE-RL documenting revision of the OSD for plutonium storage at PFP. 
HNF-SP-1234

\title{
1998 Multi-Year Work Plan Approval Sheet
}

\author{
Transition Program Division \\ U. S. Department of Energy \\ Richland Operations office
}

Assistant Manager-Contracting Officer's Representative
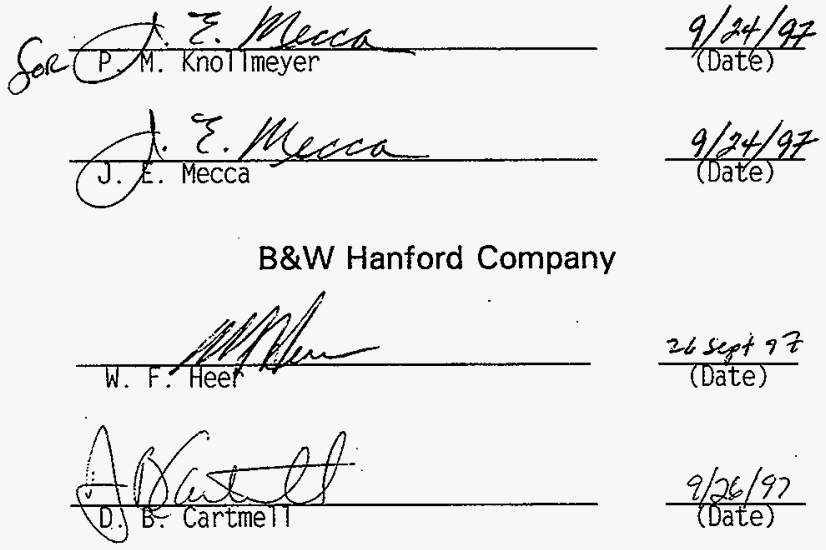

Fluor Daniel Hanford, Inc.

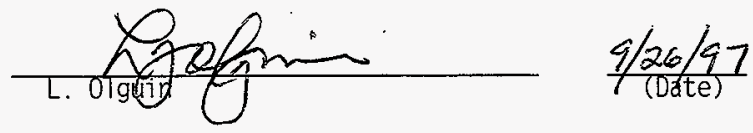


TABLE OF CONTENTS

Facility Stabilization Project Summary

Technical Baseline —__ A. 1-1

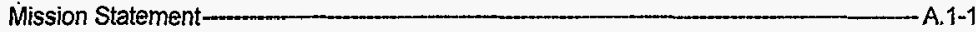

Boundary Diagram with Major Facilities $A .1-5$

Facility Responsibility Assignment Matrix _-_._. A.1-6

Planning Assumptions - A.1-8

Project Hanford Breakdown Structure -__ A.1-11

PHBS Hierarchy-__-111

Tracking Work Scope Changes from FY 1997 to FY 1998 ____.12

Schedule Baseline _-A.1-13

Project SMBS by PBS ___ _ _ _ 1-13

Cost Baseline _-_ 1-23

Estimate Basis-_____-A.1-23

Summary of Life Cycle Cost Baseline (BCWS) by Project-_____._. 1-24

Summary of Life Cycle Budget Authority $(B / A)$ by Project -

Cost Baseline (BCWS) for execution year by month by fund type-_-A.1-28

Cost Baseline (BCWS) for execution year by month by cost element -

\section{B Plant Sub-Project}

Technical Baseline -_____ B.1-1

Project Mission _-B.1-1

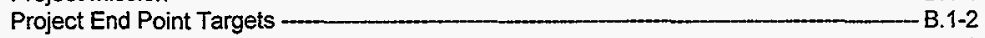

Major Facilities _-B.1-2

Drivers _- B. 1-8

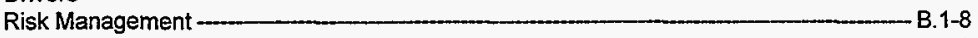

Work Breakdown Structure-_ B.1-9

WBS Hierarchy__ B.1-9

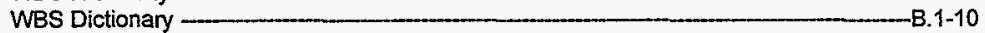

Responsibility Assignment Matrix-_B. B.1-14

Schedule Baseline-_B.1-15

Project Master Baseline Schedule (PMBS) _ B.1-15

Execution Year PMBS-___ B.1-18

Milestones (RL, HQ, EA) - B.1-21

Milestone Description Sheets _-B.1-23

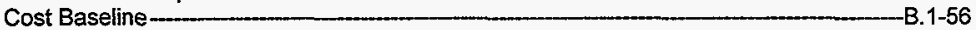

Life Cycle Cost Baseline (BCWS) by PBS -B.1-56

Life Cycle Budget Authority (B/A) by PBS _- 1-58

Execution Year Cost Baseline by month by PBS by ADS -B.1-60

Staffing -B. 1-62

\section{WESF Sub-Project}

Technical Baseline ___ B.2-1

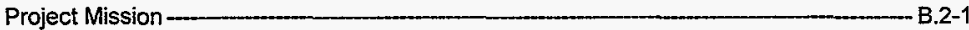

Project End Point Targets …__ B.2-1

Major Facilities _-B._- B. $2-1$

Drivers-_- B.2-8

Risk Management - B.2-8 
1.4 Drivers

1.5 Risk Management

2.0 Work Breakdown Structure

2.1 WBS Hierarchy

2.2 WBS Dictionary

2.3 Responsibility Assignment Matrix

3.3 Milestones (RL, HQ, EA)

3.4 Milestone Description Sheets

$-B .5-13$

4.0 Cost Baseline

B. $5-20$

4.1 Life Cycle Cost Baseline (BCWS) by PBS

B. 5-20

4.2 Life Cycle Budget Authority (B/A) by PBS

B. $5-22$

4.4 Staffing

B.5-24

\section{PFP Stabilization}

1.0 Technical Baseline - B.

1.1 Project Mission B.6-1

1.2 Project End Point Targets ﹎. B.6-3

1.3 Major Facilities - B.6-3

1.4 Drivers ___ B.6-8

1.5 Risk Management-__._ B.6-8

2.0 Work Breakdown Structure ___ _ _

2.1 WBS Hierarchy - B. $6-11$

2.2 WBS Dictionary - B...... B-12

2.3 Responsibility Assignment Matrix _-_B.6-13

3.0 Schedule Baseline ___ B. B-14

3.1 Project Master Baseline Schedule (PMBS) -___._. B-14

3.2 Execution Year PMBS -B.6-15

3.3 Milestones (RL, HQ, EA) _ B.6-16

3.4 Milestone Description Sheets _._._._.

4.0 Cost Baseline _B. B-23

4.1 Life Cycle Cost Baseline (BCWS) by PBS _ _ _

4.2 Life Cycle Budget Authority (B/A) by PBS _-_ B. 6-25

4.3 Execution Year Cost Baseline by month by PBS by ADS - _ B.6-27

4.4 Staffing -B.6-29

\section{PFP Vault Management}

1.0 Technical Baseline

B.7-1

1.1 Project Mission-

B. $7-1$

1.2 Project End Point Targets

B. $7-3$

1.3 Major Facilities

B.7-3

1.4 Drivers _

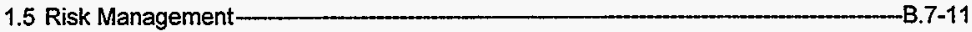

2.0 Work Breakdown Structure _ _ B.

2.1 WBS Hierarchy _-B.

2.2 WBS Dictionary _-_._._. B

2.3 Responsibility Assignment Matrix ___ B. $7-23$

3.0 Schedule Baseline ___ B.

3.1 Project Master Baseline Schedule (PMBS) _ _ - B.7-24

3.2 Execution Year PMBS ﹎._B. B-25

3.3 Milestones (RL, HQ, EA) — B.

3.4 Milestone Description Sheets ___ _ B.7-27

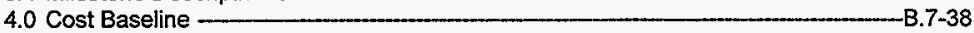


3.0 Schedule Baseline ___ B.10-45

3.1 Project Master Baseline Schedule (PMBS) B. B. 10-45

3.2 Execution Year PMBS _-_ B. 10-46

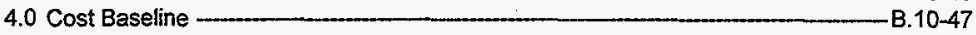

4.1 Life Cycle Cost Baseline (BCWS) by PBS _- B. 10-47

4.2 Life Cycle Budget Authority (B/A) by PBS-_B.10-49

4.3 Execution Year Cost Baseline by month by PBS by ADS ___ B.10-51

4.4 Staffing - B. 10-53

Transition Project Management

1.0 Technical Baseline -_____ B.11-1

1.1 Project Mission-_B. B. 11-1

1.2 Project End Point Targets ___ B._._._._-

1.3 Major Facilities -

1.4 Drivers _- B. $11-3$

1.5 Risk Management _____ B.11-3

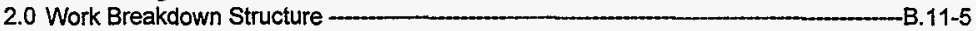

2.1 WBS Hierarchy -_-B.11-5

2.2 WBS Dictionary _- B. 11-6

2.3 Responsibility Assignment Matrix - B.11-9

3.0 Schedule Baseline ___ B. 11-10

3.1 Project Master Baseline Schedule (PMBS) _ B.11-10

3.2 Execution Year PMBS _-_ B.11-11

3.3 Milestones (RL, HQ, EA) - B.11-12

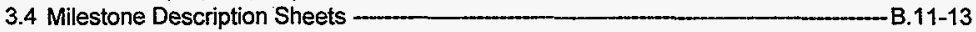

4.0 Cost Baseline _-B.11-26

4.1 Life Cycle Cost Baseline (BCWS) by PBS _ _ B.11-26

4.2 Life Cycle Budget Authority (B/A) by PBS B. B. 11-28

4.3 Execution Year Cost Baseline by month by PBS by ADS _-B.11-30

4.4 Staffing - B.11-32

\section{Hanford Surplus Facilities Program 300 Area Revitalization}

1.0 Technical Baseline -____ B.12-1

1.1 Project Mission-B.12-1

1.2 Project End Point Targets ___ B. 12-2

1.3 Major Facilities _-B.12-2

1.4 Drivers -B. B. B-75

1.5 Risk Management -____ B.12-75

2.0 Work Breakdown Structure -__ B.12-76

2.1 WBS Hierarchy - _-_ B. 12-76

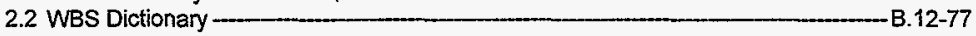

2.3 Responsibility Assignment Matrix —_B.12-79

3.0 Schedule Baseline B_ B.12-80

3.1 Project Master Baseline Schedule (PMBS) - B:12-80

3.2 Execution Year PMBS ﹎. B. 12-81

4.0 Cost Baseline -____B. B. 12-82

4.1 Life Cycle Cost Baseline (BCWS) by PBS _ _ B:12-82

4.2 Life Cycle Budget Authority (B/A) by PBS _B.12-84

4.3 Execution Year Cost Baseline by month by PBS by ADS _-B.12-86

4.4 Staffing $-B .12-88$ 


\section{A.1.0 Technical Baseline}

The MYWP technical baseline describes the work to be accomplished by the Project and the technical standards which govern that work.

\section{A.1.1 Mission Statement}

The primary Facility Stabilization mission is to provide minimum safe surveillance and maintenance of facilities and deactivate facilities on the Hanford Site, to reduce risks to workers, the public and environment, transition the facilities to a low cost, long tem surveillance and maintenance state, and to provide safe and secure storage of special nuclear materials, nuclear materials, and nuclear fuel (SNMNMNF). Facility Stabilization will protect the health and safety of the public and our workers, protect the environment, and provide beneficial use of the facilities and other resources. Work will be in accordance with the Hanford Federal Facility Agreement and Consent Order (Tri-Party Agreement), local, national, international and other agreements, and in compliance with all applicable Federal, state, and local laws. The stakeholders will be active participants in the decision processes including establishing priorities, and in developing a consistent set of rules, regulations, and laws. The work will be leveraged with a view of providing positive, lasting economic impact in the region. Effectiveness, efficiency, and discipline in all mission activities will enable us to achieve our mission in a continuous and substantive manner.

As the mission for Facility Stabilization has shifted from production to support of environmental restoration, each facility is making a transition to support the Site mission. The mission goals include the following:

- Achieve deactivation of facilities for transfer to EM-40, using Plutonium/Uranium Extraction (PUREX) plant deactivation as a model for future facility deactivation.

- Manage nuclear materials in a safe and secure condition and where appropriate, in accordance with International Atomic Energy Agency (IAEA) safeguards rules.

- Treat nuclear materials as necessary, and store onsite in long-term interim safe storage awaiting a final disposition decision by U.S. Department of Energy (DOE).

- Implement nuclear materials disposition directives. In the near term these are anticipated to mostly involve transferring uranium to other locations for beneficial use.

- Work will be in accordance with the Tri-Party Agreement, and other agreements and in compliance with all applicable Federal, state and local laws.

The transition to deactivation will be accomplished through a phased approach, while maintaining the facilities in a safe and compliant configuration. In addition, Facility Stabilization will continue to maintain safe long-term storage facilities for Special Nuclear Material (SNM), Nuclear Material (NM), and Nuclear Fuel (NF).

The FSP deactivation strategy aligns with the deactivate facilties mission outlined in Hanford Site SE documentation. Inherent to the.FSP strategies are specific Hanford Strategic Plan success indicators such as: reduction of risks to workers, the public and environment; increasing the amount of resources recovered for other uses; reduction/elimination of inventory and materials; and reduction/elimination of costly mortgages.

The FSP deactivation strategy is as follows: 
HNF-SP-1234

Revision 0

UC-900

\section{Facility Stabilization Project Fiscal Year 1998 Multi-Year Work Plan (MYWP) for WBS 1.4}

Date Published.

September 1997

Prepared for the U.S. Department of Energy

Assistant Secretary for Environmental Restoration

Project Hanford Management Contractor for the

U.S. Department of Energy under Contract DE-ACO6-96RL13200

Approved for public release; distribution is unlimited 
IEGAL DISCLAUMER

This report was prepared as an account of work sponsored by an agency of the United States Government. Neither the United States Government nor any agency thereof, nor any of their employees, nor any of their contrectors, subcontractors or their employees, makes any warranty, express or implied, or assumes any legai liability or responsibility for the accuracy, completeness, or any third party's use or the results of such use of any information, apparatus, product; or process disclosed, or represents that its use would not infringe privately owned rights. Reference herein to any specific commercial product, process, or sanice by trede name, tredemerk, marwfacturer, or otherwise, does not necessarily constitute or imply its endorsement, recommendation, or favoring by the United States Government or any agency thereof or its contractors or subcontractors. The views and opinions of authors expressed herein do not necessarily state or reflect those of the United States Government or any agency thereof.

This report has been reproduced from the best aveilable copy. Aveilable in paper copy and microfiche

Aveilable to the U.S. Department of Energy and its contractors from U.S. Department of Energy Office of Scientific and Technical Information (OSTI)

P.O. Box 62

Oak Ridge, TN 37831

(615) 576-8401

Available to the public from the U.S. Department of Commerce National Technical Information Service (NTIS)

5285 Port Royal Roed

Springtiald, VA 22161

(703) $487-4650$

Printed in the United Stetes of Americe

DISCLM-1.CHP (8-95) 


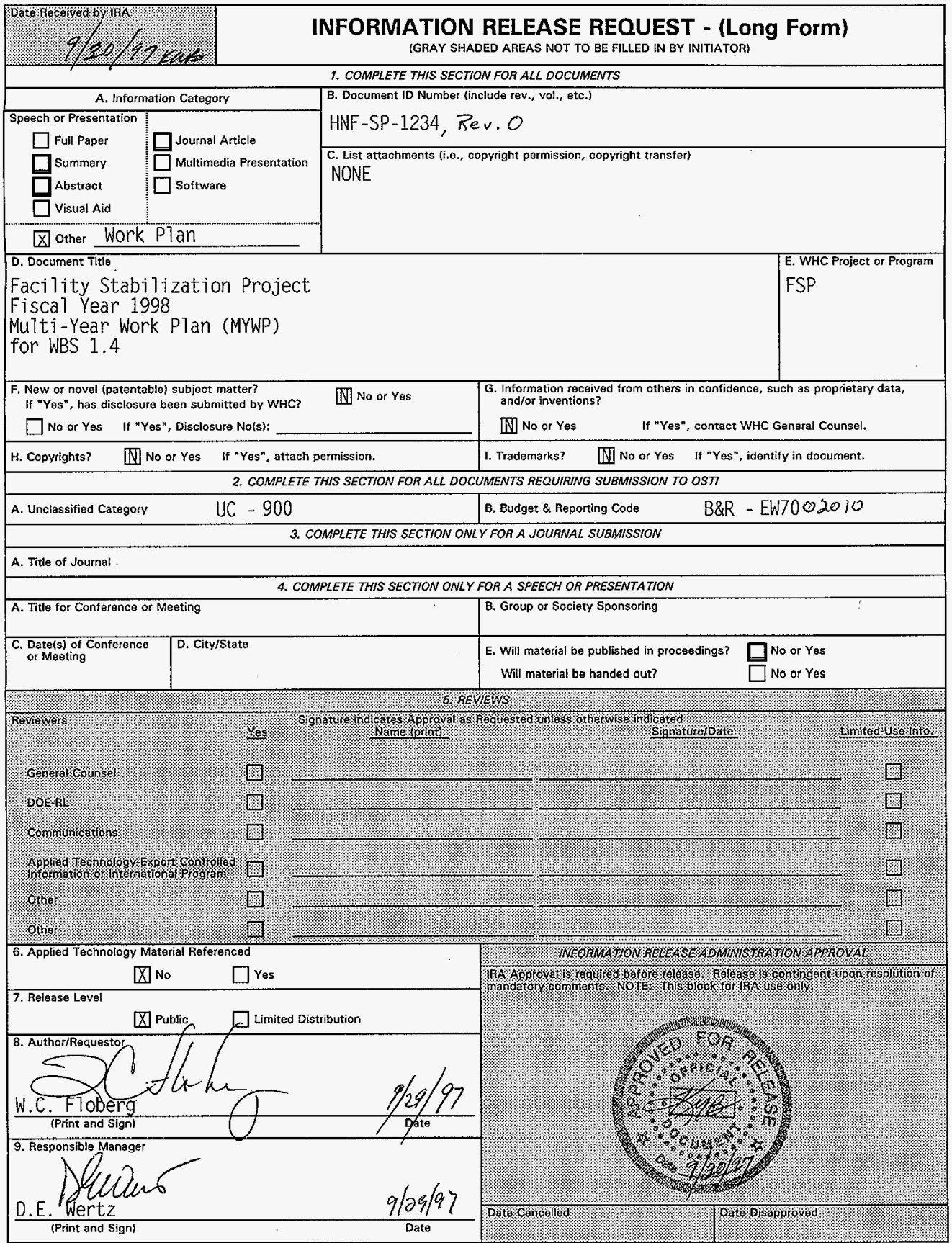





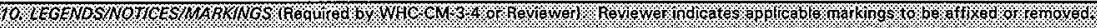

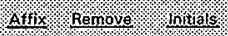

Sppited Tecinology

Avilobilio ositi

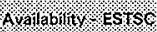

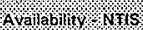

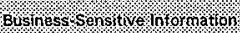

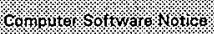

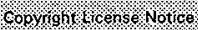

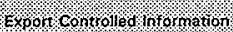

Uegitossouiner

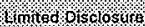

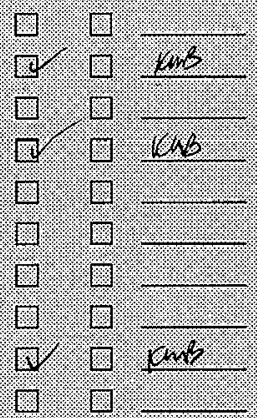

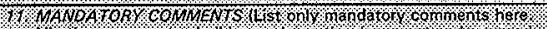
At o the comments shall be made on the focument ano roturnec of tho w 4 thor

\section{offotolsoontr \\ patent stows \\ Prodecisional lntorination \\ Progrnmato Noter

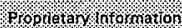

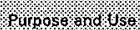 \\ Thesisioissetration

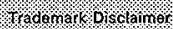 \\ otiner}

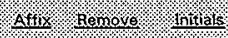

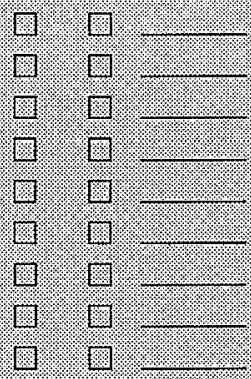

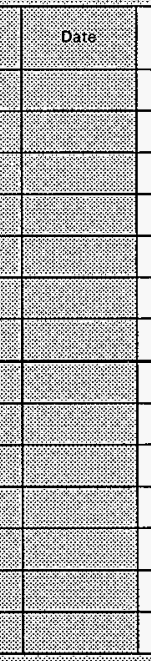


TEUS PAGE INTENTIONALLY LEFT BLANK 


\section{ERRATA SHEET}

Please make the following changes to the attached document:

1. Remove existing pages "B.5-9/B.5-10, B.6-19/B.6-20, and B.6-21/B.6-22," and replace with new pages "B.5-9/B.5-10, B.6-19/B.6-20, and B.6-21/B.6-22."

2. Page B.5-2, paragraph 10, second bullet: Change "FY 1999" to read "FY 2000"

3. Page B.6-2, first new paragraph: Change "October 1, 1997" to read "February 16, 1998"

4. Page B.6-10, first paragraph: Change "May 7002" to read "May 2002" 


\section{THIS PAGE INTENTIONALLY}

I IEFT BLANK 


\section{PFP Deactivation Work Breakdown Structure}

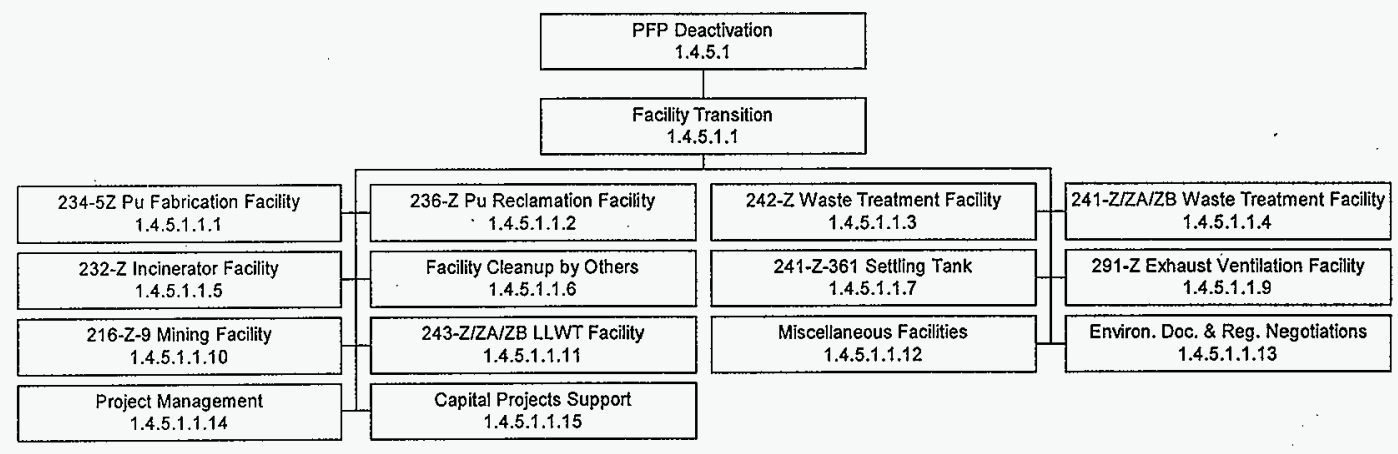


HANFORD SITE WORK BREAKDOWN STRUCTURE DICTIONARY. FACILITY STABILIZATION WBS: 1.4

\begin{tabular}{|l|c|c|c|c|}
\hline $\begin{array}{l}\text { 1. Activity Title: } \\
\text { PFP DEACTIVATION }\end{array}$ & $\begin{array}{c}\text { 2. Date } \\
7 / 31 / 1997\end{array}$ & $\begin{array}{l}\text { 3. PBS Number } \\
\text { RL-TP05 }\end{array}$ & $\begin{array}{l}4 . \text { Dict Rev } \\
0\end{array}$ \\
\hline
\end{tabular}

5. Contract WBS No. 1.4.5.1.1

6. Corresponding FDS No. 7. Baseline CR No. $\mathrm{K} 6 \mathrm{D}$

8. Organization Name 15000

10. Scope of Work

This activity provides for the cleanup, transition deactivation, and turnover of all PFP facilities, except for the $2736-Z$ vaults and vault support facilities, in accordance with EM-60 guidelines. The following activities are included:

*234-5Z Plutonium Fabrication Facility Cleanup and Transition *236-Z

Plutonium Reclamation Facility Cleanup and Transition *242-Z Waste Treatment and Americium Facility Cleanup and Transition *241-Z/ZA Tank Farm Waste Disposal Facility Cleanup and Transition *232-Z Incinerator Cleanup and Transition

*Facility Cleanup and Transition Performed by Others

*241-Z-361 Settling Tank Cleanup and Transition

*291-Z Exhaust Ventilation Building Cleanup and Transition

*216-Z-9 Mining Facility Cleanup and Transition

*243-Z, ZA, ZB Low Level Wastewater Treatment Facility Cleanup and Transition *Miscel laneous Bui Tdings Cleanup and Transition

*Environmental Documentation and Regulatory Negotiations

*Project Management 


\section{PHMC}

MILESTONE DESCRIPTION SHEET

Tit7e: COMPLETE CEMENTATION/DISCARD OR DISP. OF

1,269 KG BULK PU RESIDUE

Assigned To: FSP/PFP

Program WBS Designator: 1.4.5.2

PBS No: RL-TP06

MC \#: TRP-97-409

MILESTONE

LEVEL:

DOE-HO

$X$ DOE-RL

DOE-FO

CONTRACTOR
TPA No:

DNFSB STATUS:

TYPE:

EA

PEG

OTHER
DNFSB $(Y / N)$ :

COMMIT \#:

RECOMM \#:
CIN:

Due Date: $9 / 30 / 98$

Date: $7 / 31 / 97$ 


\section{PHMC}

MILESTONE DESCRIPTION SHEET

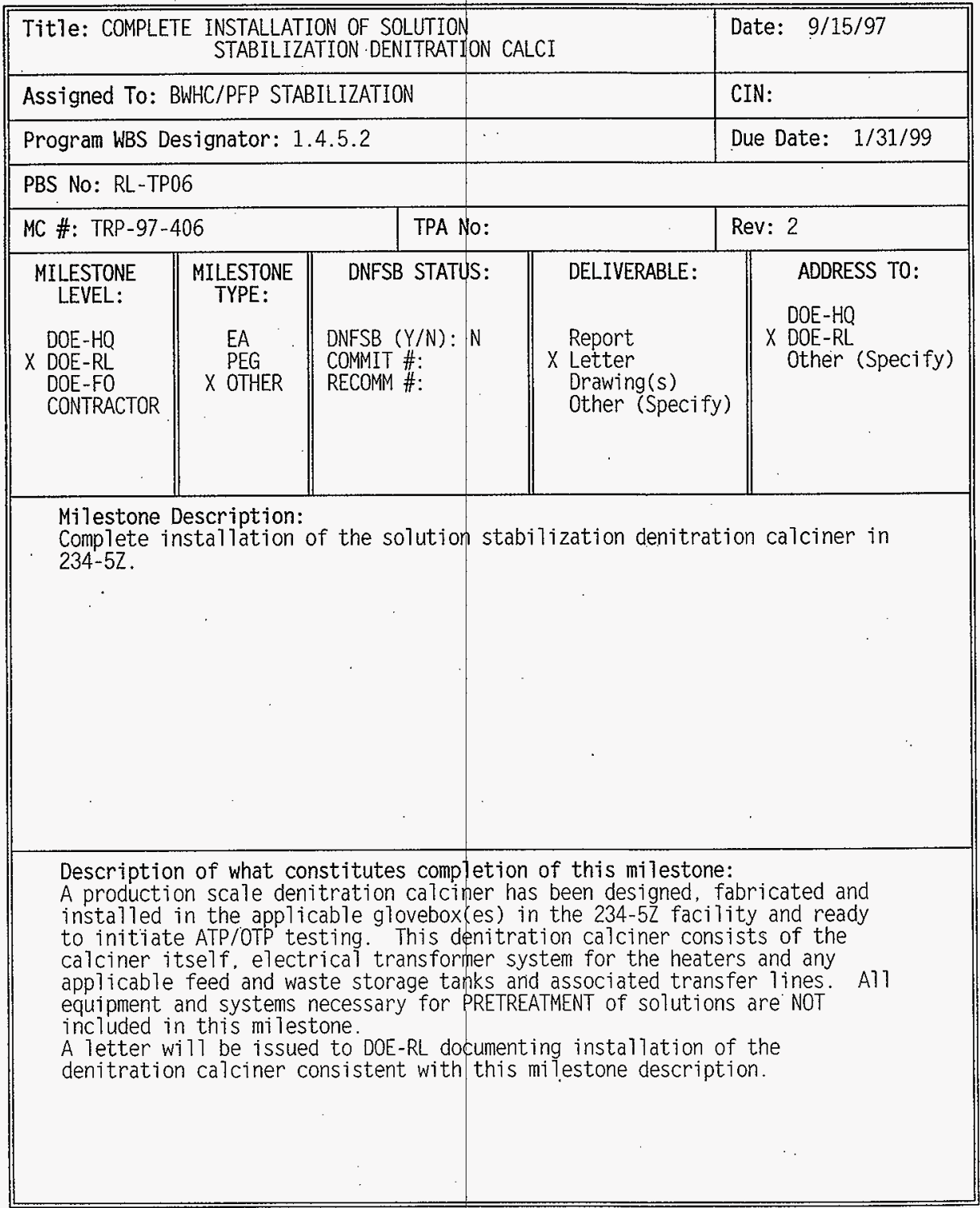




\section{PHMC \\ MILESTONE DESCRIPTION SHEET}

Tit1e: REVISE OPERATING SPECIFICATION DOCUMENT FOR OXIDE STORAGE AT PFP

Date: $7 / 31 / 97$

\begin{tabular}{|c|c|c|c|c|c|}
\hline \multicolumn{5}{|c|}{ Assigned To: FSP/PFP } & CIN: \\
\hline \multicolumn{5}{|c|}{ Program WBS Designator: 1.4 .5 .2} & Due Date: $12 / 19 / 97$ \\
\hline \multicolumn{6}{|c|}{ PBS No: RL-TPO6 } \\
\hline \multicolumn{3}{|c|}{ MC \#: TRP-98-409 } & \multicolumn{2}{|l|}{ TPA No: } & Rev: 0 \\
\hline $\begin{array}{l}\text { MILESTONE } \\
\text { LEVEL: }\end{array}$ & $\begin{array}{l}\text { MILESTONE } \\
\text { TYPE: }\end{array}$ & DNF & STATUS: & DELIVERABLE: & ADDRESS T0: \\
\hline $\begin{array}{l}\text { DOE-HQ } \\
\times \text { DOE-RL } \\
\text { DOE-FO } \\
\text { CONTRACTOR }\end{array}$ & $\begin{array}{l}\text { EA } \\
\text { PEG } \\
\text { OTHER }\end{array}$ & $\begin{array}{l}\text { DNFSB } \\
\text { COMMI } \\
\text { RECOM } \\
\vdots \\
\vdots\end{array}$ & $\begin{array}{l}Y / N): \\
\#: \\
\# !\end{array}$ & $\begin{array}{l}\text { Report } \\
\times \text { Letter } \\
\text { Drawing(s) } \\
\text { Other (Specify) }\end{array}$ & $\begin{array}{l}X \text { DOE-RL } \\
\text { Other (Specify) }\end{array}$ \\
\hline
\end{tabular}

Milestone Description:

Revise operating specification document (OSD) for oxide storage at PFP.

Description of what constitutes completion of this milestone:

Revise the operating specification document (OSD) for plutonium oxide storage at PFP consistent with technical basis documentation. The purpose is to insure that the PFP vault storage OSD provides a can configuration so that plutonium dioxide, generated either by direct denitration, oxalate conversion, or thermal stabilization can be safely stored in PFP vaults consistent with accepted technical justification.

A letter will be issued to DOE-RL documenting revision of the OSD for plutonium storage at PFP. 


\section{PHMC \\ MILESTONE DESCRIPTION SHEET}

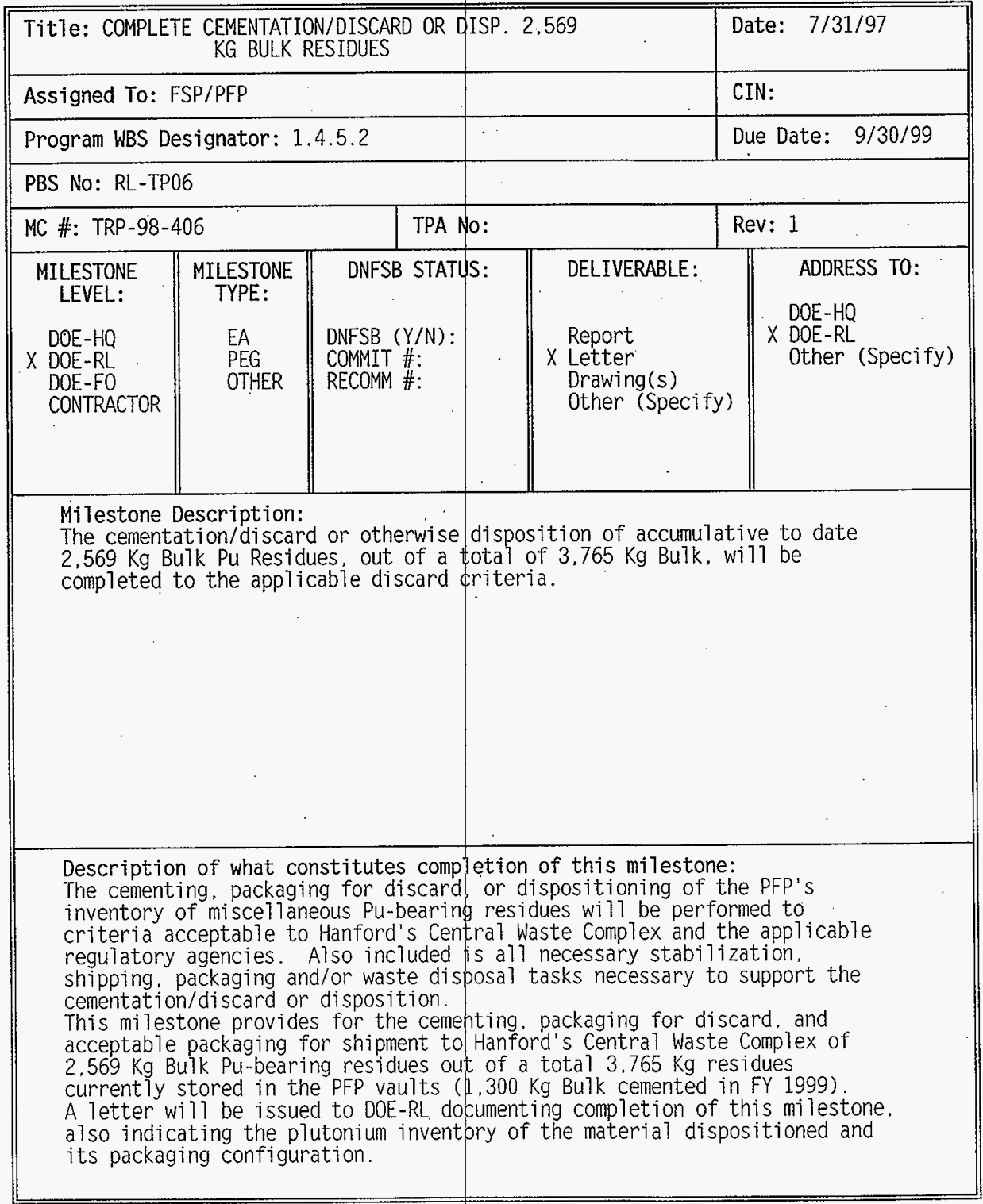




$$
\text { HNF-SP-1234 }
$$

\title{
1998 Multi-Year Work Plan Approval Sheet
}

\author{
Transition Program Division \\ U. S. Department of Energy \\ Richland Operations office
}

Assistant Manager-Contracting Officer's Representative

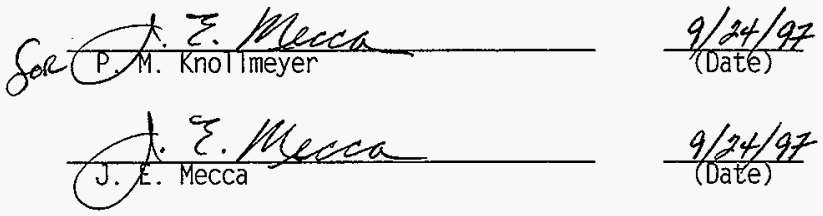

\section{B\&W Hanford Company}
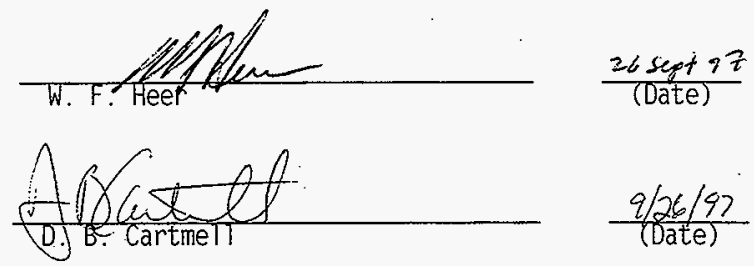

Fluor Daniel Hanford, Inc.

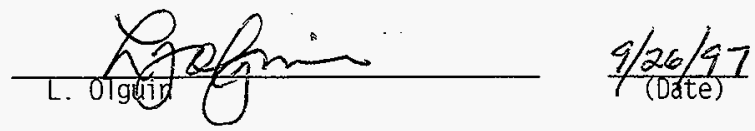




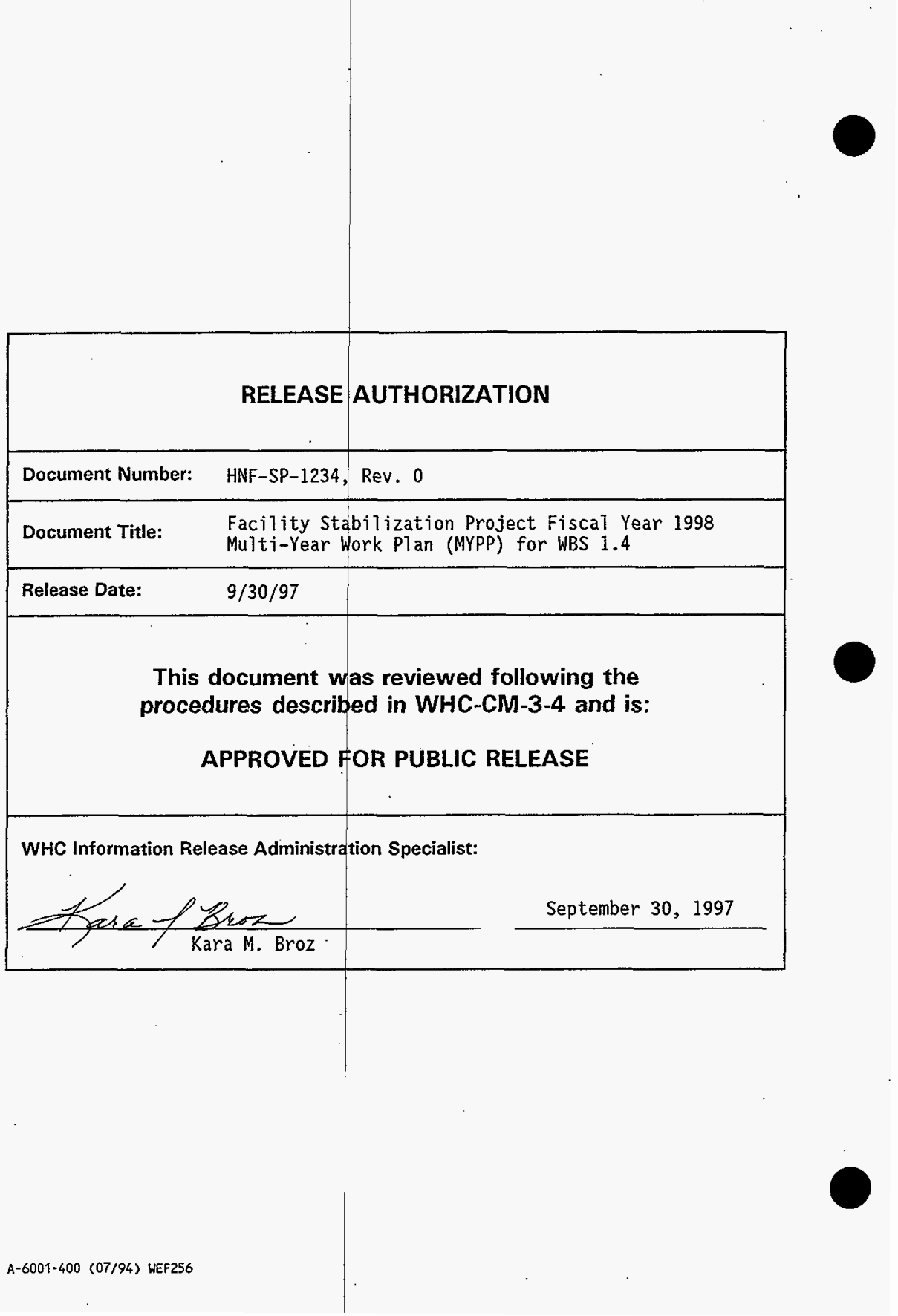




\section{TABLE OF CONTENTS}

Facility Stabilization Project Summary

Technical Baseline

A.1-1

Mission Statement

A.1-1

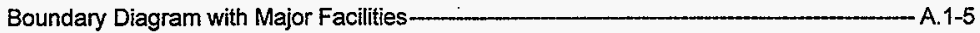

Facility Responsibility Assignment Matrix - A.1-6

Planning Assumptions

Project Hanford Breakdown Structure -

PHBS Hierarchy___A.1-11

Tracking Work Scope Changes from FY 1997 to FY 1998 ____.1-12

Schedule Baseline--_A.1-13

Project SMBS by PBS _-A.1-13

Cost Baseline -_. A.1-23

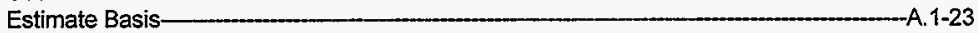

Summary of Life Cycle Cost Baseline (BCWS) by Project-_-_._. 1-24

Summary of Life Cycle Budget Authority (B/A) by Project

Cost Baseline (BCWS) for execution year by month by fund type____ A.1-28

Cost Baseline (BCWS) for execution year by month by cost element -A.1-29

\section{B Plant Sub-Project}

Technical Baseline - B.1-1

Project Mission — B.1-1

Project End Point Targets - B. 1-2

Major Facilities ___ B.1-2

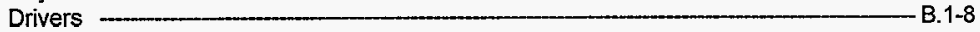

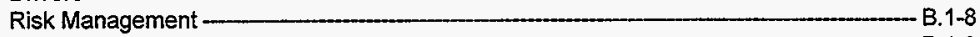

Work Breakdown Structure ___ B. 1-9

WBS Hierarchy - B.1-9

WBS Dictionary —B. B-10

Responsibility Assignment Matrix-B.1-14

Schedule Baseline-1- B.1-15

Project Master Baseline Schedule (PMBS) B._. 1-15

Execution Year PMBS - B. $1-18$

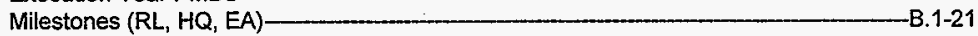

Milestone Description Sheets-___ B.1-23

Cost Baseline-_-B.1-56

Life Cycle Cost Baseline (BCWS) by PBS- B.1-56

Life Cycle Budget Authority (B/A) by PBS -B.1-58

Execution Year Cost Baseline by month by PBS by ADS -_B. $1-60$

Staffing -B.1-62

\section{WESF Sub-Project}

Technical Baseline - B. $2-1$

Project Mission _ B.2-1

Project End Point Targets - B.2-1

Major Facilities _ B.2-1

Drivers-_- B.2-8

Risk Management ___ B.2-8 
Work Breakdown Structure-_____- B.2-9

WBS Hierarchy _ B. B.2-9

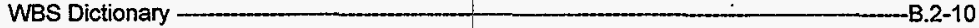

Responsibility Assignment Matrix _B. B._.

Schedule Baseline-B.2-13

Project Master Baseline Schedule (PMBS) - B.2-13

Execution Year PMBS-_-B.2-15

Milestones (RL, $H Q, E A)$ B. B

Milestone Description Sheets-_-B._-17

Cost Baseline-_B.2-27

Life Cycie Cost Baseline (BCWS) by PBS____ _ B.2-27

Life Cycle Budget Authority (B/A) by PBS -B.2-29

Execution Year Cost Baseline by month by PBS by ADS ___

Staffing -B.2-33

\section{PUREX Sub-Project}

Technical Baseline ___ B.3-1

Project Mission - B.3-1

Project End Point Targets ___ B.3-1

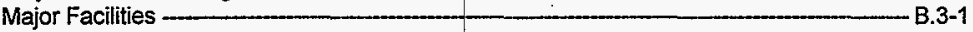

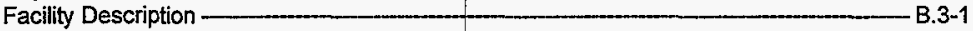

Drivers-_._- B. B.

Risk Management _-B_- B. B.

300 Area/SNM Sub-Project

1.0 Technical Baseline - B.

1.1 Project Mission-_- B.4-1

1.2 Project End Point Targets ___ B _ _ B. B

1.3 Major Facitities —_ B. B.

1.4 Drivers _- B.4-7

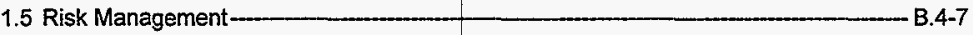

2.0 Work Breakdown Structure _- B.4-9

2.1 WBS Hierarchy —__ B. B

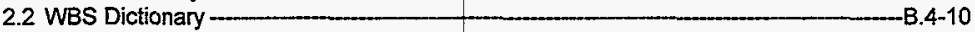

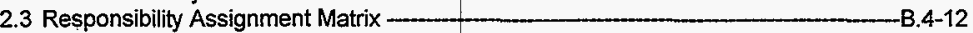

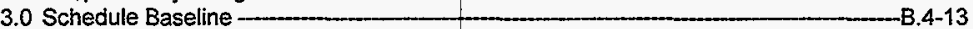

3.1 Project Master Baseline Schedule (PMBS) _____ B.4-13

3.2 Execution Year PMBS _-B.4-14

3.3 Milestones (RL, HQ, EA) _-__ B.4-16

3.4 Milestone Description Sheets _ B. B.

4.0 Cost Baseline _- B.4-26

4.1 Life Cycle Cost Baseline (BCWS) by PBS _ _ B.4-26

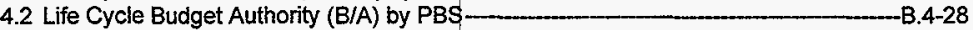

4.3 Execution Year Cost Baseline by month by PBS by ADS _- B.4-30

4.4 Staffing -B.4-32

\section{PFP Deactivation}

1.0 Technical Baseline B- B. B-1

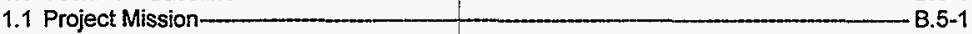

1.2 Project End Point Targets ___ B. B-3

1.3 Major Facilities _- B.5-3 
1.4 Drivers

B.5-8

1.5 Risk Management

2.0 Work Breakdown Structure

B.5-9

2.1 WBS Hierarchy

B.5-9

2.2 WBS Dictionary

B.5-10

2.3 Responsibility Assignment Matrix

3.3 Milestones (RL, HQ, EA)

3.4 Milestone Description Sheets

4.0 Cost Baseline

4.1 Life Cycle Cost Baseline (BCWS) by PBS

B.5-20

4.2 Life Cycle Budget Authority (B/A) by PBS

B.5-22

4.4 Staffing

B.5-24

\section{PFP Stabilization}

1.0 Technical Baseline B. B. -

1.1 Project Mission-_B. B-1

1.2 Project End Point Targets _-_ B. $6-3$

1.3 Major Facilities - B.6-3

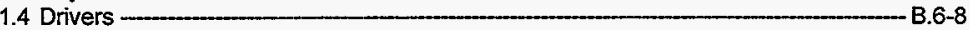

1.5 Risk Management-_B.6-8

2.0 Work Breakdown Structure

2.1 WBS Hierarchy _- B.6-11

2.2 WBS Dictionary - B. 6-12

2.3 Responsibility Assignment Matrix ___

3.0 Schedule Baseline _- B. 6-14

3.1 Project Master Baseline Schedule (PMBS) __ _ B.6-14

3.2 Execution Year PMBS …_-B.6-15

3.3 Milestones (RL, HQ, EA) —B.

3.4 Milestone Description Sheets _- B.6-17

4.0 Cost Baseline _- B.6-23

4.1 Life Cycle Cost Baseline (BCWS) by PBS -

4.2 Life Cycle Budget Authority (B/A) by PBS - B......

4.3 Execution Year Cost Baseline by month by PBS by ADS ___ _ B.6-27

4.4 Staffing —_- B.

\section{PFP Vault Management}

1.0 Technical Baseline ___ B.7-1

1.1 Project Mission-B. B. B-1

1.2 Project End Point Targets _ B B

1.3 Major Facilities _- B.7-3

1.4 Drivers -B.7-11

1.5 Risk Management _________ B. B-11

2.0 Work Breakdown Structure ___ B. B.

2.1 WBS Hierarchy _- B.

2.2 WBS Dictionary -B. B.

2.3 Responsibility Assignment Matrix ___ B.7-23

3.0 Schedule Baseline -B_- B. $3-24$

3.1 Project Master Baseline Schedule (PMBS) B.

3.2 Execution Year PMBS ___ B.

3.3 Milestones (RL, HQ, EA) - B. B.

3.4 Milestone Description Sheets —_-B.7-27

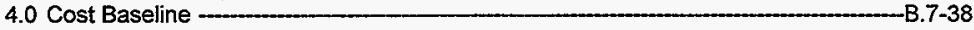


4.1 Life Cycle Cost Baseline (BCWS) by PBS

B. $7-38$

4.2 Life Cycle Budget Authority (B/A) by PBS

B. $7-40$

4.3 Execution Year Cost Baseline by month by PBS by ADS

B. $7-42$

4.4 Staffing

$-B .7-44$

\section{4/327 Facility Transition Project}

1.0 Technical Baseline

B.8-1

1.1 Project Mission

B.8-1

1.2 Project End Point Targets

B. $8-5$

1.3 Major Facilities

B.8-5

1.4 Drivers

1.5 Risk Management

$-B .8-23$

2.0 Work Breakdown Structure

B. $8-23$

2.1 WBS Hierarchy

2.2 WBS Dictionary

B.8-25

2.3 Responsibility Assignment Matrix

B. $8-25$

$-B .8-26$

3.0 Schedule Baseline

B.8-34

3.1 Project Master Baseline Schedule (PMBS)

B.8-35

3.2 Execution Year PMBS

B. 8-35

3.3 Milestones (RL, HQ, EA)

B.8-36

3.4 Milestone Description Sheets

B. 8-37

4.0 Cost Baseline

B. $8-38$

4.1 Life Cycle Cost Baseline (BCWS) by PBS

B. $8-44$

4.2 Life Cycle Budget Authority (B/A) by PBS

$-B .8-44$

4.3 Execution Year Cost Baseline by month by PBS by ADS

B. 8-46

4.4 Staffing

B. 8-48

K Basin Deactivation

1.0 Technical Baseline

1.1 Project Mission-

1.2 Project End Point Targets

1.3 Major Facilities

1.4 Drivers

1.5 Risk Management

3.0 Schedule Baseline

3.1 Project Master Baseline Schedule (PMBS)

4.0 Cost Baseline

4.1 Life Cycle Cost Baseline (BCWS) by PBS

4.2. Life Cycle Budget Authority (B/A) by PBS

\section{Accelerated Deactivation}

1.0 Technical Baseline

B. $10-1$

1.1 Project Mission

1.2 Project End Point Targets

B. $10-1$

1.3 Major Facilities

-B. 10-1

1.4 Drivers

B. 10-1

1.5 Risk Management

B. $10-15$

2.0 Work Breakdown Structure

B. 10-15

2.1 WBS Hierarchy

B. 10-41

2.2 WBS Dictionary

B. $10-41$

2.3 Responsibility Assignment Matrix

B. $10-42$

B. 10-44 
3.0 Schedule Baseline B. $10-45$

3.1 Project Master Baseline Schedule (PMBS) B. $10-45$

3.2 Execution Year PMBS B. $10-46$

4.0 Cost Baseline B. $10-47$

4.1 Life Cycle Cost Baseline (BCWS) by PBS B. 10-47

4.2 Life Cycle Budget Authority (B/A) by PBS B. $10-49$

4.3 Execution Year Cost Baseline by month by PBS by ADS B. 10-51

4.4 Staffing B. 10-53

\section{Transition Project Management}

1.0 Technical Baseline

1.1 Project Mission-

1.2 Project End Point Targets

1.3 Major Facilities

1.4 Drivers

B.11-3

1.5 Risk Management

B. 11-3

2.0 Work Breakdown Structure

B. 11-5

2.1 WBS Hierarchy

B.11-5

2.2 WBS Dictionary

2.3 Responsibility Assignment Matrix

3.0 Schedule Baseline

3.1 Project Master Baseline Schedule (PMBS)

B. $11-10$

3.2 Execution Year PMBS

B. 11-11

3.3 Milestones (RL, HQ, EA)

B. 11-12

3.4 Milestone Description Sheets B.11-13

4.0 Cost Basefine B. 11-26

4.1 Life Cycle Cost Baseline (BCWS) by PBS

B. $11-26$

4.2 Life Cycle Budget Authority (B/A) by PBS

B.11-28

4.3 Execution Year Cost Baseline by month by PBS by ADS

B. $11-30$

4.4 Staffing

B.11-32

\section{Hanford Surplus Facilities Program 300 Area Revitalization}

1.0 Technical Baseline

B. $12-1$

1.1 Project Mission

$-B .12-1$

1.2 Project End Point Targets

B.12-2

1.3 Major Facilities

B. 12-2

1.4 Drivers

B. 12-75

1.5 Risk Management

B.12-75

2.0 Work Breakdown Structure

B. 12-76

2.1 WBS Hierarchy

B. 12-76

2.2 WBS Dictionary B.12-77

2.3 Responsibility Assignment Matrix

B. $12-79$

3.0 Schedule Baseline

B. $12-80$

3.1 Project Master Baseline Schedule (PMBS)

B. $12-80$

3.2 Execution Year PMBS

B.12-81

4.0 Cost Baseline

B. $12-82$

4.1 Life Cycle Cost Baseline (BCWS) by PBS

B:12-82

4.2 Life Cycle Budget Authority (B/A) by PBS

B. 12-84

4.3 Execution Year Cost Baseline by month by PBS by ADS

B.12-86

4.4 Staffing

B. $12-88$ 


\section{HNF-SP-1234}

\section{Appendix}

Comparison of FY 1998 Multi-Year Work Plan vs. April Project Baseline Summary Submittal 


\section{A.1.0 Technical Baseline}

The MYWP technical baseline describes the work to be accomplished by the Project and the technical standards which govern that work.

\section{A.1.1 Mission Statement}

The primary Facility Stabilization mission is to provide minimum safe surveillance and maintenance of facilities and deactivate facilities on the Hanford Site, to reduce risks to workers, the public and environment, transition the facilities to a low cost, long term surveillance and maintenance state, and to provide safe and secure storage of special nuclear materials, nuclear materials, and nuclear fuel (SNM/NMNF). Facility Stabilization will protect the health and safety of the public and our workers, protect the environment, and provide beneficial use of the facilities and other resources. Work will be in accordance with the Hanford Federal Facility Agreement and Consent Order (Tri-Party Agreement), local, national, international and other agreements, and in compliance with all applicable Federal, state, and local laws. The stakeholders will be active participants in the decision processes including establishing priorities, and in developing a consistent set of rules, regulations, and laws. The work will be leveraged with a view of providing positive, lasting economic impact in the region. Effectiveness, efficiency, and discipline in all mission activities will enable us to achieve our mission in a continuous and substantive manner.

As the mission for Facility Stabilization has shifted from production to support of environmental restoration, each facility is making a transition to support the Site mission. The mission goals include the following:

- Achieve deactivation of facilities for transfer to EM-40, using Plutonium/Uranium Extraction (PUREX) plant deactivation as a model for future facility deactivation.

- Manage nuclear materials in a safe and secure condition and where appropriate, in accordance with International Atomic Energy Agency (IAEA) safeguards rules.

- Treat nuclear materials as necessary, and store onsite in long-term interim safe storage awaiting a final disposition decision by U.S. Department of Energy (DOE).

- Implement nuclear materials disposition directives. In the near term these are anticipated to mostly involve transierring uranium to other locations for beneficial use.

- Work will be in accordance with the Tri-Party Agreement, and other agreements and in compliance with all applicable Federal, state and local laws.

The transition to deactivation will be accomplished through a phased approach, while maintaining the facilities in a safe and compliant configuration. In addition, Facility Stabilization will continue to maintain safe long-term storage facilities for Special Nuclear Material (SNM), Nuclear Material (NM), and Nuclear Fuel (NF).

The FSP deactivation strategy aligns with the deactivate facilities mission cutlined in Hanford Site SE documentation. Inherent to the FSP strategies are specific Haniord Strategic Plan success indicators such as: reduction of risks to workers, the public and environment; increasing the amount of resources recovered for other uses; reduction/elimination of inventory and materials; and reduction/elimination of costly mortgages.

The FSP deactivation strategy is as follows: 
- Facilities on receipt of a shutdown notice will be deactivated to the point where a stable contiguration exists which poses a low risk to follow-on long-term surveillance and maintenance (LTS\&M), the environment and public.

- Facility deactivation plans will be developed to manage deactivation and will include defined tumover endpoints where deactivation activities end and LTS\&M or D\&D begin.

- Radioactive and hazardous materials will be identified and removed or stabilized in place. Utilities and facility inter-ties will be deactivated except as required for facility LTS\&M and security.

- Only those systems and portions of a facility involved with the active safety and compliance envelope will be maintained and operated at the completion of deactivation. All aspects of the safety envelope will be challenged during the deactivation process to reflect the continual reduction in facility hazards. All facility reconfigurations will be performed under OSHA construction requirements.

- Because long time periods may be expected between deactivation and final disposition, characterization of the facility will be performed while knowledgeable facility staff and records are available. A graded approach to characterization of the facility will be employed to focus on high risk areas.

- SNM/NM/NF materials will be consolidated early in the facility deactivation process to minimize the safety and compliance envelope. Where feasible, these materials should be removed from the facility early in the deactivation process. When deactivation is complete a facility will no longer contain inventoried quantities of SNM/NM/NF.

- Stakehoiders will be actively involved during the development of deactivation plans and their execution.

The long-term SNM/NM/NF storage mission within FSP aligns with the treat, store and disposition SNM/NM/NF materials mission outlined in Hanford Site SE documentation. Inherent to the FSP strategies are specific Hanford Strategic Plan success indicators such as: reduction of risks to workers, the public and environment through stabilization of SNM/NM/NF and reduction/elimination of costly mortgages through consolidation of SNM/NM/NF.

The SNM/NM/NF strategy is as follows:

- SNM/NM/NF will continued to be safely and compliantly stored until a national policy on their dispostion is formulated.

- SNM/NM/NF will be transferred to other beneficjal uses where possible.

- The current safety and security approach with necessary interim upgrades will be challenged for reductions until a preferred longer tem approach is selected.

- The criteria for the recejpt, storage, treatment and disposition of SNMNM/NF will continue to be developed, negotiated and implemented.

- SNM/NM/NF will be stored in a safe storage mode, and treated where necessary to provide for safe storage. Studies to determine the best alternatives for onsite material storage will continue.

- Stakeholders will be actively involved in the development of long-term treatment, storage and disposition plans through the National Environmental Policy Act process 
- Treatment for final disposition will await determination of the final disposition.

The Following are the specific sub-project mission strategies:

\section{PUREXUO3 (7.1.1)}

The Plutonium Uranium Extraction Facility (PUREX) Deactivation Sub-Project will demonstrate a safe, cost-effective model for facility transition of the PUREX and transfer to EM-40. The project's chief emphasis is on the transition activities that remove, reduce, and/or stabilize the major radioactive sources and hazardous substances within the facilities. The PUREX HVAC system will then be modified to minimize long term surveillance and maintenance requirements and the utility systems will be deactivated. During transition the Project is responsible for the safe, secure, and environmentally sound management of the facilities. The surveillance and maintenance requirements will be maintained at the minimum safe compliance level. Develop the PUREX Transition Process so that it will be used as a model for future facility transitions.

\section{Area Fuel Supply (7.1.2)}

The Fuel Supply Shutdown Facility Sub-Project will be maintained in a regulatory-compliant state until tumover to EM-40 is completed. Shutdown activities will be performed as described in the "Shutdown Plan for the 300 Area Fuel Supply Facilities".

Resource Conservation and Recovery Act of 1976 (RCRA) implementation activities are also being carried out per the 303K Facility and Waste Acid Treatment System (WATS) RCRA closure plans.

To mitigate hazards of an unsafe roof, the 313 Building south portion will be isolated (no access or utilities).

Upon completion of shutdown, RCRA activities, and SNM relocation (and/or disposition), all Fuel Supply buildings will be ready to be transferred to EM-40.

PFP (7.1.3)

The mission strategy for the Plutonium Finishing Plant (PFP) Sub-Project is to implement the Record of Decision (ROD) resulting from the PFP Stabilization Environmental Impact Statement (EIS). This currently entails the following activities:

- Implementation of Defense Nuclear Facility Safety Board (DNFSB) Recommendation 94-1, by safely stabilizing reactive scrap inventories, initiating terminal cleanout activities, implementing required capital upgrades (Plutonium Stabilization \& Handling (PUSH) System) and stabilizing vault material by calcination or other methods as appropriate in order to complete these activities, is minimally supported in FY98 and FY99 resulting in at least a 3 year delay in completion.

- Transition parts of the PFP Complex into a D\&D ready state, including the implementation of ductwork remediation and radiation zone reduction activities as necessary and the isolation of the 2736-Z Vautt complex from the balance of the plant. There is no support for PFP Facility Transition to deactivation in FY98 and FY99.

- Continue to maintain the safety envelope for the PFP Complex as defined in approved Operational Safety Requirement documentation;

- Safely and securely operate the PFP Vault complex to receive, store and ship SNM consistent with applicable Federal, State and International regulations and requirements until at least 2025; and,

- Continue to complete scheduled environmental upgrades and perfom activities necessary to maintain 
compliance with environmental regulations and compliance agreements.

Program and Environmental Management (7.1.6)

Program and Environmental Management provides centralized program/project management to plan, execute and control the Facility Stabilization baseline. Program and Environmental Management also provides for common safeguard and security support, centralized coordination of environmental and historical compliance activities, systems engineering, communications support, management of $\mathrm{SNM}$, and conduct of operations support, and future deactivation planning.

B Plant (7.1.7)

The B Plant Transition Sub-Project is moving rapidly towards a minimum cost safe storage mode pending transfer to EM-40 through accelerating the reduction of known hazards and aggressive transition activities. Accelerated hazard reduction activities such as the recently completed removal of legacy organics from the canyon are the early focus of transition to allow a quick reduction of surveillance and maintenance costs. A replacement facility exhaust system is being designed and built which will provide the required negative pressure while allowing the deactivation and isolation of the legacy filter units containing thousands of curies of radioactive material. Other transition activities such as gallery deactivation and outdoor contaminated area stabilization or decontamination will also be completed as needed to place a facility into a minimal surveillande and maintenance mode. During the accelerated hazard reduction and transition activities, the facilities will be maintained in a safe, secure, and environmentally compliant status.

\section{WESF (7.1.8)}

The WESF Transition Sub-Project is focusing on assuring the safe storage of approximately 1900 cesium and strontium capsules by upgrading their systems and structures to be capable of functioning safely for the next 20 years and without a need for services currently supplied from B Plant. Primary upgrades are planned in the next few years in the areas of response to a potential capsule leak, pool cell monitoring capabilities, and capsule monitoring equipment. Safety analyses are also being upgraded with the preparation of a new safety analysis report with accompanying operational safety requirements. These upgrades are necessary to maintain the cesium and Strontium capsules in a safe storage condition until all of the capsules are transferred out for ultimate disposal. Final capsule removal is planned to begin in 2013 and complete in 2017 . After capsule removal the facility will be deactivated and turned over to $E M-40$.

324/327 Facility (7.1.X)

On October 1, 1996 the 324 Building and 327 Building transferred to Facility Stabilization Project, and deactivation planning activities were initiated. The mission of the $324 / 327$ Facility Transition Project is to place these buildings in the lowest radiological classification possible for S\&M pending re-use where feasible or final D\&D. This project will remove and/or reduce human health and environmental hazards associated with the 324 and 327 Buildings.

The scope of the 324/327 Facility Transition Project includes minimum safe S\&M, ongoing deactivation/risk mitigation subprojects, and future deactivation subprojects.

Planning Assumptions:

The FSP will identify SNMNMNF inventories and track them through transfer, receipt, storage, and disposition. The FSP will further develop schedules for transfer, receipt, storage, and disposition of the SNM/NM/NF as NEPA RODs and other disposition decisions are made.

The FSP deactivation and stabilization actions will generate small amounts of tank waste that will be 
transferred to TWRS.

The FSP deactivation and stabilization actions will generate LAW streams (such as solid LLW, TRU solid waste, and liquid effluents) which will be transferred to the appropriate Hanford Site Contractor for disposition.

Refer to FSP Subprojects for a more detailed discussion of waste and material flows and requirements/assumptions.

Life-cycle planning and budget responsibility for major FSP facilities are identified in the subprojects. The Hanford Site Technical Baseline database uses these data to define interfaces between Hanford Site projects. The life-cycle phases are those identified in DOE Order 430.1, Life-Cycle Asset Management (DOE 1995).

Deactivation of remaining contaminated excess facilities not already in the FSP or part of the ERC (excluding the T Plant complex) are grouped into three outyear PBS's as follows:

a. K Basin Deactivation Project, which deals with the $100 \mathrm{~K}$ Area facilities connected with the KE and KW Basins

b. Hanford Surplus Facility Program 300 Area Revitalization Project, which deals with the deactivation, conversion, and D\&D of 300 Area facilities not covered by other FSP/ERC PBS's

c. Accelerated Deactivation Project, which deals with deactivation of excess contaminated facilities outside the 300 Area not included in other FSP PBS's.

\section{A.1.2 Boundary Diagram with Major Facilities}

The following table indentifies the major facilities that interface with this Project. The left column of the table identifies the major facilities that generate waste, materials, or infrastructure for this Project. The right column of the table identifies the major facilities that will receive waste and materials from this Project. The blank center column represents this Project.

Table A.1-1 Facility Stabilization Project Boundary Diagram

\begin{tabular}{|c|c|}
\hline $\begin{array}{l}\text { Extemal Interiaces } \\
\text { Hantord Legacy } \\
\text { Idaho National Engineering Laboratory } \\
\text { Hantord Site Environmental System Interfaces } \\
\text { hsems.25.3 Central Plateau Steam System } \\
\text { hsems.2.5.4 Central Plateau Water System } \\
\text { hsems.2.5.5 Central Plateau Office Facilities } \\
\text { hsems.2.5.6 Central Plateau Electrical System } \\
\text { hsems.2.5.9 Central Plateau Shop Facilities } \\
\text { hsems.2.5.13 Central Plateau Road System } \\
\text { hsems.4.3.1 Fast Fux Test Facility } \\
\text { hsems.4.4.1 South } 600 \text { Area Electrical System } \\
\text { hsems.4.4.3 South } 600 \text { Area Water System } \\
\text { hsems.4.4.6 South } 600 \text { Area Office Facilities } \\
\text { hsems.4.4.7 South } 600 \text { Area Shop Facilites } \\
\text { hsems.4.6.2 } 325 \text { Building } \\
\text { hsems.4.7.1 } 331 \text { Complex }\end{array}$ & 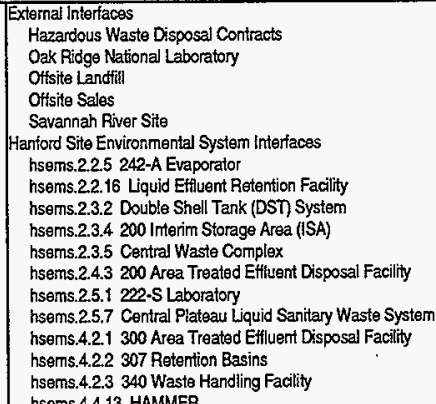 \\
\hline
\end{tabular}




\section{A.1.3 Facility Responsibility Assignment Matrix}

This section provides a table that identifies the sub-projects, major facilities, and the life cycle assignments.

Table A.1-2 Facility Responsibility Assignment Matrix

\begin{tabular}{|c|c|c|c|c|c|c|c|c|c|}
\hline \multirow{3}{*}{ Asset } & \multirow{3}{*}{$\begin{array}{l}\text { Program } \\
\text { Planning } \\
\end{array}$} & \multirow{3}{*}{$\begin{array}{c}\text { Pre } \\
\text { Conceptual }\end{array}$} & \multicolumn{4}{|c|}{ Lite oycle } & \multirow[b]{3}{*}{ O\&M } & \multirow{2}{*}{\multicolumn{2}{|c|}{ Close Out }} \\
\hline & & & \multirow{2}{*}{ Conceptual } & \multicolumn{3}{|c|}{ Execute } & & & \\
\hline & & & & Design & |Construction & TTumover & & Past Oos & $D \& D$ \\
\hline $100 \mathrm{~K}$ Area Facilities & $\begin{array}{l}\text { RL-WMO1 } \\
\text { RL-TP09 }\end{array}$ & & & & & & RL-WMO1 & RL-TPOg & $\begin{array}{l}\text { RL-ER05 } \\
\text { RL-ER05 }\end{array}$ \\
\hline 242-A Evaporator & RL-WM05 & & & & & & RL-WMO5 & RL-TP10 & $\begin{array}{l}\text { RLEPO6 } \\
\text { AL-ER05 }\end{array}$ \\
\hline Plutonium-Uranium Extraction Plant & RL-TP03 & & & & & & & $\begin{array}{l}\text { RL-TPOS } \\
\text { RL-EROS }\end{array}$ & $\begin{array}{l}\text { RL-ER06 } \\
\text { BL-ER05 }\end{array}$ \\
\hline B Plant & RL-TPOT & & & & & & & RL-TP01 & $\begin{array}{l}\text { RL-ER06 } \\
\text { RL-ER05 }\end{array}$ \\
\hline Waste Encapsulation and Storage Facility & RL-TP02 & & & & & & RL-TP02 & RL-TP02 & $\begin{array}{l}\text { RL-EROS } \\
\text { RL-ERO5 }\end{array}$ \\
\hline Plutonium Finishing Plant & RL-TP07 & & & & & & $\begin{array}{l}\text { RL-TP07 } \\
\text { RL-TP05 } \\
\text { RL-TP06 }\end{array}$ & $\begin{array}{l}\text { RL-TP07 } \\
\text { RL-TP0S } \\
\text { RL-TP05 }\end{array}$ & $\begin{array}{l}\text { RL-ER06 } \\
\text { RL-ER05 }\end{array}$ \\
\hline T-Plant Facility & RL-WMO4 & & & & & & RL-WMO4 & $\begin{array}{l}\text { RL-TP10 } \\
\text { RL-WMO4 }\end{array}$ & $\begin{array}{l}\text { RL-ER05 } \\
\text { RL-ERO5 } \\
\end{array}$ \\
\hline $2706 \mathrm{~T}$ & AL-WMO4 & & & & & & RL-WKO4 & $\begin{array}{l}\text { RL-TP10 } \\
\text { RL-WMMO4 }\end{array}$ & $\begin{array}{l}\text { RL-ERO5 } \\
\text { BLLER0S }\end{array}$ \\
\hline M-91 Facility & RL-WAO4 & RL-WHO4 & RLWWHO4 & RL-WMO4 & RL-WMO4 & RL-WHO4 & RL-WMO4 & $\begin{array}{l}\text { RL-WMO4 } \\
\text { RL-TP10 }\end{array}$ & $\begin{array}{l}\text { RL-WMO4 } \\
\text { RL-EROS }\end{array}$ \\
\hline WRAP Module 1 & RL-WHO4 & & & . & & & RL-WHO4 & $\begin{array}{l}\text { AL-TP10 } \\
\text { RL-WMO4 }\end{array}$ & $\begin{array}{l}\text { RL-WMO4 } \\
\text { RL-EROS }\end{array}$ \\
\hline Liquid Effluent Retention Facility & RL-WM05 & & & & & & RL-WM05 & RL-TP10 & $\begin{array}{l}\text { RL-ER06 } \\
\text { RL-ER05 } \\
\end{array}$ \\
\hline 200 Area Effluent Treatment Facility & RL-WMOS & & & & & & RL-WMOS & AL-TP1D & $\begin{array}{l}\text { RL-ER06 } \\
\text { RLLER05 }\end{array}$ \\
\hline Transuranic Storage and Assay Facility & RL-WMOS & & & & & & RL-WMD3 & $\begin{array}{l}\text { RL-TPIO } \\
\text { AL-WMO3 }\end{array}$ & $\begin{array}{l}\text { RL-ER06 } \\
\text { RL-ER05 }\end{array}$ \\
\hline 222-S Laboratory & AL-WMOS & & & & & & RL-WMD6 & $\begin{array}{l}\text { PLLTP10 } \\
\text { RL-WMOS }\end{array}$ & $\begin{array}{l}\text { RL-ERO6 } \\
\text { RL-ER05 }\end{array}$ \\
\hline 300 Area Fuel Supply System & AL-TPQ4 & & & & & & & AL-TP04 & $\begin{array}{l}\text { RL-ER05 } \\
\text { RL-ER05 }\end{array}$ \\
\hline South 600 Area Steam System & RL-TP13 & & & & & & $\begin{array}{l}\text { RL-H111 } \\
\text { RL-TP14 }\end{array}$ & $\begin{array}{l}\text { RL-TP13 } \\
\text { RL-TP14 }\end{array}$ & $\begin{array}{l}\text { RL-TP13 } \\
\text { RL-TP14 }\end{array}$ \\
\hline South 600 Area Water System & RL-TP13 & & & & & & $\begin{array}{l}\text { RL-1112 } \\
\text { RL-TP14 }\end{array}$ & $\begin{array}{l}\text { RL-TP13 } \\
\text { RL-TP14 }\end{array}$ & $\begin{array}{l}\text { RL-TP13 } \\
\text { RL-TP14 }\end{array}$ \\
\hline South 600 Area Liquid Sanitary Waste System & AL-TP13 & & & & & & $\begin{array}{l}\text { RL-1113 } \\
\text { RL-TP14 }\end{array}$ & $\begin{array}{l}\text { RL-TP13 } \\
\text { RL-TP14 }\end{array}$ & $\begin{array}{l}\text { RL-TP13 } \\
\text { BL-TP14 }\end{array}$ \\
\hline South 600 Area Telecommunication System & AL-TP13 & & & & & & $\begin{array}{l}\text { RL-16 } \\
\text { RL-TP14 }\end{array}$ & $\begin{array}{l}\text { RL-TP13 } \\
\text { RL-TP14 }\end{array}$ & $\begin{array}{l}\text { RL-TP13 } \\
\text { RL-TP14 }\end{array}$ \\
\hline South 600 Area Office Facilities & RL-TPY3 & & & & & & \begin{tabular}{|l|} 
RL-J13 \\
RL-TP14
\end{tabular} & $\begin{array}{l}\text { RL-TP13 } \\
\text { RL-TP14 }\end{array}$ & $\begin{array}{l}\text { RL-TP13 } \\
\text { RL-IP14 }\end{array}$ \\
\hline South 600 Area Shop Facilities & RL-TP13 & & & & & & $\begin{array}{l}\text { RL-11 } \\
\text { RL-TP14 }\end{array}$ & $\begin{array}{l}\text { RL-TP13 } \\
\text { RL-TP14 } \\
\end{array}$ & $\begin{array}{l}\text { RL-TP13 } \\
\text { RL-TP14 } \\
\end{array}$ \\
\hline South 600 Area Storage Facilities & RL-TP13 & & & & & & $\begin{array}{l}R L-17 \\
\text { RL-TP } 14\end{array}$ & $\begin{array}{l}\text { RL-TPI3 } \\
\text { RL-TPI4 }\end{array}$ & $\begin{array}{l}\text { RL-TP13 } \\
\text { RL-TP14 }\end{array}$ \\
\hline South 600 Area Land & RL-TP13 & & & & & & $\begin{array}{l}\text { RL-1123 } \\
\text { RL-TP14 }\end{array}$ & $\begin{array}{l}\text { RL-TP13 } \\
\text { RL-TP14 }\end{array}$ & $\begin{array}{l}\text { RL-TP13 } \\
\text { RL-TP14 }\end{array}$ \\
\hline South 600 Area Road System & RL-TP13 & & & & & & $\begin{array}{l}\text { RL-1T21 } \\
\text { RL-TP14 }\end{array}$ & $\begin{array}{l}\text { RL-TP13 } \\
\text { RL-TP14 }\end{array}$ & $\begin{array}{l}\text { RL-TP13 } \\
\text { RL-TPI4 }\end{array}$ \\
\hline South 600 Area Rail System & RL-TP13 & & & & & & $\begin{array}{l}\text { RL-1122 } \\
\text { RL-TP } 14\end{array}$ & $\begin{array}{l}\text { RL-TP13 } \\
\text { RL-TP14 }\end{array}$ & $\begin{array}{l}\text { RL-TP13 } \\
\text { RL-TP14 }\end{array}$ \\
\hline B24 Building & RL-TP08 & & & & & & \begin{tabular}{|l|} 
RL-TP08 \\
RL-ST01 \\
\end{tabular} & RL-TP08 & $\begin{array}{l}\text { RL-ER06 } \\
\text { RL-ER05 }\end{array}$ \\
\hline
\end{tabular}




\begin{tabular}{|c|c|c|c|c|c|c|c|c|c|}
\hline \multirow{3}{*}{ Assei } & \multicolumn{9}{|c|}{ Lifa Oycla } \\
\hline & \multirow{2}{*}{$\begin{array}{l}\text { Program } \\
\text { Pianning }\end{array}$} & \multirow{2}{*}{$\begin{array}{c}\text { Pre } \\
\text { Conceptual }\end{array}$} & \multirow[b]{2}{*}{ Conceptual } & \multicolumn{3}{|c|}{ Exearte } & \multirow[b]{2}{*}{ O\&M } & \multicolumn{2}{|c|}{ Close Out } \\
\hline & & & & Design & Construction & Tumover & & Post Ops & D\&D \\
\hline 325 Building & RL-STOI & & & & & & $\begin{array}{l}\text { RL-STOI } \\
\text { RL-STO2 - } \\
09\end{array}$ & $\begin{array}{l}\text { RL-TP14 } \\
\text { RL-ER05 }\end{array}$ & $\begin{array}{l}\text { RL-ER06 } \\
\text { RL-ER05 }\end{array}$ \\
\hline 326 Building & RL-ER10 & & & & & & RLSTO1 & $\begin{array}{l}\text { RL-TPI4 } \\
\text { RL-ER05 }\end{array}$ & $\begin{array}{l}\text { RL-ERO6 } \\
\text { RL-ER05 } \\
\end{array}$ \\
\hline 327 Building & RL-TPOS & & & & & & $\begin{array}{l}\text { RL-TP08 } \\
\text { RL-ST01 }\end{array}$ & RL-TP08 & $\begin{array}{l}\text { RL-ER06 } \\
\text { BL-ER05 }\end{array}$ \\
\hline 329 Euilding & RLSTOT & & & & & & RLSTO1 & $\begin{array}{l}\text { RL-TP14 } \\
\text { RL-ER05 }\end{array}$ & $\begin{array}{l}\text { RL-ER05 } \\
\text { RL-ER05 }\end{array}$ \\
\hline $320 / 3720 / 3745$ & RL-STO1 & & & & & & $\begin{array}{l}\text { RL-ST01 } \\
\text { RL-ST02- } \\
09\end{array}$ & $\begin{array}{l}\text { RL-TP14 } \\
\text { RL-ER05 }\end{array}$ & $\begin{array}{l}\text { RL-ER06 } \\
\text { RL-ER05 }\end{array}$ \\
\hline Misc. Rad Labs & RL-ER10 & & & & & & & $\begin{array}{l}\text { RL-TP14 } \\
\text { RL-ER05 }\end{array}$ & $\begin{array}{l}\text { RL-ERO5 } \\
\text { RL-ERO5 }\end{array}$ \\
\hline 331 Complex & RL-ERTO & & & & & & $\begin{array}{l}\text { RLSTO1 } \\
\text { RL-ST02 - } \\
\text { 09 }\end{array}$ & $\begin{array}{l}\text { RL-TP14 } \\
\text { RL-ER05 }\end{array}$ & $\begin{array}{l}\text { RL-ERO6 } \\
\text { RL-ER05 }\end{array}$ \\
\hline
\end{tabular}

RL-ERO5 - Suveillance and Maintenance

RL-ERO6 - Decontamination \& Decomrnissioning

RL-ER10 - Environmental Restoration Program Management and Support

RL-11 - DynCorp Infrastructure

RL-1111 - Steam Utilities

RL-H112 - Water Utilities

RL-1113 - Liquid Sanitary Waste Utilites

RL-1121 - Roadway Maintenance

RL-1122 - Rail Operations \& Maintenance

RL-1123 - Vehicle Operations

RL-113 - General Purpose Facilities

RL-16 - Information Resource Management

RL-17 - Asset Management

RL-ST01 - PNNL Waste Managerient Project

RL-ST02-09-Science \& Technologies Project

RL-TPO1 - B Plant Sub-Project

RL-TP02 - WESF Sub-Project

RL-TP03 - PUREX Sub-Project

RL-TP04 - 300 Area/SNM Sub-Project

RL-TP05 - PFP Deactivation

RL-TP06 - PFP Stabilization

RL-TP07 - PFP Vautt Management

RL-TP08 - 324/327 Facility Transition Project

RL-TPO9 - K Basin Deactivation

RL-TP10 - Accolerated Deactivation Project

RL-TP13 - Landlord

RL-TP14 - Hanford Surplus Facility Program 300 Area Revitalization Project

RL-WMO1 - Spent Nuclear Fuel

RL-WMC3 - Solid Waste Storage \& Disposal

RL-WMO4 - Solid Waste Treatment

RL-WM05 - Liquid Efiuents Project

RL-WMO6 - Analytical Services 


\section{A.1.4 Project Planning Assumptions}

This section contains the issues that affect the project. These include project specific issues, as well as the site-level issues that have been assigned to the project for resolution. It also contains the assumptions that are used as a basis for the development of project plans until the issues are formally resolved with records of decision. The "Champion" column determines if the Project has lead responsibility or is an affected participant. If the champion belongs to the Project, the Project has the lead. If not, the Project is an affected participant. Project plans include appropriate activities and resources for resolving these issues.

Table A.1-3 Project Issues And Assumptions

\begin{tabular}{|c|c|c|c|}
\hline \multicolumn{2}{|r|}{ ISSUE } & PLANNING ASSUMPTION & CHAMPION \\
\hline 1 & $\begin{array}{l}\text { Revitalization Project Facility Timing } \\
\text { What is the acceptance criteria and timing for the transfer of } \\
\text { facilities in the } 300 \text { Area to the Revitalization Project? }\end{array}$ & $\begin{array}{l}\text { Transter of tacilities into the Revitalization Project will begin } \\
\text { (n FY } 99 \text {. }\end{array}$ & Lund \\
\hline 2 & $\begin{array}{l}\text { PFP Budget Shortfall } \\
\text { A significant budget shortfall for the PFP Project has } \\
\text { occurred in FY98 and FY99. Minimal support to DNFSB } \\
\text { Recomrnendation } 84-01 \text { is provided. There is no support for } \\
\text { facility transition to deactivation. }\end{array}$ & $\begin{array}{l}\text { neremental turiding is not provided. As a result DNFSB } \\
\text { Recommendation } 94-01 \text { is only minimally supported in FY } 98 \\
\text { and FY } 99 \text {. A total rebaseline of the PFP Project is required } \\
\text { to establish new completion dates for PFP tacility transition to } \\
\text { ceactivation and implementation of DNSFB } \\
\text { Recommendation } 9401 \text {. }\end{array}$ & $\begin{array}{l}\text { Mecal } \\
\text { Olguin }\end{array}$ \\
\hline 3 & $\begin{array}{l}\text { Revitalization Project Facility Acquisition } \\
\text { Which facisties in the } 300 \text { Area will be transferred to the } \\
\text { Revitalization Project? }\end{array}$ & No Decision made. & Lund \\
\hline $\begin{array}{l}4 \\
.\end{array}$ & $\begin{array}{l}\text { Land Use Plan } 100 \\
\text { The interim end state for the } 100 \text { Areas has not been } \\
\text { defined. }\end{array}$ & $\begin{array}{l}\text { Soil sites remediated consistent with CERCLA-ROD cleanup } \\
\text { standards. DOE will retain control of this land througisout the } \\
\text { cleanup mission and will protect archaeological , cultural and } \\
\text { environmental resources. }\end{array}$ & Baver \\
\hline 5 & $\begin{array}{l}\text { Land Use Plan } 2002 \\
\text { The interim end state for the } 200 \text { Areas has not been defined }\end{array}$ & $\begin{array}{l}\text { The } 200 \text { Area and central plateau will be used for the } \\
\text { managenent of nuclear materials and the collection and } \\
\text { bisposal of waste materials that remain on site and for other } \\
\text { selated and compatible uses. Cleanup levels and dispasal } \\
\text { standards will be established in the CERCLA and RCRA } \\
\text { permit moditications. Soil sites will be remediated consistent } \\
\text { fith CERCLA-ROD cleanup standards. DOE will retain } \\
\text { Montrol of this land. }\end{array}$ & Bauer \\
\hline 6 & $\begin{array}{l}\text { Land Use Plan } 300 \\
\text { The interim end state for the } 300 \text { Areas has not been } \\
\text { defined. }\end{array}$ & $\begin{array}{l}\text { The } 300 \text { Area waste sites, materials, and tacilities will be } \\
\text { emediated to allow industrial and economic transition } \\
\text { opportunities. The Federal government will retain ownership } \\
\text { ff land in and adjacent to the } 300 \text { and } 400 \text { Areas, but will } \\
\text { gase land for private and public uses to support regional } \\
\text { industrial and economic development. Excoss land within } \\
\text { the } 1100 \text { and } 3000 \text { areas will be targeted for transition to } \\
\text { ton-Federal ownership. }\end{array}$ & Baner \\
\hline 7 & $\begin{array}{l}\text { End State for Camyon Facilities } \\
\text { The end state for the canyon facilities has not been clearly } \\
\text { defined. }\end{array}$ & Canyon tacilities will be entombed in-place with a bartier cap. & $\begin{array}{l}\text { Baver } \\
\text { Liodle }\end{array}$ \\
\hline 8 & $\begin{array}{l}325 \text { \& 204-AR Upgrades } \\
\text { Liquid waste collection and loading facility ( } 340 \text { tacility) is } \\
\text { scheduled for shutdown atter } F Y 1998 \text {. Initially nothing will be } \\
\text { done to preclude accepting waste at the } 340 \text { facility atter this } \\
\text { date. Transfer systems from Bldg. } 325 \text { to the tank farms via } \\
204-A R \text { facility will not be available per the current schedule. }\end{array}$ & No Decision made. & $\begin{array}{l}\text { Beard } \\
\text { Briggs }\end{array}$ \\
\hline 9 & $\begin{array}{l}325 \text { \& 204-AR Upgrades Adthoc Team } \\
\text { Line ltem Project B-472 provides an atternative waste } \\
\text { handling and processing method to be used by Building } 325 \\
\text { and 204-AR after September } 1998 \text {. }\end{array}$ & No Decision made. & Lowe \\
\hline
\end{tabular}


Table A.1-3 Project /ssues And Assumptions (Continued)

\begin{tabular}{|c|c|c|c|}
\hline \multicolumn{2}{|r|}{ ISSUE } & PLANNING ASSUMPTION & CHAMPION \\
\hline 10 & $\begin{array}{l}\text { Pu vational Disposition Policy } \\
\text { It has not been decided where, when and how surplus } \\
\text { weapons useable Pu will be dispositioned (reuse, storage, or } \\
\text { disposal). }\end{array}$ & $\begin{array}{l}\text { The ROD on PEIS recommended continued interim storage } \\
\text { for Hantord Material at PFP pending national policy on } \\
\text { disposition, and that the Hantord Site will be gvaluated for PU } \\
\text { disposition activities in the next level of NEPA studies. } \\
\text { Pu stabilization will ocour by } 2002 \text {. }\end{array}$ & $\begin{array}{c}\text { Mecca } \\
\text { Reynolds }\end{array}$ \\
\hline 11 & $\begin{array}{l}\text { Fuels Grade Pu Disposition } \\
\text { Final disposition of Fuels Grade Pu has not been determined. }\end{array}$ & $\begin{array}{l}\text { Continue inferim siorage at PFP vauls pending national } \\
\text { policy on disposition. New and/or modified vaults may be } \\
\text { reguired. }\end{array}$ & $\begin{array}{l}\text { Mecca } \\
\text { Reynoids }\end{array}$ \\
\hline 12 & $\begin{array}{l}\text { Cs \& Ss Capsules Disposition Poljey } \\
\text { it has not been decided where, how and when Cs/Sr } \\
\text { capsules will be tinally dispositioned. }\end{array}$ & $\begin{array}{l}\text { MDD: Cs/Sr capsules will continue to be interim stored at } \\
\text { WESF. } \\
\text { in the event the CsiSr capsules are declared waste, the } \\
\text { contenis will be processed to meet high-level waste feed } \\
\text { requirements, blended with other tank waste, vittitied and } \\
\text { stored onsite for eventual disposal at the geologic repository. }\end{array}$ & $\begin{array}{l}\text { Mecca } \\
\text { Reynoids }\end{array}$ \\
\hline$\overline{13}$ & $\begin{array}{l}\text { Project Life Cycle Planning } \\
\text { The forecasting information for SNF terminates with the end } \\
\text { of the Project (FY 2002). However it is clear that there will be } \\
\text { waste steams from the K-Basins and from the CSB as well } \\
\text { as infrastruchure needs. These need to be included in the } \\
\text { terecasting section of some project }\end{array}$ & No Decision made. & $\begin{array}{c}\text { Piper } \\
\text { Brentan }\end{array}$ \\
\hline 14 & $\begin{array}{l}\text { Facility Life Cycle Planning } \\
\text { In the HSTD Database, Projects do not have assigned } \\
\text { responsibisity for each life cycle phase of the on-site facilities } \\
\text { (K-Basins transition is either not assigned to or accepted by } \\
\text { SNF Tr P, or ER). }\end{array}$ & $\begin{array}{l}\text { Each Project that currently owns a tacility is responsible for } \\
\text { planning the entize life cycle or negotiating that responsibitity } \\
\text { to Transition Projects or ER }\end{array}$ & $\begin{array}{l}\text { Wisness } \\
\text { Brennan }\end{array}$ \\
\hline 15 & $\begin{array}{l}\text { HSIS / SE Imterface Differences } \\
\text { The interface information is needed to support the Hanford } \\
\text { Site Integrated Schedule preparation. The current HSIS } \\
\text { activities can not be easily linked to the SE intertaos tifies. }\end{array}$ & Use interiaces as currentiy defined in the HSTB. & $\begin{array}{l}\text { Wisness } \\
\text { Brennan }\end{array}$ \\
\hline
\end{tabular}




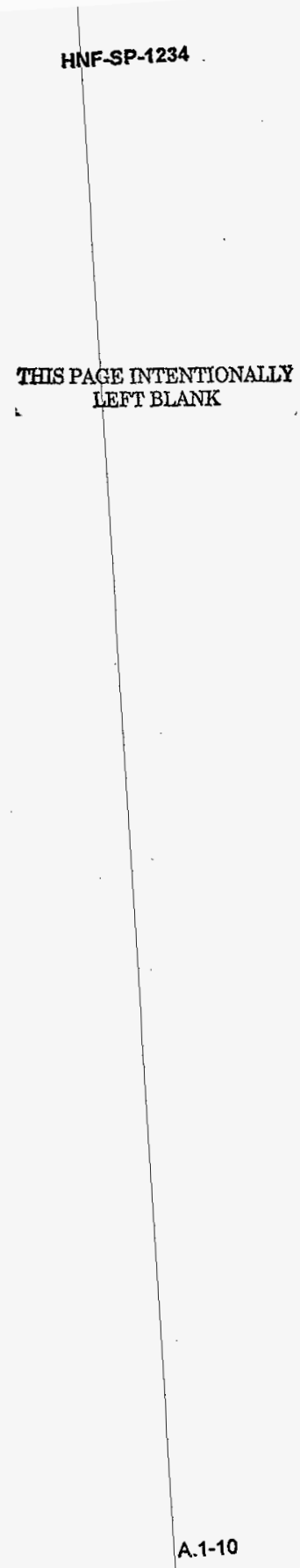




\section{Facility Stabilization Project Work Breakdown Structure}

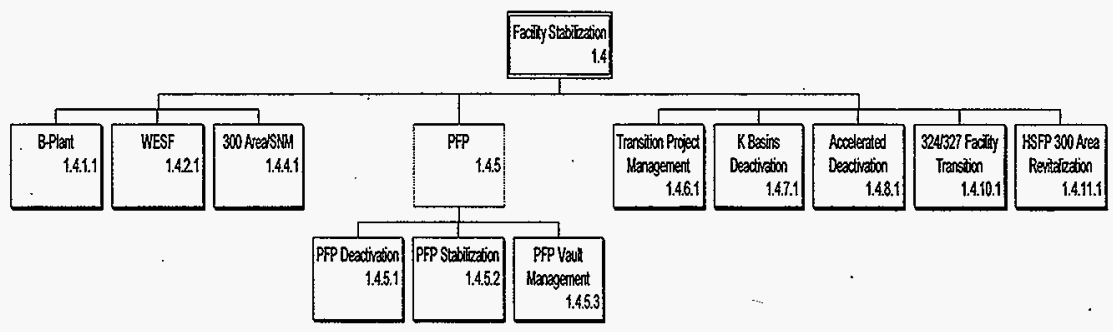




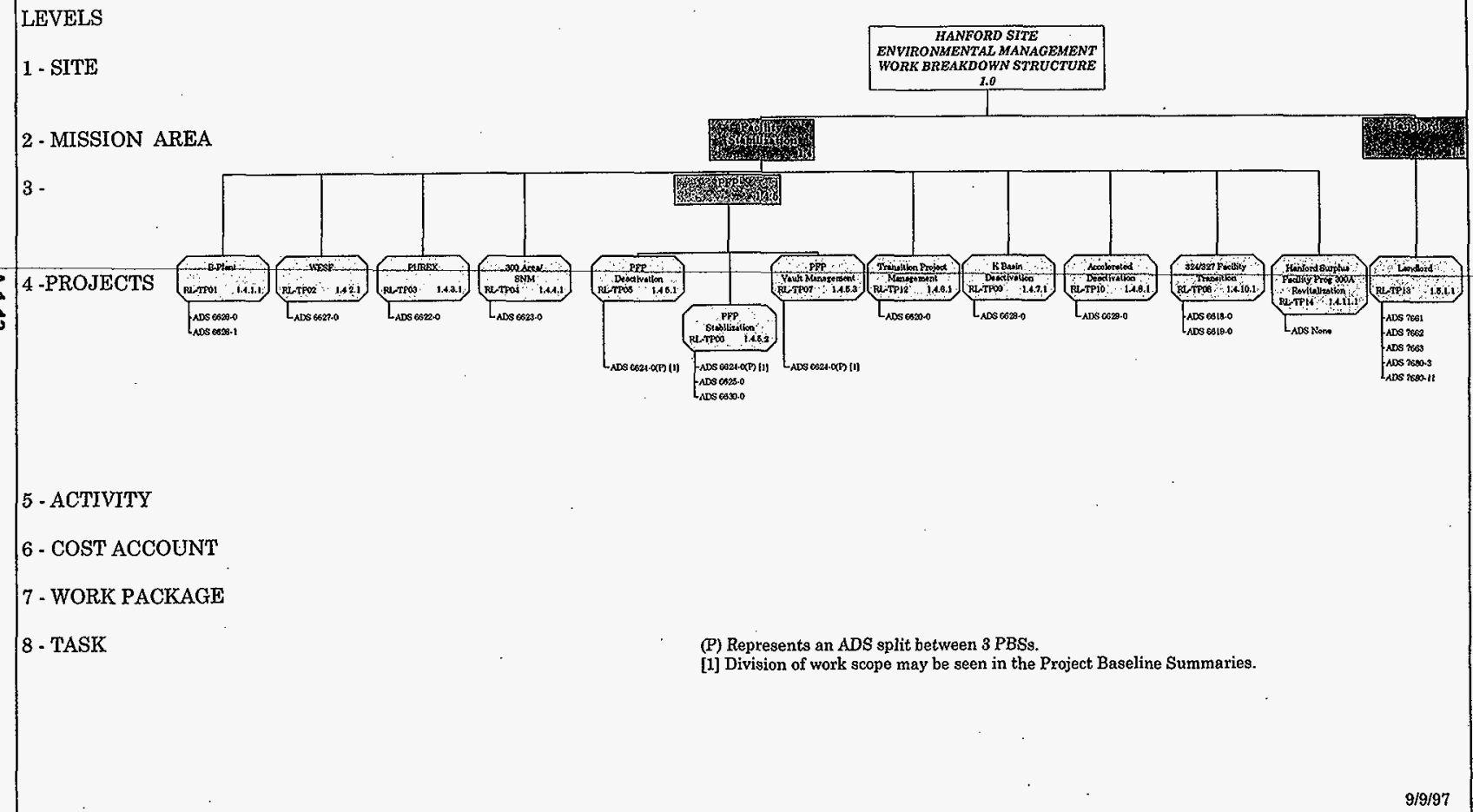

[1] Division of work scope may be seen in the Project Baseline Summaries. 


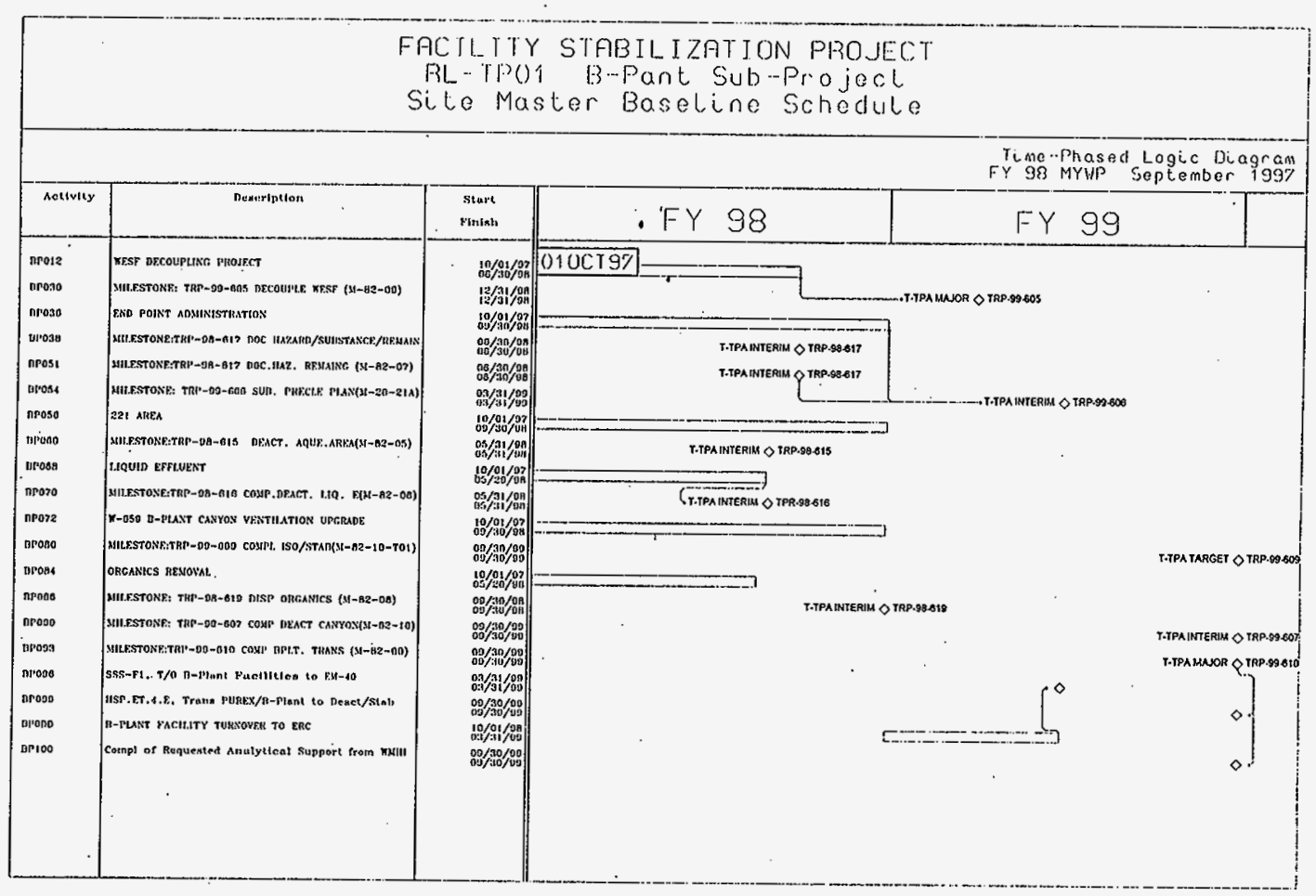


FACILITY STABILIZATION PROJECT

RL-TPO2 WESF Sub-Project

Site Master Baseline Schodule

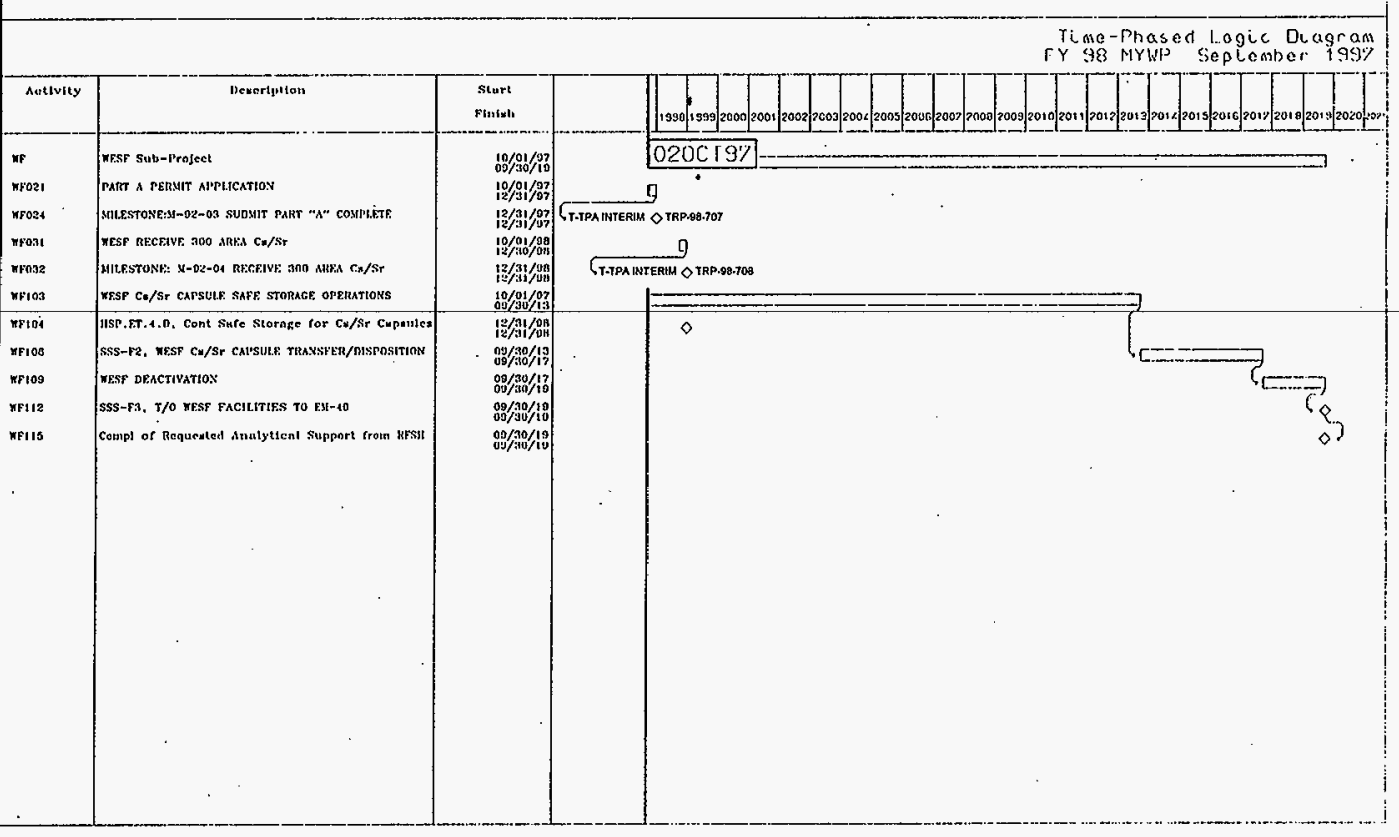


HNF-SP-1234

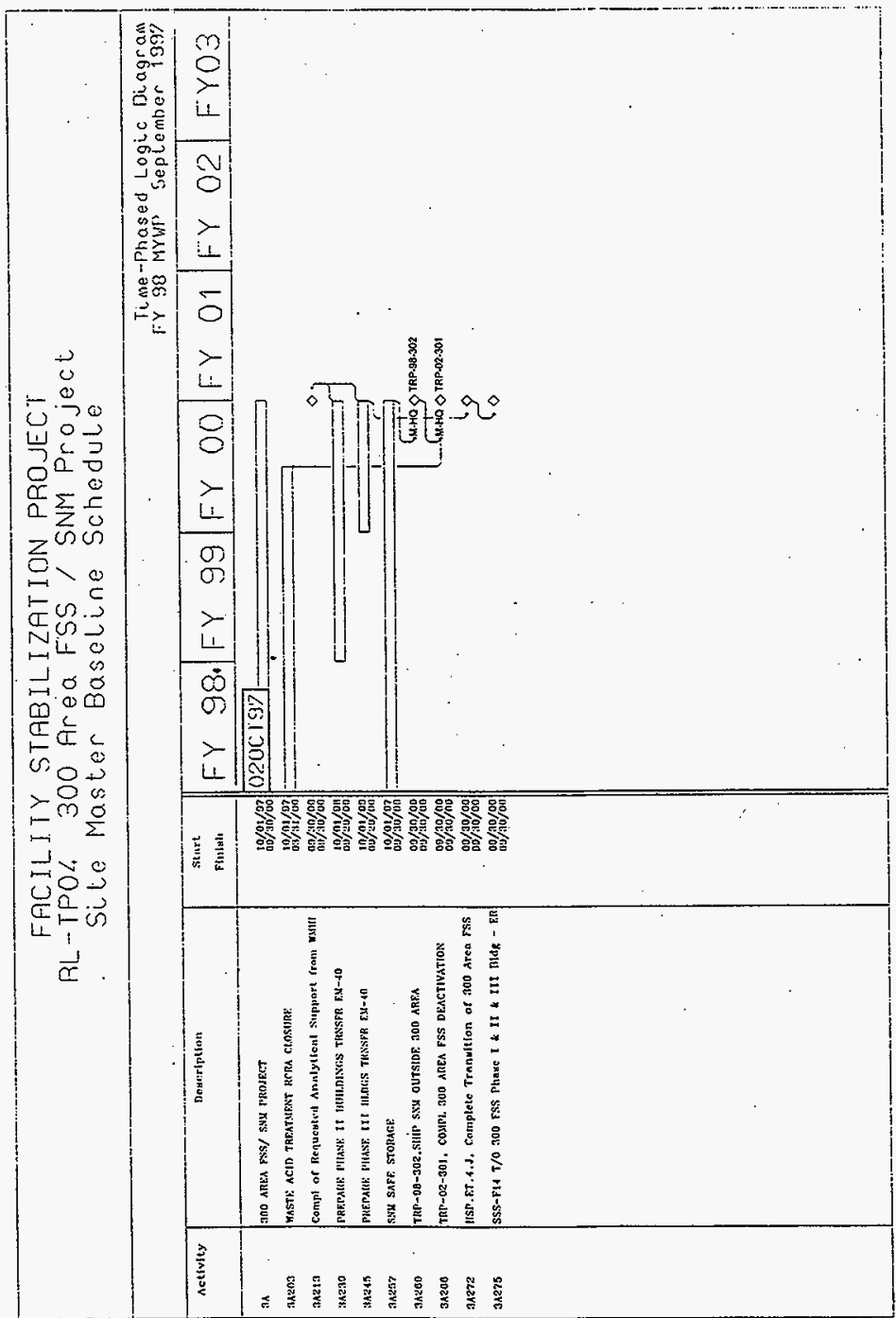




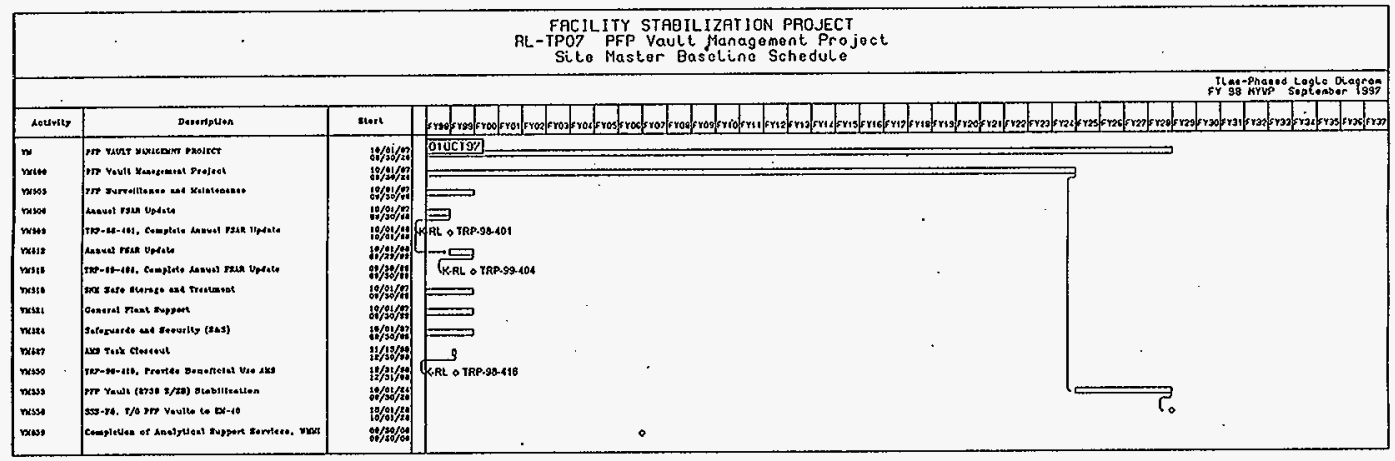




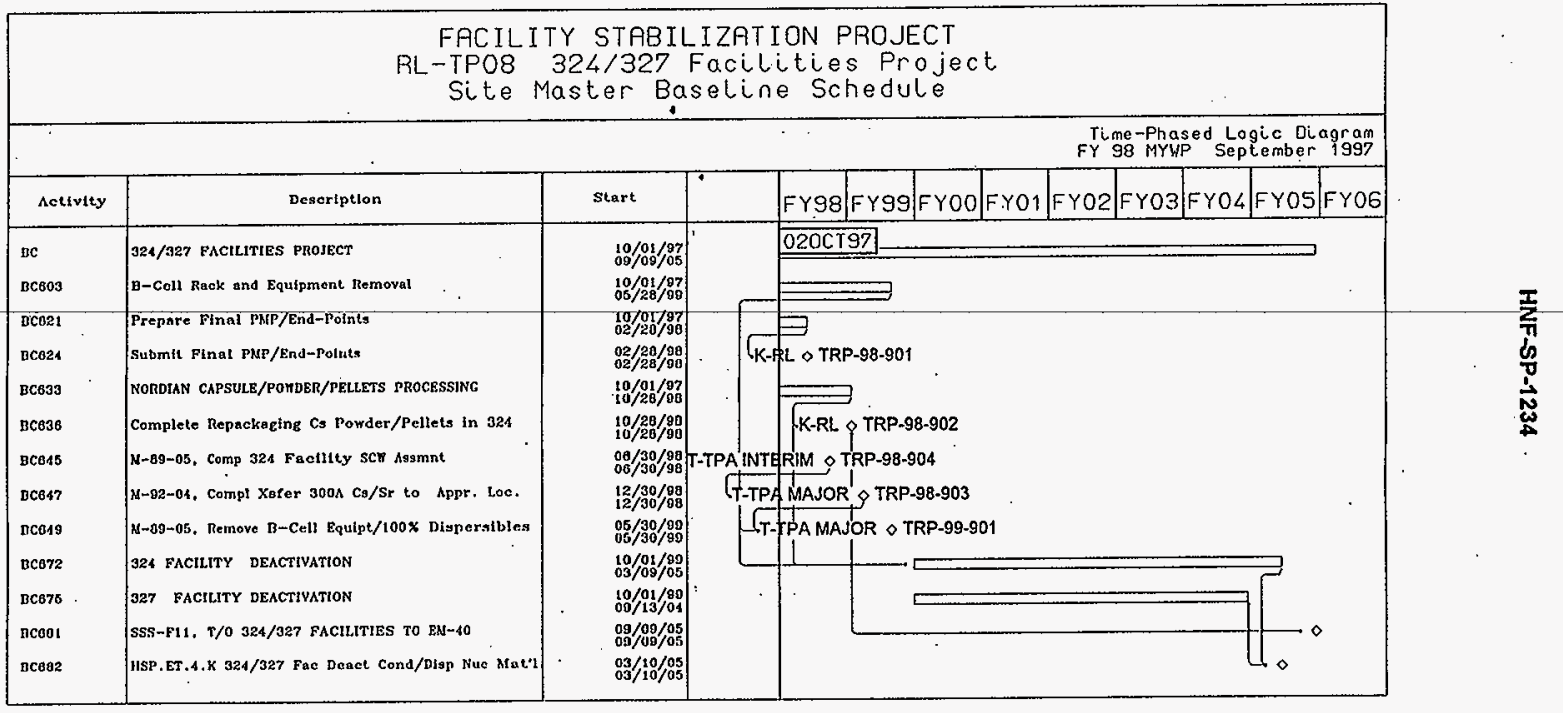




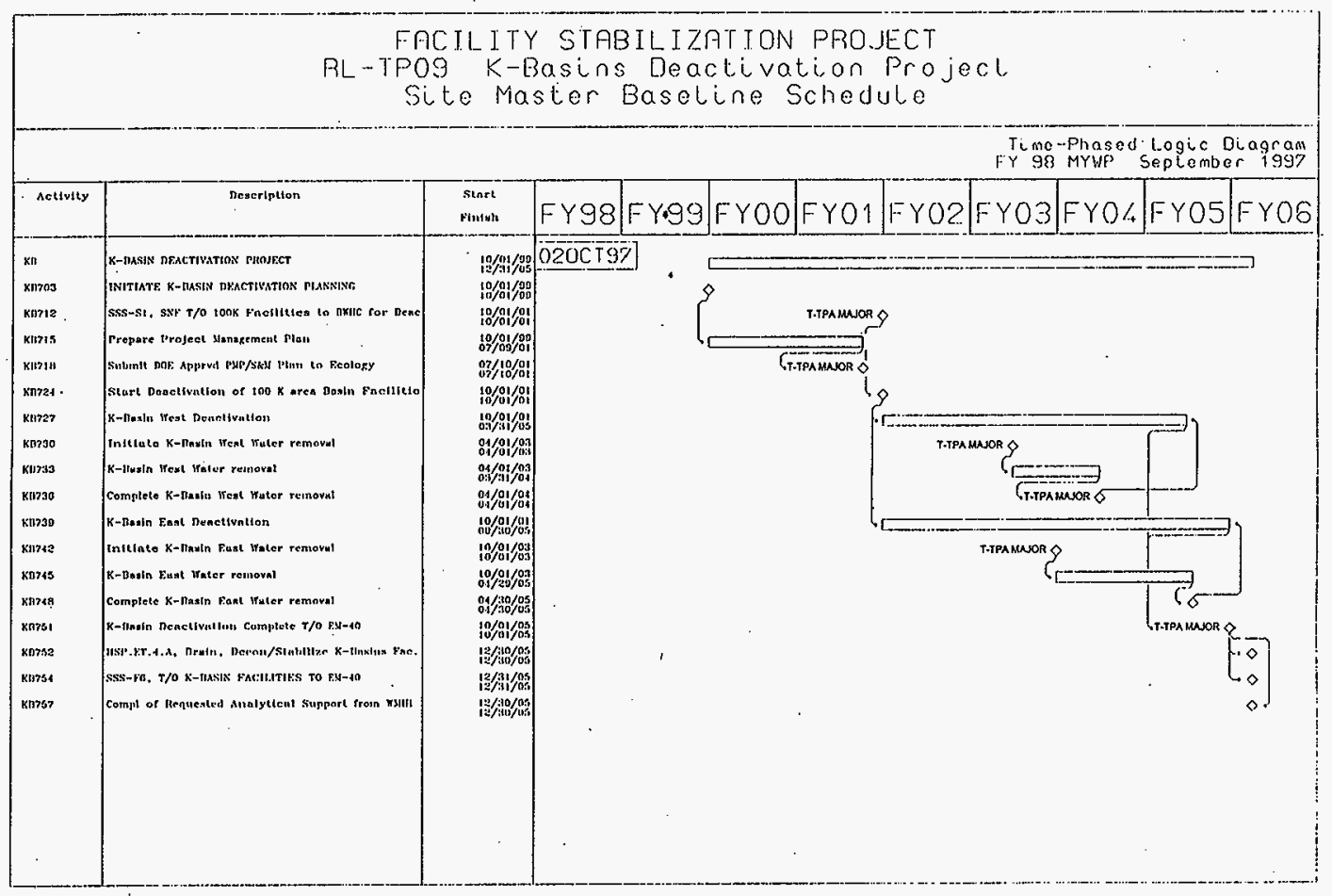




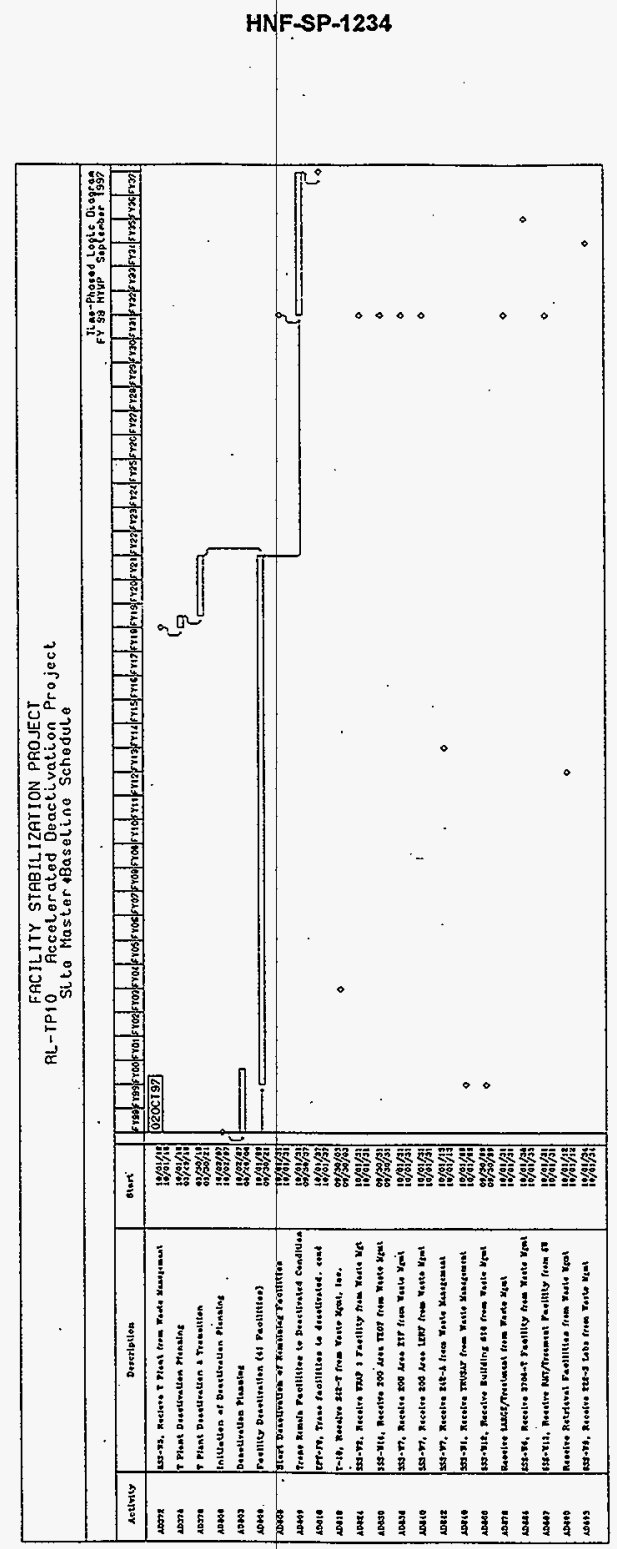




\begin{tabular}{|c|c|c|c|c|c|}
\hline & & \multicolumn{3}{|c|}{$\begin{array}{c}\text { FACILITY STABILIZAIION PROJECT } \\
\text { FL-TP12 Facility stabilization Project Management } \\
\text { Sile Master Baselione. Schedule } \\
\end{array}$} & \\
\hline & & & & & \\
\hline Aaturity & Descrivtiou & stett & & ant & \\
\hline $\mathbf{~} \times$ & 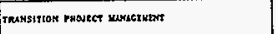 & 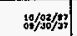 & & $020 \mathrm{cc197}$ & \\
\hline onooso & 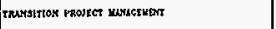 & 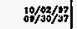 & & 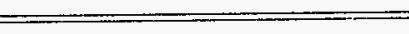 & \\
\hline resost & 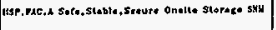 & 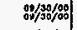 & & $\int^{\circ}$ & \\
\hline exess & 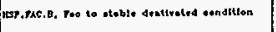 & 10\%1/30 & & & \\
\hline resosc & 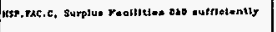 & $10 \% 013$ & & & \\
\hline rxess & 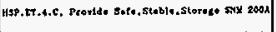 & 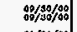 & & & \\
\hline rxoses & 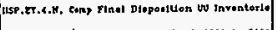 & $85,31 / 790$ & & - & \\
\hline pxosat & 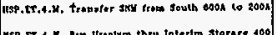 & 果 & & 50 & \\
\hline $\begin{array}{l}\text { proost } \\
\text { proos }\end{array}$ & 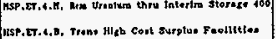 & 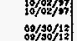 & & 0 & \\
\hline troosx & 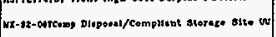 & 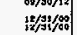 & T-TPAT Th & ARGET \& TRP.01-108 & \\
\hline wosex & 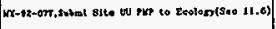 & $11 / 300 \%$ & T-TPA TARGET & TRP-92-108 & \\
\hline reose & 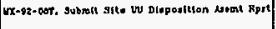 & 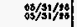 & T-TPATARGET & O TRP-98-109 & \\
\hline
\end{tabular}




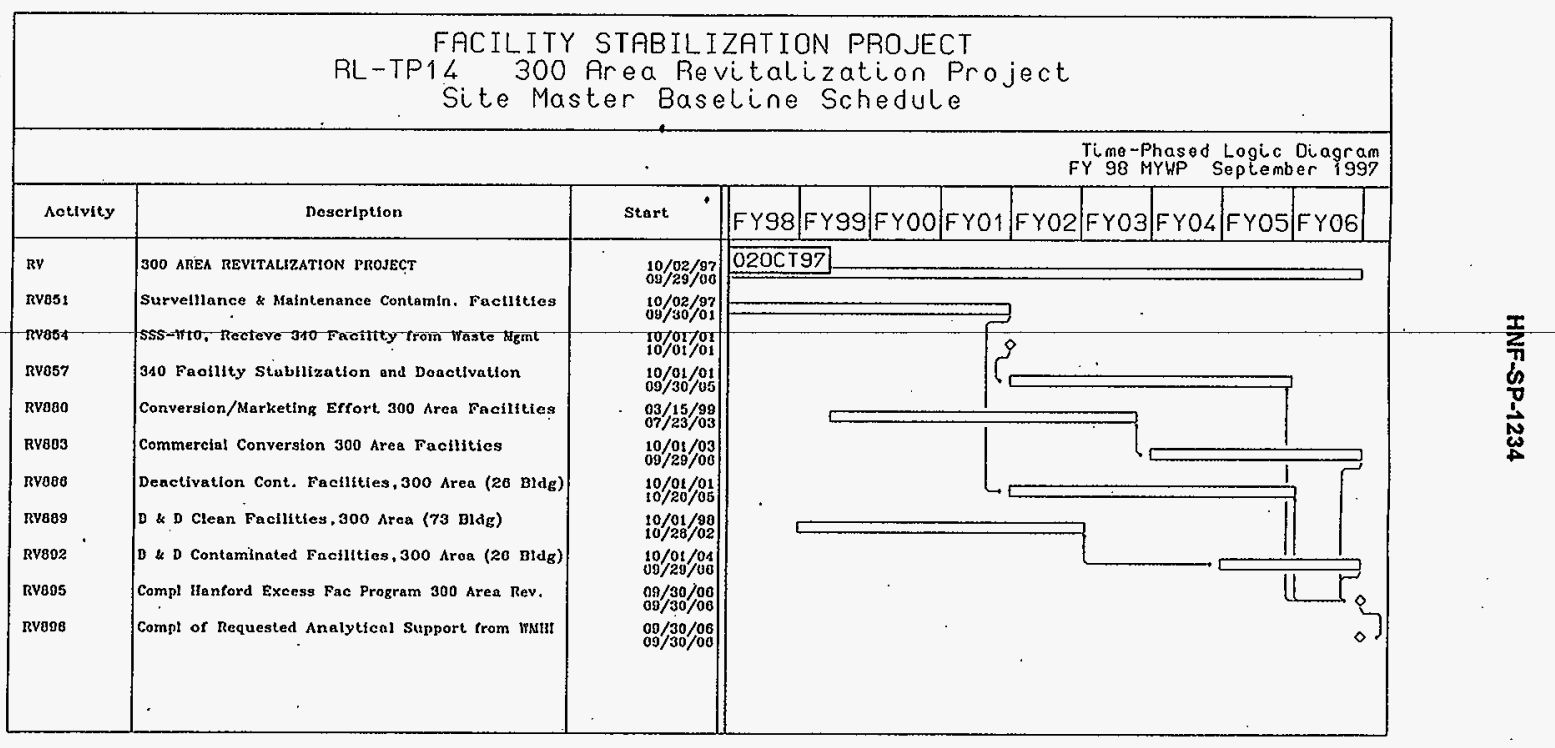




\subsection{ESTIMATE BASIS}

The cost estimates for the Facility Stabilization Project have been prepared in accordance with HNF-PR-000585, Cost Estimating, to provide a cost profile of the remaining work scope required to deactivate designated project facilities. They were developed using activity-based cost estimating techniques and applying the methodology prescribed in the U.S. Department of Energy Office of Waste Management "Cost and Schedule Estimating Guide," Section VI, "Operating Cost Estimating Methods." The scopes of the project activities are defined in the Hanford Site Technical Baseline, individual plant Standards/Requirements Identification Documents (S/RIDS), and in Section 1 of this document.

With the scope of the stabilization activities defined, cost estimates and schedules have been developed. The complexity of developing these estimates for a resource-loaded schedule required the involvement of many disciplines covering the entire spectrum of planning, scheduling, and estimating. The disciplines that provided input included technical, operational, project management, maintenance, engineering, safety, health physics, quality assurance, and security.

Approximately 24 percent of the project dollars were estimated using the level of effort technique.

Planning rates and escalation used are consistent with those developed by the FDH Chief Financial Officer and approved by the DOE-RL. Resource loaded schedules are traceable to the cost estimate packages

Final cost estimate packages contain the following:

Technical scope

Purpose of the project

Assumptions and exclusions

Estimate work breakdown structure

Technique and historical basis

Cost estimating relationship (CER) development

Labor rates, unit rates, and unit cost sources

Escalation amounts and sources

Contingency calculation development (if applicable)

Legal drivers

Labor costs

Technical logic diagram

Integrated, logic driven, resource loaded schedules

Responsibility assignment matrix

Other costs that will be reflected in the budget for the particular project

Individual activity-based cost estimate packages and their locations are as follows:

\section{ESTIMATE PACKAGE}

300 Area Baseline Estimate

FY 1997 PFP Transition Project ABC Estimate

Update

Life-Cycle Cost Estimate B Plant Transition Project

Life-Cycle Cost Estimate WESF Transition Project
LOCATION

333 Bldg/Rm 229/300

270-ZRm 66/200W

MO-410/Rm E/200E

$M O-410 / B a y / 200 E$ 
FACILITY STABILIZATION

SUMMARY OF LIFE CYCLE COST BASELINE (BCWS) BY YEAR BY

BY PROJECT BASELINE SUMMARY (PBS)

FY 1998

(\$000s)

\begin{tabular}{|c|c|c|c|c|c|c|c|c|c|c|c|c|}
\hline \multicolumn{3}{|c|}{ PROJECT WBS: 1.4} & & \multirow{3}{*}{$\begin{array}{l}\text { SUBTOT } \\
\text { FY1997- } \\
\text { FY2006 }\end{array}$} \\
\hline \multirow[b]{2}{*}{ PES TITLE } & \multirow[b]{2}{*}{ PBS NO } & \multirow[b]{2}{*}{ FY1997 } & \multirow[b]{2}{*}{ 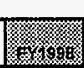 } & \multirow[b]{2}{*}{ FY1999 } & \multirow[b]{2}{*}{ FY2000 } & \multirow[b]{2}{*}{ FY2001 } & \multirow[b]{2}{*}{ FY2002 } & & & & & \\
\hline & & & & & & & & FY2003 & FY2004 & FY2005 & FY2006 & \\
\hline \multirow{13}{*}{\begin{tabular}{|l|} 
BPlant Sub-Project \\
WESF Sub-Project \\
300 Area/SNM Sub-Project \\
FFP Deacthation \\
PFP Stabllizatlon \\
FFP Vault Management \\
324r327 Facilty Transition \\
K Basin Deactivation \\
Accelerated Deactivation \\
Transition Project Management \\
Hanford Surplus Facllty Program 300 Are
\end{tabular}} & \multirow{13}{*}{$\begin{array}{l}\text { RL-TP01 } \\
\text { RL-TP02 } \\
\text { RL-TP04 } \\
\text { RL-TP05 } \\
\text { RL-TP06 } \\
\text { RL-TP07 } \\
\text { RL-TP08 } \\
\text { RL-TP09 } \\
\text { RL.-PP10 } \\
\text { RL-TP12 } \\
\text { RL-TP14 }\end{array}$} & 23,967 & 然 & 4,909 & $=$ & - & $\div$ & - & - & $=$ & - & 51,257 \\
\hline & & 13,574 & (3) & 10,747 & 16,157 & 12,597 & 12,479 & 12,467 & 12,247 & 13,034 & 13,254 & 129,669 \\
\hline & & 4,216 & $x_{m}$ & 4,894 & 8,935 & -1 & $\cdot$ & - & -2 & -1 & 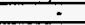 & 22,733 \\
\hline & & - & & - & 5,494 & 16,344 & 21,778 & 28,258 & 27,279 & 15,950 & 3,320 & 118,423 \\
\hline & & - & 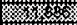 & 30,060 & 18,889 & 13,324 & 8,081 & $\cdot$ & - & - & - & 82,240 \\
\hline & & 85,201 & 4 & 62,687 & 75,140 & 70,120 & 67,068 & 61,532 & 62.406 & 63,535 & 27,329 & 635,993 \\
\hline & & 23,661 & s. & 31,042 & 38,661 & 30,329 & 23,021 & 14,132 & 10,188 & 752 & - & 205,267 \\
\hline & & - & & 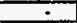 & 1,196 & 3,284 & 25,189 & 35,341 & 32,895 & 24,589 & 1,158 & 123,652 \\
\hline & & $=$ & 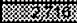 & 1,445 & 3,583 & 2,666 & 2,503 & 3,345 & 3,164 & 2,971 & 2,778 & 25,171 \\
\hline & & 10,494 & 4 & 12,026 & 11,415 & 13,564 & 13,900 & 14,248 & 15,108 & 15,478 & 13,229 & 131,058 \\
\hline & & 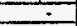 & 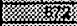 & 759 & 5,472 & 14,187 & 10,635 & 9,251 & 34,274 & 27,686 & 35,816 & 138,952 \\
\hline & & & & & & & & & & & & $\div$ \\
\hline & & & & & & & & & & & & \\
\hline (n) & & 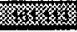 & 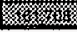 & 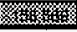 & 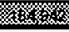 & 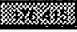 & $x$ & 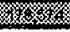 & 䶼 & S & . & 4 \\
\hline
\end{tabular}

Budgeted Cost of Work Scheduled (BCWS)

Equals Performance Measurement Basellne

(PMB); Expense Carryover is NOT Included. 
FY 1998

(\$000s)

PRONECT WBS:

\begin{tabular}{|c|c|c|c|c|c|c|c|c|c|c|c|}
\hline & \multirow{2}{*}{$\begin{array}{l}\text { TOTAL } \\
\text { FY1997- } \\
\text { FY2050 }\end{array}$} \\
\hline PBS TITLE & PES No & $\begin{array}{l}\text { FY2007- } \\
\text { FY2010 }\end{array}$ & $\begin{array}{l}\text { FY2011- } \\
\text { FY2016 }\end{array}$ & $\begin{array}{l}\text { FY2016- } \\
\text { FY2020 }\end{array}$ & $\begin{array}{l}\text { FY2021- } \\
\text { FY2026 }\end{array}$ & $\begin{array}{l}\text { FY2026- } \\
\text { FY2030 }\end{array}$ & $\begin{array}{l}\text { FY2031- } \\
\text { FY2036 }\end{array}$ & $\begin{array}{l}\text { FY2036 } \\
\text { FY2040 }\end{array}$ & $\begin{array}{l}\text { FY2041- } \\
\text { FY2046 }\end{array}$ & $\begin{array}{l}\text { FY2046 } \\
\text { FY2050 }\end{array}$ & \\
\hline \multirow{13}{*}{$\begin{array}{l}\text { 8Plant Sub-Project } \\
\text { WESF Sub-Project } \\
\text { 300 Area/SNM Sub-Project } \\
\text { PFP Deactivation } \\
\text { PFP Stabillzation } \\
\text { PFP Vault Management } \\
\text { 324/327 Facilty Transitlon } \\
\text { K Basin Deactivation } \\
\text { Accelerated Deactivation } \\
\text { Transition Prolect Management } \\
\text { Hanford Surplus Facility Program } 300 \text { Are }\end{array}$} & \multirow{13}{*}{$\begin{array}{l}\text { RL-TP01 } \\
\text { RL-TP02 } \\
\text { RL-TP04 } \\
\text { RL-TP05 } \\
\text { RL-TP06 } \\
\text { RL-TP07 } \\
\text { RL-TP08 } \\
\text { RL-TP09 } \\
\text { RL-TP10 } \\
\text { RL-TP12 } \\
\text { RL-TP14 }\end{array}$} & $\cdot$ & - & - & $\therefore$ & $\div$ & $\div$ & $\div$ & $\because$ & $\because$ & \\
\hline & & 58,650 & 82,738 & 60,552 & $\because$ & $\div$ & - & $=$ & $\because$ & - & 331,609 \\
\hline & & 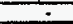 & - & - & - & $\because$ & $\because$ & 7 & - & $=$ & 22,733 \\
\hline & & - & $\because$ & $\because$ & - & 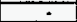 & $=$ & $\because$ & - & $=$ & 918,423 \\
\hline & & 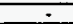 & 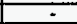 & - & 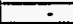 & - & . & $=$ & - & $=$ & 82,240 \\
\hline & & 185,282 & 204,667 & 335,126 & 545,784 & 255,362 & $\because$ & $=$ & - & 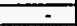 & $2,162,214$ \\
\hline & & - & - & - & - & 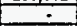 & - & - & 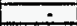 & $\div$ & 205,267 \\
\hline & & - & . & $\because$ & - & $\because$ & $\because$ & $=$ & $\div$ & $\because$ & 123,652 \\
\hline & & 20,937 & 6,000 & $\div$ & $=$ & $=$ & 20,000 & 41,000 & 45,000 & 15,400 & 173,508 \\
\hline & & 8,000 & 10,000 & 10,000 & 10,000 & 10,000 & 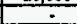 & - & - & 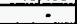 & $179 ; 058$ \\
\hline & & 31,200 & - & - & - & 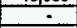 & $\therefore$ & $=$ & - & - & 170,152 \\
\hline & & & & & & & & & & & \\
\hline & & & & & & & & & & & \\
\hline$x_{3}$ & & 36 & 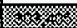 & 案樂公经 & 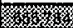 & (x) & 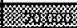 & 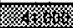 & 83 & 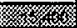 & 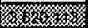 \\
\hline
\end{tabular}

'Budgeted Cost of Work Scheduled (BCWS) Equals Performance Measurement Baselline (PMB); Expense Carryover is NOT Included. 
FACILITY STABILIZATION

SUMMARY OF LIFE CYCLE BUDGET AUTHORITY (BIA) BY YEAR BY

BY PROJECT BASELINE SUMMARY (PBS)

FY 1998

(\$000s)

\begin{tabular}{|c|c|c|c|c|c|c|c|c|c|c|c|c|}
\hline \multicolumn{2}{|l|}{ PROJECT WBS : } & 1.4 & & & & & & & & & & \multirow{3}{*}{$\begin{array}{l}\text { suetor } \\
\text { FY1997- } \\
\text { FY2006 }\end{array}$} \\
\hline & & & & & & & & & & & & \\
\hline PBS TITLE & PBS NO & FY1997 & $8 \%$ & FY1999 & FY2000 & FY2001 & FY2002 & FY2003 & FY2004 & FY2005 & FY2006 & \\
\hline B Plant Sub-Project & RL-TP01 & 24,072 & 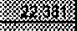 & 4,909 & - & $\div$ & $\therefore$ & - & - & - & $\bullet$ & 51,362 \\
\hline WESF Sub-Profect & RL-TPO2 & 13,619 & 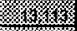 & 10,747 & 11,857 & 11,821 & 11,643 & 11,534 & 11,713 & 11,870 & 11,808 & 119,725 \\
\hline 300 ArearSNM Sub-Project & RL-TPOA & 4,305 & 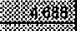 & 4,894 & 8,935 & $\therefore$ & $\cdot$ & $\therefore$ & $\therefore$ & $\therefore$ & - & 22,822 \\
\hline PFP Deacthation & RL-TP05 & $\dot{-}$ & 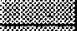 & $\therefore$ & 5,494 & 16,344 & 21,778 & 28,258 & 27,279 & 15,950 & 3,320 & 118,423 \\
\hline PFP Stabilization & RL-JP06 & $\cdot$ & 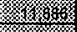 & 30,060 & 18,889 & 13,324 & 8,081 & $=$ & $=$ & $=$ & $\therefore$ & 82,240 \\
\hline PFP Vault Management & RL-TP07 & 87,180 & 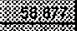 & 62,687 & 75,140 & 70,120 & 67,088 & 61,532 & 62,406 & 63,535 & 27,329 & 635,874 \\
\hline 324/327 Facility Transition & RL-TP08 & 23,661 & 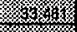 & 31,042 & 38,661 & 30,329 & 23,021 & 14,132 & 10,188 & 752 & $\cdot$ & 205,267 \\
\hline K Basin Deactivation & RL-TP09 & 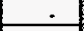 & \% & - & 1,196 & 3,284 & 25,189 & 35,341 & 32,895 & 24,589 & 1,158 & 123,652 \\
\hline Accelerated Deactivation & RL-TP10 & $\cdot$ & 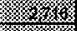 & 1,445 & 3,583 & 2,666 & 2,503 & 3,345 & 3,164 & 2,971 & 2,778 & 25,171 \\
\hline Transition Project Management & RL-TP12 & 10,494 & 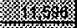 & 12,026 & 11,415 & 13,564 & 13,900 & 14,248 & 15,108 & 15,478 & 13,229 & 131,058 \\
\hline Hanford Surplus Faclity Progrem 300 Are & RL-TP14 & + & 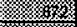 & 759 & 5,472 & 14,187 & 10,635 & 9,251 & 34,274 & 27,686 & 35,816 & 138,952 \\
\hline & & & & & & & & & & & & $=$ \\
\hline & & & & & & & & & & & & - \\
\hline 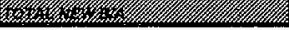 & & 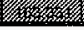 & 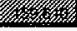 & 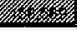 & 26 & 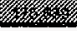 & 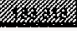 & 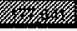 & 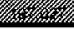 & 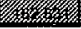 & 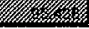 & 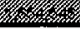 \\
\hline
\end{tabular}


SUMMARY OF LIFE CYCLE BUDGET AUTHORITY (BIA) BY YEAR BY BY PROJECT BASELINE SUMMARY (PBS)

FY 1998

\section{(\$000s)}

\begin{tabular}{|c|c|c|c|c|c|c|c|c|c|c|c|}
\hline \multicolumn{2}{|l|}{ PRONECT WBS : } & 1.4 & & & & & & & & & \multirow{2}{*}{$\begin{array}{l}\text { TOTAL } \\
\text { FY1997. } \\
\text { FY2050 } \\
\end{array}$} \\
\hline PBS TITLE & PBS NO & \begin{tabular}{|l|} 
FY2007- \\
FY2010 \\
\end{tabular} & $\begin{array}{l}\text { FY2011- } \\
\text { FY2016 } \\
\end{array}$ & $\begin{array}{l}\text { FY2016- } \\
\text { FY2020 } \\
\end{array}$ & $\begin{array}{l}\text { FY2021- } \\
\text { FY2025 } \\
\end{array}$ & $\begin{array}{l}F Y 2026 \\
F Y 2030\end{array}$ & $\begin{array}{l}\text { FY2031. } \\
\text { FY2035 }\end{array}$ & $\begin{array}{l}\text { FY2036 } \\
\text { FY2040 } \\
\end{array}$ & \begin{tabular}{|l|} 
FY2041- \\
FY2045 \\
\end{tabular} & $\begin{array}{l}\text { FY2046 } \\
\text { FY2050 } \\
\end{array}$ & \\
\hline B Plant Sub-Project & RL-TP01 & - & + & $\cdot$ & $=$ & - & - & $=$ & 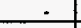 & - & \\
\hline WESF Sub-Project & RL.TP02 & 58,650 & 82,738 & 60,552 & - & $\therefore$ & $\therefore$ & - & $\therefore$ & - & 321,665 \\
\hline 300 Area/SNM Sub-Project & RL-TP04 & - & 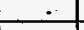 & - & $\cdot$ & - & $=$ & - & - & $\approx$ & 22,822 \\
\hline PFP Deactivation & RL-TP05 & $=$ & 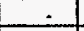 & $\therefore$ & $=$ & - & $\therefore$ & $=$ & - & $\therefore$ & 118,423 \\
\hline PFP Stabilization & RL-TF06 & $\div$ & - & $\therefore$ & $\cdot$ & 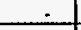 & - & $\div$ & - & - & 82,240 \\
\hline PFP Vault Management & RL-TP07 & 185,282 & 204,667 & 335,126 & 545,784 & 255,362 & - & $\therefore$ & $\dot{-}$ & - & $2,162,095$ \\
\hline $324 / 327$ Faclity Transition & RL-TP08 & $\therefore$ & - & - & $\therefore$ & $\therefore$ & 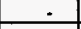 & 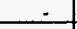 & $\stackrel{-}{-}$ & - & 205,267 \\
\hline K Basin Deactivation & RL.TP09 & - & - & - & - &. & $\therefore$ & - & $\cdot$ & 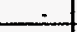 & 123,652 \\
\hline Accelerated Deactivation & $R L \cdot \pi P 10$ & 20,937 & 6,000 & $\dot{-}$ & $\therefore$ & - & 20,000 & 41,000 & 45,000 & 15,400 & 173,508 \\
\hline Transitton Project Management & RL-TP12 & 8,000 & 10,000 & 10,000 & 10,000 & 10,000 & 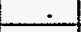 & 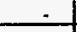 & $\div$ & $\therefore$ & 179,058 \\
\hline Hantord Surplus Faeility Program 300 Are & RL-IPI4 & 31,200 & ت & - & - & 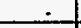 & $=$ & - & - & $\stackrel{-}{-}$ & 170,152 \\
\hline & & & & & & & & & & & $\therefore$ \\
\hline & & & & & & & & & & & $\therefore$ \\
\hline 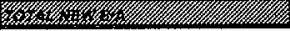 & & 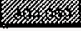 & 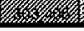 & 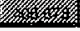 & 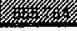 & 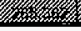 & 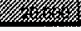 & 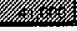 & 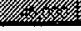 & 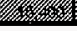 & 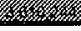 \\
\hline
\end{tabular}




\begin{tabular}{|c|c|c|c|c|c|c|c|c|c|c|c|c|c|c|c|}
\hline $\begin{array}{c}\text { PROJECT } \\
\text { WBS }\end{array}$ & PROJECT TITLE & FUND TYPE & OCT & NoV & DEC & JAN & FEB & MAR & APR & MAY & JUN & 亗 & AUO & SEP & TOTAL \\
\hline \multirow[t]{8}{*}{1.4} & \multirow[t]{8}{*}{ Facility Stabilization } & Operating Expense & 11,708 & 13,523 & 11,333 & 11,786 & 11,352 & 14,620 & 12,127 & 13,950 & 11,500 & 10,390 & 13,390 & 15,102 & 151,182 \\
\hline & & CENRTC & of & 0 & 0 & 0. & of & 0 & 0 & 0 & 0 & of & 0 & 0 & 0 \\
\hline & & GPP & of & 0 & 0 & 0 & 0 & 0 & 0 & 0 & 0 & 0 & 0 & 0 & 0 \\
\hline & & Line llem & 188 & 229 & 155 & 164 & 164 & 216 & 173 & 215 & 173 & 2,133 & 3,507 & 3,209 & 10,526 \\
\hline & & 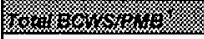 & 28 & $x$ & (x) & 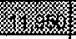 & 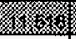 & 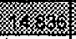 & 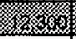 & 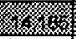 & 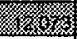 & $8 \times 2 x_{2}$ & 8 & 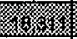 & 8 \\
\hline & & Mgmt Reserve ${ }^{2}$ & & & & & & & & & & & & & 0 \\
\hline & & Line ftem Contingency ${ }^{2}$ & & & & & & & & & & & & & $\underline{0}$ \\
\hline & & Offsite Transfers ${ }^{3}$ & & & & & & & & & & & & & 0 \\
\hline Total & & & 11,896 & 13,752 & 11,489 & 11,950 & 11,516 & 14,836 & 12,300 & 14,165 & 12,073 & 12,523 & 16,897 & 18,311 & 161,708 \\
\hline
\end{tabular}

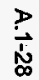

'Budgeted Cost of Work Scheduled (BCWS) Equals Pertormance Measurement Easellne (PMB); Expense Carryover Is Not Included. ${ }^{2}$ Management Reserve and Line ltem Contingenoy Held By RL. 


\begin{tabular}{|c|c|c|c|c|c|c|c|c|c|c|c|c|c|c|c|}
\hline $\begin{array}{c}\text { PROJECT } \\
\text { WES }\end{array}$ & $\begin{array}{c}\text { PROJECT } \\
\text { TITLE } \\
\end{array}$ & COST ELEMENT & OCT & Nov & DEC & JAN & FEB & MAR & APR & MAY & JUN & JUL & Avo & SEP & TOTAL \\
\hline \multirow[t]{11}{*}{1.4} & \multirow{11}{*}{ Facility stabilization } & olsalaries & 4,724 & 5,238 & 4,436 & 4,783 & 4,517 & 5,745 & 4,830 & 5,366 & 4,839 & 3,896 & 5,058 & 4,446 & 57,877 \\
\hline & & 1 Material & 494 & 572 & 466 & 428 & 384 & 679 & 593 & 678 & 580 & 489 & 672 & 583 & 6,628 \\
\hline & & 2 Purchased Serv & 750 & 791 & 772 & 712 & 682 & 936 & 674 & 771 & 773 & 689 & 723 & 885 & 9,130 \\
\hline & & 3 Other Contr Chgs & 70 & 80 & 88 & 108 & 124 & 119 & 77 & 88 & 80 & 79 & 117 & 106 & 1,133 \\
\hline & & 4 Internal Serv & 896 & 1,066 & 856 & 893 & 880 & 1,159 & 843 & 1,092 & 835 & 837 & 1,129 & 1,005 & 11,692 \\
\hline & & 5 internal Chgs & 951 & 1,218 & 1,044 & 1,088 & 1,058 & 1,333 & 1,102 & 1,223 & 1,076 & 943 & 1,267 & 1,133 & 13,436 \\
\hline & & 6LMS & 18 & 16 & 18 & 19 & 17 & 20 & 18 & 20 & 17 & 17 & 38 & 16 & 214 \\
\hline & & 7 Overheads & 2,666 & 3,118 & 2,587 & 2,693 & 2,657 & 3,301 & 2,783 & 3,205 & 2,527 & 2,882 & 3,762 & 6,354 & 38,535 \\
\hline & & 8 Revenue & 118 & 150 & 118 & 125 & 125 & 164 & 131 & 156 & 131 & 117 & 163 & 144 & 1,642 \\
\hline & & 9) Enterprise Cos & 1,265 & 1,455 & 1,131 & 1,122 & 1,074 & 1,357 & 1,170 & 1,526 & 1,136 & 2,619 & 3,848 & 3,625 & 21,421 \\
\hline & & & & & & & & & & & & & & & \\
\hline & & - & 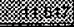 & 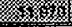 & 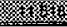 & 3 & 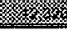 & 8 & 13 & 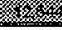 & 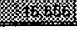 & & \\
\hline
\end{tabular}




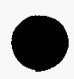

•

○ 


\section{B.1 B Plant Sub-Project (RL-TP01)}

\section{B.1.1.0 B Plant Sub-Project Technical Baseline (RL-TP01)}

\section{B.1.1.1 B Plant Sub-Project Organization Mission (RL-TP01)}

This project is to orderly transition B Plant to a deactivated facility, and place it into a configuration suitable for long term surveillance. This includes deactivation of the 800 foot long B Plant canyon building and adjoining support facilities to an environmentally secure and stable state, and turning the facility over to the ER program for final disposition at a later date.

The major project objectives are:

Maintain the B Plant facility in a safe, environmentally sound condition.

Transition B Plant and its ancillary facilities to a safe and cost-effective surveillance and maintenance configuration by the end of fiscal year (FY) 1998, and effect an orderly tumover to the Hanford Surplus Facilities Program in FY1999.

Planning Assumptions:

It is assumed that the organic solvents removed fron the B Plant canyon during FY97 can be disposed of via offsite incineration.

Removal of radioactive and hazardous liquids from B Plant tanks and vessels, similar to PUREX, is assumed and has been completed, in parallel with the development of a final management strategy and associated end points.

The need for an operating canyon ventilation system is an early assumption to support the S\&M phase of B Plant decommissioning. Retired, underground, B Plant canyon filters contain a large inventory of radioactive $\mathrm{Sr}$ and Cs. The filter design prevents total isolation of loaded filters because the retired filters and the active filter share a common inlet plenum. In addition, it is assumed that an end point will require that the outlet water seals be replaced with an alternative, more pemanent, method of isolation. An early assumption has been made to isolate the retired/old filter banks and to construct a new system under Project $W-059$. This will place the retired filters into a safe, stable shutdown condition for the S\&M phase pending their ultimate disposition.

The isolation or "decoupling" of WESF from B Plant will be needed to complete the B Plant Transition Project. B Plant currently supports the WESF mission by receiving and disposing of liquid LLW. Liquid LLW generated in WESF will be collected and disposed to tank farms or an alternate disposal site, as appropriate.

B Plant currently relies on steam to operate solution transfer jets, steam heaters for process and building heat, and steam-driven backup ventilation systems. Steam reliance shall be eliminated to reduce the costs of operating and maintaining the steam supply systems.

Routine maintenance and operations at B Plant require work in radiologically contaminated areas. Contaminated or potentially contaminated areas involve extra cost and hazard exposure to workers compared to uncontaminated areas. Cost and hazard exposure will be reduced by reducing B Plant radiological contamination areas. 


\section{B.1.1.2 B Plant Sub-Project End Point Targets from Hanford Strategic Plan}

* Transition high cost surplus facilities in the central plateau and south 600 areas to a low cost, stable, deactivated condition.

* Transition the PUREX facilly and B-Plant to low cost, stable, deactivated condition.

\section{B.1.1.3 B Plant Sub-Project Major Facilities}

\section{B.1.1.3.1 B Plant Facility}

\section{B.1.1.3.1.1 B Plant Facility Description}

B-Plant is located in the 200-E Area of Hanford. It was constructed in 1944 of reinforced concrete as a separation plant for recovering nuclear materials through a bismuth phosphate process. It was refurbished in 1961-1967 to operate as a waste fractionization plant to remove $\mathrm{Ce}, \mathrm{Pr}$, $\mathrm{Cs}$, and $\mathrm{Sr}$ from tank farm liquid waste. Its usage as a fractionization plant ended in 1985, and the plant is now being deactivated.

\section{B.1.1.3.1.2 B Plant Facility Technical Logic:}

The Department of Energy (DOE), in partnership with its contractors, shall plan, acquire, operate, maintain, and dispose of physical assets as valuable national resources. Stewardship of these physical assets shall be accomplished in a cost-effective manner to meet the DOE mission. This shall incorporate industry standards, a graded approach, and performance objectives. 
HNF-SP-1234

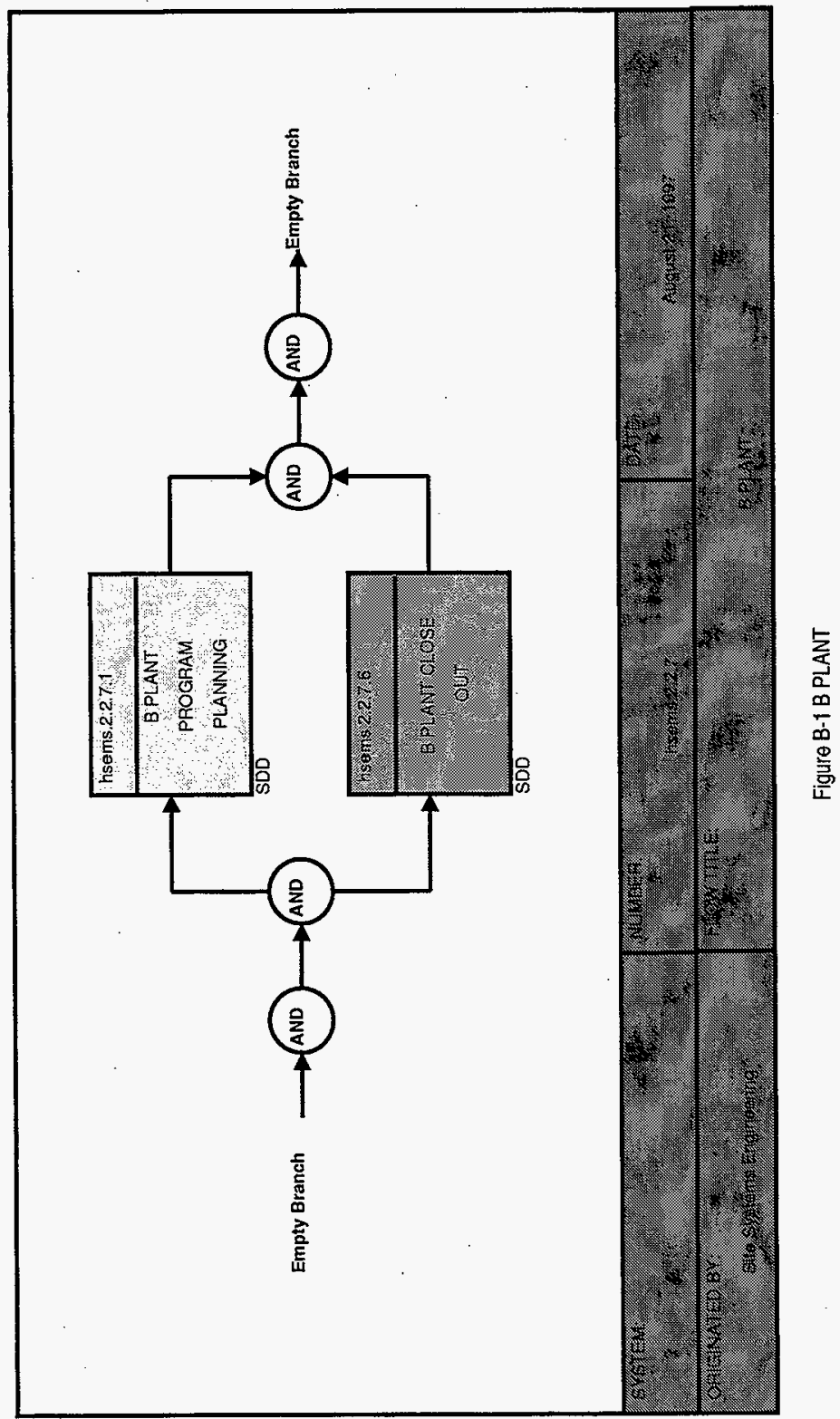




\section{B.1.1.3.1.3 B Plant Requirements and Life Cycle Function Descriptions}

Requirements:

* Facilities discharging to the 200 Area TEDF shall implement Best Available Technology (BAT)/All Known, Available, and Reasonable Treatment (AKART). The generator shall provide the information required by WAC 173-240, Submission of Plans and Reports for Construction of Waste Water Facilities.

* B Plant shall be transitioned to the surveillance and maintenance phase by October 1998

- Central Plateau inactive facilities shall be maintained within the approved safety envelope

- B Plant shall be maintained within the approved safety envelope

- Central Plateau asbestos abatement shall be performed as necessary

* Phase II liquid effluent streams shall be treated using "Best Available Technology/All Known, Available, and Reasonable Methods of Prevention, Control, and Treatment (BAT/AKART)"

\section{Life Cycle Function Descriptions:}

\section{B.1.1.3.1.3.1 B PLANT PROGRAM PLANNING WORK SCOPE SUMMARY}

Functions that include planning and developing the overall program; establishing broad priorities; providing program technical direction; preparing and defending the program budget; controlling milestones; integrating all components of the program; providing public and private sector policy liaison; expediting interface activities and follow-up actions; and retaining overall accountability for program success.

\section{B PLANT PROGRAM PLANNING SPECIFIC FUNCTIONS}

\section{B.1.1.3.1.3.2 B PLANT POST OPERATIONS WORK SCOPE SUMMARY}

Day-to-day work, including pre-stabilization surveillance and maintenance, stabilization, post-stabilization surveillance and maintenance, deactivation, and post-deactivation surveillance and maintenance, that is required to allow safe decontamination and decommissioning.

\section{B PLANT POST OPERATIONS SPECIFIC FUNCTIONS}

\section{B.1.1.3.1.3.3 Maintain Safe \& Compliant B-Plant Facility in CP Areas}

Maintain the B-Plant facility structures, operating systems and equipment, and monitoring systems within the approved safety and compliance requirements until the facilities are made available for clean-up.

\section{B.1.1.3.1.3.4 Transition B-Plant Facility}

Initiate the transition phase of decontamination and decommissioning for the B-Plant facility.

\section{B.1.1.3.1.4 B Plant Boundary Diagram}


HNF-SP-1234

Table B.1-1 B Plant Boundary Diagram

\begin{tabular}{|c|c|}
\hline $\begin{array}{l}\text { Extemal Interfaces } \\
\text { Hantord Legacy } \\
\text { Haniord Site Environmental System Interfaces } \\
\text { hsems.2.2.8 Waste Encapsulation and Storage Facility } \\
\text { hsems.2.5.3 Central Plateau Steam System . } \\
\text { hsems.2.5.4 Central Plateau Water System } \\
\text { hsems.2.5.5 Central Plateau Otice Facilities } \\
\text { hsems.2.5.6 Central Plateau Electrical System } \\
\text { hsems.2.5.9 Central Plateau Shop Facilities } \\
\text { hsems.2.5.13 Central Plateau Road System } \\
\text { hsems } 4.71331 \text { Complex }\end{array}$ & $\begin{array}{l}\text { Extemal Interiaces } \\
\text { Hazardous Waste Disposal Contracts } \\
\text { Hanford Site Environrmental System Interfaces } \\
\text { hsems.2.3.2 Double Shell Tank (DST) System } \\
\text { hsems.2.3.5 Central Waste Complex } \\
\text { hsems.2.4.3 200 Area Treated Etfluent Disposal Facility } \\
\text { hsems.2.5.1 222-S Laboratory } \\
\text { hsems.2.5.7 Central Plateau Liquid Sanitary Waste System }\end{array}$ \\
\hline
\end{tabular}




\section{B.1.1.3.1.5 B Plant Interface Description and Forecast}

\section{EXTERNAL INPUTS}

Table B.1-2 Exiernal Inputs for B Plant

\begin{tabular}{|c|c|c|c|c|}
\hline Stream & Category & Period & Baseline & Units \\
\hline \multicolumn{5}{|l|}{ X.O Hanford Legacy } \\
\hline $\begin{array}{l}\text { Legacy B Plant LLMW (Liquid) } \\
\text { LMW (Liquid) Transforred by Haniord Logacy. }\end{array}$ & LLMW (Liquid) & $1997 \cdot 1997$ & 47.0 & cubic meters \\
\hline $\begin{array}{l}\text { Legacy B Plant CH-LLMW- } \\
\text { CHLWW I Transferrod by Hanford Legacy. }\end{array}$ & CHயMWI & $1997-1997$ & 1.0 & cubic meters \\
\hline $\begin{array}{l}\text { Legacy B Plant CH-LW-1 } \\
\text { CHLW I Transierred by Han ford Legacy. }\end{array}$ & CHLWI & $1997-1997$ & 6.0 & cubic meters \\
\hline
\end{tabular}

Table B.1-3 Internal Inputs for B Plant

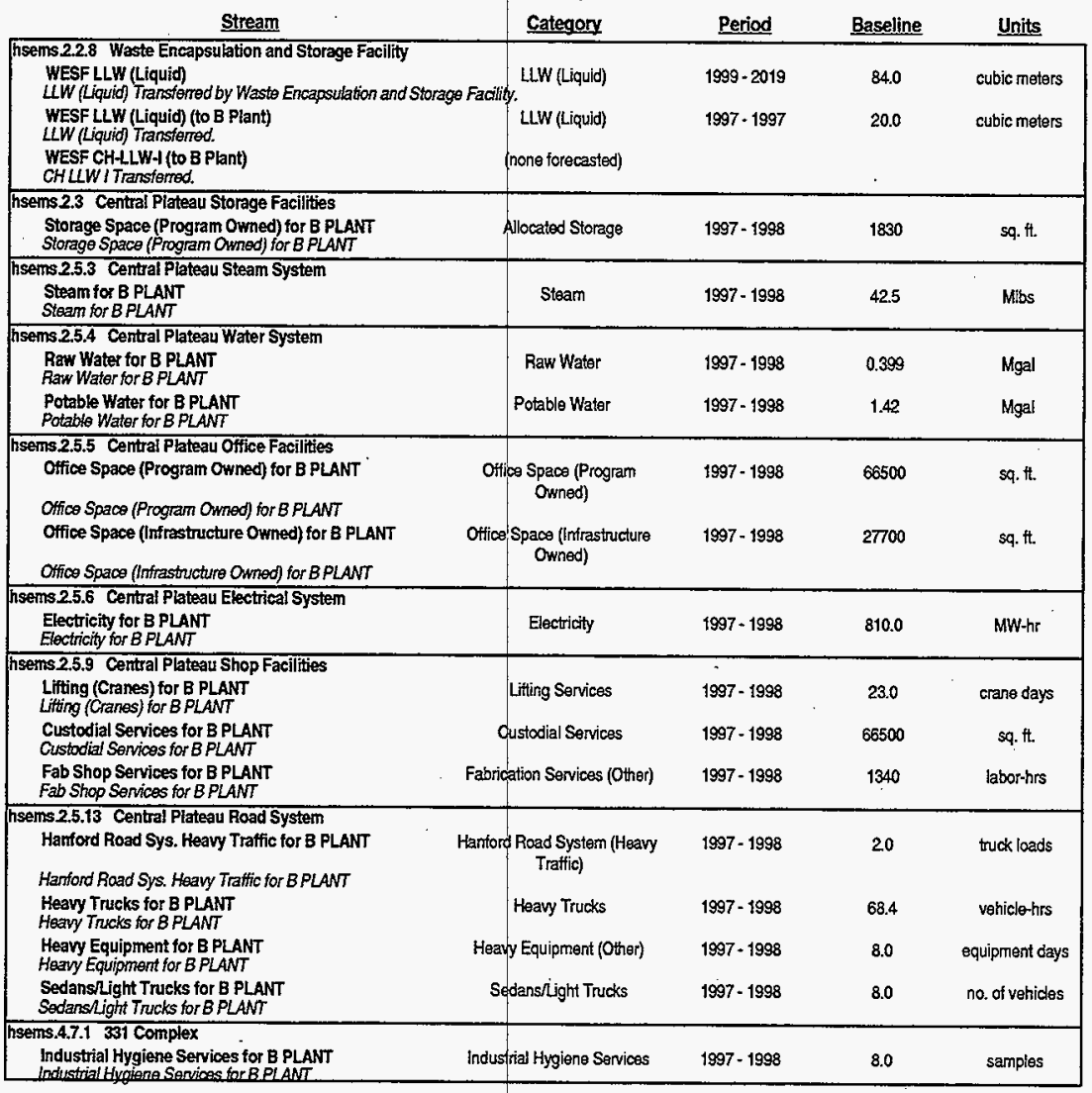


Table B.1-3 Internal Inputs for B Plant (Continued)

Stream

Category

Period

Non-rad Standards Lab

$1997-1998$

Baseline

Units

Non-rad Standards (Calibrations) for B PLANT

Services

Non-rad Standards (Calbrations) for B PLANT

\section{EXTERNAL OUTPUTS}

Table B.1-4 External Outputs for B Plant

\begin{tabular}{|lccccc|}
\multicolumn{1}{c}{ Stream } & Categony & Period & Baseline & Units \\
\hline $\begin{array}{l}\text { X Hazardous Waste Disposal Contracts } \\
\text { B Plant Asbestos } \\
\text { Asbestos Disposed by B Plant. } \\
\begin{array}{l}\text { B Plant Hazardous Waste } \\
\text { HAZ Disposed by B Plant. }\end{array}\end{array}$ & Asbestos & $1998-1998$ & 6.0 & cubic meters \\
\hline
\end{tabular}

\section{INTERNAL OUTPUTS}

Table B.1-5 Internal Outputs for B Plant

\begin{tabular}{|c|c|c|c|c|}
\hline Stream & Category & Period & Baseline & Units \\
\hline \multicolumn{5}{|l|}{ hsems.2.3.2 Double She!l Tank (DST) System } \\
\hline $\begin{array}{l}\text { BPlant-TCO (ON), HLW } \\
\text { HLW Transferred by B Plant. }\end{array}$ & HLW & $1997 \cdot 1998$ & 348.0 & cubic meters \\
\hline $\begin{array}{l}\text { BPlant-Hisc, HLW } \\
\text { HLW Transferred by B Plant }\end{array}$ & HLW & $1997-2028$ & 1130 & cubic meters \\
\hline $\begin{array}{l}\text { BPlant, LLMW (Liquid) } \\
\text { LLMW (Liquid) Disposed by B Plant }\end{array}$ & LLMW (Liquid) & $1997 \cdot 1998$ & 639.0 & cubic moters \\
\hline $\begin{array}{l}\text { BPlant, LWW (Liquid) } \\
\text { LW (Liquid) Transferred by B Piant. }\end{array}$ & LLW (Liquid) & $1997-1998$ & 40.0 & cubic metars \\
\hline \multicolumn{5}{|l|}{ hsems 2.3.5 Central Waste Complex } \\
\hline $\begin{array}{l}\text { B PLANT, CHALW-III } \\
\text { GHLWW II Trarsforted by B Plant. }\end{array}$ & CHLLWH & $1997 \cdot 1998$ & 30.0 & cubic meters \\
\hline $\begin{array}{l}\text { B PLANT, CH-LLW-1 } \\
\text { CHLLW IT Tansforrod by B Plant, }\end{array}$ & CHLLWI & $1997-1998$ & 240.0 & cubic meters \\
\hline $\begin{array}{l}\text { B PLANT, CH-LLHWW-1 } \\
\text { CHLLWW I Transferted by B Plant }\end{array}$ & CHШMW1 & $1997-1998$ & 20 & cubic meters \\
\hline $\begin{array}{l}\text { hsems.2.4.3 200 Area Treated Effluent Disposal Facility } \\
\text { B Plant Chemical Sewrer } \\
\text { Traated Liquid Effluent Transferred by B Plant. }\end{array}$ & Treated Liquid Ethuent & $1998-2019$ & 308000 & cubie meters \\
\hline \multicolumn{5}{|l|}{ hsems 2.5.1 222.5 Laboratory } \\
\hline $\begin{array}{l}\text { Analytical Laboratory Services for B PLANT } \\
\text { Anafytical Laboratory Sorvices for B PLANT }\end{array}$ & Analytical Laboratory Services & $1998-1998$ & 6.0 & samples \\
\hline \multicolumn{5}{|l|}{ hsems 2.5.7 Central Plateau Liquid Sanitary Waste System } \\
\hline $\begin{array}{l}\text { B Plant Sanitary Liquid Waste } \\
\text { Sanitary Liquid Waste Transferred by B Plant. }\end{array}$ & Sanitary Liquid Waste & $1997-1998$ & 1420 & Mgal \\
\hline
\end{tabular}




\section{B.1.1.4 Drivers for B Plant Sub-Project}

Table B.1-6 Source Documents for B Plant Sub-Project

Name

DOE/EIS-0222D

DOE/RL-89-10

DOE/RL-96-14

DOE/RL-96-92

ST 4502
Iitle

Draft Hanford Remedial Action Environmental Impact Statement and

Comprehensive Land Use Plan

Hanford Federal Facility Agreement and Consent Order (Tri-Party Agreement), Rev. 4

Updated Draft Mission Direction Document, June 1996

Hanford Strategic Plan

State Waste Discharge Permit for the 200 Area TEDF

\section{B.1.1.5 B Plant Sub-Project Risk Management}

B Plant deactivation is an ongoing project that began with a shutdown order from the Department of Energy in the Fall of 1995 and is scheduled to complete in September 1998. Following completion of deactivation, the facility will be transferred to the onsite environmental restoration contractor for long term surveillance and maintenance pending final decommissioning. Current risk sources include contamination levels as high as millions of curies of cesium and strontium contamination on process cell surfaces, contaminated equipment, and air filtration systems. These sources are protected within massive structures, with High Efficiency Particulate Air (HEPA) filters protecting from releases through the stack. Additional industrial hazards are similar to other large facilities (electrical and facility infrastructure). Activities include removal or isolation of significant hazards such as highly contaminated air filters previously used as part of the canyon and process cell exhaust system, and deactivation of most utilities and services. During the project, the driving risk scenarios are the design-basis earthquake with or without a stack collapse on the filter building, and industrial accidents. The earth quake has an anticipated frequency of 0.001 per year (once in 1000 years), while the risk of industrial accidents is similar to other large industrial operations. The radioactive release scenario results from structural failure or filter failure with subsequent failure of the filter seal, which would let radioactive particulates vent through the stack to the environment. The primary risk reduction activities are to isolate the contaminated filters and provide an alternate ventilation system, remove radioactive and hazardous liquids, deactivate equipment and systems, and stabilize other sources of contamination.

Risk management during and following deactivation requires that an understanding of the levels of risks associated with these activities. Evaluation of those risk levels is done in three categories (Public Health, Worker, and Environmental) for two time periods (deactivation and post deactivation surveillance and maintenance).

The worker risks during deactivation are considered medium and are primarily due to physical events (especially back injuries and slip-trip-fall) and industrial fire/electrical and similar events. The risks following deactivation drop to low and remain at that level until final decommissioning is started. Radiation dose risks for the worker from the design basis earthquake are calculated at $28.6 \mathrm{rem}$.

The public health and environmental risks are low due to the calculated radiation doses resulting from the earthquake being well within risk acceptance guidelines published by the Department of Energy.

Short term risks due to stopping the deactivation of B Plant prior to completion would be lower for workers since they wouldn't be exposed to the same level of industrial hazards, however longer term worker risks would increase due to restarting the project at a later time, after the experienced workers had left. Environmental and public health risks would stay the same. 


\section{B Plant Sub-Project Work Breakdown Structure}

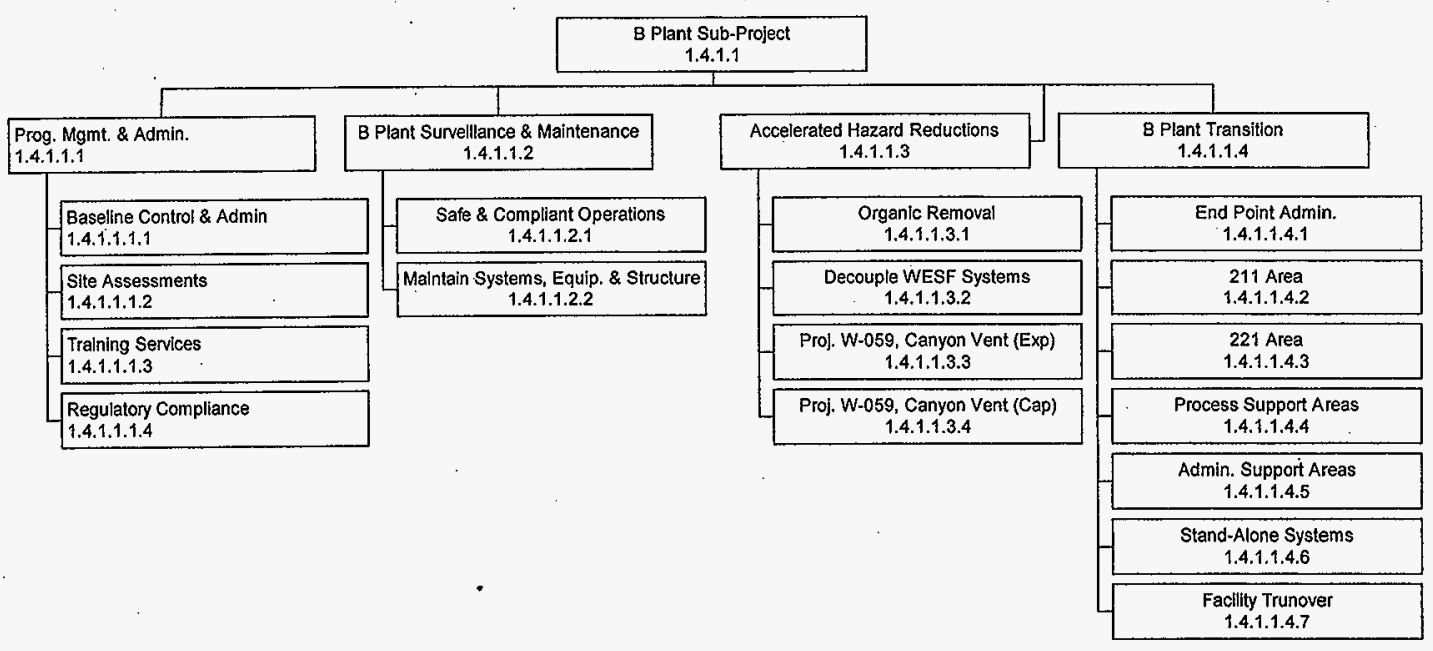


HANFORD SITE WORK BREAKDOWN STRUCTURE DICTIONARY FACILITYY STABILIZATION

WBS: 1.4

\begin{tabular}{|l|c|c|c|c|}
\hline $\begin{array}{l}\text { 1. Activity Tit]e: } \\
\text { PROGRAM MANAGEMENT AND ADMINISTRATION }\end{array}$ & $\begin{array}{l}\text { 2. Date } \\
7 / 31 / 1997\end{array}$ & $\begin{array}{l}\text { 3. PBS Number } \\
\text { RL-TPO1 }\end{array}$ & $\begin{array}{l}\text { 4. Dict Rev } \\
0\end{array}$ \\
\hline
\end{tabular}

5. Contract WBS No. 1.4.1.1.1

6. Corresponding FDS No. 7. Baseline CR No. KN1

8. Organization Name 16000

10. Scope of Work

The Program Management and Administration activity includes program management and administrative support; site assessments; training administration and in-plant training services. Program management and administrative support includes schedule development and maintenance, budget/cost development and tracking, change control support, and corrective action management support. Site assessments provides funds for utilities, rail service, and waste disposal. Training Services develops, presents, and evaluates training materials and services necessary to maintain qualified plant personnel per DOE Orders and state and federal regulations.

Ensure operations are conducted in accordance with environmental, safety, Qual ity Assurance (QA) and security requirements including RCRA, CAA, Clean Water Act (CWA), Safe Drinking Water Act (SDWA), National Environmental Policy Act (NEPA), National Historic Preservation Act (NHPA), safety, RadCon, and QA Code of Federal Regulations (CFRs), and DOE Orders; perform regulatory self-assessments; provide safety and QA support; maintain qualified compliance staff, and administer regulatory compliance officer responsibilities. 
HANFORD SITE WORK BREAKDOWN STRUCTURE DICTIONARY FACILITY STABILIZATION

WBS: 1.4

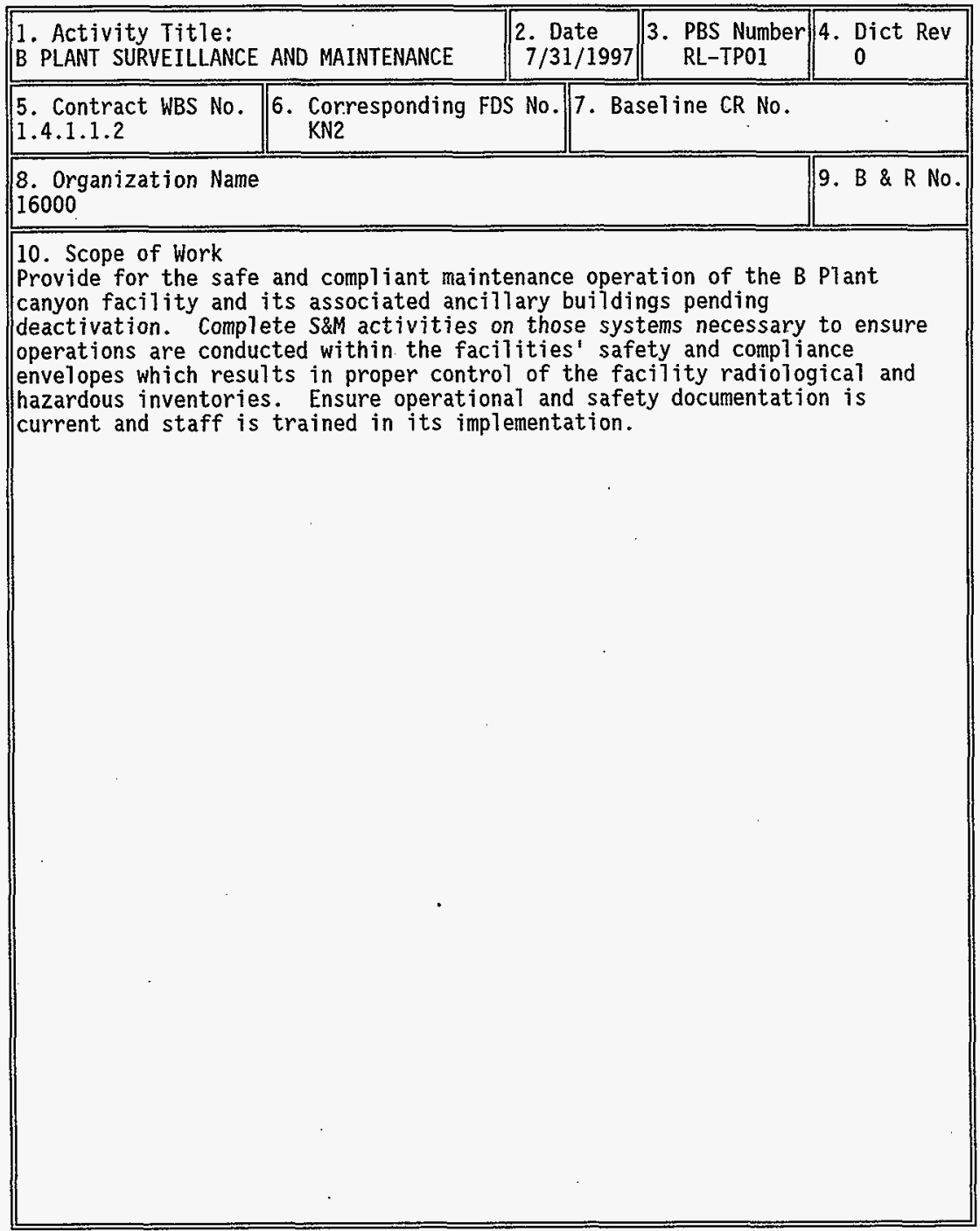


HANFORD SITE WORK BREAKDOWN STRUCTURE DICTIONARY FACILITY STABILIZATION

WBS: 1.4

\begin{tabular}{|l|c|c|c|c|}
\hline $\begin{array}{l}\text { 1. Activity Title: } \\
\text { B PLANT TRANSITION }\end{array}$ & $\begin{array}{c}\text { 2. Date } \\
7 / 31 / 1997\end{array}$ & $\begin{array}{l}\text { 3. PBS Number } \\
\text { RL-TP01 }\end{array}$ & $\begin{array}{l}\text { 4. Dict Rev } \\
0\end{array}$ \\
\hline
\end{tabular}

5. Contract WBS No. 1.4 .1 .1 .4

8. Organization Name 16000

6. Corresponding FDS No. 7. Baseline CR No. KN4

10. Scope of Work

The B Plant Transition Project scope includes deactivation of B P1ant process buildings (221-B and 212-B), ancillary support structures (271-B, 211-B, 291-B area, etc.), mobile offices, plant systems and utilities, underground filters, and waste sites associated with B Plant.

All deactivation work to be accomplished during B P1ant Transition utilizes the end point method. B Plant is applying experience from other EM-60 projects while meeting the requirements of a formal project management approach. The facility end points provide the foundation for the activities and schedules associated with the transition project, as reflected in the MYWP. Details are provided in the 'B-PIant Transition Project Management Plan', WHC-EP-0895 and in the 'B Plant End Point Document', WHC-SD-WM-TPP-054. 
HANFORD SITE WORK BREAKDOWN STRUCTURE DICTIONARY

FACILITY STABILIZATION

WBS: 1.4

\begin{tabular}{|l|l||l|l|}
\hline $\begin{array}{l}\text { 1. Activity Title: } \\
\text { ACCELERATED HAZARD REDUCTION }\end{array}$ & $\begin{array}{l}\text { 2. Date } \\
7 / 31 / 1997\end{array}$ & $\begin{array}{l}\text { 3. PBS Number } \\
\text { RL-TPO1 }\end{array}$ & $\begin{array}{l}\text { 4. Dict Rev } \\
0\end{array}$ \\
\hline $\begin{array}{l}\text { 5. Contract WBS No. } \\
\text { 1.4.1.1.3 }\end{array}$ & $\begin{array}{l}\text { 6. Corresponding FDS No. } \\
\text { KN3 }\end{array}$ & 7. Baseline CR No. \\
\hline $\begin{array}{l}\text { 8. Organization Name } \\
16000\end{array}$ & & 9. B \& R No. \\
\hline
\end{tabular}

10. Scope of Work

Reduce the hazards associated with $B$ Plant and effect an overall reduction of S\&M costs by completing the following activities:

1. Remove legacy organics from the $B$ Plant Complex.

2. Eliminate the WESF dependency on B PTant systems and utilities.

3. Isolate the previous and current onTine High-Efficiency Particulate Air (HEPA) filter banks.

4. Provide a replacement system for ventilation of the B Plant facility. 
Mission Area Responsibility Assignment Matrix

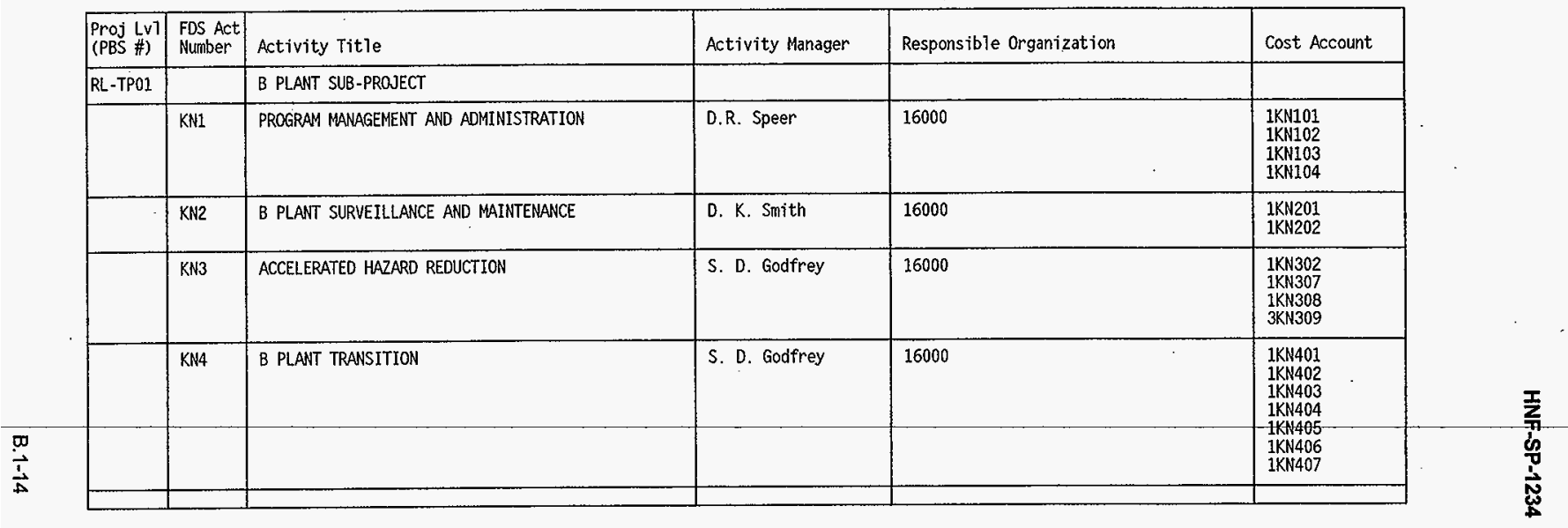




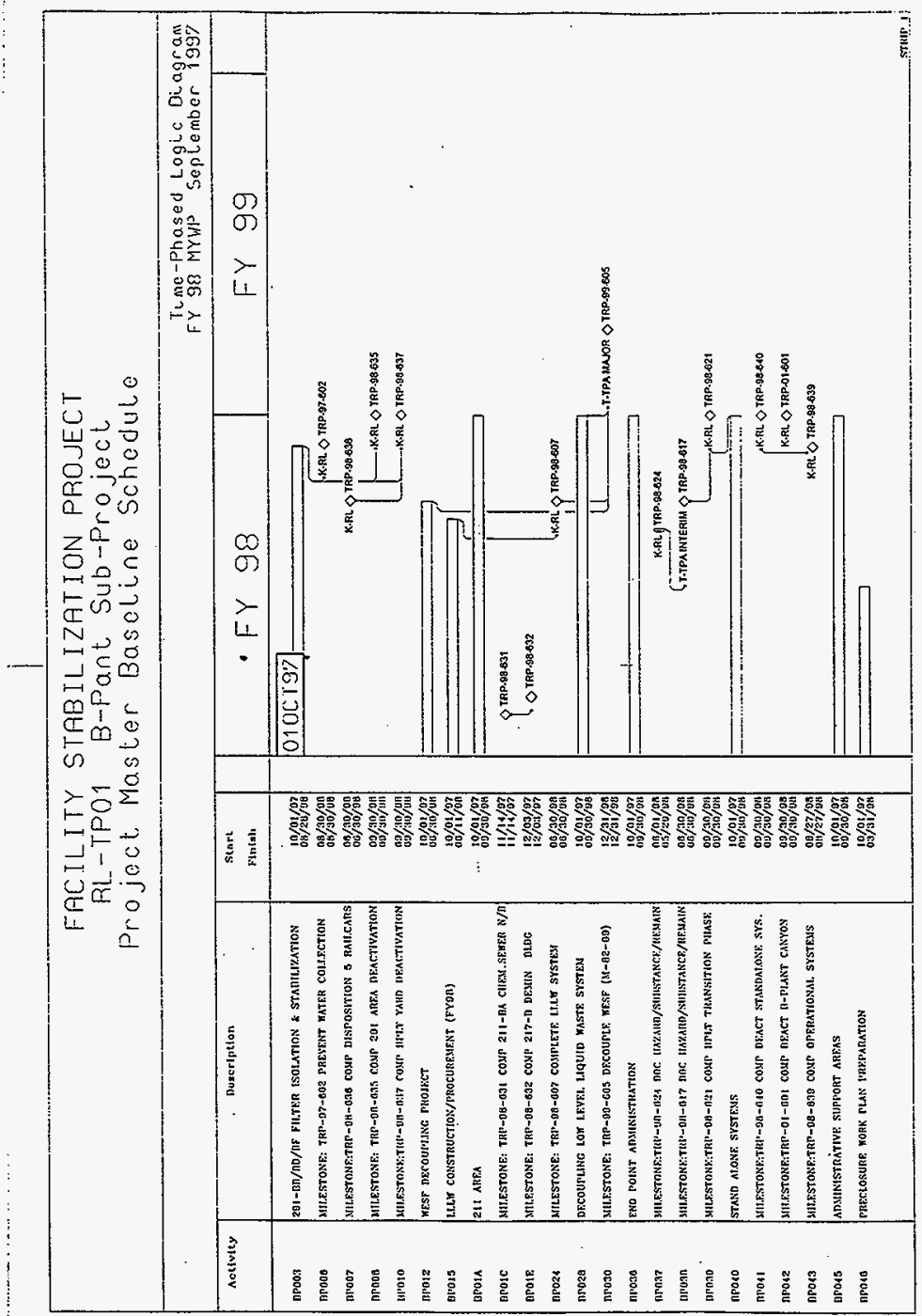




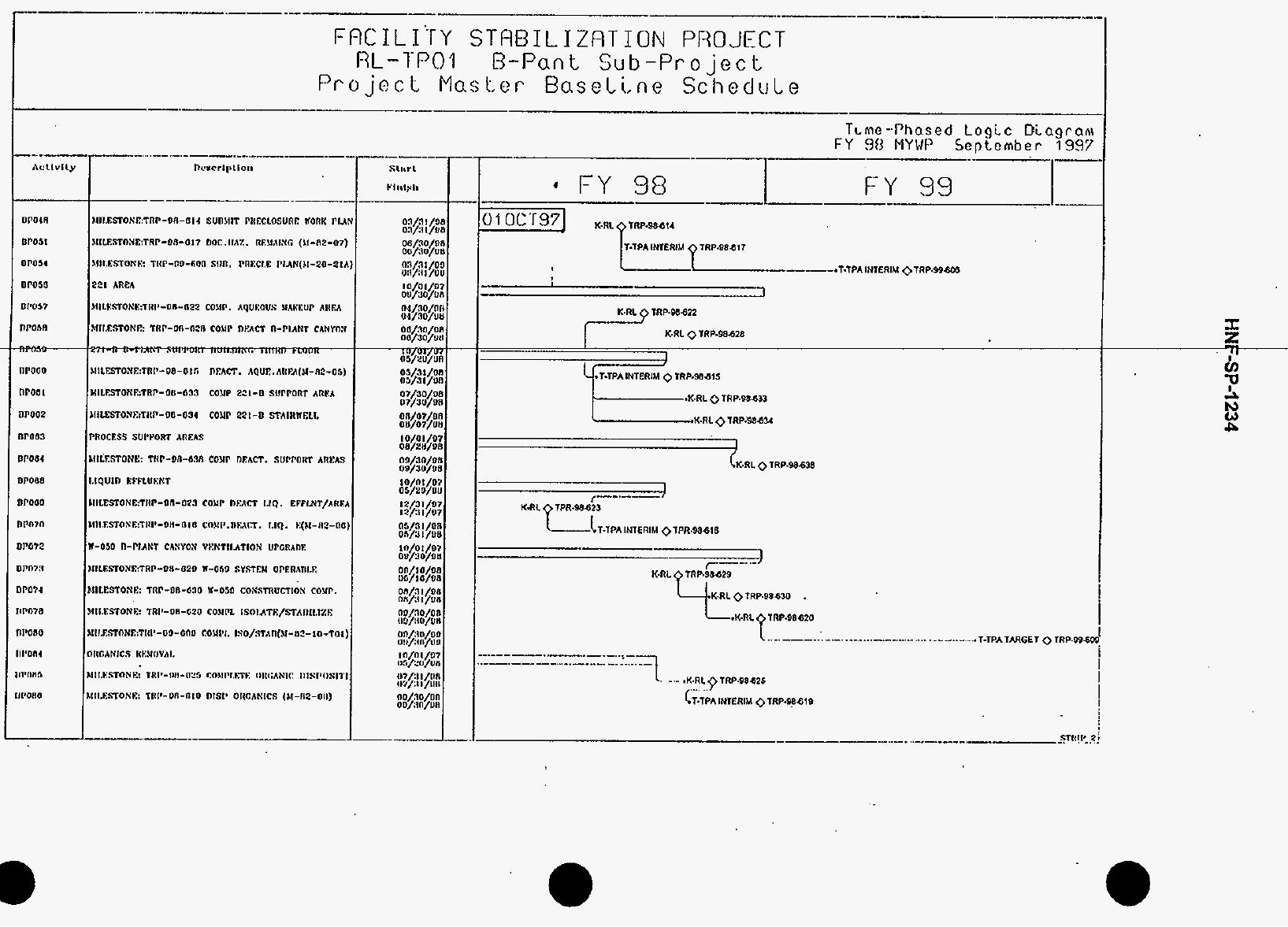




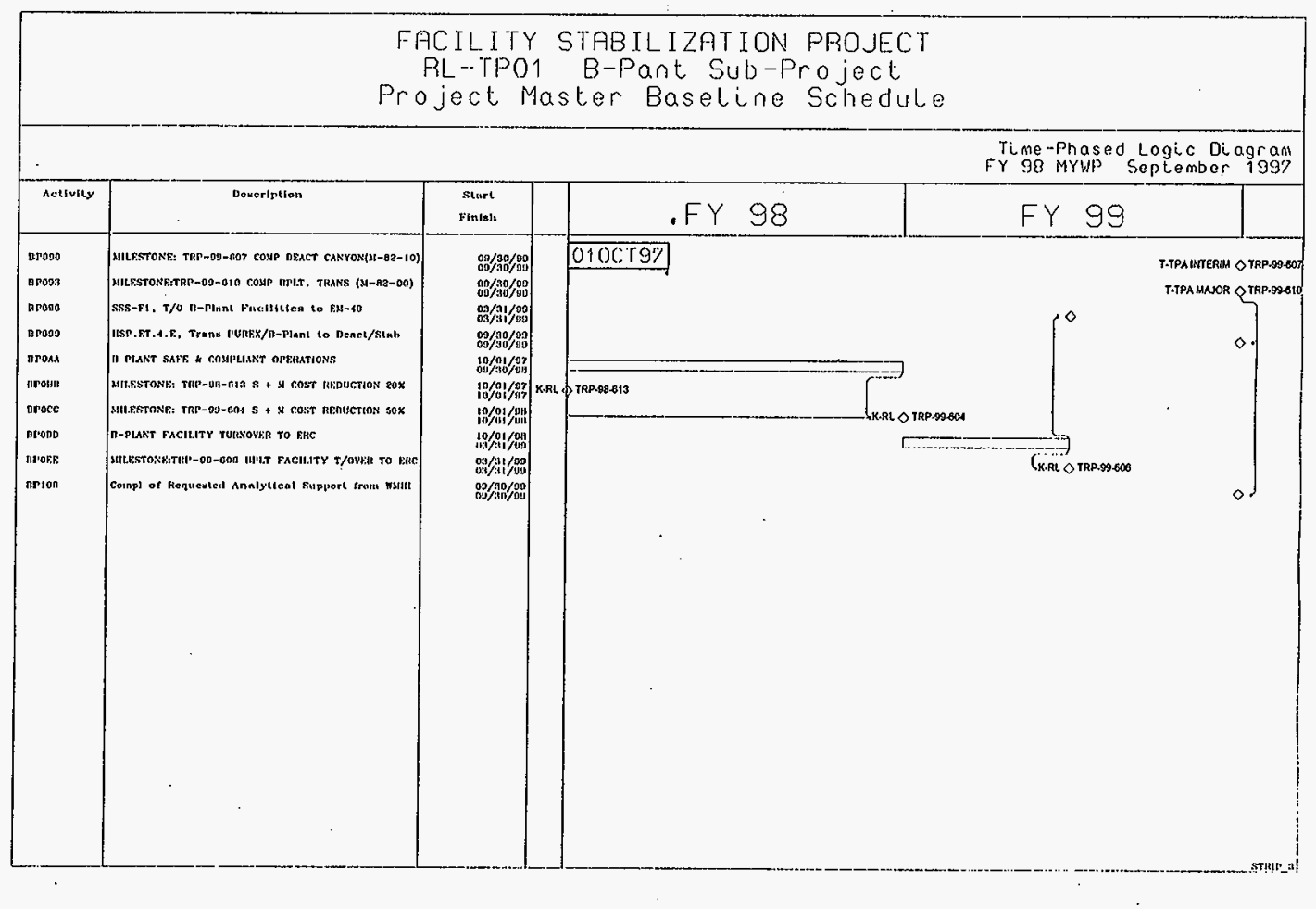




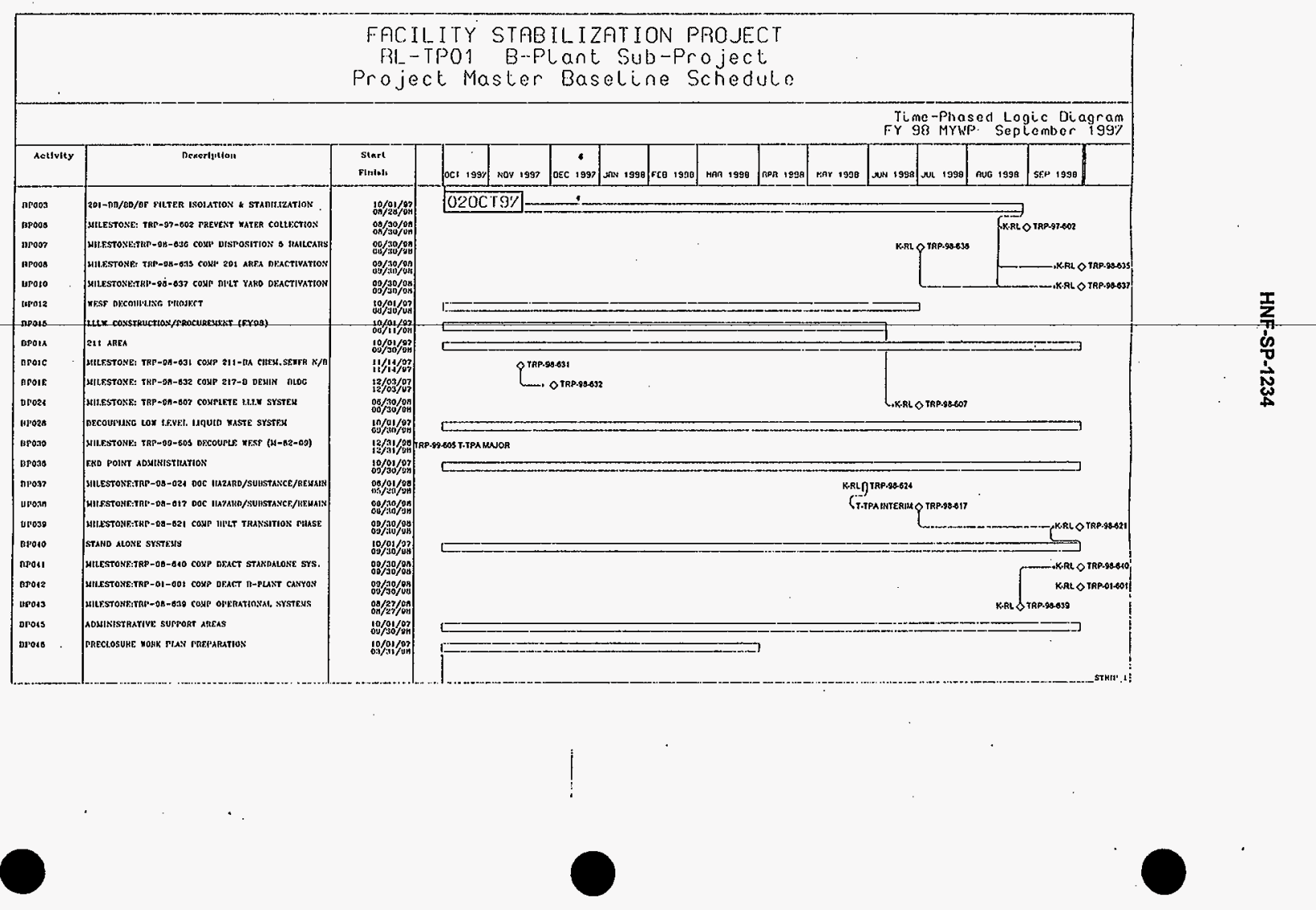




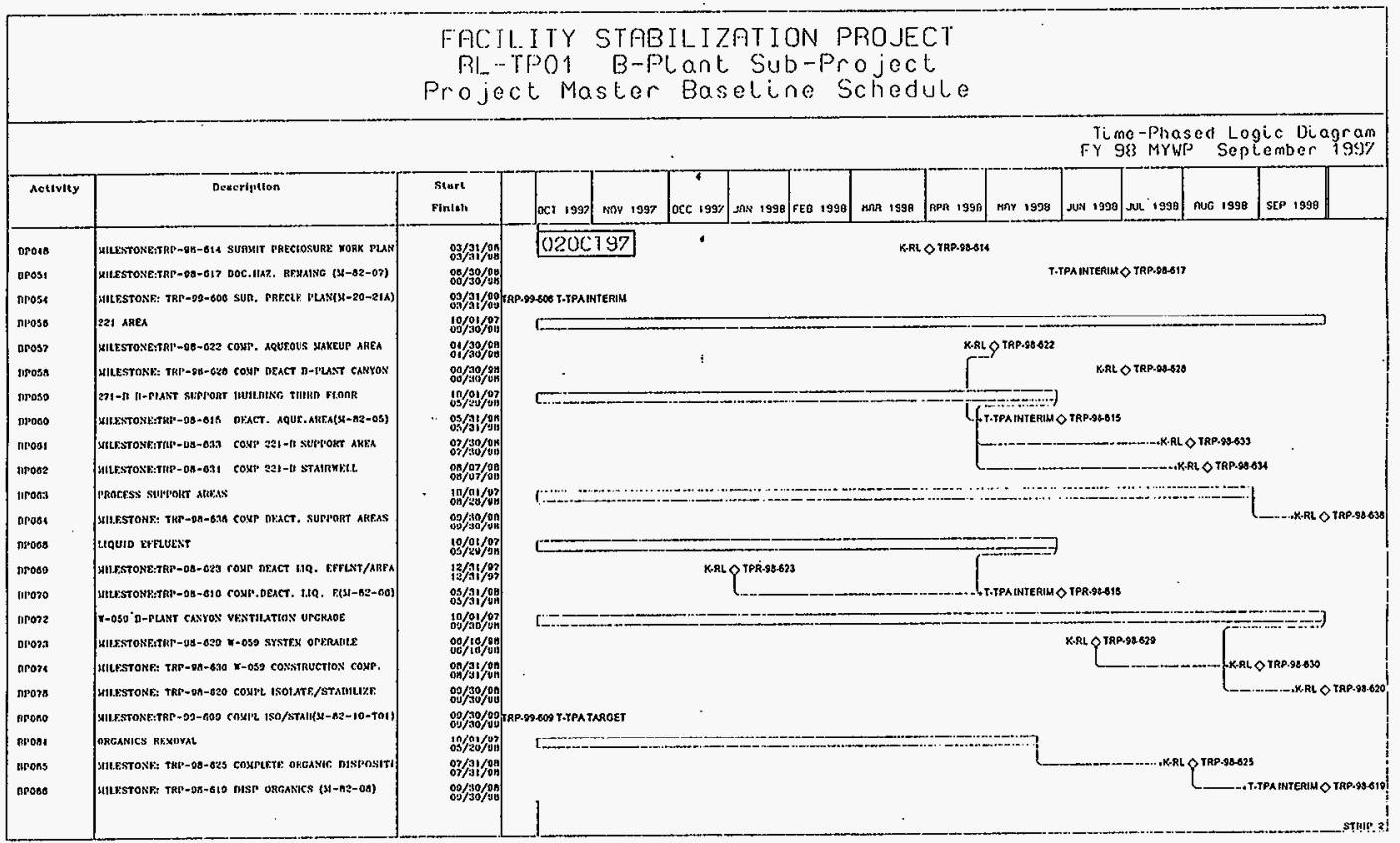




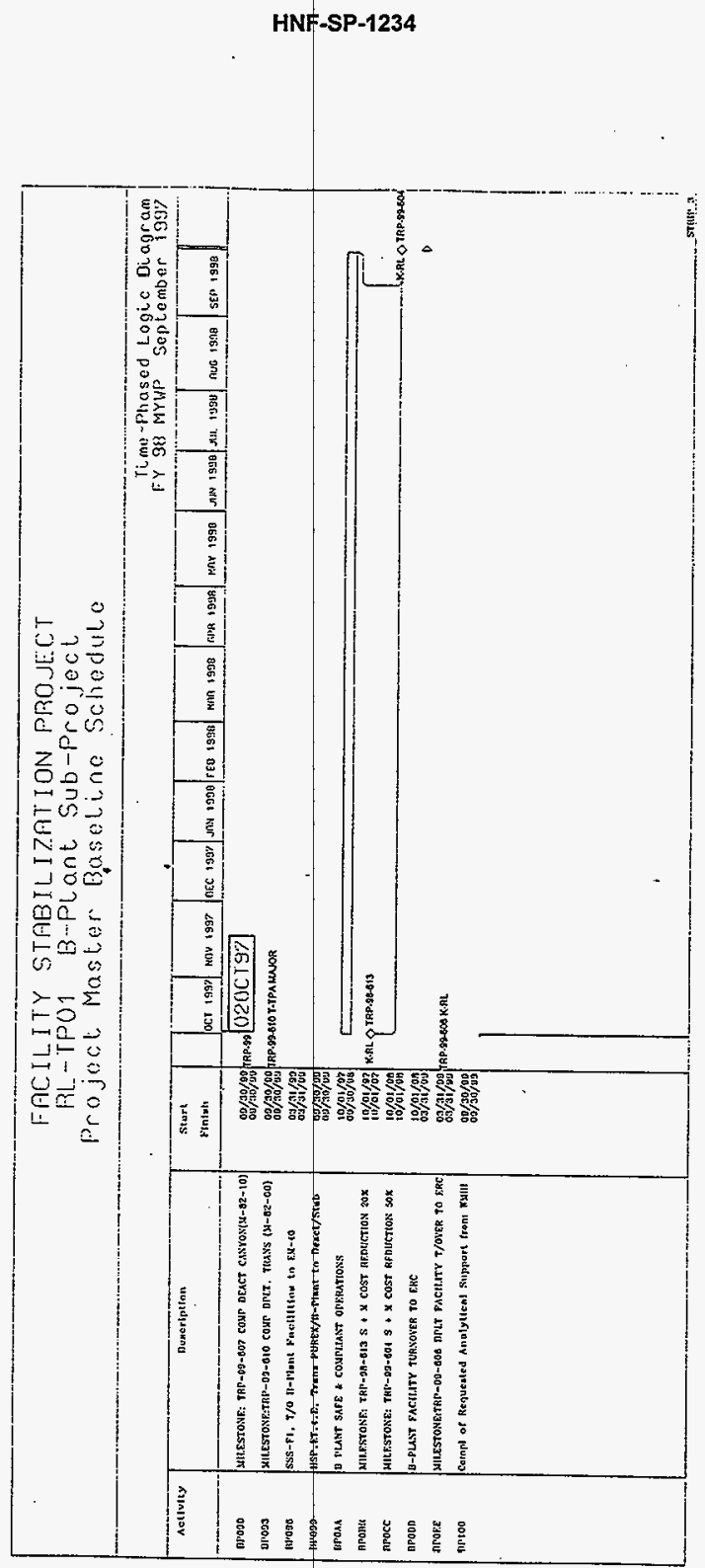

B.1-20 


\begin{tabular}{|c|c|c|c|c|c|c|c|c|c|c|}
\hline \multirow{2}{*}{ MILESTONE } & \multirow{2}{*}{ TPA-MS } & \multirow[b]{2}{*}{ TPA } & \multirow[b]{2}{*}{ MS } & & & & & & & \\
\hline & & & & & & PLANMED & APPROVED & REVISED & & \\
\hline CONTROL \# & MUMBER & TYPE & LEVEL & MS TITLE & TYPE & BASELINE & BASELINE & BASELINE & PROJ CIN & PBS \# \\
\hline (n)............. & (n)................ & $\cdots$ & $\cdots$ & (1) & $\cdots$ & (n........ & $\ldots$ & n........... & 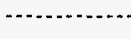 & \\
\hline TRP $-97-602$ & & & RL & PREVENT WATER COLLECTION IN B-PLANT CANYON EXHAUST FILTERS & & $8 / 30 / 98$ & & & & RL-TP01 \\
\hline TRP-98-607 & & & Fo & DECOUPLE THE WESF LOW LEVEL LIQUID WASTE SYSTEM & OTH & $6 / 30 / 98$ & $6 / 30 / 98$ & & & RL-TP01 \\
\hline TRP-98-613 & & & RL & FY97 B PLANT S\&M COSTS REDUCED BY 20\% FROM FY95 ACTUALS & & $10 / 01 / 97$ & & & & RL-TP01 \\
\hline TRP $-98=614$ & & & RL & SUBMIT A B PLANT PRECLOSURE WORK PLAN TO ECOLOGY & & $3 / 31 / 98$ & & & & RL-TP01 \\
\hline TRP-98-615 & M-82-05 & I & FO & COMPLETE DEACTIVATION OF THE B PLANT AQUEOUS MAKE-UP AREA & EA & $5 / 31 / 98$ & $5 / 31 / 98$ & & & RL-TP01 \\
\hline TRP-98-616 & $M-82-06$ & 1 & FO & COMPLETE DEACTIVATION OF THE B PLANT LIQUID EFFLUENTS AREA & EA & $5 / 31 / 98$ & $5 / 31 / 98$ & & & RL-TP01 \\
\hline TRP-98-617 & $M-82-07$ & I & FO & DOCHENT HAZARDOUS SUBST. /DANGEROUS WASTES REMAINING IN B PLANT & EA & $6 / 30 / 98$ & $6 / 30 / 98$ & & & RL-TP01 \\
\hline TRP-98-619 & $M-82-08$ & I & FO & COMPLETE DISPOSITION ORGANIC SOLVENT WASTE & EA & 9/30/98 & $9 / 30 / 98$ & & & RL-TP01 \\
\hline TRP-98-620 & & & RL & ISOLATE/STABILIZE RETRIED FILTERS \& PROVIDE CANYON VENT SYSTEM & & $9 / 30 / 98$ & & & & RL-TP01 \\
\hline TRP-98-621 & & & RL. & COMPLETE B PLANT FACILITK TRANSITION PHASE AND INITIATE S\&M PHASE & & $9 / 30 / 98$ & & & & RL-TP01 \\
\hline$T R P-98-622$ & & & RL & COMPLETE DEACTIVATION OF B-PLANT AQUEOUS MAKE-UP AREA & & $4 / 30 / 98$ & & & & RL-TP01 $\frac{1}{z}$ \\
\hline TRP-99-604 & & & RL & FY98 B PLANT S\&M COSTS REDUCED BY 50\% FROM FY95 ACTUALS & & $10 / 01 / 98$ & . & & & RL-TP01 \\
\hline TRP-99-605 & $M-82-09$ & 1 & FO & COMPLETE DECOUPLING OF HESF FROM B PLANT & EA & $12 / 31 / 98$ & $12 / 31 / 98$ & & & RL-TP01 \\
\hline TRP-99-606 & $\mathrm{M}-20-21 \mathrm{~A}$ & I & FO & SUBMIT A B PLANT PRECLOSURE WORK PLAN TO ECOLOGY & EA & $3 / 31 / 99$ & $3 / 31 / 99$ & & & RL-TP01 \\
\hline TRP-99-607 & $M-82-10$ & 1 & Fọ & COMPLETE DEACTIVATION OF THE B PLANT CANYON & EA & 9/30/99 & 9/30/99 & & & RL-TP01 Ф \\
\hline TRP-99-609 & M-82-10-T01 & $\mathrm{T}$ & RL & ISOLATE/STABTLIZE RETIRED FILTERS \& PROVIDE CANYON VENT SYSTEM & & $9 / 30 / 99$. & & & & RL-TP01 \\
\hline TRP-99-610 & $M-82-00$ & M & FO & COMPLETE B PLANT FAC. TRANSITION PHASE \& INITIATE THE S\&M PHASE & EA & 9/30/99 & $9 / 30 / 99$ & & & RL-TP01 \\
\hline TRP-01-601 & & & RL & COMPLETE DEACTIVATION OF B-PLANT CANYON & & 9/30/98 & & & & RL-TP01 \\
\hline$T R P-98-623$ & & & RL & COMPLETE DEACTIVATION OF B-PLANT LIQUID EFFLUENTS AREA & & $12 / 31 / 97$ & & & & RL-TP01 \\
\hline TRP-98-624 & & & RL & DOCUMENT HAZ. SUBSTANCES/DANGEROUS WASTES REMAINING IN B-PLANT & & $5 / 31 / 98$ & & & & RL-TP01 \\
\hline TRP-98-625 & & & RL & COMPLETE DISPOSITION OF ORGANIC SOLVENT WASTE & & $7 / 31 / 98$ & & & & RL-TP01 \\
\hline TRP-98-629 & & & RL & W-059 VENTILATION SYSTEM OPERABLE & & $6 / 16 / 98$ & & & & RL-TP01 \\
\hline $\operatorname{TRP}-98-630$ & & & RL & COMPLETE W-059 CONSTRUCTION & & $8 / 31 / 98$ & & & & RL-TP01 \\
\hline TRP-98-631 & & & RL & COMPLETE 211-BA DEACTIVATION & & $11 / 14 / 97$ & & & & RL-TP01 \\
\hline TRP-98-632 & & & RL & COMPLETE 217-B DEACTIVATION & & $12 / 03 / 97$ & & & & RL-TP01 \\
\hline TRP-98-633 & & & RL & COMPLETE 221-B SUPPORT AREA DEACTIVATION & & $7 / 30 / 98$ & & & & RL-TP01 \\
\hline TRP-98-634 & & & RL & COMPLETE 221-B STARIWELLS DEACTIVATION & & $8 / 07 / 98$ & & & & RL-TP01 \\
\hline TRP-98-635 & & & RL & COMPLETE 291 AREA DEACTIVATION & & $9 / 30 / 98$ & & & & RL-TP01 \\
\hline TRP-98-636 & & & RL & COMPLETE DISPOSITION OF FIVE (5) RAILCARS & & $6 / 30 / 98$ & & & & RL-TP01 \\
\hline TRP-98-637. & & & RL & COMPLETE B-PLANT YARD DEACTIVATION & & 9/30/98 & & & & RL-TP01 \\
\hline TRP $-98-638$ & & & RL & COMPLETE DEACTIVATION OF ADMINISTRATIVE SUPPORT AREAS & & 9/30/98 & & & & RL-TP01 \\
\hline TRP-98-639 & & & RL & COMPLETE OPERATIONAL SYSTEMS & & $8 / 27 / 98$ & & & & RL-TP01 \\
\hline TRP-98-640 & & & RL & COMPLETE DEACTIVATION OF STANDALONE SYSTEMS & & 9/30/98 & & & & RL-TP01 \\
\hline
\end{tabular}


HNF-SP-1234

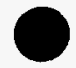

B. 1-22 


\section{PHMC \\ MILESTONE DESCRIPTION SHEET}

\begin{tabular}{|c|c|c|c|c|}
\hline \multicolumn{4}{|c|}{$\begin{array}{l}\text { Title: PREVENT WATER COLLECTION IN B-PLANT CANYON } \\
\text { EXHAUST FILTERS }\end{array}$} & Date: $1 / 29 / 96$ \\
\hline \multicolumn{4}{|c|}{ Assigned To: BWHC/B-P1ant Subproject } & CIN: \\
\hline \multicolumn{4}{|c|}{ Program WBS Designator: 1.4 .1 .1} & Due Date: $8 / 30 / 98$ \\
\hline \multicolumn{5}{|c|}{ PBS No: RL-TP01 } \\
\hline \multicolumn{2}{|c|}{ MC \#: TRP-97-602 } & & TPA No: & Rev: 2 \\
\hline $\begin{array}{l}\text { MILESTONE } \\
\text { LEVEL: }\end{array}$ & $\begin{array}{l}\text { MILESTONE } \\
\text { TYPE: }\end{array}$ & DNFSB STATUS: & DELIVERABLE: & ADDRESS TO: \\
\hline $\begin{array}{l}\text { DOE-HQ } \\
\times \text { DOE-RL } \\
\text { DOE-FO } \\
\text { CONTRACTOR }\end{array}$ & $\begin{array}{l}\text { EA } \\
\text { PEG } \\
\text { OTHER }\end{array}$ & $\begin{array}{l}\text { DNFSB }(Y / N): N \\
\text { COMMIT \#: } \\
\text { RECOMM \#: }\end{array}$ & $\begin{array}{l}\text { Report } \\
\times \text { Letter } \\
\text { Drawing(s) } \\
\text { Other (Specify) }\end{array}$ & $\begin{array}{l}X \text { DOE-RL } \\
\text { Other (Specify) }\end{array}$ \\
\hline
\end{tabular}

Milestone Description:

Provide design and construction activities needed to isolate the retired canyon exhaust filters from water intrusion.

Description of what constitutes completion of this milestone:

A11 pathways for water intrusion into the retired canyon filter banks have been sealed in accordance with accepted engineering practices. Sealing methods must have been proven in similar applications, must provide engineered barriers and must not rely upon any administrative controls for operability. Procedures which address this area of the plant have been properly revised to reflect the new conditions. 
PHMC

MILESTONE DESCRIPTION SHEET

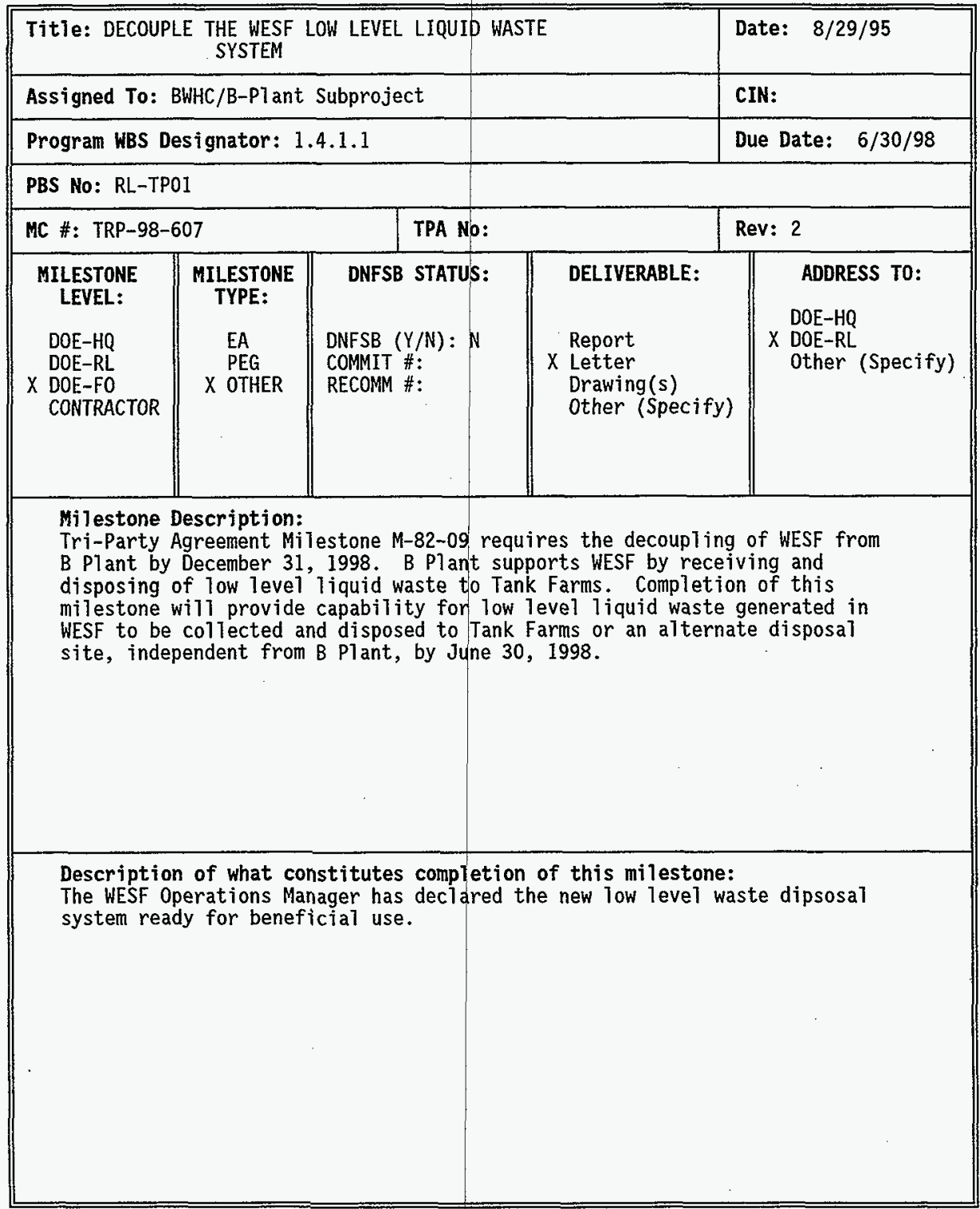




\section{PHMC \\ MILESTONE DESCRIPTION SHEET}

\begin{tabular}{|c|c|c|c|c|}
\hline \multicolumn{4}{|c|}{$\begin{array}{l}\text { Title: COMPLETE DEACTIVATION OF THE B PLANT AQUEOUS } \\
\text { MAKE-UP AREA }\end{array}$} & Date: $8 / 05 / 96$ \\
\hline \multicolumn{4}{|c|}{ Assigned To: BWHC/B-P1ant Subproject } & CIN: \\
\hline \multicolumn{4}{|c|}{ Program WBS Designator: $1: 4.1 .1$} & Due Date: $5 / 31 / 98$ \\
\hline \multicolumn{5}{|c|}{ PBS No: RL-TP01 } \\
\hline \multicolumn{2}{|c|}{ MC \#: TRP-98-615 } & \multicolumn{2}{|c|}{ TPA No: M-82-05 } & Rev: 0 \\
\hline $\begin{array}{l}\text { MILESTONE } \\
\text { LEVEL: }\end{array}$ & $\begin{array}{l}\text { MILESTONE } \\
\text { TYPE: }\end{array}$ & DNFSB STATUS: & DELIVERABLE: & ADDRESS TO: \\
\hline $\begin{array}{l}\text { DOE-HQ } \\
\text { DOE-RL } \\
\times \text { DOE-FO } \\
\text { CONTRACTOR }\end{array}$ & $\begin{array}{l}X \text { EA } \\
\text { PEG } \\
\text { OTHER }\end{array}$ & $\begin{array}{l}\text { DNFSB }(Y / N): N \\
\text { COMMIT \#: } \\
\text { RECOMM \#: }\end{array}$ & $\begin{array}{l}\text { Report } \\
\text { Letter } \\
\text { Drawing(s) } \\
\times \text { Other (Specify) } \\
\text { End Points } \\
\text { Closure }\end{array}$ & $\begin{array}{l}\text { DOE-RL } \\
X \text { Other (Specify) } \\
\text { End Points } \\
\text { Closure Files }\end{array}$ \\
\hline
\end{tabular}

Milestone Description:

Tri-Party Agreement Milestone M-82-05 requires deactivation of the $\mathrm{B} P \mathrm{P}$ ant Aqueous Makeup Area by May 31, 1998. Deactivation of the Aqueous Makeup Area includes removal of any remaining chemical inventory, flushing or emptying tanks and supply headers, isolating utilities, and decontaminating or stabilizing surfaces contaminated with hazardous materials. For the purposes of this milestone, the Aqueous Makeup Area includes the 211-BA, 271-B (first and third floors), and 221-B (a11 three galleries) facilities. Following completion of this milestone a letter will be transmitted to Ecology notifying them of its completion.

Description of what constitutes completion of this milestone: This milestone is complete when a11 end points associated with chemical storage tanks and handling systems are completed and signed off by the B P1 ant/WESF Project and Environmental Restoration Contractor representatives for 211-BA, 271-B (first and third floors) and 221-B (a11 three galleries) facilities. 


\section{PHMC}

\section{MILESTONE DESCRIPTION SHEET}

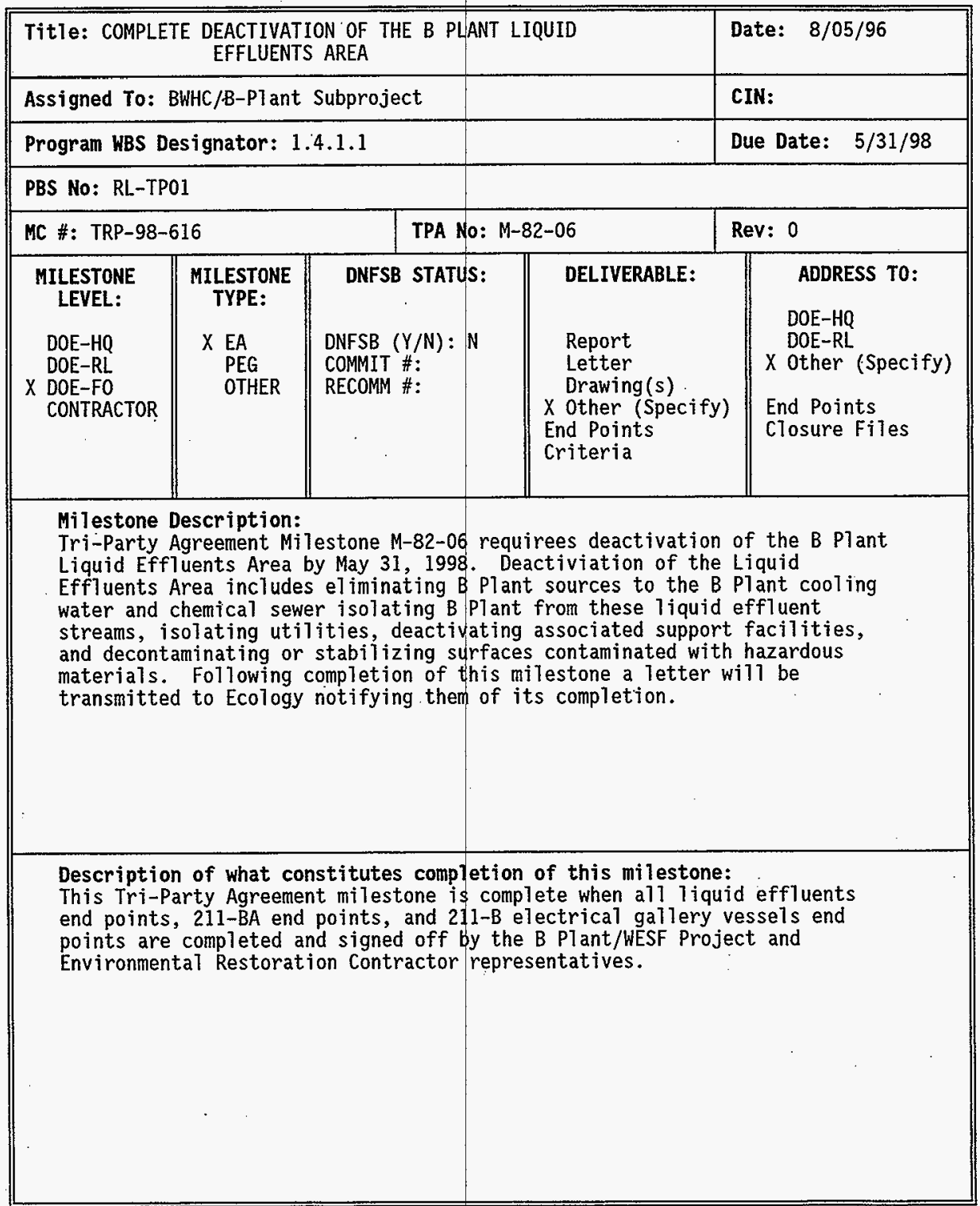




\section{PHMC \\ MILESTONE DESCRIPTION SHEET}

\begin{tabular}{|c|c|c|c|c|}
\hline \multicolumn{4}{|c|}{$\begin{array}{l}\text { Title: DOCMENT HAZARDOUS SUBST./DANGEROUS WASTES } \\
\text { REMAINING IN B PLANT }\end{array}$} & Date: $8 / 05 / 96$ \\
\hline \multicolumn{4}{|c|}{ Assigned To: BWHC/B-Plant Subproject } & CIN: \\
\hline \multicolumn{4}{|c|}{ Program WBS Designator: 1.4 .1 .1} & Due Date: $6 / 30 / 98$ \\
\hline \multicolumn{5}{|c|}{ PBS No: RL-TP01 } \\
\hline \multicolumn{2}{|c|}{ MC $\#:$ TRP-98-617 } & \multicolumn{2}{|c|}{ TPA No: M-82-07 } & Rev: 0 \\
\hline $\begin{array}{l}\text { MILESTONE } \\
\text { LEVEL: }\end{array}$ & $\begin{array}{l}\text { MILESTONE } \\
\text { TYPE: }\end{array}$ & DNFSB STATUS: & DELIVERABLE: & \multirow{2}{*}{$\begin{array}{l}\text { ADDRESS TO: } \\
\text { DOE-HQ } \\
\text { DOE-RL } \\
\text { X Other (Specify) } \\
\text { Ecology }\end{array}$} \\
\hline $\begin{array}{l}\text { DOE-HQ } \\
\text { DOE-RL } \\
\times \quad \text { DOE-FO } \\
\text { CONTRACTOR }\end{array}$ & $\begin{array}{l}X \quad \text { EA } \\
\text { PEG } \\
\text { OTHER }\end{array}$ & $\begin{array}{l}\text { DNFSB }(Y / N): N \\
\text { COMMIT \#: } \\
\text { RECOMM \#: }\end{array}$ & $\begin{array}{l}\text { Report } \\
\text { Letter } \\
\text { Drawing(s) } \\
\text { X Other (Specify) } \\
\text { Inventory Doc. } \\
\text { (S\&M PI an) }\end{array}$ & \\
\hline
\end{tabular}

Milestone Description:

Tri-Party Agreement Milestone M-82-07 requires the identification of hazardous substances/dangerous wastes remaining within B Plant by June 30 , 1998. Hazardous substances include (1) non-dangerous waste components that are highly radioactive, (2) part of the plant structure (e.g., lead shielding walls), (3) intact pieces of equipment (e.g., silver reactors, lead counterweights in jumpers, etc.), and (4) highly radioactive containerized waste stored in Cel1 4 (e.g., cesium, strontium and lead).

Description of what constitutes completion of this milestone:

This milestone is complete when documentation of hazardous substances/dangerous waste is submitted to Ecology. 


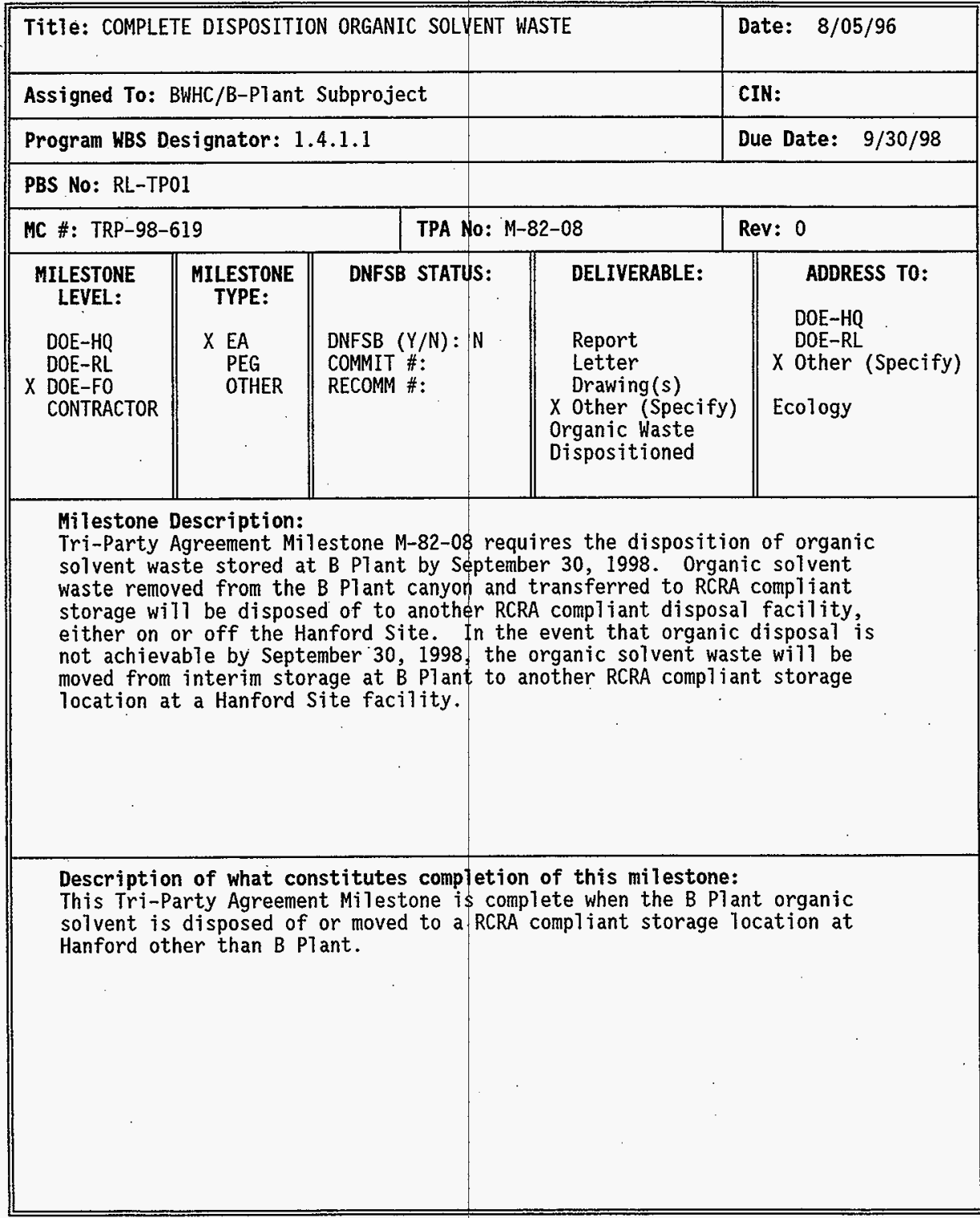




\section{PHMC \\ MILESTONE DESCRIPTION SHEET}

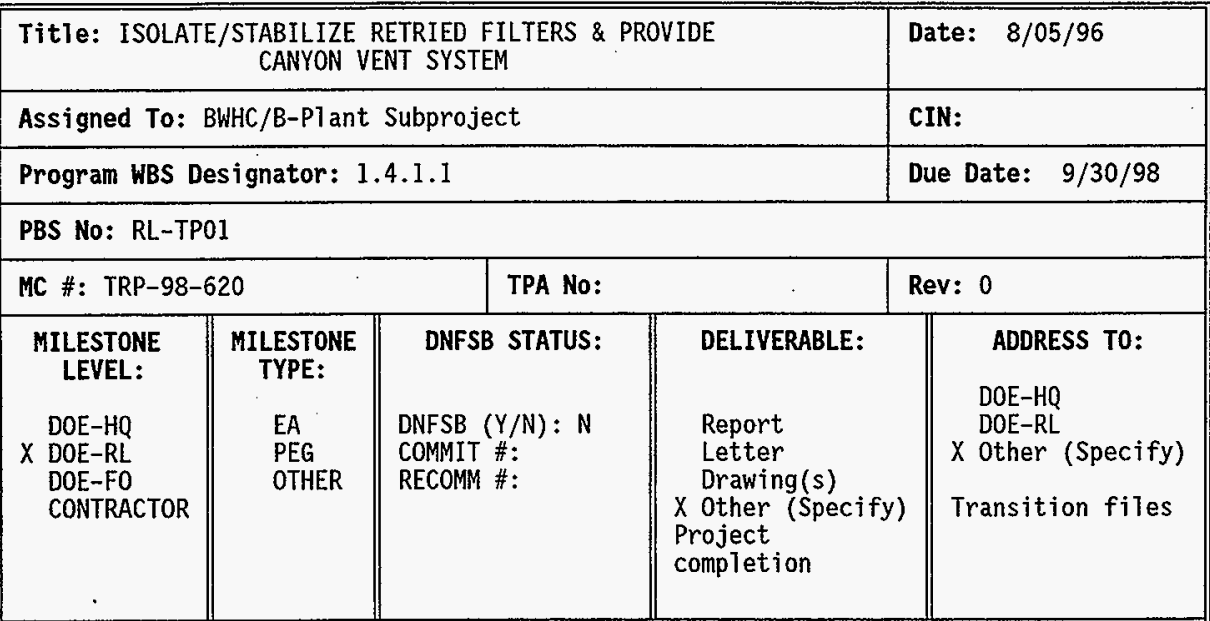

Milestone Description:

Tri-Party Agreement Milestone M-82-10-T01 requires stabilization/isolation of retired filters and provision for an operating canyon ventilation system for the S\&M phase by September 30, 1999. Retired filters (high-efficiency particulate air [HEPA] filter and sand filter) contain radionuclides inventories that must be isolated from the on-line canyon ventilation system and stabilized to ensure safe operations for the S\&M phase. Project W-059 will provide for isolation and stabilization of the retired HEPA filters and the sand filter, and will provide an active canyon ventilation system siutable for the S\&M phase.

Description of what constitutes completion of this milestone:

This RL milestone is complete when the retired B Plant filters are isolated from the on-line filters, stabilized, and an operating canyon ventilation sytem, suitable for the S\&M phase, is provided. 


\section{PHMC}

MILESTONE DESCRIPTION SHEET

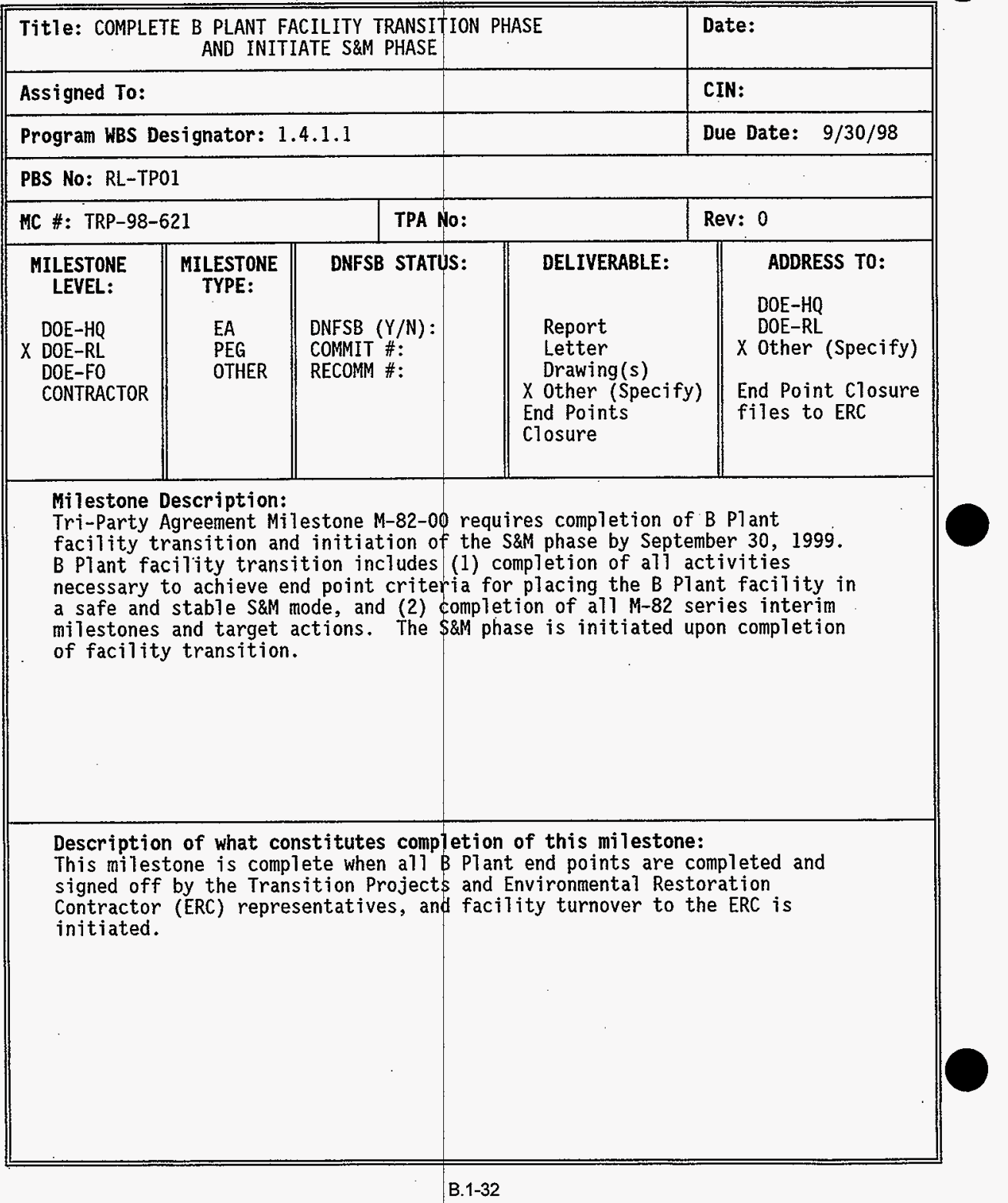




\section{PHMC}

\section{MILESTONE DESCRIPTION SHEET}

\begin{tabular}{|c|c|c|c|c|}
\hline \multicolumn{4}{|c|}{$\begin{array}{l}\text { Title: COMPLETE DEACTIVATION OF B-PLANT AQUEOUS } \\
\text { MAKE-UP AREA }\end{array}$} & Date: $8 / 14 / 97$ \\
\hline \multicolumn{4}{|c|}{ Assigned To: $B W H C / B-P 1$ ant Subproject } & CIN: \\
\hline \multicolumn{4}{|c|}{ Program WBS Designator: 1.4 .1 .1} & Due Date: $4 / 30 / 98$ \\
\hline \multicolumn{5}{|c|}{ PBS No: RL-TP01 } \\
\hline \multicolumn{3}{|c|}{ MC \#: TRP-98-622 } & TPA No: & Rev: 0 \\
\hline $\begin{array}{l}\text { MILESTONE } \\
\text { LEVEL: } \\
\text { DOE-HQ } \\
\times \text { DOE-RL } \\
\text { DOE-FO } \\
\text { CONTRACTOR }\end{array}$ & $\begin{array}{l}\text { MILESTONE } \\
\text { TYPE: } \\
\text { EA } \\
\text { PEG } \\
\text { OTHER }\end{array}$ & $\begin{array}{l}\text { DNFSB }(Y / N): N \\
\text { COMMIT \#: } \\
\text { RECOMM \#: }\end{array}$ & $\begin{array}{l}\text { DELIVERABLE: } \\
\\
\text { Report } \\
\text { Letter } \\
\text { Drawing(s) } \\
\text { X Other (Specify) } \\
\text { End Points } \\
\text { Closure }\end{array}$ & $\begin{array}{l}\text { ADDRESS TO: } \\
\text { DOE-HQ } \\
\text { DOE-RL } \\
\text { X Other (Specify) } \\
\text { End Point Closure. } \\
\text { Files }\end{array}$ \\
\hline
\end{tabular}

Milestone Description:

Tri-Party Agreement Milestone M-82-05 requires deactivation of the B Plant Aqueous Makeup Area by May 31, 1998. Deactivation of the Aqueous Makeup Area inciudes removal of any remaining chemical inventory, flushing or emptying tanks and supply headers, isolating utilities, and decontaminating or stabilizing surfaces contaminated with hazardous materials. For the purposes of this milestone, the Aqueous Makeup Area includes the chemical storage tanks and handling systems in 211-BA, 271-B (first and third floors), and 221-B (a17 three galleries) facilities. Following completion of this milestone a letter will be transmitted to Ecology notifying them of its completion.

Description of what constitutes completion of this milestone:

This milestone is complete when all end points associated with chemical storage tanks and handling sytems are completed and signed off by the $B$ Plant/WESF Project and Environmental Restoration Contractor representatives for 211-BA, 271-B (first and third floors) and 221-B (a11 three galleries) facilities. 


\section{PHMC \\ MILESTONE DESCRIPTION SHEET}

\begin{tabular}{|c|c|c|c|c|c|}
\hline \multicolumn{3}{|c|}{$\begin{array}{c}\text { Title: FY98 B PLANT S\&M COSTS REDUCED BY } \\
\text { FY95 ACTUALS }\end{array}$} & $50 \%$ & ROM & Date: $1 / 29 / 96$ \\
\hline \multicolumn{3}{|c|}{ Assigned To: BWHC/B-Plant Subproject } & & & CIN: \\
\hline \multicolumn{3}{|c|}{ Program WBS Designator: 1.4.1.1 } & & & Due Date: $10 / 01 / 98$ \\
\hline \multicolumn{6}{|c|}{ PBS No: RL-TP0I } \\
\hline \multicolumn{2}{|c|}{ MC \#: TRP-99-604 } & & TPA No: & & Rev: 0 \\
\hline $\begin{array}{l}\text { MILESTONE } \\
\text { LEVEL: } \\
\text { DOE-HQ } \\
\text { X DOE-RL } \\
\text { DOE-FO } \\
\text { CONTRACTOR }\end{array}$ & $\begin{array}{l}\text { MILESTONE } \\
\text { TYPE: } \\
\text { EA } \\
\text { PEG } \\
\text { OTHER }\end{array}$ & $\begin{array}{l}\text { DNFSB STATU } \\
\text { DNFSB }(Y / N): \\
\text { COMMIT \#: } \\
\text { RECOMM \#: }\end{array}$ & IS: & $\begin{array}{l}\text { DELIVERABLE: } \\
\\
\text { Report } \\
\times \text { Letter } \\
\text { Drawing(s) } \\
\text { Other (Specify) }\end{array}$ & $\begin{array}{l}\text { ADDRESS TO: } \\
\text { DOE-HQ } \\
\times \text { DOE-RL } \\
\text { Other (Specify) }\end{array}$ \\
\hline \multicolumn{6}{|c|}{$\begin{array}{l}\text { Milestone Description: } \\
\text { The overal1 FY } 1998 \mathrm{~B} \text { PIant operations, S\&M costs will be reduced by } 50 \% \text { as } \\
\text { a result of completion of accelerated hazard reduction activities, B P1ant } \\
\text { Transition activities, and other initiatives. }\end{array}$} \\
\hline \multicolumn{6}{|c|}{$\begin{array}{l}\text { Description of what constitutes completion of this milestone: } \\
\text { The annual costs to operate, maintain, and surveil B Plant have been } \\
\text { reduced by } 50 \% \text { when compared to the FY } 1995 \text { actual costs of } \$ 17,963 \mathrm{~K} \text {. }\end{array}$} \\
\hline
\end{tabular}




\section{PHMC \\ MILESTONE DESCRIPTION SHEET}

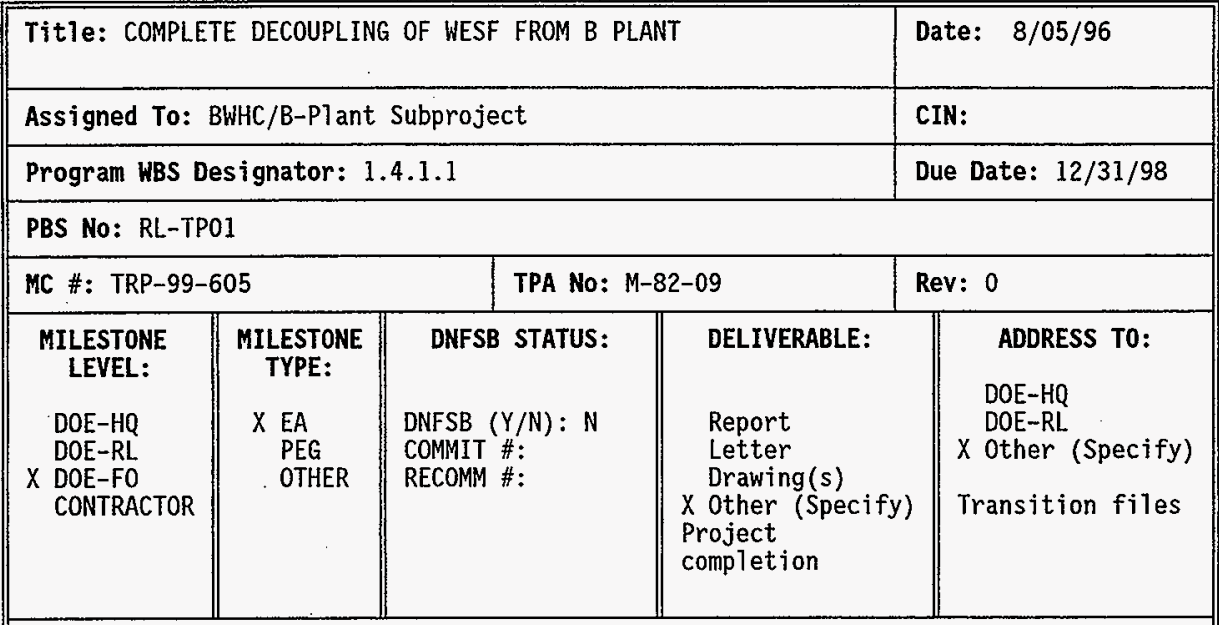

Milestone Description:

Tri-Party Agreement Milestone M-82-09 requires the decoupling of WESF from B Plant by December 31, 1998. B Plant currently supports the WESF mission by supplying deionized water, receiving and disposing of low level liquid waste, receiving solid waste, and receiving and monitoring effluent streams. The isolation of 'Decoupling' of WESF from B Plant will involve the relacement of these essential systems/services from a source other than $B$ Plant to allow standalone operation of WESF.

Description of what constitutes completion of this milestone:

This Tri-Party Agreement Milestone is complete when the essential systems/services supp Tied to WESF from B Plant are replaced and operational. Following completion of all decoupling subprojects, a completion letter will be transmitted to Ecology. 


\section{PHMC}

MILESTONE DESCRIPTION SHEET

\begin{tabular}{|c|c|c|c|c|}
\hline \multicolumn{4}{|c|}{$\begin{array}{l}\text { Title: SUBMIT A B PLANT PRECLOSURE WORK PLAN TO } \\
\text { ECOLOGY }\end{array}$} & Date: $8 / 05 / 96$ \\
\hline \multicolumn{4}{|c|}{ Assigned To: BWHC/B-P1ant Subproject } & CIN: \\
\hline \multicolumn{3}{|c|}{ Program WBS Designator: 1.4 .1 .1} & & Due Date: $3 / 31 / 99$ \\
\hline \multicolumn{5}{|c|}{ PBS No: RL-TPO1 } \\
\hline \multicolumn{3}{|c|}{ NC \#: TRP-99-606 } & TPA No: M-20-21A & Rev: 0 \\
\hline $\begin{array}{l}\text { MILESTONE } \\
\text { LEVEL: } \\
\text { DOE-HQ } \\
\text { DOE-RL } \\
\text { X DOE-FO } \\
\text { CONTRACTOR }\end{array}$ & $\begin{array}{l}\text { MILESTONE } \\
\text { TYPE: } \\
X \text { EA } \\
\text { PEG } \\
\text { OTHER }\end{array}$ & $\begin{array}{l}\text { DNFSB STATU } \\
\text { DNFSB }(Y / N): \\
\text { COMMIT \#: } \\
\text { RECOMM \#: }\end{array}$ & $\begin{array}{l}\text { DELIVERABLE: } \\
\\
\text { Report } \\
\text { Letter } \\
\text { Drawing(s) } \\
\text { x Other (Specify) } \\
\text { Preclosure Work } \\
\text { Plan }\end{array}$ & $\begin{array}{l}\text { ADDRESS TO: } \\
\text { DOE-HQ } \\
\text { DOE-RL } \\
\text { X Other (Specify) } \\
\text { Ecology }\end{array}$ \\
\hline \multicolumn{5}{|c|}{$\begin{array}{l}\text { Milestone Description: } \\
\text { Tri-Party Agreement Milestone M-20-21A requires submittat of a Preclosure } \\
\text { Work P1an to Ecology by March } 31,1999 \text {. The Preclosure Work Plan details } \\
\text { actions to be completed during the transition phase in order to facilitate } \\
\text { full RCRA closure in the future. These actions pertain to treatment, } \\
\text { storage and disposal units and hazardous substances/dangerous wastes which } \\
\text { will remain in place following transition. }\end{array}$} \\
\hline \multicolumn{5}{|c|}{$\begin{array}{l}\text { Description of what constitutes completion of this milestone: } \\
\text { This milestone is complete when Revision } 0 \text { of the B PIant Preclosure Work } \\
\text { Plan is submitted to Ecology for review and approval. }\end{array}$} \\
\hline
\end{tabular}




\section{PHMC}

MILESTONE DESCRIPTION SHEET

\begin{tabular}{|c|c|c|c|c|}
\hline \multicolumn{4}{|c|}{ Title: COMPLETE DEACTIVATION OF THE B PLANT CANYON } & Date: $8 / 05 / 96$ \\
\hline \multicolumn{4}{|c|}{ Assigned To: BWHC/B-P1ant Subproject } & CIN: \\
\hline \multicolumn{4}{|c|}{ Program WBS Designator: 1.4.1.1 } & Due Date: $9 / 30 / 99$ \\
\hline \multicolumn{5}{|c|}{ PBS No: RL-TP01 } \\
\hline \multicolumn{2}{|c|}{ MC \#: TRP-99-607 } & \multicolumn{2}{|c|}{ TPA No: $M-82-10$} & Rev: 0 \\
\hline $\begin{array}{l}\text { MILESTONE } \\
\text { LEVEL: } \\
\\
\text { DOE-HQ } \\
\text { DOE-RL } \\
\text { X DOE-FO } \\
\text { CONTRACTOR }\end{array}$ & $\begin{array}{l}\text { MILESTONE } \\
\text { TYPE: } \\
\times \text { EA } \\
\text { PEG } \\
\text { OTHER }\end{array}$ & $\begin{array}{l}\text { DNFSB STATUS: } \\
\text { DNFSB }(Y / N): N \\
\text { COMMIT \#: } \\
\text { RECOMM \#: }\end{array}$ & $\begin{array}{l}\text { DELIVERABLE: } \\
\\
\text { Report } \\
\text { Letter } \\
\text { Drawing(s) } \\
\text { X Other (Specify) } \\
\text { End Points } \\
\text { Closure }\end{array}$ & $\begin{array}{l}\text { ADDRESS TO: } \\
\text { DOE-HQ } \\
\text { DOE-RL } \\
\text { X Other (Specify) } \\
\text { End Points } \\
\text { Closure files }\end{array}$ \\
\hline \multicolumn{5}{|c|}{$\begin{array}{l}\text { Milestone Description: } \\
\text { Tri-Party Agreement Milestone. M- } 82-10 \text { requires deactivation of the B Plant } \\
\text { canyon by September } 30,1999 \text {. Deactivation of the B Plant canyon includes } \\
\text { isolating canyon piping to the external facility interfaces (e.g., Tank } \\
\text { Farms, } 216-B 3 \text { Pond, cribs, etc.), removing organic solvent waste, and } \\
\text { emptying vessels with } 7 \text { iquid above minimum heel. Liquid will be } \\
\text { appropriately disposed to Tank Farms. Sampling and analysis will be } \\
\text { performed as necessary to support disposal and to assist in developing an } \\
\text { inventory of hazardous substances/dangerous wastes to remain within the } \\
\text { facility. Flushing of vessels will not be required, but may be performed } \\
\text { at the discretion of the facility, as needed to complete disposal } \\
\text { activities. Following completion of this milestone a letter will be } \\
\text { transmitted to Ecology notifiying them of its completion. }\end{array}$} \\
\hline \multicolumn{5}{|c|}{$\begin{array}{l}\text { Description of what constitutes completion of this milestone: } \\
\text { This milestone is complete when all of the } 221-\mathrm{B} \text { canyon end points are } \\
\text { completed and signed off by the } \mathrm{B} \text { Plant/WESF Project and Environmental } \\
\text { Restoration Contractor representatives. }\end{array}$} \\
\hline
\end{tabular}




\section{PHMC \\ MILESTONE DESCRIPTION SHEET}

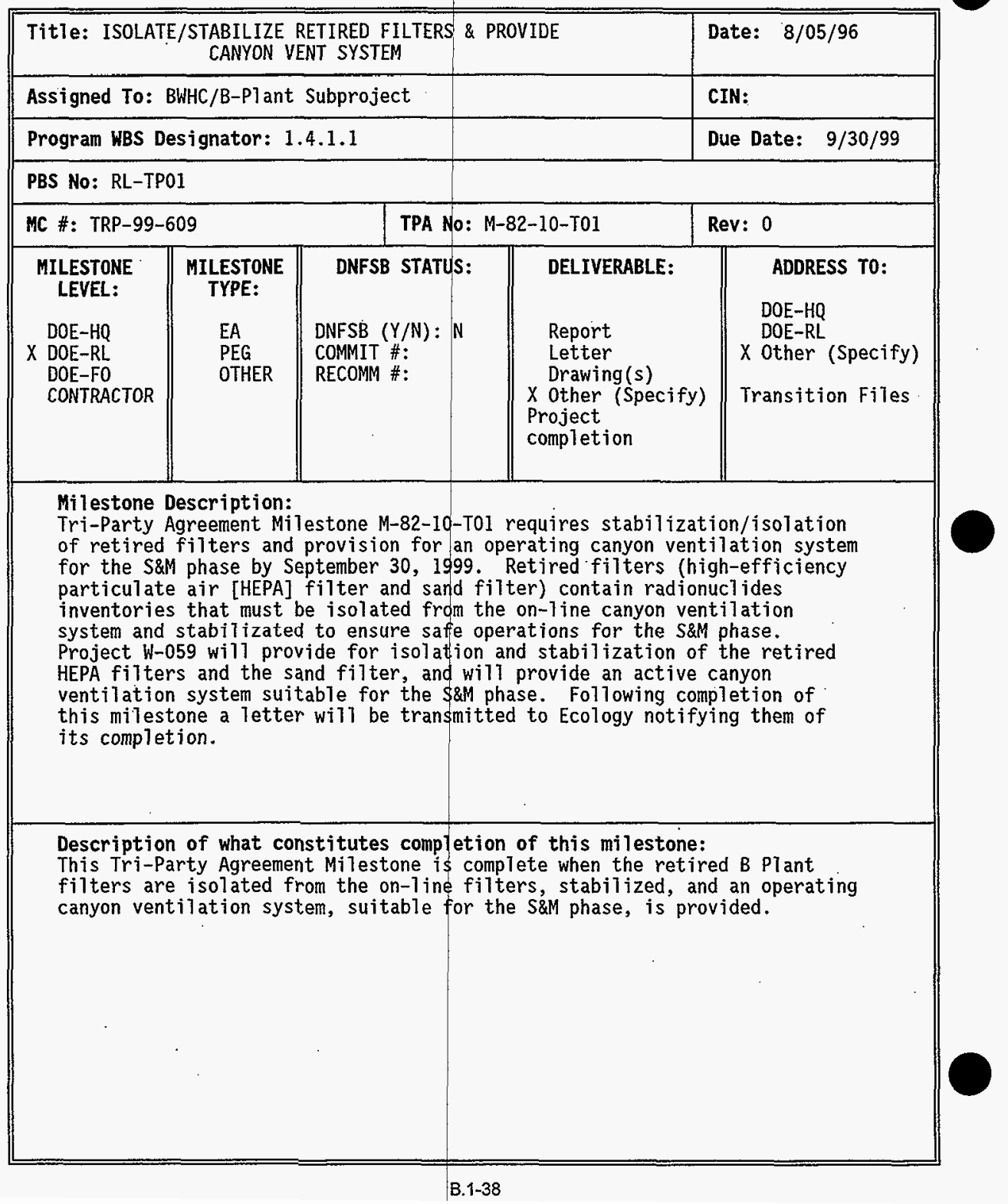




\section{PHMC}

\section{MILESTONE DESCRIPTION SHEET}

Title: COMPLETE B PLANT FAC. TRANSITION PHASE \&

INITIATE THE S\&M PHASE

Assigned To: BWHC/B-P1 ant Subproject

Program WBS Designator: 1.4:1.1

Date: $8 / 05 / 96$

CIN:

Due Date: $9 / 30 / 99$

PBS No: RL-TP01

MC \#: TRP-99-610

MILESTONE

LEVEL:

DOE-HQ

DOE-RL

$X$ DOE-FO

CONTRACTOR
TPA No: $M-82-00$

DNFSB STATUS:

MILESTONE

TYPE:

$X E A$

$P E G$

OTHER

\begin{tabular}{||l|l}
\multicolumn{1}{l|}{} & TPA No: M- \\
DNFSB STATUS: \\
DNFSB $(Y / N): N$ \\
COMMIT \#: \\
RECOMM $\#:$ \\
\\
\end{tabular}

Rev: 0

\begin{tabular}{||l||} 
\\
DELIVERABLE: \\
Report \\
Letter \\
Drawing(s) \\
X Other (Specify) \\
End Points \\
Closure
\end{tabular}

ADDRESS TO:

DOE-HQ
DOE-RL
$\times$ Other (Specify)

End Points Clos. to ERC

Milestone Description:

Tri-Party Agreement Milestone M-82-00 requires completion of B PIant facility transition and initiation of the S\&M phase by September 30, 1999. B Plant facility transition includes (1) completion of all activities necessary to achieve end point criteria for placing the B Plant facility in a safe and stable S\&M mode, and (2) completion of a11 M-82 series interim milestones and target actions. The S\&M phase is initiated upon completoin of facility transition.

Description of what constitutes completion of this milestone:

This Tri-Party Agreement Milestone is complete when all B Plant end points are completed and signed off by the B-PTant/WESF Project and Environmental Restoration Contractor representatives, and facility turnover to the Environmental Restoration Contractor is initiated. 


\section{PHMC}

MILESTONE DESCRIPTION SHEET

\begin{tabular}{|c|c|c|c|c|c|}
\hline \multicolumn{5}{|c|}{ Title: COMPLETE DEACTIVATION OF B-PLANT CANYON } & Date: $8 / 14 / 95$ \\
\hline \multicolumn{3}{|c|}{ Assigned To: BWHC/B-Plant Subproject } & & & CIN: \\
\hline \multicolumn{3}{|c|}{ Program WBS Designator: 1.4.1.1 } & & & Due Date: $9 / 30 / 98$ \\
\hline \multicolumn{6}{|c|}{ PBS No: RL-TP01 } \\
\hline \multicolumn{2}{|c|}{ MC \#: TRP-01-601 } & \multicolumn{2}{|c|}{ TPA No: } & & Rev: 0 \\
\hline $\begin{array}{l}\text { MILESTONE } \\
\text { LEVEL: } \\
\\
\text { DOE-HQ } \\
\times \text { DOE-RL } \\
\text { DOE-FO } \\
\text { CONTRACTOR }\end{array}$ & $\begin{array}{l}\text { MILESTONE } \\
\text { TYPE: } \\
\text { EA } \\
\text { PEG } \\
\text { OTHER }\end{array}$ & $\begin{array}{l}\text { DNFSB STATUS } \\
\text { DNFSB }(Y / N): \\
\text { COMMIT \#: } \\
\text { RECOMM \#: }\end{array}$ & S: & $\begin{array}{l}\text { DELIVERABLE: } \\
\text { Report } \\
\text { Letter } \\
\text { Drawing(s) } \\
\text { X Other (Specify) } \\
\text { End Points } \\
\text { Closure }\end{array}$ & $\begin{array}{l}\text { ADDRESS TO: } \\
\text { DOE-HQ } \\
\text { DOE-RL } \\
\times \text { Other (Specify) } \\
\text { End Points } \\
\text { Closure Files }\end{array}$ \\
\hline \multicolumn{6}{|c|}{$\begin{array}{l}\text { Milestone Description: } \\
\text { Tri-Party Agreement Milestone M-82-10 requires deactivation of the B Plant } \\
\text { canyon by September } 30 \text {, 1999. Deactivation of the B Plant canyon includes } \\
\text { isolating canyon piping to the external facility interfaces (e.g., Tank } \\
\text { Farms, } 216-B 3 \text { Pond, cribs, etc.), removing organic solvent waste, and } \\
\text { emptying process vessels. Vessels with liquid (other than organics) above } \\
\text { minimum heel will be emptied and the liquid will be qppropriately disposed } \\
\text { to disposal and to assist in developing an inventory of hazardous } \\
\text { substances/dangerous wastes to remain within the facility. Flushing of } \\
\text { vessels will not be required, but may be performed at the discretion of the } \\
\text { facility, as needed to complete disposal activities. }\end{array}$} \\
\hline \multicolumn{6}{|c|}{$\begin{array}{l}\text { Description of what constitutes completion of this milestone: } \\
\text { This RL milestone is complete when a11 221-B canyuon end points are } \\
\text { completed and signed off by the B P Tant/WESF Project and Environmental } \\
\text { Restoration Contractor representatives. }\end{array}$} \\
\hline
\end{tabular}




\section{PHMC \\ MILESTONE DESCRIPTION SHEET}

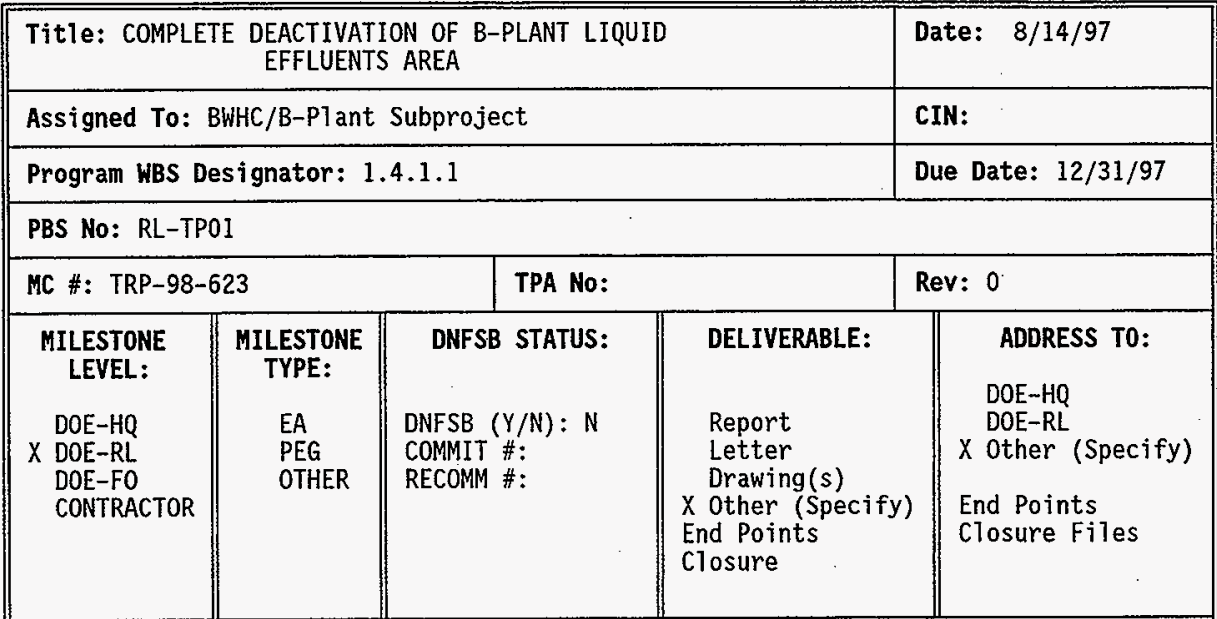

Milestone Description:

Tri-Party Agreement Milestone $M-82-06$ requires deactivation of the $B$ Plant Liquid Effluents Area by May 31, 1998. Deactivation of the Liquid Effluents Area includes eliminating B Plant sources to the B Plant cooling water and chemical sewer, isolating B Plant from these liquid effluent streams, isolating utilities, deactivating associated support facilities, and decontaminating or stabilizing surfaces contaminated with hazardous materials. Following completion of this milestone, a letter will be transmitted to Ecology notifying them of its completion.

Description of what constitutes completion of this milestone:

This milestone is complete when all liquid effluents end points, 211-BA end points, and 211-B electrical gallery vessels end points are completed and signed off by the B Plant/WESF Project and Environmental Restoration Contractor representatives. 


\section{PHMC \\ MILESTONE DESCRIPTION SHEET}

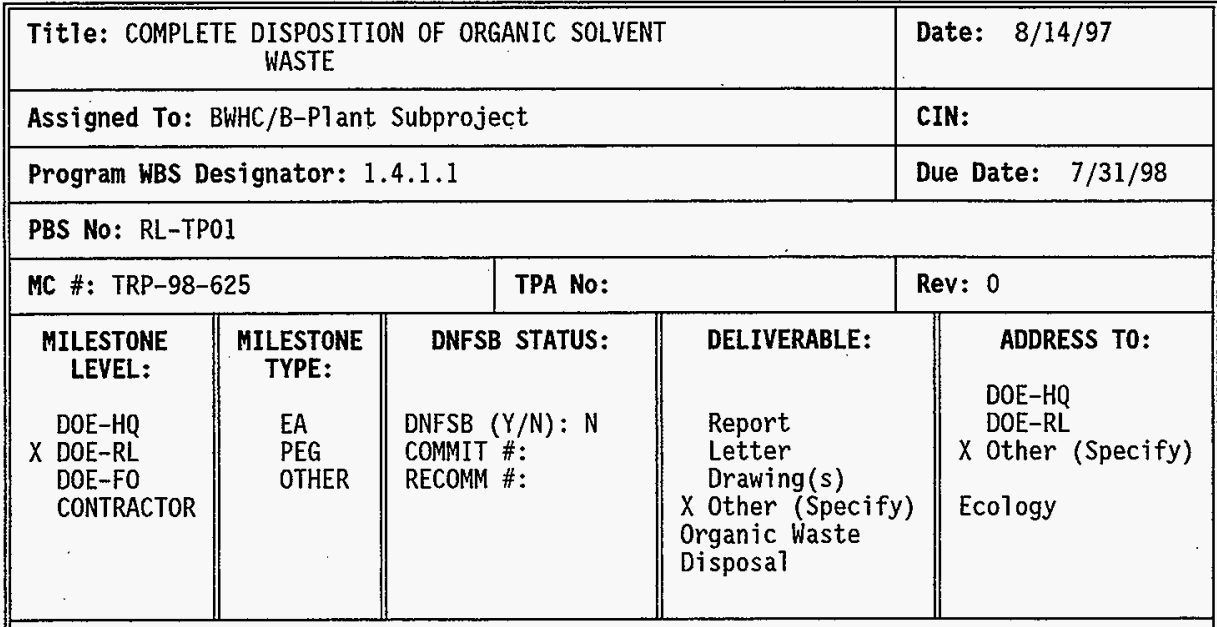

Milestone Description:

Tri-Party Agreement Milestone M-82-08 requires the disposition of organic solvent waste stored at $\mathrm{B} P \mathrm{Pl}$ ant by September 30,1998 . Organic solvent waste removed from the $B$ Plant canyon and transferred to RCRA compliant storage will be disposed of to another RCRA compliant disposal facility, either on or off the Hanford Site. In the event that organic disposal is not achievable by September 30, 1998, the organic solvent waste will be transferred from interim storage at B Plant to other RCRA comp 7 iant storage at the Hanford Site.

Description of what constitutes completion of this milestone:

This milestone is complete when the B Plant organic solvent is disposed of or moved to a RCRA compliant storage location at Hanford other than B Plant. 
MILESTONE DESCRIPTION SHEET

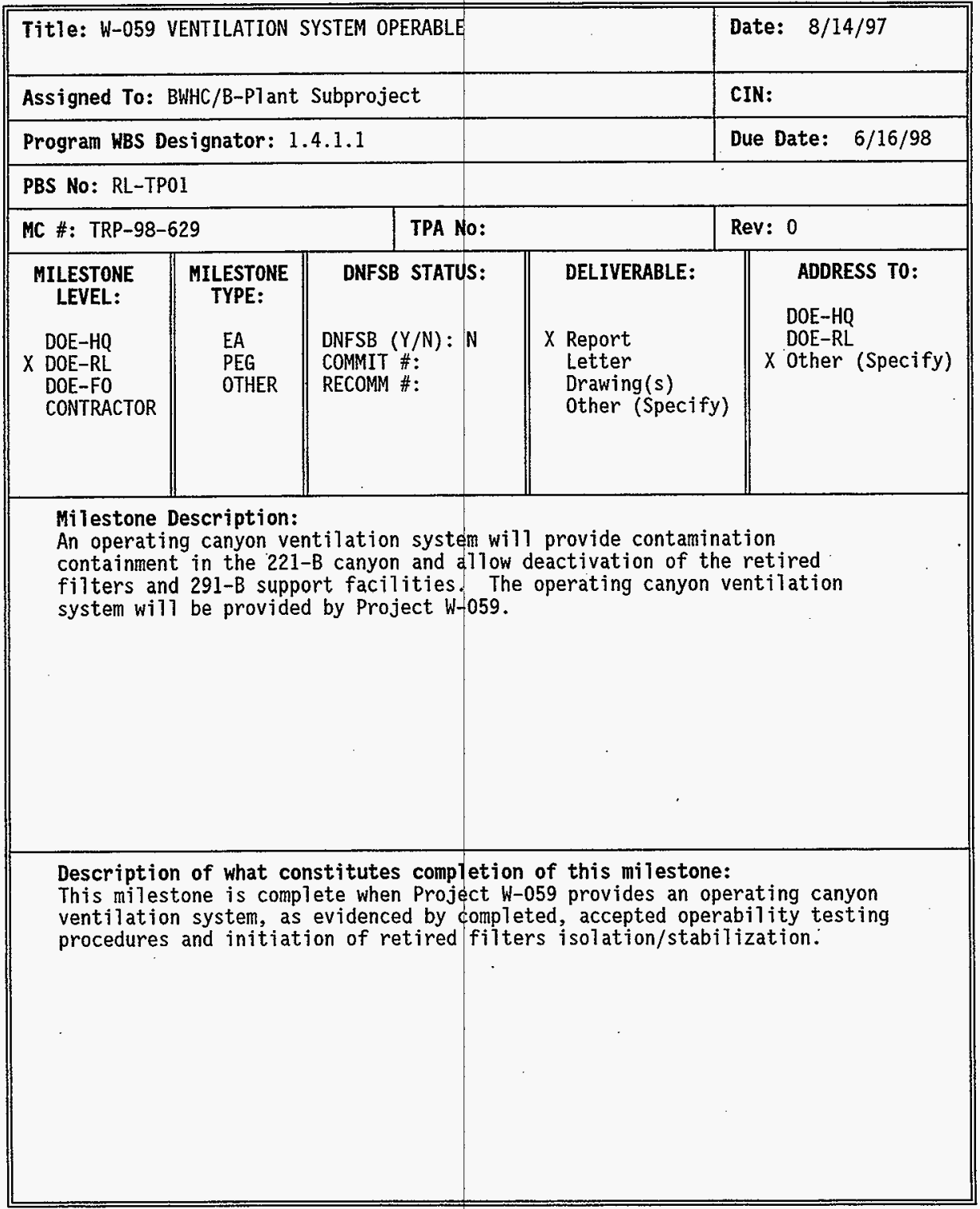




\section{PHMC \\ MILESTONE DESCRIPTION SHEET}

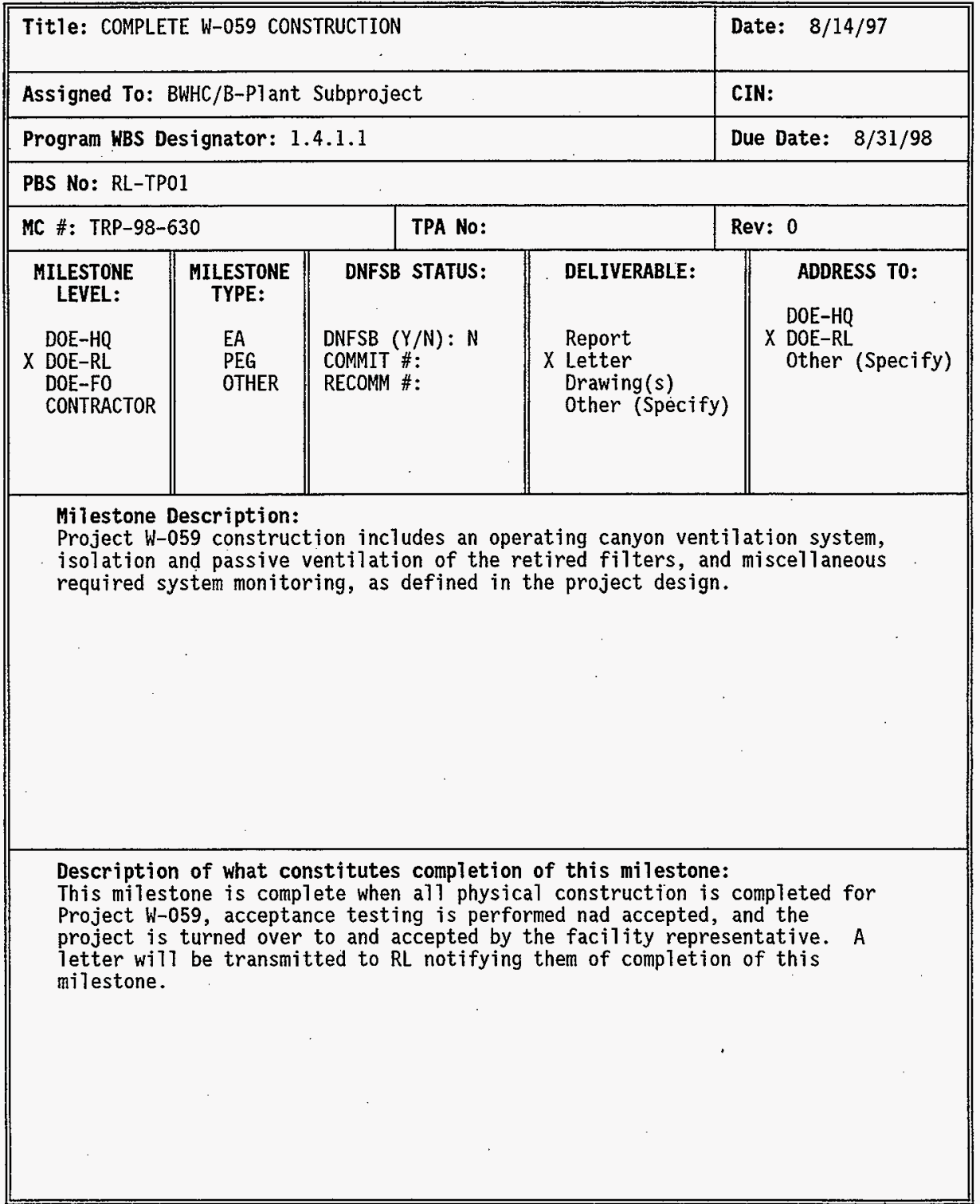


MILESTONE DESCRIPTION SHEET

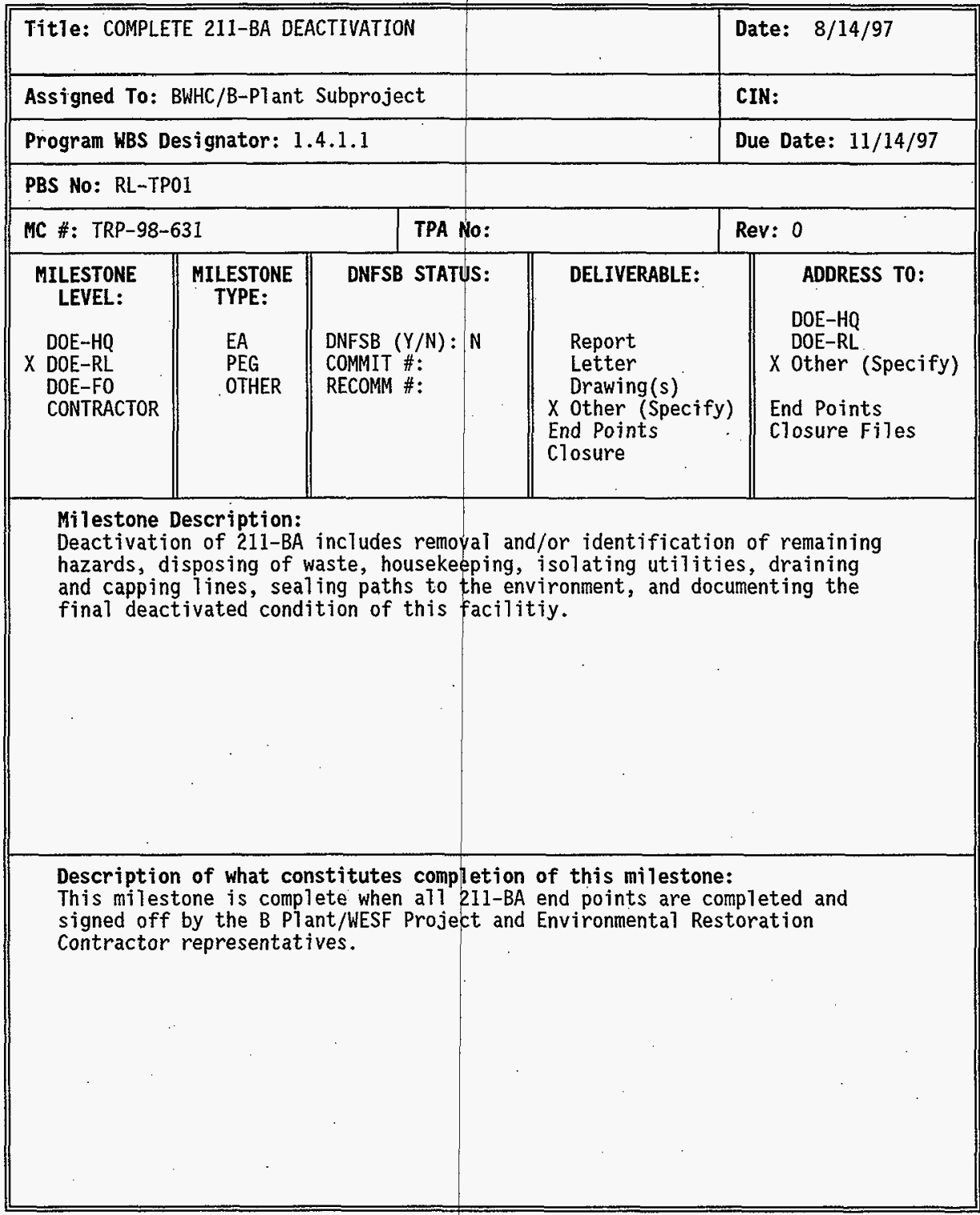


PHIMC

MILESTONE DESCRIPTION SHEET

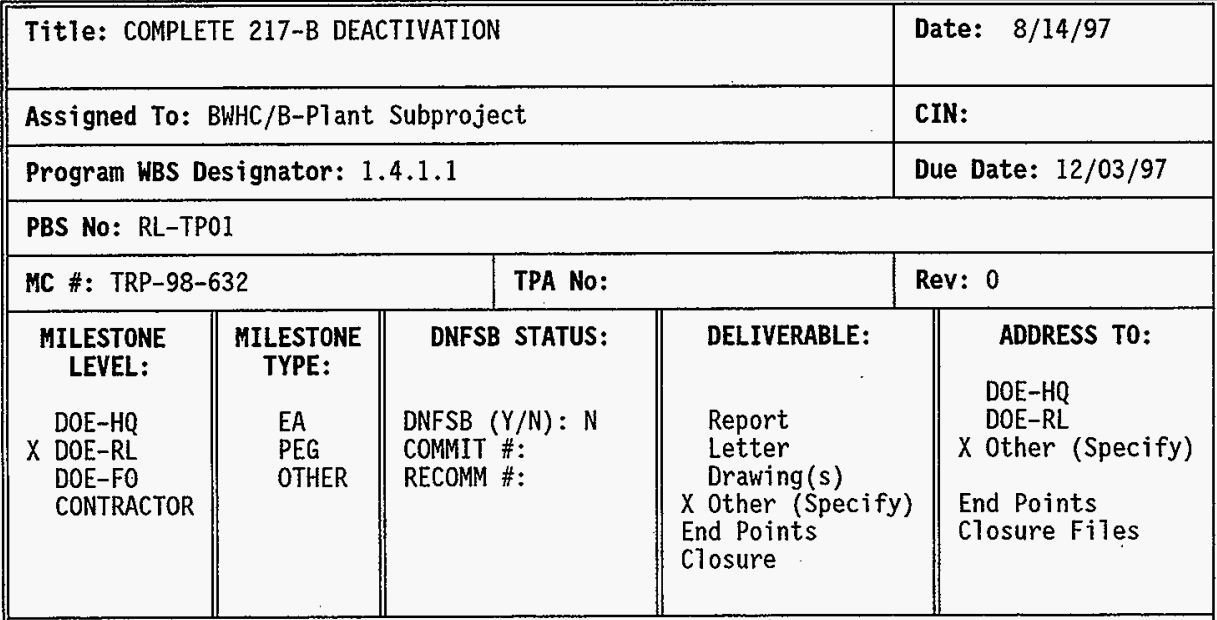

Milestone Description:

Deactivation of 217-B includes removal and/or identification of remaining hazards, disposing of waste, housekeeping, isolating utilities, draining and capping lines, sealing paths to the environment, and documenting the final deactivated condition of this facility.

Description of what constitutes completion of this milestone:

This milestone is complete when a17.217-B end points are completed and signed off by the B Plant/WESF Project and Environmental Restoration Contractor representatives. 


\section{PHMC}

MILESTONE DESCRIPTION SHEET

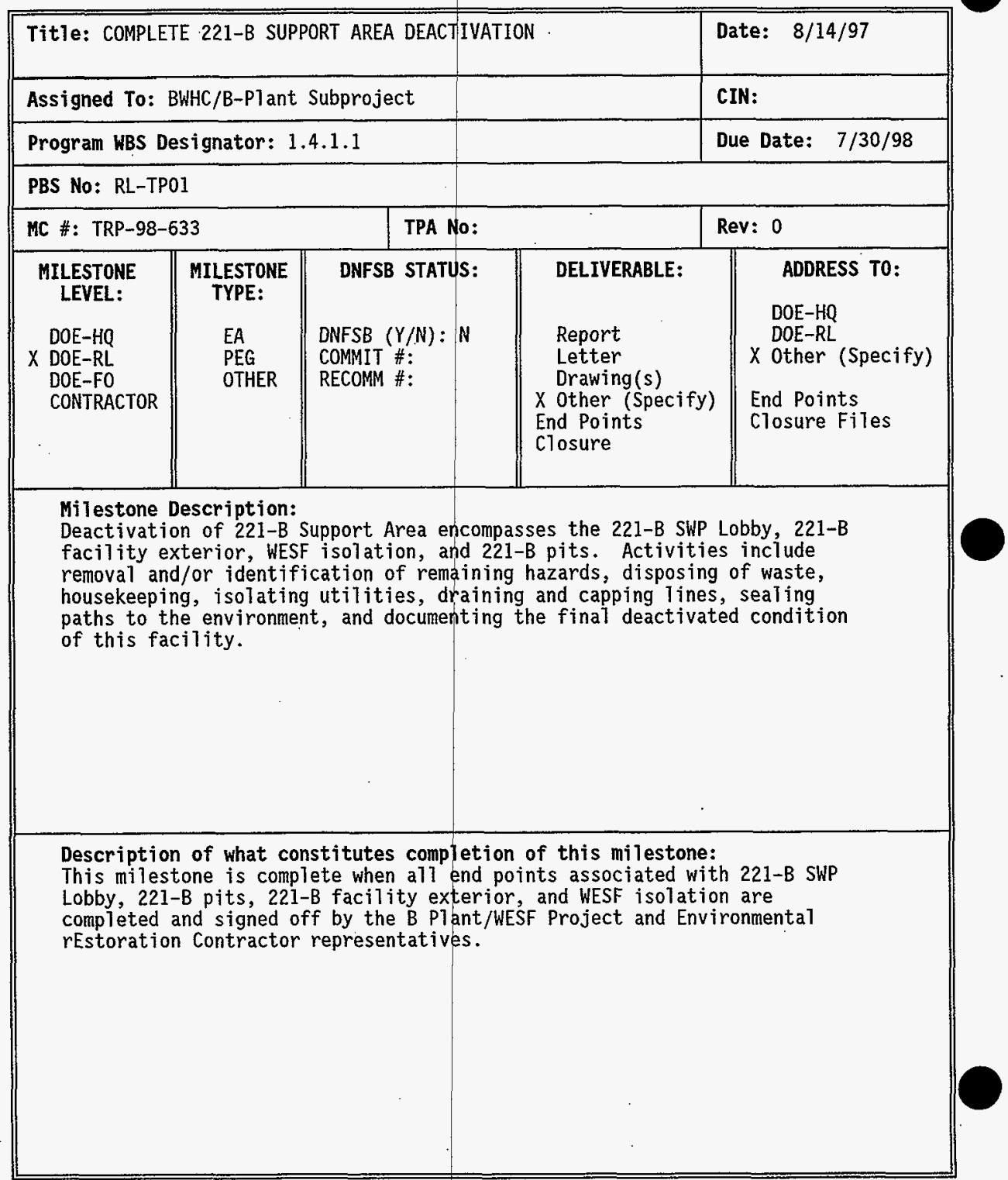




\section{PHMC \\ MILESTONE DESCRIPTION SHEET}

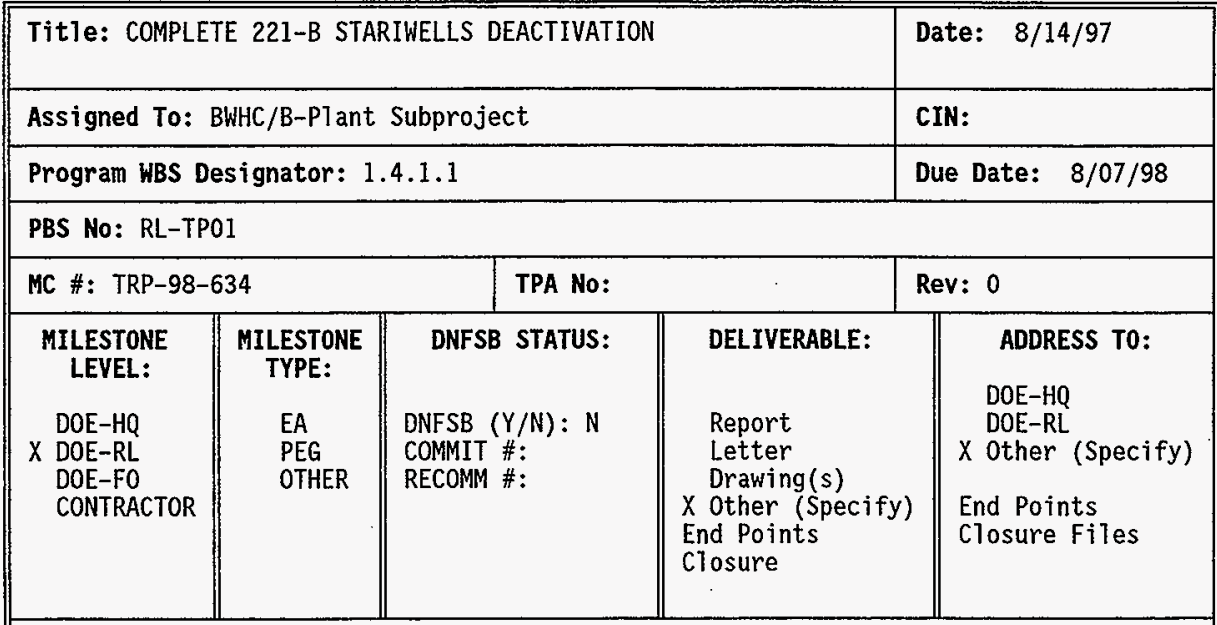

Milestone Description:

Deactivation of 221-B Stairwells includes removal and/or identification of remaining hazards, disposing of waste, housekeeping, isolating utilities, draining and capping lines, sealing paths to the environment, and documenting the final deactivated condition of this facility.

Description of what constitutes completion of this milestone:

This milestone is complete when a]1 221-B Stairwe11 end points are completed and signed off by the B Plant/WESF Project and Environmental Restoration Contractor representatives. 


\section{PHMC}

MILESTONE DESCRIPTION SHEET

\begin{tabular}{|c|c|c|c|c|c|}
\hline \multicolumn{5}{|c|}{ Title: COMPLETE 291 AREA DEACTIVATION } & Date: $8 / 14 / 97$ \\
\hline \multicolumn{3}{|c|}{ Assigned To: BWHC/B-Plant Subproject } & & & CIN: \\
\hline \multicolumn{3}{|c|}{ Program WBS Designator: 1.4 .1 .1} & & & Due Date: $9 / 30 / 98$ \\
\hline \multicolumn{3}{|c|}{ PBS No: RL-TP01 } & & & \\
\hline \multicolumn{3}{|c|}{ MC \#: TRP-98-635 } & TPA No: & & Rev: 0 \\
\hline $\begin{array}{l}\text { MILESTONE } \\
\text { LEVEL: } \\
\text { DOE-HQ } \\
\text { X DOE-RL } \\
\text { DOE-FO } \\
\text { CONTRACTOR }\end{array}$ & $\begin{array}{l}\text { MILESTONE } \\
\text { TYPE: } \\
\text { EA } \\
\text { PEG } \\
\text { OTHER }\end{array}$ & $\begin{array}{l}\text { DNFSB STATL } \\
\text { DNFSB }(Y / N): \\
\text { COMMIT \#: } \\
\text { RECOMM } \#:\end{array}$ & US: & $\begin{array}{l}\text { DELIVERABLE: } \\
\text { Report } \\
\text { Letter } \\
\text { Drawing (s) } \\
\text { X Other (Specify) } \\
\text { End Points } \\
\text { Closure }\end{array}$ & $\begin{array}{l}\text { ADDRESS TO: } \\
\text { DOE-HQ } \\
\text { DOE-RL } \\
\times \text { Other (Specify) } \\
\text { End Points } \\
\text { Closure Files }\end{array}$ \\
\hline \multicolumn{3}{|c|}{$\begin{array}{l}\text { Milestone Description: } \\
\text { Deactivation of } 291 \text { Area encompasses } \\
\text { yard, retired filters, and associated } \\
\text { include removal and/or identification } \\
\text { waste, housekeeping, isolating utilit } \\
\text { sealing paths to the environment, and } \\
\text { condition of this facility. }\end{array}$} & \multicolumn{3}{|c|}{$\begin{array}{l}\text { the 291-B stack, fans, steam turbine, } \\
\text { support buildings. Activities } \\
\text { of remaining hazards, disposing of } \\
\text { ies, draining and capping lines, } \\
\text { documenting the final deactivated }\end{array}$} \\
\hline \multicolumn{6}{|c|}{$\begin{array}{l}\text { Description of what constitutes completion of this milestone: } \\
\text { This milestone is complete when all 291-B end points are completed and } \\
\text { signed off by the B Plant/WESF Project and Environmental Restoration } \\
\text { Contractor representatives. }\end{array}$} \\
\hline
\end{tabular}




\section{PHMC \\ MILESTONE DESCRIPTION SHEET}

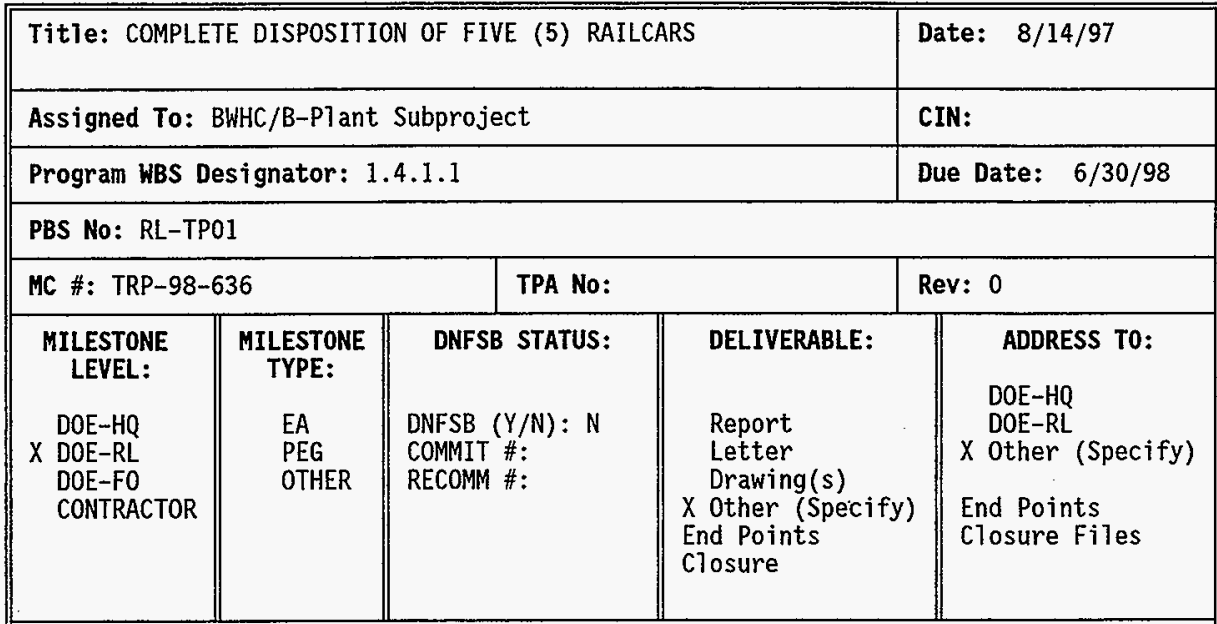

Milestone Description:

Disposition of the $5 \mathrm{~B}$ Plant regulated railcars will be accomplished by disposal, transfer to antoher on-site program, or transition to the Environmental Restoration Contractor as part of the overall B Plant transition.

Description of what constitutes completion of this milestone:

This milestone is complete when the end points for the $5 \mathrm{~B} P \mathrm{Plant}$ regulated railcars are completed and signed off by the B Plant/WESF Project and Environmental Restoration Contractor representatives. 


\begin{tabular}{|c|c|c|c|c|c|}
\hline \multicolumn{5}{|c|}{ Titie: COMPLETE B-PLANT YARD DEACTIVATION } & Date: $8 / 14 / 97$ \\
\hline \multicolumn{5}{|c|}{ Assigned To: BWHC/B-Plant Subproject } & CIN: \\
\hline \multicolumn{3}{|c|}{ Program WBS Designator: 1.4 .1 .1} & & & Due Date: $9 / 30 / 98$ \\
\hline \multicolumn{6}{|c|}{ PBS No: RL-TPO1 } \\
\hline \multicolumn{3}{|c|}{ MC \#: TRP-98-637 } & TPA Ho: & & Rev: 0 \\
\hline $\begin{array}{l}\text { MILESTONE } \\
\text { LEVEL: } \\
\text { DOE-HQ } \\
\times \text { DOE-RL } \\
\text { DOE-FO } \\
\text { CONTRACTOR }\end{array}$ & $\begin{array}{l}\text { MILESTONE } \\
\text { TYPE: } \\
\text { EA } \\
\text { PEG } \\
\text { OTHER }\end{array}$ & $\begin{array}{l}\text { DNFSB STATU } \\
\text { DNFSB }(Y / N): \\
\text { COMMIT \#: } \\
\text { RECOMM \#: }\end{array}$ & S: & $\begin{array}{l}\text { DELIVERABLE: } \\
\\
\text { Report } \\
\text { Letter } \\
\text { Drawing(s) } \\
\text { X Other (Specify) } \\
\text { End Points } \\
\text { Closure }\end{array}$ & $\begin{array}{l}\text { ADDRESS TO: } \\
\text { DOE-HQ } \\
\text { DOE-RL } \\
\times \text { Other (Specify) } \\
\text { End Points } \\
\text { Closure Files }\end{array}$ \\
\hline \multicolumn{6}{|c|}{$\begin{array}{l}\text { Milestone Description: } \\
\text { Deactivation of B Plant yard encompasses the yard, miscellaneous streams, } \\
\text { and underground storage transfer lines. Activities include removal and/or } \\
\text { identification of remaining hazards, disposing of waste, housekeeping, } \\
\text { isolating utilities, draining and capping lines, sealing paths to the } \\
\text { environment, and documenting the final deactivated condition of this } \\
\text { facility. }\end{array}$} \\
\hline \multicolumn{6}{|c|}{$\begin{array}{l}\text { Description of what constitutes completion of this milestone: } \\
\text { This milestone is complete when all B Plant yard end points are completed } \\
\text { and signed off by B Plant/WESF Project and Environmental Restoration } \\
\text { Contractor representatives. }\end{array}$} \\
\hline
\end{tabular}




\section{PHMC}

MILESTONE DESCRIPTION SHEET

\begin{tabular}{|c|c|c|c|c|}
\hline \multicolumn{4}{|c|}{$\begin{array}{l}\text { Title: COMPLETE DEACTIVATION OF ADMINISTRATIVE } \\
\text { SUPPORT AREAS }\end{array}$} & Date: $8 / 14 / 97$ \\
\hline \multicolumn{4}{|c|}{ Assigned To: BWHC/B-Plant Subproject } & CIN: \\
\hline \multicolumn{4}{|c|}{ Program WBS Designator: 1.4 .1 .1} & Due Date: $9 / 30 / 98$ \\
\hline \multicolumn{5}{|c|}{ PBS No: RL-TP01 } \\
\hline \multicolumn{2}{|c|}{ MC \#: TRP-98-638 } & \multicolumn{2}{|l|}{ TPA No: } & Rev: 0 \\
\hline $\begin{array}{l}\text { MILESTONE } \\
\text { LEVEL: } \\
\text { DOE-HQ } \\
\text { X DOE-RL } \\
\text { DOE-FO } \\
\text { CONTRACTOR }\end{array}$ & $\begin{array}{l}\text { MILESTONE } \\
\text { TYPE: } \\
\\
\text { EA } \\
\text { PEG } \\
\text { OTHER }\end{array}$ & $\begin{array}{l}\text { DNFSB STATUS: } \\
\text { DNFSB (Y/N): N } \\
\text { COMMIT \#: } \\
\text { RECOMM \#: }\end{array}$ & $\begin{array}{l}\text { DELIVERABLE: } \\
\text { Report } \\
\text { Letter } \\
\text { Drawing(s) } \\
\text { x Other (Specify) } \\
\text { End Points } \\
\text { Closure }\end{array}$ & $\begin{array}{l}\text { ADDRESS TO: } \\
\text { DOE-HQ } \\
\text { DOE-RL } \\
\times \text { Other (Specify) } \\
\text { End Points } \\
\text { Closure Files }\end{array}$ \\
\hline
\end{tabular}

Milestone Description:

Deactivation of administrative support areas encompasses 271-B, 271-BA, Mobile offices, 221-BD, 222-B, 2711-B, 2715-B, and 2716-B. Activities include removal and/or identification of remaining hazards, disposing of waste, housekeeping, isolating facilities, draining and capping lines, sealing paths to the environment, and documenting final deactivated condition of this facility

Description of what constitutes completion of this milestone:

This milestone is complete when all end points associated with 271-B, 271-BA, Mobile offices, 271-BD, 222-B, 2711-B, 2715-B, and 2716-B are completed and signed off by the B Plant/WESF Project and Environmental Restoration Contractor representatives. 


\section{PHMC}

MILESTONE DESCRIPTION SHEET

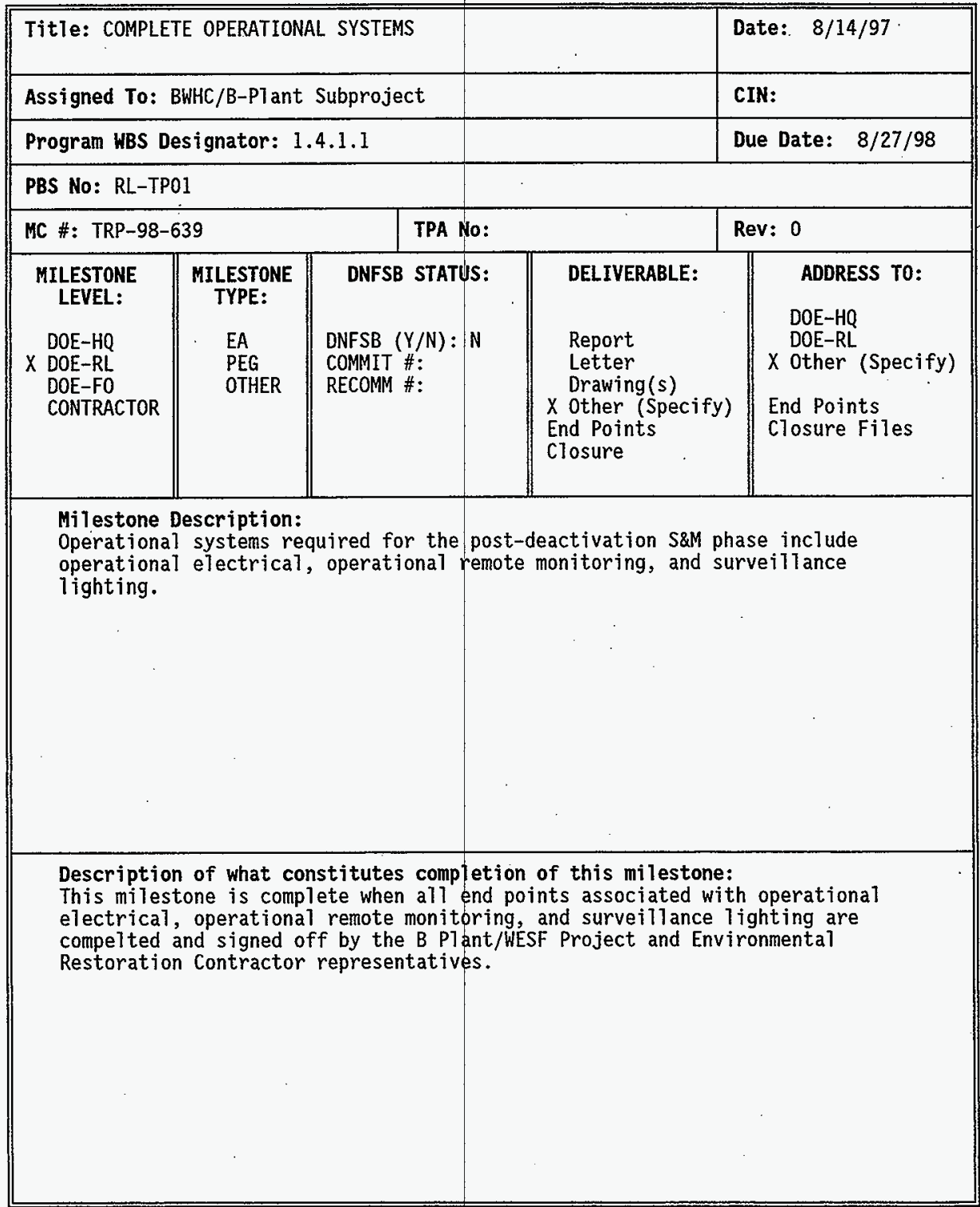




\section{PHMC \\ MILESTONE DESCRIPTION SHEET}

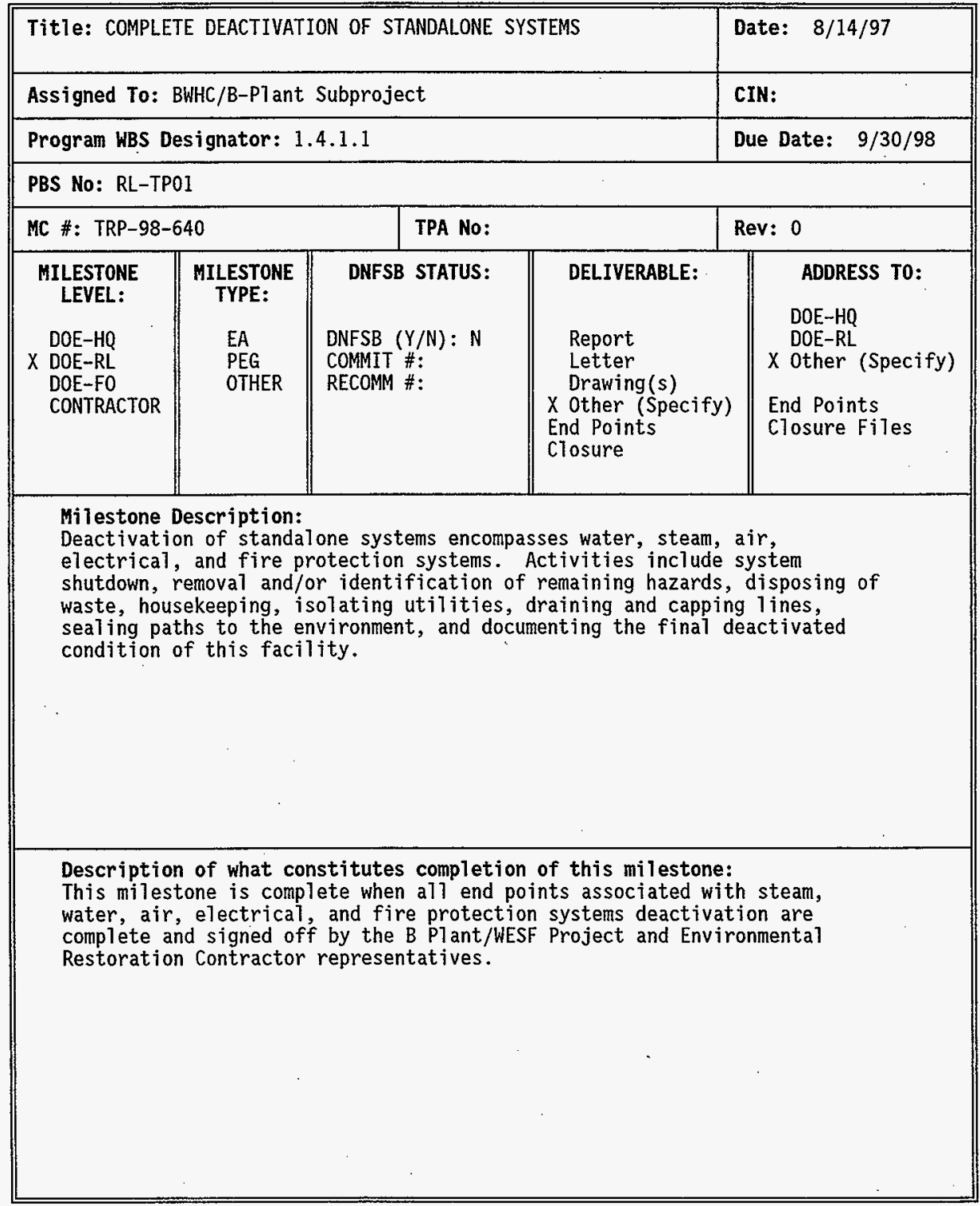


(\$000s)

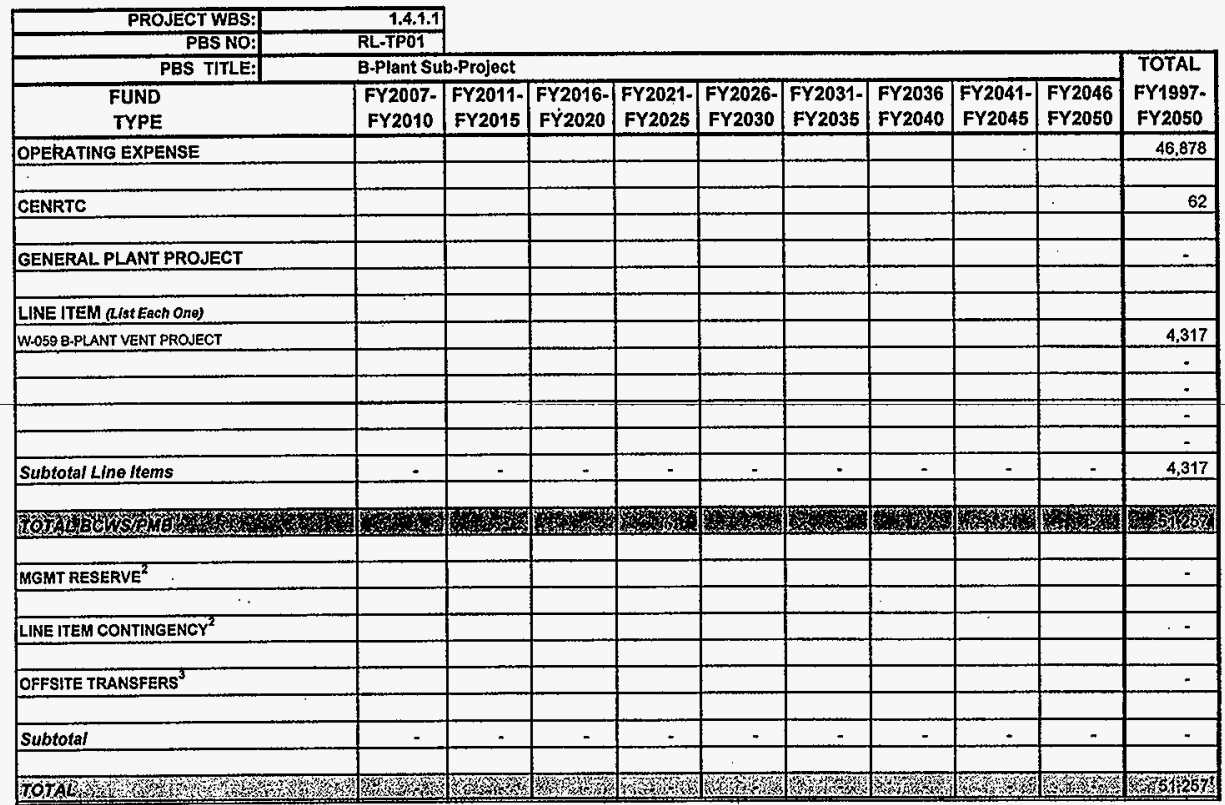

'Budgeted Cost of Work Scheduled (BCWS) Equals Performance Measurement Baseline (PMB); Expense Carryover NOT Included.

${ }^{2}$ Management Reserve and Line Item Contingency Held by RL.

"Work Performed at Sites Other Than Hanford. 
FACILITY STABILIZATION

LIFE CYCLE COST BASELINE (BCWS) BY YEAR BY FUND TYPE

BY PROJECT BASELINE SUMMARY (PBS)

FY 1998

(\$000s)

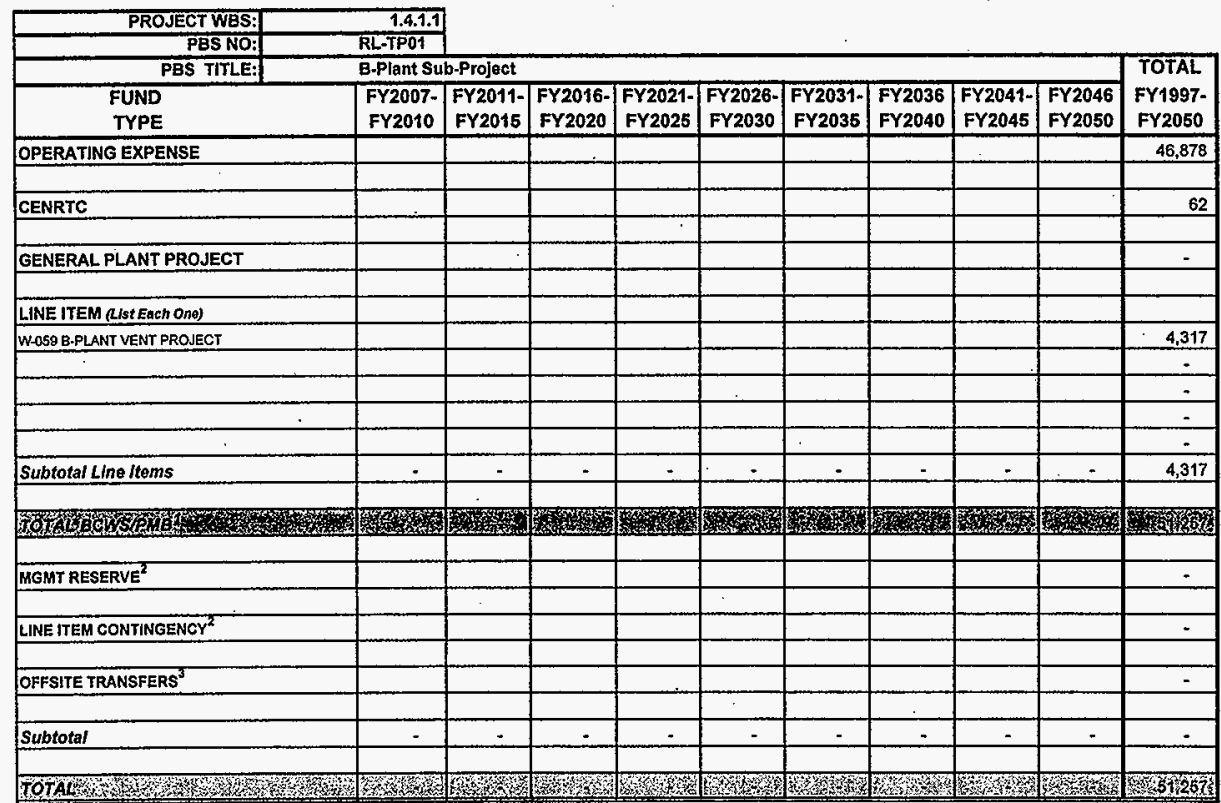

'Budgeted Cost of Work Scheduled (BCWS) Equals Performance Measurement Baseline (PMB);

Expense Carryover NOT Included.

${ }^{2}$ Management Reserve and Line Item Contingency Held by RL.

'Work Performed at Sites Other Than Hanford. 
FACILITY STABILIZATION

LIFE CYCLE BUDGET AUTHORITY (BIA) BY YEAR BY FUND TYPE

BY PROJECT BASELINE SUMMARY (PBS)

FY 1998

(\$000s)

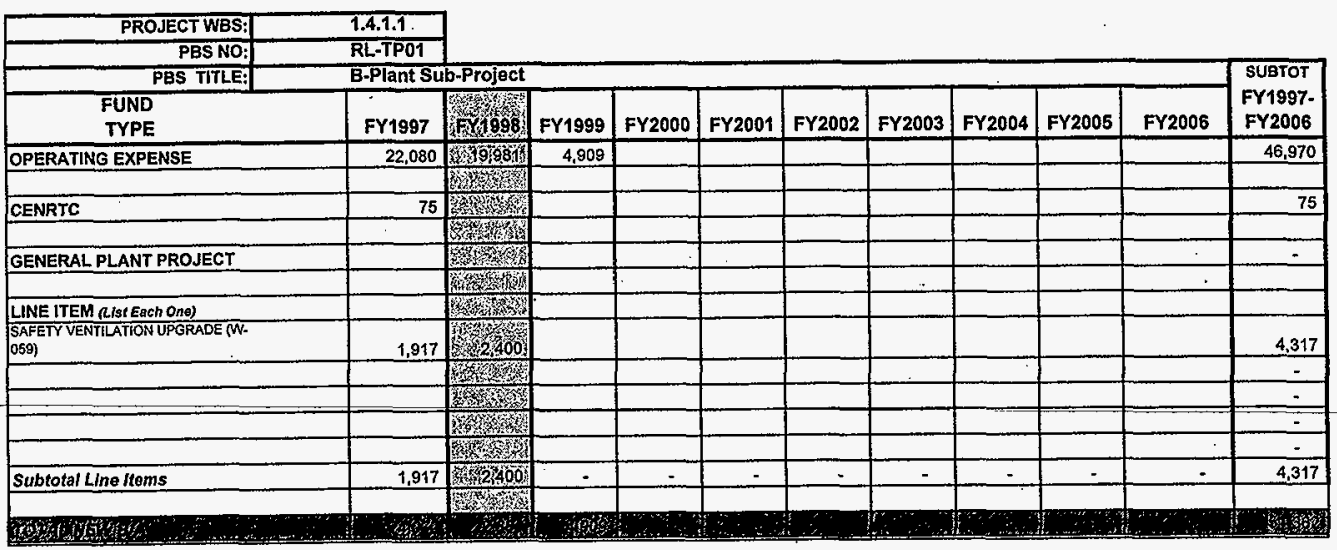


FACIEITY STABILIZATION

LIFE CYCLE BUDGET AUTHORITY (B/A) BY YEAR BY FUND TYPE BY PROJECT BASELINE SUMMARY (PBS)

FY 1998

(\$000s)

\begin{tabular}{|c|c|c|c|c|c|c|c|c|c|c|}
\hline PROJECT WBS: & 1.4.1.1 & & & & & & & & & \\
\hline PBSNO: & RL-TPO1 & & & & & & & & & \\
\hline PBS TITLE: & B-Plant S & ub-Projec & & & & & & & & TOTAL \\
\hline $\begin{array}{l}\text { FUND } \\
\text { TYPE }\end{array}$ & $\begin{array}{l}\text { FY2007- } \\
\text { FY2010 }\end{array}$ & $\begin{array}{l}\text { FY2011- } \\
\text { FY2015 }\end{array}$ & $\begin{array}{l}\text { FY2016- } \\
\text { FY2020 } \\
\end{array}$ & $\begin{array}{l}\text { FY2021- } \\
\text { FY2025 } \\
\end{array}$ & $\begin{array}{l}\text { FY2026- } \\
\text { FY2030 } \\
\end{array}$ & $\begin{array}{l}\text { FY2031- } \\
\text { FY2035 }\end{array}$ & $\begin{array}{l}\text { FY2036 } \\
\text { FY2040 }\end{array}$ & $\begin{array}{l}\text { FY2041- } \\
\text { FY2045 }\end{array}$ & \begin{tabular}{|l|} 
FY2046 \\
FY2050 \\
\end{tabular} & $\begin{array}{l}\text { FY1997- } \\
\text { FY2050 }\end{array}$ \\
\hline OPERATING EXPENSE & & & & & & & & & & 46,970 \\
\hline & & & & & & & & & & \\
\hline CENRTC & & & & & & & & & & 75 \\
\hline & & & & & & & & & & \\
\hline GENERAL PLANT PROJECT & & & & & & & & & & - \\
\hline & & & & & & & & & & \\
\hline $\begin{array}{l}\text { LINE ITEM (L/st Each Ono) } \\
\text { SAFETY VENTILAFION UPGRADE (W- }\end{array}$ & & & & & & & & & & 4317 \\
\hline $\begin{array}{l}\text { SAFETY VENTILATION UPGRADE (W- } \\
\text { O59) }\end{array}$ & & & & & & & & & & 4,318 \\
\hline & & & & & & & & & & - \\
\hline & & & & & & & & & & $=$ \\
\hline & & & & & & & & & & - \\
\hline & & & & & & & & & & - \\
\hline Subtotal Line hems & - & $=$ & - & $=$ & - & - & - & - & $\therefore$ & 4,317 \\
\hline (2) & & & & & & 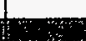 & 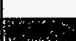 & & & 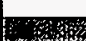 \\
\hline
\end{tabular}


B PLANT SUB-PROJECT

AVERAGE ANNUAL FULL TIME EQUIVALENTS

(includes Major Subcontractors but not Enterprise Companies)

PHBS 1.4.1.1

Submittal Date: 9/10/97

PBS Number

PBS Title

FY 1998

FY 1999

FY 2000

FY 2002

\begin{tabular}{l|l|} 
FY 2003 & FY 2004 \\
\hline
\end{tabular}

FY 2005

\begin{tabular}{|l|l|}
\hline FY 2006 & FY 2007 \\
\hline
\end{tabular}

RL-TP01 B-Plant Subproject

120

4

0

o

0

o

o

0

0

0

$\underline{0}$

$\underline{\mathbf{0}}$

$\underline{0}$

$\underline{\underline{0}}$

$\therefore \underline{\mathbf{0}}$

$\underline{0}$ 


\section{B.2 WESF Sub-Project (RL-TP02)}

\section{B.2.1.0 WESF Sub-Project Technical Baseline (RL-TP02)}

\section{B.2.1.1 WESF Sub-Project Organization Mission (RL-TP02)}

WThe Waste Encapsulation Storage Facility (WESF) project mission is assuring the safe storage of approximately 147 million curies of encapsulated radioactive material. As part of accomplishing this mission, old systems and structures must be updated to be capable of functioning safely for the next 20 years and without a need for services currently supplied from B Plant. Primary upgrades are planned in the next few years in the areas of response to a potential capsule leak, pool cell monitoring capabilities, and capsule monitoring equipment. Safety analyses are also being upgraded with preparation of a new safety analysis report with accompanying operational safety requirements. These upgrades are necessary to maintain the capsules in a safe storage condition until transfer out for ultimate disposal. Final capsule removal is planned for 2017. After capsule removal the facility will be deactivated and tumed over to the ER Project.

WESF will implement interim status requirements upon submittal of a Part A Permit Application at the end of December 1997.

\section{B.2.1.2 WESF Sub-Project End Point Targets from Hanford Strategic Plan}

* Transition high cost surplus facilties in the central plateau and south 600 areas to a low cost, stable, deactivated condition.

* Continue to provide saie storage for Cs/Sr capsules in the WESF indefinitely.

(1) WESF decoupled and a standalone facility.

- Remove non-essential, surplus buildings and facilities that don't have identified post-cleanup uses.

* Dismantle, or close through entombment, D\&D facilities in the central plateau areas currently assigned to the ER program.

\section{B.2.1.3 WESF Sub-Project Major Facilities}

\section{B.2.1.3.1 Waste Encapsulation and Storage Facility}

\section{B.2.1.3.1.1 Waste Encapsulation and Storage Facility Description}

WESF was constructed in 1974 in the 200-E Area of Hanford for the purpose of producing and storing $\mathrm{Cs}$ and $\mathrm{Sr}$ capsules.

\section{B.2.1.3.1.2 Waste Encapsulation and Storage Facility Facility Technical Logic:}

The Department of Energy (DOE), in partnership with its contractors, shall plan, acquire, operate, maintain, and dispose of physical assets as valuable national resources. Stewardship of these physical assets shall be accomplished in a cost-effective manner to meet the DOE mission. This shall incorporate industry standards, a 
graded approach, and performance objectives.

HNF-SP-1234 
HNF-SP-1234

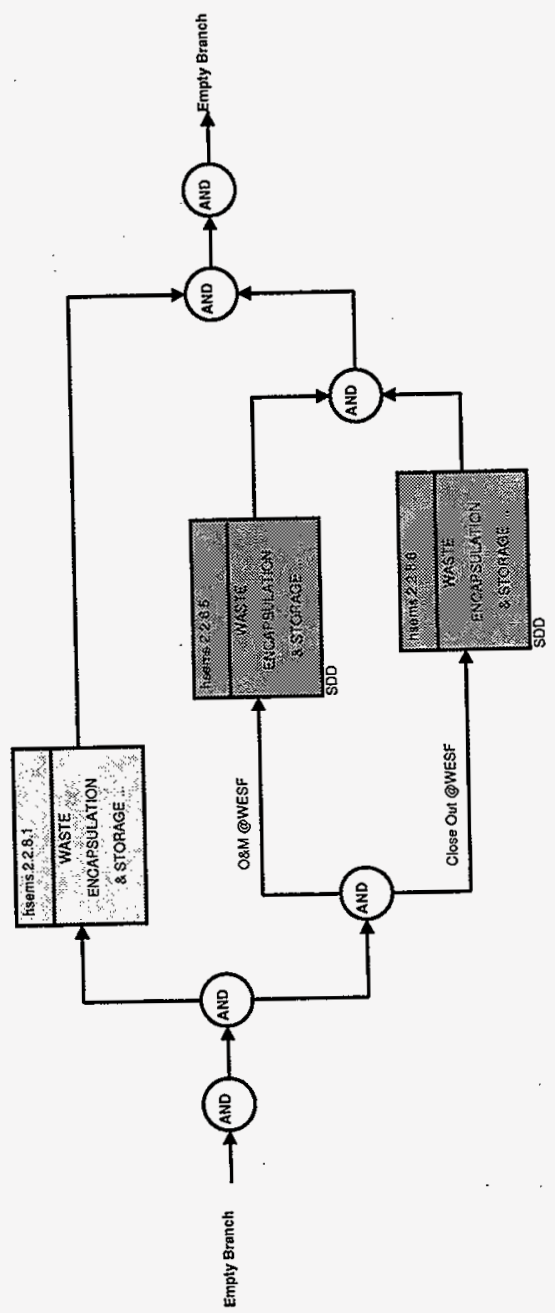

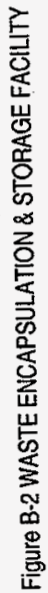




\section{B.2.1.3.1.3 Waste Encapsulation and Storage Facility Requirements and Life Cycle Function Descriptions}

\section{Requirements:}

* Complete WESF hotcell and K3 duct cleanup in support of WESF low level liquid waste system critical activities.

- WESF Solid Waste System declared operational and ready for use by WESF Plant Operations Management.

- WESF Liquid Effluent System declared operational and ready for use by WESF Plant Operations Management.

* Facilities discharging to the 200 Area TEDF shall implement Best Available Technology (BAT)/All Known, Available, and Reasonable Treatment (AKART). The generator shall provide the information required by WAC 173-240, Submission of Plans and Reports for Construction of Waste Water Facilities.

* Central Plateau high cost surplus facilities shall be transitioned to a low cost, stable, deactivated condition

* Central Plateau facilities other than processing facilities shall be dismantled

- WESF shall be decoupled from B Plant by Sep 1998

* WESF pool cell faciiities shall be maintained within the approved safety envelope

* WESF infrastructure shall be maintained within the approved safety envelope

* Central Plateau inactive facilities shall be maintained within the approved safety envelope

* Cesium capsules shall be safely stored in WESF.

* Strontium capsules shall be safely stored in WESF.

- Central Plateau asbestos abatement shall be performed as necessary

* Phase Il liquid effluent streams shall be treated using "Best Available Technology/All Known, Available, and Reasonable Methods of Prevention, Control, and Treatment (BAT/AKART)"

\section{Life Cycle Function Descriptions:}

\section{B.2.1.3.1.3.1 WASTE ENCAPSULATION \& STORAGE FACILITY PROGRAM PLANNING WORK SCOPE SUMMARY}

Functions that include planning and developing the overall program; establishing broad priorities; providing program technical direction; preparing and defending the program budget; controlling milestones; integrating all components of the program; providing public and private sector policy liaison; expediting interface activities and follow-up actions; and retaining overall accountability for program success.

\section{B.2.1.3.1.3.2 WASTE ENCAPSULATION \& STORAGE FACILITY OPERATIONS \& MAINTENANCE WORK SCOPE SUMMARY}

Day-to-day work, including preventive and predictive maintenance, that is required to maintain and preserve plant and capital equipment in a condition suitable for it to be used for its designated purpose. 


\section{WASTE ENCAPSULATION \& STORAGE FACILITY OPERATIONS \& MAINTENANCE SPECIFIC FUNCTIONS}

\section{B.2.1.3.1.3.3 Maintain Safe \& Compliant Materials (Cs/Sr Capsules) in WESF}

Materials (Sr/Cs Capsules) stored in the WESF facility will be maintained in saie condition until they are removed for disposal or treatment.

\section{B.2.1.3.1.3.4 WASTE ENCAPSULATION \& STORAGE FACILITY POST OPERATIONS WORK SCOPE SUMMARY}

Day-to-day work, including pre-stabilization surveillance and maintenance, stabilization, post-stabilization surveillance and maintenance, deactivation, and post-deactivation surveillance and maintenance, that is required to aliow safe decontamination and decommissioning.

\section{WASTE ENCAPSULATION \& STORAGE FACILITY POST OPERATIONS SPECIFIC FUNCTIONS}

\section{B.2.1.3.1.3.5 Maintain Safe \& Compliant Waste Encapsulation and Storage Facility in CP Areas}

Maintain the WESF facility structures, operating systems and equipment, and monitoring systems within the approved saiety and compliance requirements until the facilities are made available for clean-up:

\section{B.2.1.3.1.3.6 Transition Waste Encapsulation and Storage Facility}

Initiate the transition phase of decontamination and decommissioning for the WESF facility.

\section{B.2.1.3.1.4 Waste Encapsulation and Storage Facility Boundary Diagram}

Table B.2-1 Waste Encapsulation and Storage Facility Boundary Diagram

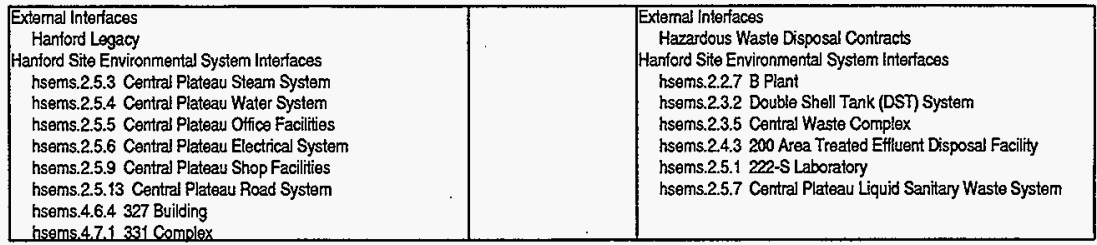




\section{B.2.1.3.1.5 Waste Encapsulation and Storage Facility Interface Description and Forecast}

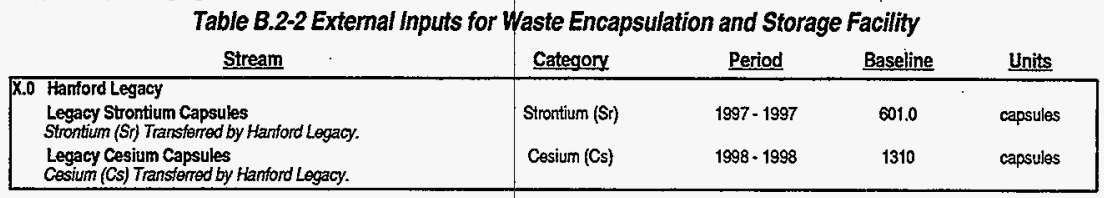

\section{INTERNAL INPUTS}

Table B.2-3 Internal Inputs for Waste Encapsulation and Storage Facility

\begin{tabular}{|c|c|c|c|c|}
\hline Stream & Category & Period & Baseline & Units \\
\hline $\begin{array}{l}\text { hsems 2.3 Central Plateau Storage Facilities } \\
\text { Storage Space (Program Owned) for WESF } \\
\text { Storage Space (Program Omed) for WESF }\end{array}$ & Allocated Storage & $1998-2019$ & 21200 & sq. th. \\
\hline $\begin{array}{l}\text { hsems } 2.5 .3 \text { Central Plateau Steam System } \\
\text { Steam for WESF } \\
\text { Steam for WESF }\end{array}$ & Steam & $1998-2019$ & 198.0 & Mlbs \\
\hline \begin{tabular}{|l} 
hsems 2.5 .4 Central Plateau Water System \\
Raw Water for WESF \\
Raw Water for WESF \\
Potable Water for WESF \\
Potable Water for WESF \\
\end{tabular} & $\begin{array}{l}\text { Raw Water } \\
\text { Potable Water }\end{array}$ & $\begin{array}{l}1998-2019 \\
1998-2019\end{array}$ & $\begin{array}{l}22.0 \\
5.45\end{array}$ & $\begin{array}{l}\text { Mgal } \\
\text { Mgal }\end{array}$ \\
\hline $\begin{array}{l}\text { hsems 2.5.5 Central Plateau Office Facilities } \\
\text { Office Space (Program Owned) for WESF } \\
\text { Office Space (Program Owned) for WESF } \\
\text { Office Space (infrastructure Owned) for WESF } \\
\text { Office Space (Infrastucture Owned) for WESF }\end{array}$ & $\begin{array}{c}\text { Otfice Space (Program } \\
\text { Owned) } \\
\text { Otfice Space (Infrastructure } \\
\text { Owned) }\end{array}$ & $\begin{array}{l}1998-2019 \\
1998-2019\end{array}$ & $\begin{array}{l}77700 \\
154000\end{array}$ & $\begin{array}{l}\text { sq. H. } \\
\text { sq. it. }\end{array}$ \\
\hline $\begin{array}{l}\text { hsems.2.5.6 Central Plateau Electrical System } \\
\text { Electricity for WESF } \\
\text { Electricity for WESF }\end{array}$ & Electricity & $1998-2019$ & 5250 & MW-hr \\
\hline $\begin{array}{l}\text { hsems.2.5.9 Central Plateau Shop Facilities } \\
\text { Fab Shop Services for WESF }\end{array}$ & Fabrication Services (Other) & $1998 \cdot 2019$ & 4040 & labor-hrs \\
\hline $\begin{array}{l}\text { Fab Shop Servicas for WESF } \\
\text { Lifting (Cranes) for WESF } \\
\text { Liting (Cranes) for WESF } \\
\text { Custodial Services for WESF } \\
\text { Custodial Services for WESF }\end{array}$ & $\begin{array}{l}\text { Lifting Servicos } \\
\text { Custodial Services }\end{array}$ & $\begin{array}{l}1998-2019 \\
1998-2019\end{array}$ & $\begin{array}{l}352.0 \\
77700\end{array}$ & $\begin{array}{l}\text { crane days } \\
\text { sq. fi. }\end{array}$ \\
\hline $\begin{array}{l}\text { hsems2.5.13 Central Plateau Road System } \\
\text { Hanford Road Sys. Heavy Traffic for WESF } \\
\text { Hanford Road Sys. Hoavy Traffic for WESF }\end{array}$ & $\begin{array}{c}\text { Haniord Road System (Heavy } \\
\text { Traffic) }\end{array}$ & $1998-2019$ & 220.0 & truck loads \\
\hline $\begin{array}{l}\text { Sedans/Light Trucks for WESF } \\
\text { Sedans/ight Trucks for WESF }\end{array}$ & Sodans/Light Trucks & $1998-2019$ & 44.0 & no. of vehides \\
\hline $\begin{array}{l}\text { Heavy Trucks for WESF } \\
\text { Heavy Trucks for WESF }\end{array}$ & Heavy Trucks & $1998-2019$ & 792.0 & vehicle-hrs \\
\hline $\begin{array}{l}\text { Heavy Equipment for WESF } \\
\text { Heary Equipment for WESF }\end{array}$ & Heavy Equipment (Other) & $1998-2019$ & 880.0 & equipment days \\
\hline $\begin{array}{l}\text { 3sems.4.6.4 327 Building } \\
327 \text { Cesium Capsules } \\
\text { Cesium (Cs) Transferred. }\end{array}$ & Cesium (Cs) & $1998 \cdot 1998$ & 13.0 & capsules \\
\hline $\begin{array}{l}\text { hisems.4.7.1 } 331 \text { Complex } \\
\text { Non-rad Standards (Calibrations) for WESF } \\
\text { Non-rad Standards (Calibrations) for WESF }\end{array}$ & $\begin{array}{l}\text { Non-rad Standards Lab } \\
\text { Services }\end{array}$ & $1998-2019$ & 1340 & calibrations \\
\hline
\end{tabular}


Table B.2-4 External Outputs for Waste Encapsulation and Storage Facility

\begin{tabular}{|lcccc|}
\multicolumn{1}{c}{ Stream } & Categen & Period & Baseline & Units \\
\hline $\begin{array}{l}\text { X Hazardous Waste Disposal Contracts } \\
\text { WESF Hazardous Waste } \\
\text { HAZ Disposed by Waste Encapsulation and Storage Facility. }\end{array}$ & HAZ & $1998-2019$ & 22.0 & cubic meters \\
\hline
\end{tabular}

\section{INTERNAL OUTPUTS}

Table B.2-5 Internal Outputs for Waste Encapsulation and Storage Facility

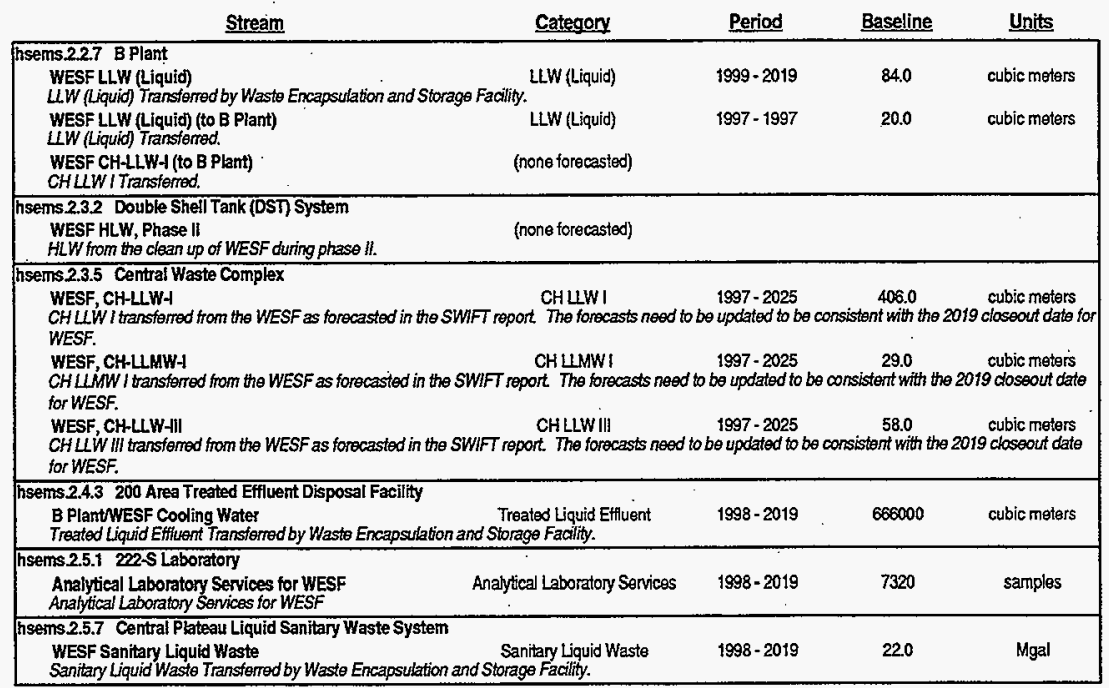




\section{B.2.1.4 Drivers for WESF Sub-Project}

\section{Table B.2-6 Source Documents for WESF Sub-Project}

Name

DE-AC06-96RL13200

DOE/EIS-0222D

DOE/RL-89-10

DOE/RL-96-14

DOE/RL-96-92

ST 4502
Titile

Project Hanford Management Contract, Fluor Daniel Hanford, Inc.

Draft Hanford Remedial Action Environmental Impact Statement and Comprehensive Land Use Plan

Hanford Federal Facility Agreement and Consent Order (Tri-Party Agreement), Rev. 4

Updated Draft Mission Direction Document, June 1998

Hanford Strategic Plan

State Waste Discharge Permit for the 200 Area TEDF

\section{B.2.1.5 WESF Sub-Project Risk Management}

WESF's mission is to store and manage the $C s$ and Sr capsules until they are transferred to a permanent storage or disposal location. Current Department of Energy plans as outlined in Project Baseline Summary number RL-TW07 shows the development, design, and construction of the Process Waste Privatization Phase II completed in 2013. WESF currently utilizes B Plant (Sub-Project PBS RL-TP01) for management of low level liquid wastes, but that dependency will be eliminated by the end of June 1998.

WESF is tasked with the safe and cost effective management of approximately 147 million curies of Cesium- 137 and Strontium-90, including their daughter products. This material is double-encapsulated in welded stainless steel canisters (approximately 1300 cesium capsules and 600 strontium capsules). The encapsulated materials are safely maintained in water-filled pools, which require utilfties, structures, and other support services. WESF, built in 1974, requires replacement of several systems and structural components due to natural aging and deterioration.

Risk management during the next 25 years while WESF stores and then ships out the capsules requires an understanding of the levels of risks associated with these activities. Evaluation of those risk levels is done in three categories (Public Health, Worker, and Environmental) for three time periods (Baseline operations, Capsule transfer, and End state).

During the Baseline operations the risks are categorized as low with a calculated maximum radiation dose of 0.017 rem to workers and $0.400 \mathrm{rem}$ to the public from an eathquake large enough to damage the facility significantly. During the four years planned for capsule transfer to the treatment and disposal facility, the risk to the workers becomes slightly higher due to additional handling. Following transfer of the capsules out of the facility, the residual risks are very low and are a result of legacy contamination remaining in the facility from past operations.

If facility operations are ceased due to lack of funding and the capsules aren't properly maintained the potential risks become extremely high with a calculated radiation dose of $2200 \mathrm{rem}$ to on site workers and $9.8 \mathrm{rem}$ to the public. This is due to failure to maintain the cooling and shielding water in the pools the capsules are stored in and the subsequent overheating and failure of multiple capsules. 


\section{WESF Sub-Project Work Breakdown Structure}

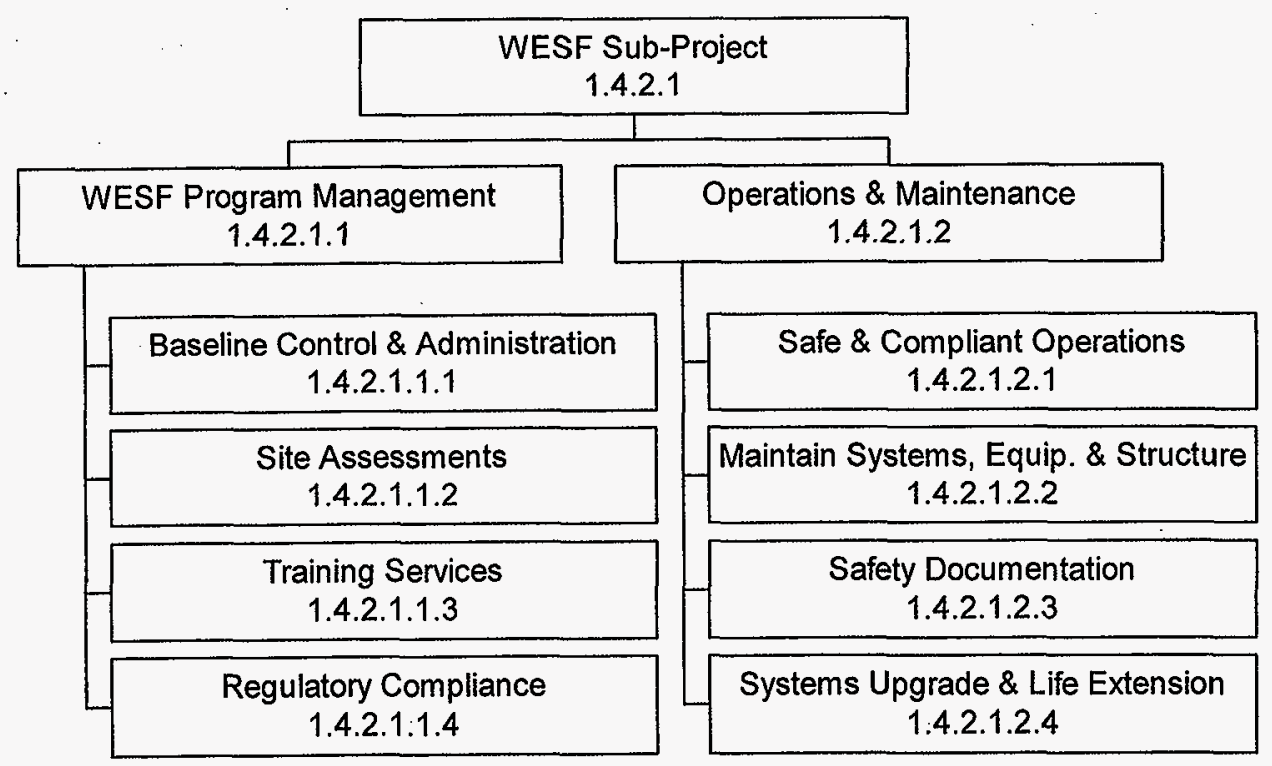


HANFORD SITE WORK BREAKDOWN STRUCTURE DICTIONARY

FACILITY STABILIZATION

WBS: 1.4

9/03/1997

\begin{tabular}{|l|c|c|c|c|}
\hline $\begin{array}{l}\text { 1. Activity Title: } \\
\text { PROGRAM MANAGEMENT AND ADMINISTRATION }\end{array}$ & $\begin{array}{l}2 . \begin{array}{l}\text { Date } \\
7 / 31 / 1997\end{array} \\
\begin{array}{l}\text { 3. PBS Number } \\
\text { RL-TPO2 }\end{array}\end{array}$ & $\begin{array}{l}\text { 4. Dict Rev } \\
0\end{array}$ \\
\hline
\end{tabular}

5. Contract WBS No.

1.4.2.1.1

6. Corresponding FDS No. 7. Baseline CR No. KWI

8. Organization Name

16000

10. Scope of Work

The Program Management and Administration activity includes program management and administrative support; site assessments; and training. Program management and administrative support includes schedule development and maintenance, budget/cost development and tracking, change control support, and corrective action management support. Site assessments provides funds for utilities, rail service, waste disposal, and computer network services. Training Services develops, presents, and evaiuates training materials and services necessary to maintain qualified plant personnel per DOE Orders and state and federal regulations.

Ensure operations are conducted in accordance with environmental, safety, $Q A$, and security requirements including RCRA, CAA, CWA, SDWA, NEAP, NHPA, safety, Radcon, and QA CFRs, and DOE Orders; perform regulatory selfassessments; provide safety and QA support; maintain qualified compliance staff; and administer regulatory compliance officer responsibilities. 
HANFORD SITE WORK BREAKDOWN STRUCTURE DICTIONARY FACILITY STABILIZATION

WBS: 1.4

\begin{tabular}{||l||l|l|l|}
\hline $\begin{array}{l}\text { 1. Activity TitTe: } \\
\text { WESF OPERATIONS AND MAINTENANCE }\end{array}$ & $\begin{array}{l}\text { 2. Date } \\
7 / 31 / 1997\end{array}$ & $\begin{array}{l}\text { 3. PBS Number } \\
\text { RL-TP02 }\end{array}$ & $\begin{array}{l}\text { 4. Dict Rev } \\
0\end{array}$ \\
\hline $\begin{array}{l}5 . \text { Contract WBS No. } \\
1.4 .2 .1 .2\end{array}$ & $\begin{array}{l}\text { 6. Corresponding FDS No. } \\
\text { KW2 }\end{array}$ & 7. Baseline CR No. \\
\hline $\begin{array}{l}\text { 8. Organization Name } \\
16000\end{array}$ & \\
\hline \hline
\end{tabular}

10. Scope of Work

Provide safe and compliant management of the $C s$ and $S r$ inventory within the WESF pool cells, hot cells, and ventilation systems pending their removal. Complete S\&M activities on those systems necessary to ensure operations are conducted within the facilities' safety and compliance envelopes. Update and implement operational and safety documentation to reflect current facility operations and conditions. 


$$
\text { WBS } 1.4
$$

Mission Area Responsibility Assignment Matrix

\begin{tabular}{|l|l|l|l|l|l|}
\hline $\begin{array}{l}\text { Proj LV1 } \\
\text { (PBS \#) }\end{array}$ & $\begin{array}{l}\text { FDS Act } \\
\text { Number }\end{array}$ & Activity Title & Activity Manager & Responsible Organization \\
\hline RL-TP02 & WESF SUB-PROJECT & & \\
\hline & KW1 & PROGRAM MANAGEMENT AND ADMINISTRATION & J. L. Pennock & 16000 \\
\hline & KW2 & WESF OPERATIONS AND MAINTENANCE & $\begin{array}{l}\text { KW102 } \\
\text { KW103 } \\
\text { KW104 }\end{array}$ & $\begin{array}{l}\text { KW201 } \\
\text { KW202 } \\
\text { KW203 } \\
\text { KW204 }\end{array}$ \\
\hline
\end{tabular}




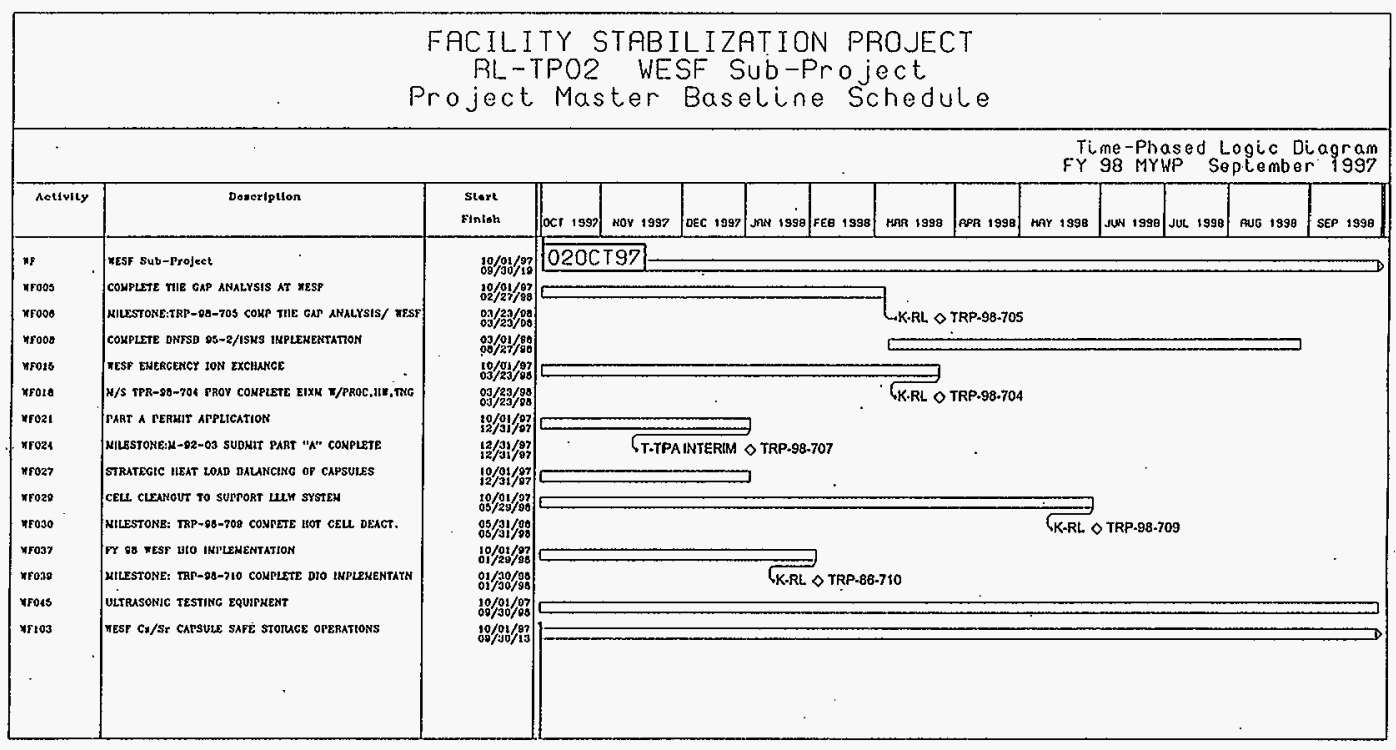




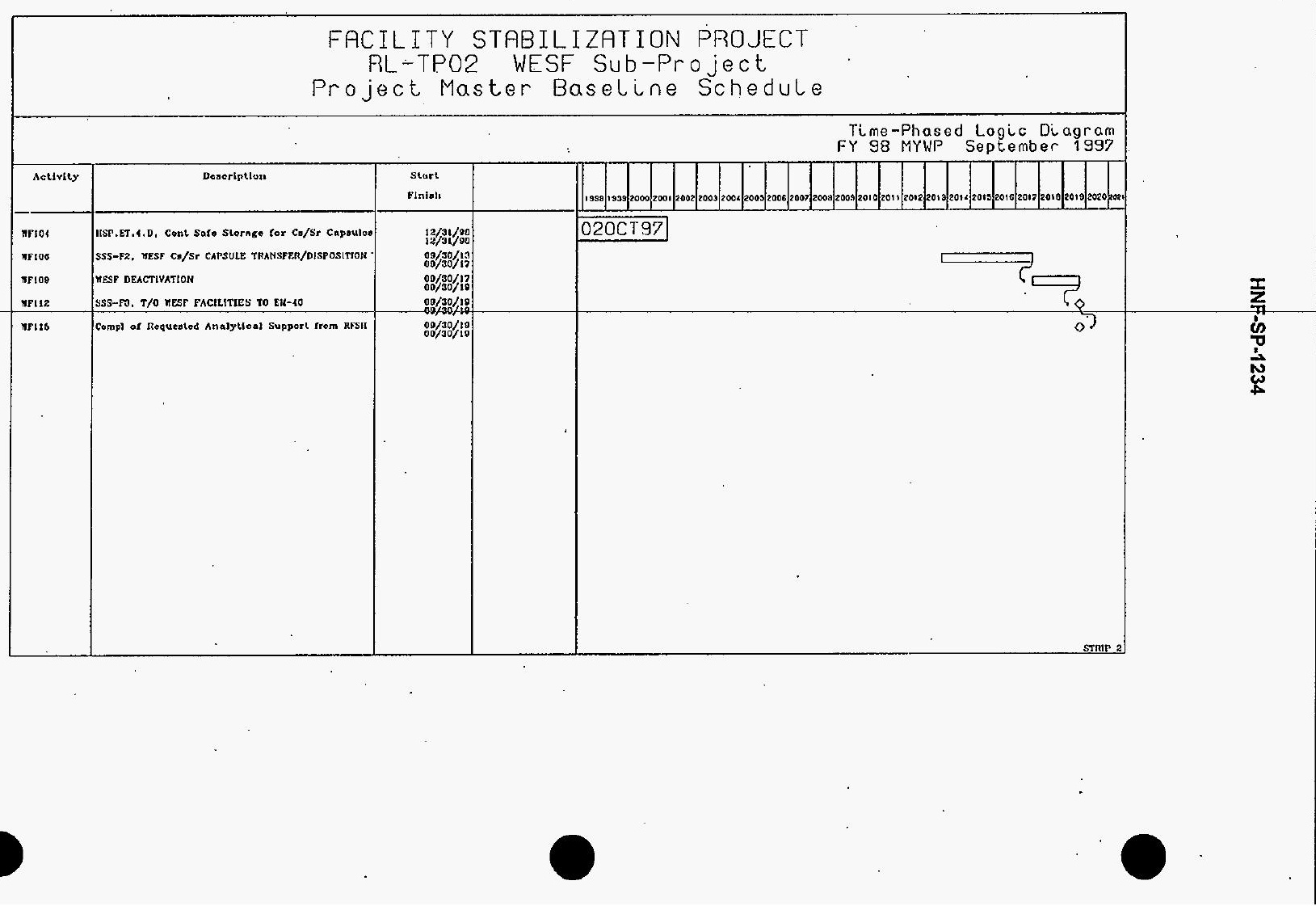




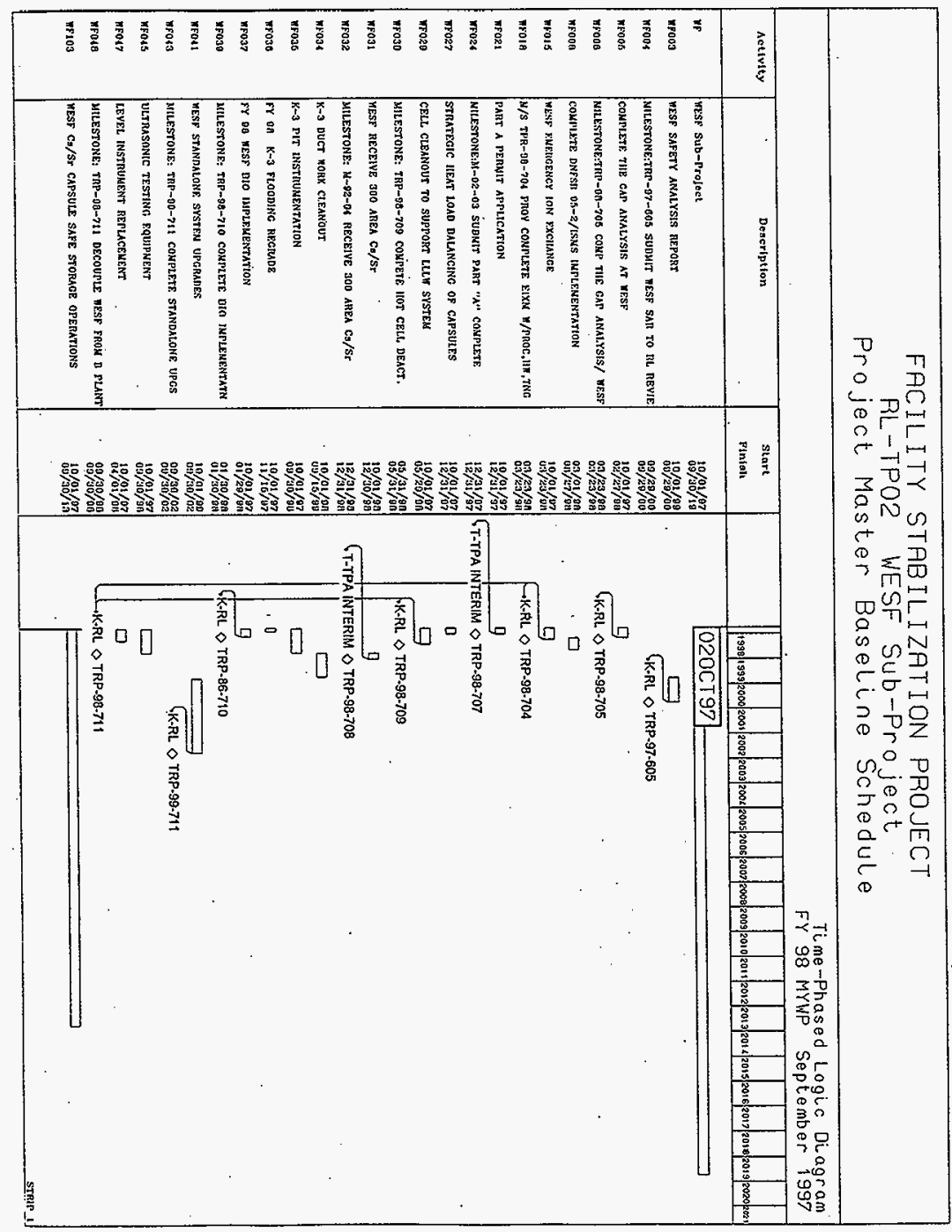




$\begin{array}{lccll}\begin{array}{l}\text { MILESTONE } \\ \text { CONTROL \# }\end{array} & \begin{array}{c}\text { TPA-MS } \\ \text { NUMBER }\end{array} & \begin{array}{c}\text { TPA } \\ \text { TYPE }\end{array} & \begin{array}{l}\text { MS } \\ \text { LEVEL }\end{array} & \text { MS TITLE } \\ \cdots & \ldots & \end{array}$

\begin{tabular}{|c|c|c|c|c|c|}
\hline TYPE & $\begin{array}{l}\text { PLANNED } \\
\text { BASE INE }\end{array}$ & $\begin{array}{l}\text { APPROVED } \\
\text { BASEL UNF }\end{array}$ & REVISED & POOI CIM & $P B S \#$ \\
\hline \multirow[t]{4}{*}{$\cdots$} & - & -........ & -........ & - & $\cdots$ \\
\hline & $9 / 30 / 00$ & & & TP-97-008 & RL-TP02 \\
\hline & $3 / 23 / 98$ & & & TP-97-014 & RL-TP02 \\
\hline & $3 / 23 / 98$ & & & & RL-TP02 \\
\hline EA & $12 / 31 / 98$ & & & & RL-TP02 \\
\hline \multirow[t]{5}{*}{$E A$} & $12 / 31 / 97$ & & & & RL-TP02 \\
\hline & $5 / 31 / 98$ & & & & RL-TP02 \\
\hline & $1 / 30 / 98$ & & & & RL-TP02 \\
\hline & $9 / 30 / 02$ & & & & RL-TP02 \\
\hline & $9 / 30 / 98$ & & & & RL-TP02 \\
\hline
\end{tabular}

RL DECOUPLE WESF FROM B-PLANT 


\section{PHMC}

\section{MILESTONE DESCRIPTION SHEET}

\begin{tabular}{|c|c|c|c|c|}
\hline \multicolumn{4}{|c|}{$\begin{array}{l}\text { Title: SUBMIT THE WESF SAFETY ANALYSIS REPORT (SAR) } \\
\text { TO RL FOR REVIEW }\end{array}$} & Date: $8 / 29 / 97$ \\
\hline \multicolumn{4}{|c|}{ Assigned To: BWHC/WESF Subproject } & CIN: TP-97-008 \\
\hline \multicolumn{4}{|c|}{ Program WBS Designator: 1.4.2.1 } & Due Date: $9 / 30 / 00$ \\
\hline \multicolumn{5}{|l|}{ PBS No: RL-TP02 } \\
\hline \multicolumn{2}{|c|}{ MC \#: TRP-97-605 } & TPA No: & & Rev: 1 \\
\hline $\begin{array}{l}\text { MILESTONE } \\
\text { LEVEL: } \\
\text { DOE-HQ } \\
\times \text { DOE-RL } \\
\text { DOE-FO } \\
\text { CONTRACTOR }\end{array}$ & $\begin{array}{l}\text { MILESTONE } \\
\text { TYPE: } \\
\text { EA } \\
\text { PEG } \\
\text { OTHER }\end{array}$ & $\begin{array}{l}\text { DNFSB STATUS: } \\
\text { DNFSB (Y/N): N } \\
\text { COMMIT \#: } \\
\text { RECOMM \#: }\end{array}$ & $\begin{array}{l}\text { DELIVERABLE: } \\
\\
X \text { Report } \\
X \text { Letter } \\
\text { Drawing (s) } \\
\text { Other (Specify) }\end{array}$ & $\begin{array}{l}\text { ADDRESS TO: } \\
\text { DOE-HQ } \\
\times \text { DOE-RL (Specify) } \\
\text { Other (Specif }\end{array}$ \\
\hline \multicolumn{5}{|c|}{$\begin{array}{l}\text { Milestone Description: } \\
\text { The WESF SAR wi } 71 \text { be upgraded to comply with current RL and BWHC } \\
\text { requirements. }\end{array}$} \\
\hline \multicolumn{5}{|c|}{$\begin{array}{l}\text { Description of what constitutes completion of this milestone: } \\
\text { Ten copies of the WESF SAR, approved in accordance with BWHC-MD-015 wi T1 be } \\
\text { deTivered to RL for review. }\end{array}$} \\
\hline
\end{tabular}




\section{PHMC}

MILESTONE DESCRIPTION SHEET

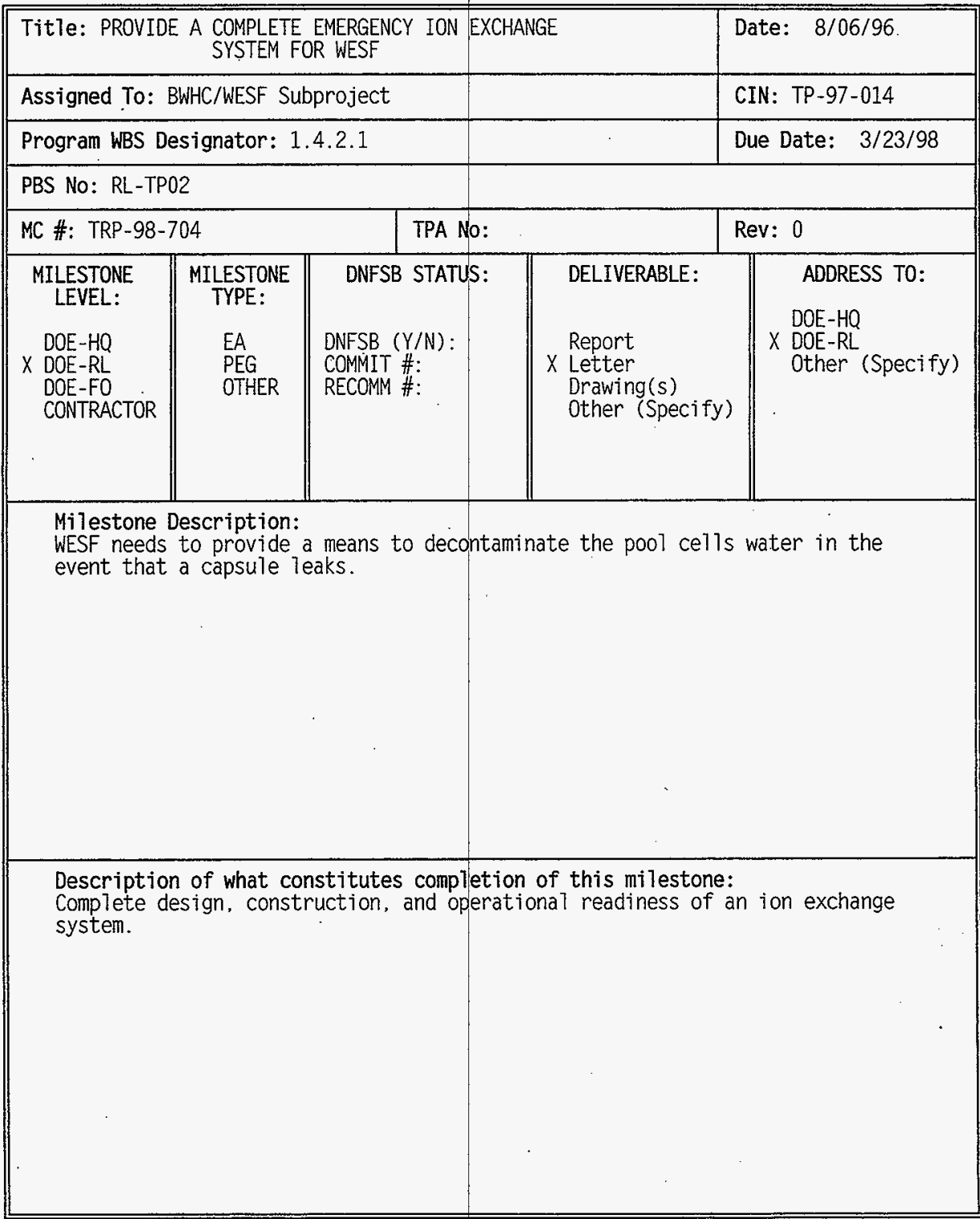


PHMC

MILESTONE DESCRIPTION SHEET

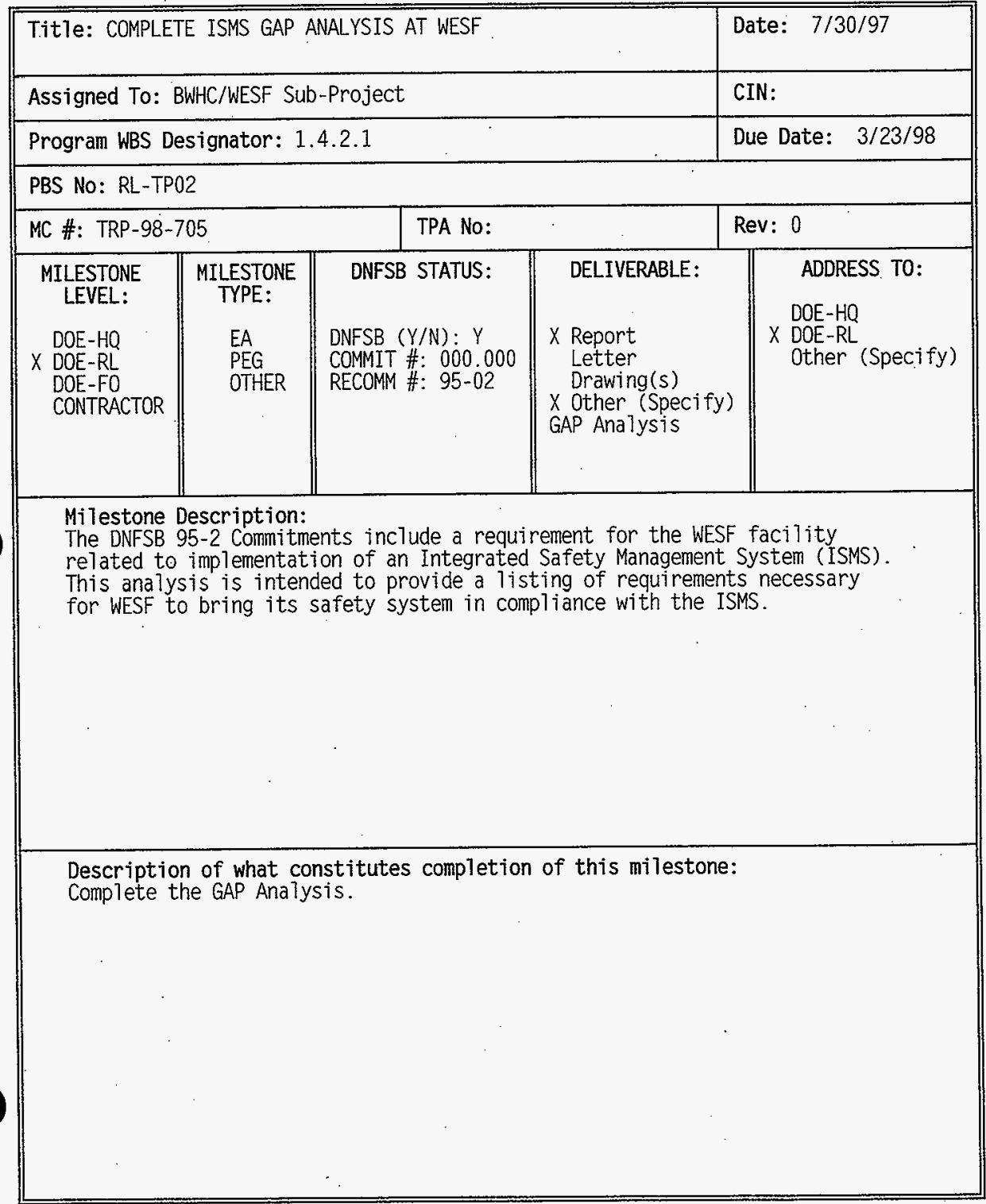




\section{PHMC}

MILESTONE DESCRIPTION SHEET

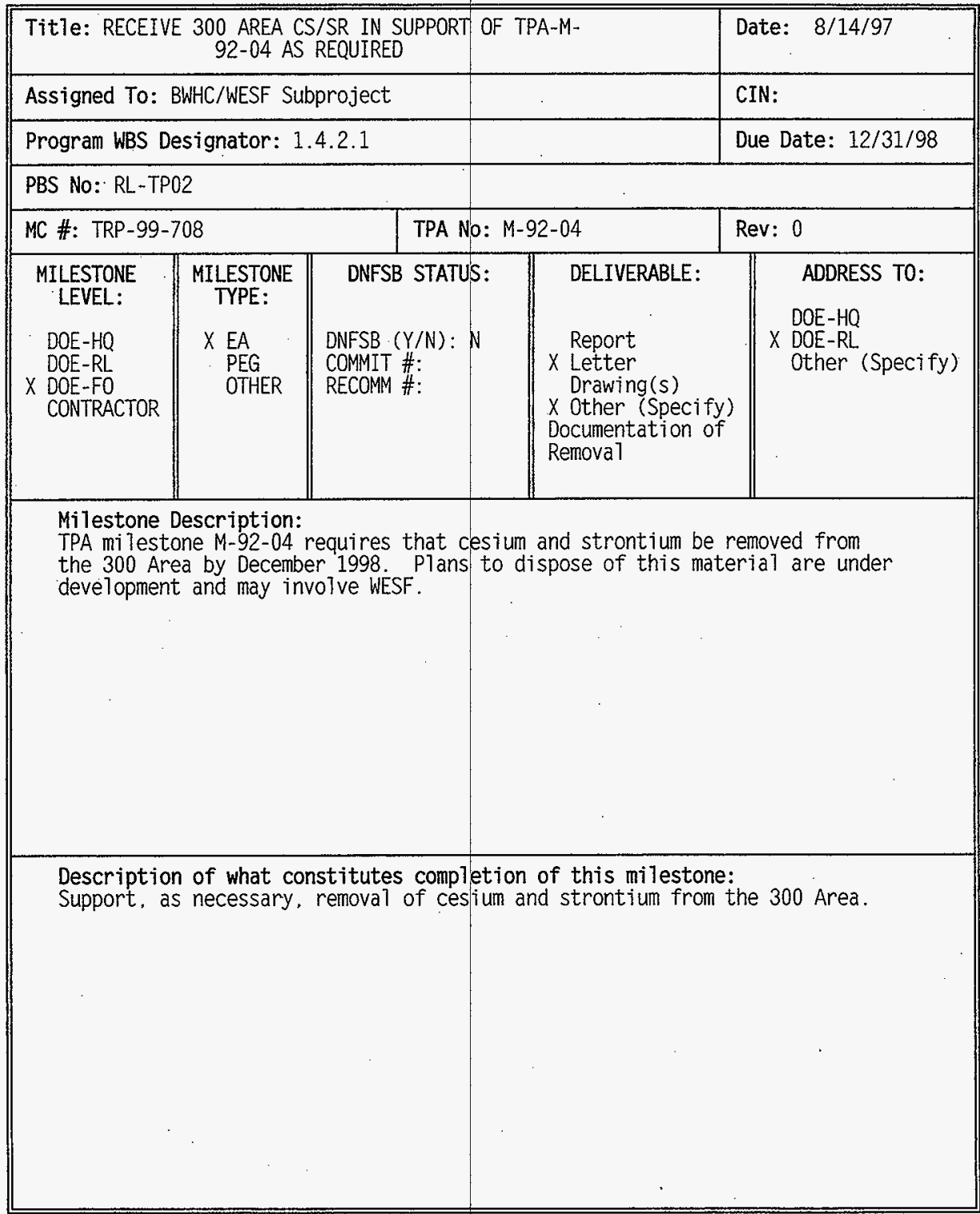


HNF-SP-1234

MILESTONE DESCRIPTION SHEET

Program WBS Designator: 1.4.2.1

Continuation Page

Milestone description: (con't)

This mi lestone incorporates the above agreement into the FY 1998 MYWP. 


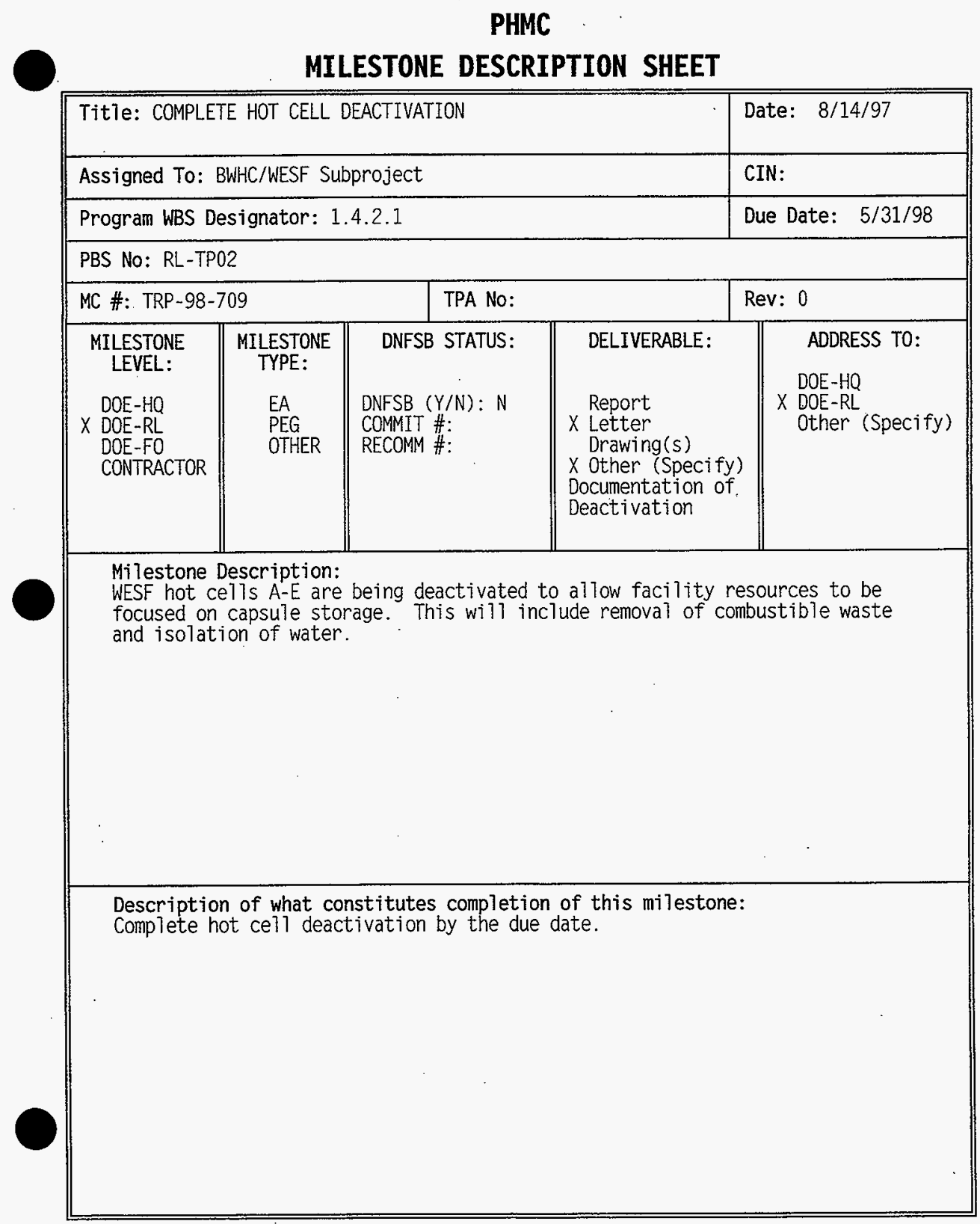


PHMC

MILESTONE DESCRIPTION SHEET

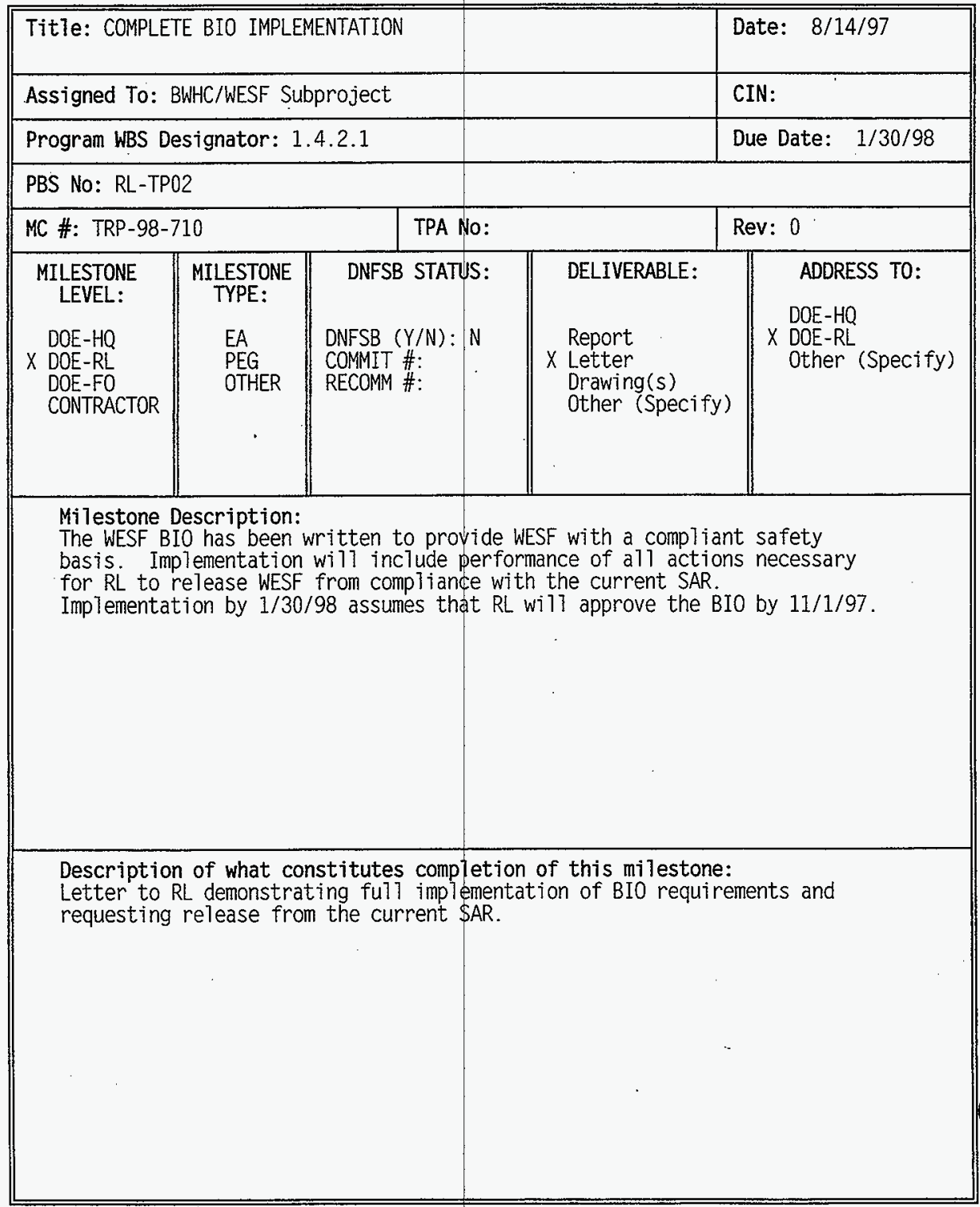




\section{PHMC \\ MILESTONE DESCRIPTION SHEET}

\begin{tabular}{|c|c|c|c|c|}
\hline \multicolumn{4}{|c|}{ Title: COMPLETE STANDALONE/SHOWCASE UPGRADES } & Date: $8 / 14 / 97$ \\
\hline \multicolumn{4}{|c|}{ Assigned To: BWHC/WESF Subproject } & CIN: \\
\hline \multicolumn{4}{|c|}{ Program WBS Designator: 1.4.2.1 } & Due Date: $9 / 30 / 02$ \\
\hline \multicolumn{5}{|c|}{ PBS No: RL-TP02 } \\
\hline \multicolumn{2}{|c|}{ MC \#: TRP-99-711 } & TPA No: & & Rev: 0 \\
\hline $\begin{array}{l}\text { MILESTONE } \\
\text { LEVEL: } \\
\text { DOE-HQ } \\
\times \text { DOE-RL } \\
\text { DOE-FO } \\
\text { CONTRACTOR }\end{array}$ & $\begin{array}{l}\text { MILESTONE } \\
\text { TYPE: } \\
\text { EA } \\
\text { PEG } \\
\text { OTHER }\end{array}$ & $\begin{array}{l}\text { DNFSB STATUS: } \\
\text { DNFSB }(Y / N): N \\
\text { COMMIT \#: } \\
\text { RECOMM \#: }\end{array}$ & $\begin{array}{l}\text { DELIVERABLE: } \\
\\
\text { Report } \\
\times \text { Letter } \\
\text { Drawing(s) } \\
\times \text { Other (Specify) } \\
\text { Documentation of } \\
\text { upgrades comp }\end{array}$ & $\begin{array}{l}\text { ADDRESS TO: } \\
\text { DOE-HQ } \\
\times \text { DOE-RL } \\
\text { Other (Specify) }\end{array}$ \\
\hline \multicolumn{5}{|c|}{$\begin{array}{l}\text { Milestone Description: } \\
\text { Complete upgrades in support of WESF standalone operation and attaining } \\
\text { showcase status; including pool cel1 level instrument upgrade, beta monitor } \\
\text { upgrades, ventilation system upgrades, communication systems upgrades, and } \\
\text { radiation monitoring equipment upgrades. }\end{array}$} \\
\hline \multicolumn{5}{|c|}{$\begin{array}{l}\text { Description of what constitutes completion of this milestone: } \\
\text { Complete specified upgrades. }\end{array}$} \\
\hline
\end{tabular}




\section{PHMC \\ MILESTONE DESCRIPTION SHEET}

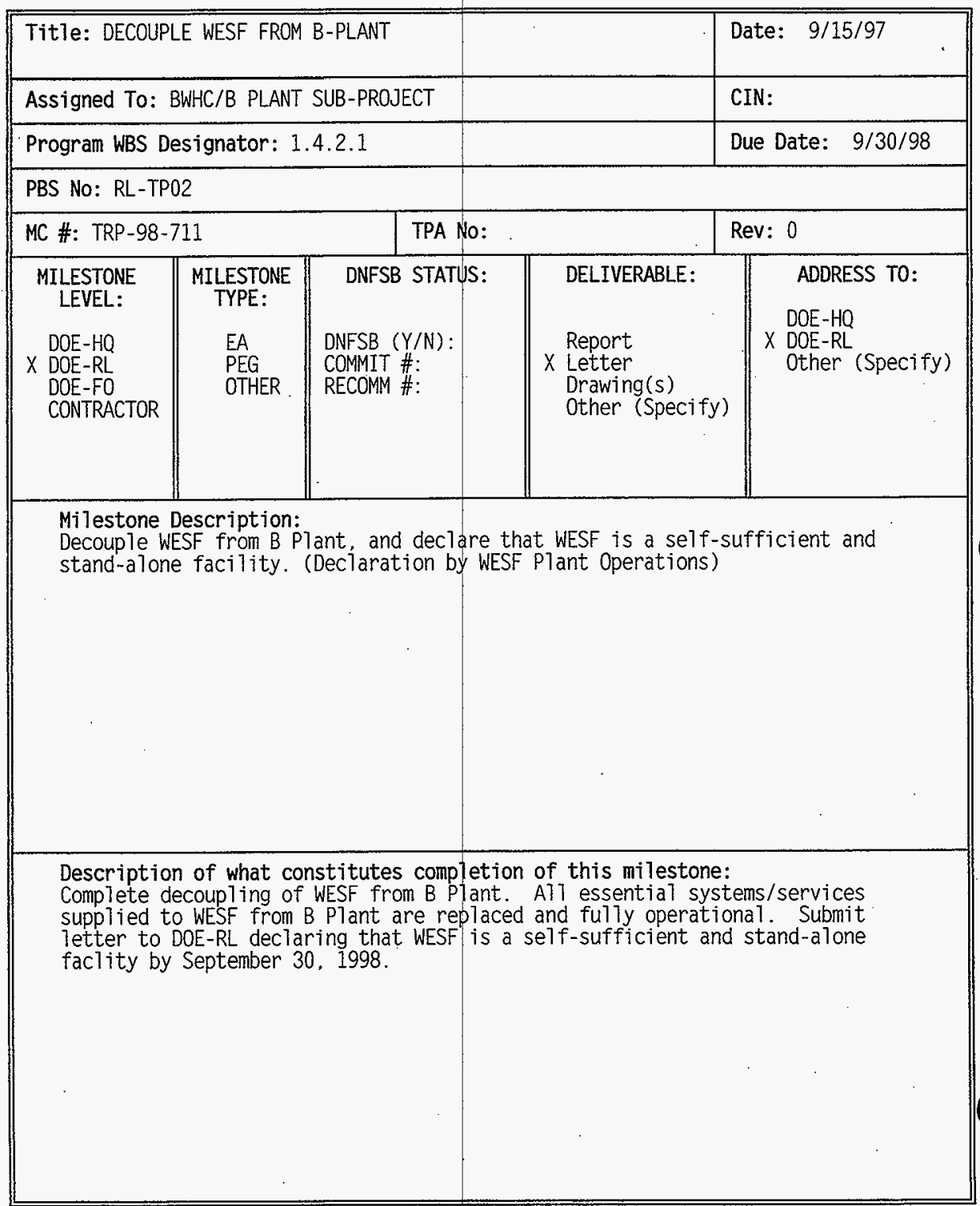


FACILITY STABILIZATION

LIFE CYCLE COST BASELINE (BCWS) BY YEAR BY FUND TYPE

BY PROJECT BASELINE SUMMARY (PBS)

FY 1998

\begin{tabular}{|c|c|c|c|c|c|c|c|c|c|c|c|}
\hline PROJECT WBS: & 1.4 .2 .1 & & & & & & & & & & \\
\hline PESNO: & RL-TPO2 & & & & & & & & & & \\
\hline PBS TITLE: & WESF Sub- & Project & & & & & & & & & SUETOT \\
\hline $\begin{array}{l}\text { FUND } \\
\text { TYPE }\end{array}$ & FY1997 & 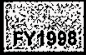 & FY1999 & FY2000 & FY2001 & FY2002 & FY2003 & FY2004 & FY2005 & FY2006 & $\begin{array}{l}\text { FY1997. } \\
\text { FY2006 }\end{array}$ \\
\hline OPERATING EXPENSE & 13,574 & K 13 , 1 & 10,747 & 16,157 & 12,597 & 12,479 & 12,467 & 12,247 & 13,034 & 13,254 & 129,669 \\
\hline & & Fis & & & & & & & & & \\
\hline CENRTC & & 18. & & & & & & & & & - \\
\hline & & $6 \%$ & & & & & & & & & \\
\hline GENERAL PLANT PROJECT & & W & & & & & & & & & - \\
\hline & & asing & & & & & & & & & \\
\hline LINE ITEM ( Ist Each Ong) & & \% & & & & & & & & & \\
\hline & & 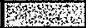 & & & & & & & & & - \\
\hline & & 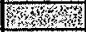 & & & & & & & & & . \\
\hline & & revers & & & & & & & & & - \\
\hline & & 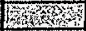 & & & & & & & & & - \\
\hline & & 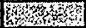 & & & & & & & & & - \\
\hline Subtotal Line ltems & - & 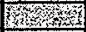 & $\therefore$ & - & - & $=$ & + & - & $\therefore$ & - & - \\
\hline & & Fing & & & & & & & & & \\
\hline 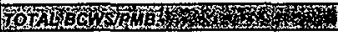 & W & m & 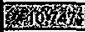 & 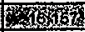 & 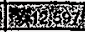 & (3) & 28 & 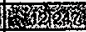 & (5) & 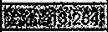 & 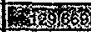 \\
\hline & & Whon & & & & & & & & & \\
\hline MGMT RESERVE ${ }^{2}$ & & 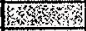 & & & & & & & & & - \\
\hline & & XX & & & & & & & & & \\
\hline LINE ITEM CONTINGENCY ${ }^{2}$ & & y.t. & & & & & & & & & $\because$ \\
\hline & & X & & & & & & & & & \\
\hline OFFSITE TRANSFERS ${ }^{3}$ & & Why & & & & & & & & & - \\
\hline & & Wist & & & & & & & & & \\
\hline Subtotal & - & \% स & - & - & $\dot{-}$ & - & $=$ & $\therefore$ & $=$ & + & - \\
\hline & & Xintw & & & & & & & & & \\
\hline 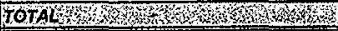 & $270,13,574$ & 543413 & 10,478 & Ens 6167 & 32357 & 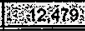 & 3. 12,67 & 320247 & 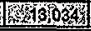 & 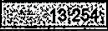 & 206669 \\
\hline
\end{tabular}

${ }^{1}$ Budgeted Cost of Work Scheduled (BCWS) Equals Performance Measurement Baseline (PMB);

Expense Camyover Not included.

${ }^{2}$ Management Reserve and Line liem Contingency Held by Rt.

'Work Performed at Sites Other Than Hanford. 
(\$000s)

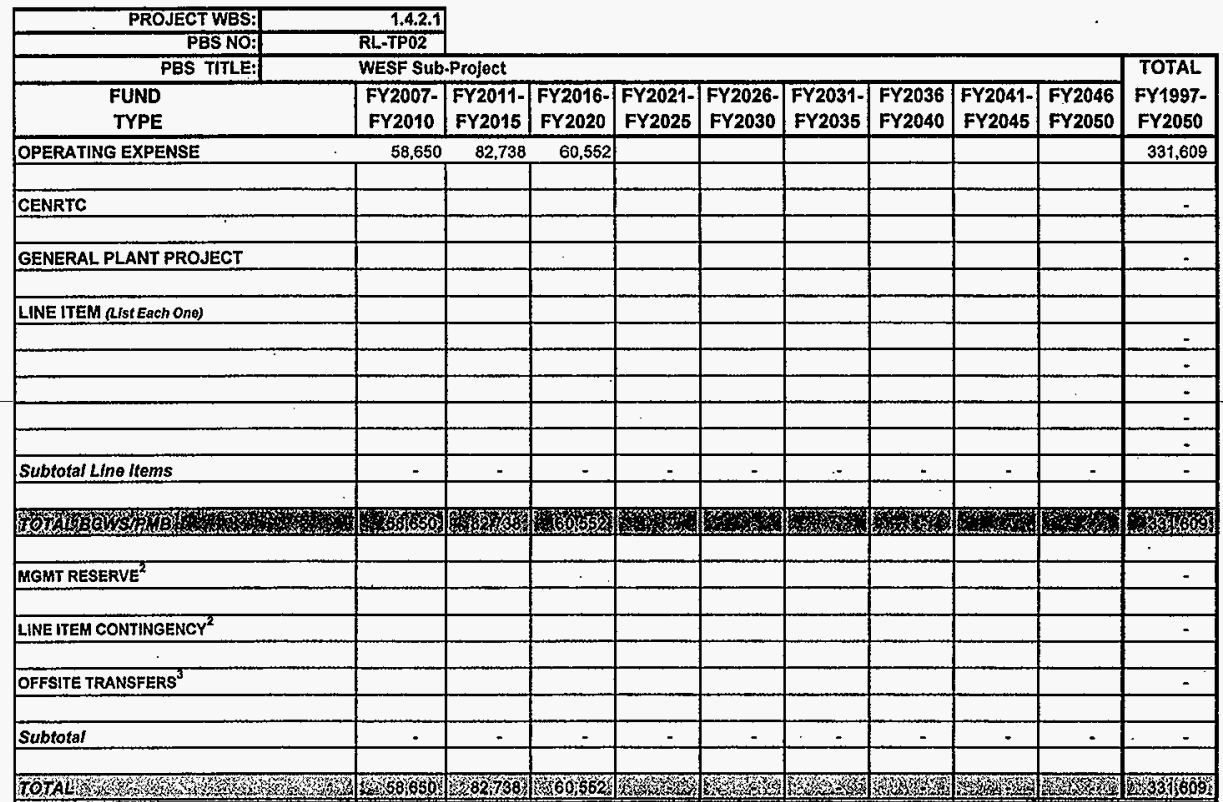

'Budgeted Cost of Work Scheduled (BCWS) Equals Performance Measurement Baseline (PMB);

Expense Carryover NOT Included.

${ }^{2}$ Management Reserve and LIne ltem Contingency Held by RL.

WWork Performed at Sites Other Than Hanford. 
FACILITY STABILIZATION

LIFE CYCLE BUDGET AUTHORITY (BIA) BY YEAR BY FUND TYPE BY PROJECT BASELINE SUMMARY (PBS)

FY 1998

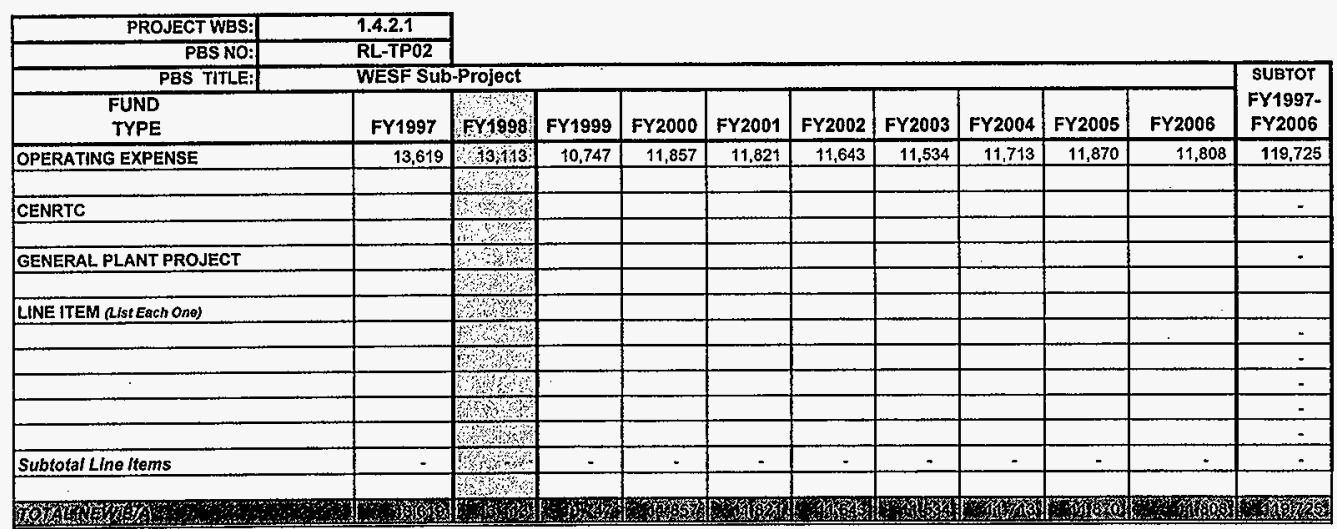


FACILITY STABILIZATION

LIFE CYCLE BUDGET AUTHORITY (B/A) BY YEAR BY FUND TYPE

BY PROJECT BASELINE SUMMARY (PBS)

FY 1998

(\$000s)

\begin{tabular}{|c|c|c|c|c|c|c|c|c|c|c|}
\hline PROJECTWBS: & 1.4.2.1 & & & & & & & & & \\
\hline PESNO: & RL-TP02 & & & & & & & & & \\
\hline PBS TITLE: & WESF SUI & D.Project & & & & & & & & TOTAL \\
\hline $\begin{array}{l}\text { FUND } \\
\text { TYPE }\end{array}$ & \begin{tabular}{|l|} 
FY2007- \\
FY2010
\end{tabular} & $\begin{array}{l}\text { FY2011- } \\
\text { FY2015 }\end{array}$ & $\begin{array}{l}\text { FY2016- } \\
\text { FY2020 }\end{array}$ & \begin{tabular}{|l|}
$F Y 2021-$ \\
FY2025
\end{tabular} & $\begin{array}{l}\text { FY2026- } \\
\text { FY2030 }\end{array}$ & $\begin{array}{l}\text { FY2031- } \\
\text { FY2035 }\end{array}$ & $\begin{array}{l}\text { FY2036 } \\
\text { FY2040 }\end{array}$ & \begin{tabular}{|l|}
$F Y 2041$ \\
FY2045
\end{tabular} & \begin{tabular}{|l|} 
FY2046 \\
FY2050
\end{tabular} & $\begin{array}{l}\text { FY1997- } \\
\text { FY2050 }\end{array}$ \\
\hline OPERATING EXPENSE & 58,650 & 82,738 & 60,552 & & & & & & & 321,665 \\
\hline & & & & & & & & & & \\
\hline \multirow{2}{*}{\multicolumn{11}{|c|}{ CENRTC }} \\
\hline & & & & & & & & & & \\
\hline GENERAL PLANT PROJECT & & & & & & & & & & - \\
\hline & & & & & & & & & & \\
\hline \multicolumn{11}{|l|}{ LINE ITEM (u/st Each One) } \\
\hline & & & & & & & & & & - \\
\hline & & & & & & & & & & $\therefore$ \\
\hline & & & & & & & - & & & - \\
\hline & & & & & & & & & & - \\
\hline Subtotal Line Items & - & - & - & - & $\div$ & - & - & - & - & $\therefore$ \\
\hline Fent & & & & & & & & & & \\
\hline
\end{tabular}




\section{FACILITY STABILIZATION}

FY 1998 COST BASELINE (BCWS) BY MONTH

BY PROJECT BASELINE SUMMARY (PBS)

BY ACTIVITY DATA SHEET (ADS)

EXECUTION YEAR

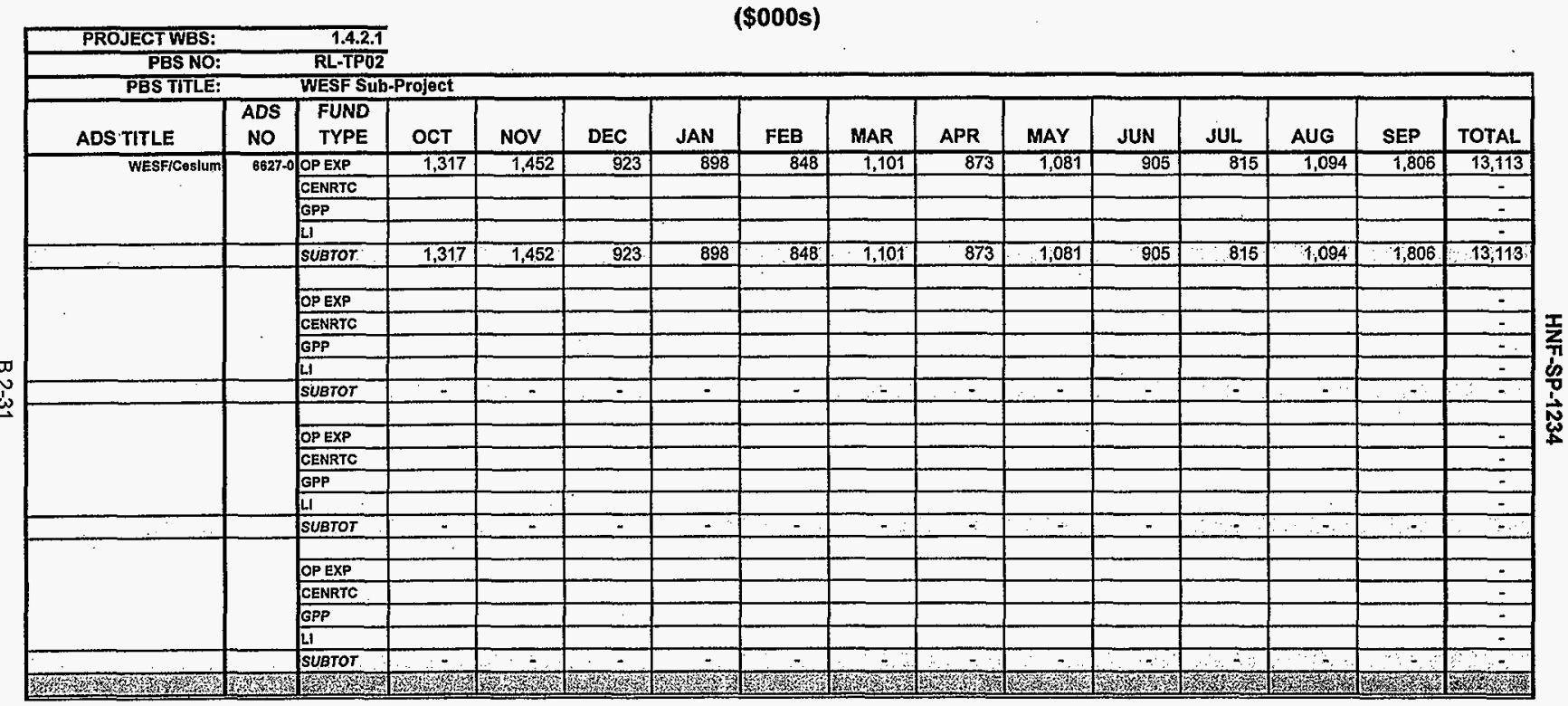

'Budgeted Cost of Work Scheduled (BCWS) Equals Performance Measurement Baseline (PMB); Expense Carryover is NOT Included. 
WESF SUB-PROJECT

AVERAGE ANNUAL FULL TIME EQUIVALENTS

(includes Major Subcontractors but not Enterprise Companies)

PHBS 1.4.2.1

Submittal Date: 9/10/97

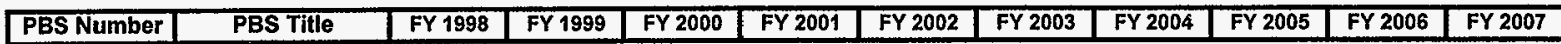

RL-TP02 WESF Subproject

76

80

77

71

72

75

75

75

75

75

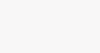

20

$\underline{\underline{80}} \underline{\underline{77}}$

11

$\underline{72}$

$\underline{75}$

$\underline{75}$

$\underline{75}$


0

-

○ 


\section{B.3 PUREX Sub-Project (RL-TP03)}

\section{B.3.1.0 PUREX Sub-Project Technical Baseline (RL-TP03)}

\section{B.3.1.1 PUREX Sub-Project Organization Mission (RL-TP03)}

This program element includes the transition of the PUREX Plant and the necessary S\&M throughout transition. The goal of the transition project is to achieve safe and environmentally secure facilities. PUREX surveillance will be assumed by D\&D Long-Tem Surveillance and Maintenance (RL-ER08) starting in FY 1998.

\section{B.3.1.2 PUREX Sub-Project End Point Targets from Hanford Strategic Plan}

-None-

\section{B.3.1.3 PUREX Sub-Project Major Facilities}

\section{B.3.1.3.1 Plutonium-Uranium Extraction Plant Facility}

\section{B.3.1.3.1.1 Plutonium-Uranium Extraction Plant Facility Description}

Commonly referred to as the PUREX facility, it is a surplus facility in the 200 -W Area of Hanford which was originally built to separate plutonium and uranium from Hanford reactor fuel. PUREX was deactivated in 1997 and is in a surveillance and maintenance mode awaiting D\&D activities. Various ancillary facilities which supported PUREX are included.

\section{B.3.1.3.1.2 Plutonium-Uranium Extraction Plant Facility Technical Logic:}

The Department of Energy (DOE), in partnership with its contractors, shall plan, acquire, operate, maintain, and dispose of physical assets as valuable national resources. Stewardship of these physical assets shall be accomplished in a cost-effective manner to meet the DOE mission. This shall incorporate industry standards, a graded approach, and periormance objectives. 


\section{B.3.1.3.1.3 Plutonium-Uranium Extraction Plant Requirements and Life Cycle Function Descriptions Requirements:}

* Facilities discharging to the 200 Area TEDF shall implement Best Available Technology (BAT)/All Known, Available, and Reasonable Treatment (AKART). The generator shall provide the information required by WAC 173-240, Submission of Plans and Reports for Construction of Waste Water Facilities.

* Central Plateau inactive facilities shall be maintained within the approved safety envelope

* PUREX shall be maintained within the approved safety envelope

\section{Life Cycle Function Descriptions:}

\section{B.3.1.3.1.3.1 PLUTONIUM-URANIUM EXTRACTION PLANT PROGRAM PLANNING WORK SCOPE SUMMARY}

Functions that include planning and developing the overall program; establishing broad priorities; providing program technical direction; preparing and defending the program budget; controlling milestones; integrating all components of the program; providing public and private sector policy liaison; expediting interface activities and follow-up actions; and retaining overall accountability for program success.

Tumover of the PUREX Facility to EM-40 for long-tem surveillance and maintenance is anticipated to occur prior to FY 1998.

\section{PLUTONIUM-URANIUM EXTRACTION PLANT PROGRAM PLANNING SPECIFIC FUNCTIONS}

\section{B.3.1.3.1.3.2 PLUTONIUM-URANIUM EXTRACTION PLANT POST OPERATIONS WORK SCOPE SUMMARY}

Day-to-day work, including post-deactivation surveillance and maintenance, that is required to allow safe decontamination and decommissioning.

\section{PLUTONIUM-URANIUM EXTRACTION PLANT POST OPERATIONS SPECIFIC FUNCTIONS}

\section{B.3.1.3.1.3.3 Maintain Safe \& Compliant Plutonium Uranium Extraction Plant Facility in CP Areas}

Maintain the PUREX facility structures, operating systems and equipment, and monitoring systems within the approved safety and compliance requirements until the facilities are made available for D \& D.

\section{B.3.1.3.1.4 Plutonium-Uranium Extraction Plant Boundary Diagram}

Table B.3-1 Plutonium-Uranium Extraction Plant Boundary Diagram

\begin{tabular}{|c|c|}
\hline $\begin{array}{l}\text { Extemal Interfaces } \\
\text {-None } \\
\text { Hantord Site Environmental System Interfaces } \\
\text { hsems.2.5.4 Central Piateau Water Systern } \\
\text { hsems.2.5.5 Central Plateau Office Facilities } \\
\text { hsems.2.5.6 Central Plateau Electrical System } \\
\text { hsems.2.5.9 Central Plateau Shop Facilities } \\
\text { hsems.2.5.13 Central Plateau Road System } \\
\text { hsems.4.7. } 331 \text { Complex }\end{array}$ & $\begin{array}{l}\text { External Interfaces } \\
\text {-None- } \\
\text { Hanford Site Environmental System Interiaces } \\
\text { isems.2.3.2 Double Shell Tank (DST) System } \\
\text { hsems.2.4.3 200.0 Area Treated Ethuent Disposal Facility }\end{array}$ \\
\hline
\end{tabular}




\section{B.3.1.3.1.5 Plutonium-Uranium Extraction Plant Interface Description and Forecast}

\section{EXTERNAL INPUTS}

-None-

INTERNAL INPUTS

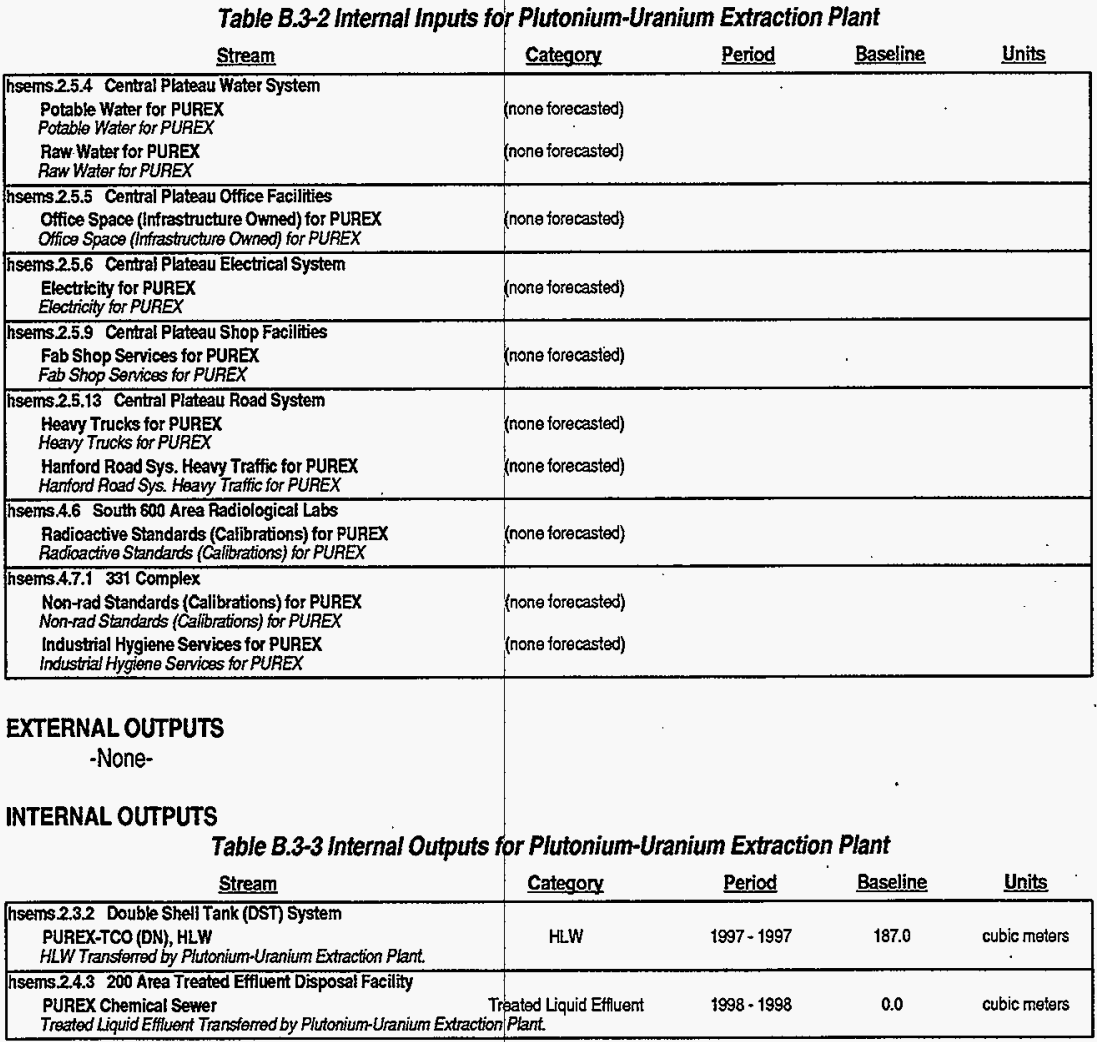




\section{B.3.1.4 Drivers for PUREX Sub-Project}

\section{Table B.3-4 Source Documents for PUREX Sub-Project}

Name

DOE/RL-96-14

Title

ST 4502

Updated Draft Mission Direction Document, June 1996 State Waste Discharge Permit for the 200 Area TEDF

\section{B.3.1.5 PUREX Sub-Project Risk Management}

Because PUREX is now in a log-term, low risk surveillance and maintenance status, any Risk Management information for the PUREX Sub-Project is included in RL-ER05 


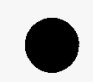




\section{B.4300 Area/SNH Sub-Project (RL-TP04)}

\section{B.4.1.0 300 Area/SNM Sub-Project Technical Baseline (RL-TP04)}

\section{B.4.1.1 300 Area/SNM Sub-Project Organization Mission (RL-TP04)}

The history of the 300 Area Fuel Supply Shutdown (FSS) complex began in 1943 when the 313 Building was constructed. Other buildings were added in time to support production of fuel for the Hanford Single Pass Reactor, which began in mid-1944. Starting in 1958, the 333 Building was constructed to support fuel fabrication for the N-Reactor. Fuel fabrication activities continued until 1987 when both $N$ Reactor and the FSS facility began a transition-to-standby status. In 1982, the FSS complex was directed to deactivate in preparation for decontamination and decommissioning (D\&D). The complex contains remaining legacies of the fuel fabrication and fuel storage mission and still includes approximately 1200 metric tons (MT) of unirradiated, low enriched fuel, which is stored in five buildings managed by FSS until relocation or final disposition. The original SNM inventory generated from fuel production operations also resulted in significant contamination of buildings and equipment, and large amounts of hazardous, mixed, and low level wastes. Due to the age of the buildings, they are showing signs of structural decay. Unsafe roof conditions in the 313 Building south side represent a large safety risk.

The FSS project's main objective is to complete deactivation/closure activities as described in the "Shutdown Plan for the 300 Area Fuel Supply Facilities," (WHC-SD-FL-SSP-002), and the facility transfer criteria while maintaining the complex in a safe, regulatory-compliant state until tumover to Environmental Restoration (ER) Project is completed. Deactivation of the Fuel Supply complex will decrease human and environmental risk by stabilizing the buildings to levels of contamination consistent with its intended long term surveillance and eventual demolition status. Relocation of the remaining inventory of Special Nuclear Materials (SNM) will reduce risk of any possible contamination to the site, nearby river, and City of Richland.

The project is subdivided into five major objectives:

1. Maintain facilities in a regulatory-compliant state until turnover to the ER Project is completed. This includes the surveillance and storage of the remaining $1200 \mathrm{MT}$ of SNM until relocation of material to the 400 Area or altemate location.

2. Complete the isolation of the 313 South Building to reduce the safety risks of an unsafe roof.

3. Closure of two remaining Resource Conservation and Recovery Act (RCRA) permitted Treatment, Storage, and Disposal (TSD) systems.

4. Complete deactivation/stabilization activities as described in the "Shutdown Plan for the 300 Area Fuel Supply Facilities." This includes stabilization of all facility buildings and deactivation of building systems to meet the predetermined endpoint criteria established with ER.

5. Relocation/disposal of $1200 \mathrm{MT}$ of low level enriched SNM. This material will be packaged and relocated in FY 2000 (under current funding) and will allow final facility shutdown.

This project will be followed by turnover to the ER Project for decontamination and decommissioning.

The planning assumptions for the 300 Area Fuel Supply shutdown are

- Resource Conservation and Recovery Act (RCRA) of 1976 implementation activities shall be carried out in accordance with the following RCRA closure plans:

- DOE/RL-90-04, 303K Storage Facility Closure Plan

- DOE/RL-90-11, The 300 Area Waste Acid Treatment System (WATS) Closure Plan 
- These RCRA closures involve the north half of $303 \mathrm{~K}$ Building as well as portions of facilities $(333,303 \mathrm{~F}, 334 \mathrm{~A}$, and the 334 and 311 Storage Tanks). The closure plans describe the sampling, characterization, and investigative studies to be performed in these facilities; defines their hazard potential; and identifies required corrective actions. The 300 Area/SNM Sub-Project will perform closure activities for buildings and equipment under EM-60.

- The WATS Plan is listed in the Hanford Facility RCRA permit (Appendix 27) for inclusion in MOD $C$ of the permit. A permit modification is being prepared by Ecology to move WATS Closure to MOD D of the permit.

- The 300 Area FSS facilities are located within 300 FF-2 operable unit, as designated in the Tri-Party Agreement (Ecology et al. 1996). The $300 \mathrm{FF}-2$ operable unit is scheduled to be remediated by the ERC Contractor under EM-40 using the CERCLA remediation investigation/feasibility study process. Therefore, any soil and groundwater contamination related to the RCRA activities will be deferred to the CERCLA remediation investigation/feasibility study process unless contamination is an imminent threat to human health or the environment. The 300 Area Facility $303 \mathrm{M}$ RCRA closure plan has not been prepared, but closure is deferred to the $300 \mathrm{FF}-2$ CERCLA Operable Unit (M-20-92-05).

- Transition Project Management (RL-TP-12) will assume the funding and risk for storage of the 300 FSS inventory of SNM and the 200 West Area UO3 inventory after 300 Area FSS deactivation is complete. Any inventory of SNM remaining after the date specified in the integrated baseline schedule will be declared waste and packaged for disposal.

- It is assumed that when the 300 Area FSS SNM is relocated, the alternate facility selected will be the responsibility of Transition Project Management. Additional building modifications (if any) will be funded separately and incorporated by Change Request at that time.

\section{B.4.1.2 300 Area/SNM Sub-Project End Point Targets from Hanford Strategic Plan}

* Transition high cost surplus facilities in the central plateau and south 600 areas to a low cost, stable, deactivated condition.

* Transfer Special Nuclear Material from the south 600 area facilities to the 200 Area for interim storage.

\section{B.4.1.3 300 Area/SNM Sub-Project Major Facilities}

\section{B.4.1.3.1 300 Area Fuel Supply System Facility}

\section{B.4.1.3.1.1 300 Area Fuel Supply System Facility Description}

The Fuel Fabrication Facility was constructed to manufacture fuel elements for Hanford single pass reactors and later for N Reactor using low enrichment uranium.

\section{B.4.1.3.1.2 300 Area Fuel Supply System Facility Technical Logic:}

The Department of Energy (DOE), in partnership with its contractors, shall plan, acquire, operate, maintain, and dispose of physical assets as valuable national resources. Stewardship of these physical assets shall be accomplished in a cost-effective manner to meet the DOE mission. This shall incorporate industry standards, a graded approach, and performance objectives. 
HNF-SP-1234

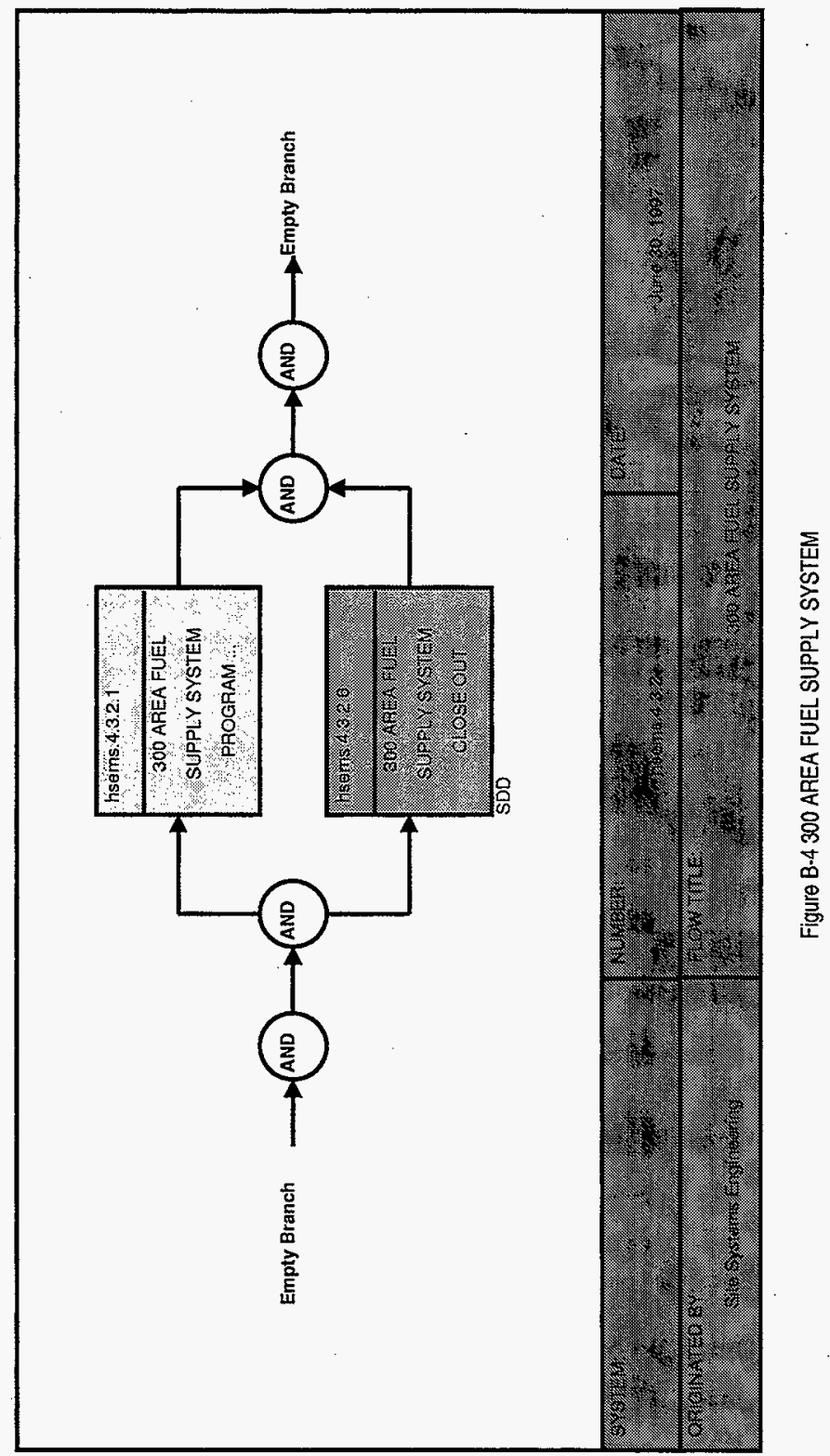




\section{B.4.1.3.1.3 300 Area Fuel Supply System Requirements and Life Cycle Function Descriptions}

Requirements:

* South 600 Area high cost surplus facilties shall be transitioned to a low cost, stable, deactivated condition

* 300 Area Fuel Supply System special nuclear materials shall be relocated to outside the 300 Area.

- South 600 Area inactive facilities shall be surveillanced and maintained within the approved safety envelope

- 300 Area Fuel Supply System SNM contained in various buildings shall be surveillanced and maintained within the approved safety envelope.

\section{Life Cycle Function Descriptions:}

\section{B.4.1.3.1.3.1 300 AREA FUEL SUPPLY SYSTEM PROGRAM PLANNING WORK SCOPE SUMMARY}

Functions that include planning and developing the overall program; establishing broad priorities; providing program technical direction; preparing and defending the program budget; controlling milestones; integrating all components of the program; providing public and private sector policy liaison; expediting interface activities and follow-up actions; and retaining overall accountability for program success.

\subsection{2 300 AREA FUEL SUPPLY SYSTEM POST OPERATIONS WORK SCOPE SUMMARY}

Day-to-day work, including pre-stabilization surveillance and maintenance, stabilization, post-stabilization surveillance and maintenance, deactivation, and post-ceactivation surveillance and maintenance, that is required to allow saie decontamination and decommissioning.

\section{AREA FUEL SUPPLY SYSTEM POST OPERATIONS SPECIFIC FUNCTIONS}

\section{B.4.1.3.1.3.3 Maintain Safe \& Compliant 300 Area Fuel Supply System}

This system includes 303F, 303K, 303M, 304, 313, 333, 334, 334A, 303A, 303B, 303E, 303G, 3707G, 3712, $334 \mathrm{TF}, 304 \mathrm{~A}, 311 \mathrm{TF}, \mathrm{MO}-052$, and 3716 Facilities. These facilities have been used to prepare fuel for the early production reactors.

\section{B.4.1.3.1.3.4 Maintain Safe \& Compliant Materials in 300 Area Fuel Supply System}

Materials stored in the 300 Area Fuel Supply System facilities will be maintained in safe and compliant state until they are relocated to a warehouse outside the 300 area.

\section{B.4.1.3.1.3.5 Remove Material from 300 Area Fuel Supply System}

Remove the nuclear materials from the 300 Area Fuel Supply System Facilities for treatment or disposition.

\section{B.4.1.3.1.3.6 Transition 300 Area Fuel Supply System}

Initiate the facility transition phase of decontamination and deactivation for the 300 Area Fuel Supply System Facilities. 
HNF-SP-1234

\section{B.4.1.3.1.4 300 Area Fuel Supply System Boundary Diagram}

Table B.4-1 300 Area Fuel Supply System Boundary Diagram

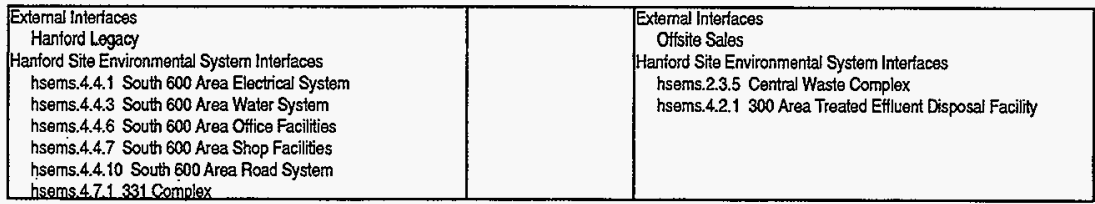




\section{B.4.1.3.1.5 300 Area Fuel Supply System Interface Description and Forecast}

\section{EXTERNAL INPUTS}

\section{Table B.4-2 Extemal Inputs for 300 Area Fuel Supply System}

\begin{tabular}{|c|c|c|c|c|}
\hline Stream & Category & Period & Baseline & Units \\
\hline \multicolumn{5}{|l|}{ X.O Hanford Legacy } \\
\hline $\begin{array}{l}\text { Legacy } 3 \text { oufFS Depleted Uranitum } \\
\text { Depleted Uranium (OU) Transferred by Hantord Legacy. }\end{array}$ & Depleted Uranium (DU) & $1997 \cdot 1997$ & 2.2 & MTIU \\
\hline $\begin{array}{l}\text { Legacy 3torfss Low Enriched Uranium } \\
\text { Low Ennched Uranium (LEU) Transferred by Hanford Legacy. }\end{array}$ & Low Enriched Uranium (LEU) & $1997-1997$ & 1110 & MT.U \\
\hline $\begin{array}{l}\text { Legacy 300/FSS Natural Uranium } \\
\text { Natural Uranium (NU) Transferred by Hanford Logacy. }\end{array}$ & Natural Uranium (NU) & $1997-1997$ & 74.0 & MTIU \\
\hline
\end{tabular}

\section{INTERNAL INPUTS}

Table B.4-3 Internal Inputs for 300 Area Fuel Supply System

\begin{tabular}{|c|c|c|c|c|}
\hline Stream & Category & Period & Baseline & Units \\
\hline $\begin{array}{l}\text { hsems.4.4.1 South 600 Area Electrical System } \\
\text { Electricity for } 300 \text {-FSS } \\
\text { Electricity for } 300 \text {-FSS }\end{array}$ & Electricity & $1998-1999$ & 764.0 & MW-hr \\
\hline $\begin{array}{l}\text { hsems } 4.4 .3 \text { Solth } 6 \% 9 \text { Area Water System } \\
\text { Potable Water for 300-FSS } \\
\text { Potable Water for 300-FSS }\end{array}$ & Potable Water & 1998 - 1999 & 224.0 & Mgal \\
\hline $\begin{array}{l}\text { hsems.4.4.6 South 600 Area Office Facilities } \\
\text { Office Space (Infrastructure Owned) for 300-FSS } \\
\text { Office Space (Infrastructure Owned) for 300-FSS }\end{array}$ & $\begin{array}{c}\text { Office Space (tintrastructure } \\
\text { Owned) }\end{array}$ & $1998-1999$ & 177000 & sq. th. \\
\hline $\begin{array}{l}\text { hseins.4.4.7 South } 600 \text { Area Shop Facilities } \\
\text { Lifting (Cranes) for 300-FsS } \\
\text { Lfting (Cranes) for 300-FSS }\end{array}$ & Litting Services & $1998-1999$ & 288.0 & crane days \\
\hline $\begin{array}{l}\text { hsems.4.4.10 South } 600 \text { Area Road System } \\
\text { Sedans/light Trucks for 300-FSS } \\
\text { SedansLight Trucks for 300-FSS }\end{array}$ & Sodans/Light Trucks & $1998-1999$ & 2.0 & no. of vehicles \\
\hline $\begin{array}{l}\text { hisems } 4.7 .1331 \text { Complex } \\
\text { Non-rad Standards (Calibrations) for 300-FSS } \\
\text { Non-rad Standards (Calibrations) for 300-FSS }\end{array}$ & $\begin{array}{l}\text { Non-rad Standards Lab } \\
\text { Services }\end{array}$ & $1998-1999$ & 8.0 & calibrations \\
\hline
\end{tabular}

\section{EXTERNAL OUTPUTS}

Table B.4-4 Extemal Outputs for 300 Area Fuel Supply System

\begin{tabular}{|c|c|c|c|c|}
\hline Stream & Category & Period & Baseline & Units \\
\hline \multicolumn{5}{|l|}{$\sqrt{\mathrm{X} \text { Offsite Sales }}$} \\
\hline $\begin{array}{l}\text { 300/FSS Low Enriched Uranium (Offsite) } \\
\text { Low Enriched Uranivm (LEU) Disposed by } 300 \text { Area Fuel Supply Sy }\end{array}$ & $\begin{array}{l}\text { Enriched Uranium (LEU) } \\
\text { stem. }\end{array}$ & $2000 \cdot 2000$ & 233.0 & MTIU \\
\hline $\begin{array}{l}\text { 300/FSS Natural Uranium } \\
\text { Natural Uranium (NU) Trarsferred by } 300 \text { Area Fuel Supply System. }\end{array}$ & Natural Uranium (NU) & $1997-1998$ & 148.0 & MT-U \\
\hline
\end{tabular}

\section{INTERNAL OUTPUTS}

Table B.4-5 Internal Outputs for 300 Area Fuel Supply System

\begin{tabular}{|c|c|c|c|c|}
\hline Stream & Category & Period & Baseline & Units \\
\hline \multicolumn{5}{|l|}{ hsems2.3.5 Central Waste Complex } \\
\hline $\begin{array}{l}\text { 30uFsS Depleted Uranium } \\
\text { Depleted Uranium (DU) Disposed by } 300 \text { Arsa Furel Supply System. }\end{array}$ & Opleted Urarium (DU) & $1997-2005$ & 19.8 & MT-U \\
\hline $\begin{array}{l}\text { 300/FSS Low Enriched Uranium } \\
\text { Low Enrichod Uranium (LEU) Disposed by } 300 \text { Area Fuel Supply Sy. }\end{array}$ & $\begin{array}{l}\text { Enrichod Uranium (LEU) } \\
\text { ystem. }\end{array}$ & $1997 \cdot 2007$ & 9510 & MTIU \\
\hline \multicolumn{5}{|l|}{ hseins.4.2.1 300 Area Treated Effluent Disposal Facility } \\
\hline $\begin{array}{l}300 \text { Area Fuel Supply System Industrial Waste Water } \\
\text { Transfer } \\
\text { Industrial waste water generated from ongoing } 300 \text { Area Fuel Suppiy } \\
\text { throughput and assuming equal contribution from all inputs to the } 30\end{array}$ & $\begin{array}{l}\text { ndustrial Waste Water } \\
\text { System operations. Wa } \\
\text { OOArea Process Sewer. }\end{array}$ & $1998-2005$ & 200000 & cu meters \\
\hline
\end{tabular}




\section{B.4.1.4 Drivers for 300 Area/SNM Sub-Project}

Table B.4-6 Source Documents for 300 Area/SNM Sub-Project

Name

DOE/EIS-0222D

DOEJRL-96-14

DOE/RL-96-92
Title

Draft Hanford Remedial Action Environmental Impact Statement and Comprehensive Land Use Plan

Updated Draft Mission Direction Document, June 1996

Hanford Strategic Plan

\section{B.4.1.5 300 Area/SNM Sub-Project Risk Management}

Risk Evaluation Narrative:

This project will deactivate the 300 Area Fuel Supply Shutdown facility at the end of FY 2000 and tum it over to Environmental Restoration for surveillance and maintenace pending final disposition.

Driving risk scenarios include:) The 313South Building roof which is deteriorating and presently a risk to personnel entering the building to perform compliance assessments and for those located in the north end of the building. The 313 South Building was constructed in the mid 1940s. Of the 1,207 precased concrete roof deck panels, 131 are defective. Of these, $70 \%$ could fall at any time. Three structural members have suffered a $25 \%$ reduction in capacity. A similar roof failed at $100 \mathrm{~F}$ area with a loss of life. Worker risks include possible injuries resulting in permanent partial or temporary total disability. Once isolation of this building is completed injuries would still be possible, but the possibility greatly reduced.

The second driving risk scenario involves the inventory storage of 1200 metric tons of SNM and potential fire. This scenario involves site, public, and environmental health. In the event of fire, a consequent release of airbome, respirable uranium could occur. The FSS facility is approximately 490 meters from the west bank of the Columbia River and approximately 1104 meters from a farm directly across the river. The maximum expected radiological release from a uranium storage building fire is 0.250 rem Effective Dose Equivalent (EDE) offsite ( 490 meters from the source). The corresponding toxicological consequence (maximum 1-hr airborne concentrations) is $0.21 \mathrm{mg} / \mathrm{U} / \mathrm{m} 3$ uranium offsite. These release values were calculated in the Interim Safety Basis assuming minimum surveillance and preventive/corrective maintenance activities are being performed. Therefore, without minimum safe surveillance and maintenance, accumulation of additional combustible material and facility deterioration would increase the probability and the severity of its consequences. Public risks include expected injuries/itiness that result in partial or temporary reversible impacts or exposures at or below regulatory levels.

In the event that the project stops, and minimum safe surveillance and maintenance including safety assessments, corrective maintenance and surveillance would not be pertormed. In addition, the facility would be unoccupied, and utilities, including the protection system, are shutdown and unavailable. Accumulation of combustible materials is possible, since no surveillance would occur. The risks to the site and public therefore would be greater with the possibility that a fire in one of the uranium storage buildings would not be promptly extinguished. The probability of such an uncontrolled random fire has been calculated to be $1.6 \mathrm{E}-07$ per year.

With the project ongoing, the possibility of a fire could still occur with risks to the environment. Dispersal of airborne uranium following a uranium storage building would result in a $3.1 \mathrm{mg} \mathrm{U} / \mathrm{m} 3$ onsite (receptor at 100 meters form the fire) and $0.21 \mathrm{mg} \mathrm{U} / \mathrm{m} 3$ at the site boundary. If accumulation of additional combustible material resulted in a more severe fire and facility deterioration, these values could be larger. Onsite, this uranium would be deposited on a combination of hard surfaces (other buildings and asphalt) and dirt. The hard surfaces require difficult, time consuming decontamination to remove the contamination to the point where radiological contamination is no longer detected. The contamination that falls on dirt is readily removed by simply removing the top few inches of ditt and 
disposing of it as low level waste. The quantity of uranium that falls in the Columbia River would be quickly dispersed below levels of detection. Environmental risks are based on the hard surface decontamination with moderate damage with geographic impacts with a two-five year recovery. 


\section{Area/SNM Sub-Project Work Breakdown Structure}

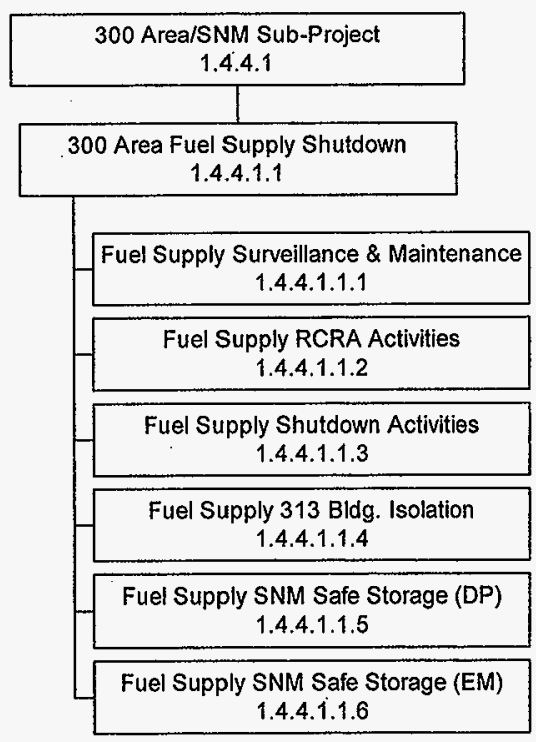


HANFORD SITE WORK BREAKDOWN STRUCTURE DICTIONARY

FACILITY STABILIZATION

WBS: 1.4

$9 / 04 / 1997$

\begin{tabular}{|c|c|c|c|c|c|}
\hline \multicolumn{2}{|c|}{$\begin{array}{l}\text { 1. Activity Title: } \\
\text { FUEL SUPPLY SHUTDOWN ACTIVITIES }\end{array}$} & \multicolumn{2}{|c|}{$\begin{array}{l}\text { 2. Date } \\
7 / 31 / 1997\end{array}$} & $\begin{array}{l}\text { 3. } \text { PBS Number } \\
\text { RL-TP04 }\end{array}$ & $\begin{array}{l}\text { 4. Dict Rev } \\
0\end{array}$ \\
\hline $\begin{array}{l}\text { 5. Contract WBS No. } \\
1.4 .4 .1 .1\end{array}$ & $\begin{array}{l}\text { 6. Correspc } \\
\text { K } 3 A\end{array}$ & S No. & 7. Bas & seline CR No. & \\
\hline \multicolumn{2}{|l|}{$\begin{array}{l}\text { 8. Organization Name } \\
19120\end{array}$} & & & & $\begin{array}{l}\text { 9. B \& R No. } \\
\text { EW70/DPO4 }\end{array}$ \\
\hline
\end{tabular}

10. Scope of Work

The Fuel Supply Shutdown (FSS) facility is being maintained in a regulatory compliant state and proceeding with Shutdown Activities as described in the 'Shutdown Plan for the 300 Area Fuel Supply Facilities.'

This sub-project includes management, budget support, engineering, maintenance support, health physics, industrial safety, and operational personnel to maintain environmental and personnel safety by complying with State and Federal regulations, including IOCFR rules. AT so included are required surveillance and maintenance necessary to manage the safe storage of Special Nuclear Materiais (SNM).

The FSS scope also includes the RCRA Closure of the 303K Facility and the 300 Area Waste Acid Treatment System (WATS). Support is also provided for the continuing monthly meeting with the Washington State Department of Ecology regarding these closure activities. Support is also provided for building isolation of the south portion of the 313 Facility and for necessary roof repairs needed to transfer buildings to EM- 40 . 
Mission Area Responsibility Assignment Matrix

\begin{tabular}{|l|l|l|l|l|l|}
\hline $\begin{array}{l}\text { Proj LV7 } \\
\text { (PBS \#) }\end{array}$ & $\begin{array}{l}\text { FDS Act } \\
\text { Number. }\end{array}$ & Activity. Title & Activity Manager & Responsible Organization & Cost Account \\
\hline RL-TP04 & & 300 AREA/SNM SUB-PROJECT & & & \\
\hline & K3A & FUEL SUPPLY SHUTDOWN ACTIVITIES & I. L. Metca\}f & 19120 & $\begin{array}{l}1 \mathrm{~K} 3 \mathrm{AO01} \\
1 \mathrm{~K} 3 \mathrm{A02} \\
1 \mathrm{~K} 3 \mathrm{A05} \\
1 \mathrm{~K} 3 \mathrm{A06}\end{array}$ \\
\hline
\end{tabular}




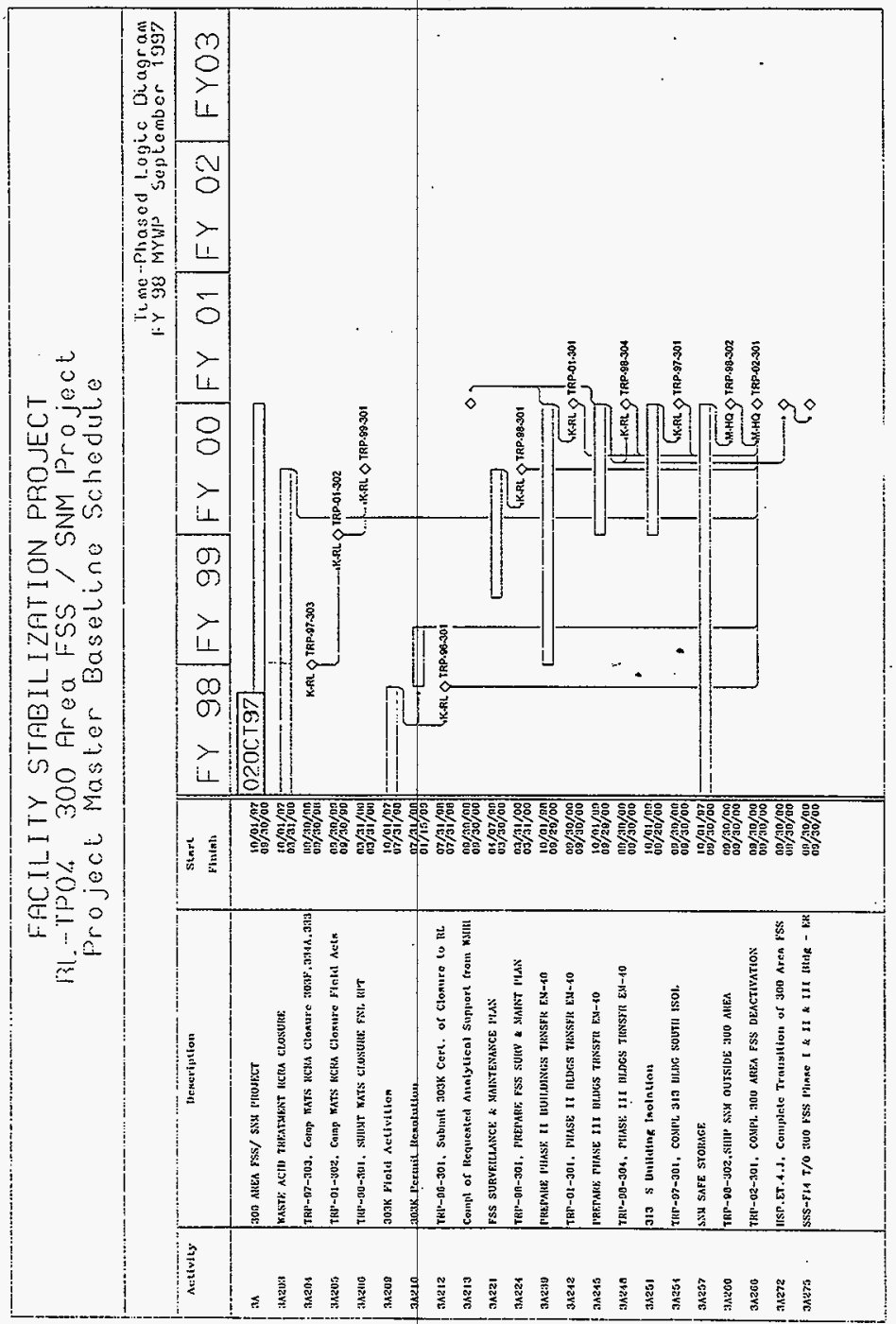




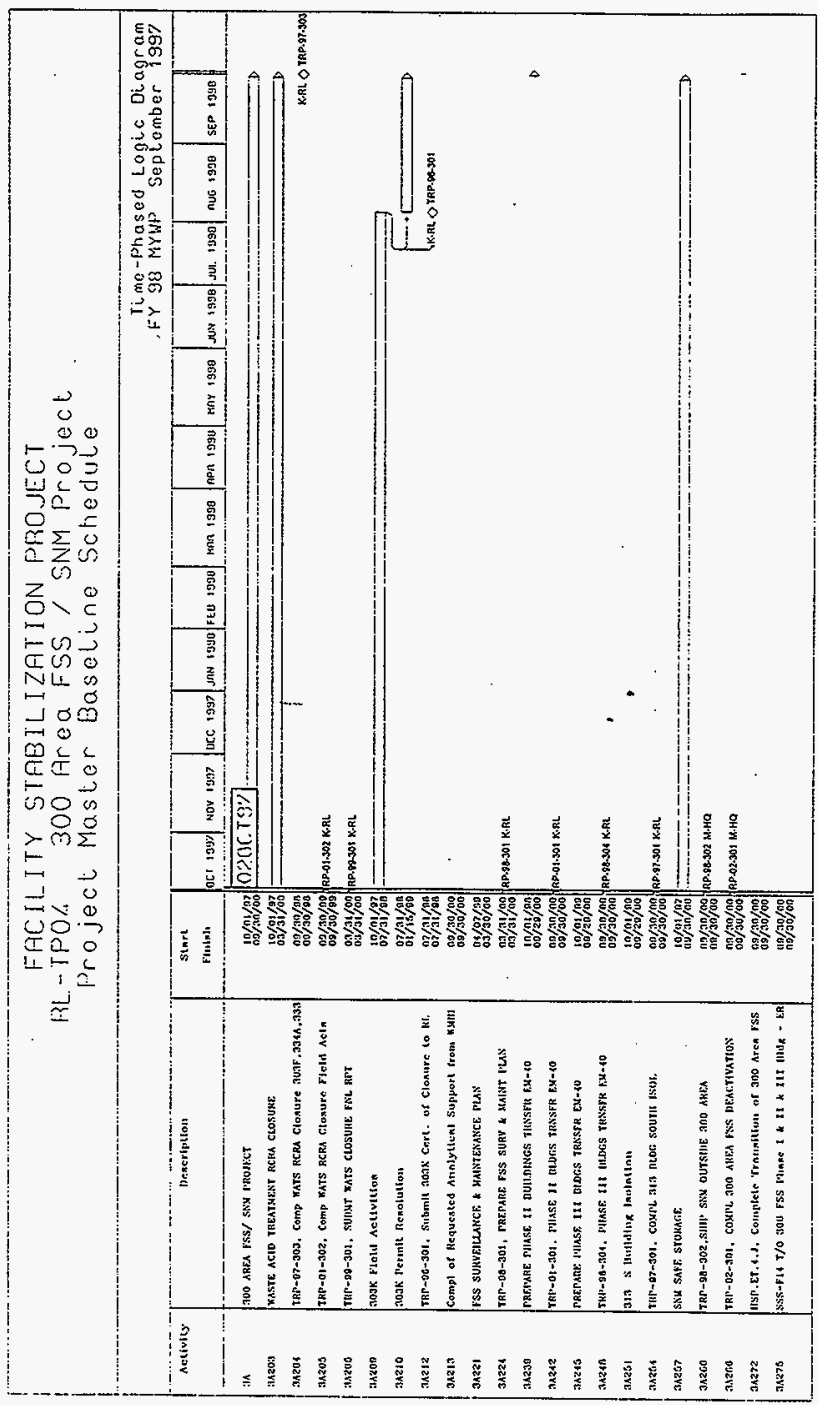




$\begin{array}{lrll}\text { MILESTONE } & \text { TPA-MS } & \text { TPA } & \text { MS } \\ \text { CONTROL \# } & \text { NUMBER TYPE LEVEL } & \text { MS TITLE } \\ \ldots & & & \end{array}$

TRP-97-301 TRP $-98-301$

RL COMPLETE ISOLATION OF 313 BUILDING SOUTH SIDE

RL PREPARE FUEL SUPPLY SURVEILLANCE AND MAINTENANCE PLAN

TRP-98-302

HQ SHIP BALANCE OF SNM TO WAREHOUSE OUTSIDE 300 AREA

TRP $-98-304$

RL PHASE III BUILDINGS PREPARED FOR TRANSFER TO EM-40

TRP-99-301

RL SUBMIT FINAL REPORT ON WATS CLOSURE ACTIVITIES TO RL.

TRP $-01-301$

RL PHASE II BUILDINGS PREPARED FOR TRANSFER TO EM-40

RL COMPLETE WASTE ACID TREATMENT SYSTEM RCRA CLOSURE FIELD ACTYS

TRP-97-303

RL COMPLETE WATS CLOSURE FIELD ACTYS IN 303F, 334A AND 333 BLDG

TRP-96-301

RL: SUBMIT 303K CERTIFICATE OF CLOSURE TO RL

TRP-02-301

HQ COMPLETE 300 AREA FUEL SUPPLY DEACTIVATION

\begin{tabular}{|c|c|c|c|c|c|}
\hline & PLANNED & APPROVED & REVISED & & \\
\hline TYPE & BASELINE & BASELINE & BASELINE & PROJ CIN & PBS \# \\
\hline \multirow[t]{3}{*}{$\cdots$} & -.......... & --.-- & (......... & $\cdots$ & \\
\hline & $.9 / 30 / 00$ & $12 / 12 / 97$ & & TP-97-008 & RL-TP04 \\
\hline & $3 / 31 / 00$ & & & & RL-TP04 \\
\hline \multirow[t]{7}{*}{ OTH } & $9 / 30 / 00$ & $9 / 30 / 98$ & & TP-97-008 & RL-TP04 \\
\hline & $9 / 30 / 00$ & & & & RL-TP04 \\
\hline & $3 / 31 / 00$ & & & & RL-TP04 \\
\hline & $9 / 30 / 00$ & $9 / 30 / 97$ & & TP-97-008 & RL-TP04 \\
\hline & 9/30/99 & & & & RL-TP04 \\
\hline & $9 / 30 / 98$ & 9/30/97 & & TP-97-008 & RL-TP04 \\
\hline & $7 / 31 / 98$ & $9 / 30 / 96$ & & TP-97-008 & RL-TPO4 \\
\hline ОТН & $9 / 30 / 00$ & & & TP-97-008 & RL-TP04 \\
\hline
\end{tabular}




\section{PHMC \\ MILESTONE DESCRIPTION SHEET}

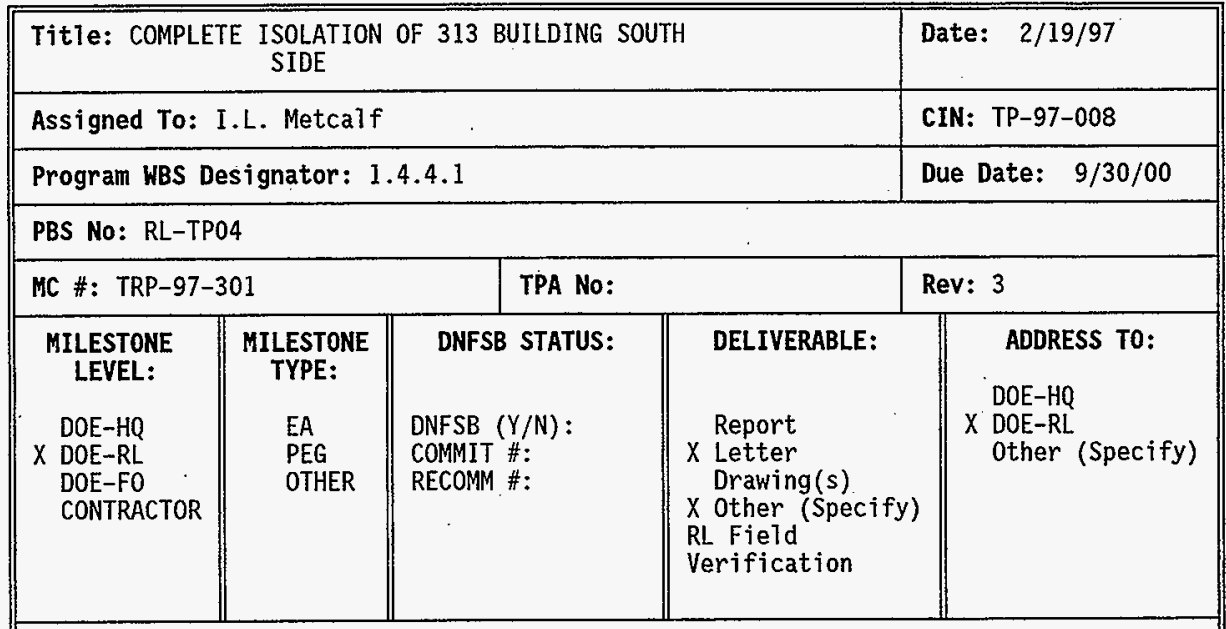

Milestone Description:

Isolation of 313 South Building access, removal of 313 South Building utilities, removal of 313 South Building roof loadings (i.e. HVAC units, etc.), completion of NEPA, historical studies, and sampling/ characterization activities, and removal of unattached radiologicaliy contaminated materials.

Description of what constitutes completion of this milestone:

Field verification by RL representative that the major isolation scope (i.e. access control, material stabilization, etc.) has been completed and the building is isolated. 


\section{PHMC \\ MILESTONE DESCRIPTION SHEET}

\begin{tabular}{|c|c|c|c|c|}
\hline \multicolumn{3}{|c|}{$\begin{array}{l}\text { Title: PREPARE FUEL SUPPLY SURVEILLANCE } \\
\text { MAINTENANCE PLAN }\end{array}$} & AND & Date: $2 / 19 / 97$ \\
\hline \multicolumn{3}{|c|}{ Assigned To: I.L. Metcalf } & & CIN: \\
\hline \multicolumn{3}{|c|}{ Program WBS Designator: 1.4 .4 .1} & & Due Date: $3 / 31 / 00$ \\
\hline \multicolumn{5}{|c|}{ PBS No: RL-TPO4 } \\
\hline \multicolumn{2}{|c|}{ MC \#: TRP-98-301 } & TPA N & No: & Rev: 1 \\
\hline $\begin{array}{l}\text { MILESTONE } \\
\text { LEVEL: } \\
\text { DOE-HQ } \\
\text { X DOE-RL } \\
\text { DOE-F0 } \\
\text { CONTRACTOR }\end{array}$ & $\begin{array}{l}\text { MILESTONE } \\
\text { TYPE: } \\
\text { EA } \\
\text { PEG } \\
\text { OTHER }\end{array}$ & $\begin{array}{l}\text { DNFSB STATU } \\
\text { DNFSB }(Y / N): \\
\text { COMMIT \#: } \\
\text { RECOMM \#: }\end{array}$ & $\begin{array}{l}\text { DELIVERABLE: } \\
\times \text { Report } \\
\text { Letter } \\
\text { Drawing(s) } \\
\text { 0ther (Specify) }\end{array}$ & $\begin{array}{l}\text { ADDRESS TO: } \\
\text { DOE-HQ } \\
\times \text { DOE-RL } \\
\text { Other (Specify) }\end{array}$ \\
\hline \multicolumn{5}{|c|}{$\begin{array}{l}\text { Milestone Description: } \\
\text { Prepare a supporting document which establishes the surveillance and } \\
\text { maintenance (S\&M) activities after deactivation of the Fuel Supply Shutdown } \\
\text { complex. }\end{array}$} \\
\hline \multicolumn{5}{|c|}{$\begin{array}{l}\text { Description of what constitutes completion of this milestone: } \\
\text { Transmittal of S\&M plan to RL for approvaT. }\end{array}$} \\
\hline
\end{tabular}




\section{PHMC \\ MILESTONE DESCRIPTION SHEET}

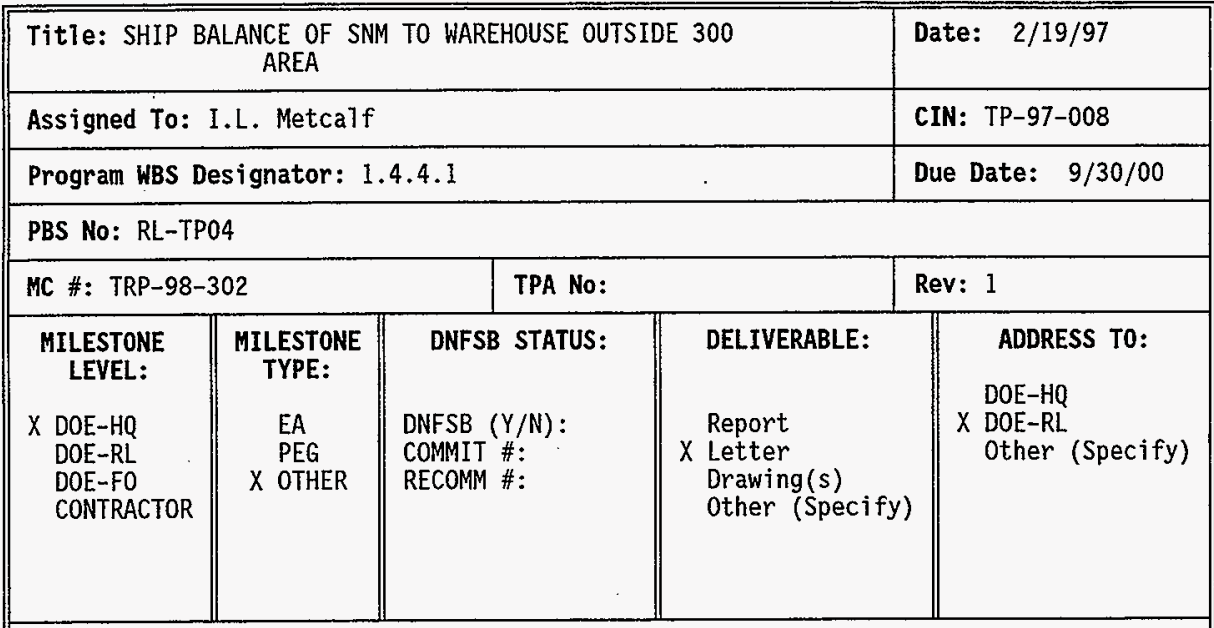

Milestone Description:

Package and ship remaining SNM to 400 Area or alternate storage facility.

Description of what constitutes completion of this milestone:

Field verification performed with $R L$ representative ensuring that the

following buildings no longer contain SNM materials: $303 \mathrm{~A}, 303 \mathrm{~B}, 303 \mathrm{E}$, $303 G, 3712,3716$. 
PHMC

MILESTONE DESCRIPTION SHEET

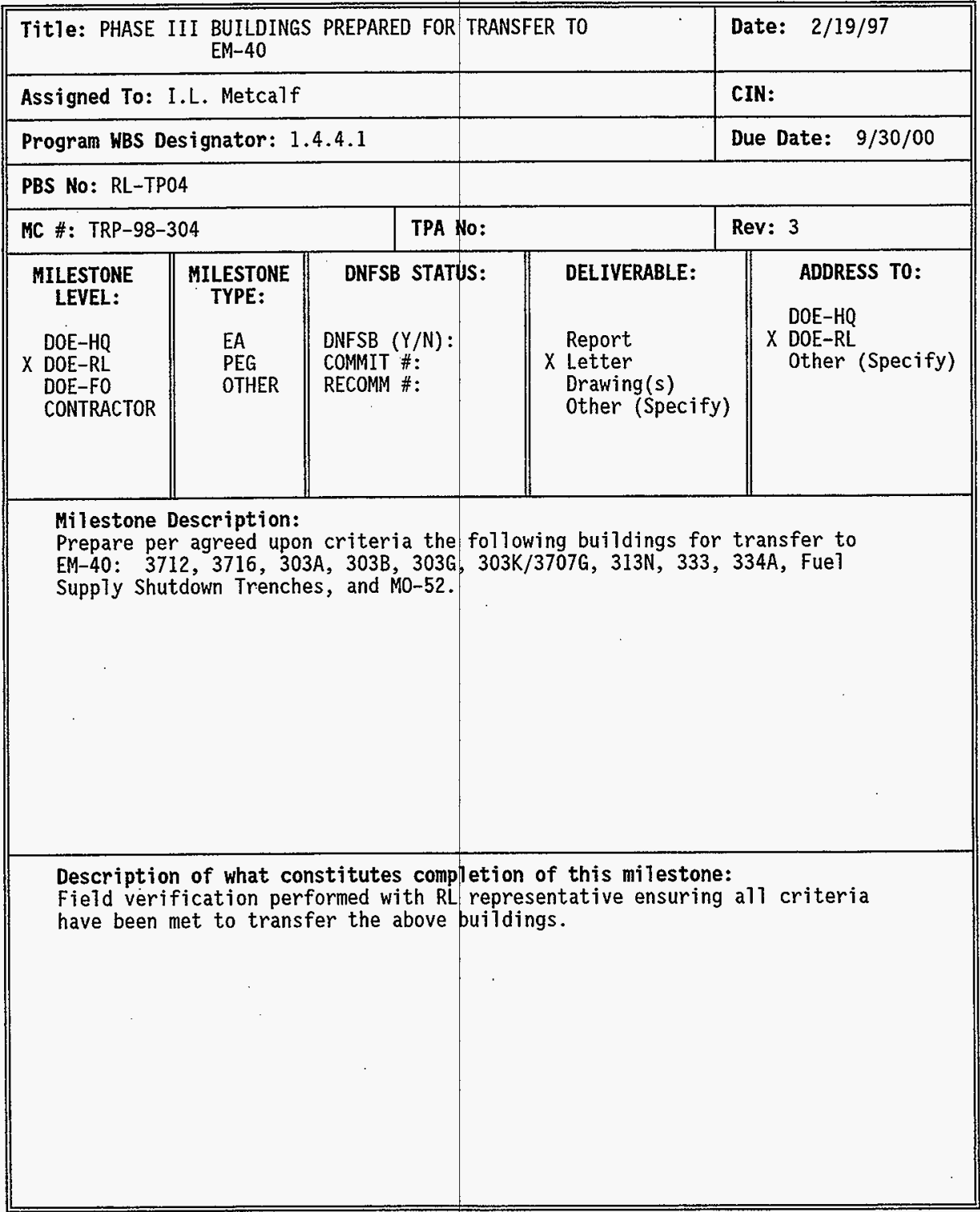




\section{PHMC \\ MILESTONE DESCRIPTION SHEET}

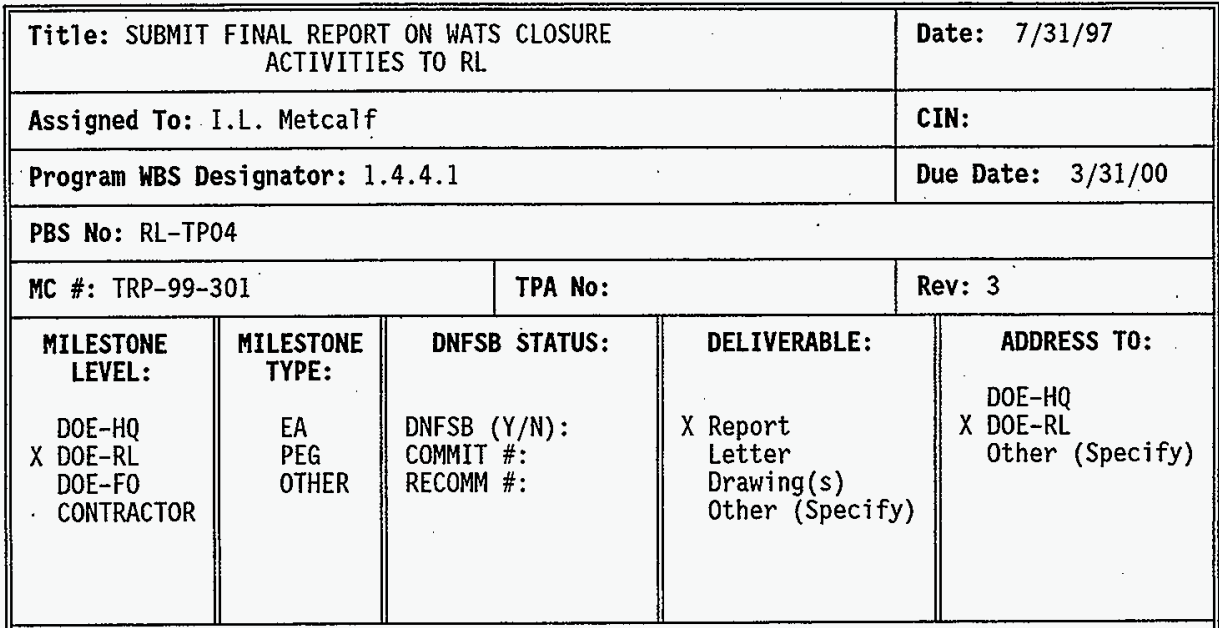

Milestone Description:

Resolve Ecology comments after their review of WATS final report and revise report, if needed. Send Ecology a copy of the Part ' $A$ ' permit stamped 'CLOSED' after Ecology agrees that clean closure has been achieved, or transfer Ecology-issued, modified open Part 'A' permit to EM-40.

Description of what constitutes completion of this milestone:

Transmittal letter to RL with modified Part ' $A$ ' permit transfer to EM40 or Part 'A' permit stamped 'CLOSED.' 
MILESTONE DESCRIPTION SHEET

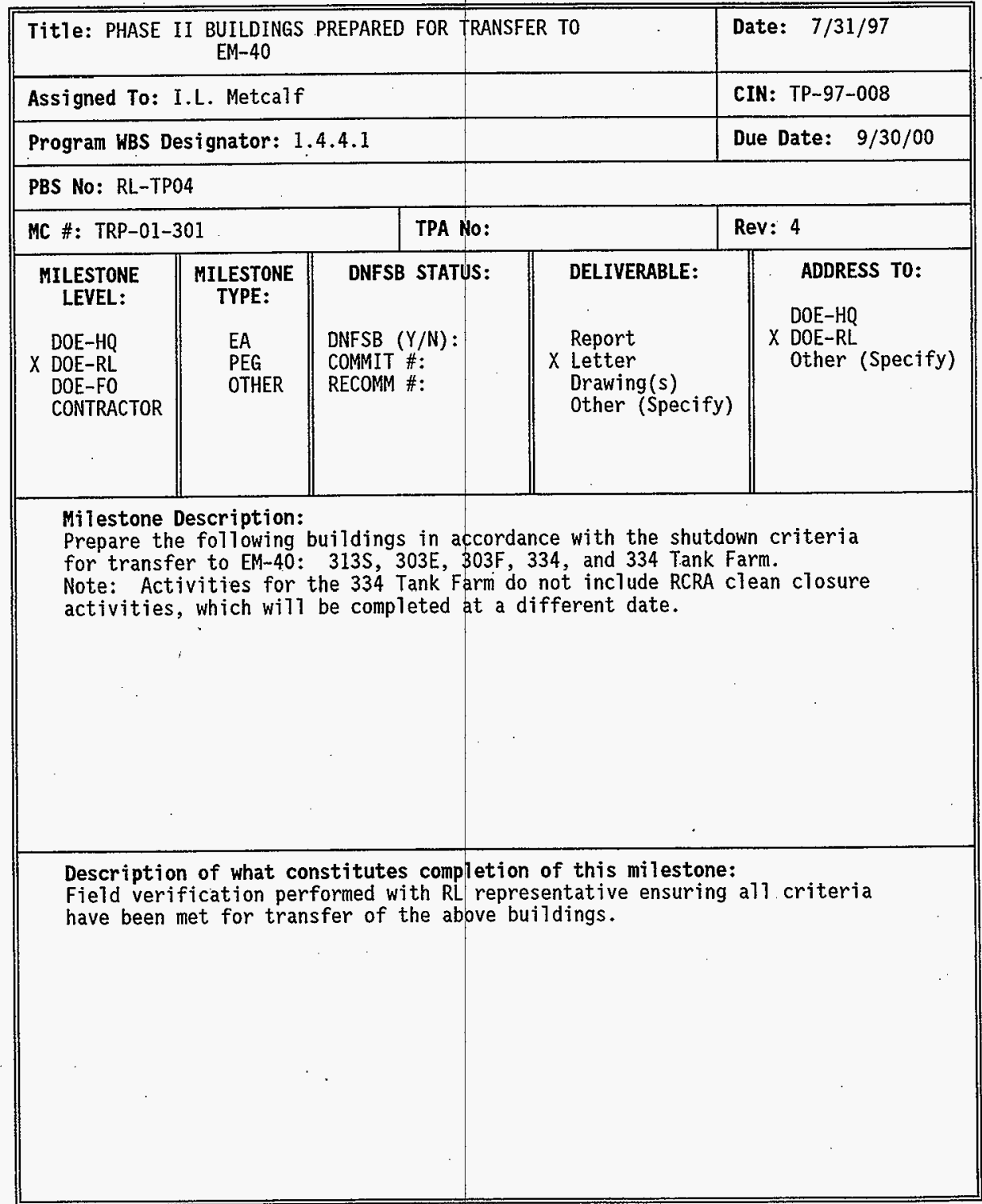




\section{PHMC \\ MILESTONE DESCRIPTION SHEET}

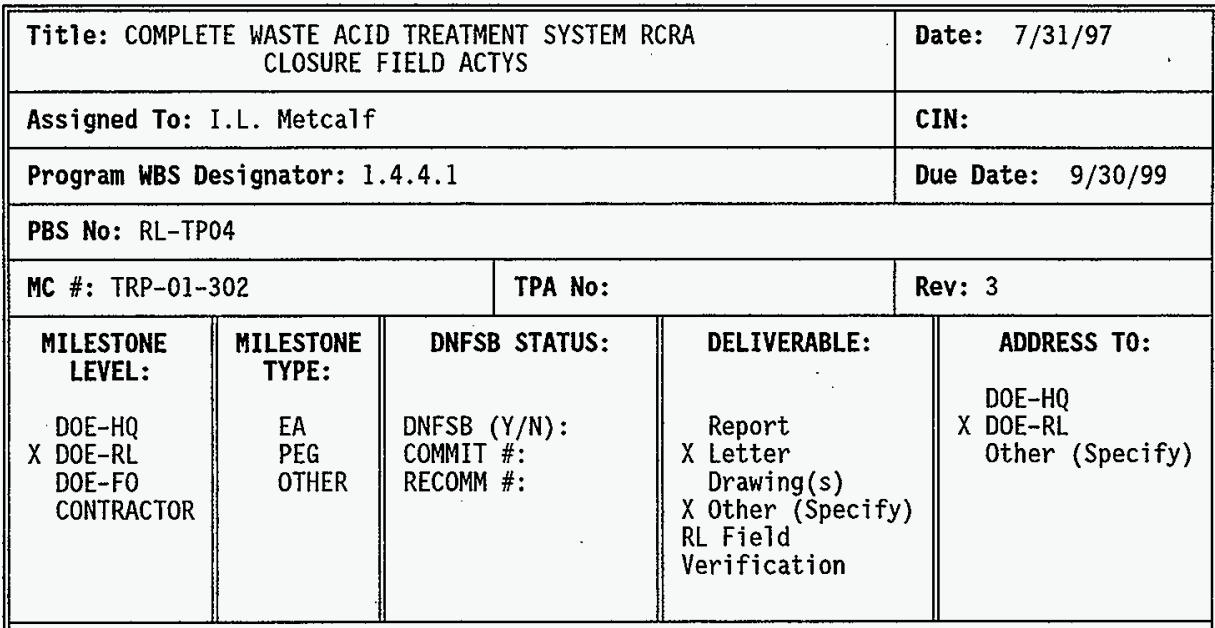

Milestone Description:

Complete the activties for 334 and 311 Tank Farms and piping trench

portions of WATS required to attain closure, as stated in Revised Closure Plan.

Description of what constitutes completion of this milestone:

A letter will be transmitted to RL. notifying that the above activities have been completed.

Field verification performed with RL representative ensuring that the above activities have been completed. 


\section{PHMC}

\section{MILESTONE DESCRIPTION SHEET}

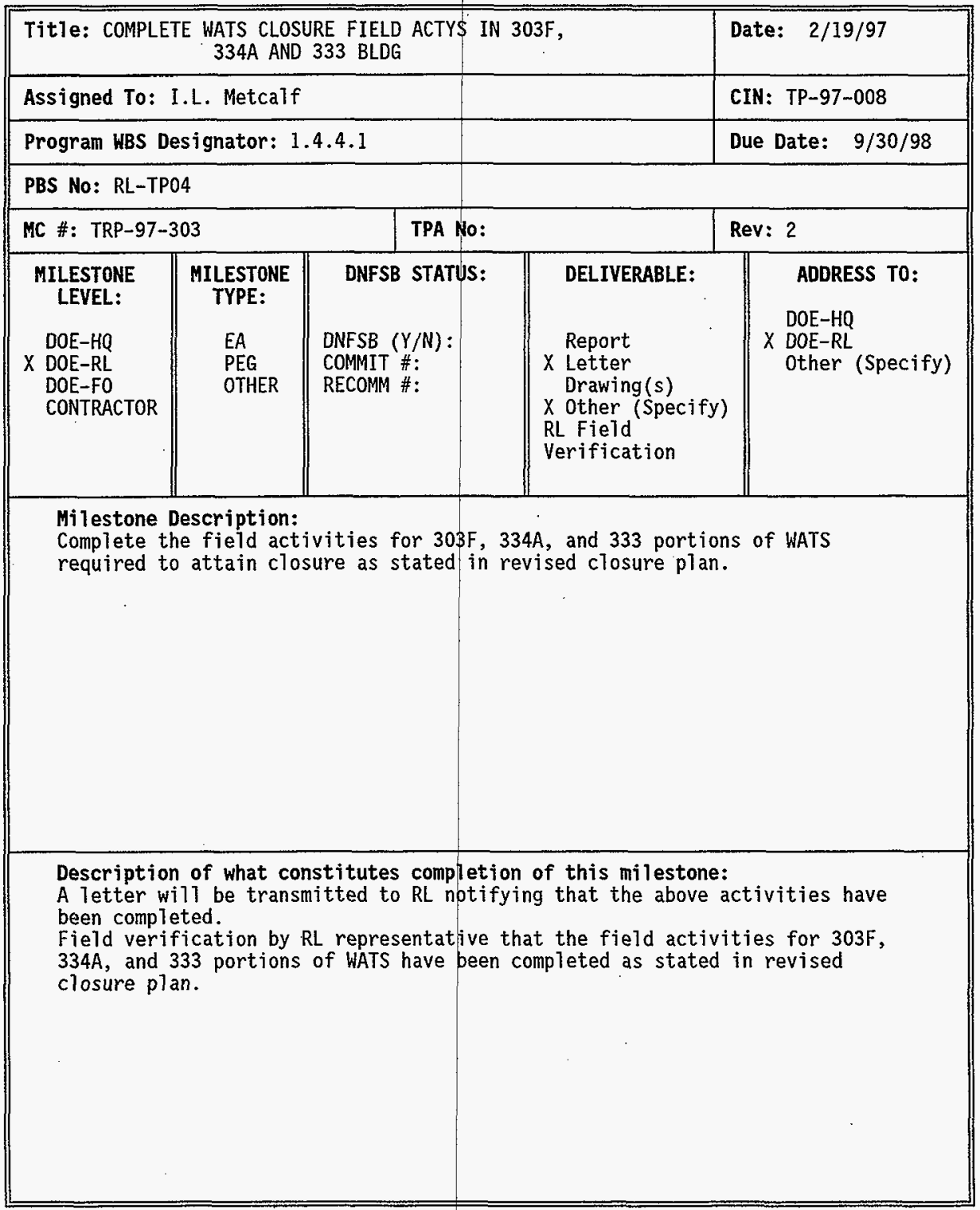




\section{PHMC \\ MILESTONE DESCRIPTION SHEET}

\begin{tabular}{|c|c|c|c|c|}
\hline \multicolumn{4}{|c|}{ Title: SUBMIT 303K CERTIFICATE OF CLOSURE TO RL } & Date: $7 / 31 / 97$ \\
\hline \multicolumn{4}{|c|}{ Assigned To: I.L. Metcalf } & CIN: TP-97-008 \\
\hline \multicolumn{4}{|c|}{ Program WBS Designator: 1.4 .4 .1} & Due Date: $7 / 31 / 98$ \\
\hline \multicolumn{5}{|c|}{ PBS No: RL-TP04 } \\
\hline \multicolumn{2}{|c|}{ MC \#: TRP-96-301 } & TPA No: & & Rev: 3 \\
\hline $\begin{array}{l}\text { MILESTONE } \\
\text { LEVEL: } \\
\\
\text { DOE-HQ } \\
\text { XOE-RL } \\
\text { DOE-FO } \\
\text { DOE-FO } \\
\text { CONTRACTOR }\end{array}$ & $\begin{array}{l}\text { MILESTONE } \\
\text { TYPE: } \\
\text { EA } \\
\text { PEG } \\
\text { OTHER }\end{array}$ & $\begin{array}{l}\text { DNFSB STATUS: } \\
\text { DNFSB }(Y / N): \\
\text { COMMIT \#: } \\
\text { RECOMM \#: }\end{array}$ & $\begin{array}{l}\text { DELIVERABLE: } \\
\\
X \text { Report } \\
X \text { Letter } \\
\text { Drawing(s) } \\
\text { Other (Specify) }\end{array}$ & \begin{tabular}{|l} 
ADDRESS TO: \\
DOE-HQ \\
$\times$ DOE-RL \\
Other (Specify)
\end{tabular} \\
\hline \multicolumn{5}{|c|}{$\begin{array}{l}\text { Milestone Description: } \\
\text { Submit certification of closure to RL for approval. Closure is based upon } \\
\text { the assumption that the Hanford Facility Resource, Conservation, and } \\
\text { Recovery Act Permit Condition V.14.B.h will not be invoked. }\end{array}$} \\
\hline \multicolumn{5}{|c|}{$\begin{array}{l}\text { Description of what constitutes completion of this milestone: } \\
\text { Transmittal letter to RL with certification of closure. }\end{array}$} \\
\hline
\end{tabular}




\section{PHMC \\ MILESTONE DESCRIPTION SHEET}

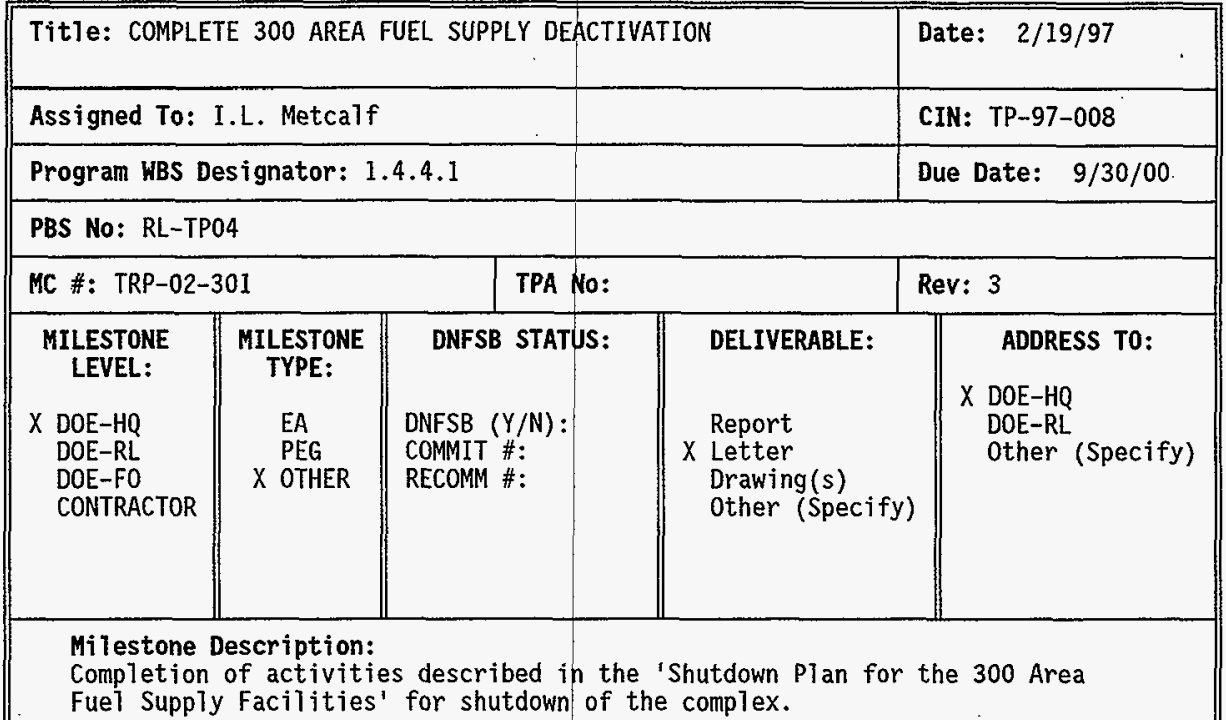

Description of what constitutes completion of this milestone:

A letter will be transmitted to RL documenting that all turn-over criteria have been met to transfer the 300 Area Fuel Supply Facility to the ERC. 
FACILITY STABILIZATION

L.IFE CYCLE COST BASELINE (BCWS) BY YEAR BY FUND TYPE

BY PROJECT BASELINE SUMMARY (PBS)

FY 1998

(\$000s)

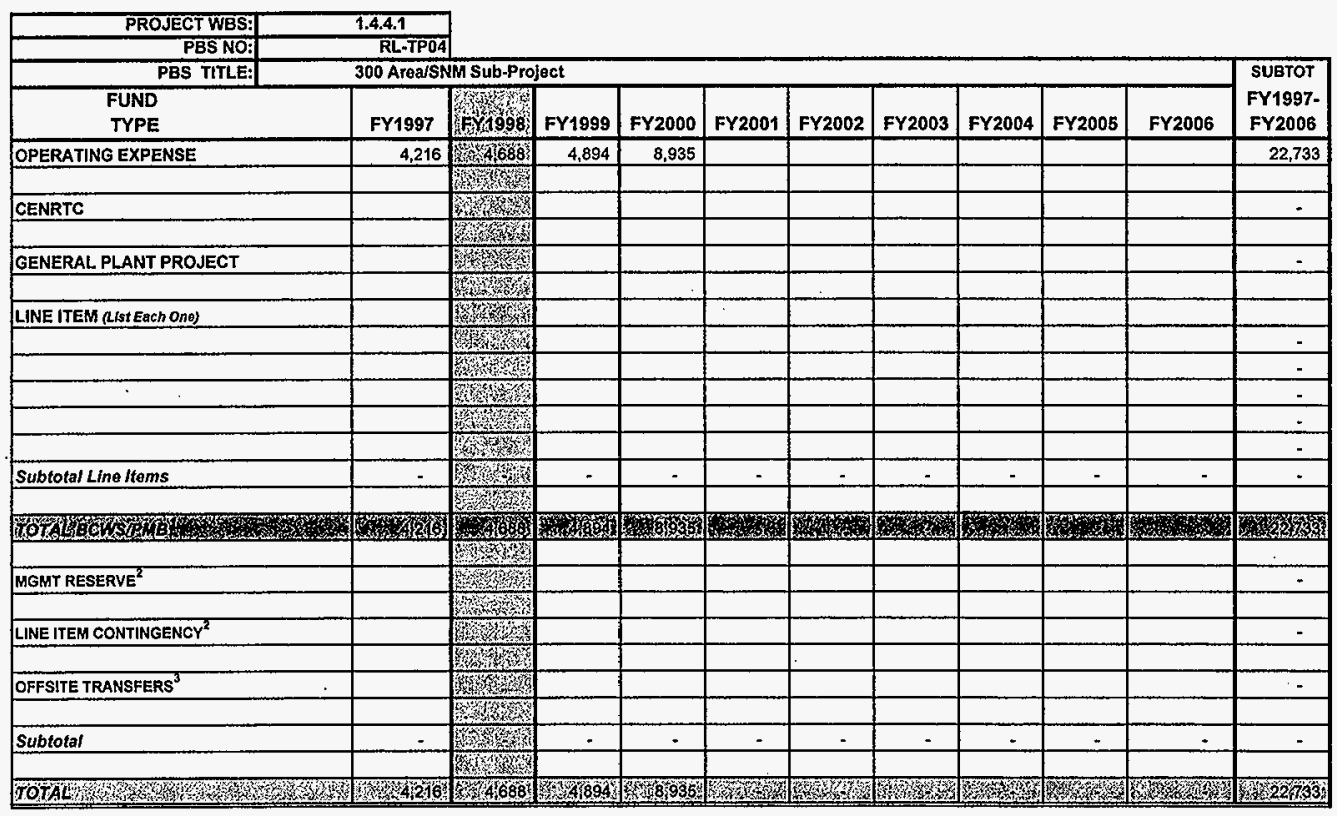

'Budgeted Cost of Work Scheduled (BCWS) Equals Performance Measurement Baseline (PMB);

Expense Carryover NOT Included.

'Management Reserve and Line Item Contingency Held by RL.

${ }^{3}$ Work Performed at Sites Other Than Hanford. 
FACILITY STABILIZATION

LIFE CYCLE COST BASELINE (BCWS) BY YEAR BY FUND TYPE

BY PROJECT BASELINE SUMMARY (PBS)

FY 1998

(\$000s)

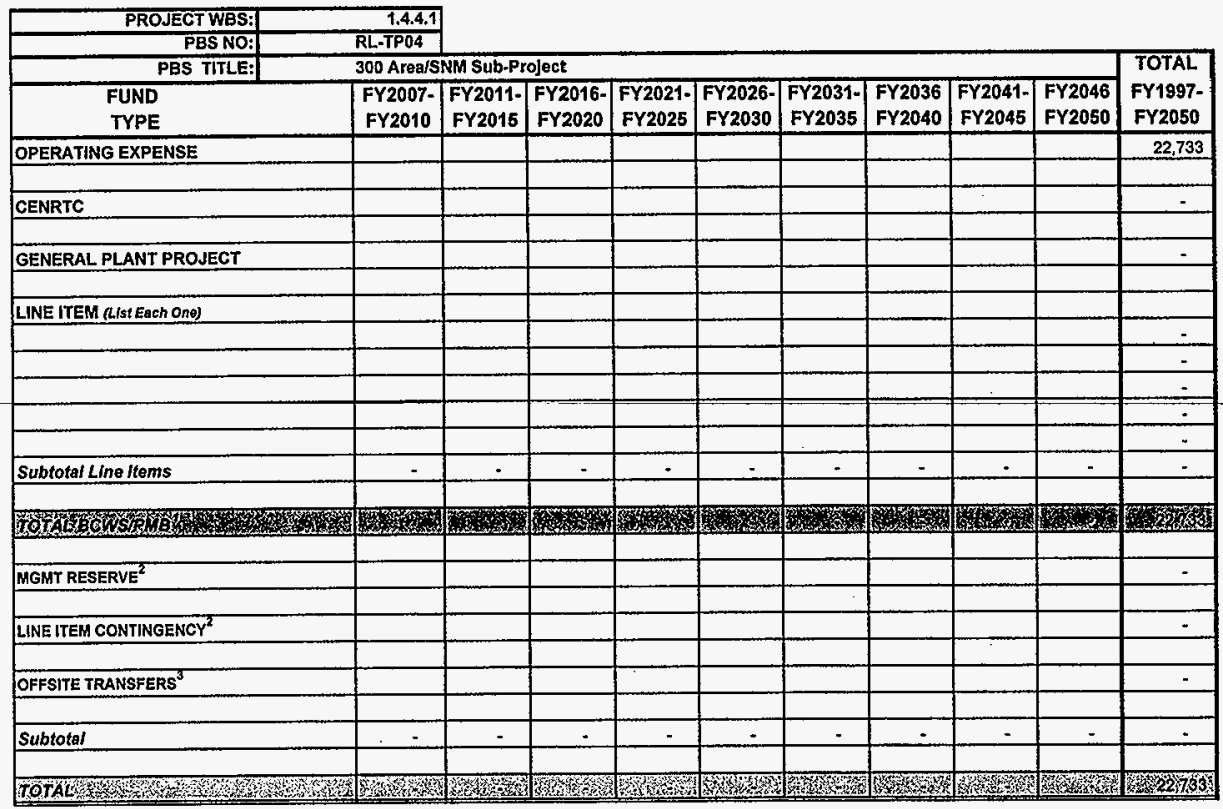

'Budgeted Cost of Work Scheduled (BCWS) Equals Performance Measurement Baseline (PMB):

Expense Carryover NOT Included.

${ }^{2}$ Management Reserve and Line ltem Contingency Held by RL.

Work Performed at Sites Other Than Hanford. 
FY 1998

(\$000s)

\begin{tabular}{|c|c|c|c|c|c|c|c|c|c|c|c|}
\hline $\begin{array}{r}\text { PROJECT WBS: } \\
\text { PBS NO: }\end{array}$ & $\frac{1.4 .4 .1}{\text { RL-TP04 }}$ & & & & & & & & & & \\
\hline PBS TITLE: & 300Areals & $\sqrt{m \text { Sub-F }}$ & roject & & & & & & & & SUBTOT \\
\hline $\begin{array}{r}\text { FUND } \\
\text { TYPE }\end{array}$ & FY1997 & FYY 198 & FY1999 & FY2000 & FY2001 & FY2002 & FY2003 & FY2004 & FY2005 & FY2006 & $\begin{array}{l}\text { FY1997- } \\
\text { FY2006 }\end{array}$ \\
\hline OPERATING EXPENSE & 4,305 & 468 & 4,894 & 8.935 & & & & & & & 22,822 \\
\hline & & Wus & & & & & & & & & \\
\hline CENRTC & & W & & & & & & & & & - \\
\hline & & W1, & & & & & & & & & \\
\hline GENERAL PLANT PROJECT & & कि & & & & & & & & & - \\
\hline & & $3 \%$ & & & & & & & & & \\
\hline LINE ITEM (List Each One) & & risto & & & & & & & & & \\
\hline 03-Dxox Other Spent Fuef & & Wh & & & & & & & & & $\dot{-}$ \\
\hline & & Ox & & & & & & & & & - \\
\hline & & W & & & & & & & & & - \\
\hline & & ens & & & & & & & & & - \\
\hline & & 7.t. & & & & & & & & & - \\
\hline Subtotal Line ftems & $=$ & \% & - & - & - & - & - & - & - & - & $=$ \\
\hline & & 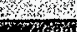 & & & & & & & & & \\
\hline
\end{tabular}


FACILITY STABILIZATION

LIFE CYCLE BUDGET AUTHORITY (B/A) BY YEAR BY FUND TYPE

BY PROJECT BASELINE SUMMARY (PBS)

FY 1998

(\$000s)

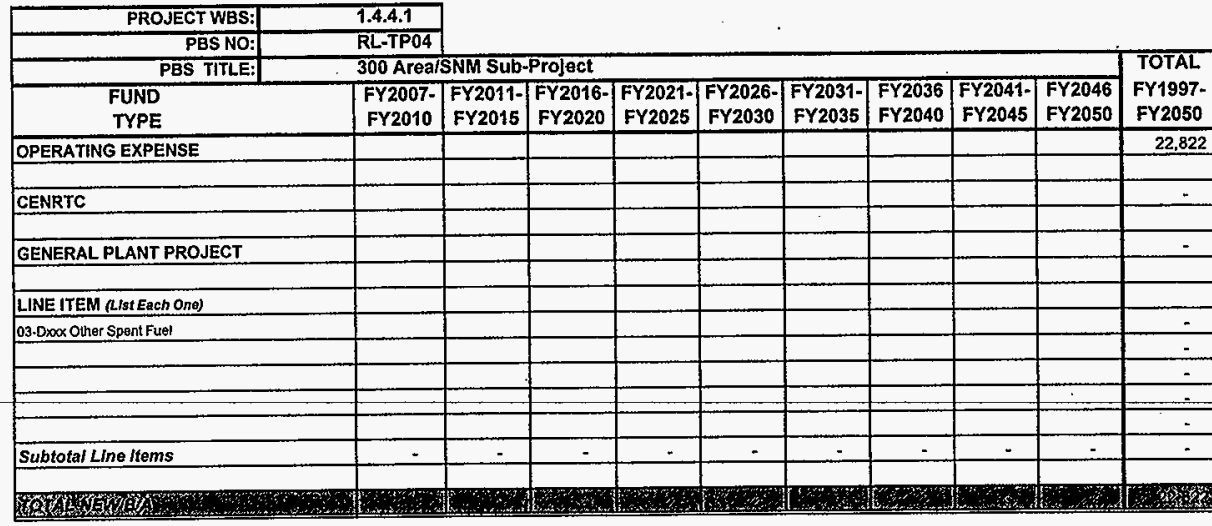


FACILITY STABILIZATION

FY 1998 COST BASELINE (BCWS) BY MONTH

BY PROJECT BASELINE SUMMARY (PBS)

BY ACTIVITY DATA SHEET (ADS)

EXECUTION YEAR

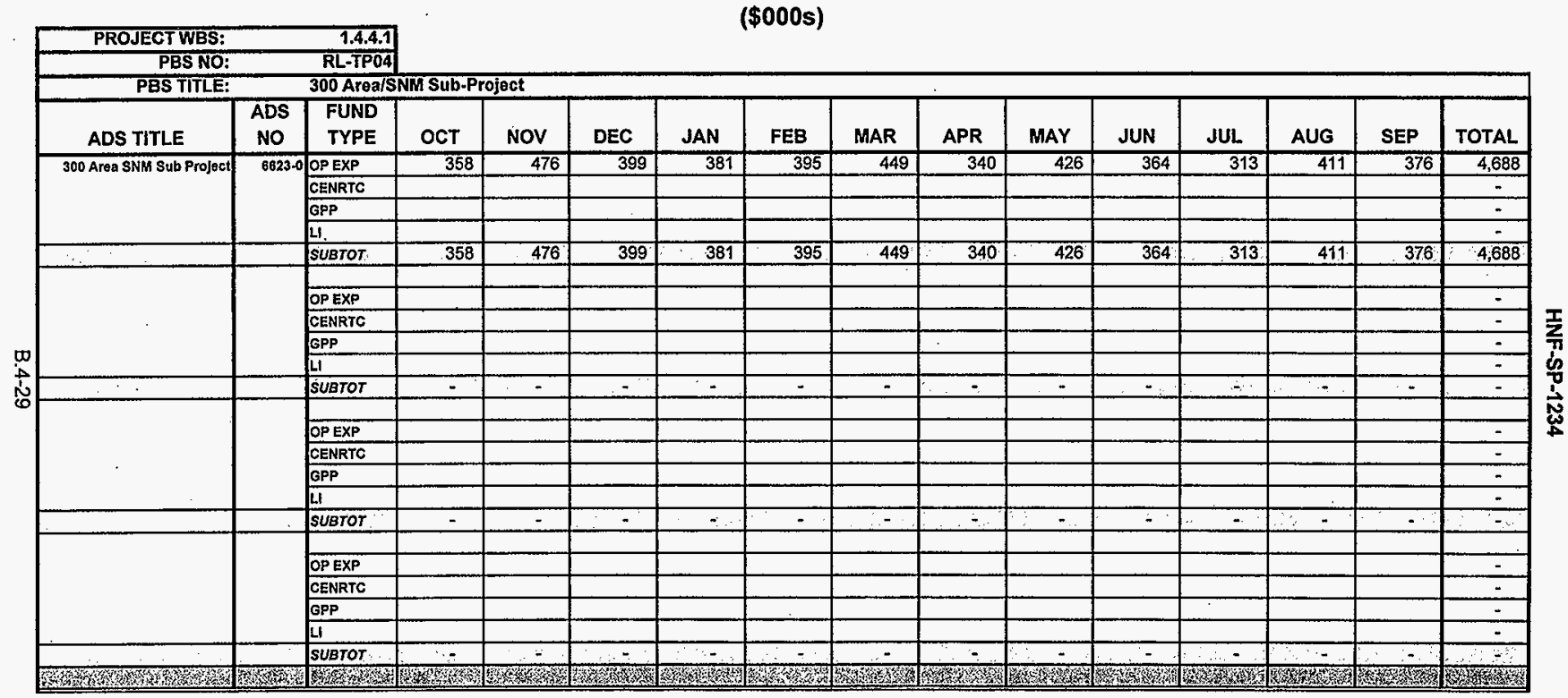

${ }^{1}$ Budgeted Cost of Work Scheduled (BCWS) Equals Performance Measurement Baseline (PMB); Expense Carryover is NOT Included. 


\section{AREA/SNM SUB-PROJECT}

AVERAGE ANNUAL FULL TIME EQUIVALENTS

(includes Major Subcontractors but not Enterprise Companies)

PHBS 1.4.4.1

Submittal Date: 9/10/97

\begin{tabular}{|l|c|c|c|c|c|c|c|c|c|c|c|}
\hline PBS Number & PBS Title & FY 1998 & FY 1999 & FY 2000 & FY 2004 & FY 2002 & FY 2003 & FY 2004 & FY 2005 & FY 2006 & FY 2007 \\
\hline
\end{tabular}

RL-TP04

300 Area FSS

24

24

32

0

o

0

0

0

$\mathbf{0}$

0

.

$\underline{0}$

$\underline{\underline{0}}$

$\underline{\underline{0}}$

o

$\underline{\underline{0}}$

$\underline{\underline{0}}$ 


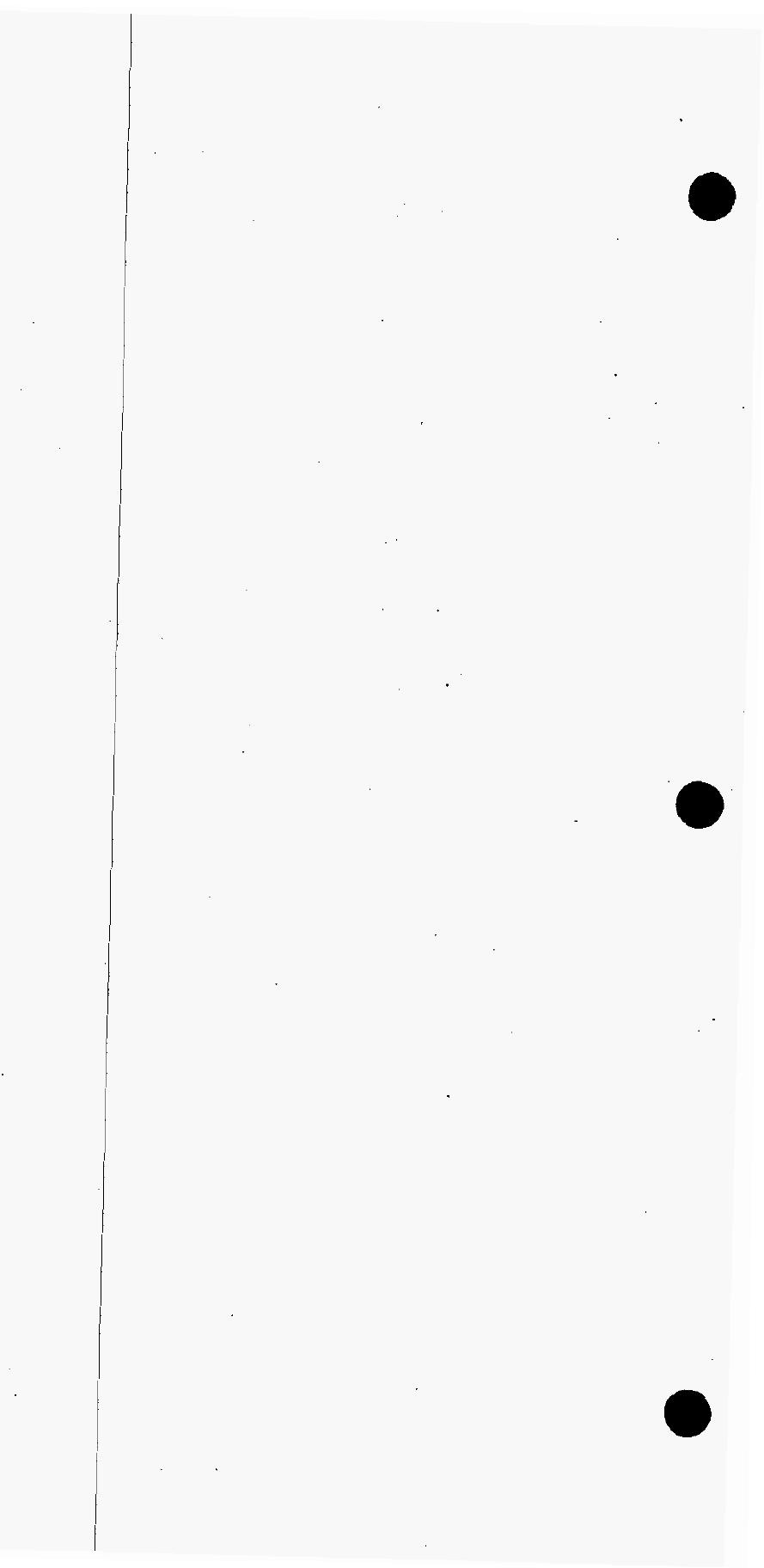




\section{B.5 PFP Deactivation (RL-TP05)}

\section{B.5.1.0 PFP Deactivation Technical Baseline (RL-TP05)}

\section{B.5.1. 1 PFP Deactivation Organization Mission (RL-TP05)}

The Plutonium Finishing Plant (PFP) Deactivation Project mission is to provide for the safe and orderly Terminal Cleanout (TCO) and deactivation of eight (8) of the ten (10) major facilities and their associated support structures at the PFP Complex. Due to a lack of FY98 funds there are no work scope activities planned for this project. Once funding is committed, the project will be replanned. The major facilities that will not be deactivated at this time include 2736ZB, Product Shipping and Receiving Facility, and 2736Z, Plutonium Storage Facility due to their mission of safe and secure storage of nuclear materials until at least 2025 (vaults are scheduled to be deactivated at that time). The remainder of the facilities were to undergo TCO and then will be deactivated to a surveillance and maintenance level by FY2011 and prepared for transfer to D\&D.

Initial construction on the Plutonium Finishing Plant (PFP, formerly called Z Plant) began in 1949 and was completed 1951. The PFP was the final link in the plutonium manufacturing chain at Hanford, processing plutonium-bearing chemical solutions and converting them into metal and oxide. This process ended in May 1989 . Over the years many additions were added to the PFP complex including the 2736Z/ZB vault storage and the $236 \mathrm{Z}$ Plutonium Reprocessing Facility as well as a number of lesser additions and/or ancillary buildings. Plutonium finishing included three operations: (1) Plutonium Metal Production--the remote mechanical $\mathrm{C}(\mathrm{RMC})$ metal fabrication line, started in 1959, converted plutonium nitrate solutions to metal form, (2) Plutonium Reclamation Facility-added in 1964, recycled scrap plutonium from Hanford and the Rocky Flats Plant in Colorado, and (3) Plutonium Storage and Support Facility-plutonium was received, analyzed, stored, packaged, and shipped.

Although processing has stopped, chemically reactive plutonium-bearing materials remain in the plant. Chemically reactive materials create radiation exposure to workers and present unnecessary risk to the public. The Defense Nuclear Facility Safety Board (DNFSB) in their Recommendation 94-1 stated that imminent hazards could arise in 2-3 years unless certain problems were corrected which result from the chemically reactive Pu-bearing materials held in storage areas and former process areas within the PFP. Until stabilization is complete, the risks from large quantities of stored reactive plutonium liquids/oxides/MOX/metals and holdup materials (plutonium left in process ducting and piping of various quantities) have NOT been reduced. The implementation of DNFSB Recommendation 94-1 at PFP to stabilize special nuclear materials and resolve Plutonium vulnerabilities at the PFP has been identified as a high priority activity at the Hanford Site by the USDOE. In order to eliminate an imminent hazard at the PFP it is necessary that all plutonium at the PFP be dispositioned or stabilized.

The PFP Deactivation Project was developed using the basic principles of a system engineering approach. This entailed continued operation of those parts of the plant needed for surveillance and maintenance, material stabilization and packaging (DNFSB 94-1 activities, material preparations for discard, and vault storage), and those systems and components required to support deactivation tasks. Before each individual facility Project Deactivation Plan is finalized, the facility will be characterized and technical alternatives outlined for major deactivation activities.

Planning Assumptions:

The PFP Deactivation Project was to be completed by the end of FY 2011 with the exception of the vault complex, but due to budget constraints this project will require replanning once funding is committed. Hazardous and radioactive materials need to be removed from the plants or stabilized in place to ensure long-term facility safety and regulatory compliance, enable plant classification as an unoccupied facility, and enable subsequent successful S\&M 
and ultimately D\&D.

The overall objective of facility transition is to achieve a safe, stable, and environmentally sound condition, suitable for an extended period, as quickly and economically as possible. Once transitioned, the facility is to be kept in its stable condition by means of a methodical S\&M program implemented by the ERC, pending ultimate disposition. The acceptable facility interim state is defined by a set of end point criteria for that particular facility.

Materials must be removed and/or stabilized sufficiently to ensure that the plant complies with HNF-CM-7-5, Environmental Compliance, and HNF-CM-1-6, Radiological Control Manual, as applicable to an unoccupied facility after completion of deactivation. As a general guide, residual contamination and radiation levels in plant areas are to be no more than the levels encountered during normal operation and occupancy of the plants. End state matrix documents will be used to document systems, structures and component (SSC) condition for turnover to ERC/EM-40.

Permanent radiation zones to be entered for surveillance shall be decontaminated and released or the surface contamination levels reduced or stabilized to minimize re-suspension and/or migration of loose contamination. Temporary radiation zones inside and outside of the buildings will be eliminated.

Loose or damaged (friable) asbestos in areas expected to be entered during surveillance must be removed or stabilized.

Fissile materials need to be removed sufficiently to eliminate the potential for a nuclear criticality excursion and the need for a criticality alarm system.

No related upgrades to PFP dangerous waste tanks systems are required beyond those already planned.

Solid waste at PFP is classified as hazardous, low-ievel radioactive, TRU radioactive, and mixed (hazardous with radioactive constituents such as LLW and TRU).

Tanks, vessels, and drums need to be drained using installed equipment and features. Heels cannot contain material classified as hazardous waste.

Operations on sludge stabilization and immobilization, in connection with terminal cleanout and deactivation, will be required until the end of the program.

The PFP Transition Project End Point was planned by September 2011, but will require replanning. This end point is NOT the cessation of all activities as with other Hanford Site facilities. Instead, this End Point assumes the continued operation of all SNM shipping, receiving, storage and vault systems, including all safeguards \& security (SAS) systems plus laboratory capabilities as needed, for an indefinite period but currently assumed to be approximately FY 2028. This end point condition is also based on the following.

- Full implementation of DNFSB Recommendation 94-1 was completed in FY 2002 and applicable Pu vulnerabilities have been mitigated.

- Deactivation is initiated in FY 1999 in parallel with 94-1 activities. Remaining facility transition to deactivation is initiated immediately following completion of DNFSB Recommendation 94-1 activities.

\section{B.5.1.2 PFP Deactivation End Point Targets from Hanford Strategic Plan}

* Transition high cost surplus facilities in the central plateau and south 600 areas to a low cost, stable, deactivated condition. 
- Transition production areas of PFP to a low cost, stable, deactivated condition; continue safe, stable, interim storage of plutonium.

\section{B.5.1.3 PFP Deactivation Major Facilities}

\section{B.5.1.3.1 Plutonium Finishing Plant Facility}

\section{B.5.1.3.1.1 Plutonjum Finishing Plant Facility Description}

PFP, formerly called Z-Plant, was constructed in 1949-1951 in the 200-W Area of Hanford. It was used to process plutonium-bearing chemical solutions and convert them into metal and oxide. The plant is currently in the process of stabilization and deactivation.

There is no support for facility transition to deactivation in FY98 and FY99. Hence, no progress will be made towards facility deactivation until FY00. Also, facility transition to deactivation activities will be rebaselined in FY98 following facility reengineering.

\section{B.5.1.3.1.2 Plutonium Finishing Plant Facility Technical Logic:}

The Department of Energy (DOE), in partnership with its contractors, shall plan, acquire, operate, maintain, and dispose of physical assets as valuable national resources. Stewardship of these physical assets shall be accomplished in a cost-effective manner to meet the DOE mission. This shall incorporate industry standards, a graded approach, and performance objectives. 


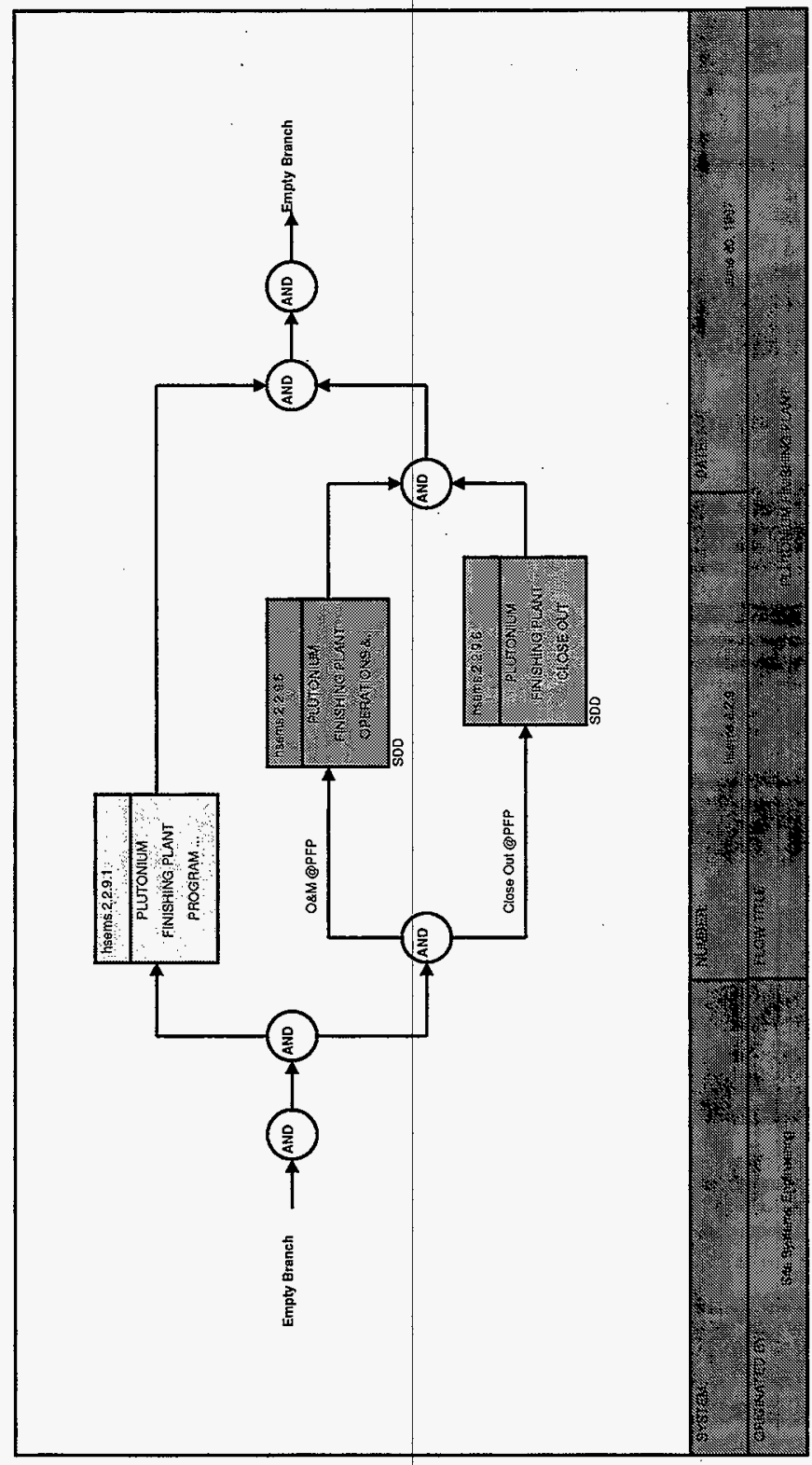

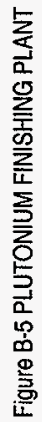




\section{B.5.1.3.1.3 Plutonium Finishing Plant Requirements and Life Cycle Function Descriptions}

Requirements:

- Complete duct segment $\# 4$ as defined in WHC SD-CP-PMP-003 by $9 / 30 / 00$.

- Complete removal of approximately $80 \mathrm{ft}$ of $232-Z$ Exhaust Ventilation Duct in $291-Z$. by $9 / 30 / 00$.

* Complete removal of approx. $200 \mathrm{ft}$ of inactive Process Vacuum System Segment $\# 5$ by 9/30/00.

- Facilities discharging to the 200 Area TEDF shall implement Best Available Technology (BAT)/All Known, Available, and Reasonable Treatment (AKART). The generator shall provide the information required by WAC 173-240, Submission of Plans and Reports for Construction of Waste Water Facilities.

* Deactivation of PFP shall comply with DOE/EIS-0244-D

* PFP was to be transitioned to the surveillance and maintenance phase by Sep 2011 if funding was made available.

* Residue bearing materials was to be removed from identifed $234-5 Z$ exhaust ventilation by Dec 1998

* Central Plateau shall be used for the collection and management of nuclear materials that remain onsite.

* PFP worker safety systems shall be maintained

* PFP safeguard and security systems shall be maintained

* PFP waste management systems shall be maintained

- Central Plateau inactive facilities shall be maintained within the approved safety envelope

- Central Plateau asbestos abatement shall be performed as necessary

\section{Life Cycle Function Descriptions:}

\section{B.5.1.3.1.3.1 PLUTONIUM FINISHING PLANT OPERATIONS \& MAINTENANCE WORK SCOPE SUMMARY}

Day-to-day work, including preventive and predictive maintenance, that is required to maintain and preserve plant and capital equipment in a condition suitable for it to be used for its designated purpose.

\section{PLUTONIUM FINISHING PLANT OPERATIONS \& MAINTENANCE SPECIFIC FUNCTIONS}

\section{B.5.1.3.1.3.2 Maintain Safe \& Compliant Materials in PFP Facility during Deactivation}

Materials stored in the PFP facility will be maintained in safe condition until they are removed for disposal or treatment.

\section{B.5.1.3.1.3.3 PLUTONIUM FINISHING PLANT POST OPERATIONS WORK SCOPE SUMMARY}

Day-to-day work, including pre-stabilization surveillance and maintenance, stabilization, post-stabilization 
surveillance and maintenance, deactivation, and post-deactivation surveillance and maintenance, that is required to allow safe decontamination and decommissioning.

Also maintain $2736-Z B / Z$ vault facilities including the storage monitoring of SNM at PFP, until final deactivation.

\section{PLUTONIUM FINISHING PLANT POST OPERATIONS SPECIFIC FUNCTIONS}

B.5.1.3.1.3.4 Maintain Safe \& Compliant Plutonium Finishing Plant Facility in CP Areas

Maintain the PFP facility structures, operating systems and equipment, and monitoring systems within the approved safety and compliance requirements until the facilities are made available for D\&D. Also maintain the $2736-\mathrm{ZB} / \mathrm{Z}$ vault facilities, including the storage and monitoring of SNM at PFP until final deactivation.

\section{B.5.1.3.1.3.5 Transition Plutonium Finishing Plant Facility}

Initiate the transition phase of decontamination and decommissioning for the PFP facility.

\section{B.5.1.3.1.4 Plutonium Finishing Plant Boundary Diagram}

Table B.5-1 Plutonium Finishing Plant Boundary Diagram

\begin{tabular}{|l|l|l|}
\hline $\begin{array}{l}\text { External Interfaces } \\
\text { None- } \\
\text { Hanford Site Environmental System Interiaces } \\
\text { Nene- }\end{array}$ & $\begin{array}{l}\text { External Interfaces } \\
\text { None- } \\
\text { Hantord Site Environmental System Interfaces } \\
-N o n e-\end{array}$ \\
\hline
\end{tabular}


B.5.1.3.1.5 Plutonium Finishing Plant Interface Description and Forecast

EXTERNAL INPUTS

-None-

INTERNAL INPUTS

-None-

EXTERNAL OUTPUTS

-None-

INTERNAL OUTPUTS

-None- 


\section{B.5.1.4 Drivers for PFP Deactivation}

\section{Table B.5-2 Source Documents for PFP Deactivation}

\author{
Name \\ DE-AC06-96RL13200 \\ DOE/EIS-0222D
}

DOEJEIS-0244-D

DOE/RL-89-10

DOE/RL-96-14

DOE/RL-96-92

ST 4502
Iitle

Project Hanford Management Contract, Fluor Daniel Hanford, Inc.

Draft Hanford Remedial Action Environmental Impact Statement and

Comprehensive Land Use Plan

Plutonium Finishing Plant Stabilization Environmental Impact Statement

Hanford Federal Facility Agreement and Consent Order (Tri-Party Agreement), Rev.4

Updated Draft Mission Direction Document, June 1996

Hanford Strategio Plan

State Waste Discharge Permit for the 200 Area TEDF

\section{B.5.1.5 PFP Deactivation Risk Management}

The PFP Project is to implement cleanup activities, DNSFB Recommendation 94-1, and correct related plutonium vulnerabilities by stabilizing, and /or properly dispositioning, all remaining plutonium residues in storage or holdup, which is the plutonium left in process ducting and piping of varying quantities. These plutonium vulnerabilities (see Plutonium Working Group Report on Environmental, Safety \& Health Vulnerabilities Associated with the Department's Plutonium Storage", Vol. 11 Appendix B, Part 2: Hanford Site Assessment Report, September 1994), can lead to "imminent hazards within 2-3 years" (DNSFB).

The primary phase of the deactivation process is to perform terminal cleanout (TCO) of those facilities to be deactivated. This activity will remove plutonium from the E-4 ventilation ducting, glove boxes, canyon floor, hoods, process piping, etc. The material retrieved from TCO will be transferred to PFP Stabilization Project (refer PBS\#:RL-TP06) to perform stablilization as required, and then to PFP Vault Management Project (refer PBS\#:RL-TP07) to provide storage for the SNM and discard the residual. The next phase of the process will deactivate the facilities to a surveillance and maintenance condition in preparation for decommissioning.

The TCO of the PFP Complex will reduce exposure to the worker, decrease the possibility of contamination spread to the environment and decrease the possibility of a nuclear criticality. Risk reduction will be ongoing through FY 2011. Deactivation of the vaults will be accomplished after relocation of the vault material in approximately FY 2028. The risk measurement will be tracked in indirect metrics, such as reduction in square footage of radiation zones, measurement of holdup material and number of deactivated facilities.

Approximately seventy-two (72) kilograms (Kgs) of plutonium are present as holdup in the exhaust ventilation ducting $(6.0 \mathrm{Kg}$ of which $2.0 \mathrm{Kg}$ have been removed), process vaccum piping $(4.3 \mathrm{Kg})$, canyon floor $(12 \mathrm{Kg}), 241-\mathrm{Z}-361$ Settling Tank (approximately $30 \mathrm{Kg}$ ) and the balance in process glove boxes, equipment and piping. Although part of this material could be released due to a loss of ventilation and/or seismic event, the most likely imminent hazard is the potential of a criticality.

Thousands of kilograms of storable, stabilized SNM, mostly plutonium, will remain in the PFP vaults, especially in Buildings $2736-\mathrm{Z}$ and $2736-\mathrm{ZB}$ in a safe and secure condition. The vaults will receive a major upgrade in $F Y$ 2015-FY 2019 to maintain the safeguards and security systems for the material and maintain the safety boundary to protect the public, the worker and the environment. The vaults will be utilized for storage until final disposition is determined and the material transferred to a new vautt facility currently forcast for FY 2025 or thereafter at which time the vault complex, existing of approximately 11 facilities will be deactivated by approximately FY 2028. 


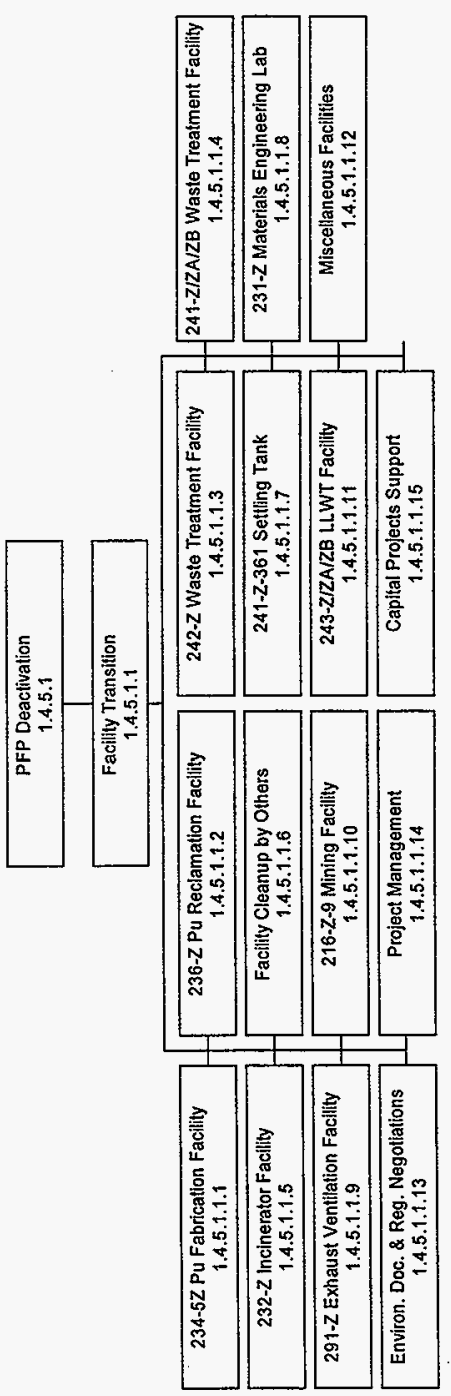


HANFORD SITE WORK BREAKDOWN STRUCTURE DICTIONARY

\section{FACILITY STABILIZATION}

WBS: 1.4

$8 / 25 / 1997$

\begin{tabular}{|c|c|c|c|}
\hline $\begin{array}{l}\text { 1. Activity Title: } \\
\text { PFP DEACTIVATION }\end{array}$ & $\begin{array}{l}\text { 2. Date } \\
7 / 31 / 1997\end{array}$ & $\begin{array}{l}\text { 3. PBS Number } \\
\text { RL-TP05 }\end{array}$ & 4. Dict Rev \\
\hline
\end{tabular}

5. Contract WBS No. 1.4.5.1.1

6. Corresponding FDS No. 7. Baseline CR No. K6D

8. Organization Name 15000

10. Scope of Work

This activity provides for the cleanup, transition deactivation, and turnover of all PFP facilities, except for the $2736-Z$ vaults and vault support facilities, in accordance with EM-60 guidelines. The following activities are included:

*234-5Z Plutonium Fabrication Facillity Cleanup and Transition

*236-Z Plutonium Reclamation Facility Cleanup and Transition

*242-Z Waste Treatment and Americium Facility Cleanup and Transition

*241-Z/ZA Tank Farm Waste Disposal Facility Cleanup and Transition

*232-Z Incinerator Cleanup and Transition

*Facility Cleanup and Transition Performed by others

*241-Z-361 Settling Tank Cleanup and Transition

*231-Z Cleanup and Transition

*291-Z Exhaust Ventilation Building Cleanup and Transition

*216-Z-9 Mining Facility Cleanup and Transition

*243-Z, ZA, ZB Low Level Wastewater Treatment Facility Cleanup and Transition

*Miscel1 aneous Buildings Cleanup and Transition

*Environmental Documentation and Regulatory Negotiations

*Project Management 


\begin{tabular}{|l|l|l|l|l|}
\hline $\begin{array}{l}\text { Proj LVI } \\
\text { (PBS \#) }\end{array}$ & $\begin{array}{l}\text { FDS Act } \\
\text { Number }\end{array}$ & Activity Title & Activity Manager & Responsible Organization \\
\hline RL-TP05 & PFP DEACTIVATION & & \\
\hline & & & & \\
\hline & K6D & PFP DEACTIVATION & D. B. Courson & 15000 \\
\hline
\end{tabular}




\begin{tabular}{|c|c|c|c|c|}
\hline MILESTONE & TPA-MS & TPA & HS & \\
\hline CONTROL \# & NUMBER & TYPE & LEVEL & MS TITLE \\
\hline 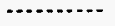 & ............ & .... & $\cdots$ & 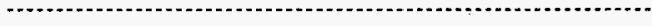 \\
\hline TRP $-97-404$ & & & Fo & COMPLETE DUCT TERMINAL CLEANOUT (TCO), SECTION \#4 \\
\hline TRP $-97-412$ & & & RL. & COMPLETE LABORATORY ENGINEERING STUDY \\
\hline $\operatorname{TR} P-97-414$ & & & RL & COMPLETE REMOVAL. OF -80 FT OF $232-\mathrm{Z}$ EXHAUST VENT, DUCT. IN $291-\mathrm{Z}$ \\
\hline$T R P-97-415$ & . & & RL & COMPLETE REMOVAL OF $200 \mathrm{FT}$ (OF 600FT) OF INACT. PROC. VACUUM SYS \\
\hline$T R P=97-408$ & & & RL & COMPLETE HF DUCT REMOVAL IN 234-5Z \\
\hline
\end{tabular}

\begin{tabular}{|c|c|c|c|c|c|}
\hline & PLANHED & APPROVED & REVISED & & \\
\hline TYPE & BASEL INE & BASELINE & BASELINE & PROS CIN & PBS \# \\
\hline$\cdots$ & - & - . & . & - & ....... \\
\hline \multirow[t]{5}{*}{ OIH } & $9 / 30 / 00$ & & & $T P-97-008$ & RL-TP05 \\
\hline & $9 / 30 / 00$ & & & $T P=97=008$ & RL-TP05 \\
\hline & $9 / 30 / 00$ & & & $T P-97-008$ & RL-TP05 \\
\hline & $9 / 30 / 00$ & & & $T P-97-008$ & $R L=T P 05$ \\
\hline & $9 / 30 / 00$ & & & TP-97-008 & RL-TP05 \\
\hline
\end{tabular}


PHMC

MILESTONE DESCRIPTION SHEET

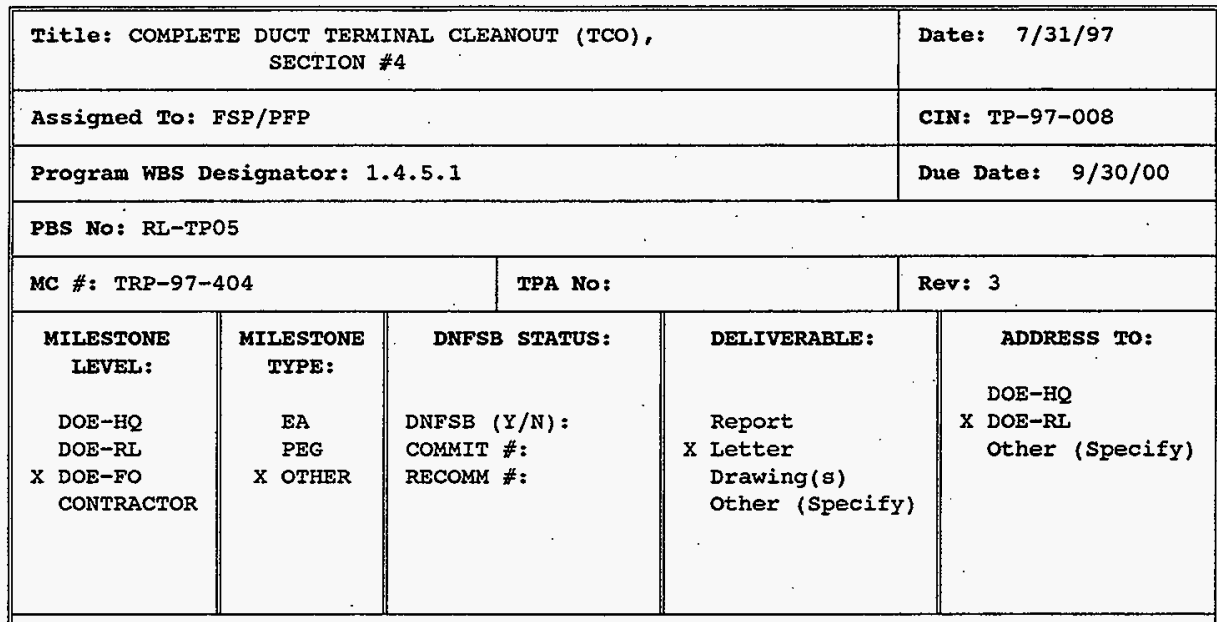

Milestone Description:

Complete the removal of segment $\# 4$, an -150 foot length of active process vacuum piping located primarily in room 262 of the $234-5 z$ building and associated branch lines ( -230 feet) as shown on the attached sketch.

Segment \#4 is clearly defined in the PFP Remediation Project Management Plan (PMP), WHC-SD-CP-PMP-003, dated March 17, 1989, and is anticipated to contain approximately $4.3 \mathrm{Kg}$ of Pu-bearing material.

Description of what constitutes completion of this milestone:

This milestone is considered complete when the -150 feet of active process vacuum piping and associated branch lines ( 230 feet), described above, has been removed, sectioned into pieces, packaged into appropriate containers and readied for shipment to the Hanford Central Waste Complex. Any Pu material removed from this piping is to be either stored as reactive scrap for stabilization (at a later date), or discarded as transuranic (TRU) waste, as appropriate. specifically excluded from this milestone is any piping that is located between the Duct Level floor and the First Floor ceiling and any piping encased in concrete walls. Replacement of piping as shown on the attached sketch is also excluded from this milestone.

A letter will be issued to DOE-RL documenting completion of this milestone, including the indication of the Pu inventory of the material and piping removed during this activity. 
PHMC

MILESTONE DESCRIPTION SHEET

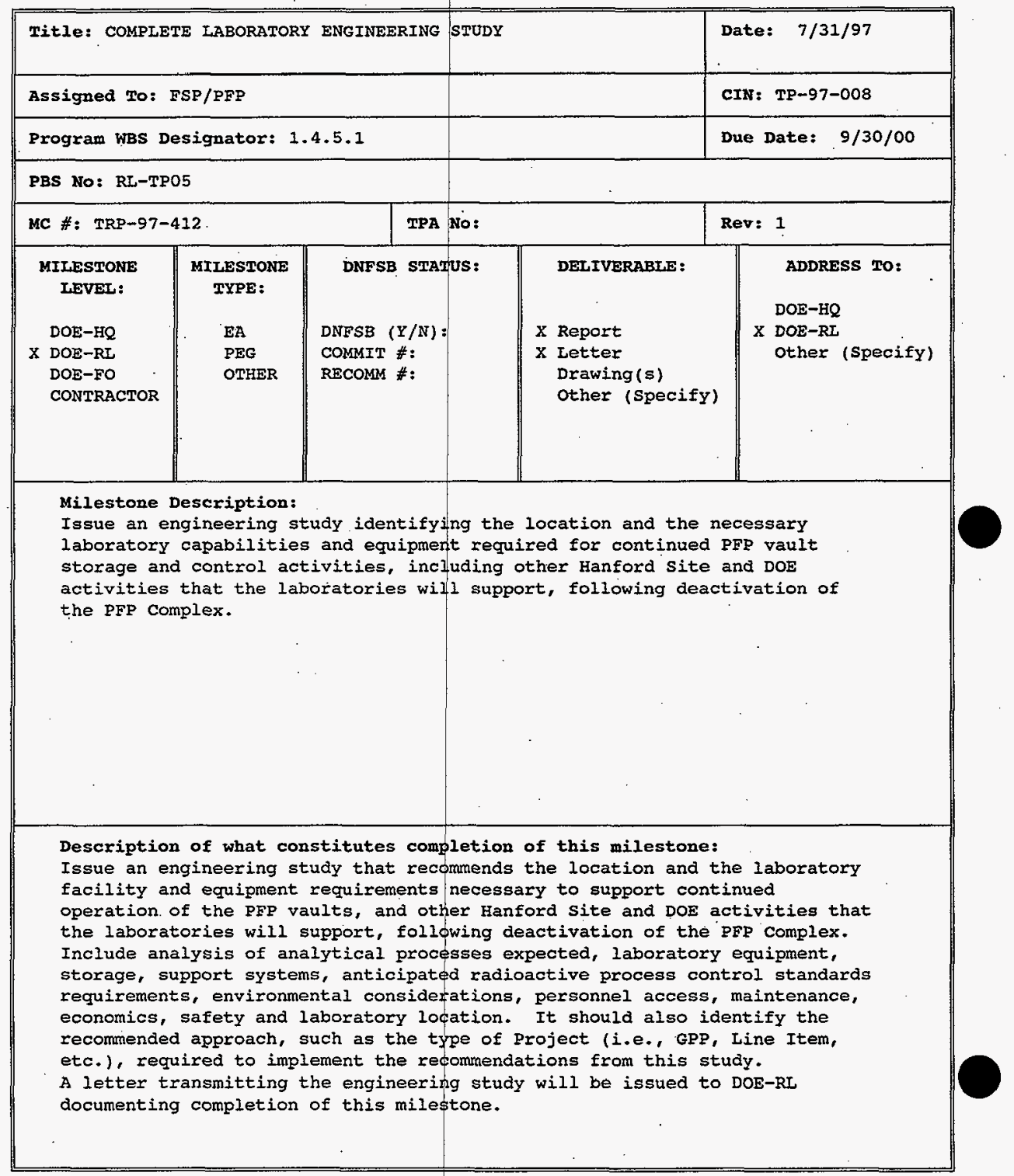


PHMC

MILESTONE DESCRIPTION SHEET

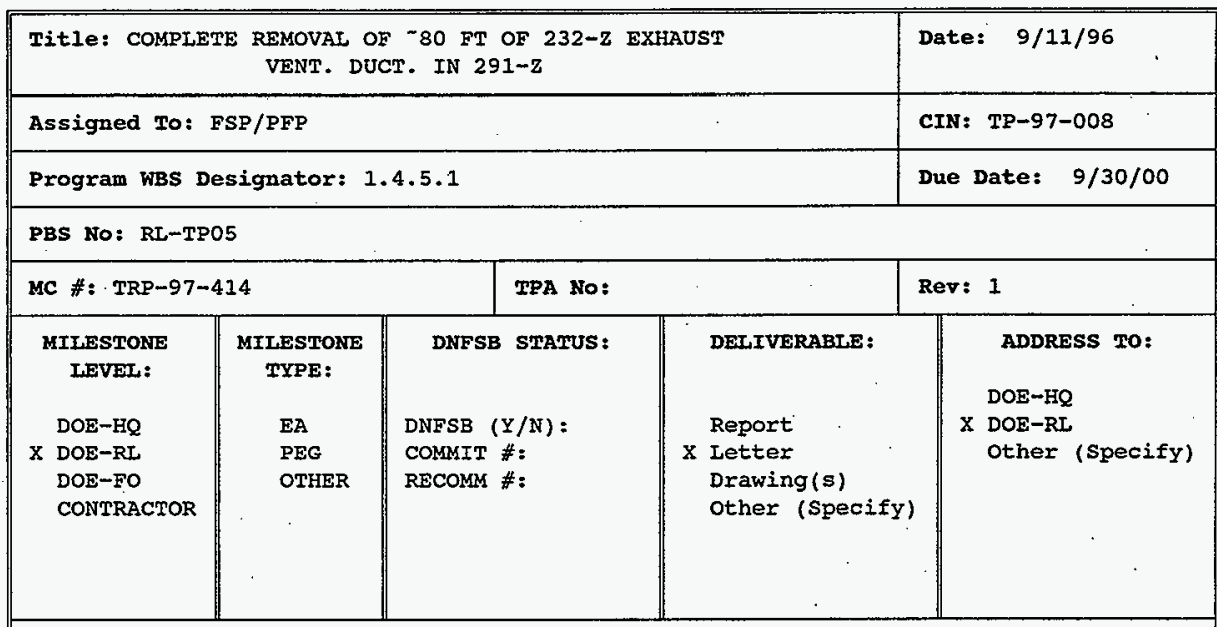

Milestone Description:

Complete the removal of $\sim 80$ feet (out of -80 feet) $232-z$ exhaust

ventilation ducting located in $291-z$. This ducting is located in the south end of 291-z (room 506) and extends from the west wall to the exhaust plenum intake near exhaust fan 8 . This ducting continues underground to the $232-\mathrm{z}$. Building which now has its own exhaust system, filters, and stack.

Description of what constitutes completion of this milestone:

This milestone is considered complete when the -80 feet of contaminated exhaust ducting has been removed, sectioned into pieces, packaged into appropriate containers and readied for shipment to the Central Waste Complex. Any plutonium-bearing material removed from this ducting is to be either stored as reactive scrap for stabilization (at a later date), or discarded as TRU waste, as appropriate. The free ends (the connection to the exhaust plenum and the flange connection at the west wall) of the ducting that is left in place shall be blanked and sealed. An ultrasonic, or equivalent, test shall be performed to document leak tight integrity. If not leak tight, the leaks shall be made leak tight.

A letter will be issued to DOE-RI documenting completion of this milestone, including the quantity of plutonium removed and length of ducting removed. 
PHMC

MILESTONE DESCRIPIION SHEET

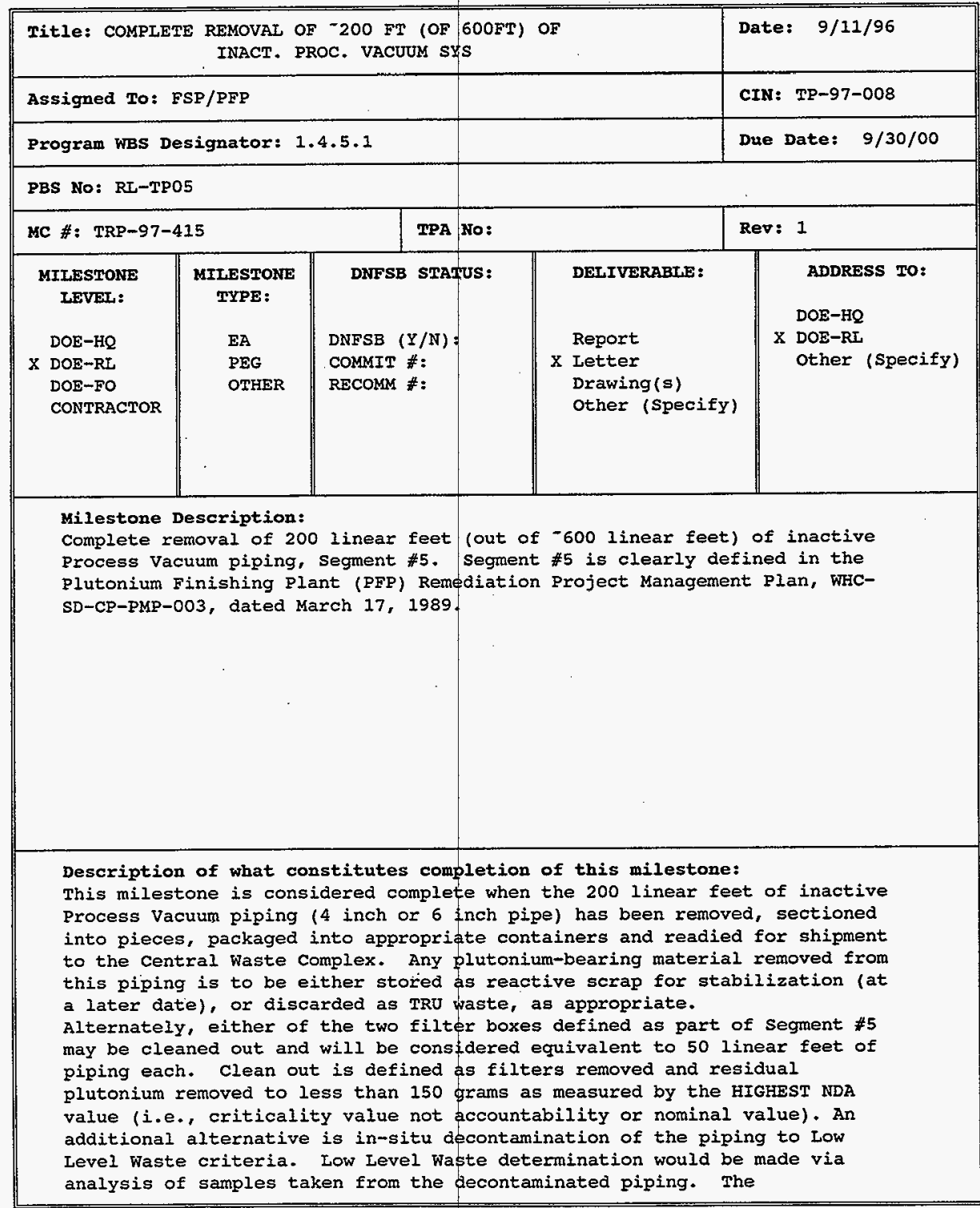


Description of what constitutes completion of this milestone: (con' $t$ )

decontaminated piping meeting the Low Level Waste criteria or cleaner would NOT require removal to meet this milestone.

A combination of the three methods may be used to measure successful completion. Also, a letter will be issued by the operating contractor to RI documenting completion of this milestone per this description including the quantity of $P u$ removed and remediated that was accomplished (length of piping removed, length of piping decontaminated, and/or number of filter boxes cleaned). 
MILESTONE DESCRIPTION SHEET

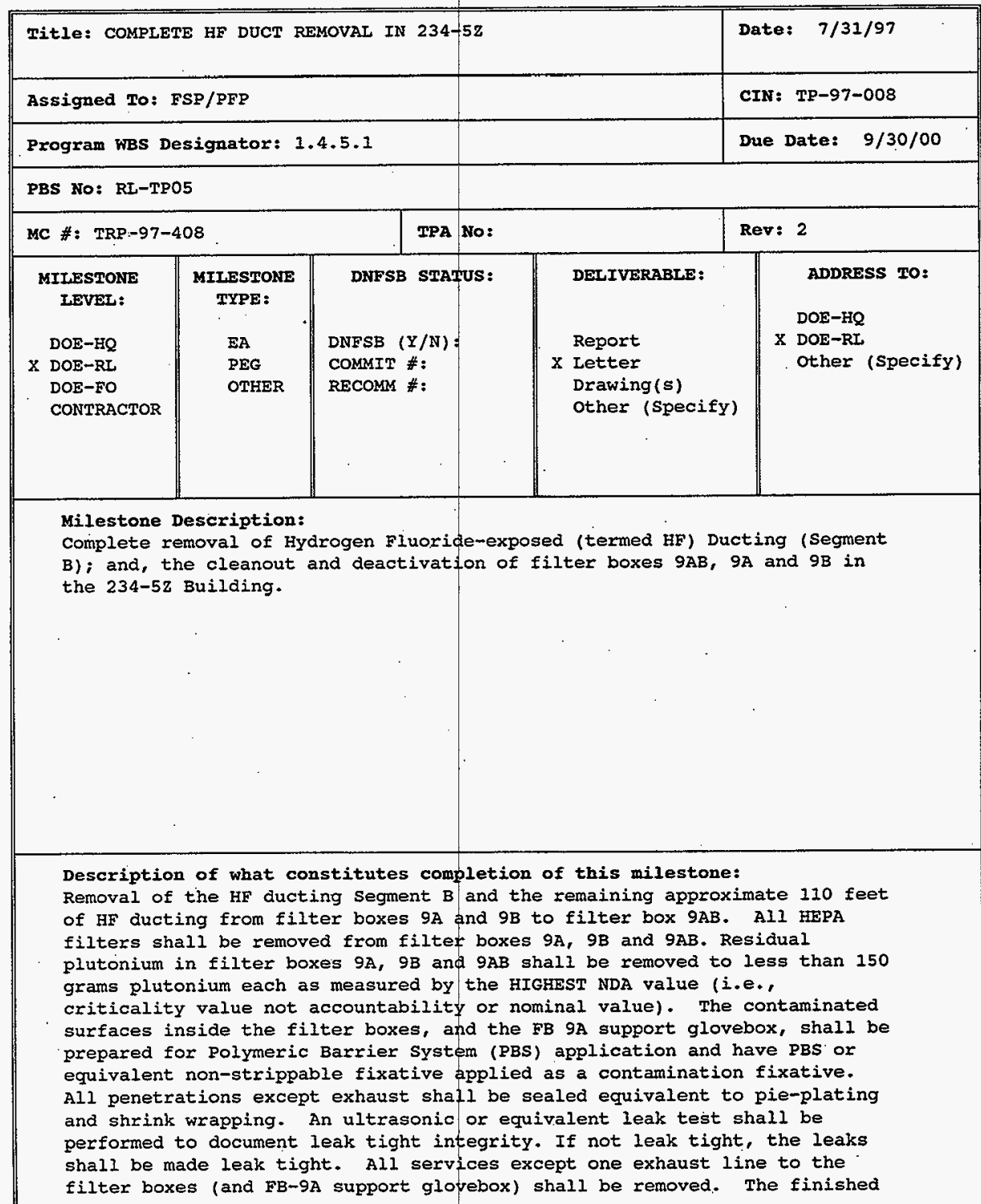




\section{HNF-SP-1234}

Description of what constitutes completion of this milestone: (con't) filter boxes shall be labeled 'Abandoned in Place' with the work package number and the final NDA values identified. Filterbox removal is an acceptable substitute to abandoning in place as described above.

Ducting, filters, and other items removed shall be sectioned into pieces (as required), packaged into appropriate containers and readied for shipment to the central Waste complex. Any Pu material removed during this activity is to be either stored as reactive scrap for stabilization (at a later date), or discarded as TRU waste, as appropriate. A letter will be issued from the Contractor to RL documenting the removal of HF ducting consistent with this description, including the quantity of plutonium and ducting removed as a result of this activity. 
FY 1998

(\$000s)

\begin{tabular}{|c|c|c|c|c|c|c|c|c|c|c|c|}
\hline PROJECT WBS: & 1.4 .6 .1 & & & & & & & & & & \\
\hline PBS NO: & RL-TP05 & & & & & & & & & & \\
\hline PBS TITLE: & PFP Deact & vation & & & & & & & & & SUBTOT \\
\hline $\begin{array}{l}\text { FUND } \\
\text { TYPE }\end{array}$ & FY1997 & $8 x 68$ & FY1999 & FY2000 & FY2001 & FY2002 & FY2003 & FY2004 & FY2005 & FY2006 & $\begin{array}{l}\text { FY1907. } \\
\text { FY2008 }\end{array}$ \\
\hline OPERATING EXPENSE & & & 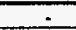 & 5,494 & 16,344 & 21,778 & 28.258 & 27,279 & 15,950 & 3,320 & 118,423 \\
\hline & & 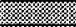 & & & & & & & & & \\
\hline GENRTC & & - & & & & & & & & & - \\
\hline & & & & & & & & & & & \\
\hline GENERAL PLANT PROJECT & & 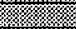 & & & & & & & & & 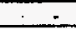 \\
\hline & & 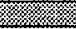 & & & & & & & & & \\
\hline LINE ITEM (Let Essch one) & & & & & & & & & & & \\
\hline & & 16 & & & & & & & & & - \\
\hline & & & & & & & & & & & - \\
\hline & & & & & & & & & & & 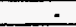 \\
\hline & & 紊 & & & & & & & & & - \\
\hline & & & & & & & & & & & $\div$ \\
\hline Subtotal Line Items. & - & & 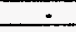 & 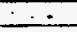 & - & - & - & $\cdot$ & 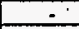 & 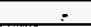 & - \\
\hline & & s. & & & & & & & & & \\
\hline 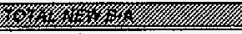 & & & & 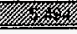 & 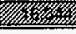 & 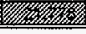 & 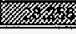 & 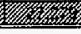 & 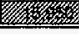 & sis & 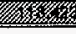 \\
\hline
\end{tabular}


FACILITY STABILIZATION

LIFE CYCLE COST BASELINE (BCWS) BY YEAR BY FUND TYPE

BY PROJECT BASELINE SUMMARY (PBS)

FY 1998

(\$000s)

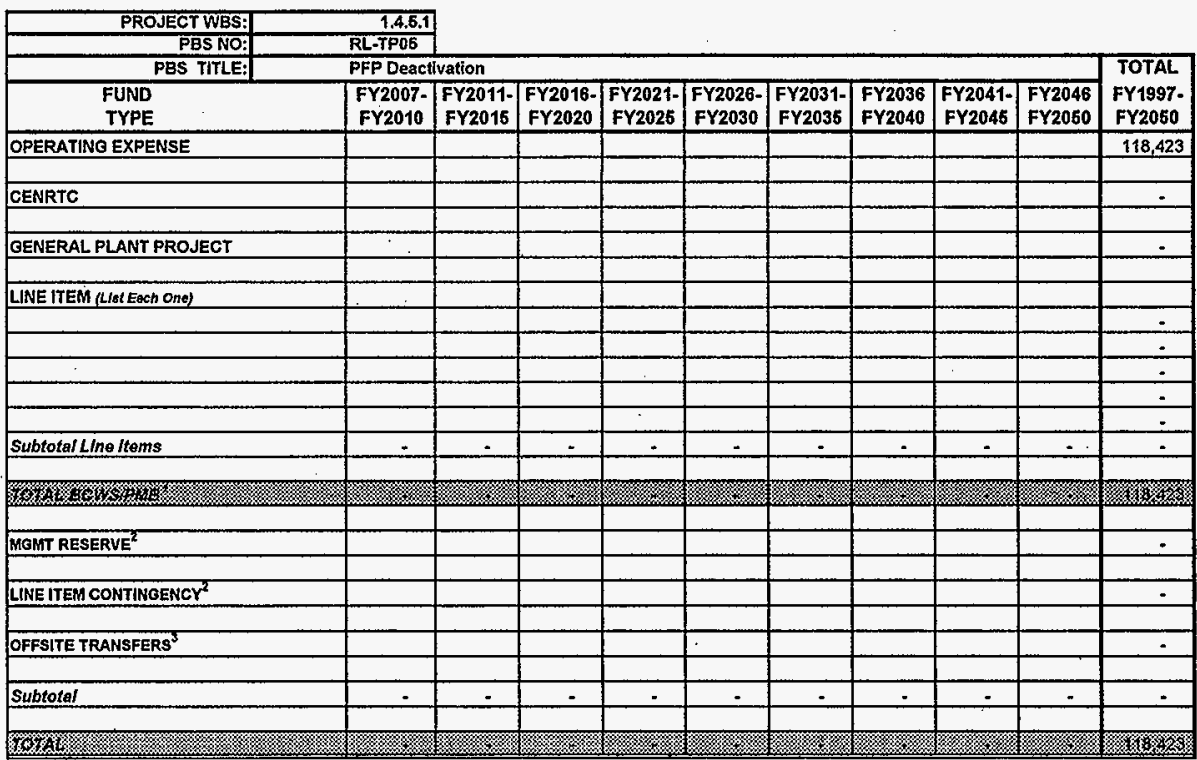

'Budgoted Cost of Work Scheduled (BCWS) Equals Performance Measurement Baseline (PMB);

Expense Carnyover Nor included.

${ }^{2}$ Management Reserve and Line Item Contingency Held by RL.

3Work Performed at Sites Other Than Hanford. 
FY 1998

(\$000s)

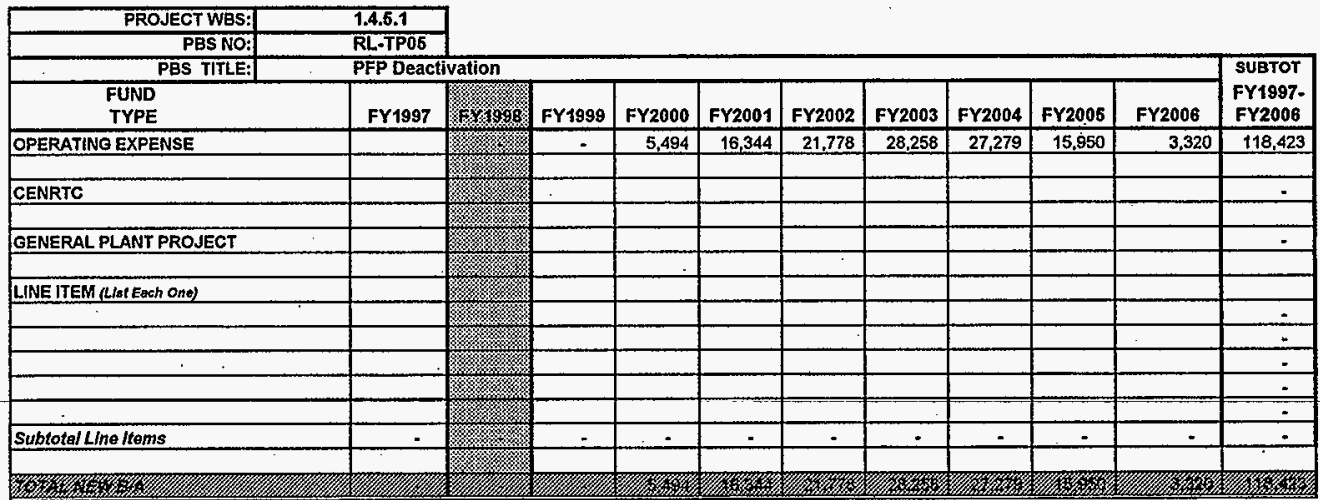


FACILITY STABILIZATION

LIFE CYCLE BUDGET AUTHORITY (BIA) BY YEAR BY FUND TYPE

BY PROJECT BASELINE SUMMARY (PBS)

FY 1998

(\$000s)

\begin{tabular}{|c|c|c|c|c|c|c|c|c|c|c|}
\hline PROJECT WBS: & 1.4.6.1 & & & & & & & & & \\
\hline $\begin{aligned} \text { PBSNO: } \\
\text { PBS TITLE: }\end{aligned}$ & $\frac{\text { RL-TP06 }}{\text { PFPDeac }}$ & vation & & & & & & & & TOTAL \\
\hline $\begin{array}{l}\text { FUND } \\
\text { TYPE }\end{array}$ & $\begin{array}{l}\text { FY2007: } \\
\text { FY2010 }\end{array}$ & $\begin{array}{l}\text { FY2011- } \\
\text { FY2015 }\end{array}$ & $\begin{array}{l}\text { FY2016- } \\
\text { FY2020 }\end{array}$ & $\begin{array}{l}\text { FY2021- } \\
\text { FY2026 }\end{array}$ & $\begin{array}{l}\text { FY2026- } \\
\text { FY2030 }\end{array}$ & \begin{tabular}{|l|} 
FY2031- \\
FY2036
\end{tabular} & $\begin{array}{l}\text { FY2036 } \\
\text { FY2040 }\end{array}$ & $\begin{array}{l}\text { FY2041- } \\
\text { FY2045 }\end{array}$ & $\begin{array}{l}\text { FY2046 } \\
\text { FY2050 }\end{array}$ & $\begin{array}{l}\text { FY1997. } \\
\text { FY2050 }\end{array}$ \\
\hline OPERATING EXPENSE & & & & & & & & & & 118,423 \\
\hline \multirow{2}{*}{\multicolumn{11}{|c|}{ CENRTC }} \\
\hline & & & & & & & & & & - \\
\hline & & & \multicolumn{8}{|c|}{ GENERAL PLANT PROJECT } \\
\hline & & & & & & & & & & \\
\hline \multicolumn{11}{|l|}{ LINE ITEM (LEt Esch One) } \\
\hline & & & & & & & & & & - \\
\hline & & & & & & & & & & - \\
\hline & & & & & & & & & & - \\
\hline & & & & & & & & & & $=$ \\
\hline & & & & & & & & & & $\div$ \\
\hline Subtotal LIne /tems & - & - & - & & $=$ & - & - & - & - & $\div$ \\
\hline 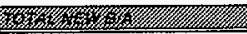 & & ZII & & & & & 2 & & & 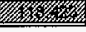 \\
\hline
\end{tabular}




\section{PFP DEACTIVATION \\ Revision 0 \\ AVERAGE ANNUAL FULL TIME EQUIVALENTS \\ (includes Major Subcontractors but not Enterprise Companies)}

PHBS 1.4.5.1

Submittal Date: 9/10/97

\begin{tabular}{|c|c|c|c|c|c|c|c|}
\hline PBS Number & PBS Title & FY 1998 & FY 1999 & FY 2000 & FY.2001 & FY 2002 & 2003 \\
\hline
\end{tabular}

RL-TP05

PFP

0

$0 \quad 37$

124

115

64

24

0

.

$2 \quad 2$

37

102

124

115

153

64

24 


\section{B.6 PFP Stabilization (RL-TP06)}

\section{B.6.1.0 PFP Stabilization Technical Baseline (RL-TP06)}

\section{B.6.1.1 PFP Stabilization Organization Mission (RL-TPO6)}

The PFP Stabilization Project mission is to implement Defense Nuclear Facilities Safety Board (DNFSB) Recommendation $94-01$ and correct related plutonium vulnerabilities by stabilizing, repackaging, immobilizing and/or properly dispositioning, all remaining plutonium-bearing materials in storage or holdup (left over residues of vanying quantities) at the Plutonium Finishing Plant (PFP). Also included is one candidate FY 1998 line item (LI) at the PFP. This $\mathrm{LI}$ is required to support the stabilization, packaging and storage of plutonium-bearing materiais at PFP in accordance with the schedule and requirements of DNFSB Recommendation 94-01. This FY 1998 line item consists of two parts (1) an automated Plutonium Stabilization \& Packaging System (SPS) to meet the requirements of DOE-STD-30 $3-96$; and, (2) 2736-Z Vault upgrades and 2736-ZB facility modifications, as necessany, to support the SPS.

As background information, initial construction on the Plutonium Finishing Plant began in 1949 and was completed in 1951. The PFP was the final link in the plutonium manufacturing chain at Hanford, processing plutonium-bearing chemical solutions and scrap solids into product-grade metal and/or oxide. This process mission, as part of the Defense Program, ended in May 1989. Over the years additional structures were added to the PFP Complex including the $2736-Z / Z B$ vault storage and handling facility, the $236-Z$ Plutonium Reclamation Facility and most recently the 243-Z Low Level Waste Treatment Facility, as well as a number of lesser structures and/or ancillary buildings. Plutonium finishing activities at PFP included three major operations: (1) Plutonium Metal Production through the remote mechanical C- \& A-Lines, which converted scrap plutonium nitrate solutions into product-grade plutonium metal, (2) the Plutonium Reclamation Facility, added in 1964, which converted scrap plutonium solutions and/or solids from Hanford and other DOE sites into product-grade plutonium nitrate solutions; and, (3) the Plutonium Storage and Handling Facility, used to nondestructively assay, store, package/repackage, and ship/receive plutonium materials to and from the Hanford site.

Although processing has stopped, chemically reactive plutonium-bearing materials remain in the plant. Chemically reactive materials create the potential for increased radiation exposure to workers and present unnecessary risk to the public. The Defense Nuclear Facility Safety Board, in their Recommendation 94-1, stated that imminent hazards could arise in 2-3 years unless identified problems were corrected which result from the chemically reactive plutonium-bearing materials held in storage and former process facilities within the DOE Complex, including the PFP. Until stabilization, packaging, immobilization and/or other appropriate disposition is complete, the risks from these quantities of chemically reactive plutonium materials is NOT mitigated. Therefore, in order to eliminate this imminent hazard at the PFP, it is necessary that all plutonium at the PFP be dispositioned consistent with the DNFSB Recommendation 94-01 Implementation Plan.

Key programmatic assumptions are as follows:

Due to signigicant budget shortfalls in both FY98 and FY99, the implementation of DNFSB Recommendation 94-01 will not be complete by May 2002. Also, as a result of these budget shortfalls, the PFP Project will require a complete rebaseline, following facility reengineering and FY98, in order to establish a new completion date for DNSFB Recommendation 94-01 at PFP.

PFP Laboratory capability restricted solely to the support of PFP programmatic activities. 
No related upgrades to PFP dangerous waste tanks systems required beyond those already planned.

Any high-level radioactive liquid wastes generated in support of programmatic activities are discharged through the 241-Z Waste Treatment Facility to the 200 West Area tank fams.

Any nonradioactive or low-level liquid wastes generated in support of programmatic activities are discharged through the 243-Z Low-Level Treatment Waste Treatment facility to the approved TEDF.

Very small quantities of radiological contaminated exhaust effluents are released from PFP stacks at levels well below with the Site's approved gaseous release limits.

Solid waste at PFP is classified as hazardous, low-level radioactive, TRU radioactive, and mixed (hazardous with radioactive constituents such as LLW and TRU).

Any solid wastes generated in support of programmatic activities at PFP are disposed to either the approved Central Waste Storage Complex or the approved Transuranic Waste Storage \& Assay Facility (TRUSAF).

Due to significant budget shortalis in FY98 and FY99, all Pu at the PFP will still be stabilized and packaged for safe storage in accordance with HNF-EP-0853, DNFSB Recommendation 94-1 Hanford Site Integrated Stabilization Management Plan (McCormack 1997); however, the May 2002 completion date will not be met.

Operations on sludge stabilization and immobilization, in connection with terminal cleanout, will continue until the end of the program in TBD.

Plutonium materials will be either stabilized, or dispositioned as waste, and packaged/repackaged to applicable specifications in DOE Standard - Criteria for Safe Storage of Plutonium Metals and Oxides (DOE-STD-3013-96) or WIPP WAC criteria as appropriate. Plutonium-bearing materials $>50$ wt\% Pu and U will continue to be stabilized at $1000 \mathrm{OC}$ and stored in vaults in accordance with DOE-STD-3013-96 criteria. Plutonium residues $<50 \mathrm{w} \%$ Pu and $U$ will be dispositioned consistent with applicable WIPP WAC criteria and regulations.

Facility modifications needed for packaging and storage of Pu containers to the DOE Standard, DOE-STD-3013-96, are scheduled to be operational by TBD. Stabilized high-assay material ( $>50$ wt\% Pu and U) will be retrieved from storage and restabilized and packaged consistent with DOE-STD-3013-96 criteria and returned to vault storage. Major vault modifications, necessary to handje the new standardized Pu storage container, will be required.

The current laboratory development program will identify and resolve any technology and equipment development issues and will serve as an adequate basis for design of the selected stabilization process systems. The PFP Analytical Laboratory and the Plutonium Process Support Laboratories will be upgraded as required. Additional instrumentation will be provided to support necessary analyses in characterization of miscellaneous solid residues and process support of the stabilization operations.

Programmatic operations will be on a 24-hour-per-day, 5-day-per-week basis (XYZ schedule) and personnel and funding will be provided to support this level of effort.

Work scope contained in the New Facility Planning ADS (6625) is now included within this program element.

The PFP Transition Project End Point is anticipated by TBD. This end point is NOT the cessation of all activities as with other Hanford Site facilities. Instead, this End Point assumes the continued operation of all SNM shipping, receiving, storage and vault systems, including all SAS systems plus laboratory capabilities as needed, for an indefinite period. This end point condition is also based on the following. 
- Full implementation of DNFSB Recommendation 94-1 is completed in FY TBD and applicable PU vuinerabilities are mitigated.

- Deactivation is initiated in parallel with DNFSB Recommendation 94-1 activities.

- The majority of facility transition to deactivation occurs during FYS TBD.

Start-up of the vertical calciner by October 1,1997 does not require a Readiness Review (Readiness Assessment only).

\section{Stabilization End-point}

The PFP Stabilization project completes when the plutonium and uranium materials at PFP, as defined by DNSFB Recommendation 94-01, are dispositioned according to the requirements of the Department of Energy's DNSFB Recommended 94-01 Implementation Plan, transmitted to the DNSFB on February 28, 1935. The mandated completion date is May 2002. By this date, all $4,056 \mathrm{Kg}$ of Plutonium at PFP has been stabilized, cemented, immobilized and/or othenvise dispositioned.

Also, assuming no plutonium materials are converted to mixed ozide and burned in reactors, $2940 \mathrm{Kg}$ of plutonium will remain in storage at PFP under PBS RL-TP07 and 1,116 Kg plutonium will have been shipped to Hanford's Central Waste Complex and/or WIPP.

\section{B.6.1.2 PFP Stabilization End Point Targets from Hanford Strategic Plan}

* Complete stabilization of plutonium in PFP (DNFSB 94-1 implementation).

\section{B.6.1.3 PFP Stabilization Major Facilities}

\section{B.6.1.3.1 Plutonium Finishing Plant Facility}

\section{B.6.1.3.1.1 Plutonium Finishing Plant Facility Description}

PFP, formerly called Z-Plant, was constructed in 1949-1951 in the 200-W Area of Hanford. It was used to process plutonium-bearing chemical solutions and convert them into metal and oxide. The plant is currently in the process of stabilization and deactivation.

There is no support for facility transition to deactivation in FY98 and FY99. Hence, no progress will be made towards facility deactivation until FYOO. Also, facility transition to deactivation activities will be rebaselined in FY98 following facility reengineering.

\section{B.6.1.3.1.2 Plutonium Finishing Plant Facility Technical Logic:}

The Department of Energy (DOE), in partnership with its contractors, shall plan, acquire, operate, maintain, and dispose of physical assets as valuable national resources. Stewardship of these physical assets shall be accomplished in a cost-effective manner to meet the DOE mission. This shall incorporate industry standards, a graded approach, and performance objectives. 


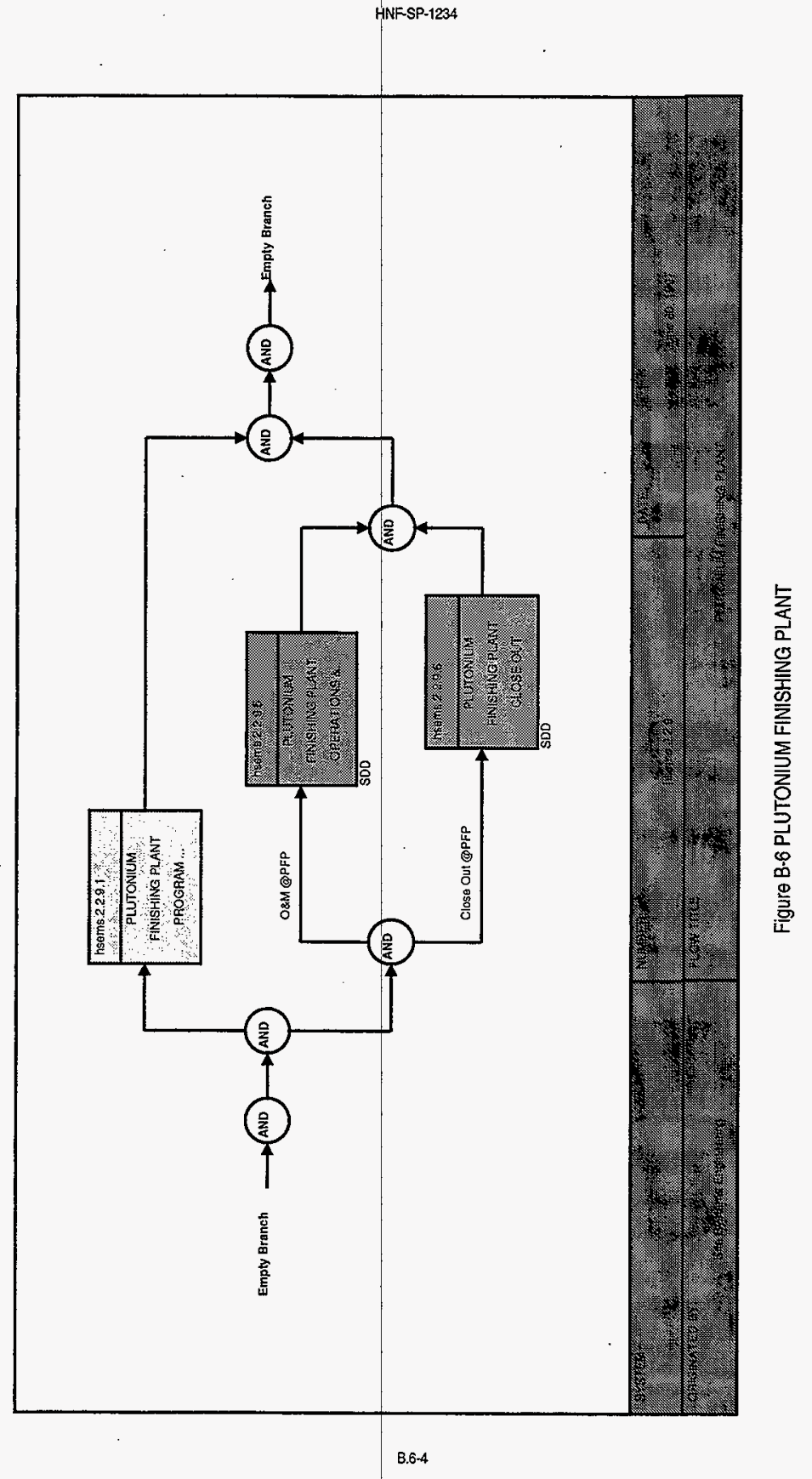




\section{B.6.1.3.1.3 Plutonium Finishing Plant Requirements and Life Cycle Function Descriptions}

Requirements:

- Complete oxidation stabilization of existing plutonium metal button (Pu) inventory within PFP vaults (approx 352 items) by TBD.

- Complete stabilization of 5,363 $\mathrm{Kg}$ Pu bulk high assay oxide/mox by TBD.

- Complete shipment of high enriched uranium materiais by $1 / 01$.

* Complete stabilization of 1,600 polycubes by TBD.

- Complete metal repackaging by TBD.

- Complete stabilization and packaging of all residues at PFP by TBD.

* Complete thermal stabilization/repackaging of all Pu oxide to meet metal/oxide storage standards at PFP by TBD.

* Complete stabilization and repackaging of interim stabilized material by TBD.

- Complete cementation, discard or otherwise disposition of $3765 \mathrm{~kg}$ of bulk plutonium residue materials by TBD.

- Complete cementation of $1269 \mathrm{~kg}$ of bulk plutonium-bearing materials (cumulative) by $9 / 30 / 98$.

* Complete cementation of $2559 \mathrm{~kg}$ of bulk plutonium-bearing materials (cumulative) by 9/30/99.

* Complete stabilization of all Pu bearing solutions ( 4300 items) by TBD.

- Central Plateau inactive facilities shall be maintained within the approved safety envelope

* Central Plateau asbestos abatement shall be performed as necessary

Life Cycle Function Descriptions:

\section{B.6.1.3.1.3.1 PLUTONIUM FINISHING PLANT OPERATIONS \& MAINTENANCE WORK SCOPE SUMMARY}

Day-to-day work, including preventive and predictive maintenance, that is required to maintain and preserve plant and capital equipment in a condition suitable for it to be used for its designated purpose.

\section{PLUTONIUM FINISHING PLANT OPERATIONS \& MAINTENANCE SPECIFIC FUNCTIONS}

\section{B.6.1.3.1.3.2 Maintain Safe \& Compliant Materials in PFP Facility during Stabilization}

Materials stored in the PFP facility will be maintained in safe condition until they are removed for disposal or treatment.

\section{B.6.1.3.1.3.3 PLUTONIUM FINISHING PLANT POST OPERATIONS WORK SCOPE SUMMARY}

Day-to-day work, including pre-stabilization surveillance and maintenance, stabilization, post-stabilization 
surveillance and maintenance, deactivation, and post-deactivation surveillance and maintenance, that is required to allow safe decontamination and decommissioning.

Also maintain $2736-Z B / Z$ vault facilities including the storage monitoring of SNM at PFP, until final deactivation.

\section{PLUTONIUM FINISHING PLANT POST OPERATIONS SPECIFIC FUNCTIONS}

\section{B.6.1.3.1.3.4 Maintain Safe \& Compliant Plutonium Finishing Plant Facility in CP Areas}

Maintain the PFP facility structures, operating systems and equipment, and monitoring systems within the approved safety and compliance requirements until the facilities are made available for $D \& D$. Also maintain the $2736-Z B / Z$ vault facilities, including the storage and monitoring of SNM at PFP until final deactivation.

\section{B.6.1.3.1.4 Plutonium Finishing Plant Boundary Diagram}

Table B.6-1 Plutonium Finishing Plant Boundary Diagram

\begin{tabular}{|l|l|}
\hline $\begin{array}{l}\text { Extemal Interfaces } \\
\text { None- } \\
\text { Hanford Site Environmental System Interfaces } \\
\text { None. }\end{array}$ & $\begin{array}{l}\text { Extemal Interfaces } \\
\text { None- } \\
\text { Hanford Site Environmental System Interfaces } \\
\text { None- }\end{array}$ \\
\hline
\end{tabular}




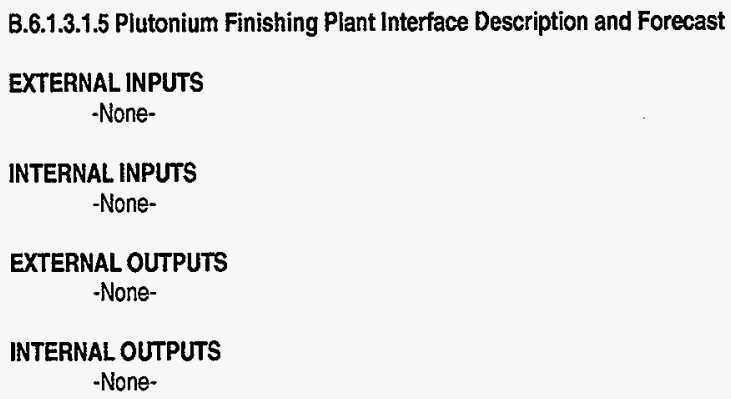




\section{B.6.1.4 Drivers for PFP Stabilization}

\section{Table B.6-2 Source Documents for PFP Stabilization}

Name

DE-AC06-96RL13200

DOE/EM-0199

DOE/RL-96-14

DOE/RL-96-92
Iitle

Project Hanford Management Contract, Fluor Daniel Hanford, Inc.

Plutonium Vulnerability Management Plan

Updated Draft Mission Direction Document, June 1996

Hanford Strategio Plan

\section{B.6.t.5 PFP Stabilization Risk Management}

The PFP Stabilization Project uses primarily the $234-5 Z$ building to stabilize, immobilize andior otherwise disposition (i.e., pyrolysis, direct denitration calcination, etc.) identified plutonium materials consistent with DNFSB Recommendation 94-01. The total inventory of plutonjum-bearing materials involved is approximately $4,056 \mathrm{Kg} \mathrm{Pu}$ and $18 \mathrm{Kg} \mathrm{U}$. The main processes to be used are muffle furnace stabilization at 1000 degree centigrade, direct denitration calcination, pyrolysis, cementation and the Stabilization \& Packaging System. The primary rooms used in the $234-5 \mathrm{Z}$ building are: $227,228 \mathrm{~A}, 228 \mathrm{~B}, 228 \mathrm{C}, 230 \mathrm{~A}, 230 \mathrm{~B}, 230 \mathrm{C}, 232$, and $235 \mathrm{~B}$ and $235 \mathrm{C}$. In addition, this project uses 2736 -ZB facilities as necessary to store the stabilized material discard the immobilized materiel as waste and to house the new plutonium Stabilization \& Packaging system. The primary hazard, as defined by the PFP Final Safety Analysis Report. is a nuclear criticality.

The PFP Stabilization Project impiements DNFSB Recommendation 94-1 and correct related plutonium vulnerabilities by stabilizing, and/or properly dispositioning, all remaining plutonium residues in storage or holdup. These plutonium vuinerabilities (see "Plutonium Working Group Report on Environmental, Safety \& Health Vulnerabilities Associated with the Department's Plutonium Storage", Vol. 11 Appendix B. Part 2: Hanford Site Assessment Report, September 1994), can lead to "... imminent hazards within 2-3 years" (DNFSB).

The most likely imminent hazard, according to Chapte- 9, "Accident Analysis", PFP Final Saiety Analysis Report (FSAR), WHC-SD-CP-SAR-021, resulting from these plutonium residues is a nuclear criticality. We have assumed that the stated impact has a $99 \%$ probability of occurring in 30 Years. This corresponds to an annual probability of 0.14 incidents per year which is the basis of the probability rating for the risk identified (i.e., probability $(P)$ between 0.1 per year and 1.0 Per year). Louis type of hazard is consistent with DNFSB Recommendation 94-1, dated May 1994,- which states "The Board has concluded from observations and discussions with others that imminent hazards could arise within 2-3 years unless certain problems are corrected". While the FSAR Chapter 9 does not have a preferred criticality scenario (i.e., many possible scenarios due to the large variety of plutonium materials), a possible scenario would be an undetected leak of plutonium nitrate from one of the $100+$ Product Receiver (PR) Cans with polypropylene inner containers stored at the PFP. The inner container would be breached due to radiation damage and the outer stainless steel container corroded by exposure to corrosive elements within the plutonium nitrate matrix, such as chlorides or fluorides. The subsequent leaking plutonium nitrate would then collect, urinoticed, in some unfavorable geometric container and go critical. The consequences of such a criticality event are based on Chapter 9 historical data. The off site dose consequence is calculated at $53 \mathrm{mrem}$ and the on site dose consequence is calculated at 730 mrem. Also based on previous nuclear criticality events in the DOE Complex and at PFP, extreme over exposure to one or more facility workers would result. There would be minimal environmental impact. However, a nuclear criticality event at PFP would also have significant negative consequences to Compliance, Mission and Mortgage Reduction due to failure to meet regulatory requirements and mission objectives resulting from the magnitude of anticipated recovery actions, the increased costs and the delays to the primary mission. 


\section{PFP Stabilization Work Breakdown Structure}

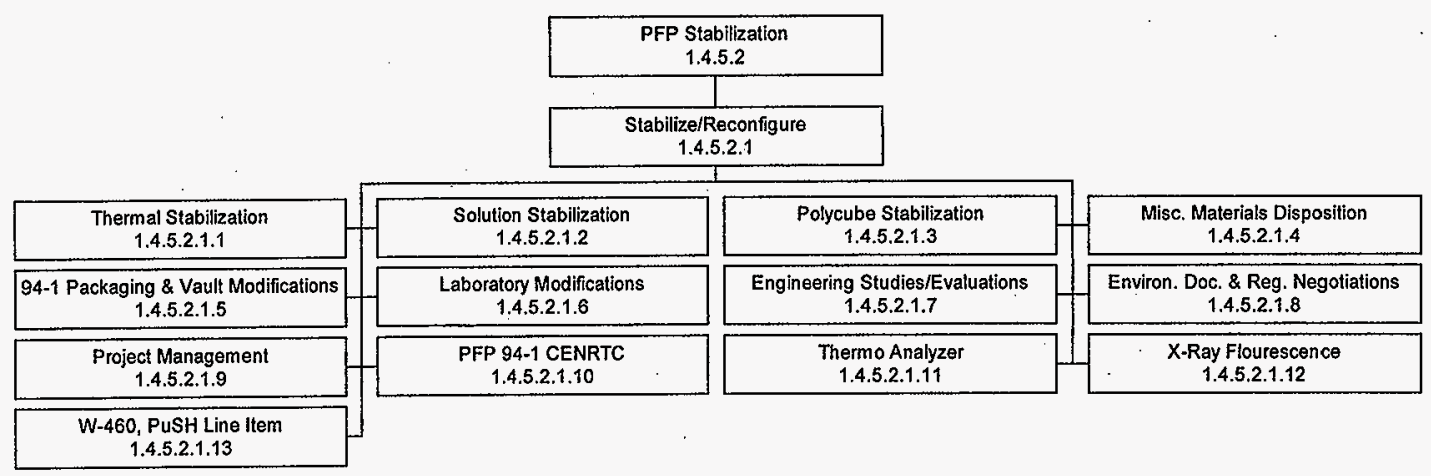


HANFORD SITE WORK BREAKDOWN STRUCTURE DICTIONARY

FACILITY STABILIZATION

WBS: 1.4

$8 / 25 / 1997$

\begin{tabular}{|l||l|l|l|}
\hline $\begin{array}{l}\text { 1. Activity Title: } \\
\text { STABILIZE/RECONFIGURE FOR MIN SURVEILLAN }\end{array}$ & $\begin{array}{l}\text { 2. Date } \\
7 / 31 / 1997\end{array}$ & $\begin{array}{l}\text { 3. PBS Number } \\
\text { RL-TP06 }\end{array}$ & $\begin{array}{l}\text { 4. Dict Rev } \\
0\end{array}$ \\
\hline
\end{tabular}

5. Contract WBS No. 1.4.5.2.1

6. Corresponding FDS No. 7. Baseline CR No. $\mathrm{K} 6 \mathrm{AB}$

8. Organization Name 15000

10. Scope of Work

This activity entails all plant tasks necessary to prepare for deactivation of nonessential systems, system components, and physical structures, and required to minimize environmental public, and personnel hazards. These actions are taken consistent with minimizing continuing facility costs while maintaining the facility capabilities sufficient to implement the Record of Decision (ROD) from the PFP Environemental Impact Statement (EIS). This activity includes the following:

*Thermal Treatment

*SoTution Treatment

*Polycube Stabilization

*Miscell aneous Materials Disposition

*DNSFB 94-1 Packaging and Vault Modifications (ADS 6625)

*Laboratory Modifications for Minimum Surveitlance

*Engineering Studies/Evaluation

*Environmenta1 Documentation and Regulatory Negotiations

*Project Management and Training

*Capital to support stabilization and DNFSB Recommendation 94-01

(1) DNFSB Recommendation 94-01 as used in this WBS includes Plutonium Vulnerability corrective actions. 


\begin{tabular}{|c|c|c|c|c|c|}
\hline $\begin{array}{l}\text { Proj Ly] } \\
\text { (PBS \#) }\end{array}$ & $\begin{array}{l}\text { FOS Act } \\
\text { Number }\end{array}$ & Activity Title & Activity Manager & Responsible Organization & Cost Account \\
\hline RL-TP06 & & PFP STABILIZATION & & & \\
\hline & $K 6 A B$ & STABILIZE/RECONFIGURE FOR MIN SURVEILLANCE & D. 8. Courson & 15000 & 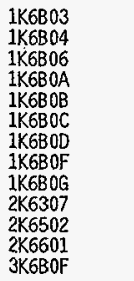 \\
\hline
\end{tabular}




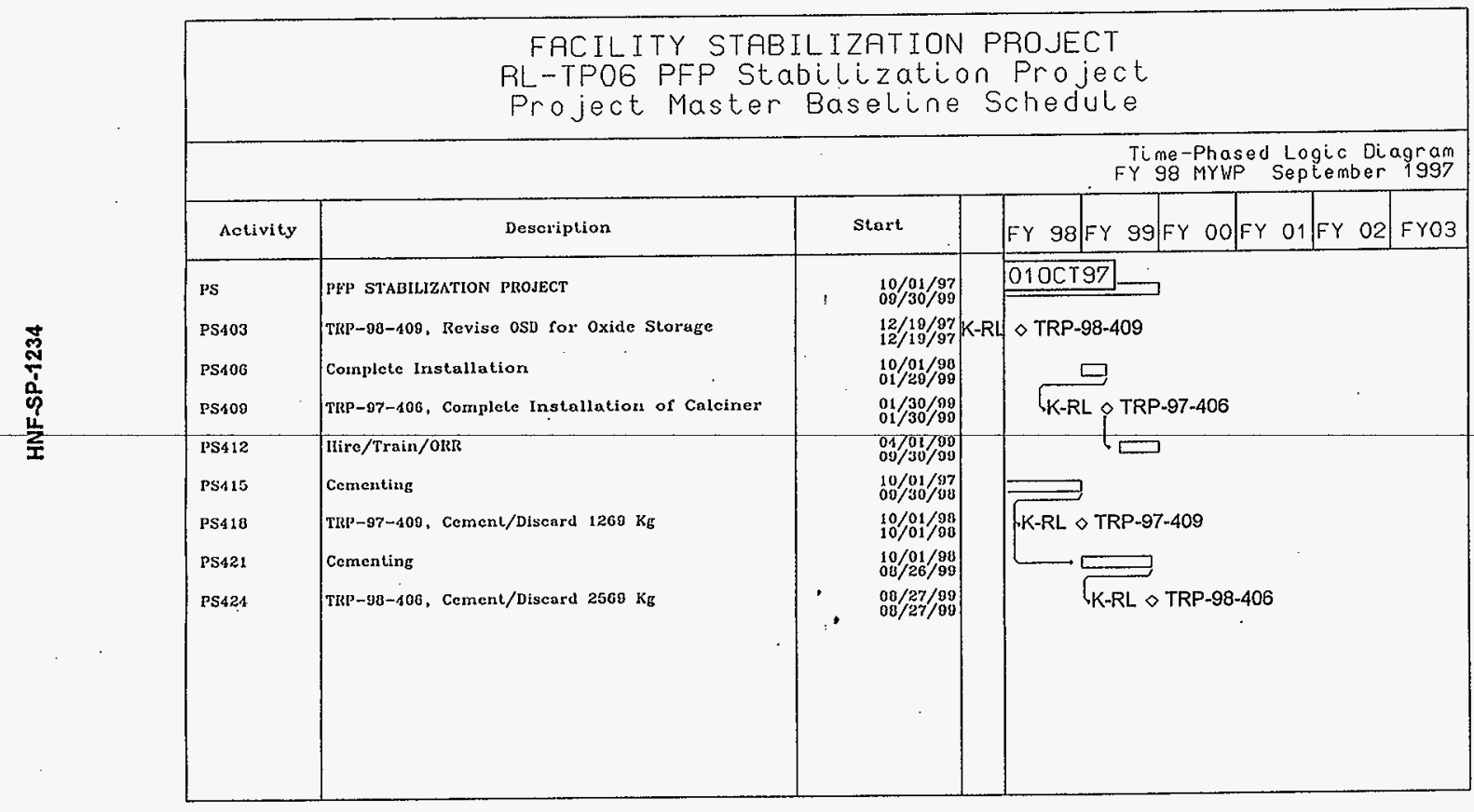




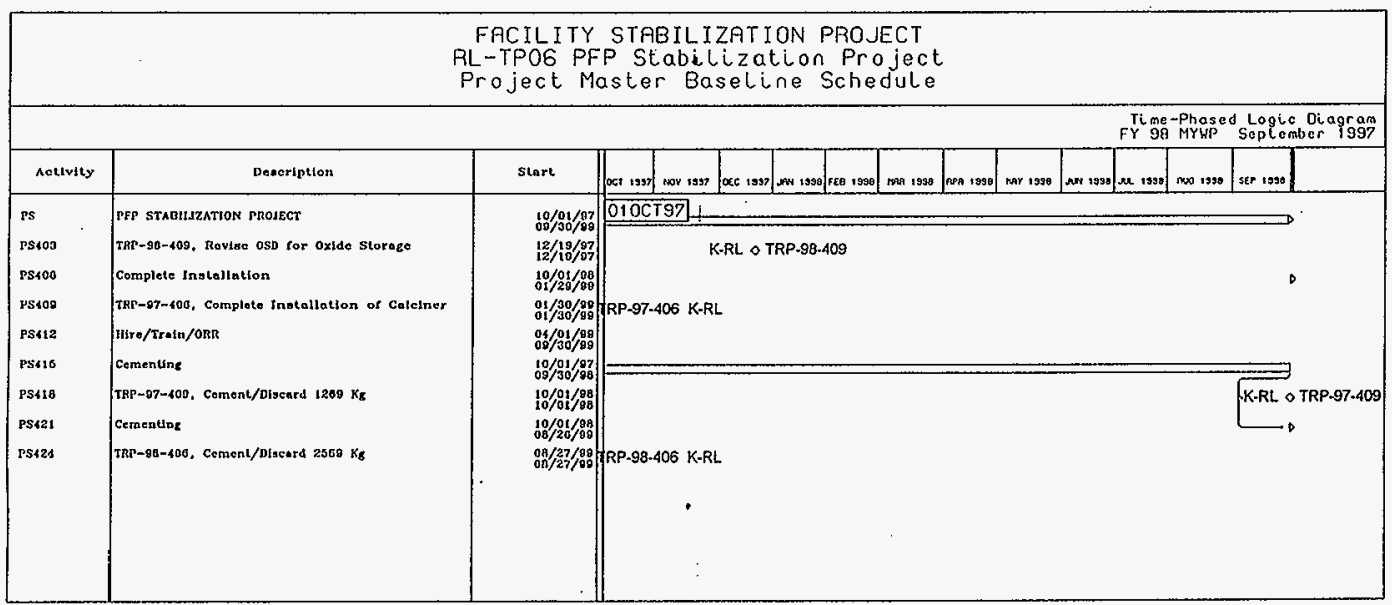




\begin{tabular}{|c|c|c|c|c|c|c|c|c|c|c|}
\hline \multirow[b]{2}{*}{ MILESTONE } & \multirow[b]{2}{*}{ TPA-MS } & \multirow[b]{2}{*}{ TPA } & & & & & & & & \\
\hline & & & & & & PLANMED & APPROVED & REVISED & & \\
\hline CONTROL \# & NUMBER & TYPE & LEVEL & MS TITLE & TYPE & BASELINE & BASELINE & BASELINE & PROJ CIN & PBS \# \\
\hline 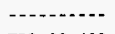 & -- & .... & $\cdots$ & גזינחדי & $\cdots$ & $-1-$. & -- & $\cdots+\cdots$ & & \\
\hline TRP-98-403 & & & RL & COMPLETE SHIPMENT OF HIGH ENRICHEO URANIUM (HEU) MATERIALS & & $1 / 31 / 01$ & & & & RL-TP06 \\
\hline TRP-97-406 & & & $\mathrm{RL}$ & COMPLETE INSTALLATION OF SOLUTION STABILIZATION DENITRATION CALCI & OTH & $1 / 31 / 99$ & & & & \\
\hline TRP-97-409 & & & $\mathrm{RL}$ & COMPLETE CEMENTATION/DISCARD OR DISP. OF $1.269 \mathrm{KG}$ BULK PU RESIDUE & & $9 / 30 / 98$ & & & & RL-TP06 \\
\hline TRP-98-409 & & & RL & REVISE OPERATING SPECIFICATION DOCUMENT FOR OXIDE STORAGE AT PFP & & $12 / 19 / 97$ & & & & RL-TP06 \\
\hline TRP-98-406 & & & RL & COMPLETE CEMENTATION/DISCARD OR DISP. $2.569 \mathrm{KG} \mathrm{BULKK} \mathrm{RESIDUES}$ & & $9 / 30 / 99$ & & & & RL-TP06 \\
\hline
\end{tabular}




\section{PHMC \\ MILESTONE DESCRIPTION SHEET}

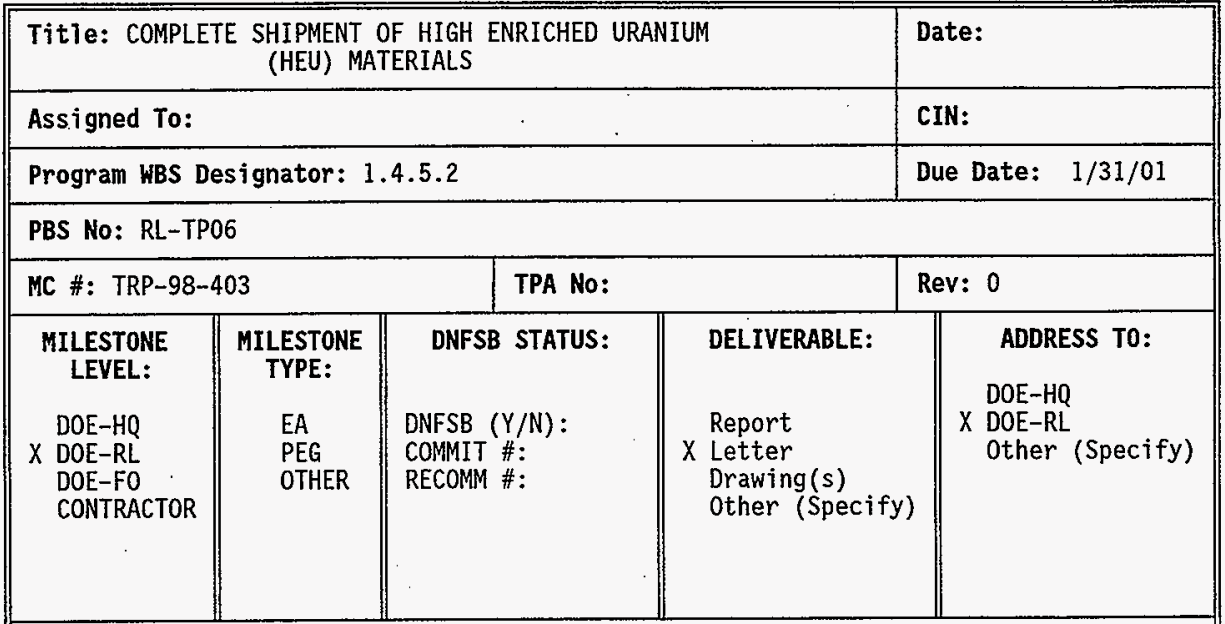

Milestone Description:

Begin the stabilization of Pu-bearing solutions at PFP using direct denitration vertical calciner technology with the production unit.

Description of what constitutes completion of this milestone:

The PFP Transition Project has either initiated stabilization of Pusolutions, using direct denitration vertical calciner technology, been authorized by FDH and DOE to commence stabilization of these solutions (i.e., completed all necessary readiness reviews/assessments, applicable NEPA documentation approved, etc.); or, has submitted a Declaration of Readiness to DOE approved by $\mathrm{FDH}$ declaring Contractor readiness to commence solution stabilization. The Deciaration of Readiness, following DOE review, is deemed technically adequate by the DOE.

The concept is that the Contractor is to have completed all its required actions to commence stabilization of Pu-solutions at PFP. If conditions, or requirements, beyond the control/responsibility of the Contractor preclude startup then this milestone is to be considered complete.

Likewise, it the Contractor has completed all its actions and the DOE has 
Description of what constitutes completion of this milestone: (con't) completed all its actions, but equipment problems, or facility conditions, under the control/responsibility of the Contractor prevent startup, then this milestone is not to be considered complete.

A letter will be issued to DOE-RL documenting completion of this milestone. 


\section{PHMC \\ MILESTONE DESCRIPTION SHEET}

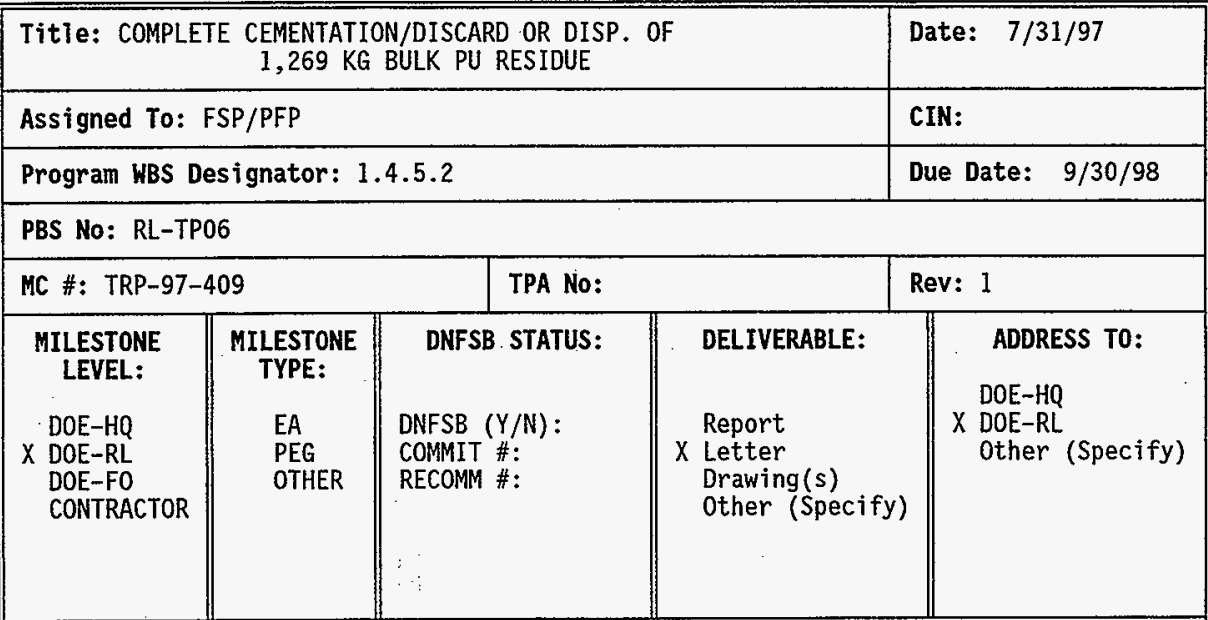

Milestone Description:

The cementation/discard or disposition of 1,852 Kg BuTk Pu Residues (total combined for FYs 1997 \& 1998) out of a total of $3,765 \mathrm{Kg} \mathrm{Bu} \mathrm{k}$ will be completed to the applicable discard criteria.

Description of what constitutes completion of this milestone:

The cementing, packaging for discard, or dispositioning of the PFP's. inventory of miscellaneous Pu-bearing residues will be performed to criteria acceptable to Hanford's Central Waste Complex and the applicable regulatory agencies. Also included is all necessary stabilization, shipping, packaging and/or waste disposal tasks necessary to support the cementation/discard or disposition.

This milestone provides for the cementing, packaging for discard, and acceptable packaging for shipment to Hanford's Central Waste Complex of approximately 1,633 (1,852 total) $\mathrm{Kg}$ Bulk Pu-bearing residues in FY 1998 out of a total $3,765 \mathrm{Kg}$ of residues currently stored in the PFP vaults. A letter will be issued to DOE-RL documenting completion of this milestone, also indicating the plutonium inventory of the material dispositioned and its packaging configuration. 


\section{PHMC}

MILESTONE DESCRIPTION SHEET

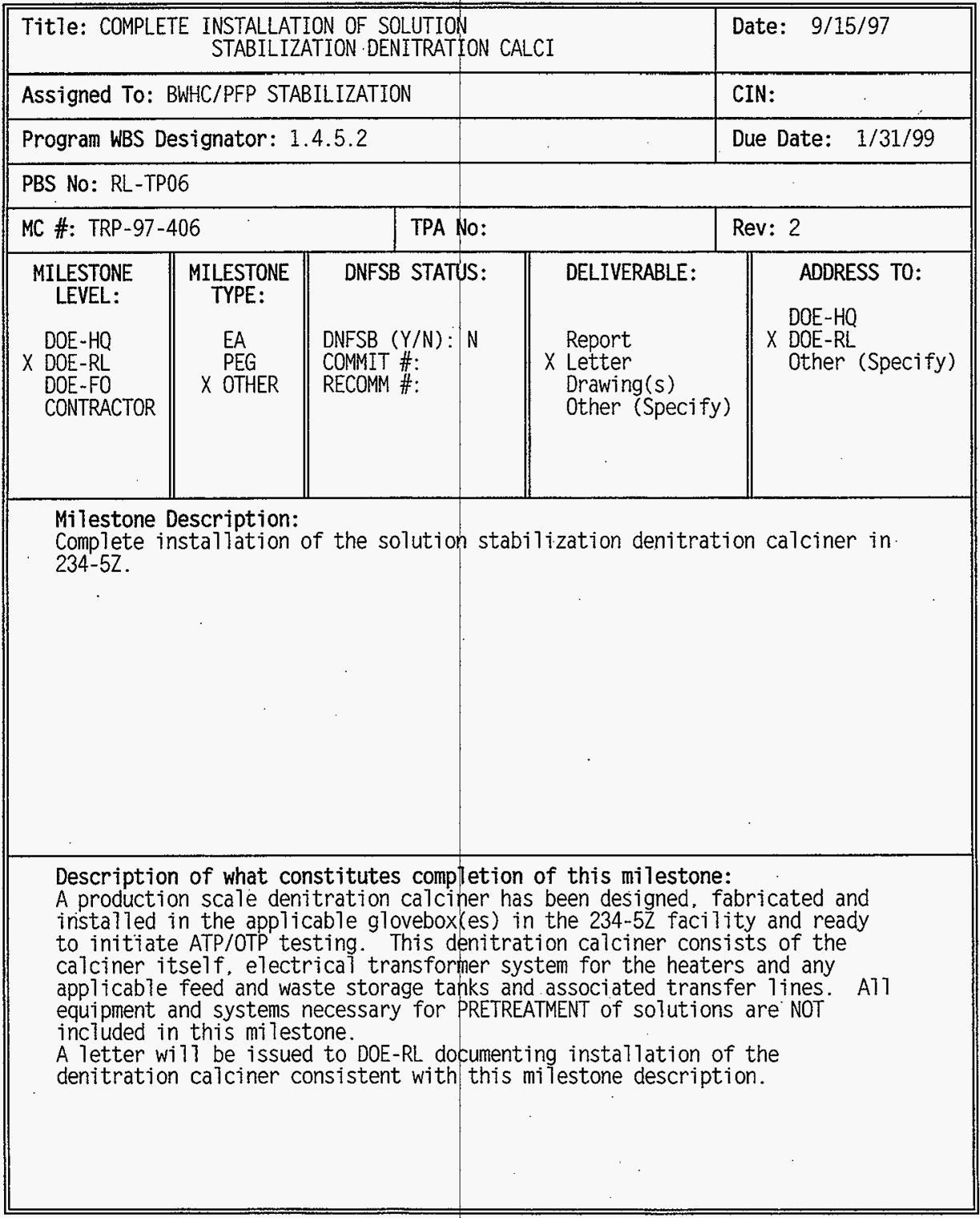


PHMC

MILESTONE DESCRIPTION SHEET

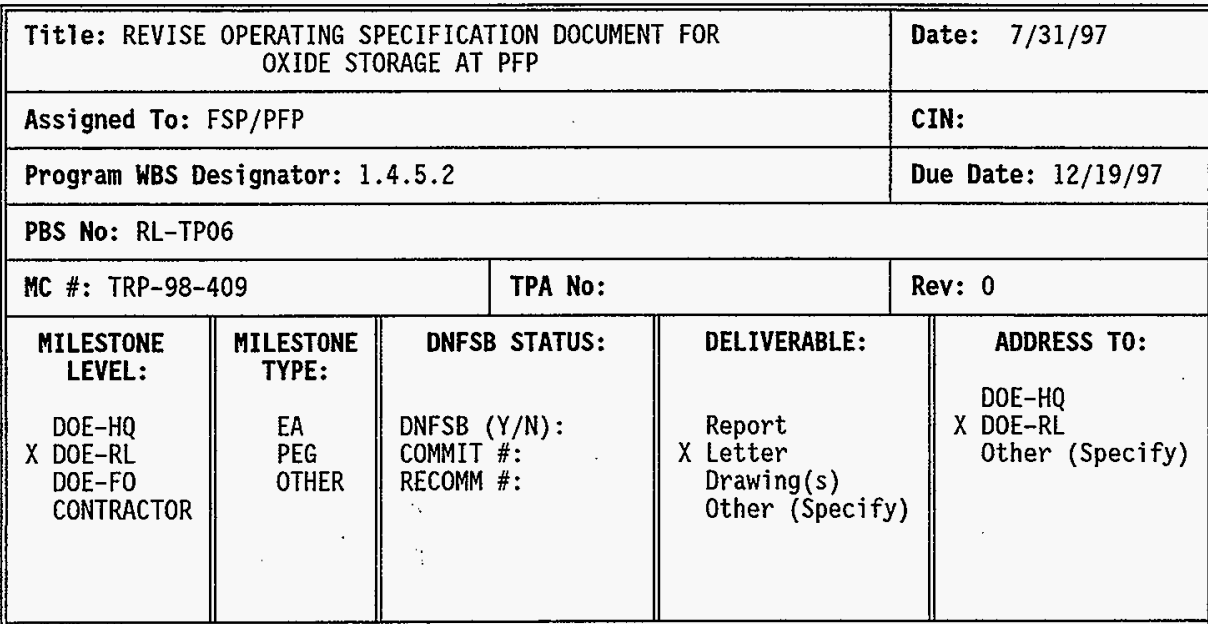

Milestone Description:

Revise operating specification document (OSD) for oxide storage at PFP.

Description of what constitutes completion of this milestone:

Revise the operating specification document (OSD) for plutonium oxide storage at PFP consistent with technical basis documentation. The purpose is to insure that the PFP vault storage OSD provides a can configuration so that plutonium dioxide, generated either by direct denitration, oxalate conversion, or thermal stabilization can be safely stored in PFP vaults consistent with accepted technical justification. A letter will be issued to DOE-RL documenting revision of the OSD for plutonium storage at PFP. 


\section{PHMC}

\section{MILESTONE DESCRIPTION SHEET}

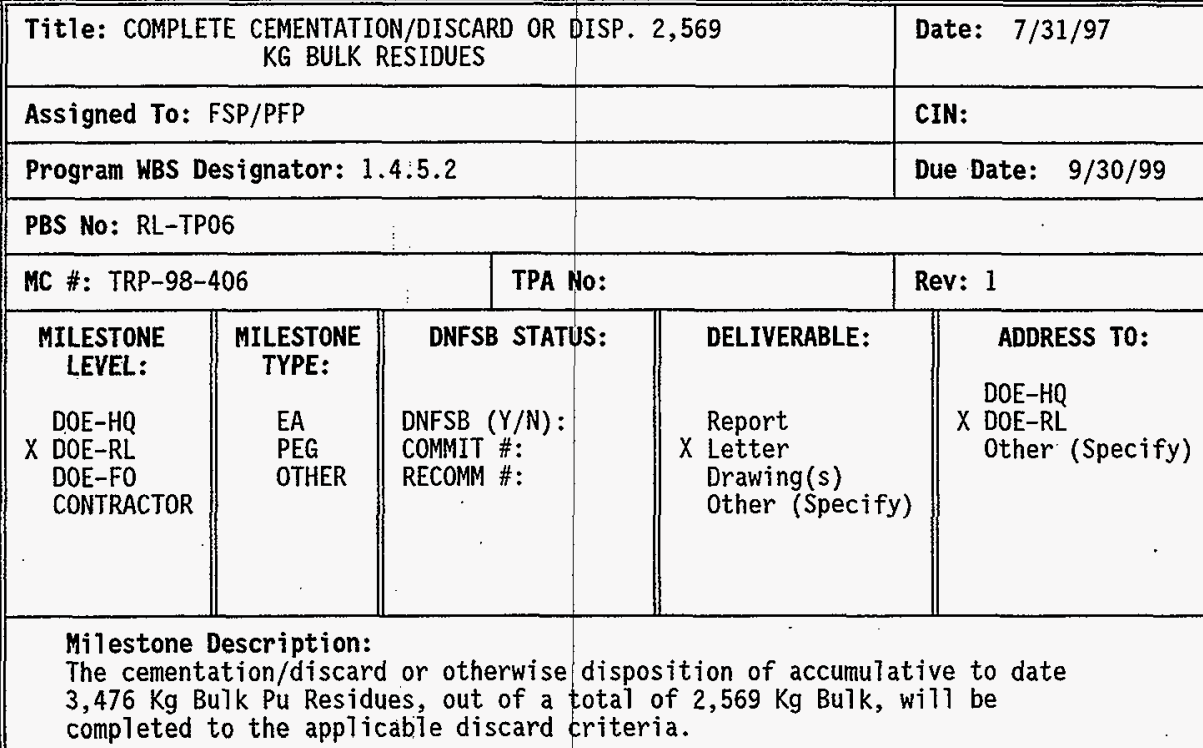

Description of what constitutes completion of this milestone:

The cementing, packaging for discard, or dispositioning of the PFP's inventory of miscellaneous Pu-bearing residues will be performed to criteria acceptable to Hanford's Central Waste Complex and the applicable regulatory agencies. Also included is all necessary stabilization, shipping, packaging and/or waste disposal tasks necessary to support the cementation/discard or disposition.

This milestone provides for the cementing, packaging for discard, and acceptable packaging for shipment to Hanford's Central Waste Complex of $3,476 \mathrm{Kg}$ Bulk Pu-bearing residues out of a total $2,569 \mathrm{Kg}$ residues currently stored in the PFP vaults (I,300 Kg Bulk cemented in FY 1999). A letter will be issued to DOE-RL documenting completion of this milestone, also indicating the plutonium inventory of the material dispositioned and its packaging configuration. 
FACILITY STABILIZATION

LIFE CYCLE COST BASELINE (BCWS) BY YEAR BY FUND TYPE

BY PROJECT BASELINE SUMMARY (PBS)

FY 1998

(\$000s)

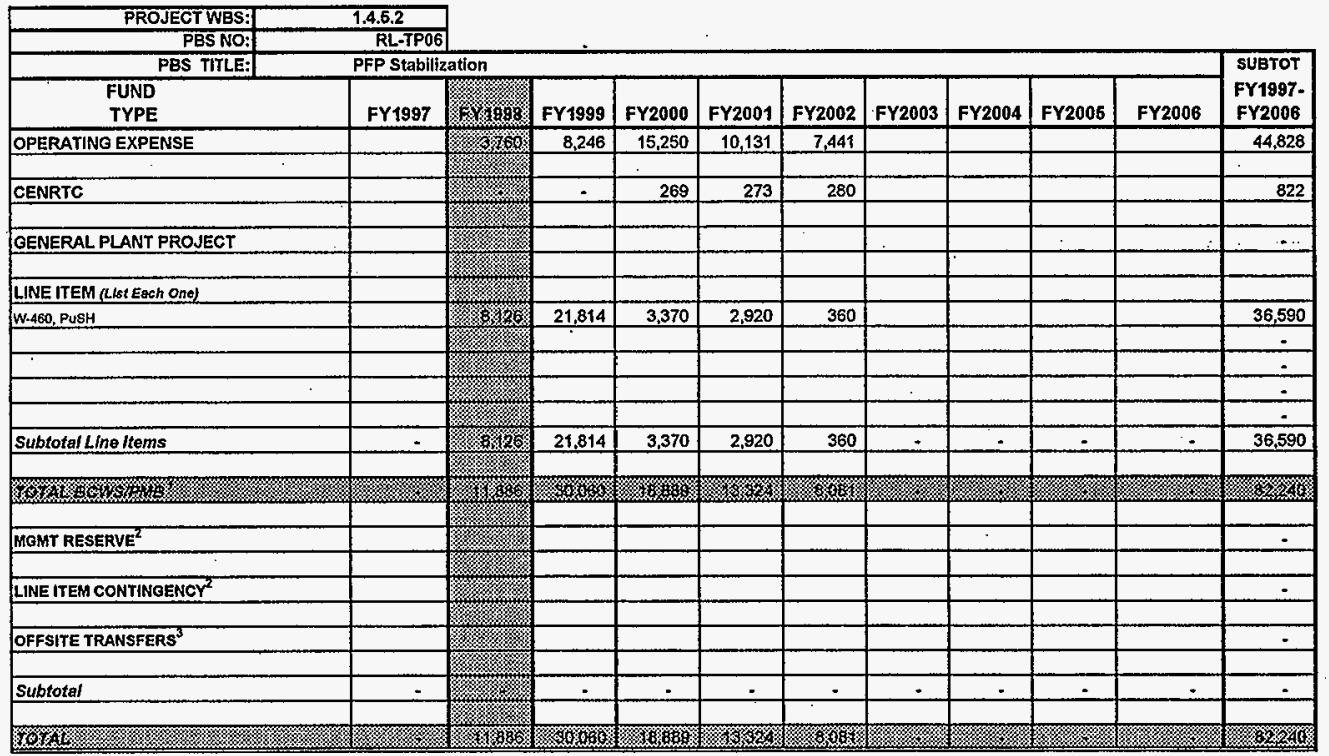

'Budgeted Cost of Work Scheduled (BCWS) Equals Performance Measurement Baseline (PMB);

Expense Carryover NOT Included.

${ }^{2}$ Management Reserve and Line Hem Contingency Held by RL.

${ }^{3}$ Work Performed at Sites Other Than Hanford. 

BY PROJECT BASELINE SUMMARY (PBS)

\section{FY 1998}

(\$000s)

\begin{tabular}{|c|c|c|c|c|c|c|c|c|c|c|}
\hline $\begin{array}{r}\text { PROJECT WBS: } \\
\text { PBS NO: }\end{array}$ & $\begin{array}{r}1.4 .6 .2 \\
R L-T P 06 \\
\end{array}$ & & & & & & & & & \\
\hline PBS TITLE: & PFP Stabil & zation & & & & & & & & TOTAL \\
\hline $\begin{array}{l}\text { FUND } \\
\text { TYPE }\end{array}$ & $\begin{array}{l}\text { FY2007- } \\
\text { FY2010 }\end{array}$ & $\begin{array}{l}\text { FY2011- } \\
\text { FY2016 }\end{array}$ & $\begin{array}{l}F Y 2016-1 \\
\text { FY2020 }\end{array}$ & $\begin{array}{l}\text { FY2021- } \\
\text { FY2025 } \\
\end{array}$ & $\begin{array}{l}\text { FY2026- } \\
\text { FY2030 }\end{array}$ & $\begin{array}{l}\text { FY2031- } \\
\text { FY2035 } \\
\end{array}$ & $\begin{array}{l}\text { FY2036 } \\
\text { FY2040 }\end{array}$ & $\begin{array}{l}\text { FY2041- } \\
\text { FY2045 }\end{array}$ & $\begin{array}{l}\text { FY2046 } \\
\text { FY2050 }\end{array}$ & $\begin{array}{l}\text { FY1997- } \\
\text { FY2050 }\end{array}$ \\
\hline OPERATING EXPENSE & & & & & & & & & & 44,828 \\
\hline & & & & & & & & & & \\
\hline CENRTC & & & & & & & & & & 822 \\
\hline & & & & & & & & & & \\
\hline GENERAL PLANT PROJECT & & & & & & & & & & $\cdot$ \\
\hline & & & & & & & & & & \\
\hline LINE ITEM (List Eech One) & & & & & & & & & & \\
\hline W-460, PuSH & & & & & & & & & & 36,590 \\
\hline & & & & & & & & & & - \\
\hline & & & & & & & & & & - \\
\hline & & & 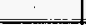 & & $=-\infty=$ & & & & & $=$ \\
\hline & & & & & & & & & & $=$ \\
\hline Subtotal Line ltems & - & $=$ & - & $=$ & - & - & - & - & - & 36,590 \\
\hline & & & & & & & & & & \\
\hline 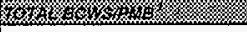 & ris & 2) & 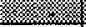 & $x$ & 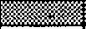 & 絧 & x. & (1) & & 20 \\
\hline & & & & & & & & 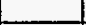 & - & \\
\hline MGMT RESERVE ${ }^{2}$ & & & & & & & & & & - \\
\hline & & & & & & & & & & \\
\hline LINE ITEM CONTINGENCY ${ }^{2}$ & & & & & & & & & & - \\
\hline & & & & & & & & & & \\
\hline OFFSITE TRANSFERS ${ }^{3}$ & & & & & & & & & & $\therefore$ \\
\hline Subtotal & - & . & - & $-\theta^{-}$ & - & - & . & . & . & - \\
\hline Sorpolat & & & & & & & $\div$ & - & & \\
\hline Fom & 2.2 & $x_{x}$ & (x) & ry. & 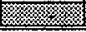 & 8 & 89 & 20 & sis & (3) \\
\hline
\end{tabular}

'Budgeted Cost of Work Scheduled (BCWS) Equals Performance Measurement Baseline (PMB);

Expense Carryover NOT Included.

${ }^{2}$ Management Reserve and Line ltem Contingency Held by RL.

WWork Performed at Sttes Other Than Hanford. 
BY PROJECT BASELINE SUMMARY (PBS)

FY 1998

(\$000s)

\begin{tabular}{|c|c|c|c|c|c|c|c|c|c|c|c|}
\hline PROJECT WBS: & 1.4 .5 .2 & & & & & & & & & & \\
\hline PBS NO: & RL-TP06 & & & & & & & & & & \\
\hline PBS TITLE: & PFP Stabil & zation & & & & & & & & & SUBTOT \\
\hline $\begin{array}{l}\text { FUND } \\
\text { TYPE }\end{array}$ & FY1997 & 26 & FY†999 & FY2000 & FY2001 & FY2002 & FY2003 & FY2004 & FY2005 & FY2006 & $\begin{array}{l}\text { FY1997- } \\
\text { FY2006 }\end{array}$ \\
\hline OPERATING EXPENSE & & 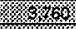 & 8,246 & 15,250 & 10,131 & 7,441 & & & & & 44,828 \\
\hline & & & & & & & & & & & \\
\hline CENRTC & & & - & 268 & 273 & 280 & & & & & 822 \\
\hline & & & & & & & & & & & \\
\hline GENERAL PLANT PROJECT & & 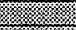 & & & & & & & & & - \\
\hline & & 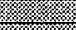 & & & & & & & & & \\
\hline LINE ITEM ( $\mu$ Lst Each One) & & 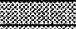 & & & & & & & & & \\
\hline W-460, PuSH & & 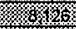 & 21,814 & 3.370 & 2,920 & 360 & & & & & 36,590 \\
\hline & & (3) & & & & & & & & &. \\
\hline & & 28 & & & & & & & & & - \\
\hline & & X) & & & & & & & & & - \\
\hline & & 2 & & & & & & & & & 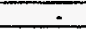 \\
\hline Subtotel Line Items & - & 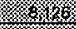 & 21,814 & 3,370 & 2.920 & 360 & $\therefore$ & - & $\therefore$ & - & 36,590 \\
\hline 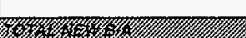 & & 椀 & 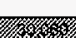 & 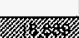 & 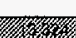 & 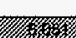 & & & & & $x^{2}$ \\
\hline
\end{tabular}


FACILITY STABILIZATION

LIFE CYCLE BUDGET AUTHORITY (B/A) BY YEAR BY FUND TYPE BY PROJECT BASELINE SUMMARY (PBS)

FY 1998

(\$000s)

\begin{tabular}{|c|c|c|c|c|c|c|c|c|c|c|}
\hline PROJECT WBS: & $\begin{array}{l}1.4 .5 .2 \\
\text { RL-TP06 }\end{array}$ & & & & & & & & & \\
\hline $\begin{array}{r}\text { PBS NO: } \\
\text { PBS TITLE: }\end{array}$ & $\frac{\text { RL-TP06 }}{\text { PFF Stabi }}$ & ization & & & & & & & & TOTAL \\
\hline $\begin{array}{l}\text { FUND } \\
\text { TYPE }\end{array}$ & $\begin{array}{l}\text { FY2007- } \\
\text { FY2010 }\end{array}$ & $\begin{array}{l}\text { FY2011- } \\
\text { FY2015 }\end{array}$ & $\begin{array}{l}\text { FY2016- } \\
\text { FY2020 }\end{array}$ & $\begin{array}{l}\text { FY2021- } \\
\text { FY2025 }\end{array}$ & $\begin{array}{l}\text { FY2026- } \\
\text { FY2030 }\end{array}$ & $\begin{array}{l}\text { FY2031- } \\
\text { FY2036 }\end{array}$ & $\begin{array}{l}\text { FY2036 } \\
\text { FY2040 }\end{array}$ & \begin{tabular}{|l|} 
FY2041- \\
FY2045
\end{tabular} & $\begin{array}{l}\text { FY2046 } \\
\text { FY2050 }\end{array}$ & $\begin{array}{l}\text { FYis97. } \\
\text { FY2050 }\end{array}$ \\
\hline OPERATINO EXPENSE & & & & & & & & & & 44,828 \\
\hline CENRTC & & & & & & & & & & 822 \\
\hline & & & & & & & & & & \\
\hline GENERAL PLANT PROJECT & & & & & & & & & & - \\
\hline & & & & & & & & & & \\
\hline LINE ITEM (Llst Eech One) & & & & & & & & & & \\
\hline W.460, PUSH & & & & & & & & & & 36,590 \\
\hline & & & & & & & & & & - \\
\hline & & & & & & & & & & $=$ \\
\hline & & & & & & & & & & - \\
\hline & & & & & & & & & & - \\
\hline Subtotal Lime ftems & - & - & - & - & - & - & - & $=$ & - & 36,590 \\
\hline 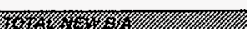 & & & & & & & & & & (2) \\
\hline
\end{tabular}


FACILITY STABILIZATION

FY 1998 COST BASELINE (BCWS) BY MONTH

BY PROJECT BASELINE SUMMARY (PBS)

BY ACTIVITY DATA SHEET (ADS)

EXECUTION YEAR

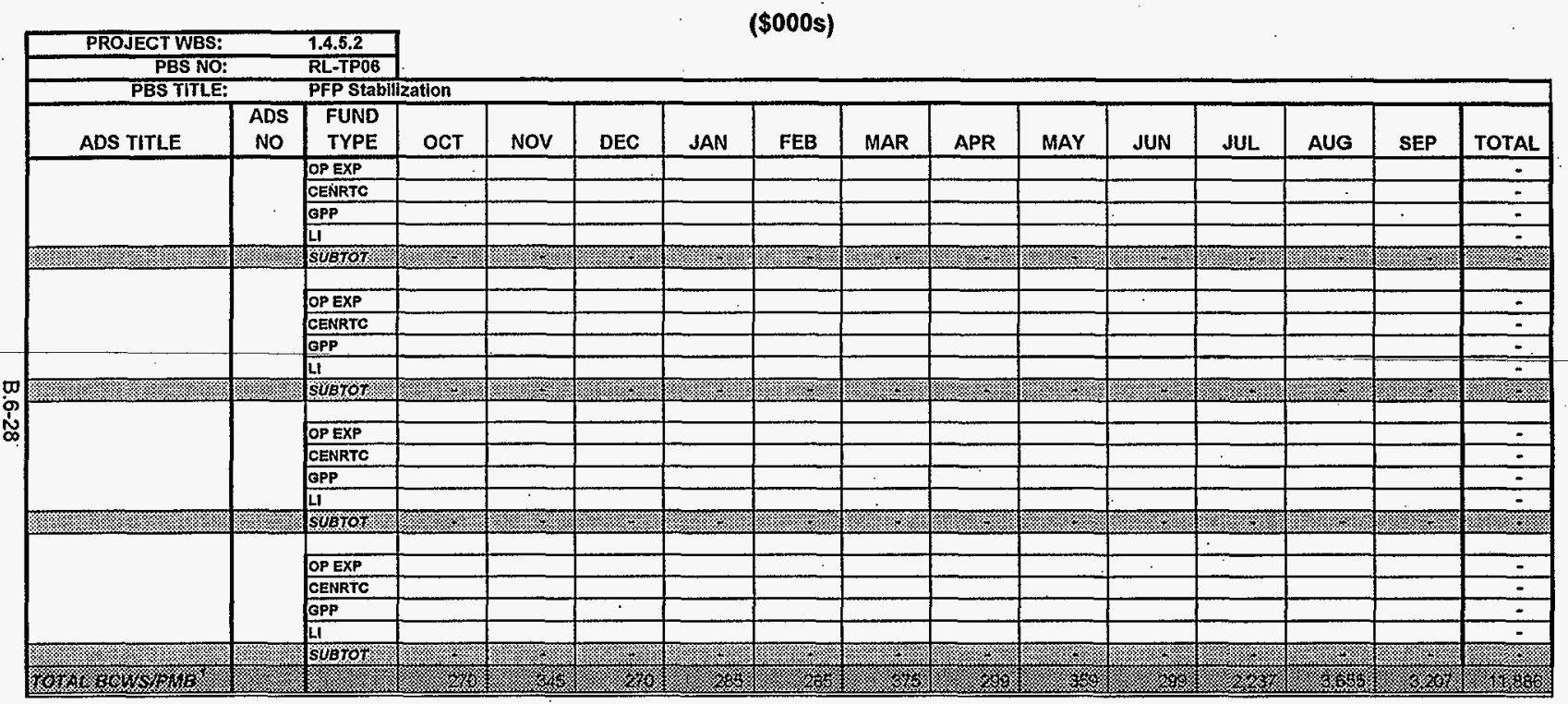

${ }^{1}$ Budgeted Cost of Work Scheduled (BCWS) Equals Performance Measurement Baseline (PMB); Expense Carryover Is NOT Included. 


\section{PFP STABILIZATION \\ Revision 0}

AVERAGE ANNUAL FULL TIME EQUIVALENTS

(includes Major Subcontractors but not Enterprise Companies)

PHBS 1.4.5.2

Submittal Date: 9/10/97

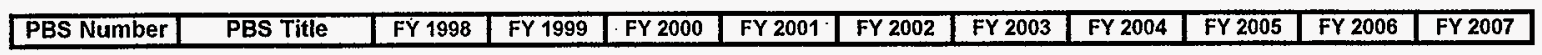

RL-TP06

PFP

37

64

120

108

75

0

0

0

0

0

:

STABILIZATION

Total PBS FTEs
$37 \quad 64$

120

108

Z5

o

0

o

g

o 


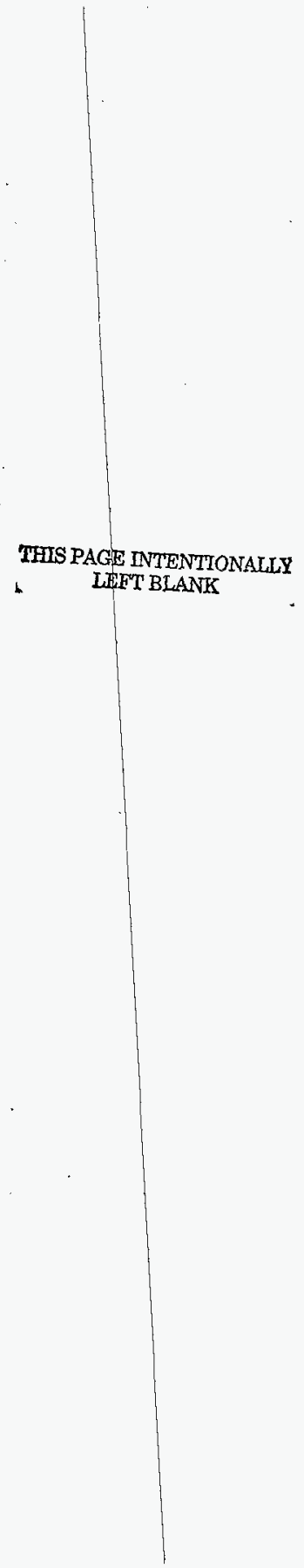




\section{B.7 PFP Vault Management (RL-TP07)}

\section{B.7.1.0 PFP Vault Management Technical Baseline (RL-TP07)}

\section{B.7.1.1 PFP Vault Management Organization Mission (RL-TP07)}

Due to a lack of funding for PFP Deactivation (RL-TP05) and PFP Stabilization (RL-TP06) subprojects, the vault management support for these subprojects will also require replanning.

The Plutonium Finishing Plant (PFP) Vault Management Project mission is to provide for the safe and secure storage for special nuclear materials at the PFP Complex and to provide the basic infrastructure with which the PFP stabilization and deactivation projects are dependent. Nuclear materials will be stored and safequarded at the PFP until at least 2025 (vaults are scheduled to be deactivated at that time); and plant infrastructure support will be proveded until at least fiscal year TBD when all nuclear materials will have been stabilized and the balance ot the PFP Complex (excluding the vaults) will have been deactivated. The PFP will receive, store, and ship SNM and other material forms in support of the overall Hanford site mission as directed.

Initial construction on the Plutonium Finishing Plant (PFP-formerly called Z Plant) began in 1949 and was completed 1951. The PFP was the final link in the plutonium manufacturing chain at Hanford, processing plutonium-bearing chemical solutions and converting them into metal and oxide. This process ended in May 1989. Over the years many additions were added to the PFP complex including the $2736 Z / Z B$ vault storage and the $236 Z$ Plutonium Reprocessing Facility as well as a number of lesser additions or ancillary buildings. Plutonium finishing included three operations: (1) Plutonium Metal Production--the remote mechanical C (RMC) metal fabrication line, started in 1959, converted plutonium nitrate solutions to metal form, (2) Plutonium Reclamation Facility--added in 1964, recycled scrap plutonium from Hanford and the Rocky Flats Plant in Colorado, and (3) Plutonium Storage and Support Facility--plutonium was received, analyzed, stored, packaged, and shipped.

Although processing has stopped, chemically reactive plutonium-bearing materials remain in the plant. Chemically reactive materials create radiation exposure to workers and present unnecessary risk to the public. The Defense Nuclear Facility Safety Board (DNFSB) in their Recommendation 94-1 stated that imminent hazards could arise in 2-3 years unless certain problems were corrected which result from the chemically reactive Pu-bearing materials held in storage areas and former process areas within the PFP. Until stabilization is complete, the risks from large quantities of stored reactive plutonium liquids/oxides/MOX/metals and holdup materials have NOT been reduced. The implementation of DNFSB Recommendation 94-1 at PFP to stabilize special nuclear materials and resolve Plutonium vulnerabilities at the PFP has been identified as a high priority activity at the Hanford Site by the USDOE. Therefore, in order to eliminate an imminent hazard at the PFP it is necessary that all plutonium at the PFP be dispositioned or stabilized.

The PFP Vault Management Project supports the PFP Stabilization Project which will utilize the existing plant systems with some necessary modifications to stabilize and disposition all of the chemically reactive material, provide appropriate packaging, and place the material in the safe and secure vaults for storage until a National decision has been made for its ultimate destiny. The material not stabilized for vault storage will be prepared for disposal, packaged, and transported to a RCRA licensed TSD.

Planning Assumptions:

It is assumed that the facility will be maintained to the minimum safety-compliant configuration at all times. This 
will be necessary until the last building at PFP has been deactivated.

Stored Pu will be transported to the onsite High-Level Waste Immobilization Facility and the remaining PFP Vault buildings will be deactivated in accordance with the PFP baseline schedule.

Storage of SNM within existing PFP secure vault areas will continue throughout the foreseeable future. AS permitted by the State of Washington and required by site support needs, SNM will be consolidated at PFP to permit the reduction in the number of protected areas throughout the Hanford Site.

Vault 3 will remain under the safeguards of the IAEA during DNFSB Recommendation 94-1 activities at PFP. No more vaults or materials will be made available for IAEA safeguards until after ail DNFSB Recommendation 94-1 activities have been completed in FY 2002. Funds for converting additional vaults to IAEA safeguards are not included.

The PFP Deactivation Subproject end point is targeted for completion in FY TBD. This end point is NOT the cessation of all activities as with other Hanford Site facilities. Instead, this End Point assumes the continued operation of all SNM shipping, receiving, storage, and vault systems, including all SAS systems plus laboratory capabilities as needed until at least through 2025 . Deactivation of the vaults and associated facilities will commence upon transfer of the materials to the onsite High-Level Waste Immobilization Facility.

There is an activity-based cost estimate to support the costs presented for 1997 only. Cost estimate data for FY98 through 2003 are not supported by an activity-based cost estimate.

A variety of dissimilar fuel types are or will be stored at PFP, including LAMPRE fuel and FFTF unirradiated fuel assemblies. The planning basis assumes that these unirradiated fuel assembly inventories will remain at PFP at least until final disposition is determined through the EIS.

Modifications to receive and store FFTF fuel assemblies will be funded from the Nuclear Energy Program. The Advanced Reactors Transition Project will transfer $285.9 \mathrm{~kg}$ of $\mathrm{Pu}, 860.6 \mathrm{~kg}$ of U, and $0.61 \mathrm{MT}$ of heavy metal as disposition-ready material if and when a decision to terminate the FFTF has been made. The storage casks containing FFTF unirradiated fuel assemblies designated for storage at PFP will be transported to an outdoor location inside PFP's protected area for storage on a precast concrete pad. The unirradiated FFTF fuel pins and assemblies at PFP are considered acceptable as-is for long-term storage and no further actions are envisioned for these materials.

The PFP Vault Management Project will be restricted to the operation, maintenance, safeguarding, and securing of the 2736-Z/ZB vautt complex. Als NM will have been stabilized or dispositioned and the other PFP facilities will have been deactivated. Support will be provided for the IAEA safeguards of Vault 3 , and any other vaults/materials that may be turned over to the IAEA. Specifically the scope will be composed of the following activities:

The PFP vault complex will continue to be operated and maintained to ensure the safe and secure receipt, shipping and storage of SNM/NM/NF is implemented. Activities also include SNM inventories, minor vault modifications, and engineering studies/assessments supporting material storage. Analytical Laboratory capabilities will be maintained to support the temporary storage of SNM.

The safety boundaries for the vault complex will receive required maintenance, operation surveillance tasks, environmental compliance tasks, corrective maintenance, procedure maintenance, preventative maintenance, plant specific support, nuclear process/radiation surveillance, project management, ventilation/power surveillance, environmental compliance, and safety boundary and emergency planning.

The SAS direction and oversight activities will continue to ensure safe, secure and compliant storage of stabilized SNM/NM/NF material is maintained. 
Only basic services support to the $2736-Z Z Z B$ vault complex including such activities as water, utilities, telephone services, etc., which are made available from outside sources will be provided. It also includes all management, training, administrative support, administrative and progress reporting, project budget Work scope/schedule baseline control, administrative supplies and equipment, and environmental assessments (e.g., solid waste burials).

Due to a lack of FY98 funds, programmatic work such as SNM shipments, vault modifications for compliance to new/revised security/safeguards requirements, pollution prevention waste minimization compliance, S/RIDs compliance. The Price-Anderson Amendment Act compliance will continue; and DOE Requests implementation will not be performed.

Plutonium storage shall continue in a safe and secure manner pending implementation of a national SNM Programmatic EIS ROD regarding final disposition.

Piutonium and HEU shall be managed in accordance with DOE Order $5660.1 \mathrm{~B}$, Management of Nuclear Materials (DOE 1994). Plutonium and HEU S\&S shall be in accordance with DOE Orders.

Highly enriched uranium shall continue to be stored at PFP until shipped offsite (Oak Ridge, Tennessee).

\section{B.7.1.2 PFP Vault Management End Point Targets from Hanford Strategic Plan}

- Complete stabilization of plutonium in PFP (DNFSB 94-1 implementation).

\section{B.7.1.3 PFP Vault Management Major Facilities}

\section{B.7.1.3.1 Plutonium Finishing Plant Facility}

\section{B.7.1.3.1.1 Plutonium Finishing Plant Facility Description}

PFP, formerly called Z-Plant, was constructed in 1949-1951 in the 200-W Area of Hanford. It was used to process plutonium-bearing chemical solutions and convert them into metal and oxide. The plant is currently in the process of stabilization and deactivation.

There is no support for facility transition to deactivation in FY98 and FY99. Hence, no progress will be made towards facility deactivation until FY00. Also, facility transition to deactivation activities will be rebaselined in FY98 following facility reengineering.

\section{B.7.1.3.1.2 Plutonium Finishing Plant Facility Technical Logic:}

The Department of Energy (DOE), in partnership with its contractors, shall plan, acquire, operate, maintain, and dispose of physical assets as valuable national resources. Stewardship of these physicai assets shall be accomplished in a cost-effective manner to meet the DOE mission. This shall incorporate industry standards, a graded approach, and performance objectives. 


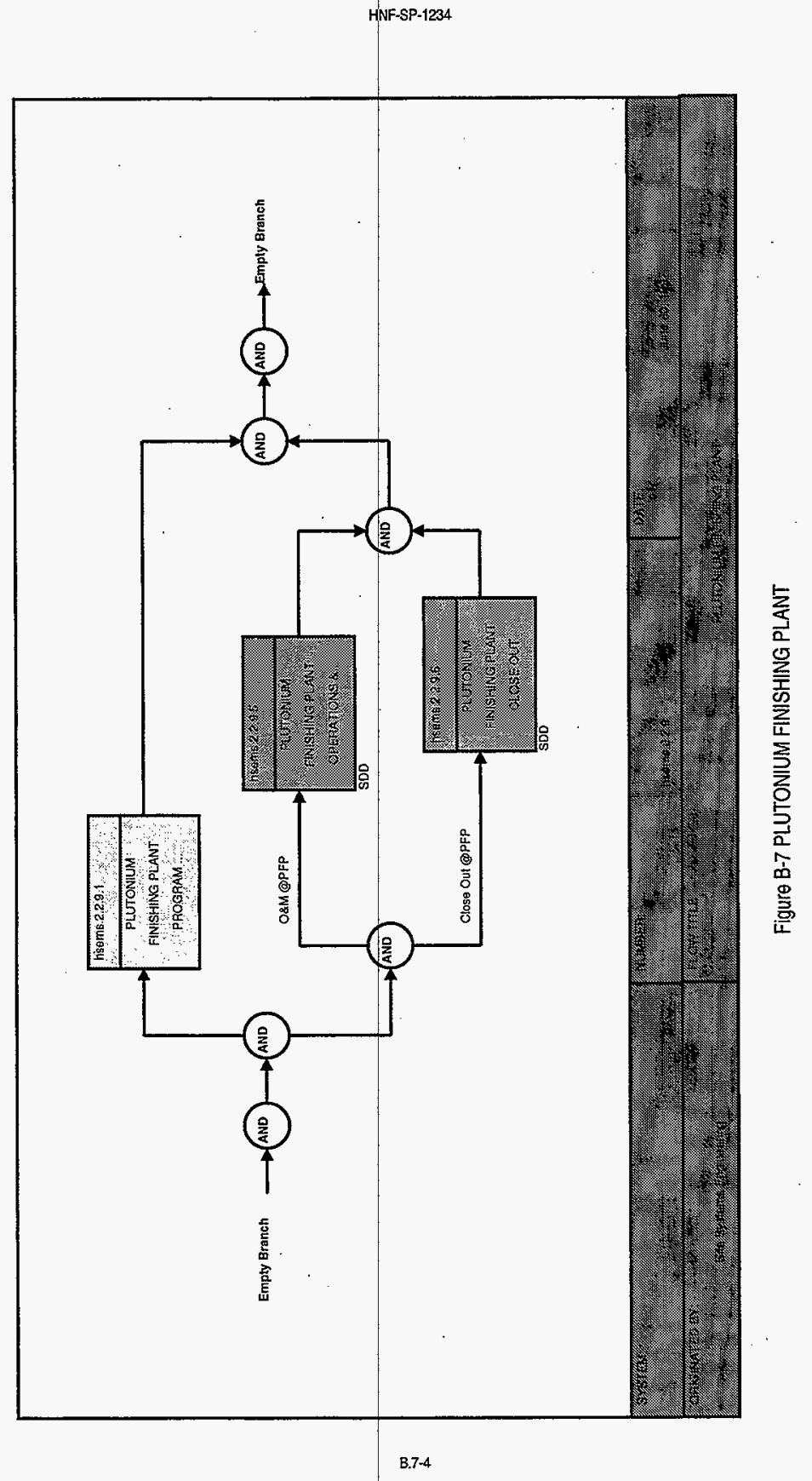




\section{B.7.1.3.1.3 Plutonium Finishing Plant Requirements and Life Cycle Function Descriptions}

\section{Requirements:}

* The Occupational Safety and Health Act applies to any action involving the health and safety of employees in the work place. Period inspections are done at the PFP facilities to verify compliance with the OSHA Act. Everything at PFP has to comply with the OSHA Act and access any new starts/restarts of projects to the act. Continuous walk-throughs are done by the Safety Organization to ensure compliance with OSHA. PFP managers periodically review the safety and health issues to ensure compliance with OSHA-and 29-CFR-19t0 guidelines Safety and Health assess level of chemicals by PFP Industrial Hygienist.

* Facilities discharging to the 200 Area TEDF shall implement Best Available Technology (BAT)/All Known, Available, and Reasonable Treatment (AKART). The generator shall provide the information required by WAC 173-240, Submission of Plans and Reports for Construction of Waste Water Facilities.

* The Clean Water Act establishes water quality standards for surface water and pretreatment standards for waste waters released to public-owned treatment works. All PFP support necessary to cease all discharges to the 21 6-Z-20 crib was completed prior to June 301995.

* Deactivation of PFP shall comply with DOE/EIS-0244-D

- Various DOE Orders provide and/or implement best management practices for policy and guidance to Transition Projects. The work scope, cost, and schedule are a direct result of conforming to these various orders. DOE Conduct of Operations and maintenance activities at PFP are driven by DOE 5480.19 and $4330.4 \mathrm{~B}$.-

* Central Plateau shall be used for the collection and management of nuclear materials that remain onsite.

- Central Plateau inactive facilities shall be maintained within the approved safety envelope

- Central Plateau asbestos abatement shall be performed as necessary

- Special nuclear materials shall be safely stored in the PFP

* PFP plutonium shall be stabilized and either placed in vault storage or disposed of properly.

- The Federal Facility Compliance Act establishes the framework for DOE to enter into Federal Facility Compliance Agreements with the individual states to address environmental issues.

All PFP support necessary to complete compliance actions contained in the Hantord Federal Facility Compliance Agreement and Consent Order signed by the U.S. Department of Energy, the U.S. Environmental Protection Agency, and the State of Washington Department of Ecology. All PFP support necessary to complete compliance actions contained in the Federal Facility Compliance Agreement for Radionuclide NESHAP signed by the U.S. Department of Energy and the State of Washington Department of Ecology.

* RCRA All hazardous waste is collected, counted and identified for shipment to the Hanford Site Central Waste Storage complex

- The Comprehensive Environmental Response, Compensation, and Liability Act provides EPA with enforcement authority for remedial and corrective action activities at contaminated subproject waste sites, and is part of the 
regulatory authority for the Tri-Party Agreement. PFP support necessary to meet reporting requirements and complete corrective actions under CERCLA.

* The Clean Air Act provides policy and guidance related to release of air emissions that may be present during shutdown and cleanup activities. Prepare and submit Etle 5 operating permit for entire site including PFP, 291-Z Stack Monitoring System is being readied to comply with the NESHAPS section of 40 CFR 61 .

\section{Life Cycie Function Descriptions:}

\section{B.7.1.3.1.3.1 PLUTONIUM FINISHING PLANT PROGRAM PLANNING WORK SCOPE SUMMARY}

Functions that include planning and developing the overall program; establishing broad priorities; providing program technical direction; preparing and defending the program budget; controlling milestones; integrating all components of the program; providing public and private sector policy liaison; expediting interface activities and follow-up actions; and retaining overall accountability for program success.

\section{B.7.1.3.1.3.2 PLUTONIUM FINISHING PLANT OPERATIONS \& MAINTENANCE WORK SCOPE SUMMARY}

Day-to-day work, including preventive and predictive maintenance, that is required to maintain and preserve plant and capital equipment in a condition suitable for it to be used for its designated purpose.

\section{PLUTONIUM FINISHING PLANT OPERATIONS \& MAINTENANCE SPECIFIC FUNCTIONS}

\section{B.7.1.3.1.3.3 Maintain Safe \& Compliant Materials in PFP Facility}

Materials stored in the PFP facility will be maintained in safe condition until they are removed for disposal or treatment.

The PFP vault complex will be operated and maintained to ensure the safe and secure receipt, shipping and storage of Special Nuclear Material.(SNM) until final disposition of SNM, Nuclear Materials (NM) and Nuclear Fuels (NF) is implemented. Activities also incllude SNM Inventories, minor Vault Modifications, and engineering studies/assessments supporting material storage. Analytical Laboratory capabilities will be maintained to support the temporary storage of SNM.

The safety boundaries for the vault complex and former operation/process areas will receive required maintenance, operation surveillance tasks, environmental compliance tasks, corrective maintenance, procedure maintenance, preventative maintenance, plant specific support, nuclear process/radiation surveillance, project management, ventilation/power surveillance, environmental compliance, and safety boundary and emergency planning.

The Safeguards and Security (SAS) direction and oversite activities will ensure safe, secure and compliant storage of SNM/NM/NF until final disposition of the material is accomplished. SAS includes physical security, safeguards accounting and material control, record keeping, studies, evaluations and assessments.

Basic services support to the facility includes such activities as steam, water, utilities, services, etc., which are made available to the facility from outside sources and costs assessed on a pro rata basis. It also includes a proportional share of senior management, generic training, administrative support, adiministrative and progress reporting, project budget/Work scope/schedule basetine control, administrative supplies and equipment, and environmental assessments (e.g., solid waste burials).

The PFP Project plant infrastructure systems will be maintained. This includes maintenance of systems or facilities such as steam, water, electrical, fire, vacuum and facility common use items, such as roofs, sidewalks, 
stairs, parking lots, elevators, etc., necessary to enable programmatic work to continue. Also included are all general upgrades and/or modifications to these infrastructure systems.

Specific programmatic work is also included. Programmatic work such as all SNM shipments, vault modifications for compliance to new/revised security/safeguards requirements, pollution prevention waste minimization compliance, S/RIDS compliance, Price-Anderson Amendment Act compliance, and DOE Requests implementation.

\section{B.7.1.3.1.3.4 Remove Material from PFP}

Remove nuclear material from the PFP vaults.

\section{B.7.1.3.1.3.5 Store Miscellaneous Nuclear Materials (NM)}

Upon receipt of Miscellaneous Nuclear Material, provide safe and compliant storage for this material currently stored on the Hanford Site. The transfer of the stored Miscellaneous Nuclear Material to the Disposition Function will be invoked by formal agreement of the Receiving Entity.

\section{B.7.1.3.1.3.6 Store Pu/HEU}

Upon receipt of Pu/HEU, provide safe and compliant storage for this material. The transfer of the stored Pu/HEU to the Disposition Function will be invoked by formal agreement of the Receiving Entity.

\section{B.7.1.3.1.3.7 PLUTONIUM FINISHING PLANT POST OPERATIONS WORK SCOPE SUMMARY}

Day-to-day work, including pre-stabilization surveillance and maintenance, stabilization, post-stabilization surveillance and maintenance, deactivation, and post-deactivation surveillance and maintenance, that is required to allow safe decontamination and decommissioning.

Also maintain 2736-ZB/Z vault facilities including the storage monitoring of SNM at PFP, until final deactivation.

\section{PLUTONIUM FINISHING PLANT POST OPERATIONS SPECIFIC FUNCTIONS}

\section{B.7.1.3.1.3.8 Maintain Safe \& Compliant Plutonium Finishing Plant Facility in CP Areas}

Maintain the PFP facility structures, operating systems and equipment, and monitoring systems within the approved safety and compliance requirements until the facilities are made available for D\&D. Also maintain the 2736-ZB/Z vault facilities, including the storage and monitoring of SNM at PFP until final deactivation.

\section{B.7.1.3.1.3.9 Transition Plutonium Finishing Plant Facility}

Initiate the transition phase of decontamination and decommissioning for the PFP facility.

\section{B.7.1.3.1.4 Plutonium Finishing Plant Boundary Diagram}


Table B.7-1 Plutonium Finishing Plant Boundary Diagram

\begin{tabular}{|c|c|}
\hline $\begin{array}{l}\text { External Interiaces } \\
\text { Hanford Logacy } \\
\text { Hanford Site Environmental System interiaces } \\
\text { hsems.2.5.4 Central Piateau Water System } \\
\text { hsems.2.5.5 Contral Plateau Office Facilities } \\
\text { hsems.2.5.6 Central Plateau Electrical System } \\
\text { hsems.2.5.9 Central Piateau Shop Facilities } \\
\text { hsems.2.5.13 Central Plateau Road System } \\
\text { hsems.4.3.1 Fast Fux Test Facility } \\
\text { hsems.4.6.2 } 325 \text { Building }\end{array}$ & $\begin{array}{l}\text { External Interiaces } \\
\text { Hazardous Waste Disposal Contracts } \\
\text { Oak Ridge National Laboratory } \\
\text { Ofisite Landfil } \\
\text { Savannah River Site } \\
\text { Hanford Site Environmental System Interiaces } \\
\text { hsems.2.3.2 Double Shell Tank (DS7) System } \\
\text { hsems.2.3.5 Central Waste Complex } \\
\text { hsems.2.4.3 200 Area Treated Etiluent Disposal Facility } \\
\text { hsems.2.5.1 222-S Laboratory }\end{array}$ \\
\hline
\end{tabular}

External Interiaces

Offisite Landfill

hsems.2.3.2 Double Shell Tank (DS7) System

hsems.4.6.2 325 Building

hsems,4.71 331 Complex 


\section{B.7.1.3.1.5 Plutonium Finishing Plant Interface Description and Forecast}

\section{EXTERNAL INPUTS}

Table B.7-2 External Inputs for Plutonium Finishing Plant

\begin{tabular}{|c|c|c|c|c|}
\hline Streami & Category & Period & Baseline & Units \\
\hline \multicolumn{5}{|l|}{ X.O Hanford Legacy } \\
\hline $\begin{array}{l}\text { Legacy PFP Low Enriched Uranium } \\
\text { Low Enriched Uranium (LEU) Transfored by Hanford Legacy. }\end{array}$ & Low Enriched Uranium (LEU) & $1997-1997$ & 0.3 & MITU \\
\hline $\begin{array}{l}\text { Legacy PFP Natural Uranium } \\
\text { Natural Uranium (NU) Transferred by Hanford Legacy. }\end{array}$ & Natural Uraritum (NU) & $1997-1997$ & 2.1 & MTNU \\
\hline $\begin{array}{l}\text { Legacy PFP Depleted Uranium } \\
\text { Depleted Uranium (DU) Transferred by Hanford Logacy. }\end{array}$ & Depleted Uranium (DU) & $1997 \cdot 1997$ & 1.6 & MT.U \\
\hline $\begin{array}{l}\text { Legacy PFP Plutonium } \\
\text { Plutonium (Pu) Transterted by Hanford Legacy. }\end{array}$ & Plutonium ( $\mathrm{Fu}$ ) & $1997-1997$ & 4060 & $\mathrm{Kg}$ \\
\hline Legacy PFP Highly Enriched Uranium & $\begin{array}{l}\text { Highly Enriched Uranium } \\
\text { (HEU) }\end{array}$ & $1997-1997$ & 246.0 & $\mathrm{Kg}$ \\
\hline \multicolumn{5}{|c|}{ Highy Enriched Uranium (HEU) Transterred by Hantord Legacy. } \\
\hline $\begin{array}{l}\text { Legacy PFP Spent Nuclear Fuel } \\
\text { Spent Nuclear Fuel (SNF) Transfered by Hanford Legacy. }\end{array}$ & Spent Nuclear Fuel (SNF) & $1997-1997$ & 0.0 & MTHM \\
\hline
\end{tabular}

\section{INTERNAL INPUTS}

Table B.7-3 Intemal Inputs for Plutonium Finishing Plant

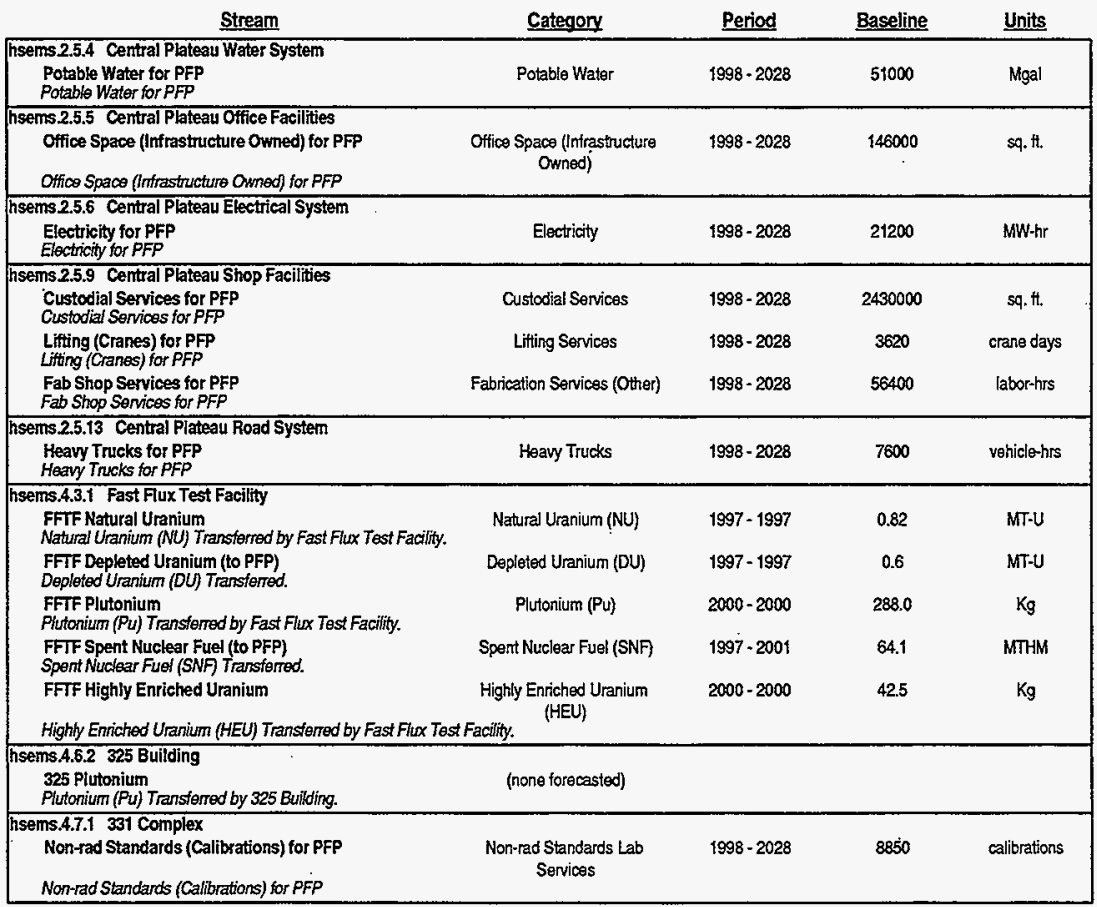




\begin{tabular}{|c|c|c|c|c|}
\hline Stream & Category & Period & Baseline & Units \\
\hline $\begin{array}{l}\text { X Hazardous Waste Disposal Contracts } \\
\text { PFP Asbestos } \\
\text { Asbestos Disposed by Plutonium Finishing Plant }\end{array}$ & Asbestos & $1997-2028$ & 157.0 & cubic meters \\
\hline $\begin{array}{l}\text { PFP Hazardous Waste } \\
\text { HAZ Disposod by Plutonium Finishing Plant. }\end{array}$ & HAZ & $1997-2028$ & 8.59 & cubic meters \\
\hline $\begin{array}{l}\text { Oak Ridge National Laboratory } \\
\text { PFP Highiy Enriched Uranium (to ORNL) } \\
\text { Highty Enriched Uranium (HEU) Transferrod by Plutonium Fin }\end{array}$ & $\begin{array}{l}\text { Highly Enriched Uranium } \\
\text { (HEU) } \\
\text { hing Plant. }\end{array}$ & $2000-200 t$ & 18.0 & $\mathrm{Kg}$ \\
\hline $\begin{array}{l}\text { Offisite Landffll } \\
\text { PFP Sanitary Solid Waste } \\
\text { Sanitary Solid Waste Disposed by Plutonium Finishing Plamt. }\end{array}$ & Sanitary Solid Waste & $1997-2028$ & 30700 & cubic meters \\
\hline $\begin{array}{l}\text { Savannah River Site } \\
\text { PFP Highly Enriched Uranium (to SRS) } \\
\text { Highly Enriched Uranium (HEU) Transferred by Piutonium Fin }\end{array}$ & $\begin{array}{l}\text { Highly Enriched Uranium } \\
\text { (HEU) }\end{array}$ & $1999-1999$ & 77.9 & $\mathrm{Kg}$ \\
\hline
\end{tabular}

\section{INTERNAL OUTPUTS}

\section{Table B.7-5 Internal Outputs for Plutonium Finishing Plant}

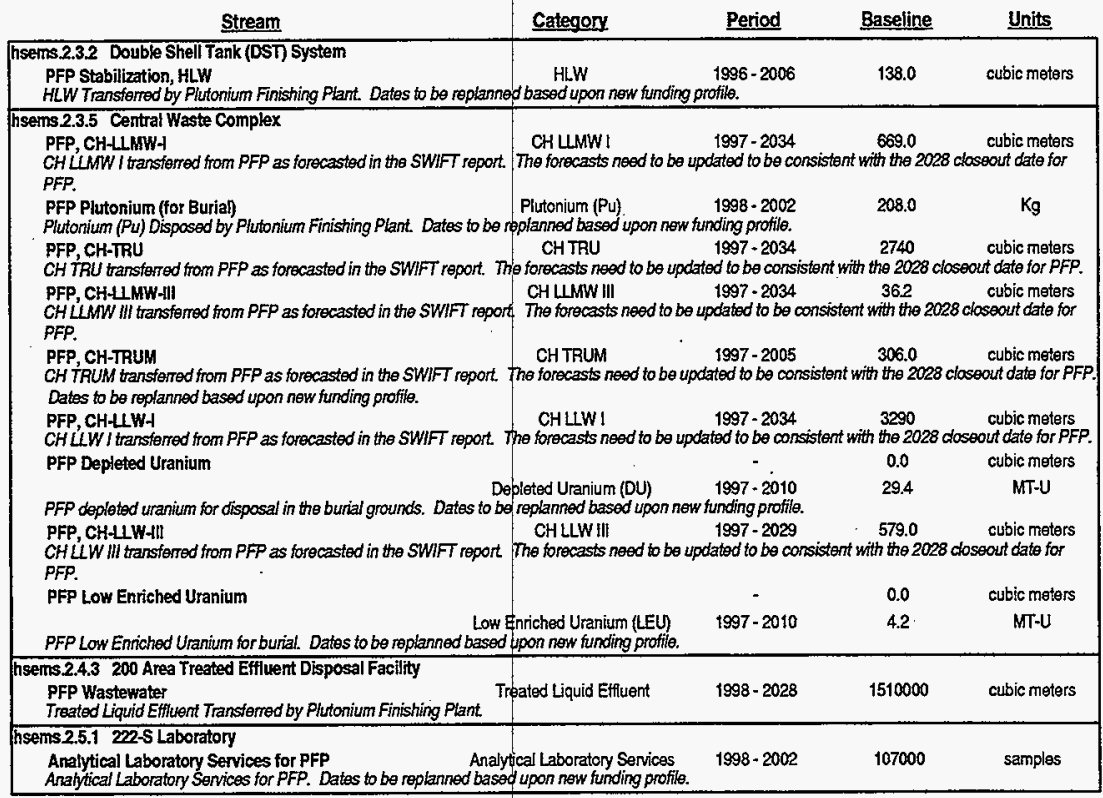




\section{B.7.1.4 Drivers for PFP Vault Management}

Table B.7-6 Source Documents for PFP Vault Management

29 CFR 1910
40 CFR 61
42 USC 6901 , et seq.
DOE Order 5400.4
DOE Order 5480.19
DOE/EIS-02220
DOE/EIS-0229
DOE/EIS-0244-D
DOE/RL-96-14
DOE/RL-96-92
FFCA for HESHAP (2/7/94)
PL $92-500$
ST 4502

Occupational Safety and Health Standards

National Emissions Standards for Hazardous Air Pollutants

Resource Conservation and Recovery Act of 1976 (RCRA)

Comprehensive Environmental Response, Compensation, and Liability Act

(CERCLA) Requirements

Conduct of Operations Requirements for DOE Facilities

Draft Hanford Remedial Action Environmental Impact Statement and

Comprehensive Land Use Plan

Storage and Disposition of Weapons Useable Fissile Materials Final

Programmatic Environmental Impact Statement

Plutonium Finishing Plant Stabilization Environmental Impact Statement

Updated Draft Mission Direction Document, June 1996

Hanford Strategic Plan

The National Emission Standards for Hazardous Air Pollutants: Federal Facility

Compliance Agreement for the Hanford Site

Federal Water Pollution Control Act Amendments of 1972 (Clean Water Act)

State Waste Discharge Permit for the 200 Area TEDF

\section{B.7.1.5 PFP Vault Management Risk Management}

Risk Evaluation Narrative:

The most significant Safety and Health risk at the PFP would be the theft and/or diversion of a quantity of special nuclear material (SNM) by unknown agents. The theft and/or diversion of a 1 kilogram quantity of SNM material (solid form, plutonium dioxide) from the PFP Complex is possible and represents a very high risk to public safety and health. It is assumed that the theft, and/or diversion, of the SNM material has been undertaken to commit radiological sabotage and/or nuclear blackmail. For this reason, the possibility of theft of unguarded SNM material represents an immediate significant hazard to public safety and health if the Vault Management Project was not funded.

With the Vault Management Project funded the theft and/or diversion of SNM material from the PFP Complex is no longer possible. However, the PFP Transition Project is not actively reducing the risks from its large quantities of stored reactive plutonium residues and holdup materials. Consequently, the most likely hazard, according to Chapter 9 "Accident Analysis", PFP Final Safety Analysis Report (FSAR), WHC-SD-CP-SAR-021, resulting from these plutonium residues is a nuclear criticality. We have assumed that the stated impact has a $99 \%$ probability of occurring in 30 years. This corresponds to an annual probability of 0.14 per year which is the basis of the "B." probability rating for the risk identified (i.e., probability (P) between 0.1 per year and 1.0 per year). This type of hazard is consistent with DNFSB Recommendation 94-1, dated May 1994 which states "The Board has concluded from observations and discussions with others that imminent hazards could arise within 2-3 years uniess certain problems are corrected". While Chapter 9 does not have a preferred criticality scenario (i.e., many possible scenarios due to the large variety of plutonium materials), a possible scenario would be an undetected leak of piutonium nitrate from one of the $100+$ Product Receiver (PR) Cans with inner containers stored at PFP. The inner container would be breached due to radiation damage and the outer stainless steel container corroded by exposure to corrosive elements within the plutonium nitrate matrix, such as chlorides or fluorides. The subsequent leaking plutonium nitrate would then collect, unnoticed, in some unfavorable geometric configuration and go critical. The consequences of such a criticality event are based on FSAR Chapter 9 historical data. The off site dose 
consequence is calculated at 53 mrem and the on site dose consequence is calculated at no mrem. Also, based on previous nuclear criticality events in the DOE Complex and at PFP, extreme over exposure to one or more facility workers would result. There would be minimal environmental impact. Of course, a nuclear criticality event at PFP would also have significant negative consequences to Compliance, Mission and Mortgage Reduction due to failure to meet regulatory requirements and mission objectives resulting from the magnitude of anticipated recovery actions, the increased costs and the delays to the primary mission. 

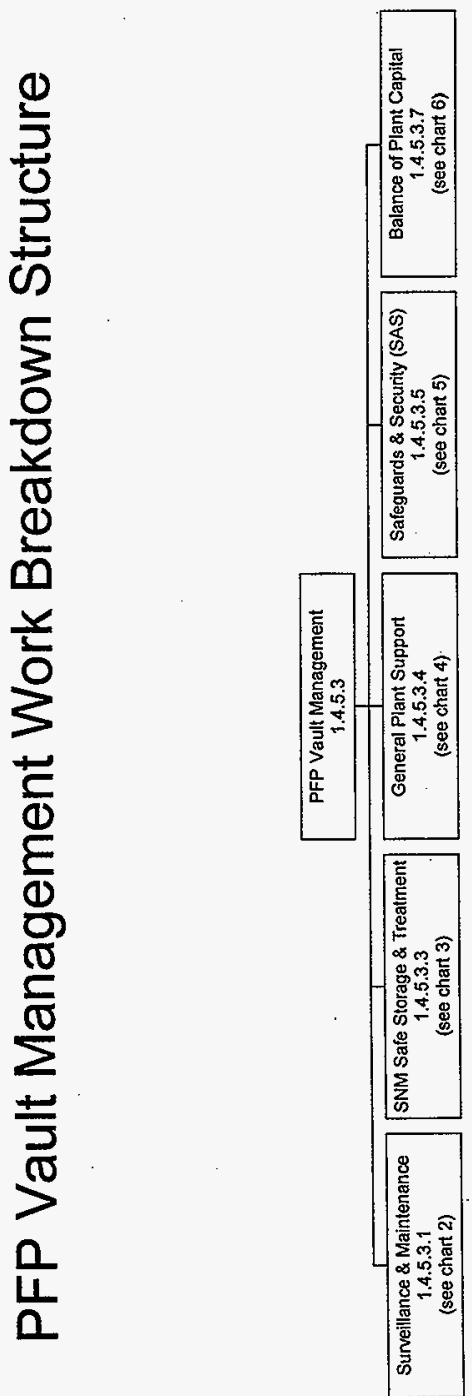


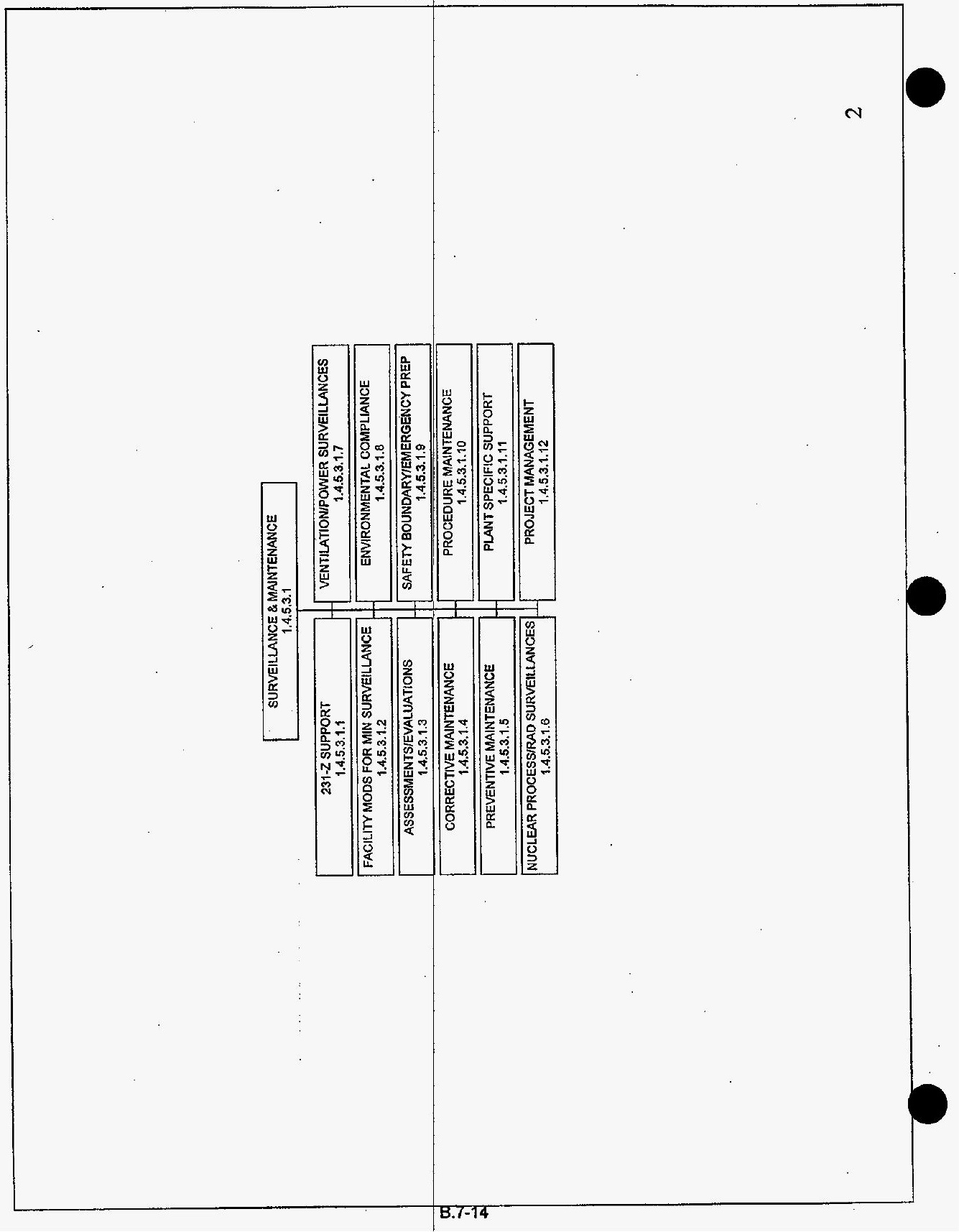




\begin{tabular}{|c|c|c|}
\hline \multicolumn{2}{|c|}{$\begin{array}{l}\text { SNM SAFE STORAGE \& TREATMENT } \\
1.4 .5 .3 .3\end{array}$} & \\
\hline $\begin{array}{c}\text { SNM SHIPMENT AND RECEIPT } \\
1.4 .5 .3 .3 .1 \\
\end{array}$ & CORR & $\begin{array}{l}\text { EE MAINTENANCE } \\
.5 .3 .3 .6 \\
\end{array}$ \\
\hline $\begin{array}{l}\text { SNM INVENTORIES } \\
1.4 .5 .3 .3 .2\end{array}$ & PREVEI & $\begin{array}{l}\text { IVE MAINTENANCE } \\
\text { 4.6.3.3.7 }\end{array}$ \\
\hline $\begin{array}{c}\text { VAULT MODIFICATIONS (MINOR) } \\
1.4 .5 .3 .3 .3\end{array}$ & NUCLEAR PROCE & $\begin{array}{l}\text { RADIATION SURVEILLANCES } \\
4.5 .3 .3 .8\end{array}$ \\
\hline $\begin{array}{l}\text { ENVIRONMENTAL COMPLIANCE } \\
1.4 .5 .3 .3 .4\end{array}$ & VENTILATIO & $\begin{array}{l}\text { WEER SURVEILLANGES } \\
\text { 4.5.3.3.9 }\end{array}$ \\
\hline 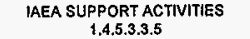 & & $\begin{array}{l}\text { TMANAGEMENT } \\
4.5 .3 .3 .10 \\
\end{array}$ \\
\hline
\end{tabular}




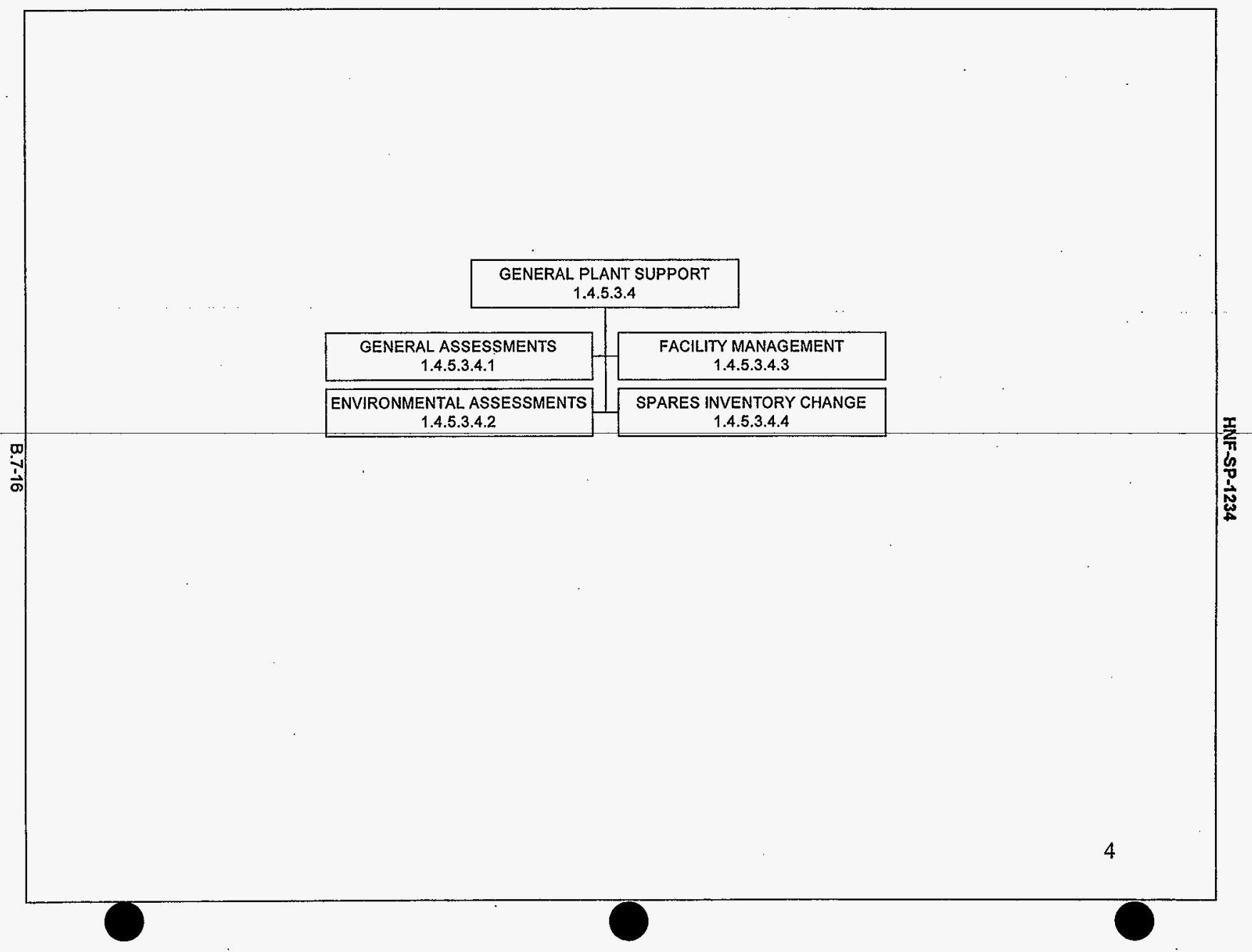




\begin{tabular}{|c|c|}
\hline \multicolumn{1}{|c|}{$\begin{array}{c}\text { SAFEGUARDS AND SECURITY (SAS) } \\
\text { BASIC PHYSICAL SECURITY } \\
1.4 .5 .3 .5 .1\end{array}$} \\
\hline $\begin{array}{c}\text { SNM CUSTODIAL SUUPPORT } \\
1.4 .5 .3 .5 .2\end{array}$ \\
\hline $\begin{array}{c}\text { SAS LIFE EXTENSION MODIFICATIONS } \\
1.4 .5 .3 .5 .4\end{array}$ \\
\hline $\begin{array}{c}\text { SECURITY CONTROL DOCUMENTATION } \\
\text { AND STUDIES } \\
1.4 .5 .3 .5 .3\end{array}$ \\
\hline
\end{tabular}


HANFORD SITE WORK BREAKDOWN STRUCTURE DICTIONARY

FACILITY STABILIZATION

WBS: 1.4

$8 / 25 / 1997$

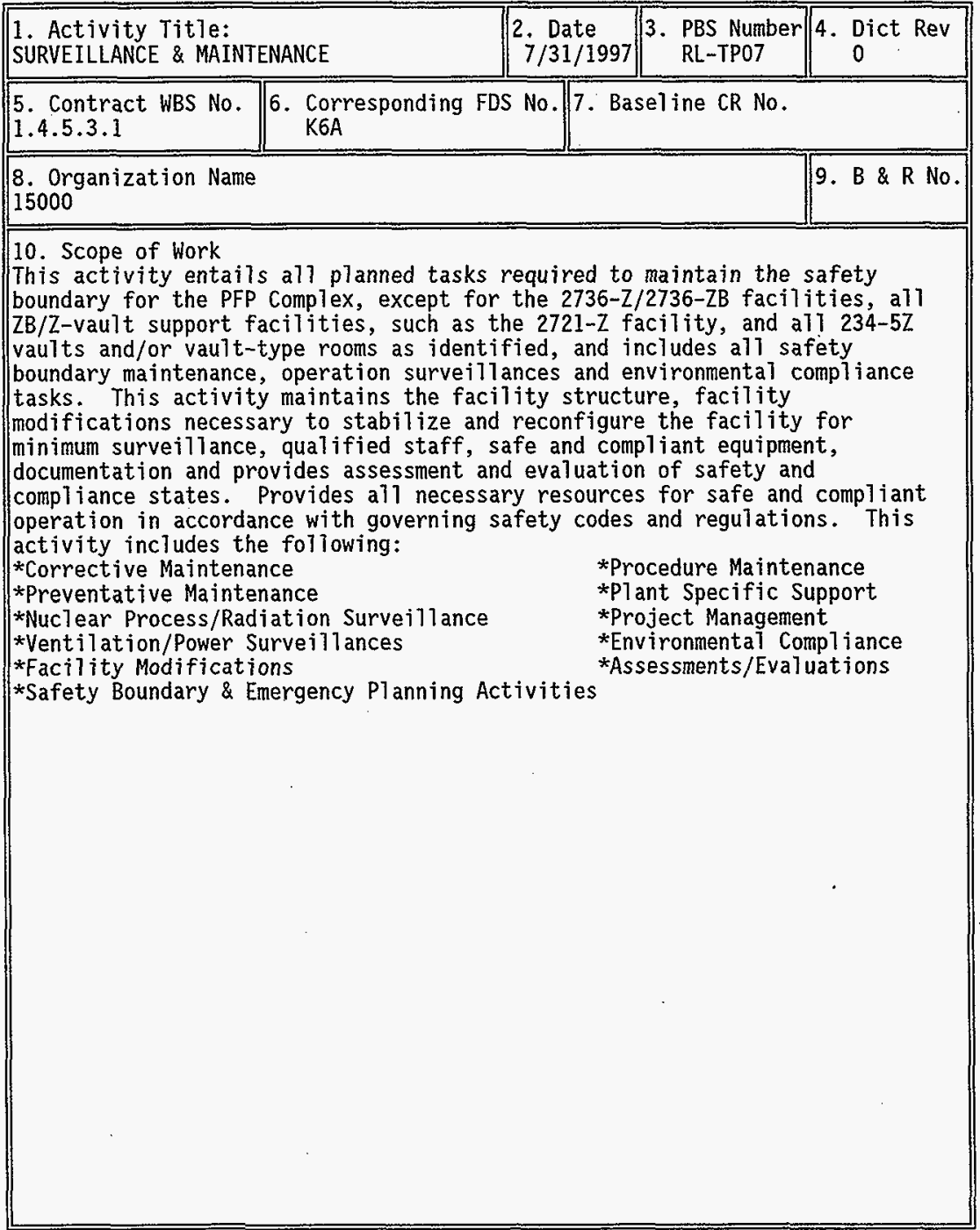


HANFORD SITE WORK BREAKDOWN STRUCTURE DICTIONARY

FACILITY STABILIZATION

WBS: 1.4

$8 / 25 / 1997$

\begin{tabular}{|c|c|c|c|}
\hline $\begin{array}{l}\text { 1. Activity Title: } \\
\text { SNM SAFE STORAGE \& TREATMENT }\end{array}$ & \begin{tabular}{|l|l|} 
2. Date \\
$7 / 31 / 1997$
\end{tabular} & $\begin{array}{l}\text { 3. } \text { PBS Number } \\
\text { RL-TP07 }\end{array}$ & 4. Dict Rev \\
\hline
\end{tabular}

5. Contract WBS No. 1.4.5.3.3

6. Corresponding FDS No. 7. Baseline CR No. K6AC

8. Organization Name

15000

10. Scope of Work

This activity provides for the management of Special Nuclear Materials (SNM), Nuclear Materials (NM) and Nuclear Fuels (NF) to ensure that this material is received, handled, processed, stored and transferred for ultimate disposition in a safe and efficient way. SNM/NM/NF in this function includes plutonium, uranium and thorium as inventoried, retrieved special materials, irradiated/non-irradiated fuels and nonwaste materials such as neptunium, cal ifornium and nuclear standards and sources. The activity includes any area within the PFP complex that is qualified, classified and utilized as a vault, or vault-type storage area. Also covered is any SNM 'treatment' required for the safe storage of SNM within the PFP Complex or to enable final disposition of SNM at, or from, the PFP complex. The activities include the following:

*SNM Shipment/Receipts

*SNM Inventories

* Vault Modification

*Environmental Compliance

* IAEA Support Activities

*Corrective Maintenance

* Preventative Maintenance

* Nuclear Process/Radiation Surveitlance

*Ventilation/Power Surveillances

*Project Management 
HANFORD SITE WORK BREAKDOWN STRUCTURE DICTIONARY

FACILITY STABILIZATION

WBS: 1.4

\begin{tabular}{|l||l||l|l|l|l|l|l|l|l}
\hline $\begin{array}{l}\text { 1. Activity Title: } \\
\text { GENERAL PLANT SUPPORT }\end{array}$ & $\begin{array}{l}\text { Date } \\
7 / 31 / 1997\end{array}$ & $\begin{array}{l}\text { PBS Number } \\
\text { RL-TP07 }\end{array}$ & $\begin{array}{l}\text { Dict Rev } \\
0\end{array}$ \\
\hline
\end{tabular}

5. Contract WBS No. 1.4.5.3.4

6. Corresponding FDS No. 7. Basel ine CR No. $\mathrm{K} 6 \mathrm{E}$

8. Organization Name 15000

10. Scope of Work

This activity provides the base support to the facility for which the cost is not directly attributable to an individual project. It includes basic requirements such as steam, water, utilities, solid waste burials, etc. which are made availabie to the facility from an outside source and costs assessed on a pro rata basis. It also includes senior management, basic training, administrative support, administrative and progress reporting, project baseline control, administrative supplies and equipment, etc. This includes the following:

*General Assessments (e.g., water, steam, electricity, etc.)

*Environmental Assessments (e.g., solid waste burials)

*Facility Management

*Spares Inventory Change 


\begin{tabular}{|l|l|l|l|l|}
\hline 1. Activity Title: & & $\begin{array}{l}\text { Date } \\
\text { Th/31/1997 }\end{array}$ & $\begin{array}{l}\text { 3. PBS Number } \\
\text { RL-TP07 }\end{array}$ & $\begin{array}{l}4 \text {. Dict Rev } \\
0\end{array}$ \\
\hline
\end{tabular}

5. Contract WBS No. 1.4.5.3.5

6. Corresponding FDS No. 7. Baseline CR No. $\mathrm{K} 6 \mathrm{~F}$

8. Organization Name

15000

9. $B \& R$ No.

10. Scope of Work

This activity provides the safeguards and security resources, direction and oversight to provide safe, secure and compliant storage of SNM/NM/NF until final disposition of the material is accomplished. Contains resources to provide physical security, safeguards accounting and material control, record keeping, studies, evaluations and assessments. Also included is any facility modifications required to maintain compliance/safety and to meet Site mission goals. This includes the following:

*Basic Physical Security

*SNM Custodia] Support

*Security Control Documentation and Studies

*SAS Life Extension Modification

*SAS Maintenance

*Project Management 
Mission Area Responsibility Assignment Matrix

\begin{tabular}{|c|c|c|c|c|c|}
\hline $\begin{array}{l}\text { Proj Lv1 } \\
\text { (PBS \#) }\end{array}$ & $\begin{array}{l}\text { FOS Act } \\
\text { Number }\end{array}$ & Activity Title & Activity Manager & Responsible Organization & Cost Account \\
\hline \multirow[t]{5}{*}{ RL-TP07 } & & PFP VAULT MANAGEMENT & & & \\
\hline & KGA & SURVEILLANCE \& MAINTENANCE & D. T. Mildon & 15000 & $\begin{array}{l}1 \mathrm{~K} 6 \mathrm{~A} 01 \\
1 \mathrm{~K} 6 \mathrm{~A} 02 \\
1 \mathrm{~K} 6 \mathrm{~A} 03 \\
1 \mathrm{~K} 6 \mathrm{AO} 4 \\
1 \mathrm{~K} 6 \mathrm{A0} \\
1 \mathrm{~K} 6 \mathrm{A06} \\
1 \mathrm{~K} 6 \mathrm{A07} \\
1 \mathrm{~K} 6 \mathrm{A08} \\
1 \mathrm{~K} 6 \mathrm{A09} \\
1 \mathrm{~K} 6 \mathrm{AOA} \\
1 \mathrm{~K} 6 \mathrm{AOB} \\
1 \mathrm{~K} 6 \mathrm{AOC}\end{array}$ \\
\hline & $\mathrm{K} 6 \mathrm{AC}$ & SAM SAFE STORAGE \& TREATMENT & D. W. Bartlett & 15000 & 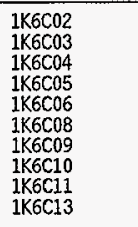 \\
\hline & KGE & GENERAL PLANT SUPPORT & P. D. Jensen & 15000 & $\begin{array}{l}1 \mathrm{~K} 6 \mathrm{E} 01 \\
1 \mathrm{~K} 6 \mathrm{E} 02 \\
1 \mathrm{~K} 6 \mathrm{E} 03 \\
1 \mathrm{~K} 6 \mathrm{E} 04\end{array}$ \\
\hline & $\mathrm{K} 6 \mathrm{~F}$ & SAFEGUARDS \& SECURITY & W. F. Russell & 15000 & $\begin{array}{l}1 \mathrm{~K} 6 \mathrm{~F} 01 \\
1 \mathrm{~K} 6 \mathrm{~F} 02 \\
1 \mathrm{~K} 6 \mathrm{~F} 03 \\
1 \mathrm{~K} 6 \mathrm{~F} 04 \\
1 \mathrm{~K} 6 \mathrm{~F} 05 \\
1 \mathrm{~K} 6 \mathrm{~F} 06\end{array}$ \\
\hline
\end{tabular}




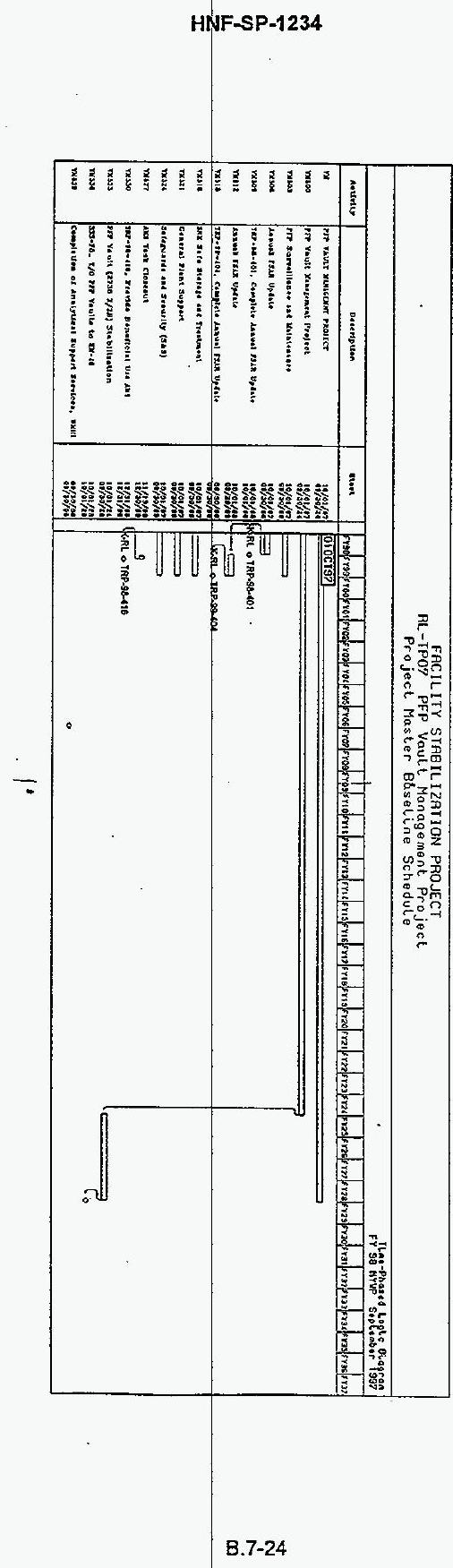




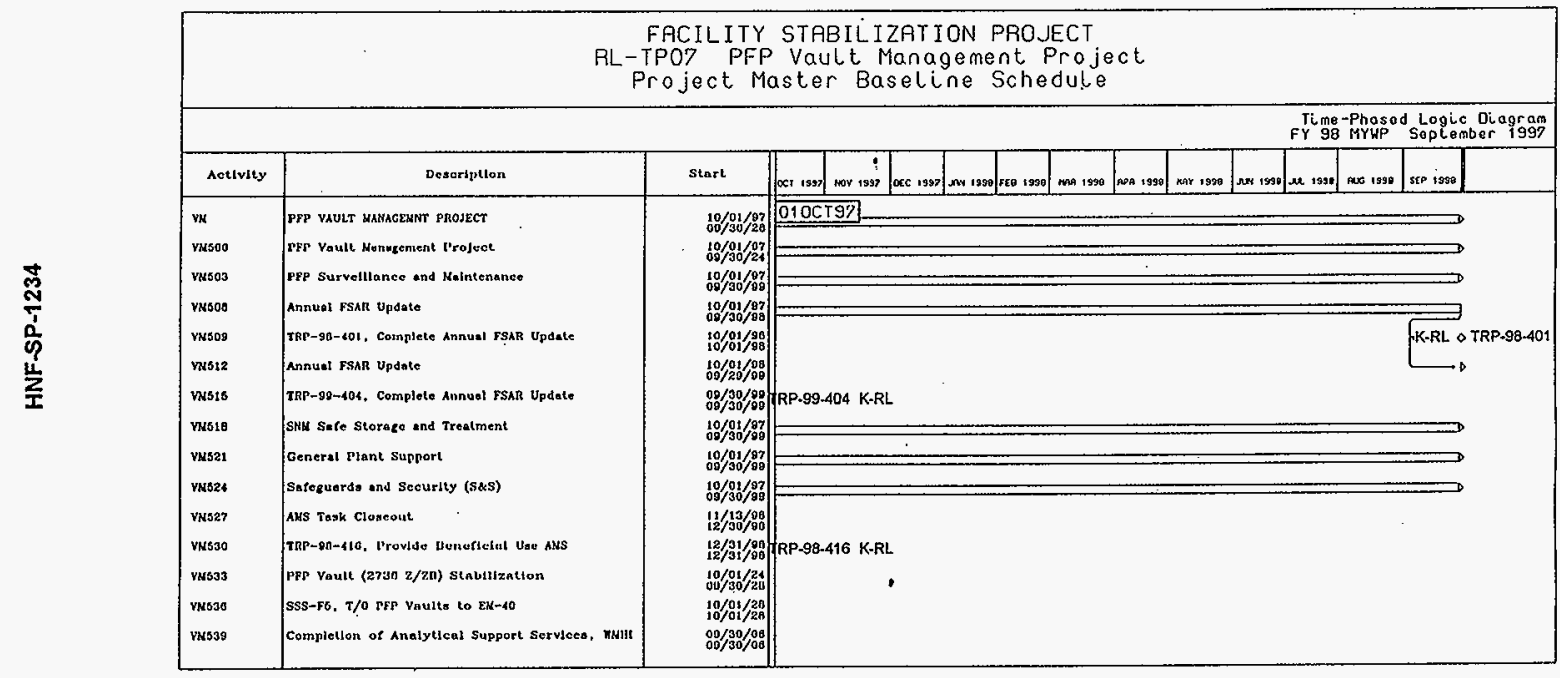


MILESTONE

CONTROL \#

TRP-97-416

TRP-98-401

TRP-99-404

TRP-00-403

TRP $-01-402$

TRP - 02-403
MYWP/SSPP PLANNING MILESTONE LIST

REPORTING PERIOD 10/01/97 TO 9/30/205
Page 1

\begin{tabular}{llllll}
\multicolumn{1}{c}{ PLANNED } & APPROVED & REVISED & & \\
TYPE & BASELINE & BASELINE & BASELINE & PROJ CIN & PBS \# \\
\hline OTH & $3 / 31 / 99$ & & & & RL-TP07 \\
& $9 / 30 / 98$ & & & & RL-TP07 \\
$9 / 30 / 99$ & & & & RL-TP07 \\
$9 / 30 / 00$ & & & RL-TP07 \\
$9 / 30 / 01$ & & & RL-TP07 \\
$9 / 30 / 02$ & & & RL-TP07
\end{tabular}

TPA-MS TPA MS

NUMBER TYPE, LEVEL

PROVIDE BENEFICIAL USE OF PC-BASED ALARM MONITORING SYS AT PFP COMPLETE ANNUAL FSAR UPDATE

COMPLETE ANNUAL FSAR UPDATE

COMPLETE AMNUAL FSAR UPDATE

COMPLETE ANNUAL FSAR UPDATE

COMPLETE ANNUAL FSAR UPDATE 
PHMC

MILESTONE DESCRIPTION SHEET

\begin{tabular}{|c|c|c|c|c|}
\hline \multicolumn{4}{|c|}{$\begin{array}{c}\text { Title: PROVIDE BENEFICIAL USE OF PC-BASED ALARM } \\
\text { MONITORING SYS AT PFP }\end{array}$} & Date: $7 / 31 / 97$ \\
\hline \multicolumn{4}{|c|}{ Assigned To: BWHC/PFP VAULT MANAGEMENT } & CIN: \\
\hline \multicolumn{4}{|c|}{ Program WBS Designator: 1.4 .5 .3} & Due Date: $3 / 31 / 99$ \\
\hline \multicolumn{5}{|c|}{ PBS No: RL-TP07 } \\
\hline \multicolumn{2}{|c|}{ MC \#: TRP-97-416 } & TPA No: & & Rev: 0 \\
\hline $\begin{array}{l}\text { MILESTONE } \\
\text { LEVEL: } \\
\\
\text { DOE-HQ } \\
\text { X DOE-RL } \\
\text { DOE-FO } \\
\text { CONTRACTOR }\end{array}$ & $\begin{array}{l}\text { MILESTONE } \\
\text { TYPE: } \\
\\
\text { EA } \\
\text { PEG } \\
X \text { OTHER }\end{array}$ & $\begin{array}{l}\text { DNFSB STATUS: } \\
\text { DNFSB }(Y / N): \\
\text { COMMIT \#: } \\
\text { RECOMM \#: }\end{array}$ & $\begin{array}{l}\text { DELIVERABLE: } \\
\text { Report } \\
\text { X Letter } \\
\text { Drawing(s) } \\
\text { Other (Specify) }\end{array}$ & $\begin{array}{l}\text { ADDRESS TO: } \\
\text { DOE-HQ } \\
\text { X DOE-RL } \\
\text { Other (Specify) }\end{array}$ \\
\hline
\end{tabular}

Milestone Description:

Complete the installation of the Alarm Monitoring System for beneficial use at the PFP facility by March 31, 1999.

Description of what constitutes completion of this milestone:

The milestone is considered complete when the system design, field. installation and final acceptance test report is released. 
PHMC

MILESTONE DESCRIPTION SHEET

\begin{tabular}{|c|c|c|c|c|c|}
\hline \multicolumn{5}{|c|}{ Title: COMPLETE ANNUAL FSAR UPDATE } & Date: $9 / 10 / 96$ \\
\hline \multicolumn{4}{|c|}{ Assigned To: FSP/PFP } & & CIN: \\
\hline \multicolumn{4}{|c|}{ Program WBS Designator: 1.4 .5 .3} & & Due Date: $9 / 30 / 98$ \\
\hline \multicolumn{6}{|c|}{ PBS No: RL-TP07 } \\
\hline \multicolumn{3}{|c|}{ MC \#: TRP-98-401 } & TPA No: & & Rev: 1 \\
\hline $\begin{array}{l}\text { MILESTONE } \\
\text { LEVEL: } \\
\\
\text { DOE-HQ } \\
\text { DOE-RL } \\
\text { X DOE-FO } \\
\text { CONTRACTOR }\end{array}$ & $\begin{array}{l}\text { MILESTONE } \\
\text { TYPE: } \\
\text { EA } \\
\text { PEG } \\
\text { OTHER }\end{array}$ & $\begin{array}{l}\text { DN } \\
\text { DNFS } \\
\text { COMM } \\
\text { RECO }\end{array}$ & $\begin{array}{l}\text { B STATUS: } \\
(Y / N): \\
\#: \\
\#:\end{array}$ & $\begin{array}{l}\text { DELIVERABLE: } \\
X \text { Report } \\
\text { Letter } \\
\text { Drawing(s) } \\
\text { Other (Specify) }\end{array}$ & $\begin{array}{l}\text { ADDRESS TO: } \\
\text { DOE-HQ } \\
\times \text { DOE-RL } \\
\text { Other (Specify) }\end{array}$ \\
\hline \multirow{2}{*}{\multicolumn{6}{|c|}{$\begin{array}{l}\text { Milestone Description: } \\
\text { Issue the annual update of the PFP SAR in accordance with DOE Order } \\
5480.23 \text {. }\end{array}$}} \\
\hline & & & & & \\
\hline \multicolumn{6}{|c|}{$\begin{array}{l}\text { Description of what constitutes completion of this milestone: } \\
\text { Issue updated SAR to RL for approval after providing opportunity for review } \\
\text { and comment resolution by RL Transition Program Division on the same } \\
\text { schedule as the Contractor review and comment resolution. If RL resources } \\
\text { are insufficient to support the Contractor schedule RL comments will be } \\
\text { resolved and incorporated as required after completion of the milestone. } \\
\text { The SAR will be submitted to RL for approval after securing the approval of } \\
\text { the required Contractor SAR committees. SAR Annual Update Requirements: } \\
\text { Contractors shall be required to review and update as necessary, SARs } \\
\text { annually, pursuant to this Order to ensure that the information in each SAR } \\
\text { is current and remains applicable. Revisions shall be submitted to the } \\
\text { Program Senior official (PSO) at least annully and shall reflect all } \\
\text { changes implemented up to } 6 \text { months prior to the filing of the updated SAR. } \\
\text { The DOE approval of any unresolved safety question (USQ) pursuant to DOE } \\
5480.21 \text {, amendments to the Technical Safety Requirements (TSR), and the }\end{array}$} \\
\hline
\end{tabular}


Description of what constitutes completion of this milestone: (con't material submitted by the contractor to the PSO in support of these approvals shall be considered and addendum to the SAR until the information is incorporated into the SAR as part of the next annual update.'

A separate letter, from the FSAR update letter, will be issued by the Contractor to RL documenting completion of this specific annual FSAR update. 
PHMC

MILESTONE DESCRIPTION SHEET

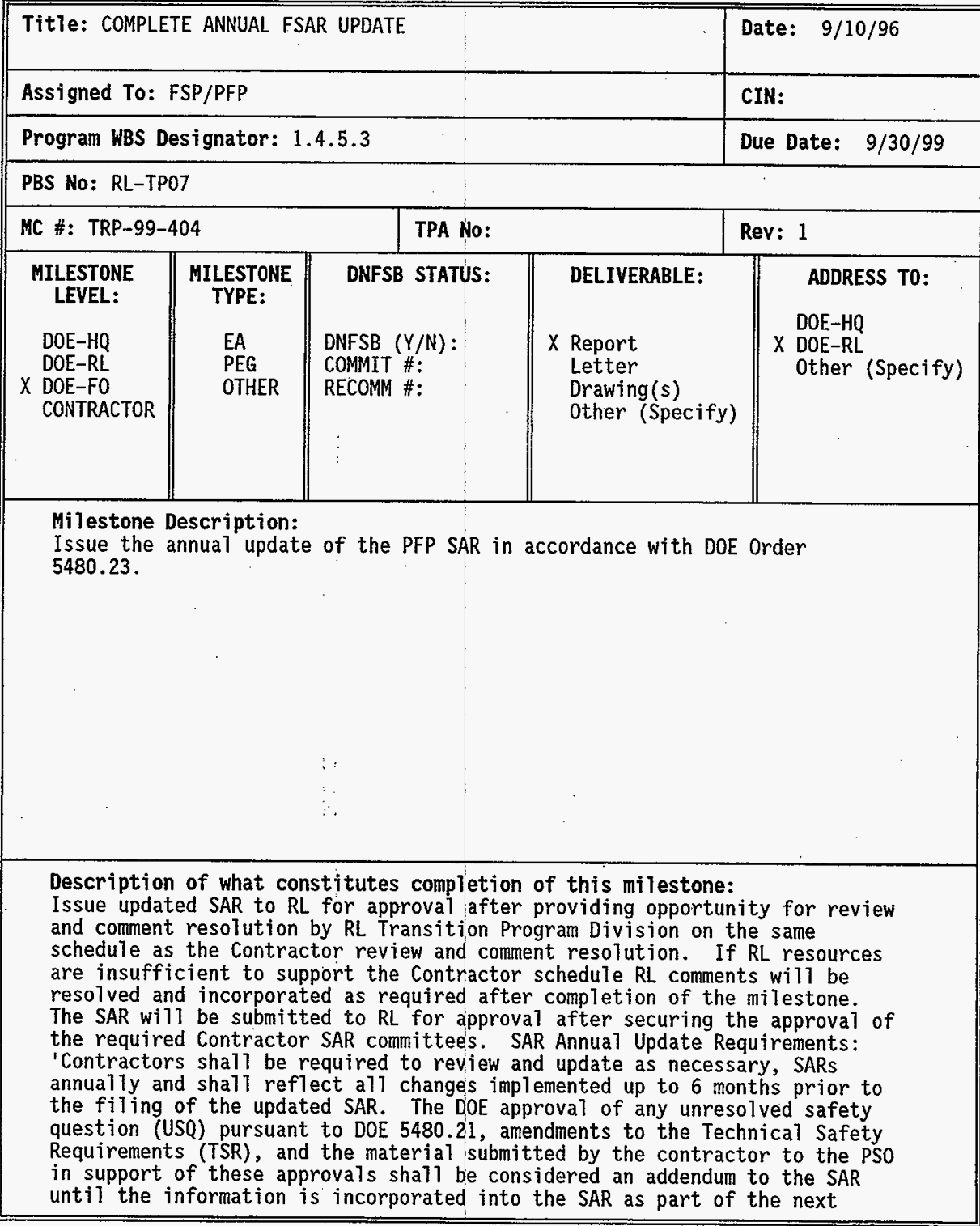


Description of what constitutes completion of this milestone: (con't) annuat update.

A separate letter, from the FSAR update letter, will be issued to DOE-RL documenting completion of this specific annual FSAR update. 


\section{PHMC}

\section{MILESTONE DESCRIPTION SHEET}

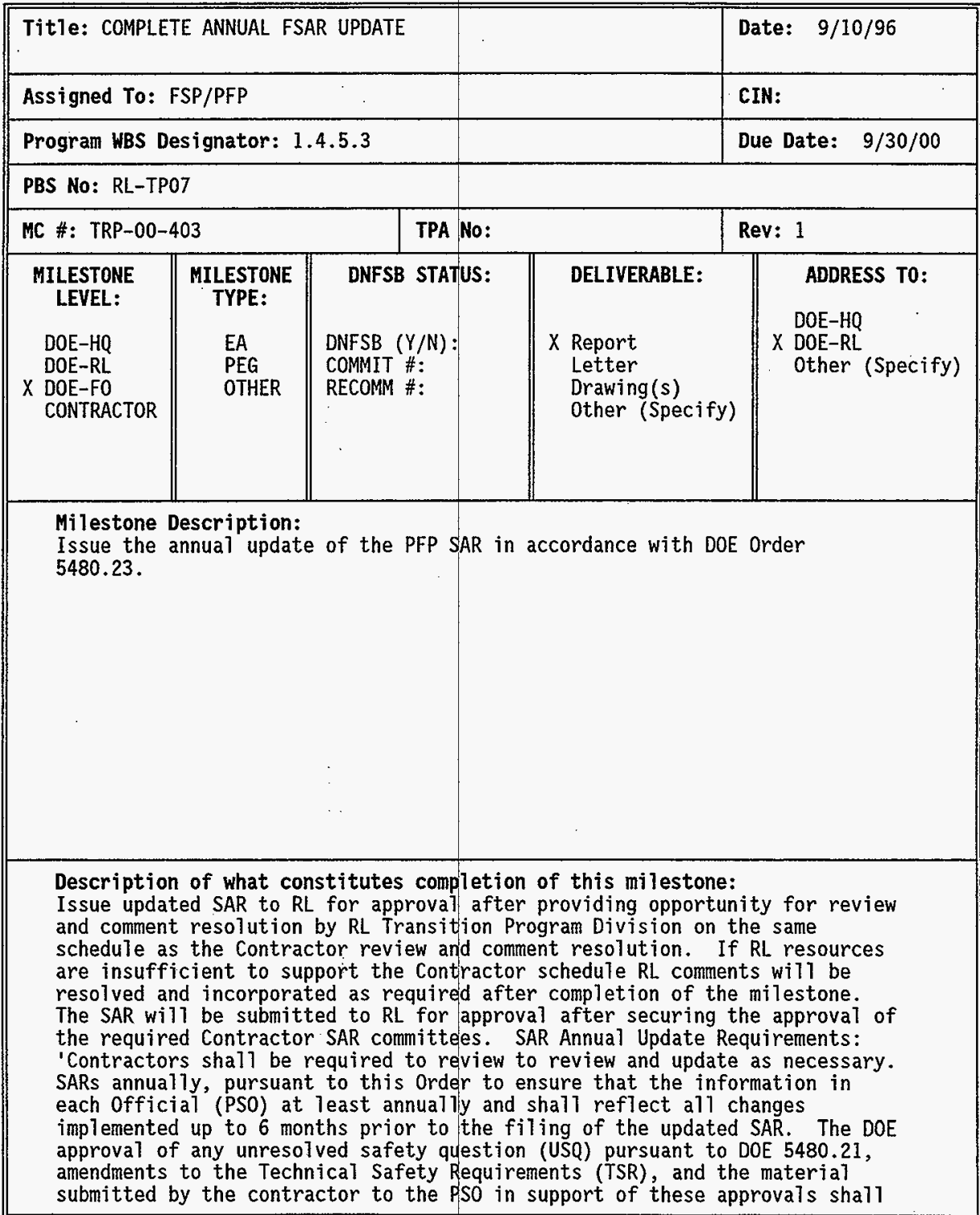


Description of what constitutes completion of this milestone: (con't) be considered an addendum to the SAR until the information is incorporated into the SAR as part of the next annual update.'

A separate letter, from the FSAR update letter, will be issued by the Contractor to RL documenting completion of this specific annual FSAR update. 


\section{PHMC}

\section{MILESTONE DESCRIPTION SHEET}

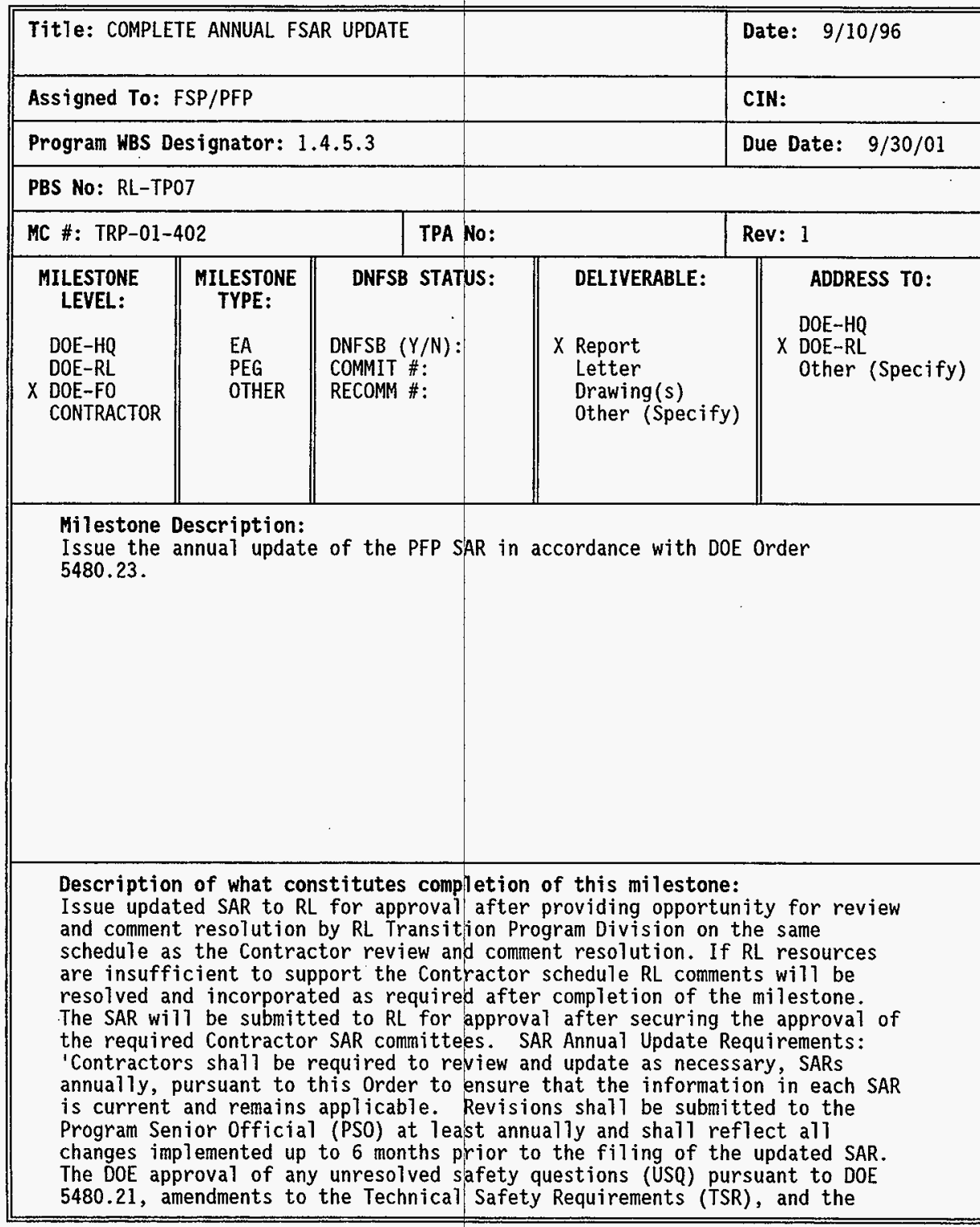


Description of what constitutes completion of this milestone: (con't) material submitted by the contractor to the PSO in support of these approvals shall be considered an addendum to the SAR until the information is incorporated into the SAR as part of the next annual update.'

A separate letter, from the FSAR update letter, will be issued by the Contractor to RL documenting completion of this specific annual FSAR update. 
PHMC

MILESTONE DESCRIPTION SHEET

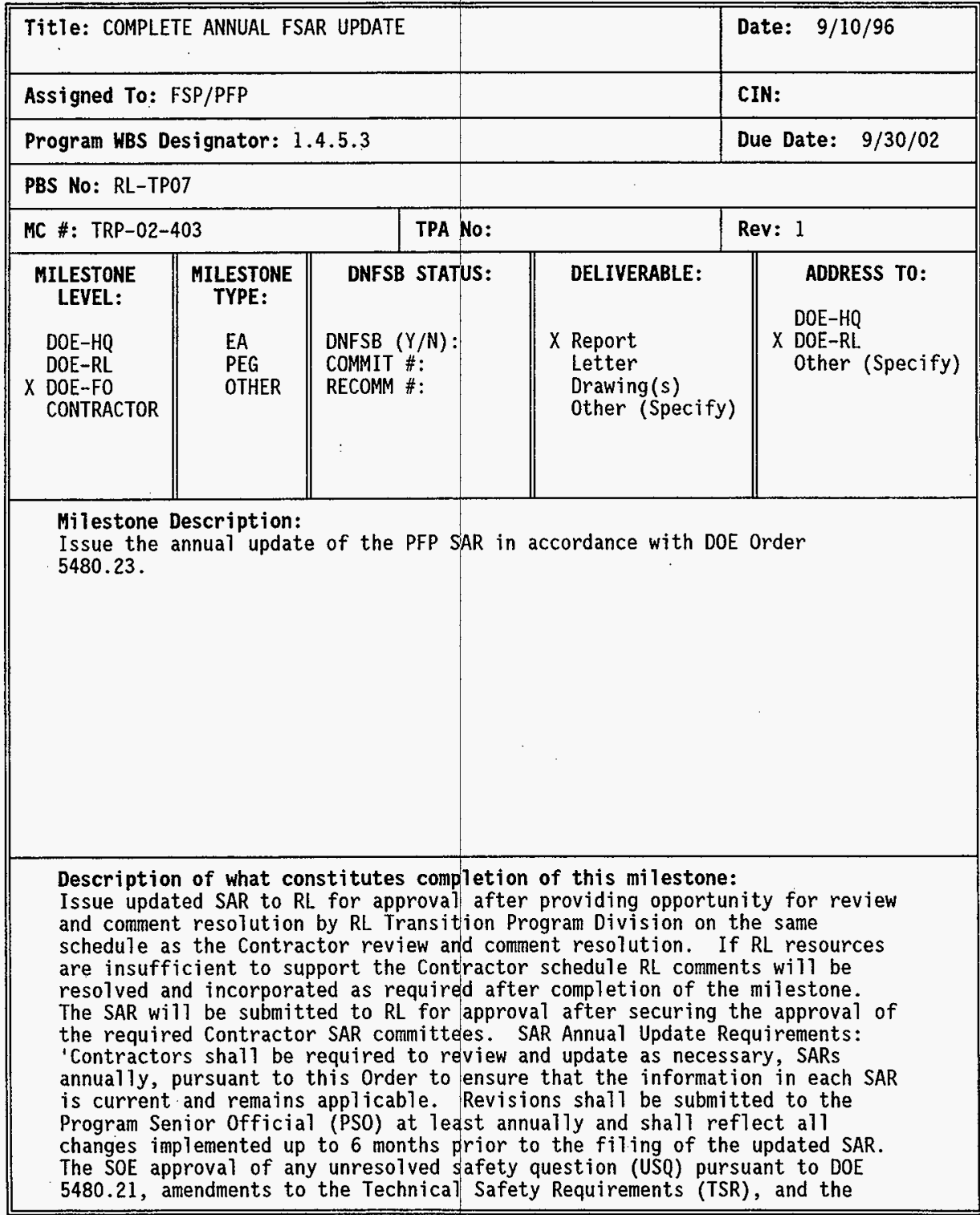


Description of what constitutes completion of this milestone: (con't material submitted by the contractor to the PSO in support of these approvals shall be considered an addendum to the SAR until the information is incorporated into the SAR as part of the next annual update.'

A separate letter, from the FSAR update letter, will be issued to DOE-RL. documenting completion of this specific annual FSAR update. 
FACILITY STABILIZATION

LIFE CYCLE COST BASELINE (BCWS) BY YEAR BY FUND TYPE

BY PROJECT BASELINE SUMMARY (PBS)

FY 1998

(\$000s)

\begin{tabular}{|c|c|c|c|c|c|c|c|c|c|c|c|}
\hline $\begin{array}{r}\text { PROJECT WBS: } \\
\text { PBS NO: } \\
\end{array}$ & $\frac{1.4 .5 .3}{\text { RL-TP07 }}$ & & & & & & & & & & \\
\hline PBS TITLE: & PFP Vault M & anagement & & & & & & & & & SUBTOT \\
\hline $\begin{array}{l}\text { FUND } \\
\text { TYPE }\end{array}$ & FY1997 & r & FY1999 & FY2000 & FY2001 & FY2002 & FY2003 & FY2004 & FY2005 & FY2006 & $\begin{array}{l}\text { FY1997- } \\
\text { FY2006 }\end{array}$ \\
\hline OPERATING EXPENSE & & 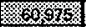 & 62,687 & 75,140 & 70,120 & 67,068 & 61.532 & 62,406 & 63,535 & 27,329 & 550,792 \\
\hline & & 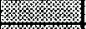 & & & & & & & & & \\
\hline CENRTC & & (2) & & & & & & & & & - \\
\hline & & & & & & & & & & & \\
\hline GENERAL PLANT PROJECT & & & & & & & & & & & - \\
\hline & & 1) & & & & & & & & & \\
\hline LINE ITEM (LLA Each One) & & 3 & & & & & & & & & \\
\hline & & 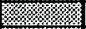 & & & & & & & & & - \\
\hline & & las & & & & & & & & & $=$ \\
\hline & & 1, & & & & & & & & & $\div$ \\
\hline & & 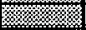 & & & & & & & & & - \\
\hline & & 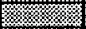 & & & & & & & & & $\dot{-}$ \\
\hline Subtotel Line hems & - & 1 & - & - & $\div$ & $=$ & $\overline{-}$ & $\overline{-}$ & $\overline{-}$ & $\overline{-}$ & - \\
\hline & & 4 & & & & & & & & & \\
\hline$x_{2}$ & (2) & (6) & 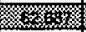 & 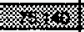 & 要 & 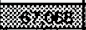 & 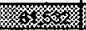 & 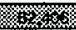 & 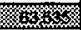 & 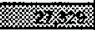 & w \\
\hline & & Fin & & & & & & & & & \\
\hline MGMT RESERVE ${ }^{2}$ & & ) & & & & & & & & & $\dot{-}$ \\
\hline & & F & & & & & & & & & \\
\hline LINE ITEM CONTINGENCY ${ }^{2}$ & & In: & & & & & & & & & - \\
\hline & & I & & & & & & & & & \\
\hline OFFSITE TRANSFERS ${ }^{3}$ & & 1. & & & & & & & & & $\div$ \\
\hline & & r & & & & & & & & & \\
\hline Subtotal & E & 米 & $\dot{-}$ & $\div$ & $\cdot$ & $\cdot$ & $\cdot$ & $\cdot$ & - & $\div$ & $\div$ \\
\hline & & . & & & & & & & & & \\
\hline Wrat & 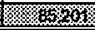 & Edor & 6 & F5: & $170 \% 20$ & 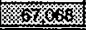 & 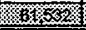 & 6264062 & 63535\% & 23k & 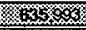 \\
\hline
\end{tabular}

'Budgeted Cost of Work Scheduled (BCWS) Equals Performance Measurement Baseline (PMB);

Expense Carryover NOT Included.

${ }^{2}$ Manegement Reserve and Line ltem Contingeney Held by RL.

"Work Performed at Sites Other Than Hanford. 


\section{FY 1998}

(\$000s)

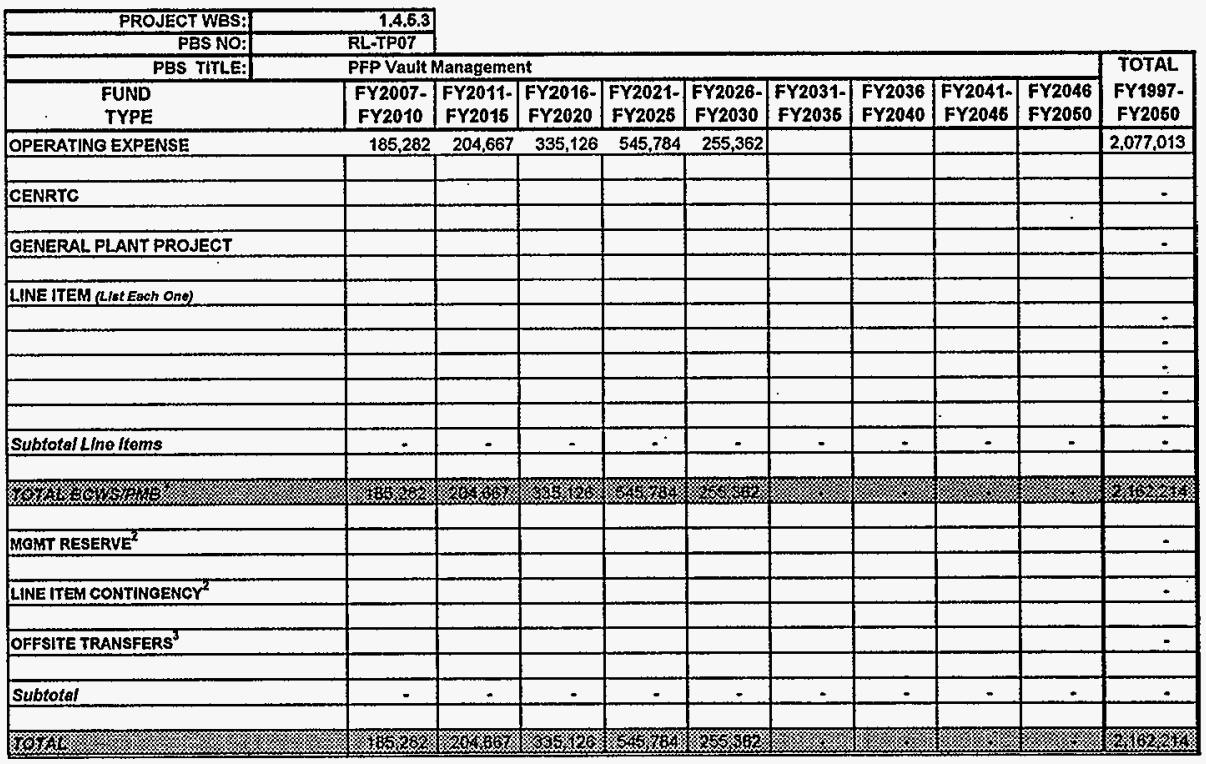

'Budgeted Cost of Work Scheduled (BCWS) Equals Performance Measurement Baseline (PMB); Expense Carryover NOT Included.

"Management Reserve and Line ltem Contingency Held by RL.

Work Performed at Sttes Other Than Hanford. 
FACILITY STABILIZATION

LIFE CYCLE BUDGET AUTHORITY (B/A) BY YEAR BY FUND TYPE

BY PROJECT BASELINE SUMMARY (PBS)

FY 1998

(\$000s)

\begin{tabular}{|c|c|c|c|c|c|c|c|c|c|c|c|}
\hline PROJECT WBS: & 1.4 .5 .3 & & & & & & & & & & \\
\hline PBS NO: & RL-TP07 & & & & & & & & & & \\
\hline PBS TITLE: & PFP Vault & Managem & & & & & & & & & SUETOT \\
\hline $\begin{array}{l}\text { FUND } \\
\text { TYPE }\end{array}$ & FY1997 & $5 \times 10.8$ & FY1999 & FY2000 & FY2001 & FY2002 & FY2003 & FY2004 & FY2005 & FY2008 & $\begin{array}{l}\text { FY1997- } \\
\text { FY2006 }\end{array}$ \\
\hline OPERATING EXPENSE & & $88.68 \%$ & 62,687 & 75,140 & 70,120 & 67,068 & 61,532 & 62,406 & 63,535 & 27,329 & 548,694 \\
\hline & & & & & & & & & & & \\
\hline CENRTC & & & & & & & & & - & & $=$ \\
\hline & & & & & & & & & & & \\
\hline OENERAL PLANT PROJECT & & 在 & & & & & - & & & & $\stackrel{-}{*}$ \\
\hline & & . & & & & & & & & & \\
\hline LINE ITEM (LIst Each One) & & m & & & & & & & & & \\
\hline & & 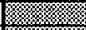 & & & & & & & & & $\dot{-}$ \\
\hline & & & & & & & & & & & - \\
\hline & & 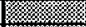 & & & & & & & & & - \\
\hline & & r & & & & & & & & & - \\
\hline & & 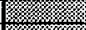 & & & & & & & & & - \\
\hline Subtotal Line /tems & $=$ & 8. & - & - & - & - & - & $\overline{-}$ & - & - & 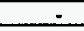 \\
\hline & & 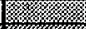 & & & & & & & & & \\
\hline 层3 & 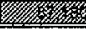 & 3) & 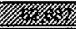 & 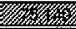 & 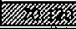 & 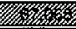 & 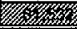 & 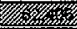 & 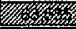 & 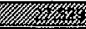 & 4 \\
\hline
\end{tabular}


FACILITY STABILIZATION

LIFE CYCL.E BUDGET AUTHORITY (B/A) BY YEAR BY FUND TYPE BY PROJECT BASELINE SUMMARY (PBS)

FY 1998

(\$000s)

\begin{tabular}{|c|c|c|c|c|c|c|c|c|c|c|}
\hline \multirow{3}{*}{$\begin{array}{r}\text { PROJECT WBS: } \\
\text { PBS NO: } \\
\text { PBS TITLE: }\end{array}$} & \multirow{2}{*}{\multicolumn{10}{|c|}{$\frac{1.4 .5 .3}{\text { RL-TP07 }}$}} \\
\hline & & & & & & & & & & \\
\hline & \multicolumn{9}{|c|}{ PFP Vault Management } & \multirow{2}{*}{$\begin{array}{l}\text { TOTAL } \\
\text { FY1997. } \\
\text { FY2050 }\end{array}$} \\
\hline $\begin{array}{l}\text { FUNDD } \\
\text { TYPE }\end{array}$ & $\begin{array}{l}\text { FY2007:- } \\
\text { FY2010 }\end{array}$ & $\begin{array}{l}\text { FY2011- } \\
\text { FY2015 }\end{array}$ & \begin{tabular}{|l|} 
FY2016- \\
FY2020
\end{tabular} & $\begin{array}{l}\text { FY2021- } \\
\text { FY2025 }\end{array}$ & $\begin{array}{l}\text { FY2026- } \\
\text { FY2030 }\end{array}$ & $\begin{array}{l}\text { FY2031- } \\
\text { FY2036 }\end{array}$ & $\begin{array}{l}\text { FY2036 } \\
\text { FY2040 }\end{array}$ & $\begin{array}{l}\text { FY2041- } \\
\text { FY2045 }\end{array}$ & $\begin{array}{l}\text { FY2046 } \\
\text { FY2050 }\end{array}$ & \\
\hline \multirow{2}{*}{\multicolumn{11}{|c|}{$\begin{array}{lllll}185,282 & 204,667 & 335,126 & 545,784 & 255,362 \\
\end{array}$}} \\
\hline & & & & & & & & & & \\
\hline \multicolumn{11}{|l|}{ CENRTC } \\
\hline & & & & & & & & & & \\
\hline \multicolumn{11}{|l|}{ OENERAL PLANT PROJECT } \\
\hline \multirow{2}{*}{\multicolumn{11}{|c|}{ LINE ITEM (List Each One) }} \\
\hline & & & & & & & & & & $\dot{-}$ \\
\hline & & & & & & & & & & $=$ \\
\hline & & & & & & & & & & - \\
\hline & & & & & & & & & & - \\
\hline & & & & & & & & & & $=$ \\
\hline Subtotal Line Items & $\div$ & - & - & $=$ & - & - & - & $=$ & $\cdot$ & 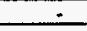 \\
\hline & & & & & & & & & & \\
\hline 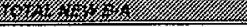 & 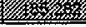 & 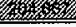 & 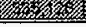 & 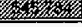 & 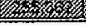 & $3 x$ & & & & 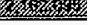 \\
\hline
\end{tabular}


FACILITY STABILIZATION

FY 1998 COST BASELINE (BCWS) BY MONTH

BY PROJECT BASELINE SUMMARY (PBS)

BY ACTIVITY DATA SHEET (ADS)

EXECUTION YEAR

\begin{tabular}{|c|c|c|c|c|c|c|c|c|c|c|c|c|c|c|c|}
\hline$\frac{\text { PROJECT WBS: }}{\text { PBS NO }}$ & & $\begin{array}{l}1.4 .5 .3 \\
\text { RL-TP07 }\end{array}$ & & & & & (\$000s) & & & & & & & & \\
\hline PBS TITLE & & PFP Vauil & Managem & & & & & & & & & & & & \\
\hline ADS TITLE & $\begin{array}{l}\text { ADS } \\
\text { NO }\end{array}$ & $\begin{array}{l}\text { FUND } \\
\text { TYPE }\end{array}$ & OCT & NOV & DEC & JAN & FEB & MAR & APR & MAY & JUN & JUL & AUG & SEP & TOTAL \\
\hline PFP PROJECT & $6624-0$ & OP EXP & 4,478 & $.5,547$ & 4,478 & 4,650 & 4,642 & 5,910 & 4,853 & 5,934 & 4,864 & 4,430 & 5,909 & 5,280 & 60,975 \\
\hline & & 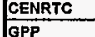 & & & & & & & & & & & & & - \\
\hline & & 4 & & & & & & & & & & & & & - \\
\hline 4 & 2 & SUBTOT & 4 4 428 & $85,547$. & 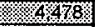 & 8.8650 & 8.6642 & $56910 \%$ & 84853 & 859934 & 8864 & 8.4800 & 45909 & 5 & 609875 \\
\hline & & DSExp & & & & & & & & & & & & & \\
\hline & & CENRTC & & & & & & & & & & & & & \\
\hline & & GPP & & & & & & & & & & & & & - \\
\hline 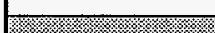 & W. & $\frac{14}{4}$ & 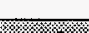 & 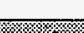 & . & (x) & 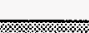 & (n) & s. & 等 & 策 & & 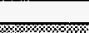 & & - \\
\hline & & & & & & & & & & & & & & 3 & 3 \\
\hline & & OPEXP & & & & & & & & & & & & & - \\
\hline & & CENRTC & & & & & & & & & & & & & \\
\hline & & GPP & & {[} & 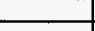 & 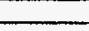 & T- & -5 & 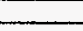 & - & $-m$ & & & & $=$ \\
\hline 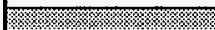 & s & st & $x:=x$ & 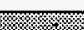 & 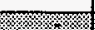 & 沙, & 2 & 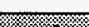 & s: & 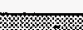 & & & 氺 & & (x冈m \\
\hline & & & & & & & & & & & & & & & \\
\hline & & OPEXP & & & & & & & & & & & & & - \\
\hline & & CENRTC & & & & & & & & & & & & & -9 \\
\hline & & & & & & & & & & & & & & & $\because$ \\
\hline 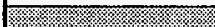 & m: & SÜBTOT: & W: : : & ; & W & x: $:$ : ; ; & (1) & s. & W: & 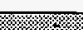 & (2) & & 然 & & 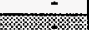 \\
\hline & 型 & & & & & & 4 & & & w & ras & & & -1 & 2x \\
\hline
\end{tabular}

${ }^{1}$ Budgeted Cost of Work Scheduled (BCWS) Equals Performance Measurement Baseline (PMB); Expense Carryover is NOT Included. 
BY ACTIVITY DATA SHEET (ADS)

EXECUTION YEAR

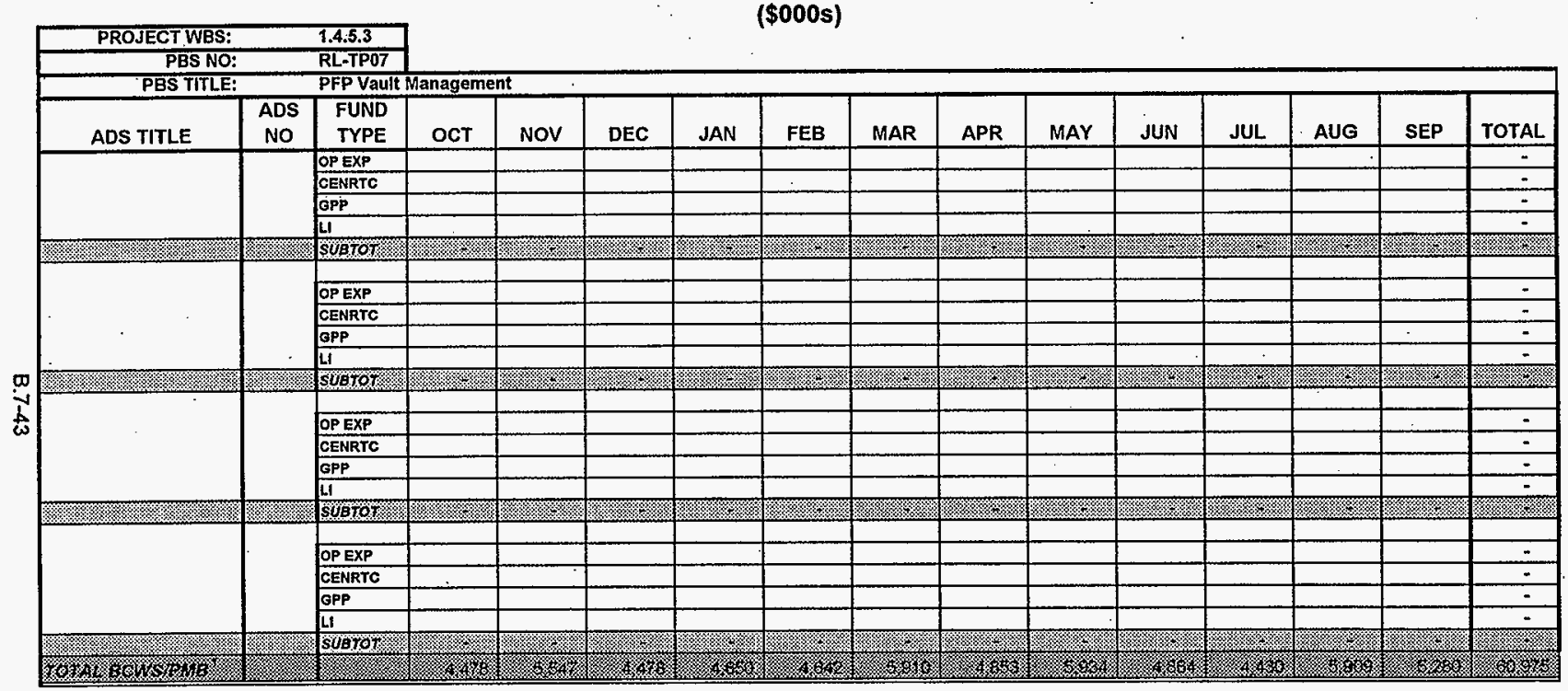

'Budgeted Cost of Work Scheduled (BCWS) Equals Performance Measurement Baseline (PMB); Expense Carryover-Is NOT Included. 


\begin{tabular}{|c|c|c|c|c|c|c|c|c|c|c|c|}
\hline \multirow{3}{*}{$\begin{array}{l}\text { PHBS 1.4.5.3 } \\
\begin{array}{|l}\text { PBS Number }\end{array}\end{array}$} & \multicolumn{8}{|c|}{$\begin{array}{c}\text { PFP VAULT MANAGEMENT } \\
\text { Revision } 0 \\
\text { AVERAGE ANNUAL FULL TIME EQUIVALENTS } \\
\text { (includes Major Subcontractors but not Enterprise Companies) }\end{array}$} & \multirow{2}{*}{\multicolumn{3}{|c|}{ Submittal Date: $9 / 10 / 97$}} \\
\hline & & & & & & & & & & & \\
\hline & PBS Title & FY 1998 & FY1999 & FY 2000 & FY 2001 & FY, 2002 & FY 2003 & FY 2004 & FY 2005 & \begin{tabular}{|l|l|} 
FY 2006 \\
\end{tabular} & FY 2007 \\
\hline RL-TP07 & $\begin{array}{c}\text { PFP VAULT } \\
\text { MANAGEMENT }\end{array}$ & 238 & 258 & 365 & 34 & 313 & 263 & 263 & 263 & 71 & 71 \\
\hline
\end{tabular}




\title{
B.8 324/327 Facility Transition Project (RL-TP08)
}

\section{B.8.1.0 324/327 Facility Transition Project Technical Baseline (RL-TP08)}

\section{B.8.1.1 324/327 Facility Transition Project Organization Mission (RL-TP08)}

\author{
324/327 Facility Transition Project Technical Baseline (RL-TP08)
}

The purpose of the 324/327 Facilities Stabilization Project is to establish a passively safe and environmentally secure configuration of the 324 and 327 Facilities at the Hanford Site, and to preserve that configuration for 10 years. The 10-year horizon will be used to predict future maintenance requirements and represents the typical time span needed to define, authorize, and initiate the follow-on decontamination and decommissioning (D\&D) activities.

The project removes, reduces, and/or stabilizes the radioactive and the nonradioactive hazardous materials within the 324 and 327 Facilities. Completing these activities reduces hazards to workers and the public and allows for a reduced level of surveillance during the extended surveillance period following deactivation. Worker health and safety is a primary goal of deactivation. A Voluntary Protection Program is being implemented. Deactivation places the plant in a condition that no longer requires high levels of surveillance and maintenance (S\&M) to maintain safe conditions.

When fully deactivated, the facilities will be unoccupied, empty, and locked. The facilities will contain no active systems or utilities except for survellance lighting and any necessary monitoring instrumentation.

\section{Enabling Assumptions:}

The facility will achieve a radiological facility hazard category. The radiological facility limits given in DOE-STD-1027 are inherently conservative for establishing post-deactivation inventory limits. If the actual conditions at the 324 Facility is such that a lower release fraction can be justified for plausible accident scenarios, then it may be possible to show that higher residual radionuclide inventory than the radiological facility limits may be acceptable through a rigorous hazards analysis. If the hazards analysis shows that adequate safety to workers, offsite individuals, and the environment can be maintained with only passive mitigating facility systems under plausible accident scenarios, then deactivating all safety systems would be acceptable, whether or not the generic radiological inventory limits of DOE-STD-1027 have been attained

The fire hazards analysis will determine that fire detection and suppression systems will not be required post deactivation.

The roof assessment and building exterior structural analysis will not find any significant deficiencies, however, cost for repairs will be estimated at $\$ 1-M$ for contingency planning (per facility).

The asbestos assessment will not find any significant quantities of friable asbestos and that the majority of non-friable and encapsulated asbestos-containing material is in an acceptable end state.

Clean closure requirements for the REC, the HLV and LLV, the piping, and the miscellaneous areas will include removing the wasie inventory with subsequent decontamination, as necessary, to meet closure periormance standards per WAC 173-303-610 (2). Clean closure of the soil will consist of demonstrating that the Facility's concrete and liners had kept contaminants from reaching the soil. If potential through-thickness cracks indicate containment failure that would preclude subsequent waste storage operations, the soil contamination cleanup will be 
coordinated and integrated with the CERCLA remedial action process for the operable unit

\section{4/327 Facility Transition Project Organization Mission (RL-TP08)}

The 324 Facility Stabilization Project mission is to achieve a safe, stable, and environmentally sound facility condition by stabilization and deactivation, that would be suitable for an extended period of Surveillance and Maintenance (S\&M) pending final decommissioning, as quickly and economically as possible, and to place the facility in a condition acceptable for transfer from the Office of Facility Transition and Management (EM-60) to the Office of Environmental Restoration ( $E M-40$ ). Final decontamination and decommissioning will be accomplished after transfer to the Office of Environmental Remediation (EM-40).

The 324/327 Project will remove radioactive, along with hazardous waste material, to the extent that the current "fissionable material facility" category may be reduced to a "radiological facility" category in accordance with the guidelines given in DOE-STD-1027-92, Hazard Categorization and Accident Analysis Techniques for Compliance with DOE Order 5480.23, Nuclear Safety Analysis Reports.

The 324 Facility deactivation phase will also include closure actions for areas of the 324 Facility. DOE-RL and Ecology have agreed that these areas are: 1) the B-Cell, 2) two portions of the D-Cell: the waste oil drum storage area and the HLV and liquid treatment process equipment, 3) the airlock, 4) the pipe trench, 5) the HLV, 6) the Low Level Vault (LLV), 7) the piping from the second floor gallery that runs into B-Cell and the HLV, 8) the sample room (Room 145), and 9) the Engineering Development Laboratory (EDL) (Room 146). The strategy and activities required for closure of these portions of the 324 Facility are given in the reference draft Closure Plan, The 324 Building Radiochemical Engineering Cells and High-Level Vault Closure Plan (DOE-RL 1997).

\section{4/327 Facility Transition Project Principle End Point Targets}

Reduce the annual $324 / 327$ Surveillance and Mainterance costs for each facility. (Current baseline is $\$ 400,000$ for both facilities).

Accomplish the deactivation and placement of the 324 and 327 Facilities into low-cost S\&M by Oct 1, 2003.

Facility configuration will be established such that active systems are not required for safety and environmental confinement.

Deactivation will be perfomed in a way that will result in a redesignation of the 324 and 327 Facilities as radiological facilities in accordance with the criteria and guidelines provided in DOE-STD-1027, Hazard Categorization and Accident Analysis Techniques for Compliance with DQE Order 5480.23, Nuclear Safety Analysis Reports.

Closure activities will be completed for the radiochem cal engineering cells (REC) and high level vault (HLV) to meet current Tri-Party Agreement (TPA) commitments.

\section{4/327 Facility Transition Project Supported End Point Targets}

The acceptable end state is defined by the following programmatic and physical results.

Programmatic:

- The facility stabilization phase was completed with temination of operations, establishment of a Surveillance and Maintenance (S\&M) program, achievement of facility-specific end points, and initiation of the S\&M Phase.

- The 324 Facility was placed in a condition acceptable for transfer from the Office of Facility Transition and Management (EM-60) to the Office of Environmental Restoration (EM-40).

- The facility stabilization activities placed the facility in a condition that achieves a "radiological facility" category (DOE 1992). 
- A memorandum of agreement (MOA) between BWHC and BHI is approved and issued that delineates and transfers responsibilities for the future facility S\&M activities to $\mathrm{BHI}$.

- Stabilization activities that required removal and disposal of radioactive, dangerous, and mixed waste (e.g., during tank flushing, excessing, RCRA permitting and waste disposal) complied with Federal, State, and Local regulations and requirements.

- The facility is maintained in a safe and stable condition by means of a methodical surveillance and maintenance (S\&M) program.

- Material accountability, such as the SNM inventory, was reconciled.

- Facility structural integrity was verified for a minimum of five years and documented in the facility tumover package.

- Legacy equipment was identified, documented in the turnover package, and abandoned in place.

- The facility was placed in a physical condition adequate to contain and monitor any radioactive contamination.

- The "as left" radiation contamination survey of the facility and surrounding areas was included in the deactivation records as part of the turnover package.

- The SNM, fuels, and solid and liquid radioactive, hazardous, and mixed waste inventories were removed from the facility, or exceptions of nuclear and hazardous material remaining in the facility was identified and characterized by location, type, quantity, and controls for such materials, were documented and approved for which an end condition cannot be determined.

- The facility was left unoccupied, empty, locked, and maintained with minimum entry requirements pending decontamination and decommissioning.

- The facility personnel have been relocated

- Radioactive, dangerous, and mixed wastes were removed using Reasonable Best Effort Methodology and disposed. of in compliance with applicable regulations and requirements. Reasonable Best Effort is characterized by reducing parameters to "As Low As Economically Achievable" (ALEA) and implies use of a "Best Management Practices" approach to reach realistic, logical, and cost-effective end states or conclusions.

Physical:

- Fissionabie material was removed to the necessary extent to allow the 324 Facility to achieve a "radiological facility" category (DOE 1992).

- Hazards, nuclear and non-nuclear, were eliminated or reduced by removing, isolating, draining, and minimizing hazardous material.

- Radiation fields were eliminated, reduced, shielded or isolated, with proper radiological posting of remaining radiation fields.

- Radioactive contamination was removed, reduced, or isolated/contained to mitigate and prevent spreading. - Housekeeping was performed and removal of unattached (e.g., portable and/or mobile) material, equipment, office furniture and files, and chemicals was completed.

- Remaining facility hazards were isolated and contained from personnel and the environment using blanking, plugging, covering, removal, screening, and sealing of doors, windows, pipe penetrations, holes, drains, etc.

- Facility doors were locked from the inside except those required for entrance by surveillance personnel.

- To maximum extent possible, unsurveilled areas of the facility were sealed to prevent unauthorized access.

- Areas requiring access for inspection were sufficiently decontaminated.

- Installation of instrumentation such as alarms, windows in ancillary buildings, and surveillance lighting was completed to enable monitoring, surveillance, and control of the facility pending final disposition.

- Structural repairs, roof sealing, and facility modifications (e.g, upgrade the of the ventilation system) were completed to establish a safe and stable facility.

- Proper equipment labeling was provided to enable future D\&D activities.

- Chemical and radioactive inventories were stabilized to minimize facility risks and allow for reduced S\&M.

- Mobile quantities of SNM and SNF and related items were removed.

- The facility process vessels and tanks were emptied/drained and flushed with some process equipment

disassembled to remove inventory.

- Failed equipment/jumpers were removed.

- Piping to external facility interfaces was isolated unless deemed necessary to support D\&D. 
- Facility supplies were removed.

- Facility high-radiation areas were shielded to enable S\&M and D\&D activities.

- Facility laboratory hoods containing significant SNM were decontaminated.

- Facility laboratory hoods were decontaminated/isolated and hood exhaust ductwork was isolated/contained.

- Facility floor drains were plugged, removed, or isolated.

- Facility room floors, wall, and ceiling surfaces were decontaminated of hazardous and radioactive materials and resurfaced as necessary to enable S\&M and D\&D activities.

- Facility system headers were drained and flushed as necessary to hazardous and radioactive materials.

- Facility friable asbestos materials were sealed/stabil/zed to enable S\&M and D\&D activities.

- Facility laboratory gloveboxes were decontaminated and residual contamination fixed to enable S\&M and D\&D activities:

- Facility liquid and gaseous effluent streams were eliminated.

- Facility organic solvents, acid solutions, recovered acid, and chemical and acid inventories were removed. Utilities/Instrumentation Systems:

- The facility contains no active systems or utilities with the exception of the heating, ventilation, and air conditioning (HVAC) system as required to maintain the final confinement barrier, and systems required for monitoring and emission control.

- Systems required for monitoring and emission control, protection of surveillance personnel, the general public and environment, and vital equipment were sustained.

- Systems required to respond to emergency conditions expected in the facility's deactivated state and to prevent

- structural degradation were sustained.

- Unnecessary utilities and HVAC system lines were isolated.

- Facility instrument and equipment controls de-energized.

- Facility steam, water, and compressed air service was eliminated.

- Facility emergency electrical loads were minimized or eliminated.

- Facility electrical sevice was provided for selected lighting paneis as necessary to support subsequent S\&M and D\&D activities.

- Facility monitoring functions consolidated at a single monitoring location.

- Facility security systems and procedures are adequate to prevent unauthorized entry.

The technical strategy for the 324 Facility includes the following objectives:

- Establish a 324 Facility configuration such that active systems are not required for safety and environmental confinement.

- Perform stabilization in a manner that will result in a redesignation of the 324 facility as a "radiological facility" in accordance with the criteria and guidelines provided in DOE-STD-1027, Hazard Categorization and Accident Analysis Techniques for Compliance with DOE Order 5480.23, Nuclear Safety Analysis Reports.

- Complete closure activities for the Radiochemical Engineering Cells (REC) and High Level Vault (HLV) to meet current TPA commitments.

- Protect the environment from contamination during any stabilization activities and associated structure upgrades and modifications required to complete the project goals.

- Sustain the systems required for protection of surveillance personnel, the general public and environment, and vital equipment.

- Sustain the systems required to respond to emergency conditions expected in the facility's deactivated state and to prevent structural degradation.

- Ensure that hazards to personnel or the environment are controlled through partial closure, removal, isolation, mitigation, or stabilization of such hazards.

- Ensure structures be maintained in a safe condition with threats to human health and safety removed or appropriate compensatory measures (barriers, access controls, administrative controls, etc.) implemented.

The technical strategy for 327 Facility includes the following objectives: 
- Establish a 327 Facility configuration such that active systems are not required for safety and environmental confinement.

- Perform stabilization in a manner that will result in a redesignation of the 327 facility as a "radiological facility" in accordance with the criteria and guidelines provided in DOE-STD-1027, Hazard Categorization and Accident Analysis Techniques for Compliance with DOE Order 5480.23, Nuclear Safety Analysis Reports.

- Protect the environment from contamination during any stabilization activities and associated structure upgrades and modifications required to complete the project goals.

. Sustain the systems required for protection of surveillance personnel, the general public and environment, and vital equipment.

- Sustain the systems required to respond to emergency conditions expected in the facility's deactivated state and to prevent structural degradation.

- Ensure that hazards to personnel or the environment are controlled through partial closure, removal, isolation, mitigation, or stabilization of such hazards.

- Ensure structures be maintained in a safe condition with threats to human health and safety removed or appropriate compensatory measures (barriers, access controls, administrative controls, etc.) implemented.

\section{B.8.1.2.324/327 Facility Transition Project End Point Targets from Hanford Strategic Plan}

* Transition high cost surpius facilities in the central plateau and south 600 areas to a low cost, stable, deactivated condition.

* Transition the $324 / 327$ Buildings to a low cost, stable, deactivated condition and disposition their nuclear materials (including 324 Building radioactive tank wastes).

- Transfer Special Nuclear Material from the south 600 area facilities to the 200 Area for interim storage.

* Reuse facilities in the south 600 area for economic diversification where feasible.

\section{B.8.1.3 324/327 Facility Transition Project Major Facilities}

\section{B.8.1.3.1 324 Building Facility}

\section{B.8.1.3.1.1 324 Building Facility Description}

The 324 Facility, known as the Waste Technology Engineering Laboratory (WTEL), is located in the 300 Area of the Hanford Site. Facility construction was completed in 1965 to begin a mission to support high-level radioactive chemical processing and metallurgical studies. Currently, the 324 Facility supports non-radioactive and waste treatability studies, along with continued Surveillance and Maintenance (S\&M) and cleanup activities.

The 324 Facility provides office and laboratory space for scientific and engineering staff who conduct multi-disciplinary research in areas of waste characterization and immobilization, waste remediation and cleanup methodology development, biomass research, spent fuel characterization, tritium production methodology development, and cesium chloride encapsulation.

The 324 Facility is classified as a Hazard Category 2 nonreactor nuclear facility and for criticality safety is designated as a "fissionable material facility" (PNL 1995). A "fissionable material facility," as defined in PNL-MA-25, Criticality Safety (PNL 1992), is a facility that contains or procedurally could contain greater than $45 \%$ of a minimum critical mass of fissionable material or greater than $50 \%$ of a guaranteed subcritical mass or greater than $10 \%$ of a critical mass of sealed sources sealed into welded metal capsules. 
B.8.1.3.1.2 324 Building Facility Technical Logic:

The Department of Energy (DOE), in partnership with its contractors, shall plan, acquire, operate, maintain, and dispose of physical assets as valuable national resources. Stewardship of these physical assets shall be accomplished in a cost-effective manner to meet the DOE mission. This shall incorporate industry standards, a graded approach, and performance objectives. 
HNF-SP-1234

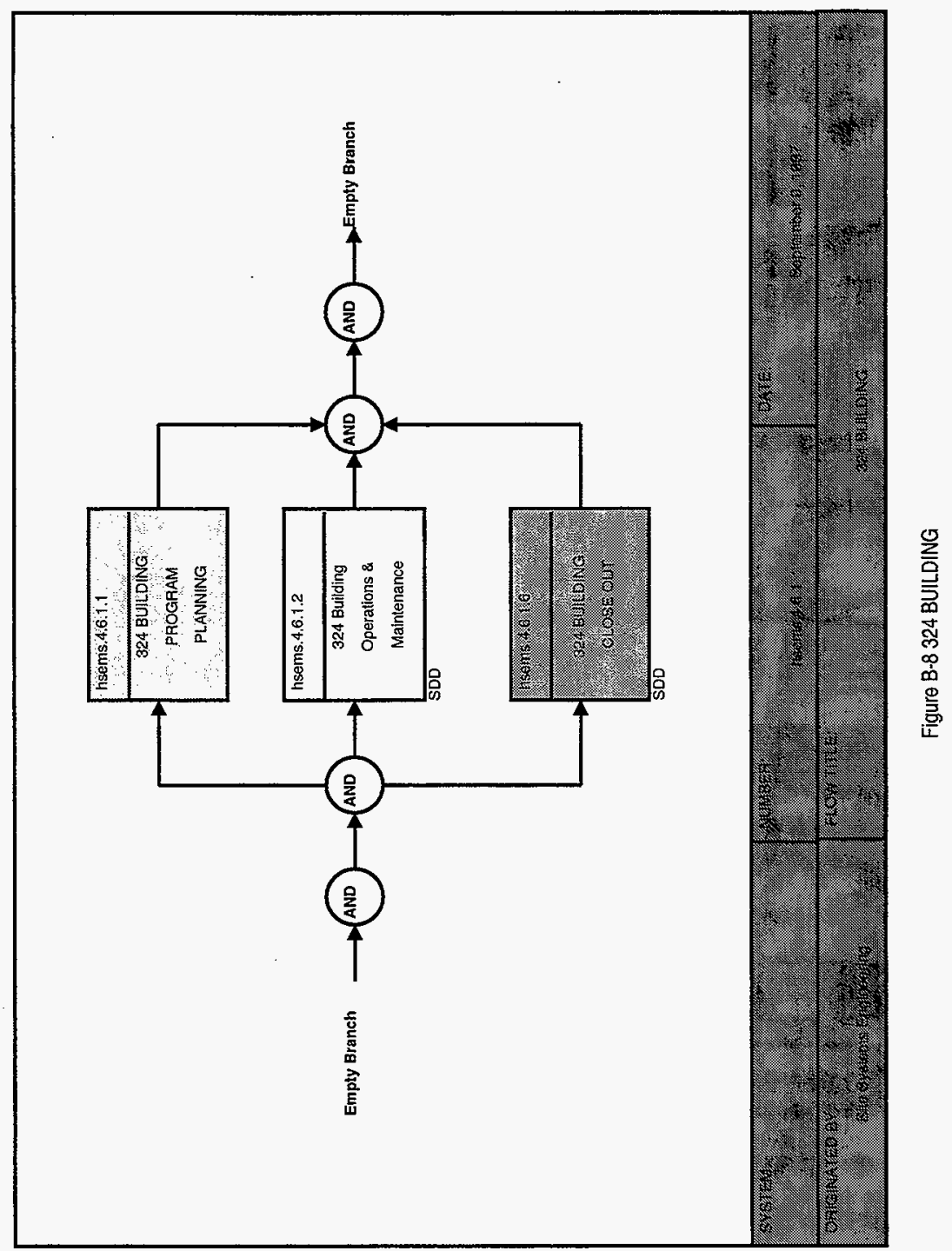




\section{B.8.1.3.1.3 324 Building Requirements and Life Cycle Function Descriptions}

\section{Requirements:}

- Empty and flush process systems to eliminate the need to generate RCRA pemits for storage tanks.

* Establish hazardous material inventories to ensure the location and amount of all material is known

- Remove and dispose of filters and other such equipment that contain radioactive or hazardous materials

consistent with facility operation requirements.

- Conduct stabilization activities with consideration for waste minimization and pollution prevention.

- Remove fissionable material to the extent required to enable the 324 facility hazard category to be reduced from

a "fissionable material facility" to one of a "radioactive facility."

* - Conduct a facility assessment (i.e., characterize the hazards, risks, liabilities, and costs) to provide a technical basis for future 324 Facility Stabilization Project decisions.

* Eliminate or reduce hazards, nuclear and non-nuclear.

- Eliminate, shield, or isolate radiation fields to enable S\&M and D\&D activities.

* Reduce contamination and prevent its spread or migration.

- Accomplish waste disposal during stabilization and deactivation activities in compliance with applicable laws and regulations.

* - Isolate and contain residual, potentially hazardous materials or conditions.

- Provide capability for ongoing monitoring and control of the facility.

* Provide additional facility modification or refurbishment to support future work (S\&M or D\&D)

* Provide turnover documentation and equipment labeling.

- RCRA, as amended (42 U.S.C., sec. 6901 et seq. and implemented in Washington State through Washington Administrative Code [WAC] 173-303), regulates the generation, transportation, storage, treatment, and disposal of solid and hazardous waste. The RCRA provisions govern cleanup of hazardous waste constituents released to the environment from hazardous or solid waste management units.

- Complete all activities to allow shipment of the Federal Republic of Gemany logs from 324.

- Section V of the Clean Air Act of 1977 (CAA), adopted in the 1990 amendments to the CAA, establishes a federal permitting program, which will be administered by the states. Any "major source" of criteria pollutants or of hazardous air pollutants will be required to obtain a permit to operate the source.

- The Clean Water Act of 1877 (CWA) requires any source that discharges a "pollutant" into a surface water body to obtain and operate in compliance with a National Pol ution Discharge Elimination System (NPDES) permit. The CWA includes radioactive materials in its definition of pollutant (33 U.S.C. 1362 (6)). However, the EPA has 
HNF-SP-1234

intepreted "pollutant" to exclude radioactive materials regulated under the Atomic Energy Act of 1954 (AEA). The CWA applies to naturally occurring and accelerator-produced radioisotopes; it does not apply to source, special, or byproduct materials as the AEA defines those terms. Currently, four effluent streams are discharged from the 324 and 327 Facilities.

- Reduce facility cost to the minimum needed to support surveillance and maintenance pending final facility decontamination and decommissioning.

* Complete the 324 facility special case waste (SCW) assessment in support of 324 closure

* - The 324 Facility will be clean closed with respect to dangerous waste contamination in specific areas that resulted from the treatment or storage of dangerous waste for greater than 90 days.

* Clean closure requirements for the REC, the high-level vault (HLV) and low-level vault (LLV), the piping, and the miscellaneous areas will include removing the waste inventory with subsequent decontamination, as necessary, to meet closure performance standards per WAC $173-303-610$ (2).

* Clean closure of the soil immediately beneath the radiochemical engineering cells (REC) and HLV will consist of demonstrating that the Facility's concrete and liners had kept contaminants from reaching the soil..

* The clean closure performance standard for metal surfaces and concrete will be the "clean debris surface" as defined in 40 CFR 268.45 as follows: "A clean debris surface means the surface, when viewed without magnification, shall be free of all visible contaminated soil and hazardous waste except residual staining from soil and waste consisting of light shadows, slight streaks, or minor discolorations and soil and waste in cracks, crevices, and pits may be present provided that such staining and waste and soil in cracks, crevices, and pits shall be limited to no more that $5 \%$ of each square inch of surface area."

* - Decontamination of concrete will be done to meet the criteria of the "debris rule".

* Accomplish stabilization and deactivation activities to place the 324 Facility into low cost Surveillance and Maintenance, to achieve a 324 Facility safety class designation of "radiological facility" using the STD 1027 standard and implementation guide, and to place the facility in a condition acceptable for transfer from the Office of Facility Transition and Management (EM-60) to the Office of Environmental Restoration (EM-40) by Oct 1, 2003.

* Complete RCRA closure on specific facility areas (REC/HLV) as the preferred option to meet current TPA Milestone commitments.

* Reduce the annual suveillance and maintenance costs for both the 324 and 327 Facilities to less than $\$ 400,000$ (PNNL 1997).

* Establish a passively safe (i.e., no active systems required) and environmentally secure facility configuration, including implementation of contamination controls, for safety and environmental confinement that may be retained through the post-deactivation period until final facility disposition activities begin.

- The Hanford Site Infrastructure shall be optimized.

* South 600 Area high cost surplus facilties shall be transitioned to a low cost, stable, deactivated condition

- 324 building shall be transitioned to a low cost and stable deactivated condition

* South 600 area facilities shall be made available for other uses. 
* South 600 Area special nuclear materials shall be moved to the Central Plateau

* 300 Area nuclear materials shall be remediated

* 300 area FRG cesium shall be removed .

* 324 B Cell dispersible material shall be contained and removed by May 31, 1999

* 324 building shall be maintained within the approved safety envelope

- 324 building shall be operated within the approved safety envelope

* 324 building B Cell safety issues shall be resolved by Dec 1998

* 300 Area SNM contained in various buildings shall be surveilled and maintained within the approved safety envelope

* TPA Milestone M-20-55, completed in December 1995, required submittal of a closure plan for non-permitted mixed waste units located in the 324 Facility REC B-Cell, REC D-Cell, and HLV.

- Complete closure of non-permitted mixed waste units in the 324 Buiding REC B-cell, REC D-cell and high level vault. Due Date:TBD

* TPA Milestone M-89-01, completed September 5, 1996, required removal of 324 Facility HLV Tank mixed waste (e.g., TK-104, TK-105, and TK-107) with the exception of residues which may remain following flushing and draining to the extent possible.

- TPA Milestone M-89-01A, completed March 31, 1995, identifies the HLV tanks that contained mixed waste as tanks 104, 105, and 107, and directs the U.S. Department of Energy, Richland Operations Office (DOE-RL) to flush and drain these tanks.

- TPA Miletone M-89-02, due May 31,1999, requires removal of 324 facility B-Cell mixed waste and equipment. Actions under this milestone include containment and removal of all B Cell dispersible materials, excess equipment and debris. Containerized MW will be managed in compliance with Chapter 173.303 WAC, thereby reducing risks to human health and the environment. Any remaining residues following removal actions will be managed through the final closure process. USDOE's 324 Building Rec B Cell clean-out project (BCCP) will be used as a guide for containerizing dispersible MW and removing unnecessary equipment and materials from B-Cell.

TPA milestone actions include:

- Complete removal of dispersible materials from 324 Building REC B-cell.

- Complete removal of excess equipment from 324 Building REC B-cell.

* Complete removal of debris from 324 Building REQ B-cell.

* Containerized MW removed from 324 Building REC B-cell will be managed in compliance with Chapter 173-303 WAC

- Any remaining residues from removal of containerized MW removed from 324 Building REC B-cell will be managed through the final closure process. 
* USDOE's 324 Building REC B-cell cleanout project (BCCP) will be used as a guide for containerizing dispersible MW and removing unnecessary equipment and materials from B-cell.

- TPA Milestone M-89-03, completed in March 1995, required compliance with interim-status facility standards for the non-permitted 324 Facility areas. Because of the high radiation fields associated with mixed waste stored in the Radiochemical Engineering Cells (REC) and the HLV, alternative compliance measures for some interim status requirements were used.

* TPA Milestone M-89-04, completed in June 1995, required DOE-RL to identify mixed waste management atternatives and USDOE's proposal for achieving clean closure of the 324 Facility REC B-Cell, D-Cell, and HLV.

* TPA Milestone M-89-05, due June 30,1998, requires completion of the 324 facility special case waste (SCW) assessment in support of 324 closure.

* TPA Milestone M-92-04: Complete transfer of all 300 Area Cs/Sr to WESF and/or an approved storage location by $12 / 31 / 98$.

- Complete acquisition of new facilities, modification of existing facilities, and/or modification of planned facilities necessary for consolidated storage prior to disposal of Hanford Site 300 Area Special Case Waste (SCW).

Due Date: 9/30/2006

* M-92-13 Submit 300 Area SCW PMP to Ecology pursuant to Agreement Action Pian, Section 11.5, by September 2000.

* Complete removal and transfer, and initiate storage of Phase I 300 Area SCW and materials (one third of the total inventory) by September 30, 2002.

- Complete removal and transfer, and initiate storage of Phase 11300 Area SCW and materials (one half the total inventory) by September 30, 2004.

- Complete removal and transfer, and initiate storage of Phase III 300 Area SCW and materials by September 30 , 2006.

* Protect workers, the public, and the environment during stabilization and deactivation activities.

* Facilitate 324 Facility S\&M to ensure that remaining process equipment does not fail and release any residual materials.

* Comply with regulations and requirements during stabilization and deactivation activities.

* Establish baseline data for $\$ \& M$ to enable record keeping to identify systems and/or components that may be deteriorating and to advise decommissioning personnel about the potential hazards.

* - Hazardous and radioactive materials shall be removed from the facility or reduced and stabilized sufficiently to reduce hazards to workers and the public, to ensure long-term facility safety and regulatory compliance, to reduce the level of required surveillance during the extended surveillance period following deactivation, to enable plant classification as a "radiological facility", and to enable subsequent successful D\&D.

* Promote facility decommissioning by preparing the facility to be one that is cleaned of process materials to the greatest extent possible. 
* National Environmental Protection Act/State Environmental Policy Act Status and Strategy. The NEPA is a review and documentation process promulgated under 10 CFR 1021 and 40 CFR 1508.27 and also executed pursuant to DOE Order $5440.1 E$, Chapter $V$. This documentation requires that all federal agencies identify the environmental impacts associated with the proposed remedial actions that may significantly affect the environment.

- National Historic Preservation Act (NHPA) provisions found in 36 CFR 800, "Determination of Eligibility for Inclusion in National Register," require federal agencies to survey all lands and structures under their control, and to identify and evaluate all properties for eligibility to be listed in the National Register of Historic Places.

\section{Life Cycle Function Descriptions:}

\section{B.8.1.3.1.3.1 324 BUILDING PROGRAM PLANNING WORK SCOPE SUMMARY}

Functions that include planning and developing the overall program; establishing broad priorities; providing program technical direction; preparing and defending the program budget; controlling milestones; integrating all components of the program; providing public and private sector policy liaison; expediting interface activities and follow-up actions; and retaining overall accountability for program success.

\section{B.8.1.3.1.3.2 324 Building Operations \& Maintenance WORK SCOPE SUMMARY}

No Description

324 Building Operations \& Maintenance SPECIFIC FUNCTIONS

\section{B.8.1.3.1.3.3 Provide R\&D support for the SNF and other Projects}

Building 324 has been transferred to the TrP Organization for Post Operations Transition work. Due to the urgent need for the SNF project it has been assigned to PNNL for R\&D work.

Past 324 Facility operations activities have supported high-level radioactive chemical processing and metallurgical studies. Currently, operations supports non-radioactive and waste treatability studies, aiong with continued S\&M and cleanup activities. These activities make use of the facility office and laboratory space provided for scientitic and engineering staff. The operations objectives are to conduct multi-disciplinary research in areas of waste characterization and immobilization, waste remediation and cleanup methodology development, biomass research, spent fuel characterization, tritium production methodology development, and cesium chloride encapsulation. The stabilization objective is to curtail these operations to enable facility deactivation work tasks to begin.

\section{B.8.1.3.1.3.4 324 BUILDING POST OPERATIONS WORK SCOPE SUMMARY}

Day-to-day work, including pre-stabilization surveillance and maintenance, stabilization, post-stabilization surveillance and maintenance, deactivation, and post-deactivation surveillance and maintenance, that is required to allow safe decontamination and decommissioning.

\section{BUILDING POST OPERATIONS SPECIFIC FUNCTIONS}

\section{B.8.1.3.1.3.5 Maintain Safe \& Compliant 324 Building in South 600 Areas}

Maintain the 324 facility structures, operating systems and equipment, and monitoring systems within the approved safety and compliance requirements until the facilities are made available for clean-up. 


\section{B.8.1.3.1.3.6 Maintain Safe \& Compliant Materials in 324 Building}

Materials stored in 324 building will be maintained in safe and compliant states until they are made available for clean-up.

\section{B.8.1.3.1.3.7 Remove Material from 324 Building}

Remove the nuclear materials from the 324 Building for treatment or disposition.

\section{B.8.1.3.1.3.8 Transition 324 Building}

Initiate the transition phase of decontamination and decommissioning for the 324 Building

This phase is characterized by activities associated with removing legacy wastes, residual contamination, facility systems and/or areas from operational service with the intent of being ready for facility stabilization to transition the facility to final decommissioning. The objective of deactivation is to expeditiously reduce the hazards, risks, and costs (i.e., the mortgage) associated with a surplus facility until final disposition can be achieved.

In addition, this phase is characterized by activities necessary to place the 324 facility in a safe, stable, and environmentally sound condition, suitable for an extended period of surveillance and maintenance pending final disposition. Facility stabilization starts with termination of operations, includes the establishment of a $S \& M$ program, and ends with the achievement of facility-specific goais, objectives, and end points.

\section{B.8.1.3.1.4 324 Building Boundary Diagram}

Table B.8-1 324 Building Boundary Diagram

\begin{tabular}{|l|l|}
\hline $\begin{array}{l}\text { External Interiaces } \\
\text { Hantord Legacy } \\
\text { Idaho National Engineering Laboratory } \\
\text { Hanford Site Environmental System Interiaces } \\
\text { None- }\end{array}$ & $\begin{array}{l}\text { External Interfaces } \\
\text {-None- } \\
\text { Hantord Site Environmental System Interiaces } \\
\text { hsems.2.3.2 Double She!l Tank (DST) System } \\
\text { hsems.2.3.4 200 Interim Storage Area (ISA) } \\
\text { isems.2.3.5 Central Waste Complex } \\
\text { hisems.4.2.2.307 Retention Basins }\end{array}$ \\
\hline
\end{tabular}




\title{
B.8.1.3.1.5 324 Building Interface Description and Forecast
}

\section{EXTERNAL INPUTS}

Table B.8-2 External Inputs for 324 Building

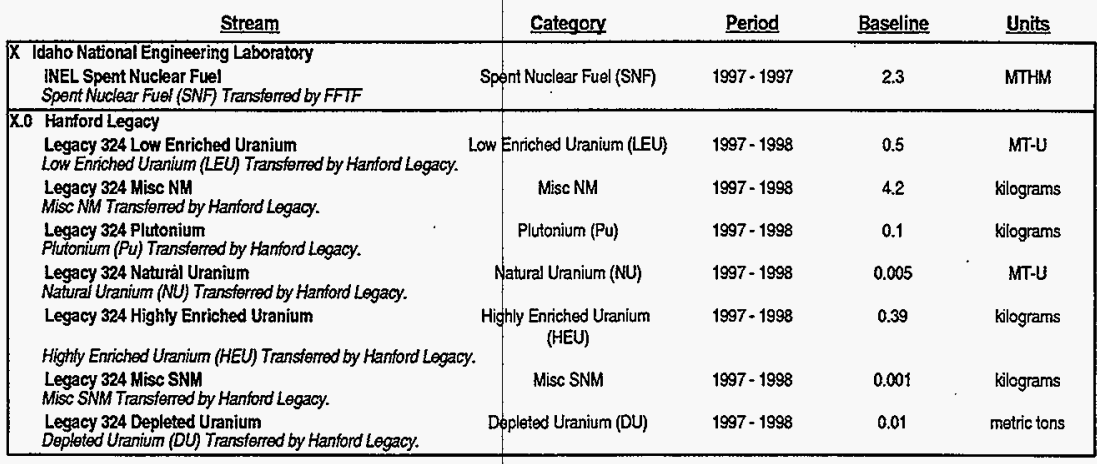

\section{INTERNAL INPUTS} -None-

\section{EXTERNAL OUTPUTS}

\author{
-None-
}

\section{INTERNAL OUTPUTS}

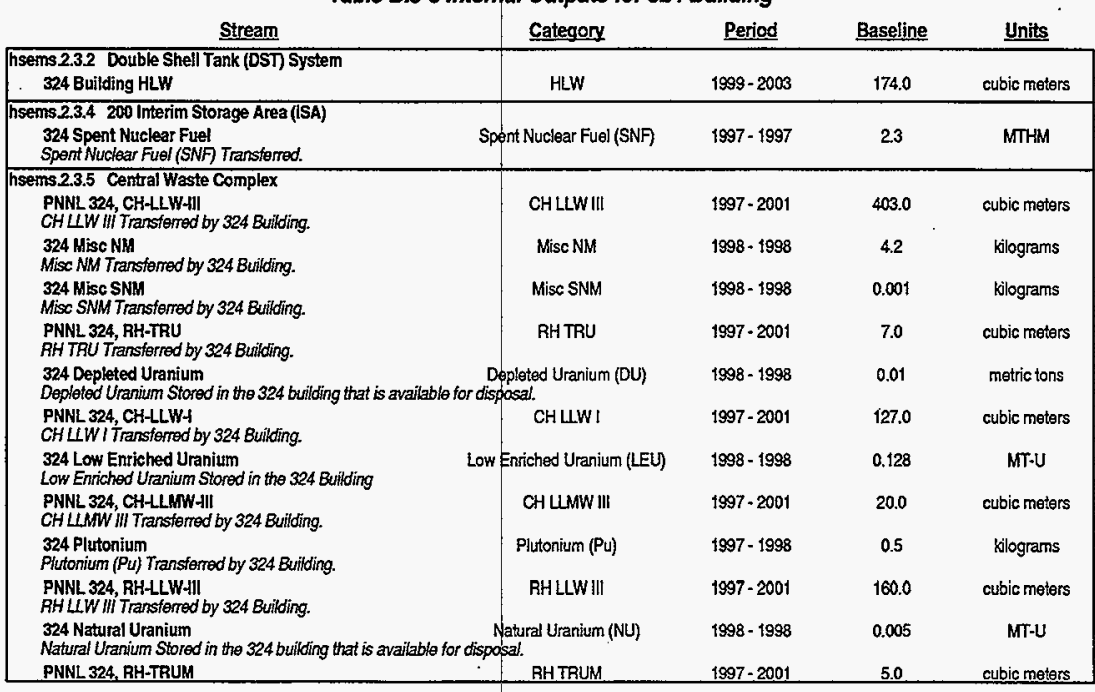


HNF-SP-1234

Table B.8-3 Internal Outputs for 324 Building (Continued)

Stream

Category

Period

Baseline

Units

RH TRUM Transfemod by 324 Bullíing.

hsems.4.2.2 307 Retention Basins

324 Potentially Contaminated Waste Water

Industrial Waste Water

$1998-2003$

43900

cu moters Industrial waste water from 324 Building operations. The volume of waste water is estimated based on historical throughput to the 307 Retention Basins and assuming equal contribution trom all inputs to the RPS. 


\section{B.8.1.3.2 327 Building Facility}

\section{B.8.1.3.2.1 327 Building Facility Description}

The 327 Facility, known as the Post-irradiation Testing Laboratory or PTL (fommerly known as the Radiometallurgy Facility), is located in the 300 Area of the Hanford Site. Facility construction was completed in 1953 to begin a mission of examination and testing of irradiated materials, particularly metals. The 327 Facility also performed rupture analysis of fuel elements for the Hanford production reactors, and later, for various U.S. Department of Energy (DOE) test reactors (such as PRTR, SP-100, FFTF, EBR-II). Currently, the 327 Facility supports fuel analysis for several DOE and foreign projects, including the Hanford Site Spent Nuclear Fuel Project.

\section{B.8.1.3.2.2 327 Building Facility Technical Logic:}

The Department of Energy (DOE), in partnership with its contractors, shall plan, acquire, operate, maintain, and dispose of physical assets as valuable national resources. Stewardship of these physical assets shall be accomplished in a cost-effective manner to meet the DOE mission. This shall incorporate industry standards, a graded approach, and performance objectives. 
HNF-SP-1234

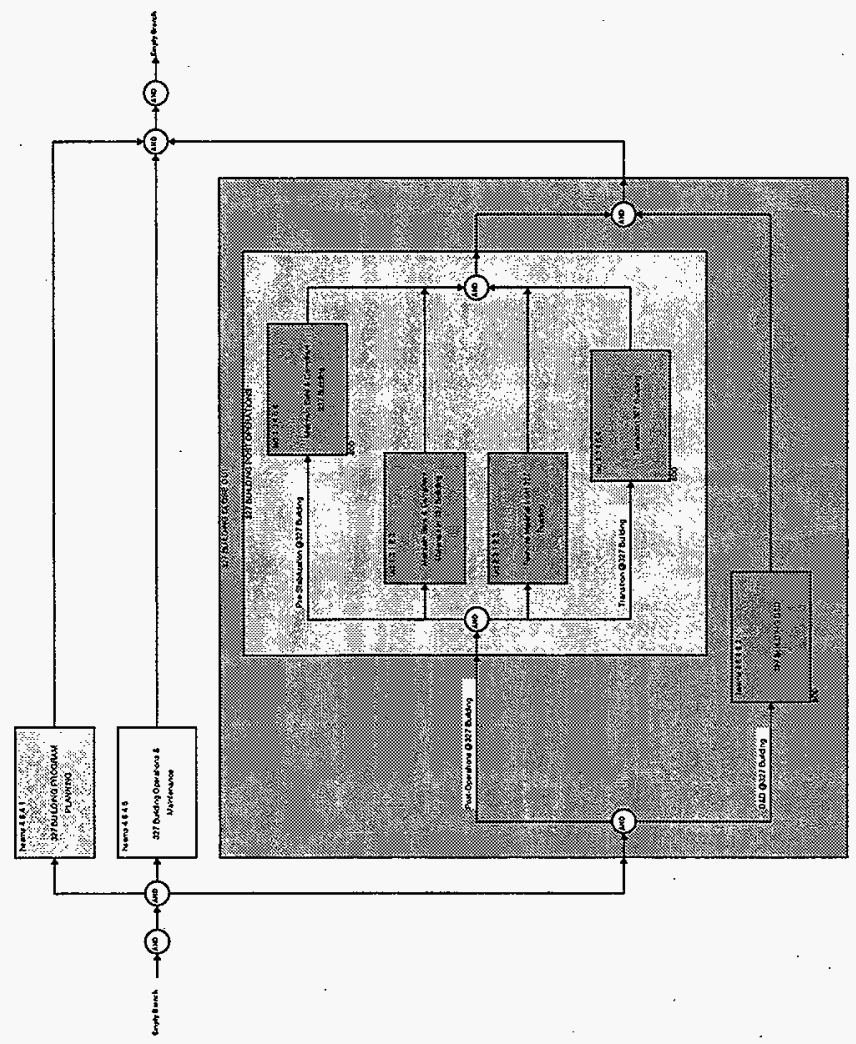

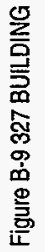




\section{B.8.1.3.2.3 327 Building Requirements and Life Cycle Function Descriptions}

\section{Requirements:}

- Protect workers, the public, and the environment during stabilization and deactivation activities.

* Comply with regulations and requirements during stabilization and deactivation activities.

* - Reduce facility cost to the minimum needed to support surveillance and maintenance pending final facility decontamination and decommissioning.

* Complete the 327 facility special case waste (SCW) assessment in support of 327 closure.

* Accomplish stabilization and deactivation activities to place the 327 Facility into low cost Surveillance and Maintenance, to achieve a 327 Facility safety class designation of "radiological facility" using the STD 1027 standard and implementation guide, and to place the facility in a condition acceptable for transfer from the Office of Facility Transition and Management (EM-60) to the Office of Environmental Restoration (EM-40) by Oct 1, 2003.

* Reduce the annual surveillance and maintenance costs for both the 324 and 327 Facilities to less than $\$ 400,000$ (PNNL 1997).

* Establish a passively safe (i.e., no active systems required) and environmentally secure facility configuration, including implementation of contamination controls, for safety and environmental confinement that may be retained through the post-deactivation period until final facility disposition activities begin.

* Facilitate 327 Facility S\&M to ensure that remaining process equipment does not fail and release any residual materials.

* Establish baseline data for S\&M to enable record keeping to identify systems and/or components that may be deteriorating and to advise decommissioning personnel about the potential hazards.

* Hazardous and radioactive materials shail be removed from the facility or reduced and stabilized sufficiently to reduce hazards to workers and the public, to ensure long-term facility safety and regulatory compliance, to reduce the level of required surveillance during the extended surveillance period following deactivation, to enable plant classification as a "radiological facility", and to enable subsequent successiul D\&D.

* Promote facility decommissioning by preparing the facility to be one that is cleaned of process materials to the greatest extent possible.

* Empty and flush process systems to eliminate the need to generate RCRA permits for storage tanks.

* Establish hazardous material inventories to ensure the location and amount of all material is known.

* - Remove and dispose of filters and other such equipment that contain radioactive or hazardous materials consistent with facility operation requirements.

* - Conduct stabilization activities with consideration for waste minimization and pollution prevention.

- Remove fissionable material to the extent required to enable the 327 facility hazard category to be reduced from a "fissionable material facility" to one of a "radioactive facility." 
* Eliminate or reduce hazards, nuclear and non-nuclear.

* Eliminate, shield, or isolate radiation fields to enable S\&M and D\&D activities.

* Reduce contamination and prevent its spread or migration.

* Accomplish waste disposal during stabilization and deactivation activities in compliance with applicable laws and regulations.

* Isolate and contain residual, potentially hazardous materials or conditions.

* Provide capability for ongoing monitoring and control of the facility.

* Provide additional facility modification or refurbishment to support future work (S\&M or D\&D)

* Provide turnover documentation and equipment labeling.

* RCRA, as amended (42 U.S.C., sec. 6901 et seq. and implemented in Washington State through Washington Administrative Code [WAC] 173-303), regulates the generation, transportation, storage, treatment, and disposal of solid and hazardous waste. The RCRA provisions govern cleanup of hazardous waste constituents released to the environment from hazardous or solid waste management units.

- Place fuel pins and pieces in 327 basin in casks and ship to TBD storage location.

* Remove Cs capsules from 327 Bldg.

- Section V of the Clean Air Act of 1977 (CAA), adopted in the 1990 amendments to the CAA, establishes a federal permitting program, which will be administered by the states. Any "major source" of criteria pollutants or of hazardous air pollutants will be required to obtain a permit to operate the source.

- The Clean Water Act of 1977 (CWA) requires any source that discharges a "pollutant" into a surface water body to obtain and operate in compliance with a National Pollution Discharge Elimination System (NPDES) permit. The CWA includes radioactive materials in its definition of pollutant (33 U.S.C. $1362(6)$ ). However, the EPA has interpreted "pollutant" to exclude radioactive materials regulated under the Atomic Energy Act of 1954 (AEA). The CWA applies to naturally occurring and accelerator-produced radioisotopes; it does not apply to source, special, or byproduct materials as the AEA defines those terms. Currently, four effluent streams are discharged from the 324 and 327 Facilities.

- South 600 Area high cost surplus facilties shall be transitioned to a low cost, stable, deactivated condition

* 327 building shall be transitioned to the surveillance and maintenance phase

* South 600 area facilities shall be made available for other uses.

* South 600 Area special nuclear materials shall be moved to the Central Plateau

- 300 Area nuclear materials shall be remediated

* 327 building shall be maintained within the approved safety envelope 
* 327 building shall be operated within the approved safety envelope

* 327 inventory system shall be maintained within the approved safety envelope

* 327 HVAC system shall be maintained within the approved safety envelope

* 327 building radiation monitoring system shall be maintained within the approved safety envelope

* 327 building safeguard system shall be maintained within the approved safety envelope

* TPA Milestone M-92-04: Complete transfer of all 300 Area Cs/Sr to WESF and/or an approved storage location by $12 / 31 / 98$.

- National Environmental Protection Act/State Environmental Policy Act Status and Strategy. The NEPA is a review and documentation process promulgated under 10 CFR 1021 and 40 CFR 1508.27 and also executed pursuant to DOE Order $5440.1 E$, Chapter $V$. This documentation requires that all federal agencies identify the environmental impacts associated with the proposed remedial actions that may significantly affect the environment.

* National Historic Preservation Act (NHPA) provisions found in 36 CFR 800, "Determination of Eligibility for Inclusion in National Register," require federal agencies to survey all lands and structures under their control, and to identify and evaluate all properties for eligibility to be listed in the National Register of Historic Places.

\section{Life Cycle Function Descriptions:}

\section{B.8.1.3.2.3.1 327 BUILDING PROGRAM PLANNING WORK SCOPE SUMMARY}

Functions that include planning and developing the overall program; establishing broad priorities; providing program technical direction; preparing and defending the program budget; controlling milestones; integrating all components of the program; providing public and private sector policy liaison; expediting interface activities and follow-up actions; and retaining overall accountability for program success.

\section{B.8.1.3.2.3.2 327 Building Operations \& Maintenance WORK SCOPE SUMMARY}

Past 327 Facility operations activities have supported examination and testing of irradiated materials, particularly metals, including rupture analysis of fuel elements for the Hanford production reactors along with various U.S. Department of Energy (DOE) test reactors. Currently, operations supports fuel analysis for several DOE and foreign projects, including the Hanford Site Spent Nuclear Fuel Project. These activities make use of the facility office and laboratory space provided for scientific and engineering staff. The stabilization objective is to curtail these operations to enable facility deactivation work tasks to begin.

\section{B.8.1.3.2.3.3 327 BUILDING POST OPERATIONS WORK SCOPE SUMMARY}

Day-to-day work, including pre-stabilization surveillance and maintenance, stabilization, post-stabilization surveillance and maintenance, deactivation, and post-deactivation surveillance and maintenance, that is required to allow safe decontamination and decommissioning.

\section{BUILDING POST OPERATIONS SPECIFIC FUNCTIONS}

\section{B.8.1.3.2.3.4 Maintain Safe \& Compliant 327 Building}

Maintain the 327 facility structures, operating systems and equipment, and monitoring systems within the approved safety and compliance requirements until the facilities are made available for clean-up. 


\section{Operations Phase}

Past 327 Facility operations activities have supported examination and testing of irradiated materials, particulariy metals, including rupture analysis of fuel elements for the Hanford production reactors along with various U.S. Department of Energy (DOE) test reactors. Currently, operations supports fuel analysis for severai DOE and foreign progects, including the Haniord Site Spent Nuclear Fuel Project. These activities make use of the facility office and laboratory space provided for scientific and engineering staff. The stabilization objective is to curtail these operations to enable facility deactivation work tasks to begin.

\section{B.8.1.3.2.3.5 Remove Material from 327 Building}

Remove the nuclear materials from the 3247 Building for treatment or disposition.

\section{B.8.1.3.2.3.6 Transition 327 Building}

Initiate the transition phase of decontamination and decommissioning for the 327 Building

This phase is characterized by activities associated with removing of legacy wastes, residual contamination, facility systems and/or areas from operational service with the intent of being ready for facility stabilization to transition the facility to final decommissioning. The objective of deactivation is to expeditiously reduce the hazards, risks, and costs (i.e., the mortgage) associated with a surplus facility until final disposition can be achieved.

In addition, this phase is characterized by activities necessary to place the 327 facility in a safe, stable, and environmentally sound condition, suitable for an extended period of surveillance and maintenance pending final disposition. Facility stabilization starts with termination of operations, includes the establishment of a S\&M program, and ends with the achievement of facility-specific goals, objectives, and end points (see Section 2.8.1).

\section{B.8.1.3.2.4 327 Building Boundary Diagram}

Table B.8-4 327 Building Boundary Diagram

\begin{tabular}{|l|l|}
\hline $\begin{array}{l}\text { Extemal Intertacss } \\
\text {-None- } \\
\text { Hanford Site Environmental System Interlaces } \\
\text {-None- }\end{array}$ & $\begin{array}{l}\text { External Interiaces } \\
\text {-None- } \\
\text { Hanford Site Environmental System Intertaces } \\
\text { hsems.2.2.8 Waste Encapsulation and Storage Facility } \\
\text { hsems.2.3.2 Double Shell Tank (DST) Systern } \\
\text { hsems.2.3.5 Central Waste Complex } \\
\text { hsems.4.2.2 307 Retentien Basins }\end{array}$ \\
\hline
\end{tabular}


B.8.1.3.2.5 327 Building Interface Description and Forecast

EXTERNAL INPUTS

-None-

INTERNAL INPUTS

-None-

EXTERNAL OUTPUTS

-None-

INTERNAL OUTPUTS

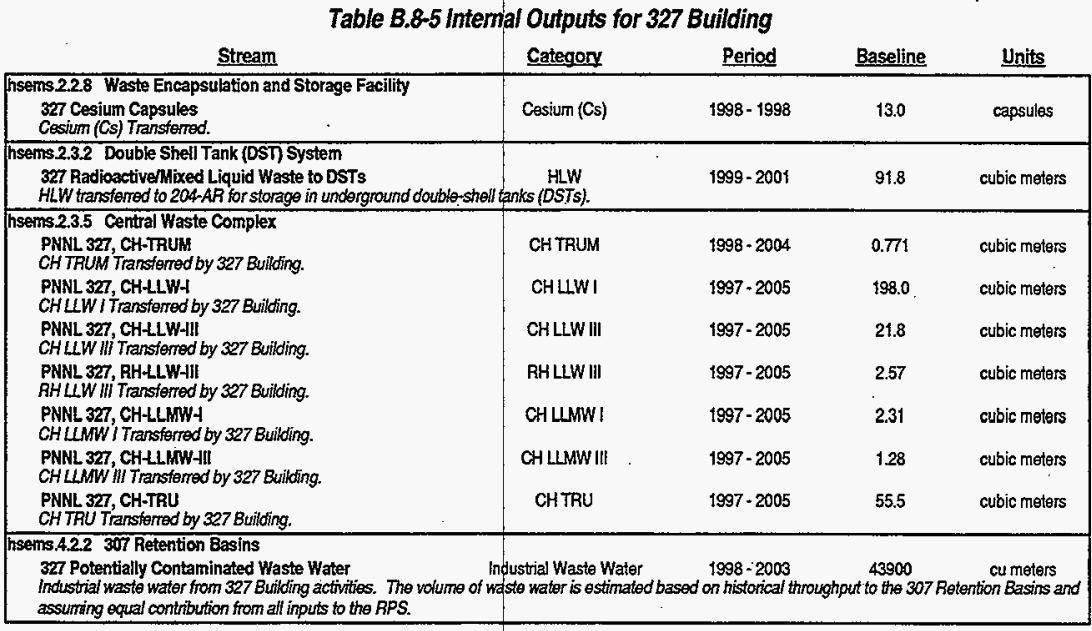




\section{B.8.1.4 Drivers for 324/327 Facility Transition Project}

Table B.8-6 Source Documents for 324/327 Facility Transition Project

\begin{tabular}{ll}
\multicolumn{1}{c}{ Name } & NEPA Implementing Procedures \\
10 CFR 1021 & National Historic Preservation Act as amended \\
36 CFR 800 & Resource Conservation and Recovery Act of 1976 (RCRA) \\
42 USC 6901, et seq. & 324 Building End Point Specification Document \\
BWHC-SD-WM-TPP-TBD & 327 Building End Point Specification Document \\
BWHC-SD-WM-TPP-TBD1 & Project Hanford Management Contract, Fluor Daniel Hanford, Inc. \\
DE-AC06-96RL13200 & Draft Hanford Remedial Action Environmental Impact Statement and \\
DOE/EIS-0222D & Comprehensive Land Use Plan \\
DOE/RL-89-10 & Hanford Federal Facility Agreement and Consent Order (Tri-Party Agreement), \\
& Rev.4 \\
DOE/RL-96-14 & Updated Draft Mission Direction Document, June 1996 \\
DOE/RL-96-73 & The 324 Radiological Engineering Cells and High - Level Vault Closure Plan \\
DOE/RL-96-92 & Hanford Strategic Plan \\
HNF-IP-1289 & $324 / 327$ Deactivation Project, Draft Project Management Plan \\
PL 92-500 & Federal Water Pollution Control Act Amendments of 1972 (Clean Water Act) \\
RCW 70.94 & Washington Clean Air Act
\end{tabular}

\section{B.8.1.5 324/327 Facility Transition Project Risk Management}

This section outlines a methodology which will be used to qualitatively/subjectively assess and manage project risk. The 324 and 327 Facilities contain significant inventories of high dose rate material. This combined with the close proximity to the Columbia River, public schools, and a residential zone will require risk management and mitigation throughout the life of the facilities. In the context of this section, project risk means risk to one of the project baselines (technical, cost or schedule) and should not be confused with health and safety risks. However, health and safety issues are considered to the extent that they impact the risk to the project baselines.

Risk assessments, as described in section 12.0 of the $324 / 327$ Project Management Plan, HNF-IP-1289, Rev 0, will typically be performed by an assessment team comprised of project managers, tecinical staff, operatingffield staff, customers (RL, DOE-HQ and FOH) and selected stakeholders as appropriate based upon the project element and its position in the baseline hierarchy (i.e., project level, sub-project level or task/activity level). A team leader will be assigned or selected to schedule, lead and document the results of the risk assessment session. The results of all project risk assessments will be maintained in an appendix to this PMP. An initial assessment will be performed at the project level with follow-on assessments performed at other levels of the project baseline hierarchy based on the results of the initial assessment. Assessments will then be performed throughout the life of the project. Typically risk assessments will be performed to support the change request process, when baseline adjustments are necessary or to support the decision process for selection and implementation of technical alternatives.

Athough a formal assessment of project risk has not been completed at this point in the project, the items listed below are considered to represent the high risk areas based on the judgement of project personnel. This section will be updated to reflect the high risk areas based upon the results of the risk assessment process prior to final issuance of this PMP document.

The following represents a preliminary list of assumptions/issues that could impact the overall implementation, cost, and schedule of the sub-project. A thorough analysis of project risk that will be managed will be conducted during completion of the final PMP and end point process. 
CsCl Legacy Safety/Cleanout Sub-project

- The baseline assumes that existing casks can be obtained for overpacking and interim storage.

- The special form container, for the packaging of the cesium powder and pellets, for interim storage has not been designed.

Legacy Fuel Removal (327)

- The project uses process knowledge to determine the percentage of existing waste containers that will meet the Contact-Handled LLW and remote handled transuranio waste classifications. RH TRU is considerably more expensive for handling and packaging.

- Projects assumes same packaging and storage pathway for the metallurgical mounts as the fuel pin tubes processed in FY 97.

B-Cell (324)

- B Cell Clean out. The Clean out of $B$ cell is considered high risk due to the high radiation levels and regulatory issues.

Special Case Waste Pad

- Currently a study is underway to determine the interim disposition location for the 300 Area SCW. This project describes one viable option.

- The design, construction, and permitting for the FRG Log Pad which was used as a basis for this project has not been approved for use as a permitted (MW) pad.

- The transport casks in the baseline have not been approved for use as a MW storage container.

324/327 Minimum Safe Status

- Implementation of compliance upgrades (Conduct of Operations, Radiological Control and S/RIDs) has been ongoing with full implementation schedule for November 1, 1998. The Facility Evaluation Board (FEB) may conclude that this implementation strategy is inadequate.

324 Radioactive Liquid Waste system

- This project includes the refurbishment of the liquid waste filtration/treatment system that was used to treat the decontamination fluids used in the cleanout of the HLV tanks. Different system configuration and treatment trains may be required to treat the deactivation fluids.

- This project assumes the use of the LLV tanks for storage prior to loadout and shipment.

- Minimal piping upgrades will be required in 324 and none are planned for 327.

324/327 Deactivation

- A conceptual plan has been developed for the deactivation of the facilities based on known contamination levels. Additional engineering and trade studies will be required to increase reliability of estimate. 


\section{4/327 Facility Transition Work Breakdown Structure}

\begin{tabular}{|c|c|c|c|c|c|c|c|}
\hline & & & $324 / 327 \mathrm{Fac}$ & \begin{tabular}{r|} 
Transition \\
1.4 .10 .1 \\
\end{tabular} & & & \\
\hline \begin{tabular}{|c|}
324 Minimum Safo \\
Project \\
1.4.10.1.1
\end{tabular} & \begin{tabular}{|c|c|}
324 & B Cell Cleanoutt \\
& Project \\
& 1.4.10.1.2
\end{tabular} & \begin{tabular}{|c|}
324 Ceslum Legacy \\
Cleanout Prolect \\
1.4.10.1.3
\end{tabular} & \begin{tabular}{|c|}
324 PNNLL Legacy \\
Waste \\
$\mathbf{1 . 4 . 1 0 . 1 . 4}$
\end{tabular} & $\begin{array}{c}24 \text { Deactivation } \\
\text { Projoct } \\
1.4 .10 .1 .5\end{array}$ & \begin{tabular}{|c|}
324 Minimum Safo \\
Prolect \\
1.4.10.1.8
\end{tabular} & \begin{tabular}{|c|}
327 Legacy Fuel \\
Removal Projoct \\
1.4.10.1.7
\end{tabular} & $\begin{array}{c}327 \text { Deactivation } \\
\text { Prolect } \\
\text { 1.4.10.1.8 }\end{array}$ \\
\hline
\end{tabular}


HANFORD SITE WORK BREAKDOWN STRUCTURE DICTIONARY FACILITY STABILIZATION

WBS: 1.4

$8 / 28 / 1997$

\begin{tabular}{|l|c||l|l|}
\hline $\begin{array}{l}\text { 1. Activity Tit7e: } \\
324 \text { MINIMUM SAFE PROJECT }\end{array}$ & $\begin{array}{l}\text { 2. Date } \\
7 / 31 / 1997\end{array}$ & $\begin{array}{l}\text { 3. PBS Number } \\
\text { RL-TP08 }\end{array}$ & $\begin{array}{l}\text { 4. Dict Rev } \\
0\end{array}$ \\
\hline
\end{tabular}

\begin{tabular}{|l|l|l}
\hline $\begin{array}{l}\text { 5. Contract WBS No. } \\
1.4 .10 .1 .1\end{array}$ & $\begin{array}{l}\text { Corresponding FDS No. } \\
\text { K4A, K4M, K4S }\end{array}$ & 7. Baseline CR No. \\
\hline
\end{tabular}

8. Organization Name 19000

10. Scope of Work

Minimum safe activities protect the public, workers and environment from exposure posed by loss of containment and control over nuclear material and industrial hazards associated with these facilities. Minimum safe activities will be conducted over the life of the facility, decreasing in scope as risks are removed/reduced within the facilities. This is comprised of the facility surveillance and maintenance required to maintain facility systems and structures. This activity includes required preventative maintenance and calibrations; repair of failed and malfunctioning equipment; walkdown of safety systems, equipment, and facility grounds (operational surveillances); routine radiological surveys, source checks, and dosimetry; facility utilities and assessments; and waste management assessments. This also includes Management and Assessment activities including the project direction, management and controls, and environmental, quality and safety oversight for the minimum safe condition (sub-deactivation project specific oversight is included in the sub-project). This also includes OSHA, Resource Conservation and Recovery Act (RCRA) and DOE mandated training. Facility orientation, facility specific building emergency, and response training is covered in this activity. This activity also provides safe, secure and compliant storage of nuclear materials until final disposition of the material is accomplished. Contains physical security, safeguards accounting and material control, record keeping, studies, evaluations and assessments. 
HANFORD SITE WORK BREAKDOWN STRUCTURE DICTIONARY

FACILITY STABILIZATION

WBS: 1.4

$8 / 28 / 1997$

\begin{tabular}{|l||l|l|l|}
\hline $\begin{array}{l}\text { 1. Activity Title: } \\
\text { 324 B CELL CLEANOUT PROJECT }\end{array}$ & $\begin{array}{l}\text { 2. Date } \\
7 / 31 / 1997\end{array}$ & $\begin{array}{l}\text { 3. PBS Number } \\
\text { RL-TP08 }\end{array}$ & $\begin{array}{l}\text { 4. Dict Rev } \\
0\end{array}$ \\
\hline
\end{tabular}

5. Contract WBS No. 1.4.10.1.2

6. Corresponding FDS No. 7. Base]ine CR No. K4B

8. Organization Name

19000

10. Scope of Work

The B-Cel1 Cleanout Project (BCCP) is a muiti-year effort to eliminate legacy equipment and disposable nuclear material from the B-Cell in the 324 Facility. The BCCP is the most significant deactivation activity currently being conducted in 324 and is required to meet TPA milestone M-89-02, 'Complete removal of 324 Facility REC B-Ce11 Mixed Waste (MW) and Equipment, ' TPA Milestone by May 31, 1999. B-Cell was designed to handle high activity radioactive wastes and materials in a research setting, with remote handling capabilities, and with appropriate shielding under unique space considerations. During 25 years of Research and Development (R\&D) activities, B-Cell has accumulated a significant volume of radioactive and radioactive Mh which contains over 2.5 million curies, of which 1.5 million is in a potentially dispersible form.

The current baseline requires the removal of heavily contaminated process racks (1A Rack, 2A Rack, IB Rack) via several destructive techniques including, plasma arc torches, abrasive cutting blades, reciprocal saws, and cutting shears. Size reduced equipment is then placed in liners that are grouted prior to shipment to the Centrat Waste Complex as Category III low level waste (LLW). Beneath these racks is over 1.5 million curies of dispersible radioactive material. These Dispersibles will be packaged pending disposition at a to-be-named location (current baseline is the MW storage pad at the Central Waste Complex in the 200 Area of the Hanford Site). In addition 7 fuel assemblies will be packaged and shipped to the 200 Area Interim Storage Pad for storage. Remaining fuel pieces will be packaged and managed as RH-TRU for interim storage at the central waste RHTRU storage pad.

Upon final cleanout of the legacy materiats, equipment and decontamination (to meet TPA Milestone M-89-02) a final cell cleanout effort will be undertaken potentially including removal of the cell liner to meet the overall project objective of obtaining radiological facility status. 
HANFORD SITE WORK BREAKDOWN STRUCTURE DICTIONARY

FACILITY STABILIZATION

WBS: 1.4

$8 / 28 / 1997$

\begin{tabular}{|l|l|l|l|l|}
\hline $\begin{array}{l}\text { I. Activity TitTe: } \\
324 \text { CESIUM LEGACY CLEANOUT PROJECT }\end{array}$ & $\begin{array}{l}\text { Date } \\
7 / 31 / 1997\end{array}$ & $\begin{array}{l}\text { 3. PBS Number } \\
\text { RL-TP08 }\end{array}$ & $\begin{array}{l}\text { 4. Dict Rev } \\
0\end{array}$ \\
\hline
\end{tabular}

5. Contract WBS No. 6. Corresponding FDS No. 7. Baseline CR No. 1.4.10.1.3

8. Organization Name 19000

10. Scope of Work

The CSCT project is a multi-year risk mitigation/deactivation project. The objective of this project is to assure safe, secure storage of Cs-137 in the 324/327 Facilities prior to permanent storage and/or disposal. In addition, this project will take the steps necessary to prepare the CsCl for removal from the 300 Area. This activity provides disposition of capsules, pellets, and powder that were generated by several DOE programs dealing with $\mathrm{CsCl}$. Originally, approximately 1.5 million curies of $\mathrm{Cs}-137$ existed in the 300 Area inventory. Additional work also includes the decontamination of the 324 Facility South Cell to allow manned entry to replace filters and perform preventative maintenance on the crane, the disposition of the powder and pellets, and the final decontamination and cleanout of the South Cell.

The powder and pellets (resulting form earlier failed capsules) and the Nordion Capsule (CsCl) will be packaged in special form containers and transferred in transfer/interim storage casks to a to-be-named location (current baseline is the MW storage pad at the Central Waste Complex in the 200 Area of the Hanford Site). 
HANFORD SITE WORK BREAKDOWN STRUCTURE DICTIONARY FACILITY STABILIZATION

WBS: 1.4

\begin{tabular}{|c|c|c|c|}
\hline $\begin{array}{l}\text { 1. Activity Title: } \\
\text { 324 PNNL LEGACY WASTE }\end{array}$ & \begin{tabular}{|l|} 
2. Date \\
$7 / 31 / 1997$
\end{tabular} & 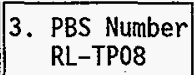 & 4. Dict Rev \\
\hline
\end{tabular}

5. Contract WBS No. 6. Corresponding FDS No, 7, Baseline CR No. 1.4 .10 .1 .4 K4P

8. Organization Name 19000

10. Scope of Work

This activity contains three sub-projects required to remove and/or handle (treat and dispose) of legacy wastes currently existing in the 324/327 facilities and liquid wastes to be generated during deactivation.

These projects include completing verification and repackaging of noncomp $7 i$ ant waste containers transferred from PNNL with the facilities, design and construction of a waste storage pad for the B-Cell Dispersible wastes and remaining 300 Area Cesium inventory, and refurbishment of the radioactive liquid waste filtration system.

The project for the PNNL legacy waste includes the transportation, verification (examination and assay) and repackaging of the remaining waste containers inherited in the transfer of facilities from the PNNL to the Project Hanford Management Contract (PHMC). PNNL has been cited by the Hanford Solid Waste organization for poor management practices due to the existence of prohibited articles in their LLW stream. The presence of these articles required these containers to be managed as suspect low level mixed waste ( LLMW). These containers require $100 \%$ verification (examination) and a high percentage will require waste segregation and repackaging.

The project for the Special Case Waste Pad will design, construct, and permit a solid waste storage pad for the receipt and interim storage of the 324 SCW (i.e., B-Cel1 Dispersibles, CSCl powder and pellets, Nordion Capsule). This pad assumes similar design and construction requirements as was used for the Fiscal Year 1997 FRG Log Pad.

The 324 radioactive liquid waste filtration system previously used for the treatment of liquid waste from the vault sample cleanout activities will be refurbished. It will be used for decontamination fluid processing and will include minor piping reconfiguration to allow for collection, processing and loadout of these fluids generated during deactivation. 
HANFORD SITE WORK BREAKDOWN STRUCTURE DICTIONARY

FACILITY STABILIZATION

WBS: 1.4

$8 / 28 / 1997$

\begin{tabular}{||l|l|l|l|l|}
\hline $\begin{array}{l}\text { 1. Activity Title: } \\
\text { 324 DEACTIVATION PROJECT }\end{array}$ & $\begin{array}{l}\text { 2. Date } \\
7 / 31 / 1997\end{array}$ & $\begin{array}{l}\text { 3. PBS Number } \\
\text { RL-TP08 }\end{array}$ & $\begin{array}{l}\text { 4. Dict Rev } \\
0\end{array}$ \\
\hline \hline
\end{tabular}

\begin{tabular}{|l||l||l|l|l}
\hline $\begin{array}{l}\text { 5. Contract WBS No. } \\
1.4 .10 .1 .5\end{array}$ & $\begin{array}{l}\text { 6. Corresponding FDS No. } \\
\text { K4Z }\end{array}$ & 7. Baseline CR No. \\
\hline
\end{tabular}

8. Organization Name 19000

9. $B \& R$ No.

10. Scope of Work

The 324 deactivation project will remove significant hazards and risks associated with the 324 facility and will greatly reduce the costs of surveillance and maintenance. Activities will include the removal of a11 residue chemical hazards, decontamination or stabilization of radiological areas, isolation of equipment and litilities, and removal of combustible material and wastes.

Key technical objectives for deactivation will include establishing facility configuration such that active systems are not required for safety and environmental confinement. Deactivation will be performed in a way that will result in a redesignation of the 324 facility as a radiological facility in accordance with the criteria and guidel ines provided in DOESTD-1027, Hazard Categorization and Accident Analys is Techniques for Compliance with DOE Order 5480.23, Nuclear Safety AnaTysis Reports. Another objective will be closure activities associated with the radiochemical engineering cells (REC) and high level vault (HLV) to meet current Tri-Party Agreement (TPA) commitments.

Applied lessons learned from commercial and other deactivation projects (i.e., Plutonium-Uranium Extraction Facility (PUREX) and B Plant), involvement of regulators and stakeholders, and innovative and costeffective methods used in a graded approach will be used to meet environmental, safety, and health requirements to reduce overal1 deactivation costs.

Upon completion of the deactivation project it is anticipated that 324 facility will be in a position for long term low-cost Surveillance and Maintenance. 
HANFORD SITE WORK BREAKDOWN STRUCTURE DICTIONARY

FACILITY STABILIZATION

WBS: 1.4

$8 / 28 / 1997$

\begin{tabular}{|l||l||l||l|}
\hline $\begin{array}{l}\text { 1. Activity Tit]e: } \\
\text { 327 MINIMUM SAFE PROJECT }\end{array}$ & $\begin{array}{l}\text { 2. Date } \\
7 / 31 / 1997\end{array}$ & $\begin{array}{l}\text { 3. PBS Number } \\
\text { RL-TP08 }\end{array}$ & $\begin{array}{l}\text { 4. Dict Rev } \\
0\end{array}$ \\
\hline $\begin{array}{l}\text { 5. Contract WBS No. } \\
\text { 1.4.10.1.6 }\end{array}$ & $\begin{array}{l}\text { 6. Corresponding FDS No. } \\
\text { K7A, K7M, K7S }\end{array}$ & 7. Baseline CR No. \\
\hline $\begin{array}{l}\text { 8. Organization Name } \\
19000\end{array}$ & 9. B \& R No. \\
\hline
\end{tabular}

10. Scope of Work

Minimum safe activities protect the public, workers and environment from exposure posed by loss of containment and control over nuclear material and industrial hazards associated with these facilities. Minimum safe activities will be conducted over the life of the facility, decreasing in scope as risks are removed/reduced within the facilities. This is comprised of the facility surveillance and maintenance required to maintain facility systems and structures. This activity includes required preventative maintenance and calibrations; repair of failed and malfunctioning equipment; walkdown of safety systems, equipment, and facility grounds (operational surveillances); routine radiological surveys, source checks, and dosimetry; facility utilities and assessments; and waste management assessments. This also includes Management and Assessment activities including the project direction, management and controls, and environmental, quality and safety oversight for the minimum safe condition (sub-deactivation project specific oversight is included in the sub-project). This also includes OSHA, Resource Conservation and Recovery Act (RCRA) and DOE mandated training. Facility orientation, facility specific building emergency, and response training is covered in this activity. This activity also provides safe, secure and compliant storage of nuclear materials until final disposition of the material is accomplished. Contains physical security, safeguards accounting and material control, record keeping, studies, evaluations and assessments. 
HANFORD SITE WORK BREAKDOWN STRUCTURE DICTIONARY

FACILITY STABILIZATION

WBS: 1.4

$8 / 28 / 1997$

\begin{tabular}{|c|c|c|c|}
\hline $\begin{array}{l}\text { 1. Activity Tit\}e: } \\
\text { 327 LEGACY FUEL REMOVAL PROJECT }\end{array}$ & $\mid \begin{array}{l}\text { 2. Date } \\
7 / 31 / 1997\end{array}$ & $\begin{array}{l}\text { 3. PBS Number } \\
\text { RL-TP08 }\end{array}$ & 4. Dict Rev \\
\hline
\end{tabular}

5. Contract WBS No. 1.4.10.1.7

6. Corresponding FDS No. 7. Baseline CR No. K7F

8. Organization Name 19000

10. Scope of Work

The legacy fuel removal project is a multi-year legacy waste cleanout project. The fuel examination mission at 327 Facility has resulted in the accumulation of a significant quantity of radioactive material/waste within the facility. This project includes consolidation and disposal of legacy fuel and materials currently located at the facility. The project will package fuel, fuel segments and pins, and related material; characterize the existing and resultant waste material; and prepare the containers for transport to the 200 area Central Waste Complex. The 327 Facility is continuing programmatic fuels examination work for Spent Nuclear Fue 1 and fuels examination for other entities as approved by DOE. Spent Nuclear Fuel Project will remove all $\mathrm{N}$-Reactor fuel and associated equipment/waste.

This project will be conducted in two phases. Phase one includes remova1, consolidation, packaging, and preparation of the legacy experimental fuel stored dry storage cells primarily in metallurgical mounts and prepared for shipping to the 200 Area Central Waste Complex. Phase two includes removal, packaging, and preparation of the RH-TRU waste buckets located in the facility for shipping to the 200 Area Central Waste Complex. 
HANFORD SITE WORK BREAKDOWN STRUCTURE DICTIONARY FACILITY STABILIZATION

WBS: 1.4

\begin{tabular}{|l||l|l|l}
\hline $\begin{array}{l}\text { 1. Activity Title: } \\
327 \text { DEACTIVATION PROJECT }\end{array}$ & $\begin{array}{l}\text { 2. Date } \\
7 / 31 / 1997\end{array}$ & $\begin{array}{l}\text { 3. PBS Number } \\
\text { RL-TP08 }\end{array}$ & $\begin{array}{l}4 . \text { Dict Rev } \\
0\end{array}$ \\
\hline
\end{tabular}

5. Contract WBS No. 6. Corresponding FDS No. 7. Baseline CR No. 1.4 .10 .1 .8 $\mathrm{K} 7 \mathrm{Z}$

8. Organization Name 19000

10. Scope of Work

The 327 deactivation project will remove all hazards and risks associated with the 327 facility that will greatly reduce the costs of surveillance and maintenance. Activities will include the removal of all residue chemical hazards, decontamination or stabilization of radiological areas, isolation of equipment and utilities, and combustible and waste removal.

Key technical objectives for deactivation will include establishing facility configuration such that active systems are not required for safety and environmental confinement. Deactivation will be performed in a way that will result in a redesignation of the 327 facility as a radiological facility in accordance with the criteria and guidelines provided in DOESTD-1027, Hazard Categorization and Accident Analysis Techniques for Compliance with DOE Order 5480.23, Nuclear Safety Analys is Reports.

Applied lessons learned from commercial and other deactivation projects (i.e., Plutonium-Uranium Extraction Facility (PUREX) and B Plant), involvement of regulators and stakeholders, and innovative and costeffective methods used in a graded approach will be used to meet environmental, safety, and health requirements to reduce overall deactivation costs.

Upon completion of the deactivation project it is anticipated that 324 facility will be in a position for long term low-cost Surveillance and Maintenance. 


\begin{tabular}{|c|c|c|c|c|}
\hline MILESTONE & TPA-MS & TPA & MS & \\
\hline CONTROL \# & NUMBER & TYPE & LEVEL & MS TITLE \\
\hline TRP-98-901 & & & $\mathrm{RL}$ & SUBMIT FINAL PMP/END-POINTS \\
\hline TRP-98-902 & & & RL & COMPLETE REPACKAGING OF CESIUM POWDER AND PELLETS IN 324 \\
\hline TRP-98-903 & $M-92-04$ & & RL & SHIPMENT OF ALL CS/SR/TO APPROVED STORAGE LOCATION \\
\hline TRP-99-901 & $M-89-02$ & I & FO & REMOVE B-CELL EQUIPMENT AND $100 \%$ OISPERSIBLES \\
\hline TRP-98-904 & $M-89-05$ & & $\mathrm{RL}$ & 324 SPECIAL CASE WASTE ASSESSMENT \\
\hline
\end{tabular}

\begin{tabular}{|c|c|c|c|c|c|}
\hline & PLANNED & APPROVED & REVISED & & \\
\hline TYPE & BASELINE & BASELINE & BASELINE & PROJ CIN & PBS \# \\
\hline \multirow[t]{4}{*}{$\cdots$} & 2108108 & ......... & - & - & - \\
\hline & $2 / 28 / 98$ & & & & RL-TP08 \\
\hline & $9 / 28 / 98$ & & & & RL-TP08 \\
\hline & $12 / 30 / 98$ & & & & RL-TP08 \\
\hline \multirow[t]{2}{*}{ EA } & $5 / 30 / 99$ & & & & RL-TP08 \\
\hline & $6 / 30 / 98$ & & & & RL-TP08 \\
\hline
\end{tabular}




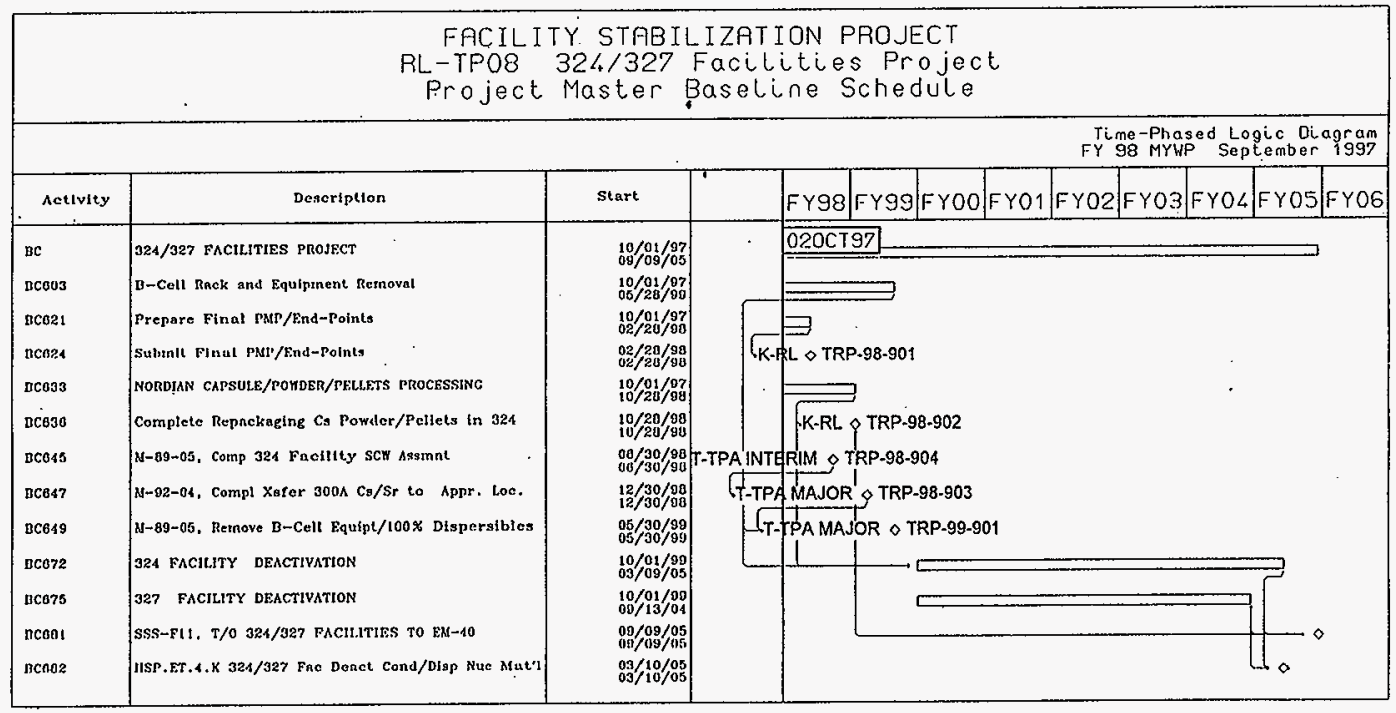




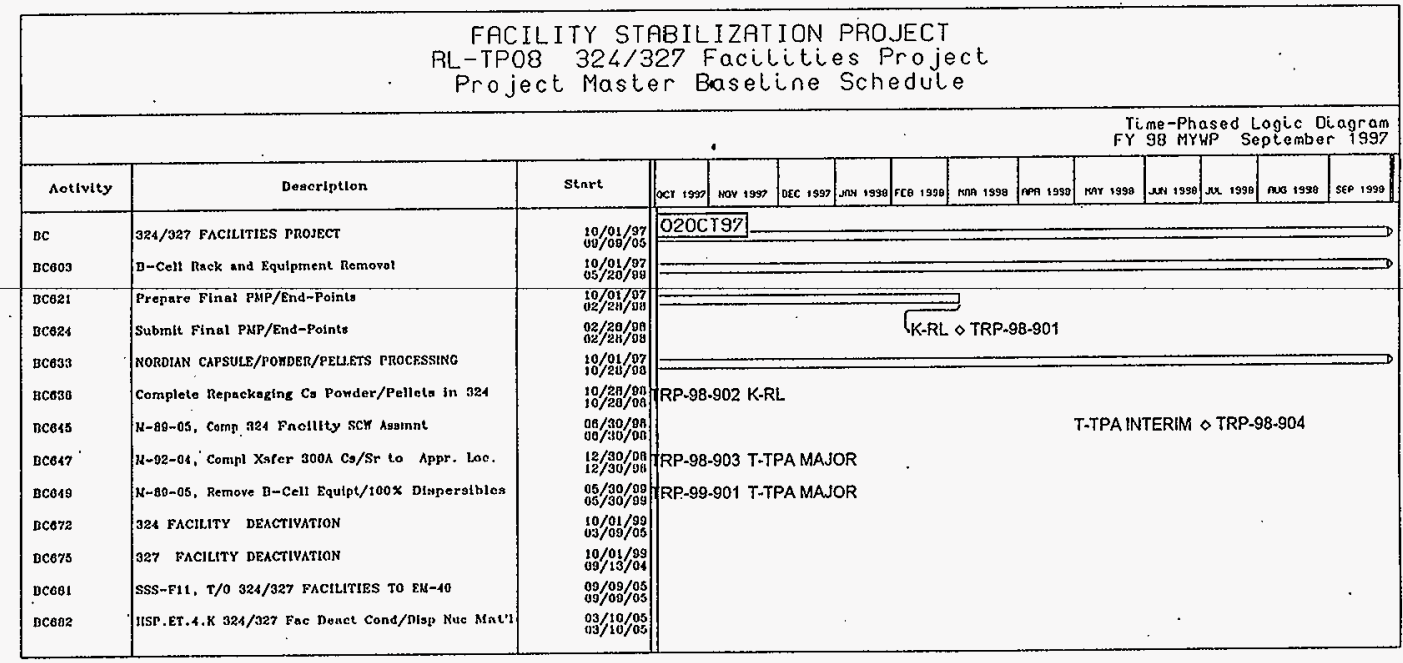




MS
SUBMIT FINAL, PMP/END-POINTS

RL COMPLETE REPACKAGING OF CESIUM PONDER AND PELLETS IN 324

RL SHIPMENT OF ALL CS/SR/TO APPROVED STORAGE LOCATION

RL REMOVE B-CELL EQUIPMENT AND 100\% DISPERSIBLES

RL 324 SPECIAL CASE WASTE ASSESSMENT

$\begin{array}{lll}\text { PLANNED } & \text { APPROVED } & \text { REVISED } \\ \text { BASELINE } & \text { BASELINE } & \text { BASELINE }\end{array}$

TYPE BASELINE

$2 / 28 / 98$

$9 / 28 / 98$

$12 / 30 / 98$

$5 / 30 / 99$

$6 / 30 / 98$
PBS \#

RL-TP08

RL-TP08

RL-TP08

RL-TP08

RL-TP08 


\section{PHMC}

MILESTONE DESCRIPTION SHEET

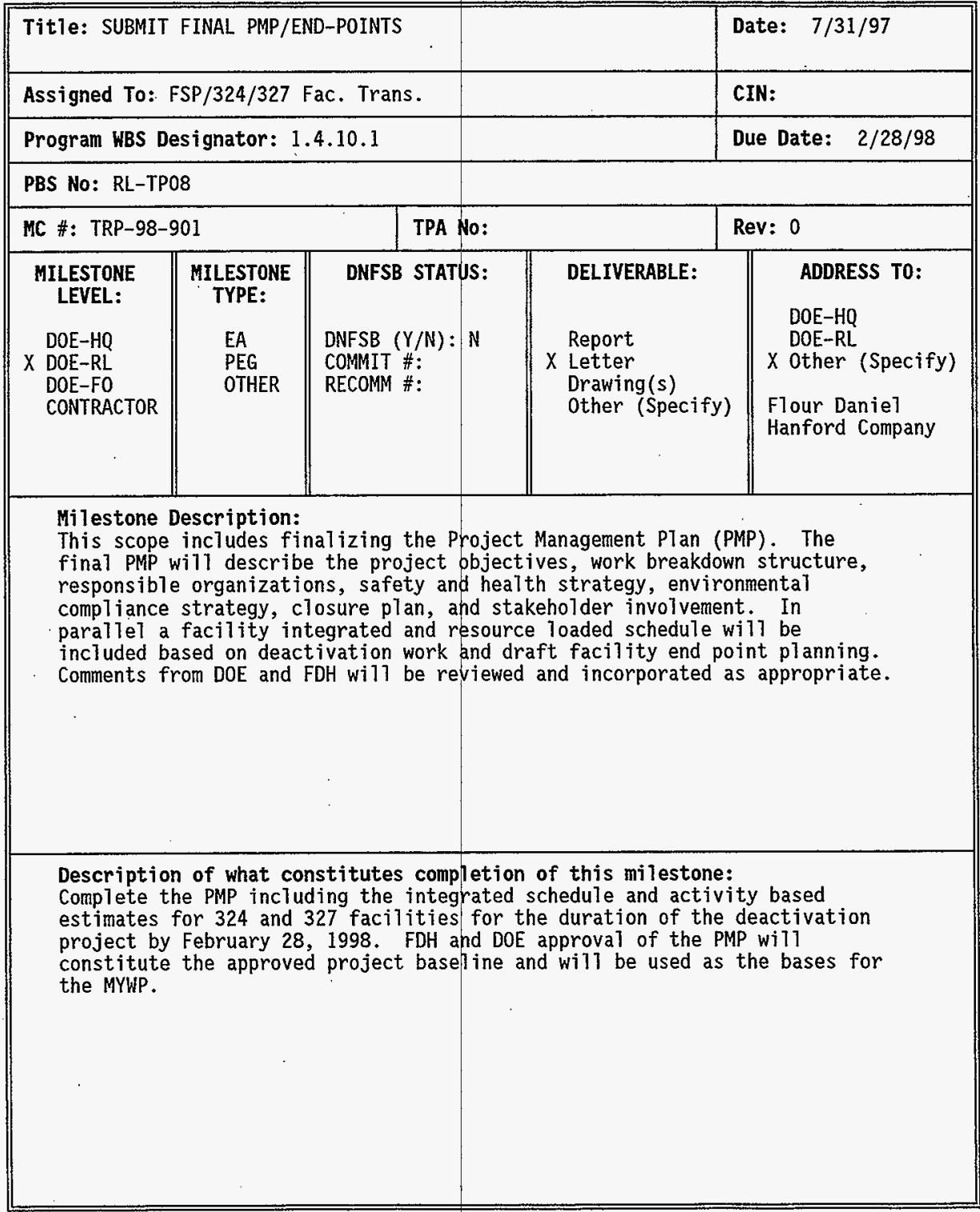




\section{PHMC \\ MILESTONE DESCRIPTION SHEET}

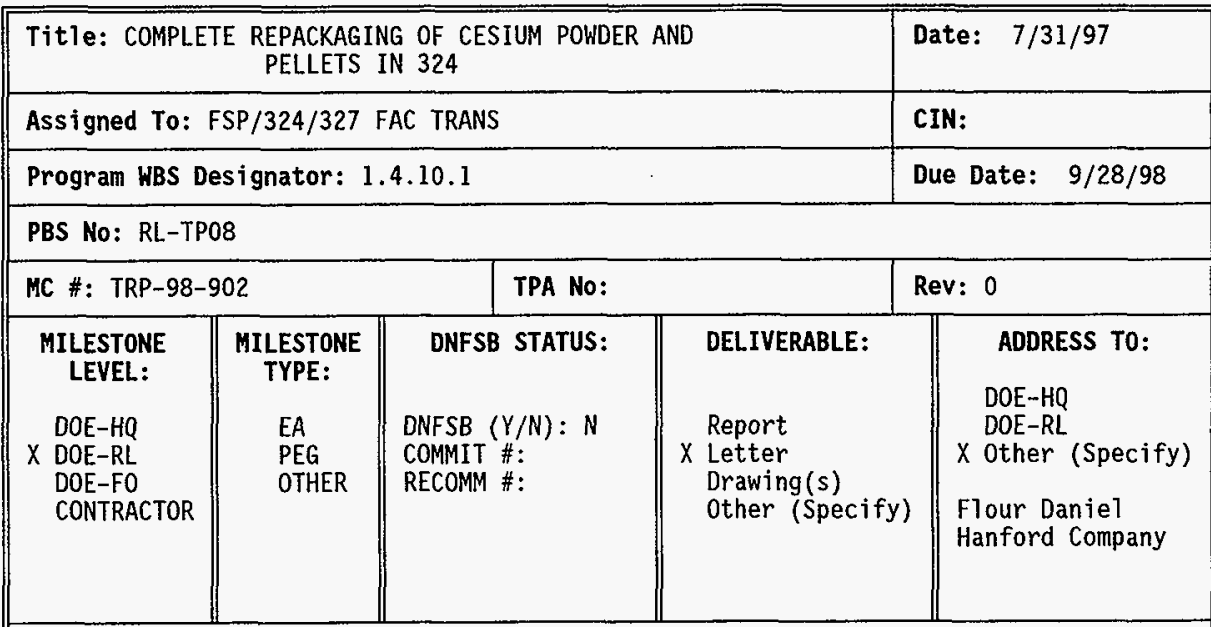

Milestone Description:

CsCl powder, pellets, and capsules are currently stored in the 324 shielded material facilities. The powder and pellets (resulting from earlier failed capsules) and the Nordian Capsule (CsCl) will be packaged in special form containers and transferred in transfer/interim storage casks to a to-benamed location (current baseline is the MW storage pad at the Central Waste Complex in the 200 Area of the Hanford Site).

Description of what constitutes completion of this milestone:

Complete design and procurement of the packaging system and be prepared to start packaging of the powder and pellets in special containers for shipment to storage by September 29, 1998. 


\section{PHMC \\ MILESTONE DESCRIPTION SHEET}

\begin{tabular}{|c|c|c|c|c|}
\hline \multicolumn{4}{|c|}{$\begin{array}{l}\text { Title: SHIPMENT OF ALL CS/SR/TO APPROVED STORAGE } \\
\text { LOCATION }\end{array}$} & Date: $7 / 31 / 97$ \\
\hline \multicolumn{4}{|c|}{ Assigned To: FSP $/ 324 / 327$ FAC TRANS } & CIN: \\
\hline \multicolumn{4}{|c|}{ Program WBS Designator: 1.4 .10 .1} & Due Date: $12 / 30 / 98$ \\
\hline \multicolumn{5}{|c|}{ PBS No: RL-TP08 } \\
\hline \multicolumn{3}{|c|}{ MC \#: TRP-98-903. } & TPA No: M-92-04 & Rev: 0 \\
\hline $\begin{array}{l}\text { MILESTONE } \\
\text { LEVEL: } \\
\\
\text { DOE-HQ } \\
\text { X DOE-RL } \\
\text { DOE-FO } \\
\text { CONTRACTOR }\end{array}$ & $\begin{array}{l}\text { MILESTONE } \\
\text { TYPE: } \\
\text { EA } \\
\text { PEG } \\
\text { OTHER }\end{array}$ & $\begin{array}{l}\text { DNFSB STATU } \\
\text { DNFSB }(Y / N): \\
\text { COMMIT \#: } \\
\text { RECOMM \#: }\end{array}$ & $\begin{array}{l}\text { DELIVERABLE: } \\
\\
\text { Report } \\
\times \text { Letter } \\
\text { Drawing(s) } \\
\text { Other (Specify) }\end{array}$ & $\begin{array}{l}\text { ADDRESS TO: } \\
\text { DOE-HQ } \\
\times \text { DOE-RL } \\
\text { Other (Specify) }\end{array}$ \\
\hline \multicolumn{5}{|c|}{$\begin{array}{l}\text { Milestone Description: } \\
\text { CSCl powder, pellets, and capsules are currently stored in the } 324 \text { shielded } \\
\text { material facilities. The powder and pellets (resulting from earlier failed } \\
\text { capsules) and the Nordian Capsule (CSCT) will be packaged in special form } \\
\text { containers and transferred in transfer/interim storage casks to a to-be- } \\
\text { named location (current baseline is the MW storage pad at the Central Waste } \\
\text { Complex in the } 200 \text { Area of the Hanford Site). This milestone is to } \\
\text { complete the effort to remove CS/Sr material from the } 324 / 327 \text { Facilities to } \\
\text { an approved storage location. This will consist of packaging remaining } \\
\text { material into approved cask, decontamination and release from the SMF, and } \\
\text { shipment to the storage location. }\end{array}$} \\
\hline \multicolumn{5}{|c|}{$\begin{array}{l}\text { Description of what constitutes completion of this milestone: } \\
\text { Complete shipments for the removal of Cs/Sr material from the } 324 \text { and } 327 \\
\text { facility by December } 30,1998 \text {. }\end{array}$} \\
\hline
\end{tabular}




\section{PHMC}

\section{MILESTONE DESCRIPTION SHEET}

\begin{tabular}{|c|c|c|c|c|}
\hline \multicolumn{4}{|c|}{$\begin{array}{l}\text { Tit1e: REMOVE B-CELL EQUIPMENT AND } 100 \% \\
\text { DISPERSIBLES }\end{array}$} & Date: $7 / 31 / 97$ \\
\hline \multicolumn{4}{|c|}{ Assigned To: FSP/324/327 FAC TRANS } & CIN: \\
\hline \multicolumn{4}{|c|}{ Program WBS Designator: 1.4 .10 .1} & Due Date: $5 / 30 / 99$ \\
\hline \multicolumn{5}{|c|}{ PBS No: RL-TP08 } \\
\hline \multicolumn{2}{|c|}{ MC \#: TRP-99-901 } & \multicolumn{2}{|c|}{ TPA No: M-89-02 } & Rev: 0 \\
\hline $\begin{array}{l}\text { MILESTONE } \\
\text { LEVEL: } \\
\text { DOE-HQ } \\
\text { DOE-RL } \\
\text { X DOE-FO } \\
\text { CONTRACTOR }\end{array}$ & $\begin{array}{l}\text { MILESTONE } \\
\text { TYPE: } \\
\text { X EA } \\
\text { PEG } \\
\text { OTHER }\end{array}$ & $\begin{array}{l}\text { DNFSB STATUS: } \\
\text { DNFSB }(Y / N): \\
\text { COMMIT \#: } \\
\text { RECOMM \#: }\end{array}$ & $\begin{array}{l}\text { DELIVERABLE: } \\
\\
\text { Report } \\
\times \text { Letter } \\
\text { Drawing(s) } \\
\text { Other (Specify) }\end{array}$ & $\begin{array}{l}\text { ADDRESS TO: } \\
\text { DOE-HQ } \\
\times \text { DOE-RL } \\
\text { Other (Specify) }\end{array}$ \\
\hline
\end{tabular}

Mijestone Description:

The $\mathrm{B}-\mathrm{Ce} 11$ Cleanout sub-project (BCCP) is a multi-year effort to el iminate legacy equipment and potential dispersible nuclear material from the B-Cell in the 324 Facility. B-Cell was designed to handie high activity radioactive wastes and materials in a research setting, with remote handling capabilities, and with appropriate shielding under unique space considerations. Due to a process jumper failure in the mid eighties significant quantities of potential dispersible materials were spilled on the $\mathrm{B}-\mathrm{C}$ Tll liner. This material has accumulated under the large process racks within the cell. This milestone removes, size reduces, and disposes of the process racks and equipment (racks 1-A, 2-A, and 1-B) from B-Ce11 and collects the Dispersibles underneath the racks.

Tri-Party Agreement mi lestone M-89-02 was established for the removal of the $\mathrm{B}-\mathrm{Ce} 17$ dispersible waste and the associated process equipment. This

Description of what constitutes completion of this milestone:

Complete the removal of Equipment and $100 \%$ dispersible material located in B-Cell by $5 / 30 / 99$. 


\section{Milestone description: (con't $t$ )}

milestone will be to complete the removal of equipment located in B-Cell as well as packaging, and disposal of the material located within the cell. 


\section{PHMC \\ MILESTONE DESCRIPTION SHEET}

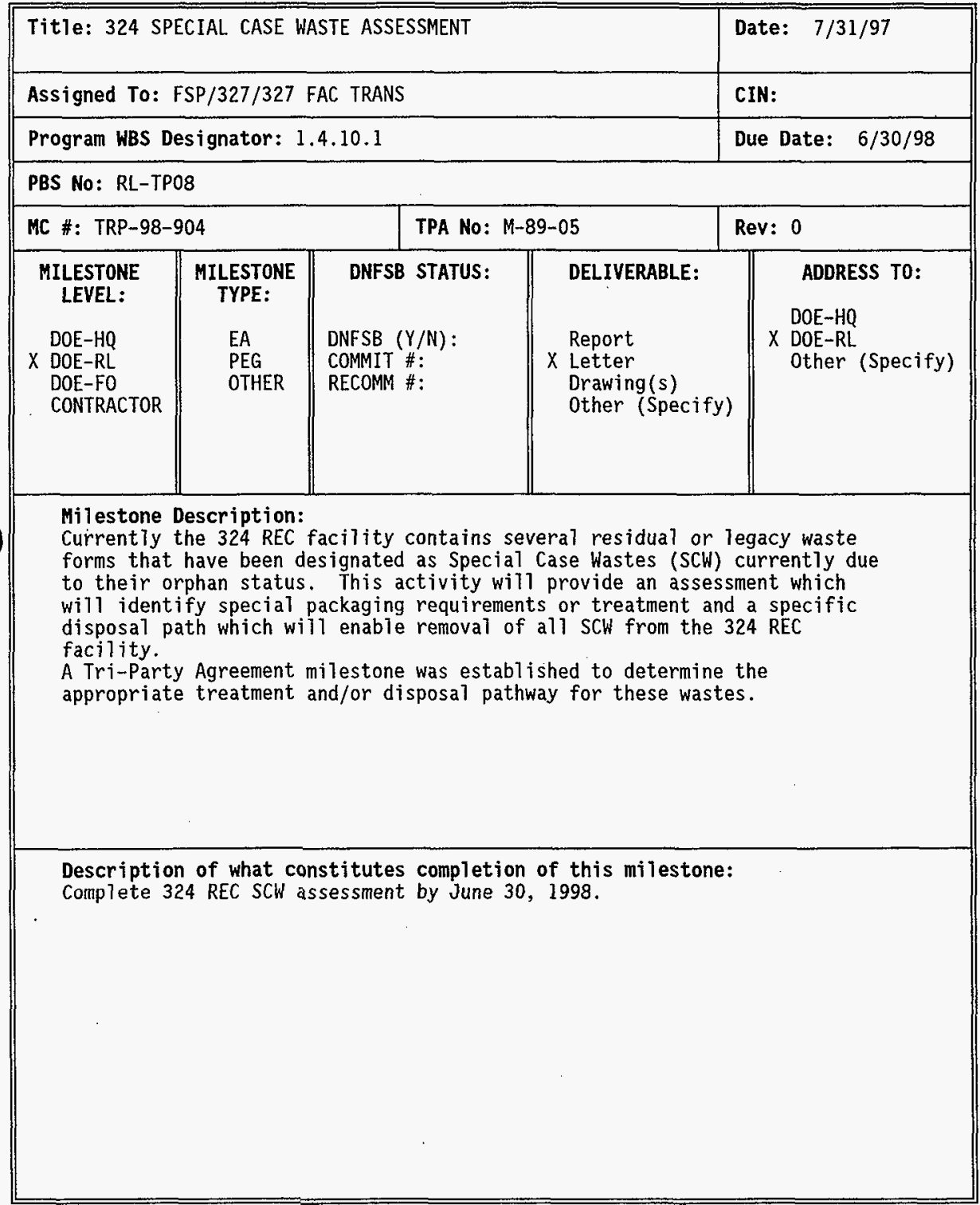




\section{FY 1998}

(\$000s)

\begin{tabular}{|c|c|c|c|c|c|c|c|c|c|c|c|}
\hline $\begin{array}{r}\text { PROJECT WBS: } \\
\text { PBS NO: } \\
\end{array}$ & $\frac{1.4 .10 .1}{R L-T P 08}$ & & & & & & & & & & \\
\hline PQS TITLE: & $324 / 327 \mathrm{Fac}$ & litity Trans & & & & & & & & & SUBTOT \\
\hline $\begin{array}{l}\text { FUND } \\
\text { TYPE }\end{array}$ & FY1997 & K & FY1999 & FY2000 & FY2001 & FY2002 & FY2003 & FY2004 & FY2005 & FY2008 & $\begin{array}{l}\text { FY1997- } \\
\text { FY2006 }\end{array}$ \\
\hline OPERATING EXPENSE & 23,661 & 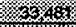 & 31,042 & 38,661 & 30,329 & 23,021 & 14,132 & 10,188 & 752 & & 205,267 \\
\hline & & - & & & & & & & & & \\
\hline CENRTC & & r & & & & & & & & & - \\
\hline & & & & & & & & & & & \\
\hline GENERAL PLANT PROJECT & & 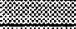 & & & & & & & & & $\dot{-}$ \\
\hline & & 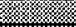 & & & & & & & & & \\
\hline LINE ITEM (ust Exch One) & & 3 & & & & & & & & & \\
\hline & & 药落 & & & & & & & & & 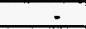 \\
\hline & & 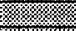 & & & $\therefore$ & & & & & & - \\
\hline & & 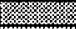 & & & & & & & & & $\div$ \\
\hline & & 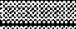 & & & & & & & & & 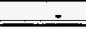 \\
\hline & & 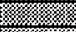 & & & & & & & & & $\overline{-}$ \\
\hline Subtotol L/ne hams & . & 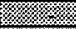 & $\because$ & $=$ & 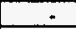 & 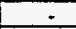 & $\cdot$ & - & - & - & - \\
\hline & & \% & & & & & & & & & \\
\hline 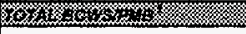 & 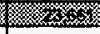 & 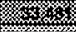 & 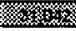 & 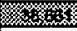 & (3) & 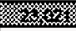 & (3) & 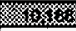 & 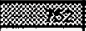 & & Wy \\
\hline & & 聯 & & & & & & & & & \\
\hline MSMT RESERVE ${ }^{2}$ & & 11 & & & & & & & & & F \\
\hline & & 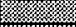 & & & & & & & & & \\
\hline LINE ITEA CONTINGENCY ${ }^{2}$ & & 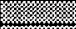 & & & & & & & & & $=$ \\
\hline & & 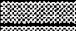 & & & & & & & & & \\
\hline OFFSITE TRANSFERS & & 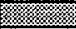 & & & & & & & & & 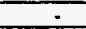 \\
\hline & & 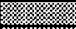 & & & & & & & & & \\
\hline Subtotal & $=$ & 18 & + & $\overline{-}$ & $\div$ & $\div$ & - & $=$ & - & $=$ & $\dot{-}$ \\
\hline & & 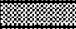 & & & & & & & & & \\
\hline ros & 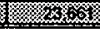 & 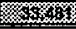 & 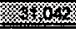 & 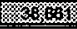 & 302320 & 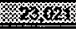 & (6) & 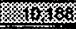 & 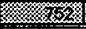 & & 262 \\
\hline
\end{tabular}

'Budgeted Cost of Work Schoduled (BCWS) Equals Performance Measurement Baseline (PMB); Expense Carryover NOT Included.

${ }^{2}$ Management Roserve and Line item Contingency Held by RL.

"Work Porformod at Sttes Other Than Hanford. 
FACILITY STABILIZATION

LIFE CYCLE COST BASELINE (BCWS) BY YEAR BY FUND TYPE

BY PROJECT BASELINE SUMMARY (PBS)

FY 1998

(\$000s)

\begin{tabular}{|c|c|c|c|c|c|c|c|c|c|c|}
\hline $\begin{array}{r}\text { PROJECT WBS: } \\
\text { PBS NO: }\end{array}$ & $\begin{array}{l}1.4 .10 .1 \\
\text { RL-TP01 }\end{array}$ & & & & & & & & & \\
\hline PBS TITLE: & $324 / 327 \mathrm{Fa}$ & cility Trans & ition & & & & & & & TOTAL \\
\hline $\begin{array}{l}\text { FUND } \\
\text { TYPE }\end{array}$ & $\begin{array}{l}\text { FY2007- } \\
\text { FY2010 }\end{array}$ & $\begin{array}{l}\text { FY2011- } \\
\text { FY2015 }\end{array}$ & $\begin{array}{l}\text { FY2016- } \\
\text { FY2020 }\end{array}$ & $\begin{array}{l}\text { FY2021- } \\
\text { FY2026 }\end{array}$ & \begin{tabular}{|l|} 
FY2026- \\
FY2030
\end{tabular} & $\begin{array}{l}\text { FY2031- } \\
\text { FY2036 }\end{array}$ & $\begin{array}{l}\text { FY2036 } \\
\text { FY2040 }\end{array}$ & \begin{tabular}{|l|} 
FY2041- \\
FY2045
\end{tabular} & $\begin{array}{l}\text { FY2046 } \\
\text { FY2050 }\end{array}$ & $\begin{array}{l}\text { FY1997- } \\
\text { FY2060 }\end{array}$ \\
\hline OPERATING EXPENSE & & & & & & & & & & 205,267 \\
\hline & & & & & & & & & & \\
\hline CENRTC & & & & & & & & & & - \\
\hline & & & & & & & & & & \\
\hline OENERAL PLANT PROJECT & & & 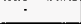 & & & & & & & $=$ \\
\hline & & & & & & & & & & \\
\hline LINE ITEM (List Each One) & & & & & & & & & & \\
\hline & & & & & & & & & & - \\
\hline & & & & & & & & & & $=$ \\
\hline & & & & & & & & & & - \\
\hline & & & & & & & & & & $=$ \\
\hline & & & & & & & & & & - \\
\hline Subtotal Line /tems & - & - & - & - & - & - & - & - & - & - \\
\hline & & & & & & & & & & \\
\hline 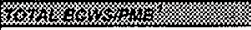 & & & 2 & 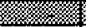 & se & 泣 & 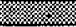 & 19 & & 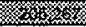 \\
\hline & & & & & & & & & & \\
\hline MOMT RESERVE ${ }^{2}$ & & & & & & & & & & - \\
\hline & & & & & & & & & & \\
\hline LINE ITEM CONTINGENCY ${ }^{2}$ & & & & & & & & & & $\dot{-}$ \\
\hline & & & & & & & & & & \\
\hline OFFSITE TRANSFERS ${ }^{3}$ & & & & & & & & & & $=$ \\
\hline Subtotal & - & - & - & - & • & - & - & - & - & - \\
\hline & & & & & & & & & & \\
\hline 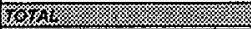 & & & 2 & 誉 & 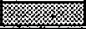 & (1) & S. & 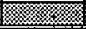 & 3 & 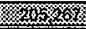 \\
\hline
\end{tabular}

'Budgeted Cost of Work Scheduled (BCWS) Equals Performance Measurement Baseline (PMB); Expense Carryover NOT Included.

${ }^{2}$ Management Reserve and Line Item Contingency Held by RL.

Work Performed at Sttes Other Than Hanford. 
FACILITY STABILIZATION

LIFE CYCLE BUDGET AUTHORITY (B/A) BY YEAR BY FUND TYPE BY PROJECT BASELINE SUMMARY (PBS)

FY 1998

(\$000s)

\begin{tabular}{|c|c|c|c|c|c|c|c|c|c|c|c|}
\hline PROJECT WBS: & 1.4.10.1 & & & & & & & & & & \\
\hline PBS NO: & RL-TPOB & & & & & & & & & & \\
\hline PES TITLE: & $324 / 327 \mathrm{Fa}$ & cillity Tran & siftion & & & & & & & & SUBTOT \\
\hline $\begin{array}{l}\text { FUND } \\
\text { TYPE }\end{array}$ & FY1997 & 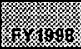 & FY1999 & FY2000 & FY2001 & FY2002 & FY2003 & FY2004 & FY2006 & FY2006 & $\begin{array}{l}\text { FY1997- } \\
\text { FY2006 }\end{array}$ \\
\hline OPERATING EXPENSE & 23,661 & sis & 31,042 & 38,661 & 30,329 & 23,021 & 14,132 & 10,188 & 752 & & 205,267 \\
\hline & & 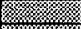 & & & & & & & & & \\
\hline CENRTC & & & & & & & & & & & - \\
\hline & & 1 & & & & & & & & & \\
\hline GENERAL PLANT PROJECT & & . & & & & & & & & & 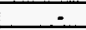 \\
\hline & & & & & & & & & & & \\
\hline LINE ITEM (Lat Each Ono) & & - & & & & & & & & & \\
\hline & & & & & & & & & & & $\overline{-}$ \\
\hline & & 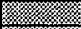 & & & & & & & & & - \\
\hline & & m. & & & & & & & & & $\dot{-}$ \\
\hline & & & & & & & & & & & - \\
\hline & & & & & & & & & & & - \\
\hline Subtotal Line ltems & - & & 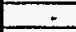 & $=$ & $\therefore$ & - & $\dot{\square}$ & $=$ & $\dot{ \pm}$ & $\dot{-}$ & 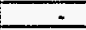 \\
\hline & & & & & & & & & & & \\
\hline 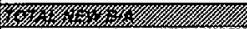 & 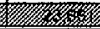 & 桻被 & 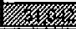 & rsty & 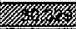 & 3ris & 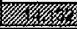 & 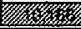 & 稵 & & 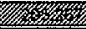 \\
\hline
\end{tabular}


FACILITY STABILIZATION

LIFE CYCLE BUDGET AUTHORITY (B/A) BY YEAR BY FUND TYPE BY PROJECT BASELINE SUMMARY (PBS)

\section{FY 1998}

(\$000s)

\begin{tabular}{|c|c|c|c|c|c|c|c|c|c|c|}
\hline PROJECT WBS: & 1.4.10.1 & & & & & & & & & \\
\hline PBS NO: & RL-TP08 & & & & & & & & & \\
\hline PBS TIJLE: & $324 / 327 \mathrm{~F}$ & cility Tra & nsition & & & & & & & TOTAL \\
\hline $\begin{array}{l}\text { FUND } \\
\text { TYPE }\end{array}$ & $\begin{array}{l}\text { FY2007- } \\
\text { FY2010 }\end{array}$ & $\begin{array}{l}\text { FY2011- } \\
\text { FY2016 }\end{array}$ & \begin{tabular}{|l|}
$F Y 2016-$ \\
FY2020
\end{tabular} & $\begin{array}{l}\text { FY2021- } \\
\text { FY2026 }\end{array}$ & \begin{tabular}{|l|}
$F Y 2026-$ \\
FY2030 \\
\end{tabular} & $\begin{array}{l}\text { FY2031- } \\
\text { FY2035 }\end{array}$ & $\begin{array}{l}\text { FY2036 } \\
\text { FY2040 }\end{array}$ & \begin{tabular}{|l|} 
FY20441- \\
FY2045
\end{tabular} & $\begin{array}{l}\text { FY2046 } \\
\text { FY2050 }\end{array}$ & $\begin{array}{l}\text { FY1997- } \\
\text { FY2050 }\end{array}$ \\
\hline OPERATINO EXPENSE & & & & & & & & & & 205,267 \\
\hline & & & & & & & & & & \\
\hline GENRTC & & & & & & & & & & - \\
\hline & & & & & & & & & & \\
\hline GENERAL PLANT PROJECT & & & & & & & & & & - \\
\hline LINE ITEM (List Eseh One) & & & & & & & & & & \\
\hline & & & & & & & & & & - \\
\hline & & & & & & & & & & - \\
\hline & & & & & & & & & & - \\
\hline & & & & & & & & & & $\therefore$ \\
\hline & & & & & & & & & & $\dot{.}$ \\
\hline Subtotal Line items & - & $=$ & $\cdot$ & - & - & - & - & - & $\dot{-}$ & $=$ \\
\hline 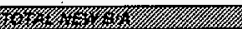 & & & & & & 83 & setere & 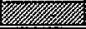 & w & sisn \\
\hline
\end{tabular}




\section{4/327 FACILITY TRANSITION}

AVERAGE ANNUAL FULL TIME EQUIVALENTS

(includes Major Subcontractors but not Enterprise Companies)

\section{PHBS 1.4.5.3}

Submittal Date: 9/10/97

PBS Number

PBS Title

FY 1998

FY 1999

FY 2000

FY 2001

\begin{tabular}{|l|l|}
\hline FY 2002 & FY 2003 \\
\hline
\end{tabular}

FY 2004 1 FY 2005

\begin{tabular}{|l|l|}
\hline FY 2006 & FY 2007 \\
\hline
\end{tabular}

RL-TP08

324/327 Facility

193

178

260

207

146

93

63

2

0

0

93

63.

2

Q 


\section{B.9 K Basin Deactivation (RL-TP09)}

\section{B.9.1.0 K Basin Deactivation Technical Baseline (RL-TP09)}

\section{B.9.1.1 K Basin Deactivation Organization Mission (RL-TP09)}

The purpose of this project is to deactivate the $\mathrm{K}$ Basins and associated ancillary facilities beginning in FY 2002, after the fuel and sludge have been removed. Deactivation of these facilities will reduce risk to the public, environment, and on-site workers by removing and/or stabilizing radiological and hazardous contamination, removing the basin water, and placing these high risk facilities into a "caretaker" status until they can be demolished.

There are 18 facilities that will be deactivated by this project. The eleven facilities associated with Fish rearing will be deactivated and/or modified to allow continued operation as economically as possible. There are 14 mobile office trailers which will be dispositioned by this project unless EM-40 wants them to support long-term surveillance and maintenance and future decontamination and decommissioning.

The KE \& KW Basins were designed and constructed in the early 1950's for wet storage of Spent Nuclear Fuel (SNF). Each basin contains over 1 million gallons of water. The KE Basin was never coated with any type of sealant. SNF storage in open containers has resulted in the decomposition of SNF and a release of radionuclides into the basin water and concrete. $\mathrm{KW}$ Basin had a sealant applied in 1981. Initial characterization activities indicate the spent fue! in the sealed MKII fuel cannisters in KW Basin, has decomposed just like the fuel in the KE Basin. Current Spent Nuclear Fuel Project (SNFP) plans to remove the KW Basin fuel wouid result in release of radionuclides into the water with the end result that it would be as contaminated as that in KE Basin. Both basins are in close proximity to the Columbia river which is open to the public. Radioactive constituents in the KE Basin water exceeding derived concentration guidelines (DCG's) include: strontium, cesium, uranium, plutonium, americium and tritium. The basins are beyond their design life and episodes of substantial leakage which did not arise from identifiable causes have occurred. Radionuclides could be released over time via air, ground and water pathways if the basin facilities are not maintained and deactivated, potentially overexposing members of the public, on-site workers and the environment. - Lack of adequate surveillance and maintenance could result in the loss of basin water and overexposure of the on-site workers (up to 50 operations, surveillance and maintenance, engineering, and radjological personnel) to high radiation and airborne radionuclide releases caused by the existing "bathtub" ring of radionuclides that has built up on the KE Basin walls. The half life of many of these materials is beyond 30 years, and any further contamination spread to the environment or within the basin facility would further complicate and increase the scope of D\&D and future operable unit remediation activities.

Planning Assumptions:

Because the total scope to deactivate these facilities to a "caretaker" status has not yet been determined, deactivation end point criteria and project management plans will be developed to establish the project scope, cost, and schedules.

Nuclear materials and SNF inventories in all facilities are assumed to be removed before their transfer into this project.

A reduction in radiation levels through the use of either additional shielding or removal of radionuclides will be necessary to achieve acceptable background radiation levels at the KE Basin. Both basins will require some form of radiological contaminant fixative application on the basin walls before removal of basin water. 
Existing NEPA documentation is sufficient to allow deactivation of the CVDF, both basins, and associated ancillary facilities.

Both KE and KW Basin water can be cleaned up by the water purification system at each basin to allow the water to be disposed of at the 200 East Area ETF. The ETF will be able to obtain a permit modification to allow it to accept the basin ion-exchange column treated basin water for disposition.

No additional safety documentation is necessary to deactivate the basins. Only a revision to the existing safety basis will be necessary to allow deactivation to take place under a reduced hazard classification. schedules.

Hanford Site assigned radiological dose allocations will not result in impacts to basin deactivation

The CVDF will not be grossly contaminated when it is tumed over for deactivation (i.e., contamination will only reside within process piping, tanks, and ductwork).

\section{B.9.1.2 K Basin Deactivation End Point Targets from Hanford Strategic Plan}

- Spent fuel removed and K-Basins cleaned sufficient to transition to D\&D.

* Drain, decontaminate, and stabilize K-Basins Facility.

\section{B.9.1.3 K Basin Deactivation Major Facilities}

\section{B.9.1.3.1 100 K Area Facilities}

\section{B.9.1.3.1.1 $100 \mathrm{~K}$ Area Facilities Description}

The scope of the $100 \mathrm{~K}$ Area facilities includes the K Băsins, Cold Vacuum Drying (CVD) facility, the multi-canister overpacks, cask/transportation system, and ancillary support facilities.

\section{B.9.1.3.1.2 100 K Area Facilities Facility Technical Logic:}

The Department of Energy (DOE), in partnership with its contractors, shall plan, acquire, operate, maintain, and dispose of physical assets as valuable national resoufces. Stewardship of these physical assets shall be accomplished in a cost-effective mannier to meet the DOE mission. This shall incorporate industry standards, a graded approach, and performance objectives. 
HNF-SP-1234

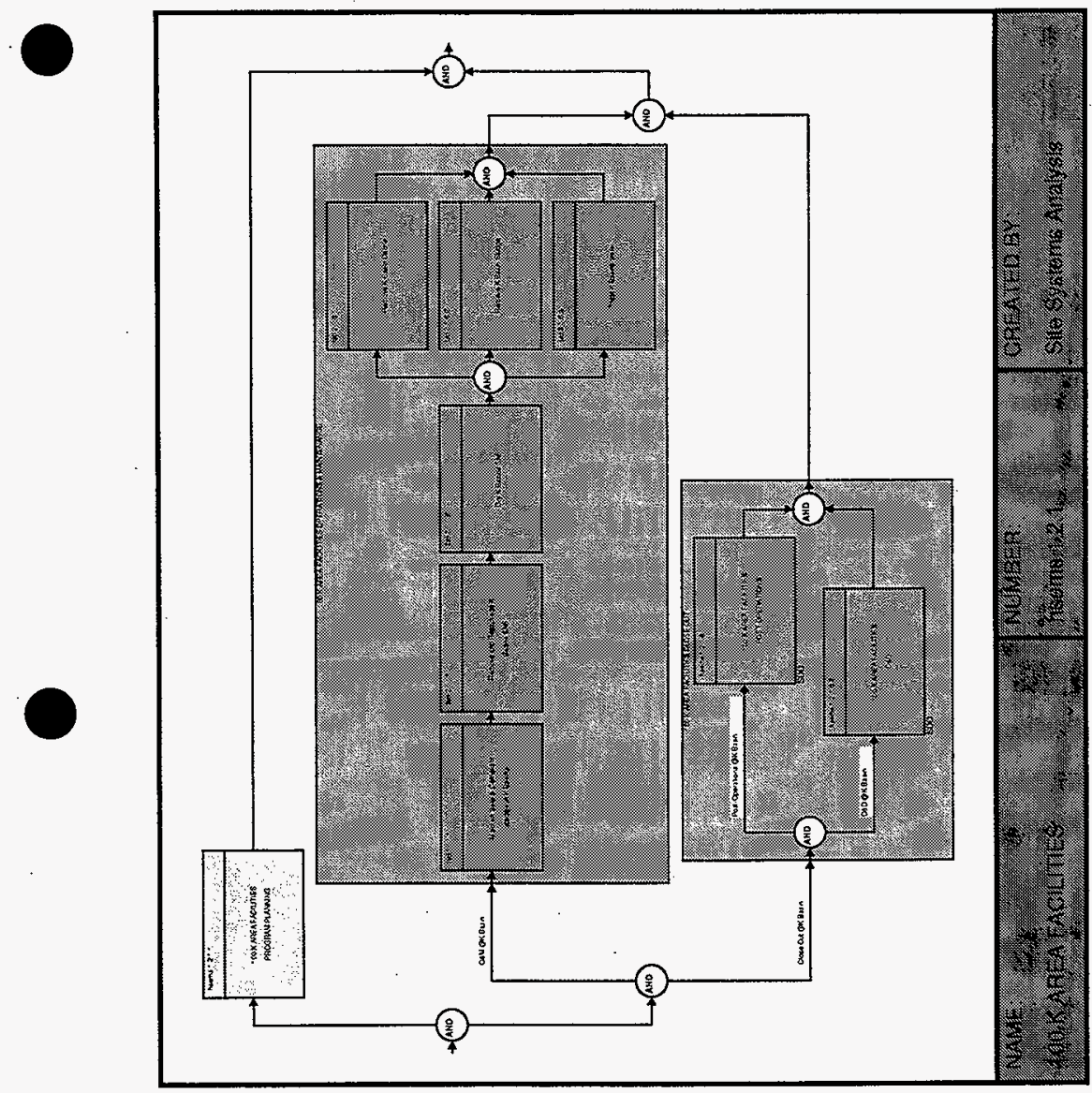

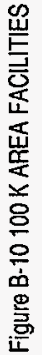




\section{B.9.1.3.1.3 100 K Area Facilities Requirements and Life Cycle Function Descriptions}

\section{Requirements:}

- K Basins shall be cleaned sufficiently to transition to the D\&D phase by Dec 31, 2005

- Reactors on the River facillities shall be transitioned to a low cost, stable, deactivated condition.

- K Basins shall be drained

* K Basins shall be stabilized

* Reactors on the River gaseous effluent releases shall be monitored

- KBasins criticality control shall be maintained

* K Basins corrosion control system shall be operated

- K Basins facility shall be monitored for deterioration

* $1706 \mathrm{KE} / \mathrm{KEL} / \mathrm{KER}$ Facility shall be surveilled and maintained within the approved safety envelope

- Reactors on the River asbestos abatement shall be performed as necessary

* Complete actions specified by agreed interim milestones related to remediation of the K-East basins. Due Date: TBD

- Contaminated K-East basin water will be removed for treatment. Due Date TBD.

- Accept K-Basins from SNFP after fuel, sludge and debris is removed.

* Characterize facility condition.

* Dispose of basin water.

* Tum over remaining facilities, systems and areas to the Environmental Restoration program for decommissioning.

- Fabricate sludge removal system. Complete sludge characterization '97.

* Procure debris decontamination services.

\section{Life Cycle Function Descriptions:}

\section{B.9.1.3.1.3.1 100 K AREA FACILITIES PROGRAM PLANNING WORK SCOPE SUMMARY}

Functions that include planning and developing the overall program; establishing broad priorities; providing program technical direction; preparing and defending the program budget; controlling milestones; integrating all components of the program; providing public and private sector policy liaison; expediting interface activities and follow-up actions; and retaining overall accountability for program success. 


\section{B.9.1.3.1.3.2 100 K AREA FACILITIES POST OPERATIONS WORK SCOPE SUMMARY}

Day-to-day work, including pre-stabilization surveillance and maintenance, stabilization, post-stabilization surveillance and maintenance, deactivation, and post-deactivation surveillance and maintenance, that is required to allow safe decontamination and decommissioning.

\section{$100 \mathrm{~K}$ AREA FACILITIES POST OPERATIONS SPECIFIC FUNCTIONS}

\section{B.9.1.3.1.3.3 Maintain Safe \& Compliant K-Basin Facility}

Maintain the K-Basin facility structures, operating systems and equipment, and monitoring systems within the approved safety and compliance requirements until the facilities are made available for clean-up.

\section{B.9.1.3.1.3.4 Transition K-Basins}

Initiate the facility transition phase of decontamination and deactivation for K-Basins.

\section{B.9.1.3.1.4 100 K Area Facilities Boundary Diagram}

Table B.91 $100 \mathrm{~K}$ Area Facilities Boundary Diagram

\begin{tabular}{|l|l|l|}
\hline $\begin{array}{l}\text { Extemal Interiaces } \\
\text { NNone- } \\
\text { Hanford Site Environmental System Interfaces } \\
\text {-None- }\end{array}$ & $\begin{array}{l}\text { Exiemal Interfaces } \\
\text {-None- } \\
\text { Hantord Site Environmental System Interfaces } \\
\text { hsems.2.2.16 Liquid Efiluent Retention Facility } \\
\text { hsems.2.3.5_Central Waste Comedex }\end{array}$ \\
\hline
\end{tabular}




\section{B.9.1.3.1.5 100 K Area Facilities Interface Description and Forecast}

\section{EXTERNAL INPUTS}

-None-

\section{INTERNAL INPUTS}

-None-

\section{EXTERNAL OUTPUTS}

-None-

\section{INTERNAL OUTPUTS}

\section{Table B.9-2 Internal Outputs for $100 \mathrm{~K}$ Area Facilities}

\begin{tabular}{|c|c|c|c|c|}
\hline Stream & Category & Period & Baseline & Units \\
\hline $\begin{array}{l}\text { Hsems } 2.2 .16 \text { Liquid Etfluent Retention Facility } \\
\text { KBasin Deactivation Wastewater } \\
\text { Waste water generatod during deactivation of the K Basins. }\end{array}$ & Waste Water & $2003-2005$ & 9080 & cubic meters \\
\hline hsems 2.3.5 Central Waste Complex & & & & \\
\hline $\begin{array}{l}\text { KBasin Deactivation, CH-LLW- } \\
\mathrm{CHLLW} \text { l transferred during deactivation of the } \mathrm{K} \text {-Basins as forecaste }\end{array}$ & $\begin{array}{l}\text { CH } \\
\text { din the SWIFT report. }\end{array}$ & $2002-2005$ & 833.0 & cubic maters \\
\hline $\begin{array}{l}\text { K Basin Deactivation, CH LLWWI } \\
\text { CHLLAW I transfored during deactivation of the K-Basins as forecas }\end{array}$ & $\begin{array}{l}\text { CH ШMWI } \\
\text { ted in the SWIFT report. }\end{array}$ & $2004-2005$ & 29.0 & cubic meters \\
\hline $\begin{array}{l}\text { K Basin Deactivation, CH TRU } \\
\text { CH TRU transferrod during deactivation of tho K Basins as forecasted }\end{array}$ & $\begin{array}{l}\text { CH TRU } \\
\text { in the SWIFT report. }\end{array}$ & $2004-2005$ & 14.2 & cubic meters \\
\hline $\begin{array}{l}\text { KOPER, CH-LLWWH } \\
\text { CHLLMW I Transferred by } 100 \text { K Area Facilities. }\end{array}$ & CHUMW I & $1997 \cdot 2000$ & 5.14 & cubic meters \\
\hline $\begin{array}{l}\text { KBasin Deactivation, RH TRU } \\
\text { RH TRU transferred during deactivation of the K Basins as forecasted }\end{array}$ & $\begin{array}{l}\text { RH TRU } \\
\text { in the SWIFT report }\end{array}$ & $2004-2005$ & 3.4 & cubic meters \\
\hline $\begin{array}{l}\text { KPROJECT, CH-TRU } \\
\text { CH TRU Transterted by } 100 \mathrm{~K} \text { Area Facilitios. }\end{array}$ & CH TRU & $1997-1999$ & 16.2 & cubic moters \\
\hline
\end{tabular}




\section{B.9.1.4 Drivers for K Basin Deactivation}

Table B.9-3 Source Documents for K Basin Deactivation

Name

DOE/RL-89-10

DOE/RL-96-14

DOE/RL-96-92
Title

Hanford Federal Facility Agreement and Consent Order (Tri-Party Agreement),

Rev. 4

Updated Draft Mission Direction Document, June 1996

Hanford Strategic Plan

\section{B.9.1.5 K Basin Deactivation Risk Management}

The KE \& KW Basins were designed and constructed in the early 1950's for wet storage of Spent Nuclear Fuel (SNF). Each basin contains over 1 million gallons of water. The KE Basin was never coated with any type of sealant. SNF storage in open containers has resulted in the decomposition of SNF and a release of radionuclides into the basin water and concrete. KW Basin had a sealant applied in 1981. Initial characterization activities indicate the spent fuel in the seaied MKIl fuel cannisters in KW Basin, has decomposed just like the fuel in the KE Basin. Current Spent Nuclear Fuel Project (SNFP) plans to remove the KW Basin fuel would result in release of radionuclides into the water with the end result that it would be as contaminated as that in KE Basin. Both basins are in close proximity to the Columbia river which is open to the public. Radioactive constituents in the KE Basin water exceeding derived concentration guidelines (DCG's) include: strontium, cesium, uranium, plutonium, americium and tritium. The basins are beyond their design life and episodes of substantial leakage which did not arise from identifiable causes have occurred. Radionuclides could be released over time via air, ground and water pathways if the basin facilities are not maintained and deactivated, potentially overexposing members of the public, on-site workers and the environment.

Lack of adequate S\&M could result in the loss of basin water and overexposure of the on-site workers (up to 50 operations, surveillance and maintenance, engineering, and radiological personnel) to high radiation and airborne radionuclide releases caused by the existing "bathtub" ring of radionuclides that has built up on the KE Basin walls. The half life of many of these materials is beyond 30 years, and any further contamination spread to the environment or within the basin facility would further complicate and increase the scope of decontamination and decommissioning (D\&D) and future operable unit remediation activities as well as the risk associated with performance of these actions.

Work activities likely to place the workers at risk are: removal of fuel processing and retrieval equipment, cannister cleaning equipment, storage racks and associated seismic bracing; removal of residual radionuclides in the KE Basin walls and floor; removal of the water in both basins; disposition of ion exchange media; and deactivation of water purification systems. 
HNF-SP-1234
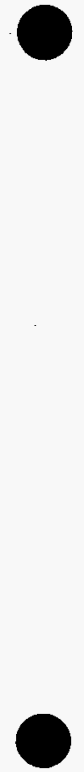

B. $9-8$ 
HNF-SP-1234

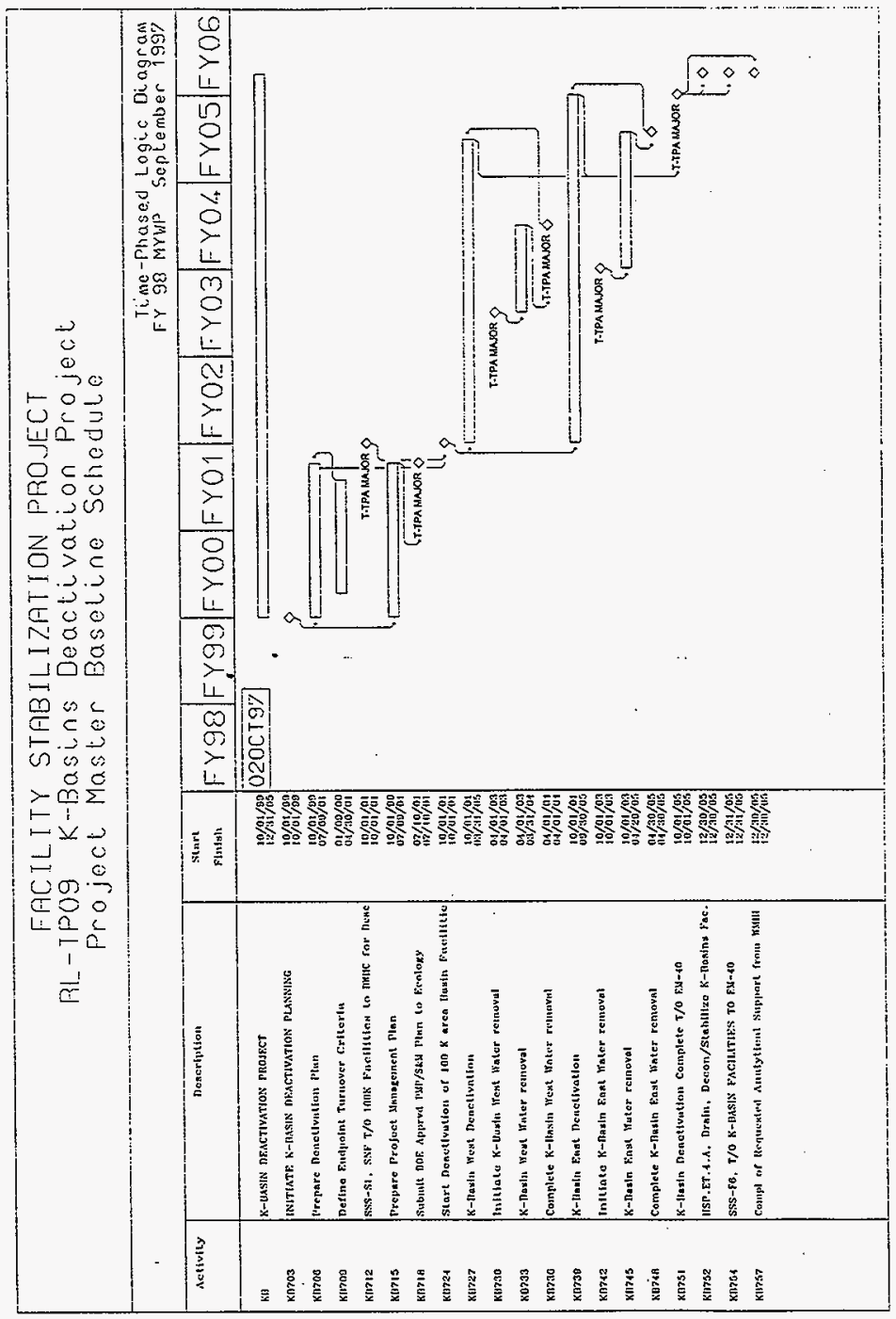


HNF-SP-1234

\section{THIS PAGE INTENTIONALLY}

\section{LEFT BLANK}




\section{FY 1998}

(\$000s)

\begin{tabular}{|c|c|c|c|c|c|c|c|c|c|c|c|}
\hline $\begin{array}{r}\text { PROJECT WBS: } \\
\text { PBSNO: }\end{array}$ & $\frac{1.4 .7 .1}{\text { RL-TP09 }}$ & & & & & & & & & & \\
\hline PBS TITLE: & KBasins D & eactivation & & & & & & & & & SUBTOT \\
\hline $\begin{array}{l}\text { FUND } \\
\text { TYPE }\end{array}$ & FY1997 & FYy & FY1999 & FY2000 & FY2001 & FY2002 & FY2003 & FY2004 & FY2005 & FY2006 & $\begin{array}{l}\text { FY1997" } \\
\text { FY2006 }\end{array}$ \\
\hline OPERATING EXPENSE & & Hots & & 1,196 & 3,284 & 25,189 & 35,341 & 32,895 & 24,589 & 1,158 & 123,652 \\
\hline & & W & & & & & & & & & \\
\hline CENRTC & & 3inision & & & & & & & & & - \\
\hline & & 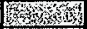 & & & & & & & & & \\
\hline GENERAL PLANT PROJECT & & W & & & & & & & & & - \\
\hline & & Mos & & & & & & & & & \\
\hline LINE ITEM (List Each One) & & 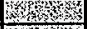 & & & & & & & & & \\
\hline & & 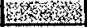 & & & & & & & & & $\dot{-}$ \\
\hline & & 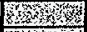 & & & & & & & & & - \\
\hline & & 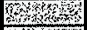 & & & & & & & & & - \\
\hline & & 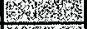 & & & & & & & & & - \\
\hline & & 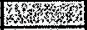 & & & & & & & & & 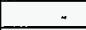 \\
\hline Subtotal Line ltems & - & 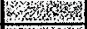 & - & - & $=$ & - & - & - & $=$ & - & - \\
\hline & & 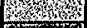 & & & & & & & & & \\
\hline Hou & 15. & But & B. & Busing & 2 & S & - & 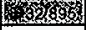 & 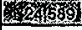 & ris & 1. \\
\hline & & 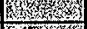 & & & & & & & & & \\
\hline MGMT RESERVE ${ }^{2}$ & & 8. & & & & & & & & & $=$ \\
\hline & & 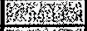 & & & & & & & & & \\
\hline LINE ITEM CONTINGENCY ${ }^{2}$ & & 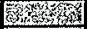 & & & & & & & & & - \\
\hline & & 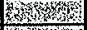 & & & & & & & & & \\
\hline OFFSITE TRANSFERS ${ }^{3}$ & & W. & & & & & & & & & - \\
\hline & & 1. & & & & & & & & & \\
\hline Subtotal & - & 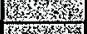 & - & $=$ & - & - & - & - & & $\therefore$ & - \\
\hline TOTAL $\mathrm{N}$ \% & 禁 & S & 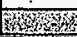 & 40 & 623284 & 25096 & 1036,340 & 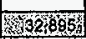 & & 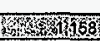 & W6 \\
\hline
\end{tabular}

'Budgeted Cost of Work Scheduled (BCWS) Equals Performance Measurement Baseline (PMB);

Expense Carryover NoT Included.

'Management Reserve and Line ltem Contingency Held by RL.

${ }^{3}$ Work Performed at Sites Other Than Hanford. 
(\$000s)

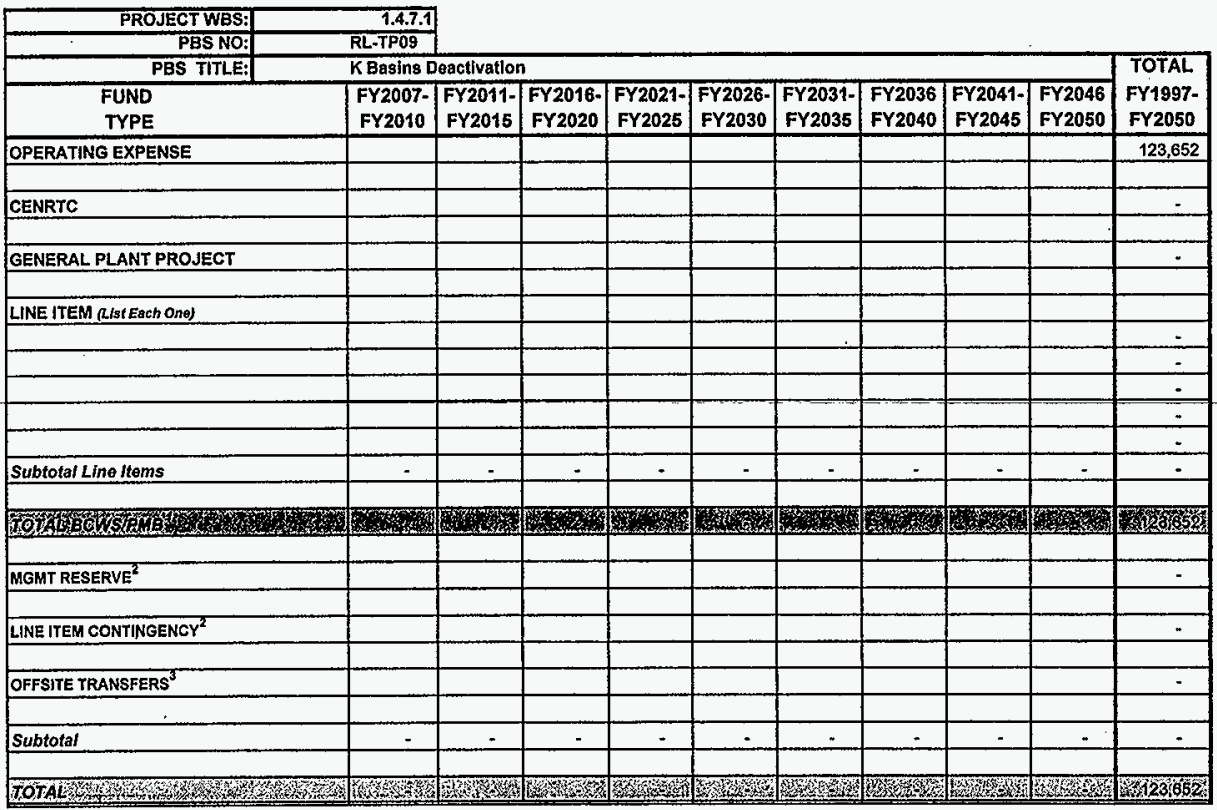

'Budgeted Cost of Work Scheduled (BCWS) Equals Performance Measurement Baseline (PMB);

Expense Carryover NoT Included.

${ }^{2}$ Management Reserve and Line item Contingency Held by RL.

WWork Performed at Sites Other Than Hanford. 
FACILITY STABILIZATION

LIFE CYCLE BUDGET AUTHORITY (BIA) BY YEAR BY FUND TYPE

BY PROJECT BASELINE SUMMARY (PBS)

FY 1998

(\$000s)

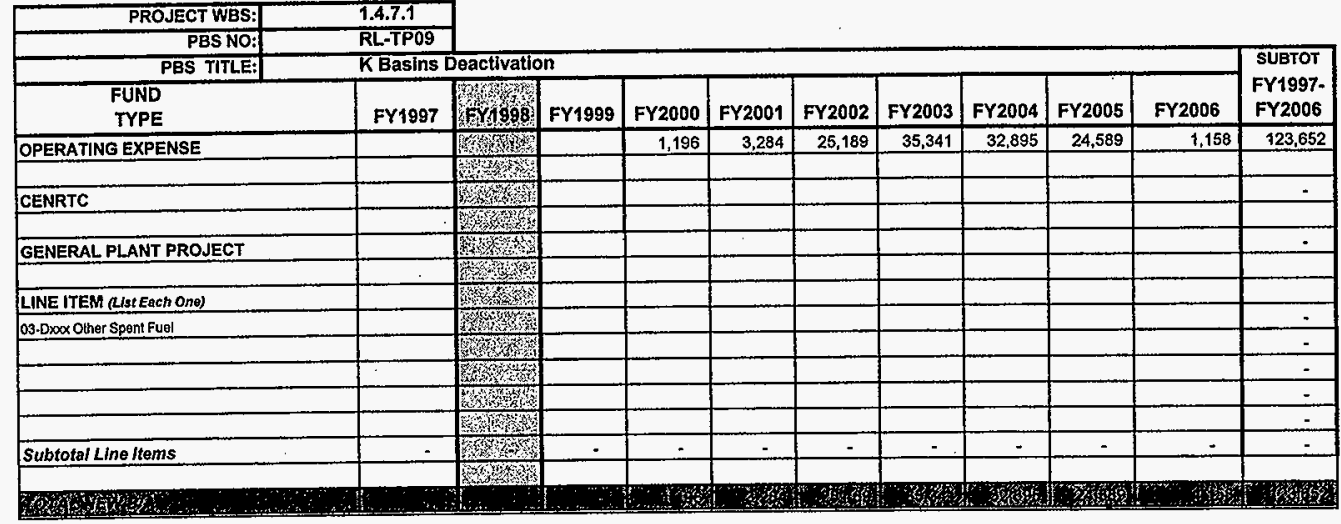


FACILITY STABILIZATION

LIFE CYCLE BUDGET AUTHORITY (BIA) BY YEAR BY FUND TYPE

BY PROJECT BASELINE SUMMARY (PBS)

FY 1998

(\$000s)

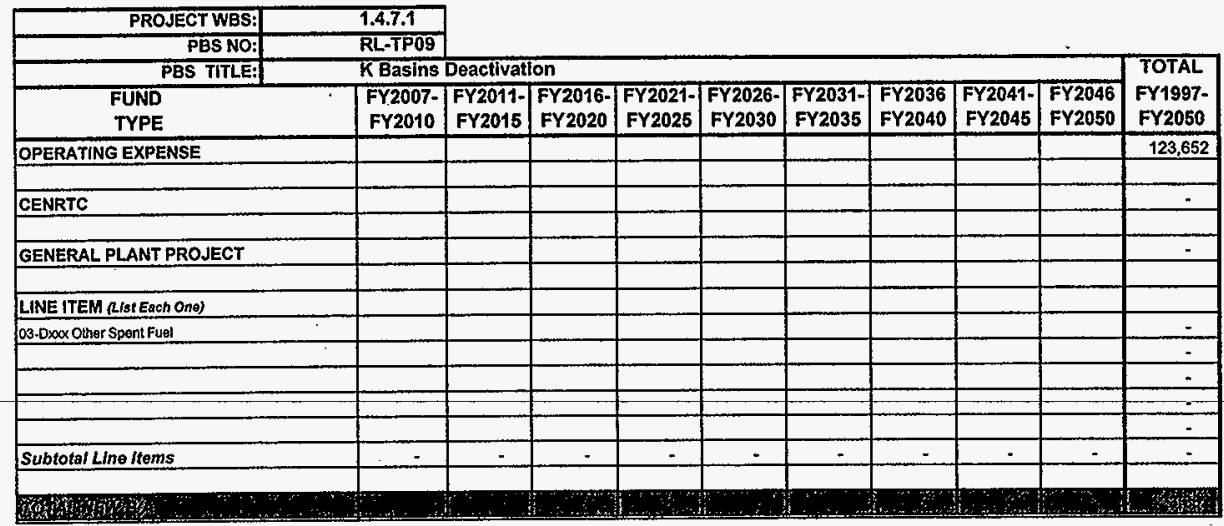




\section{B.10 Accelerated Deactivation Project (RL-TP10)}

\section{B.10.1.0 Accelerated Deactivation Project Technical Baseline (RL-TP10)}

\section{B.10.1.1 Accelerated Deactivation Project Organization Mission (RL-TP10)}

The purpose of this project is to provide minimum safe surveillance and maintenance and deactivate all Hanford contaminated facilities not currently being deactivated or scheduled for deactivation under another PBS. Initially, those facilities that no longer have a current mission and those expected to no longer have a viable mission after FY 2000 will be deactivated. All other included radiological and hazardous contaminated facilities expected to have viable missions after FY 2000 will be deactivated upon their mission completion (which could extend 20 years or more into the future). Since these facilities are contaminated and many are beyond their intended design life, deactivation of these facilities reduces risk to the public, environment and on-site workers by removing and/or stabilizing radiological and hazardous contamination and placing these high risk facilities in a low risk "caretaker" status until they can be demolished.

There are 39 non-mobile contaminated facilities that are assumed to either currently no longer have a viable mission or are expected to no longer have viable missions after FY 2000. Four of the 39 (231-Z, 222T, 222U, and 2704C) were recently transferred to Facility Stabilization Project (FSP) and the transfer of four others (242B, 242BL, 209E, and $2718 \mathrm{E}$ ) is expected during the next fiscal year.

Most of the facilities covered in this project are not in close proximity to the Columbia River or other areas occupied by the general public. However, the facilities are contaminated with both radiological and hazardous materials. Contaminants of concern include cesium, strontium, uranium, mixed fission products, fuels processing and chemical contamination that includes various acids and bases, and a wide variety of cleaning agents and solvents. Many of these facilities have also exceeded their design life. A fire, containment system failure or structural collapse due to natural causes or facility deterioration could result in a release of contaminants to the environment via air, ground and water pathways overexposing on-site workers. Most areas outside these facilities already contain radiological and hazardous contaminants in the soil and an additional release of contaminants would further complicate and increase the scope and risks of future remediation efforts.

\section{B.10.1.2 Accelerated Deactivation Project End Point Targets from Hanford Strategic Plan}

* Transition high cost surplus facilities in the central plateau and south 600 areas to a low cost, stable, deactivated condition.

- Remove non-essential, surplus buildings and facilities that don't have identified post-cleanup uses.

* Dismantle, or close through entombment, D\&D facilities in the central plateau areas currently assigned to the ER program.

\section{B.10.1.3 Accelerated Deactivation Project Major Facilities}

B.10.1.3.1 242-A Evaporator Facility 


\section{B.10.1.3.1.1 242-A Evaporator Facility Description}

The 242-A Evaporator concentrates dilute liquid tank wastes by evaporation. The volume of tank wastes is reduced to eliminate the need to construct additional storage tanks. The concentrated tank waste is retumed to the DSTs for storage. Process condensate from the 242-A Evaporator is sent to the LERF for storage while awaiting treatment in the ETF. The 242-A Evaporator is a RCRA-compliant facility and the only waste volume reduction facility for tank wastes. It began operation in 1977 and has a waste yolume reduction capacity of 70,000 galday.

\section{B.10.1.3.1.2 242-A Evaporator Facility Technical Logic:}

The technical logic for the 242-A Evaporator is captured in the facility's functional flow block diagram which shows the functions performed for each applicable life cycle phase of the facility and the sequence in which the functions are executed. 


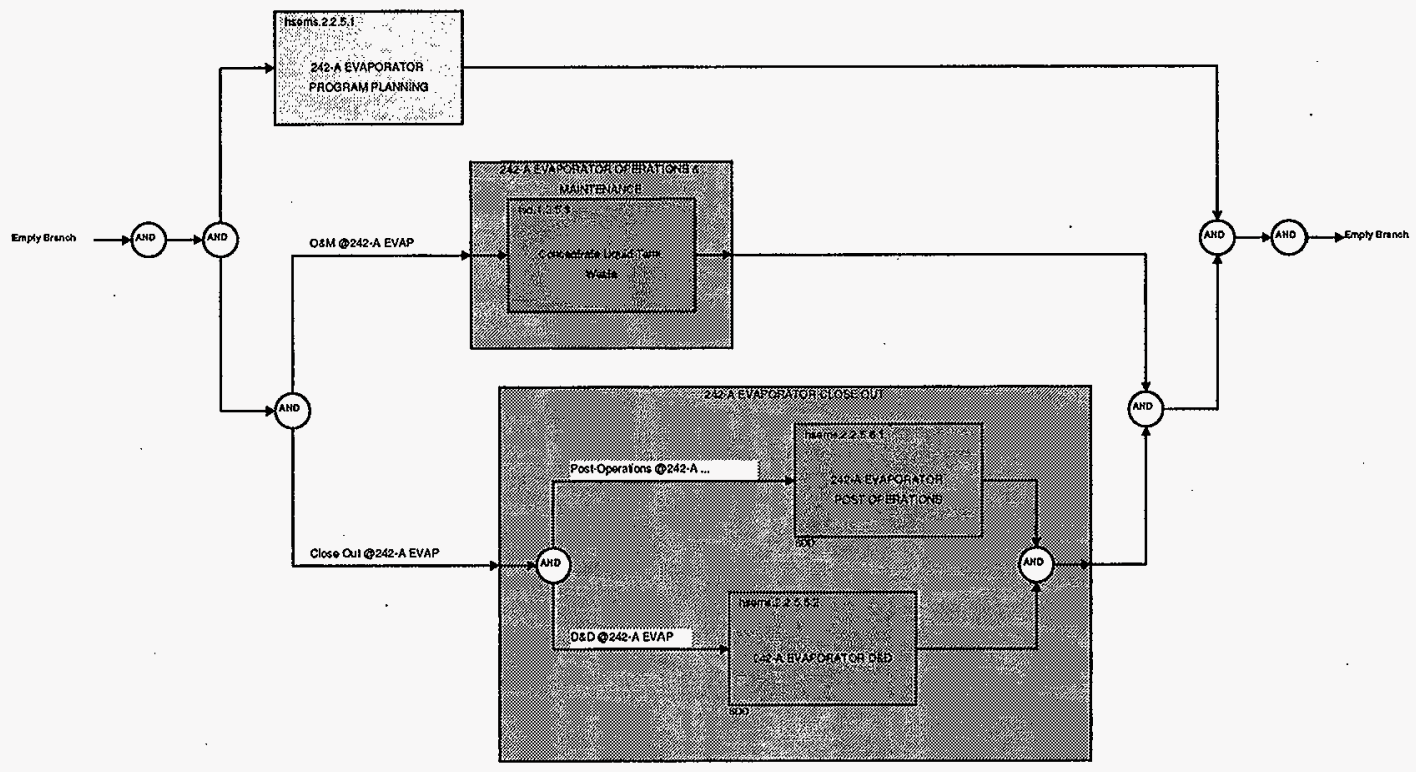

Figure B-11 242-A EVAPORATOR 


\section{B.10.1.3.1.3 242-A Evaporator Requirements and Life Cycle Function Descriptions}

\section{Requirements:}

* Central Plateau high cost surplus facilities shall be transitioned to a low cost, stable, deactivated condition

* Central Plateau facilities other than processing facilities shall be dismantled

* Central Plateau inactive facilities shall be maintained within the approved safety envelope

- 242A Evaporator shall be operated within the approved safety envelope

* $242 A$ Evaporator shall be maintained within the approved safety envelope

* 242A Evaporator feed tanks shall be operated within the approved safety envelope

* 242A Evaporator feed tanks shall be maintained within the approved safety envelope

* 242A Evaporator receiver tanks shall be operated within the approved safety envelope

* 242A Evaporator receiver tanks shall be maintained within the approved safety envelope

- Central Plateau asbestos abatement shall be periormed as necessary

* Phase Il liquid effluent streams shall be treated using "Best Available Technology/All Known, Available, and Reasonable Methods of Prevention, Control, and Treatment (BAT/AKART)"

\section{Life Cycle Function Descriptions:}

\section{B.10.1.3.1.3.1 242-A EVAPORATOR POST OPERATIONS WORK SCOPE SUMMARY}

Day-to-day work, including pre-stabilization surveillance and maintenance, stabilization, post-stabilization surveillance and maintenance, deactivation, and post-deactivation surveillance and maintenance, that is required to allow safe decontamination and decommissioning.

\section{2-A EVAPORATOR POST OPERATIONS SPECIFIC FUNCTIONS}

\section{B.10.1.3.1.3.2 Maintain Safe \& Compliant 242-A Evaporator Facility in CP Areas}

Maintain the 242-A facility structures, operating systems and equipment, and monitoring systems within the approved safety and compliance requirements until the facilities are made available for clean-up.

\section{B.10.1.3.1.3.3 Transition 242-A Evaporator Facility}

Initiate the transition phase of decontamination and decommissioning for the 242-A evaporator.

\section{B.10.1.3.1.4 242-A Evaporator Boundary Diagram}


HNF-SP-1234

Table B.10-1 242-A Evaporator Boundary Diagram

\begin{tabular}{|l|l|}
\hline $\begin{array}{c}\text { External Interiaces } \\
\text { None- } \\
\begin{array}{c}\text { Hanford Site Environmental System Interfaces } \\
\text { None- }\end{array}\end{array}$ & $\begin{array}{l}\text { External Interfaces } \\
\text {-None- } \\
\text { Hanford Site Environmental System Interfaces } \\
\text {-None- }\end{array}$ \\
\hline
\end{tabular}


B.10.1.3.1.5 242-A Evaporator Interface Description and Forecast

EXTERNAL INPUTS

-None-

INTERNAL INPUTS

-None-

EXTERNAL OUTPUTS

-None-

INTERNAL OUTPUTS

-None. 


\section{B.10.1.3.2 T-Plant Facility}

\section{B.10.1.3.2.1 T-Plant Facility Description}

T-Plant was constructed in 1944 in the 200-W Area of Hanford. It originally operated as a separation facility for irradiated production reactor fuel. Later it was used for high-level decontamination and repair of equipment as well as storage of fuel assemblies (PWR Core il).

\section{B.101.3.2.2 T-Plant Facility Facility Technical Logic:}

The technical logic for the T Plant facility is captured in the facility's functional flow block diagram which shows the functions performed for each applicable life cycle phase of the facility and the sequence in which the functions are executed. 


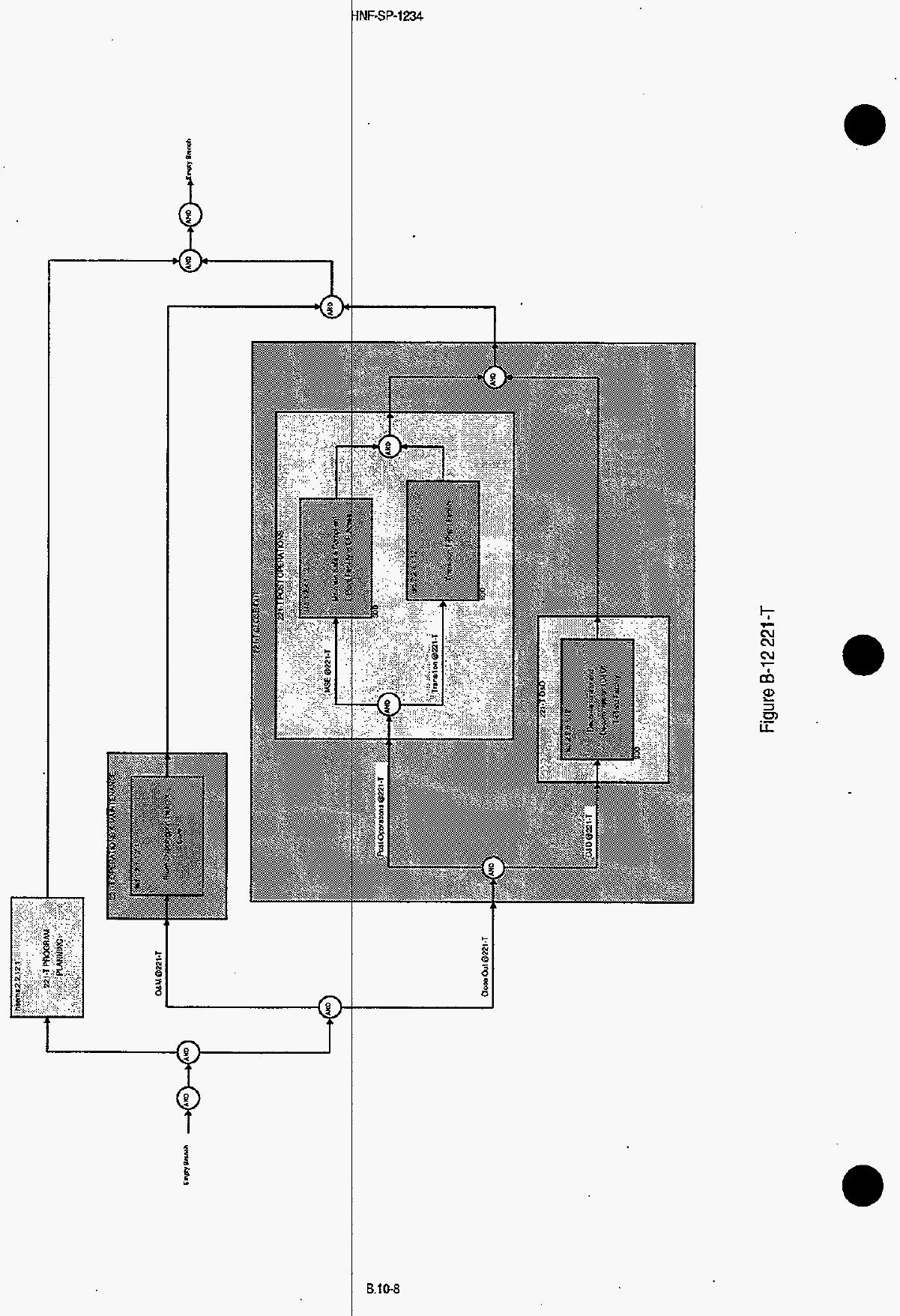




\section{B.10.1.3.2.3 T-Plant Facility Requirements and Life Cycle Function Descriptions}

Requirements:

-None-

\section{Life Cycle Function Descriptions:}

\section{B.10.1.3.2.3.1 221-T POST OPERATIONS WORK SCOPE SUMMARY}

Day-to-day work, including pre-stabilization surveillance and maintenance, stabilization, post-stabilization surveillance and maintenance, deactivation, and post-deactivation surveillance and maintenance, that is required to allow safe decontamination and decommissioning.

\section{1-T POST OPERATIONS SPECIFIC FUNCTIONS}

\section{B.10.1.3.2.4 T-Plant Facility Boundary Diagram}

Table B.10-2 T-Plant Facility Boundary Diagram

\begin{tabular}{|l|l|}
\hline $\begin{array}{l}\text { External Interfaces } \\
\text { None- } \\
\text { Hanford Site Environmental System Intertaces } \\
\text { None- }\end{array}$ & $\begin{array}{l}\text { Extemal Interfaces } \\
\text {-None- } \\
\text { Hanford Site Environmental System Interfaces } \\
\text {-Nene: }\end{array}$ \\
\hline
\end{tabular}


B.10.1.3.2.5 T-Plant Facility Interface Description and Forecast

\section{EXTERNAL INPUTS}

-None-

INTERNAL INPUTS

-None-

EXTERNAL OUTPUTS

-None-

INTERNAL OUTPUTS

-None- 


\section{B.10.1.3.3 2706-T Facility}

\section{B.10.1.3.3.1 2706-T Facility Description}

2706-T Facility is located in the 200-W Area of Hanford and is used as an equipment low-level decontamination facility.

\section{B.10.1.3.3.2 2706-T Facility Technical Logic:}

The Department of Energy (DOE), in partnership with its contractors, shall plan, acquire, operate, maintain, and dispose of physical assets as valuable national resources. Stewardship of these physical assets shall be accomplished in a cost-effective manner to meet the DOE mission. This shall incorporate industry standards, a graded approach, and performance objectives. 
HNF-SP-1234

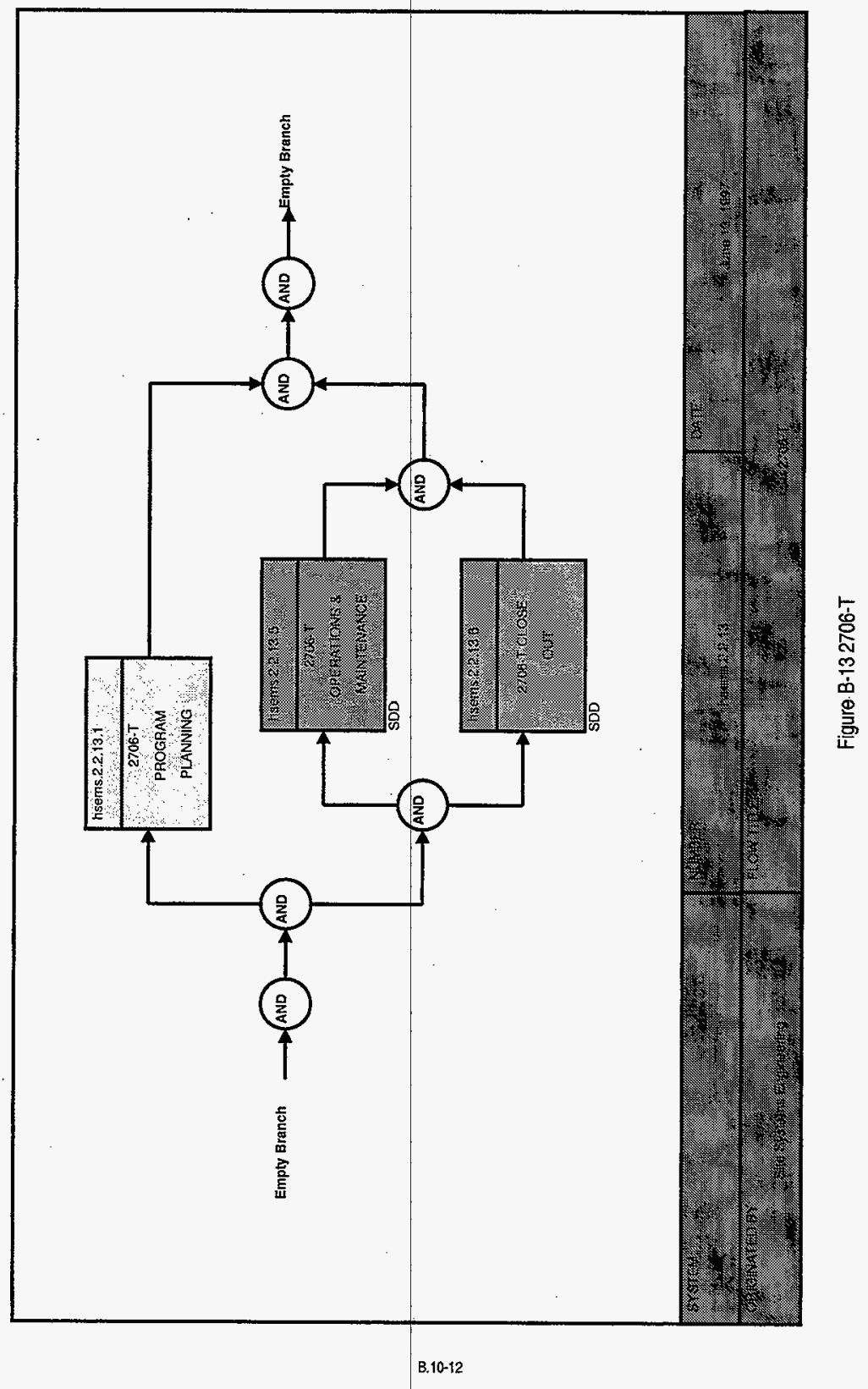




\section{B.10.1.3.3.3 2706-T Requirements and Life Cycle Function Descriptions}

Requirements:

-None-

\section{Life Cycle Function Descriptions:}

\section{B.10.1.3.3.3.1 2706-T POST OPERATIONS WORK SCOPE SUMMARY}

Day-to-day work, including pre-stabilization surveillance and maintenance, stabilization, post-stabilization surveillance and maintenance, deactivation, and post-deactivation surveillance and maintenance, that is required to allow safe decontamination and decommissioning.

2706-T POST OPERATIONS SPECIFIC FUNCTIONS

\section{B.10.1.3.3.4 2706-T Boundary Diagram}

Table B.10-3 2706-T Boundary Diagram

\begin{tabular}{|l|l|l|}
\hline $\begin{array}{c}\text { Extemal Interiaces } \\
\text { None- } \\
\text { Hanford Site Environmental System Interfaces } \\
\text { None- }\end{array}$ & $\begin{array}{l}\text { External Interfaces } \\
\text { None- } \\
\text { Hanford Site Environmental System Interfaces } \\
\text { None- }\end{array}$ \\
\hline
\end{tabular}


B.10.1.3.3.5 2706-T Interface Description and Forecast

\section{EXTERNAL INPUTS \\ -None- \\ INTERNALINPUTS \\ -None- \\ EXTERNAL OUTPUTS \\ -None- \\ INTERNAL OUTPUTS \\ -None-}




\section{B.10.1.3.4 M-91 Facility}

\section{B.10.1.3.4.1 M-91 Facility Description}

The primary functions of M-91 include processing, packaging, and certification of retrieved and newly generated RH-TRU wastes, retrieved and newly generated remote handled radioactive mixed waste, and handling, processing, repackaging, and certification for retrieved and newly generated CH-TRU waste that cannot be processed in WRAP 1 or other commercial options.

\section{B.10.1.3.4.2 M-91 Facility Facility Technical Logic:}

The technical logic for the M-91 facility is captured in the facility's functional flow block diagram which shows the functions performed for each applicable life cycle phase of the facility and the sequence in which the functions are executed. 


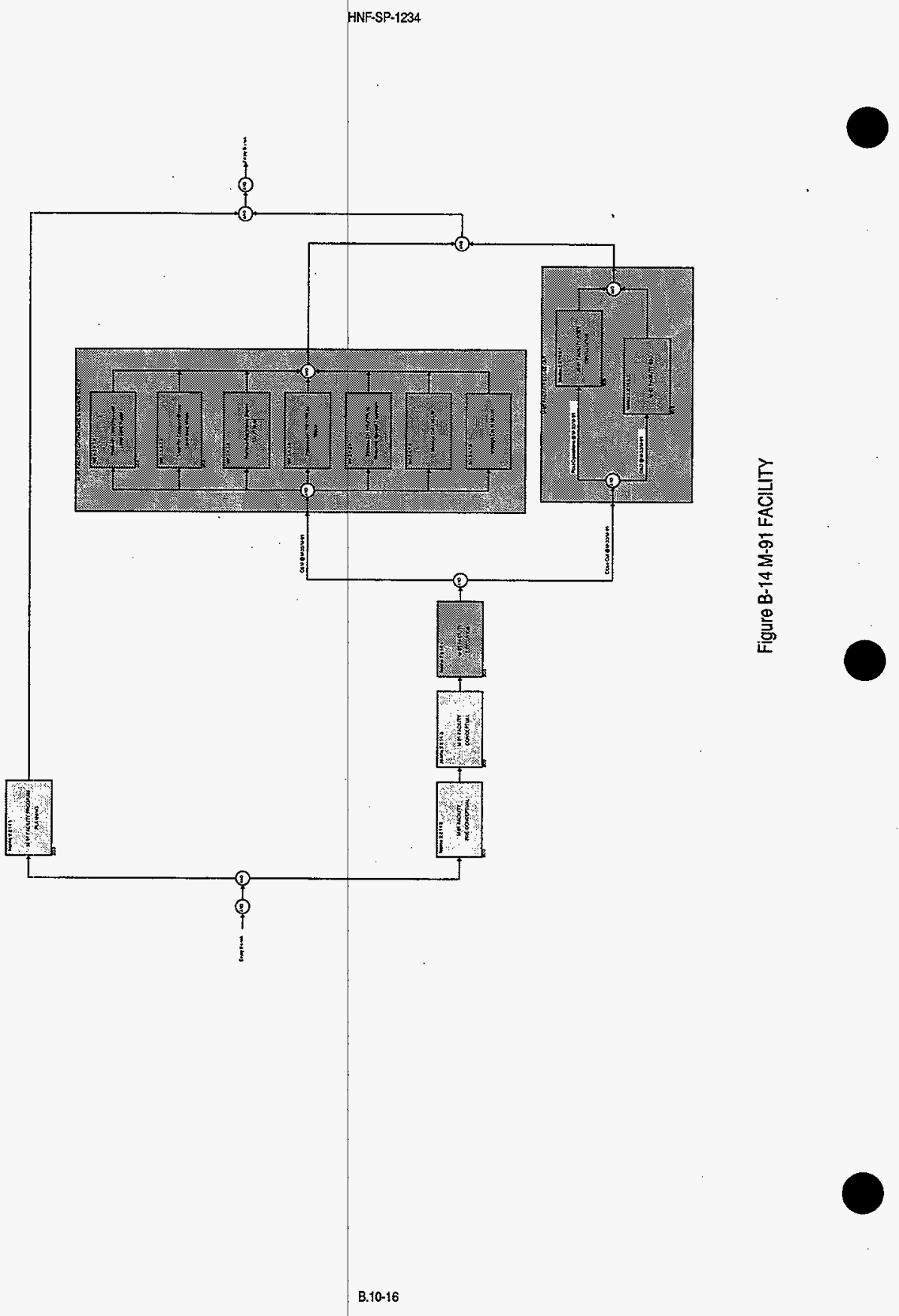




\section{B.10.1.3.4.3 M-91 Facility Requirements and Life Cycle Function Descriptions}

Requirements:

-None-

\section{Life Cycle Function Descriptions:}

\section{B.10.1.3.4.3.1 M-91 FACILITY POST OPERATIONS WORK SCOPE SUMMARY}

Day-to-day work, including pre-stabilization surveillance and maintenance, stabilization, post-stabilization surveillance and maintenance, deactivation, and post-deactivation surveillance and maintenance, that is required to allow safe decontamination and decommissioning.

\section{M-91 FACILITY POST OPERATIONS SPECIFIC FUNCTIONS}

\section{B.10.1.3.4.4 M-91 Facility Boundary Diagram}

Table B.10-4 M-91 Facility Boundary Diagram

\begin{tabular}{|l|l|}
\hline $\begin{array}{l}\text { Extemal Interfaces } \\
\text { None- } \\
\text { Hanford Sile Environmental System Interiaces } \\
\text {-None- }\end{array}$ & $\begin{array}{l}\text { External Interfaces } \\
\text { None- } \\
\text { Hanford Site Enviroimental System Intertaces } \\
\text {-Nene- }\end{array}$ \\
\hline
\end{tabular}


B.10.1.3.4.5 M-91 Facility Interface Description and Forecast

$$
\begin{gathered}
\text { EXTERNAL INPUTS } \\
\text {-NONe- } \\
\text { INTERNAL INPUTS } \\
\text {-NONe- } \\
\text { EXTERNAL OUTPUTS } \\
\text {-NONe- } \\
\text { INTERNAL OUTPUTS } \\
\text {-None- }
\end{gathered}
$$

\section{EXTERNAL OUTPUTS}




\subsection{WRAP Module 1 Facility}

\section{B.10.1.3.5.1 WRAP Module 1 Facility Description}

The WRAP I facility will accept contact handled low level and mixed low level waste (CH-LLW and CH-MLLW) and transuranic (CH-TRU and $\mathrm{CH}-\mathrm{TRUM}$ ) waste for inspection, certification, and preparation for final disposal. The facility began processing $\mathrm{CH}-\mathrm{LLW}$ in March of 1997 and will commence processing of $\mathrm{CH}-\mathrm{TRU}, \mathrm{CH}-\mathrm{TRUM}$ waste in 1998. WRAP I will be operational 175 days per year (70\% TOE). WRAPI is designed to process annually. 6,825 drums $(4,200$ drums newly generated waste and 2,625 drums retrieved waste) and 70 standard waste boxes.

\section{B.30.1.3.5.2 WRAP Module 1 Facility Technical Logic:}

The technical logic for the WRAP facility is captured in the facility's functional flow block diagram which shows the functions performed for each applicable life cycle phase of the facility and the sequence in which the functions are executed. 


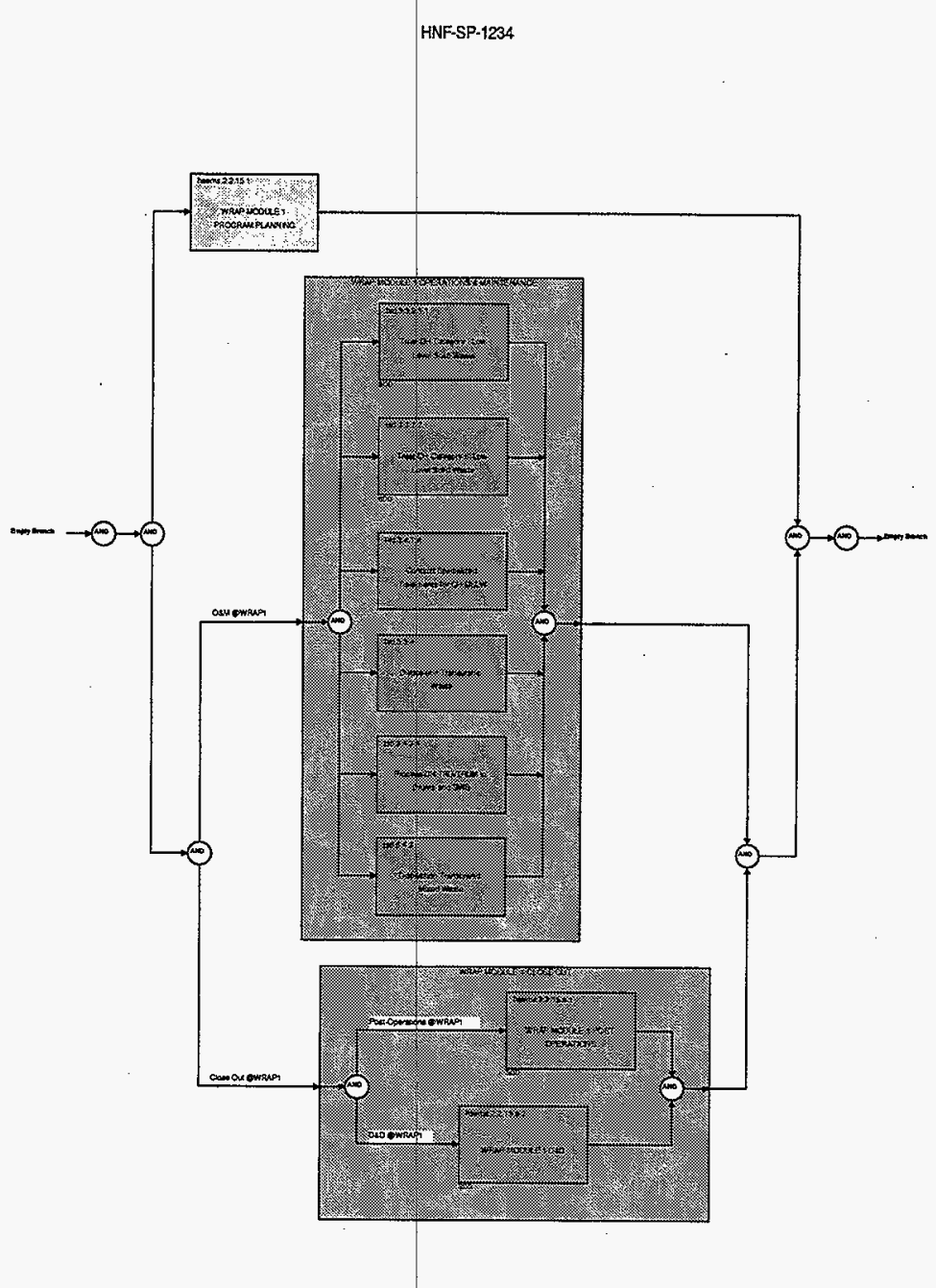

Figure B-15 WRAP MODULE 1 


\section{B.10.1.3.5.3 WRAP Module 1 Requirements and Life Cycle Function Descriptions}

Requirements:

-None-

\section{Life Cycle Function Descriptions:}

\section{B.10.1.3.5.3.1 WRAP MODULE 1 POST OPERATIONS WORK SCOPE SUMMARY}

Day-to-day work, including pre-stabilization surveillance and maintenance, stabilization, post-stabilization surveillance and maintenance, deactivation, and post-deactivation surveillance and maintenance, that is required to allow safe decontamination and decommissioning.

WRAP MODULE 1 POST OPERATIONS SPECIFIC FUNCTIONS

\section{B.10.1.3.5.4 WRAP Module 1 Boundary Diagram}

Table B.10-5 WRAP Module 1 Boundary Diagram

\begin{tabular}{|l|l|l|}
\hline $\begin{array}{c}\text { Extemal Interfaces } \\
\text {-None- } \\
\text { Hanford Site Environmental System Interfaces } \\
\text {-None- }\end{array}$ & $\begin{array}{l}\text { Extemal Interfaces } \\
\text {-None- } \\
\text { Hanford Site Environmental System Interiaces } \\
\text { None- }\end{array}$ \\
\hline
\end{tabular}


B.10.1.3.5.5 WRAP Module 1 Interface Description and Forecast EXTERNAL INPUTS -None-

INTERNAL. INPUTS -None-

EXTERNAL OUTPUTS -None-

INTERNAL OUTPUTS -None- 


\section{B.10.1.3.6 Liquid Effluent Retention Facility}

\section{B.10.1.3.6.1 Liquid Effiuent Retention Facility Description}

The LERF consists of three RCRA-compliant surface impoundments for temporarily storing process condensate from the 242-A Evaporator and other liquid effluents. The LERF provides equalization of the flow and $\mathrm{pH}$ of the feed to the ETF. Each LERF basin has a capacity of 6.5 million gallons. Spare capacity is maintained equal to the volume of one LERF basin as contingency in the event a leak should develop in an operational basin. The basins are constructed of two high-density polyethylene (HDPE) flexible membrane liners. A system is provided to detect, collect, and remove leachate from between the primary and secondary liners. Beneath the secondary liner is a $3 \mathrm{ft}$ thick soillbentonite barrier should the primary and secondary liners fail. Each basin has a mechanically-tensioned floating membrane cover constructed of very low-density polyethylene (VLDPE) to keep out unwanted material and to minimize evaporation of the basin contents. The LERF began operation in April 1994 and is designed for a 20-year life.

\section{B.10.1.3.6.2 Liquid Effluent Retention Facility Facility Technical Logic:}

The technical logic for the Liquid Effluent Retention Facility is captured in the facility's functional flow block diagram which shows the functions performed for each applicable life cycle phase of the facility and the sequence in which the functions are executed. 


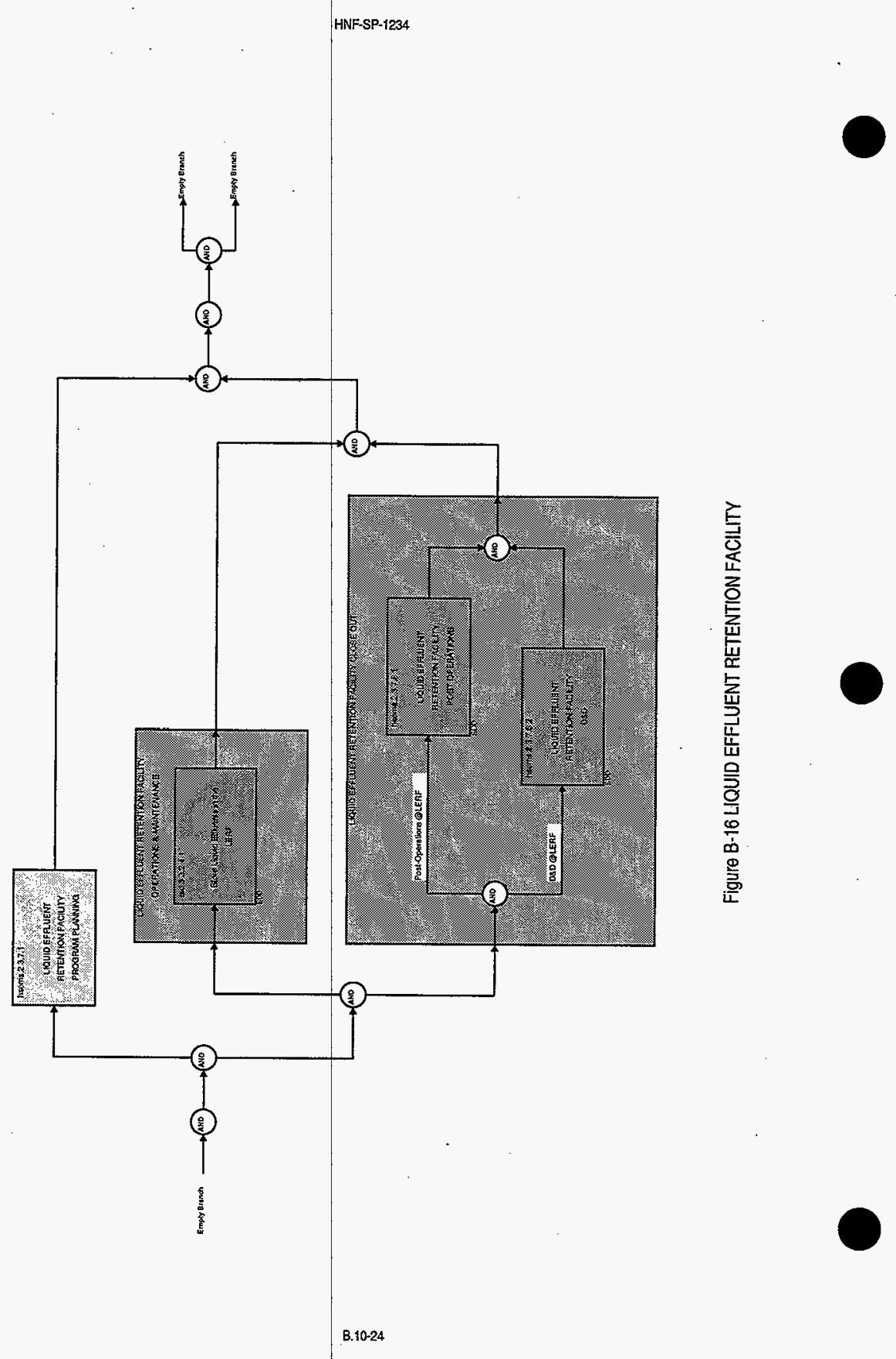




\section{B.10.1.3.6.3 Liquid Effluent Retention Facility Requirements and Life Cycle Function Descriptions}

Requirements:

* Central Plateau high cost surplus facilities shall be transitioned to a low cost, stable, deactivated condition

* Central Plateau facilities other than processing facilities shall be dismantled

- Central Plateau inactive facilities shall be maintained within the approved safety envelope

* LERF shall be operated within the approved safety envelope

* Safe Operation of LERF - Operation and maintenance of the LERF shall be in accordance with LERF Safety Analysis Report (Woeland 1991

- Solids shall not be allowed to accumulate in the LERF basins which may require special cleanout actions. [LERF Treatment Exemption (95-LEP-015), 40 CFR 258.4.]

* Waste will be stored in LERF for up to one year prior to treatment in the ETF. [LERF Treatment Exemption (95-LEP-015), 40 CFR 268.4]

\section{Life Cycle Function Descriptions:}

\section{B:10.1.3.6.3.1 LIQUID EFFLUENT RETENTION FACILITY POST OPERATIONS WORK SCOPE SUMMARY}

Day-to-day work, including pre-stabilization surveillance and maintenance, stabilization, post-stabilization surveillance and maintenance, deactivation, and post-deactivation surveillance and maintenance, that is required to allow safe decontamination and decommissioning.

\section{LIQUID EFFLUENT RETENTION FACILITY POST OPERATIONS SPECIFIC FUNCTIONS}

\section{B.10.1.3.6.3.2 Maintain Safe \& Compliant Liquid Effluent Retention Facility in CP Areas}

Maintain the LERF facility structures, operating systems and equipment, and monitoring systems within the approved safety and compliance requirements until the facilities are made available for clean-up.

\section{B.10.1.3.6.3.3 Transition Liquid Effluent Retention Facility}

Initiate the transition phase of decontamination and decommissioning for the Liquid Effluent Retention Facility

\section{B.10.1.3.6.4 Liquid Effluent Retention Facility Boundary Diagram}

Table B.10-6 Liquid Effluent Retention Facility Boundary Diagram

\begin{tabular}{|l|l|}
\hline $\begin{array}{l}\text { Extemal Interfeces } \\
\text {-None- } \\
\begin{array}{c}\text { Hantord Site Environmental System Interfaces } \\
\text {-None- }\end{array}\end{array}$ & $\begin{array}{l}\text { External Interfaces } \\
\text { None- } \\
\text { Hantord Site Environmental System Interiaces } \\
\text {-None- }\end{array}$ \\
\hline
\end{tabular}


B.101.3.6.5 Liquid Effiuent Retention Facility Interface Description and Forecast EXTERNAL INPUTS

-None-

INTERNAL INPUTS

-None-

\section{EXTERNAL OUTPUTS}

-None-

\section{INTERNAL OUTPUTS}

-None- 


\section{B.10.1.3.7 200 Area Effluent Treatment Facility}

\section{B.10.1.3.7.1 200 Area Effluent Treatment Facility Description}

Liquid effluents from the LERF are treated in the ETF to remove toxic metals, radionuclides, and ammonia and to destroy organics. The ETF treatment process constitutes best available treatment (BAT) technology and includes $\mathrm{pH}$ adjustment, fitration, uttraviolet light/peroxide (UV/OX) destruction of organics, reverse osmosis (RO), and ion exchange. Treatment capacity of the ETF is $150 \mathrm{gal} / \mathrm{min}$. Storage tanks allow for holdup of the treated effluent to allow verification that the effluent has been treated to acceptable levels prior to discharge. The treated effluent is discharged under a WAC 173-216 State Waste Discharge Permit to a state-approved land disposal site (SALDS) located north of the 200 West Area. The ETF began operation in December, 1995 and has a 30 year design life.

The LERF/ETF can generally accept low level, RCRA-regulated, mixed low level, and CERCLA-regulated liquid effluents, and also industrial wastewaters for storage and treatment. A delisting petition was specifically approved for treating 242-A Evaporator process condensate for the waste codes F001 through F005, and F039 leachate (as derived from F001 through F005). A truck unioading station enables liquid effluents to be received from other projects and transferred to either the LERF for storage, or directly to the ETF for treatment. A groundwater transfer system is available for transferring groundwater from the 200 West Area to LERF for treatment in the ETF.

\section{B.10.1.3.7.2 200 Area Eftluent Treatment Facility Facility Technical Logic:}

The technical logic for the 200 Area. Effluent Treatment Facility is captured in the facility's functional flow block diagram which shows the functions performed for each applicable life cycle phase of the facility and the sequence in which the functions are executed. 


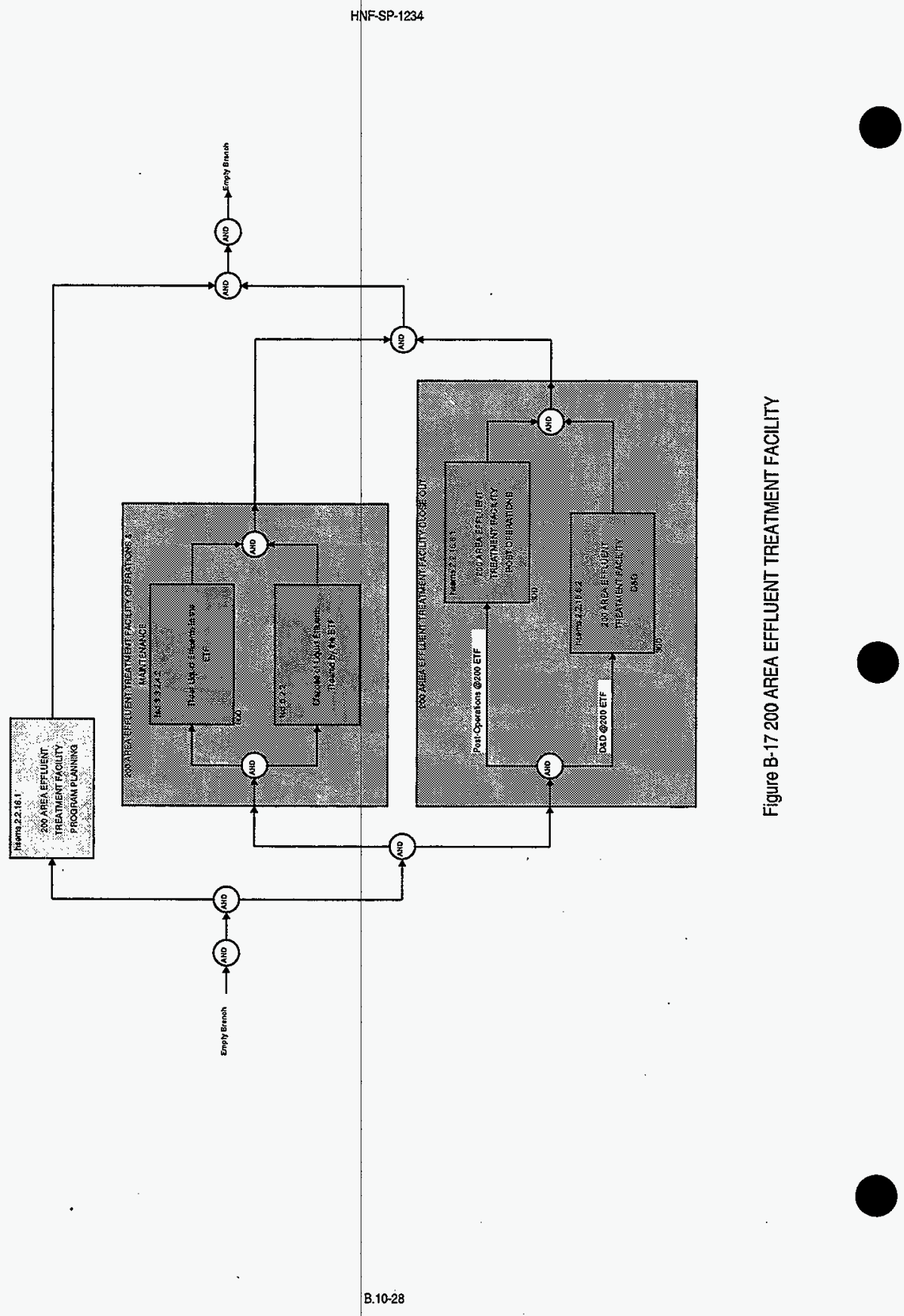




\section{B.10.1.3.7.3 200 Area Effluent Treatment Facility Requirements and Life Cycle Function Descriptions} Requirements:

* Central Plateau high cost surplus facilities shall be transitioned to a low cost, stable, deactivated condition

* Central Plateau inactive facilities shall be maintained within the approved safety envelope

* 200 Area ETF shall be maintained within the approved safety envelope

* 200 Area ETF shall be operated within the approved safety envelope

\section{Life Cycle Function Descriptions:}

\section{B.10.1.3.7.3.1 200 AREA EFFLUENT TREATMENT FACILITY POST OPERATIONS WORK SCOPE SUMMARY}

Day-to-day work, including pre-stabilization surveillance and maintenance, stabilization, post-stabilization surveillance and maintenance, deactivation, and post-deactivation surveillance and maintenance, that is required to allow safe decontamination and decommissioning.

\section{AREA EFFLUENT TREATMENT FACILITY POST OPERATIONS SPECIFIC FUNCTIONS}

\section{B.10.1.3.7.3.2 Maintain Safe \& Compliant 200 Area Effluent Treatment Facility in CP Areas}

Maintain the 200 Area ETF facility structures, operating systems and equipment, and monitoring systems within the approved safety and compliance requirements until the facilities are made available for clean-up.

\section{B.10.1.3.7.3.3 Transition 200 Area Effluent Treatment Facility}

Initiate the transition phase of decontamination and decommissioning for the 200 Area Effluent Treatment Facility

\section{B.10.1.3.7.4 200 Area Effluent Treatment Facility Boundary Diagram}

Table B.10-7 200 Area Effluent Treatment Facility Boundary Diagram

\begin{tabular}{|c|c|}
\hline $\begin{array}{l}\text { Extemal Interfaces } \\
\text { - None- } \\
\text { Hanford Site Environmental System Interfaces } \\
\text {-None- }\end{array}$ & $\begin{array}{l}\text { Extemal Interfaces } \\
\text { None- } \\
\text { Hantord Site Environmental System Interlaces } \\
\text { hsems.2.57 Central PlateauLLiouid Sanitary Waste System }\end{array}$ \\
\hline
\end{tabular}


B.10.1.3.7.5 200 Area Effluent Treatment Facility Interface Description and Forecast EXTERNAL INPUTS -NoneINTERNAL INPUTS
-None-

\section{EXTERNAL OUTPUTS} -None-

\section{INTERNAL OUTPUTS}

\section{Table B.10-8 Internal Outputs for 200 Area Effluent Treatment Facility}

\begin{tabular}{|c|c|c|c|c|}
\hline Stream & Categon & Period & Baseline & Units \\
\hline $\begin{array}{l}\text { hsems.2.5.7 Central Plateau Liquid Sanitary Waste System } \\
\text { ETF, Sanitary Liquid Waste } \\
\text { Sanitary Liquid Waste from day to day operations of treated liquid wo }\end{array}$ & $\begin{array}{l}\text { Santitary Liquid Waste } \\
\text { astes. }\end{array}$ & $1998-2032$ & 17.5 & Mgal \\
\hline
\end{tabular}




\section{B.10.1.3.8 Transuranic Storage and Assay Facility}

\section{B.10.1.3.8.1 Transuranic Storage and Assay Facility Description}

The Transuranic Storage and Assay Facility (TRUSAF) provides storage for TRU and TRUM waste in drums. Limited assay capability is provided. TRUSAF is assumed to have a capacity of 200055 -gal drums, or 520 cubic meters.

\section{B.10.1.3.8.2 Transuranic Storage and Assay Facility Facility Technical Logic:}

The technical logic for the Transuranic Storage and Assay Facility is captured in the facility's functional flow block diagram which shows the functions performed for each applicable life cycle phase of the facility and the sequence in which the functions are executed. 
HNF-SP-1234

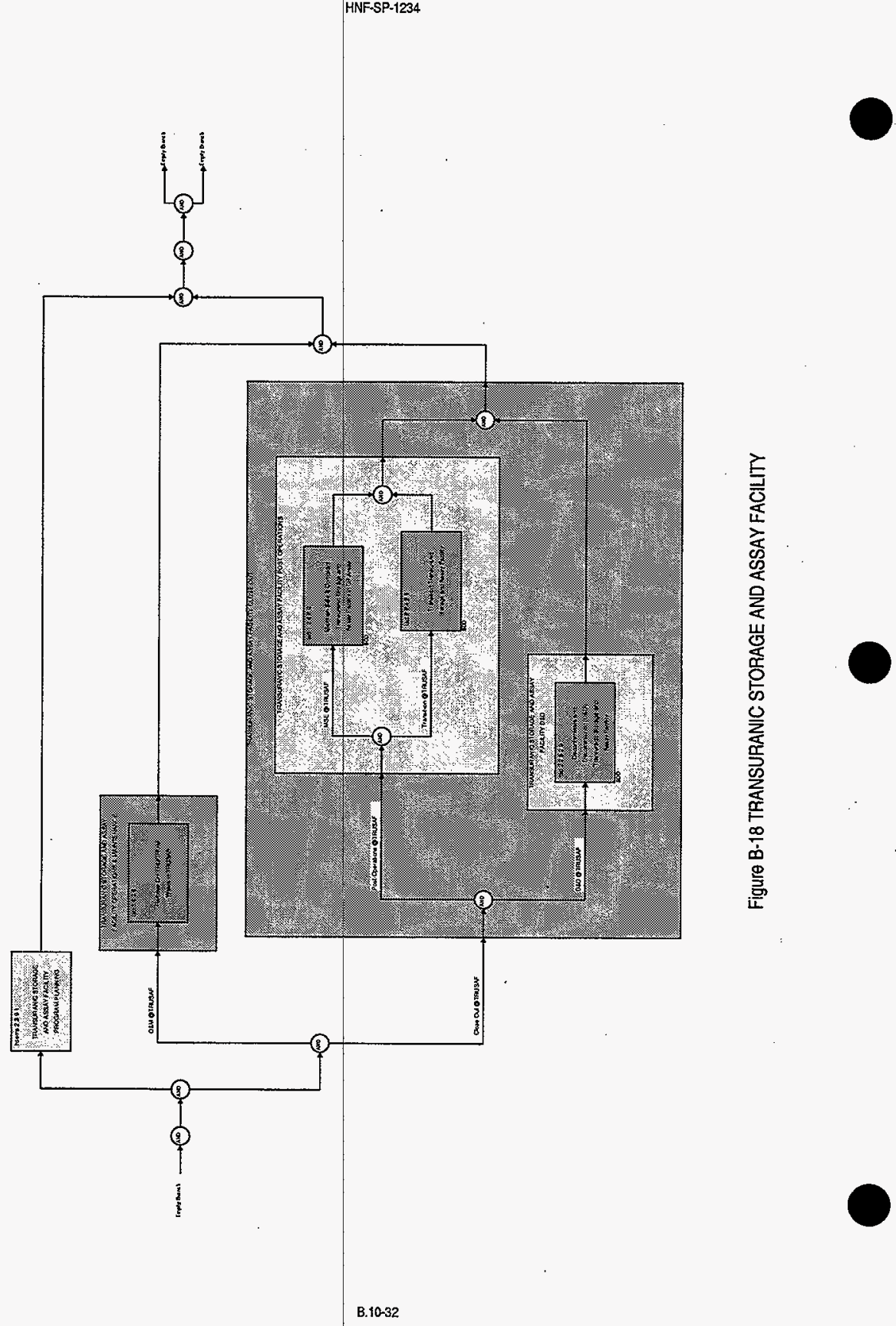


B.10.1.3.8.3 Transuranic Storage and Assay Facility Requirements and Life Cycle Function Descriptions Requirements:

-None-

Life Cycle Function Descriptions:

\section{B.10.1.3.8.3.1 TRANSURANIC STORAGE AND ASSAY FACILITY POST OPERATIONS WORK SCOPE SUMMARY}

Day-to-day work, including pre-stabilization surveillance and maintenance, stabilization, post-stabilization surveillance and maintenance, deactivation, and post-deactivation surveillance and maintenance, that is required to allow safe decontamination and decommissioning.

TRANSURANIC STORAGE AND ASSAY FACILITY POST OPERATIONS SPECIFIC FUNCTIONS

\section{B.10.1.3.8.4 Transuranic Storage and Assay Facility Boundary Diagram}

Table B.10-9 Transuranic Storage and Assay Facility Boundary Diagram

\begin{tabular}{|l|l|}
\hline $\begin{array}{l}\text { Extemal Interlaces } \\
\text { None- } \\
\text { Hanford Site Environmental System Interfaces } \\
\text { None- }\end{array}$ & $\begin{array}{c}\text { External Interfaces } \\
\text {-None- } \\
\text { Hanford Site Environmental System Interiaces } \\
\text {-None- }\end{array}$ \\
\hline
\end{tabular}


B.101.3.8.5 Transuranic Storage and Assay Facility Interface Description and Forecast

EXTERNAL INPUTS

-None-

INTERNAL INPUTS

-None-

EXTERNAL OUTPUTS

-None-

INTERNAL OUTPUTS

-None- 


\section{B.10.1.3.9 222-S Laboratory Facility}

\section{B.10.1.3.9.1 222-S Laboratory Facility Description}

The 222-S Laboratory is a laboratory facility in the 200-W Area of Hanford used for characterization of high level radioactive waste/materials. It was buitt in 1950-1951 and houses an analytical laboratory and a chemical sciences laboratory. Two of its three general areas contain radionuclides.

\section{B.10.1.3.9.2 222-S Laboratory Facility Technical Logic:}

The Department of Energy (DOE), in partnership with its contractors, shall plan, acquire, operate, maintain, and dispose of physical assets as valuable national resources. Stewardship of these physical assets shall be accomplished in a cost-effective manner to meet the DOE mission. This shall incorporate industry standards, a graded approach, and performance objectives. 


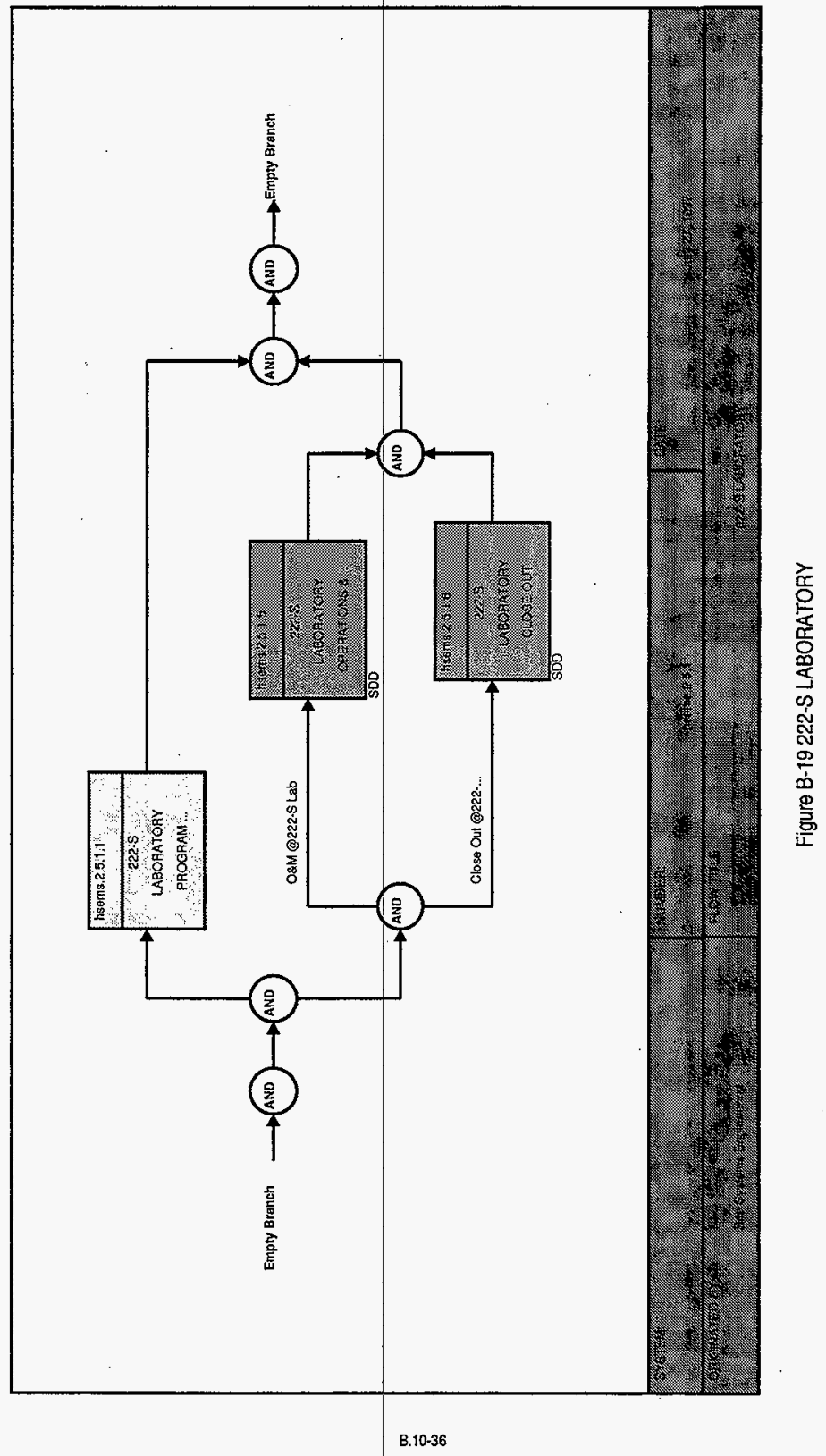




\section{B.10.1.3.9.3 222-S Laboratory Requirements and Life Cycle Function Descriptions}

Requirements:

-None-

\section{Life Cycle Function Descriptions:}

\section{B.10.1.3.9.3.1 222-S LABORATORY POST OPERATIONS WORK SCOPE SUMMARY}

Day-to-day work, including pre-stabilization surveillance and maintenance, stabilization, post-stabilization surveillance and maintenance, deactivation, and post-deactivation surveillance and maintenance, that is required to allow safe decontamination and decommissioning.

\section{2-S LABORATORY POST OPERATIONS SPECIFIC FUNCTIONS}

\section{B.10.1.3.9.4 222-S Laboratory Boundary Diagram}

Table B.10-10 222-S Laboratory Boundary Diagram

\begin{tabular}{|l|l|}
\hline $\begin{array}{l}\text { Extemal Interiaces } \\
\text {-None- } \\
\text { Hanford Site Environmental System Interiaces } \\
\text {-Nene- }\end{array}$ & $\begin{array}{l}\text { External Interfaces } \\
\text {-None- } \\
\text { Hanford Site Environmental System Interfaces } \\
\text { Noge- }\end{array}$ \\
\hline
\end{tabular}


B.10.1.3.9.5 222-S Laboratory Interface Description and Forecast

EXTERNAL INPUTS
-NONE-
INTERNAL INPUTS
-NONE-
EXTERNAL OUTPUTS
-NONE-
INTERNAL OUTPUTS
-NONe-

-None- 


\section{B.10.1.4 Drivers for Accelerated Deactivation Project}

Table B.10-11 Source Documents for Accelerated Deactivation Project

Name

95-LEP-015

DOE/EIS-0222D

DOE/RL-89-10

DOE/RL-96-14

DOE/RL-96-92

WHC-SD-W105-SAR-001
Iitie

LERF Treatment Exemption

Draft Hanford Remedial Action Environmental Impact Statement and Comprehensive Land Use Plan

Hanford Federal Facility Agreement and Consent Order (Tri-Party Agreement), Rev.4

Updated Dratt Mission Direction Document, June 1996

Hanford Strategic Plan

LERF Safety Analysis Report

\section{B.10.1.5 Accelerated Deactivation Project Risk Management}

There are 39 non-mobile contaminated facilties that are assumed to either currently no longer have a viable mission or are expected to no longer have viable missions after FY 2000.

Most of the facilities covered in this project are not in close proximity to the Columbia River or other areas occupied by the general public. The facilities are contaminated with both radiological and hazardous materials. Contaminants of concern include cesium, strontium, uranium, mixed fission products, fuels processing and chemical contamination that includes various acids and bases, and a wide variety of cleaning agents and solvents. Many of these facilities have also exceeded their design life. A fire, containment system failures or structural collapse due to natural causes or facility deterioration could result in a release of contaminants to the environment via air, ground and water pathways overexposing on-site workers and the environment. Most areas outside these facilities already contain radiological and hazardous contaminants in the soil and an additional release of contaminants would further complicate and increase the scope of decontamination and decommissioning (D\&D) and future operable unit remediation activities as well as the risk associated with performance of these actions.

Work activities likely to place the workers at risk include: removing inventory materials [Special Nuclear Materials, Nuclear Materials, Nuclear Fuel (SNM/NM/NF)]; flushing, isolating and blanking of process or subprocess systems; removing radioactive and hazardous materials and mixed wastes; deactivating non-essential systems and utilities; reconfiguring systems to facilitate long-term surveillance and maintenance (LTS\&M) and eventual decontamination and decommissioning (D\&D); "mothballing" of systems necessary for LTS\&M and D\&D; limited decontaminating and stabilizing of radioactive contamination; and closing facility penetrations to prevent bird, animal and weather intrusion. 
HNF-SP-1234

B. $10-40$ 


\section{Accelerated Deactivation Work Breakdown Structure}

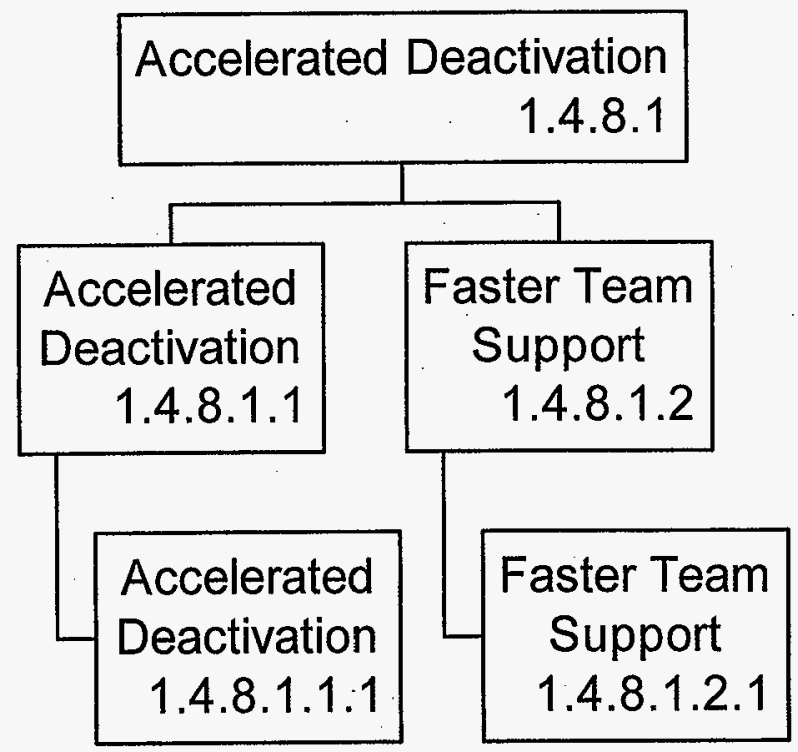


HANFORD SITE WORK BREAKDOWN STRUCTURE DICTIONARY

FACILITYY STABILIZATION

WBS: 1.4

$9 / 11 / 1997$

\begin{tabular}{|l|l|l|l|l|}
\hline $\begin{array}{l}\text { I. Activity Tit7e: } \\
\text { ACCELERATED DEACTIVATION }\end{array}$ & $\begin{array}{l}\text { 2. Date } \\
7 / 31 / 1997\end{array}$ & $\begin{array}{l}\text { 3. PBS Number } \\
\text { RL-TP10 }\end{array}$ & $\begin{array}{l}\text { 4. Dict Rev } \\
0\end{array}$ \\
\hline
\end{tabular}

5. Contract WBS No. 1.4.8.1.1

6. Corresponding FDS No. 7. Baseline CR No. KA1

8. Organization Name

17000

10. Scope of Work

This activity provides support to establish and maintain the facility within the authorization basis and compliant with environmental and regulatory laws and regulations. It includes requirements for project management, compliance activities, evaluations, routine radiological control, operations surveillance, waste handling, and preventative and corrective maintenance activities. This activity also includes facility assessments as well as minimum safe upgrades which may be necessary. Additionally, this activity includes tasks which may result in risk and/or cost reductin for minimum safe surveillance and maintenance. 
HANFORD SITE WORK BREAKDOWN STRUCTURE DICTIONARY FACILITY STABILIZATION

HBS: 1.4

$9 / 11 / 1997$

\begin{tabular}{|l|l|l|l|}
\hline $\begin{array}{l}\text { 1. Activity Title: } \\
\text { FASTER TEAM SUPPORT }\end{array}$ & $\begin{array}{l}\text { 2. Date } \\
7 / 31 / 1997\end{array}$ & $\begin{array}{l}\text {. PBS Number } \\
\text { RL-TP10 }\end{array}$ \\
\hline $\begin{array}{l}\text { 5. Contract WBS No. } \\
1.4 .8 .1 .2\end{array}$ & $\begin{array}{l}\text { 6. Corresponding FDS No. } \\
\text { KA2 }\end{array}$ & 7. Baseline CR No. \\
\hline
\end{tabular}

8. Organization Name

17000

10. Scope of Work

This activity provides support to disseminate deactivation methods and practices throughout the DOE complex. Specifically, it involves

'jumpstarting' projects by assisting with the development of project end points, project management plans, safety authorization bases, regulatory strategies, reengineering of business processes, work breakdown structures and bases for cost estimates, and other project management elements. This activity also includes information transfer through upfront training to project teams, conferences and seminar attendance, development of lessons learned documents, and updating the EM-60 Deactivation Handbook. Additionally, it provides technical assistance to projects with specific and often unique technical issues. 


\section{FACILITY STABILIZATION}

Mission Area Responsibility Assignment Matrix

\begin{tabular}{|l|l|l|l|l|l|}
\hline $\begin{array}{l}\text { Proj LVI } \\
(\text { PBS \#) }\end{array}$ & $\begin{array}{l}\text { FOS Act } \\
\text { Number }\end{array}$ & Activity Title & Activity Manager & Responsible Organization & Cost Account \\
\hline RL-TP10 & & ACCELERATED DEACTIVATION & & & \\
\hline & KA1 & ACCELERATED DEACTIVATION & J. P. Hayfield & 17000 & 1 KA101 \\
\hline & KA2 & FASTER TEAM SUPPORT & J. P. Hayfield & 17000 & 1 KA201 \\
\hline
\end{tabular}




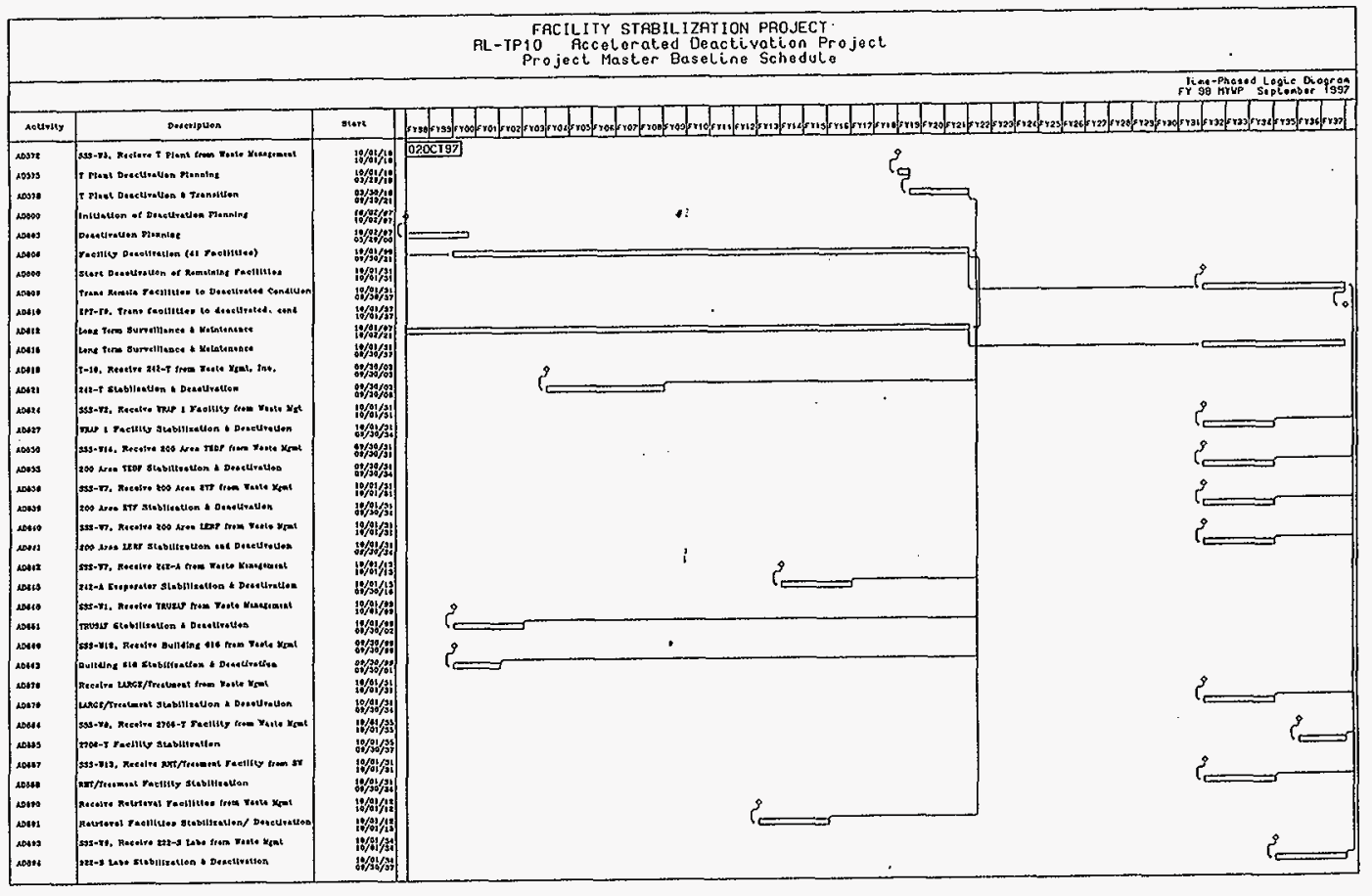




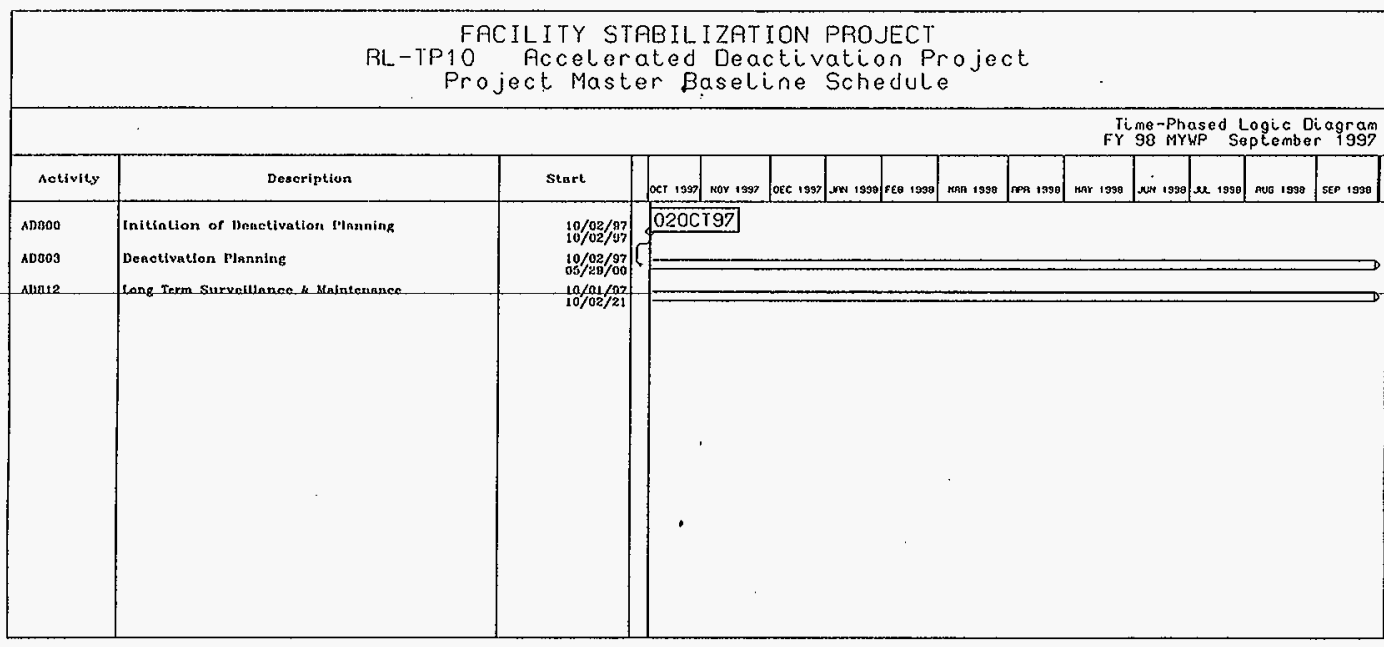


(\$000s)

\begin{tabular}{|c|c|c|c|c|c|c|c|c|c|c|c|}
\hline PROJECT WBS: & $\frac{1.4 .8 .1}{\text { RL-TP10 }}$ & & & & & & & & & & \\
\hline $\begin{array}{r}\text { PBS NO: } \\
\text { PBS TITLE: }\end{array}$ & $\frac{\text { RL-TP10 }}{\text { Accelerated }}$ & Deactivatio & & & & & & & & & SUBTOT \\
\hline $\begin{array}{l}\text { FUND } \\
\text { TYPE }\end{array}$ & FY1997 & 期 & FY1999 & $F Y 2000$ & FY2001 & FY2002 & FY2003 & FY2004 & FY2005 & FY2006 & $\begin{array}{l}\text { FY1997- } \\
\text { FY2006 }\end{array}$ \\
\hline OPERATING EXPENSE & & (152 & 1,445 & 3,583 & 2,666 & 2,503 & 3,345 & 3,164 & 2,971 & 2,778 & 25,171 \\
\hline & & s. & & & & & & & & & \\
\hline GENRTC & & 15 & & & & & & & & & - \\
\hline & & Sis & & & & & & & & & \\
\hline GENERAL PLANT PROJECT & & Fis; & & & & & & & & & - \\
\hline & & 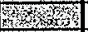 & & & & & & & & & \\
\hline LINE ITEM RIst Each Ono) & & 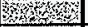 & & & & & & & & & \\
\hline & & 保诲; & & & & & & & & & $\therefore$ \\
\hline & & y. & & & & & & & & & - \\
\hline & & Whin & & & & & & & & & . \\
\hline & & 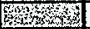 & & & & & & & & & - \\
\hline & & 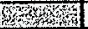 & & & & & & & & & - \\
\hline Subtotal Line /tems & $\dot{-}$ & Wy & $=$ & - & - & + & - & - & $=$ & $=$ & - \\
\hline & & - & & & & & & & & & \\
\hline 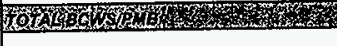 & 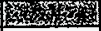 & 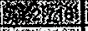 & 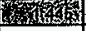 & 4. & 4 & 14 & 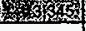 & 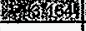 & 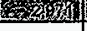 & 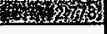 & Its. \\
\hline & & W. & & & & & & & & & - \\
\hline MGMT RESERVE ${ }^{2}$ & & thos & & & & & & & & & - \\
\hline LINE ITEM CONTINGENCY ${ }^{2}$ & & W & & & & & & & & & - \\
\hline & & Xxis & & & & & & & & & \\
\hline OFFSITE TRANSFERS ${ }^{3}$ & & row3. & & & & & & & & & - \\
\hline & & W 1 & & & & & & & & & \\
\hline Subtotal & . & 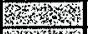 & $\therefore$ & $=$ & 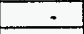 & - & $=$ & - & - & $\therefore$ & - \\
\hline & & 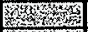 & & & & & & & & & \\
\hline TOTAL & 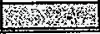 & 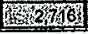 & 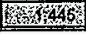 & 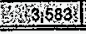 & 28 - & 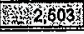 & 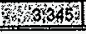 & 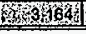 & 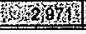 & 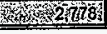 & Mas \\
\hline
\end{tabular}

'Budgeted Cost of Work Scheduled (BCWS) Equals Performance Measurement Baseline (PMB); Expense Caryover NOT included.

${ }^{2}$ Management Reserve and Line llem Contingency Held by RL.

'Work Performed at Sites Other Than Hanford. 
FACILITY STABILIZATION

LIFE CYCLE COST BASELINE (BCWS) BY YEAR BY FUND TYPE BY PROJECT BASELINE SUMMARY (PBS)

FY 1998

$(\$ 000$ s)

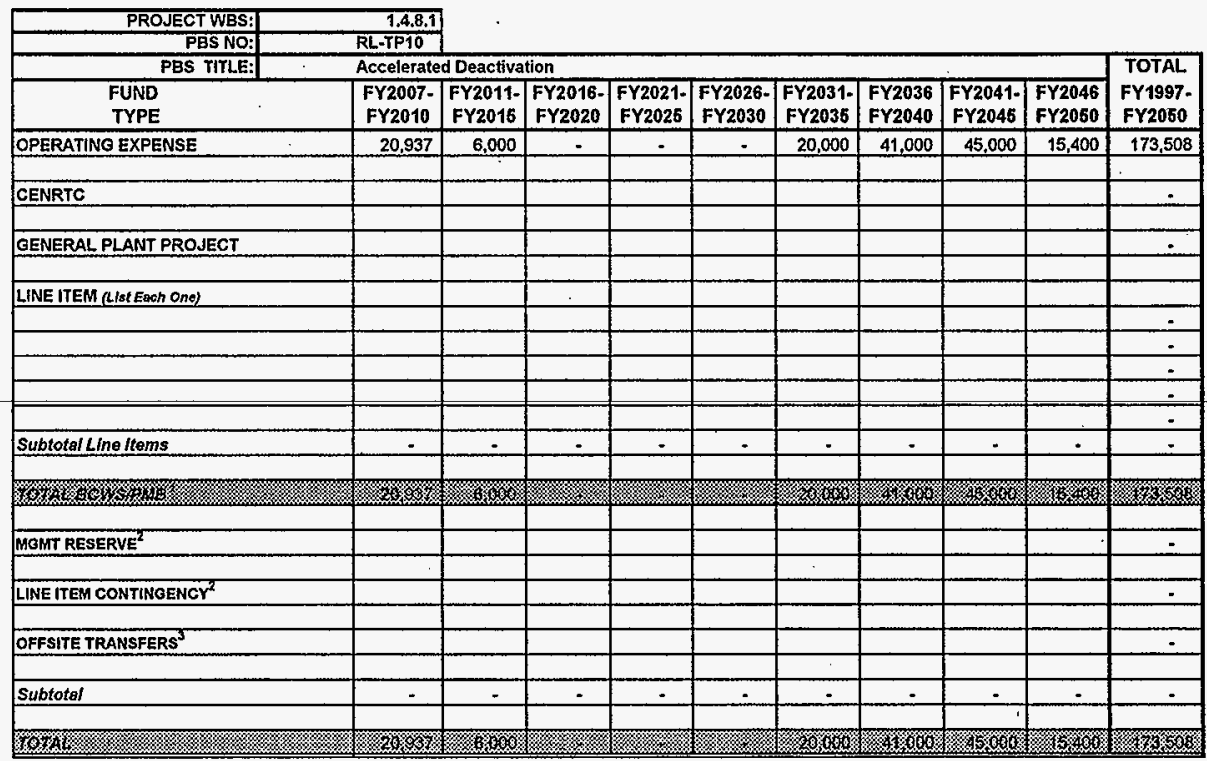

'Budgeted Cost of Work Scheduled (BCWS) Equals Performance Measurement Baseline (PMB);

Expense Caryover NoT Included.

"Management Reserve and Line Item Contingency Held by RL.

'Work Performed at Sites Other Than Hanford. 
FACILITY STABILIZATION

LIFE CYCLE BUDGET AUTHORITY (B/A) BY YEAR BY FUND TYPE

BY PROJECT BASELINE SUMMARY (PBS)

FY 1998

(\$000s)

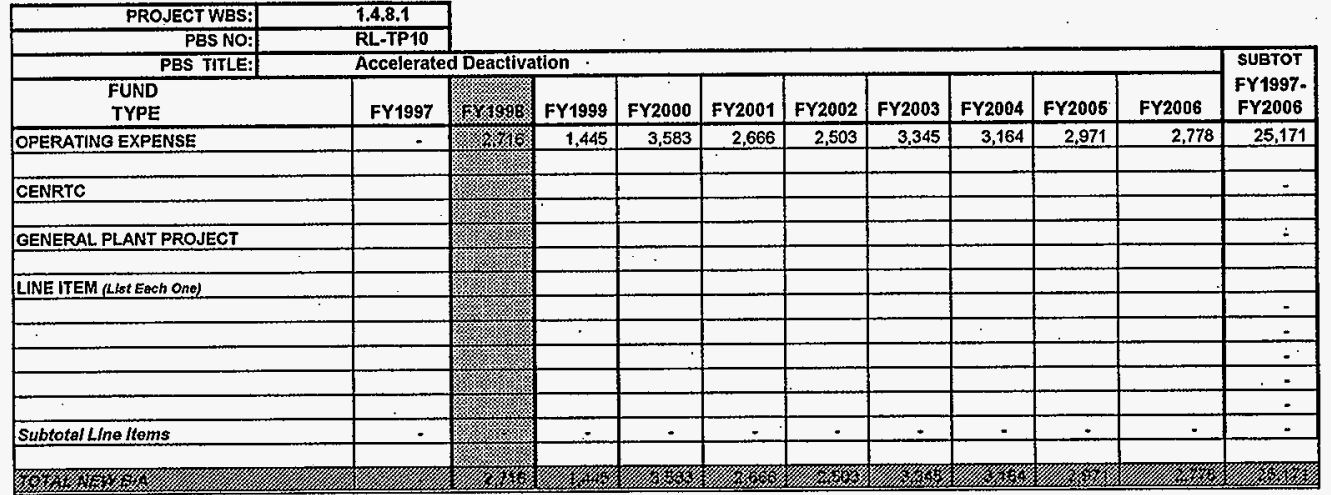


FY 1998

(\$000s)

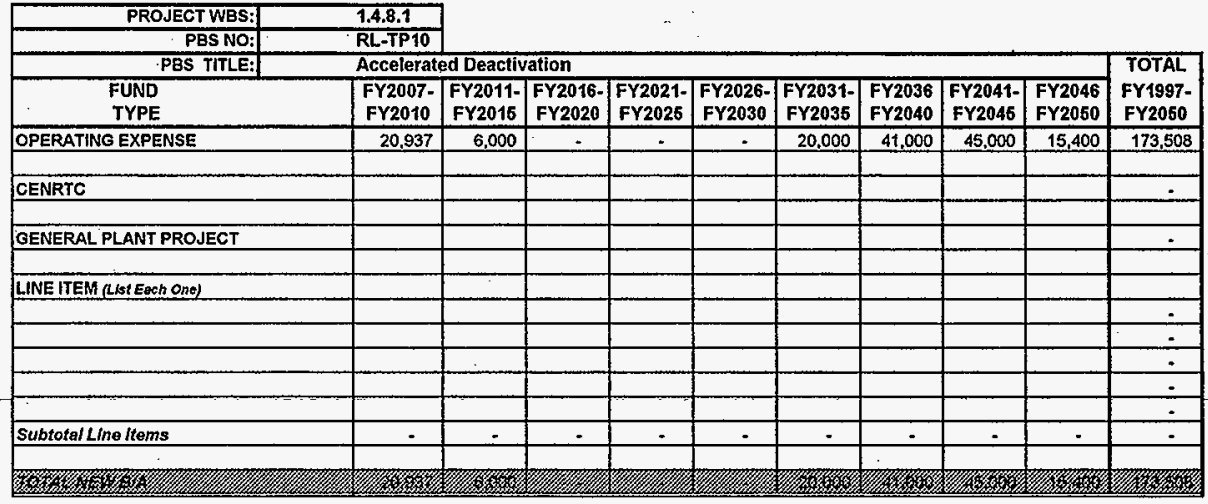


FACILITY STABILIZATION

FY 1998 COST BASELINE (BCWS) BY MONTH

BY PROJECT BASELINE SUMMARY (PBS)

BY ACTIVITY DATA SHEET (ADS)

EXECUTION YEAR

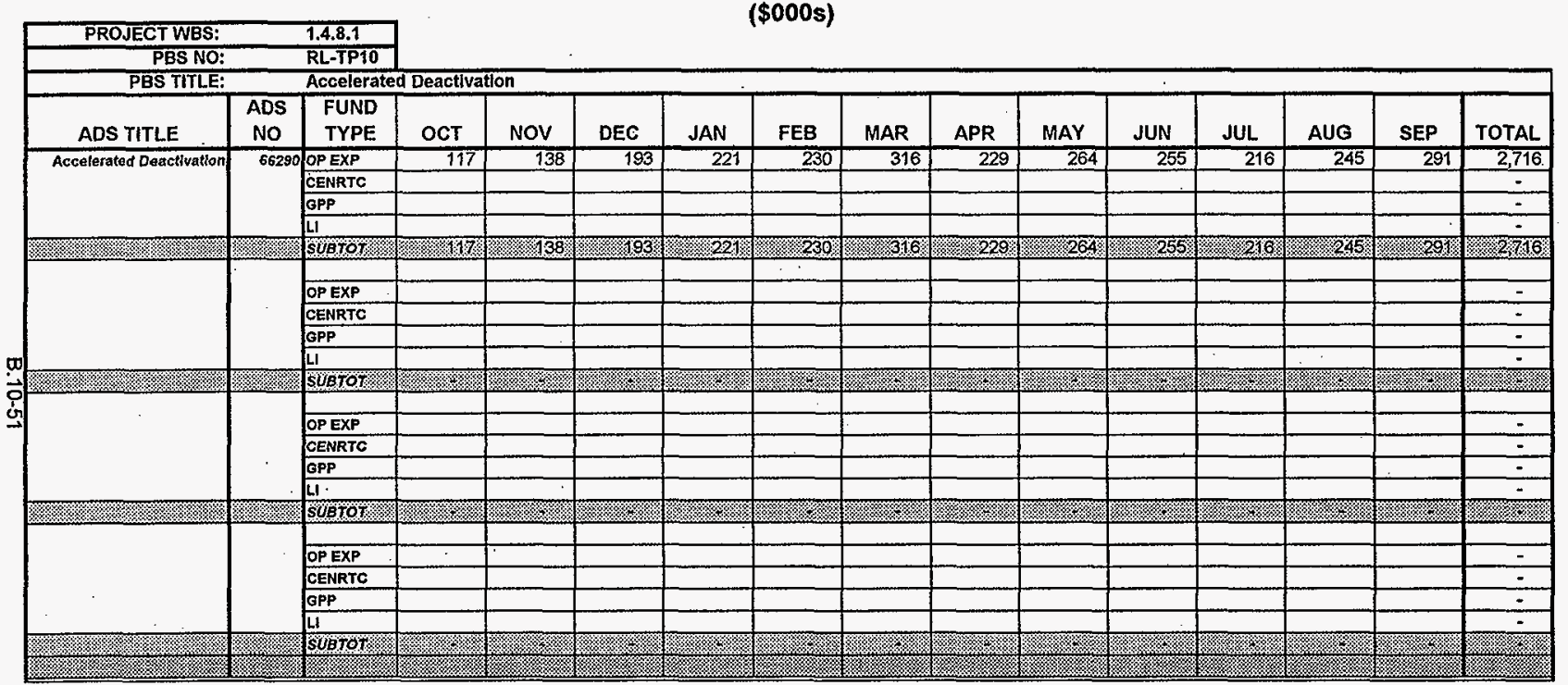

'Budgeted Cost of Work Scheduled (BCWS) Equals Performance Measurement Baseline (PMB); Expense Carryover Is NOT Inciuded. 
FACILITY STABILIZATION

\section{FY 1998 COST BASELINE (BCWS) BY MONTH \\ BY PROJECT BASELINE SUMMARY (PBS) \\ BY ACTIVITY DATA SHEET (ADS) \\ EXECUTION YEAR}

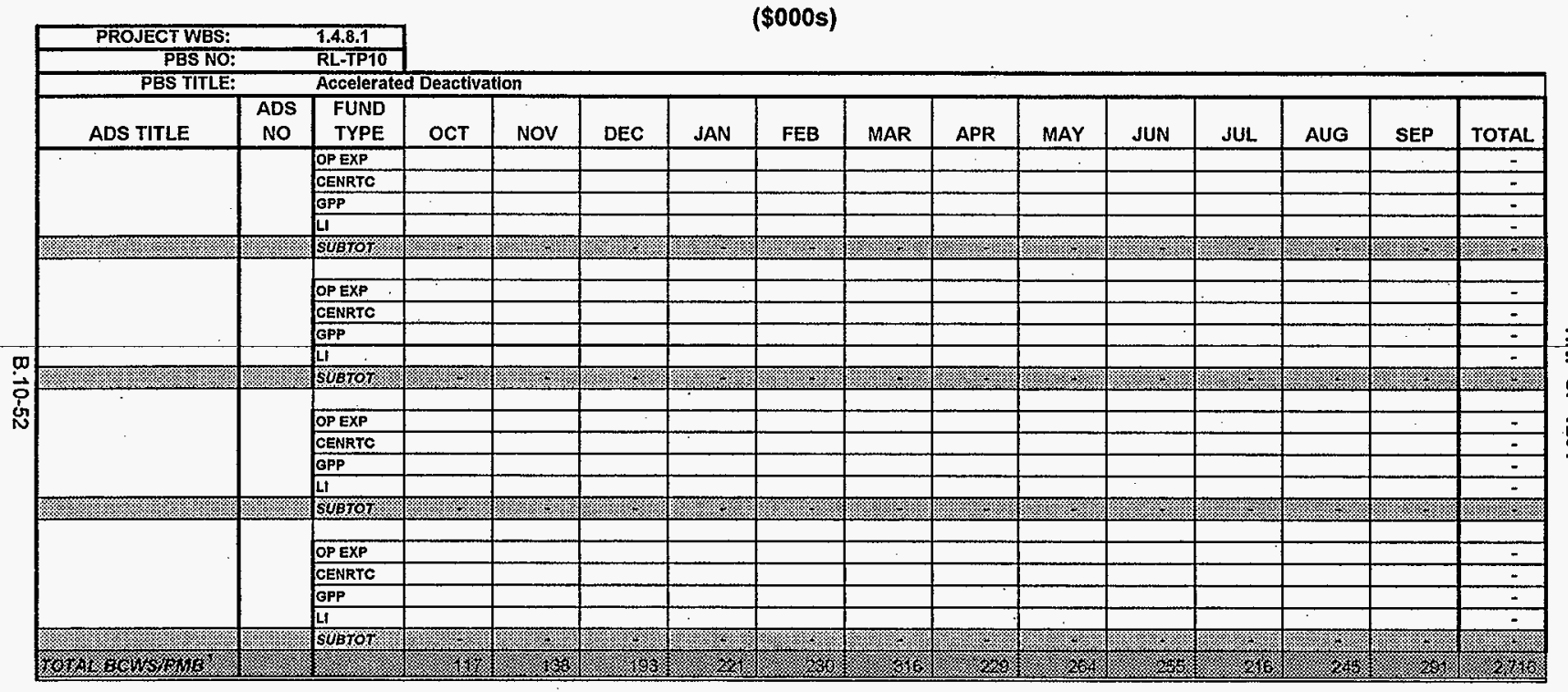

'Budgeted Cost of Work Scheduled (BCWS) Equals Performance Measurement Baseline (PMB); Expense Carryover is NOT Included. 


\section{ACCELERATED DEACTIVATION}

AVERAGE ANNUAL FULL TIME EQUIVALENTS

(includes Major Subcontractors but not Enterprise Companies)

PHBS 1.4.8.1

Submittal Date: 9/10/97

\section{PBS Number}

PBS Title

FY 1998

FY 1999

FY 2000

FY 2001

FY 2002

FY 2003

FY 2004

FY 2005

FY 2006

FY 2007

RL-TP10 Acc. Deac

14

8

22

22

22

22

22

22

22

22

22

22

22

22

22

22

22

22 


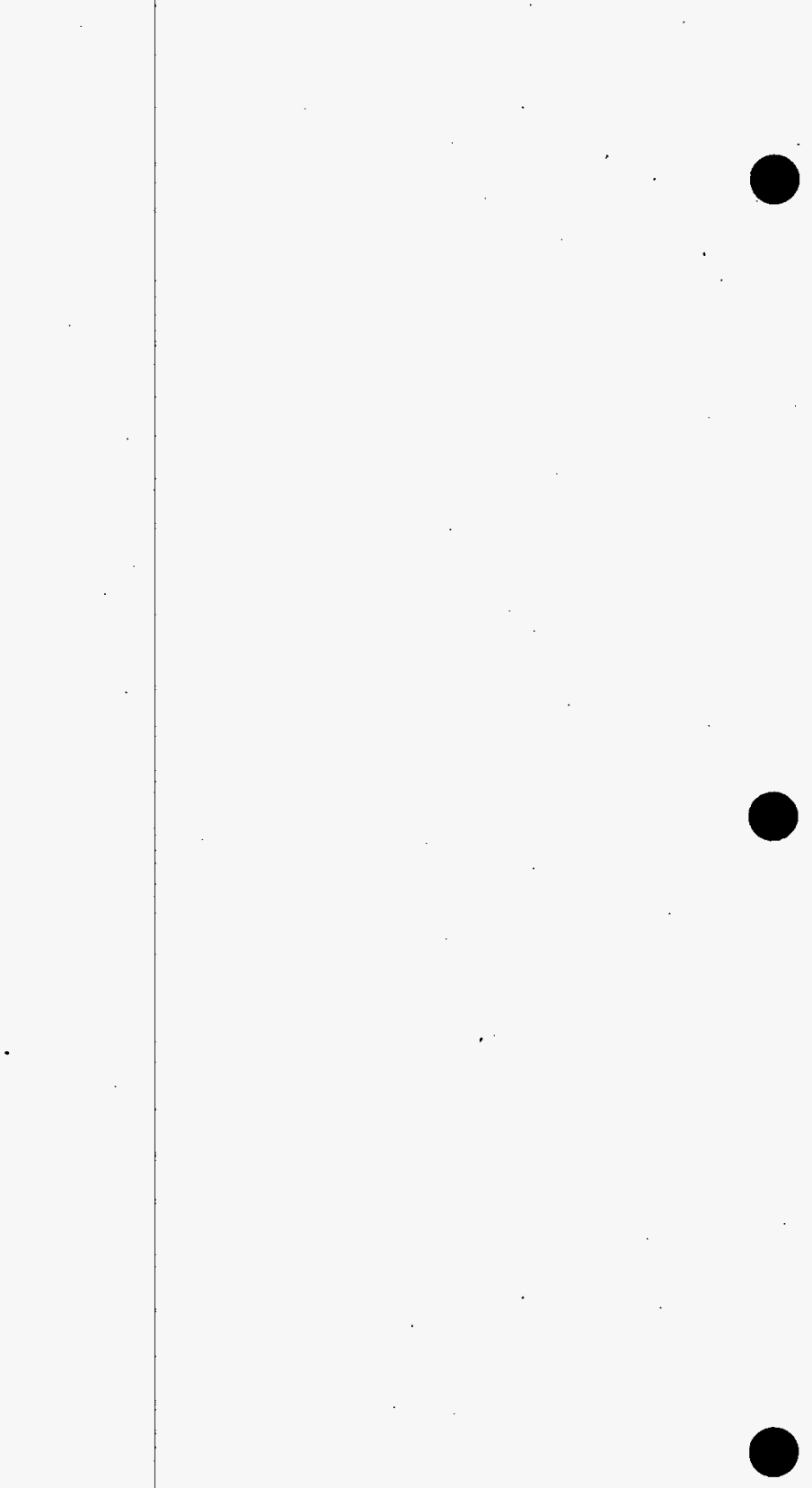




\section{B.11 Transition Project Management (RL-TP12)}

\section{B.11.1.0 Transition Project Management Technical Baseline (RL-TP12)}

\section{B.11.1.1 Transition Project Management Organization Mission (RL-TP12)}

Transition Project Management provides centralized program, project and business management to plan, execute and control the Facility Stabilization Project (FSP). Transition Project Management provides for common safeguard and security (SAS) support; centralized coordination of environmental, safety, health, radiological control and quality assurance; systems engineering (SE); new technology development and implementation support; policies and procedure development; excess facility and material planning (includes development of special projects such as $\mathrm{K}$ Basin deactivation project, Hanford Surplus Facility Program 300 Area Revitalization project, Accelerated Deactivation project, etc.); FSP strategic planning; procurement support; management of Special Nuclear Materials (SNM); and operations integration support. Support for technical development of 200 Area Canyon Entombment, and Fluor Daniel Hanford, Inc. (FDH) project management direction is also provided.

The primary FSP mission is to deactivate contaminated facilities on the Hanford Site, reduce risks to workers, the public and environment, transition the facilities to a low cost, long-term surveillance and maintenance state and to provide safe and secure storage of Special Nuclear Materials, Nuclear Materials, and Nuclear Fuel (SNM/NM/NF). Facility deactivation will protect the health and safety of the public, on-site workers and the environment, and also provides for beneficial use of facilities, equipment and other resources.

As the mission for FSP has shifted from production to support of environmental restoration, each facility is making a transition to support the Site Cleanup Mission. FSP high level mission goals include: achieving deactivation of facilities and turnover of these facilities to EM-40; using Plutonium/Uranium Extraction (PUREX) plant deactivation as a model for future facility deactivation; managing SNM/NM/NF in a safe and secure manner, and where appropriate, in accordance with International Atomic Energy Agency (IAEA) safeguards rules; treating SNM/NM/NF as necessary and storing these materials onsite in long-term storage awaiting final disposition decisions by the U.S. Department of Energy (DOE); implementing nuclear materials disposition directives; working in accordance with the Tri-Party Agreement (TPA), and other compliance agreements; and maintaining compliance with all applicable Federal, state and local laws.

Specific activities include:

Program, Business and Financial Management:

- Prioritize scope and budgets, and support strategic planning.

- Coordinate management of capital-funded activities for FSP.

- Provide direct financial management to all FSP Program activities.

- Prepare budget alternatives and special analyses as requested by DOE or company management.

- Develop and maintain activity-based cost estimates and resource-loaded schedules.

- Prepare and maintain financial documents required by the Site Management System (SMS) and budget planning process including Mutti-Year Program Plans (MYPPs), Activity Data Sheets (ADSs), Cost Account

Authorizations(CAAs), monthly reporting and budget alternatives and analysis.

Environmental Compliance, Safety, Heath, Radiation Control and Quality Assurance:

- Provide central coordination of environmental activities within FSP, including selective central program oversight of the implementation of TPA, environmental protection, facility compliance, and RCRA permitting activities.

- Develop/maintain environmental management system. 
- Participate in the Hanford Central Environmental Committee.

- Develop/maintain Environmental, Safety and Health (ES\&H) Management Plan.

- Provide Waste Minimiaztion/Pollution Prevention/Dangerous Waste reporting.

- Provide Radiation Control technical support and oversight.

- Provide integration of Radiation Control procedures.

- Interface with FDH on Radiation Control issues.

- Track and trend Radiation Control performance indicators.

- Coordinate and integrate identification and resolution of FSP Quality Assurance (QA) issues.

- Provide oversight and direction on QA issues to facility management and personnel.

- Measure, analyze, evaluate and report on the effectiveness of the FSP QA program.

- Maintain the Occupational Safety and Health Administration (OSHA) 200 Occupational Injuries/llnesses (OII) $\log$.

- Determine OSHA recordability classification of Oll's.

- Coordinate all accident information and interface with FDH Safety, FDH Worker's Compensation and Hanford Environment Health Foundation (HEHF).

- Provide Oll case management assistance.

Safeguards and Security:

- Provide support for nonplant-specific administration and coordination of security system engineering, security projects, education and asset protection.

- Provide maintenance and testing support and system development for the Patrol Operations Center (POC) and Alarm Monitoring Operational Support System (AMOSS).

- Maintain the SNM accountability database.

- Develop and maintain policies and procedures governing the use, control, and accountability of SNM.

- Coordinate visits by foreign nationals.

Operations Integration:

- Arrange for expert in plant mentoring \& Conduct of Operations (COO) champions.

- Support COO Champions Program.

- Coordinate facility COO Assessments.

- Provide outside commercial nuclear operations perspective in review of plant operations.

- Support Maintenance Champions Program.

- Coordinate Conduct of Maintenance Self-Assessment Program.

- Support facilities reengineering.

- Distribute lessons learned within FSP and provide input to site-wide lessons learned program.

- Assist in development, review and evaluation of operations Performance Indicators.

Technical integration:

- Support new technology development and implementation.

- Support policies and procedure development.

- Special projects development (i.e. 200 Area Canyon Entombment, K Basin Deactivation project, Hanford Suplus Facility Program 300 Area Revitalization project, Accelerated Deactivation project, and other excess facility planning projects).

- FSP strategic planning.

- Systems engineering.

Systems Engineering:

- Interface with Site SE personnel to develop, under their guidance, Hanford Site specification, interface, and issue documents.

- Maintain the program SE documentation in the Hanford Site Technical Baseline (HSTB).

- Continue development of program-level alternatives, and maintain current selected plant altematives in accordance with division strategic planning. 
- Provide support for Project Project Baseline Summary (PBS), MYPP and other budget documentation development.

- Provide technical support for further development of the plant-level SE components to determine facility cleanup needs and the optimum cleanup strategy.

- Support development of plant and company interface agreements.

- Provide SE guidance, allowing facility work breakdown structures, resource-loaded activity schedules, and other budget documentation to be revised to ensure that FSP technical, cost, and schedule baselines reflect current SE results.

- Provide SE guidance and assistance in the development of SE documents for other existing contaminated facilities entering the FSP program.

- Support excess facility disposition planning.

Nuclear Materials Management:

- Continue development of Plutonium strategies and strategic analysis for Hanford.

- Coordinate SNM material receipts and shipments.

- Develop DOE Order 5660.1B reports (i.e. Inventory Assessment Report, Material Management Plan, etc.).

- Support DOE in development of Disposition Management Plans.

- Special project development (i.e. uranium disposition projects, etc.).

Canyon Entombment:

- Provide technical design support for development of environmental documentation.

- Provide project management support for technical development of canyon disposition options.

Waste Minimization/Pollution Prevention:

- Identify priority waste streams and perform pollution prevention assessments, evaluate and implement poilution prevention opportunities, and report results to DOE and regulators.

B.11.1.2 Transition Project Management End Point Targets from Hanford Strategic Plan

-None-

\section{B.11.1.3 Transition Project Management Major Facilities}

\section{B.11.1.4 Drivers for Transition Project Management}

-None-

\section{B.11.1.5 Transition Project Management Risk Management}

-None- 
HNF-SP-1234

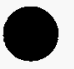

\section{B.11-4}




\section{Transition Project Management Work Breakdown Structure}

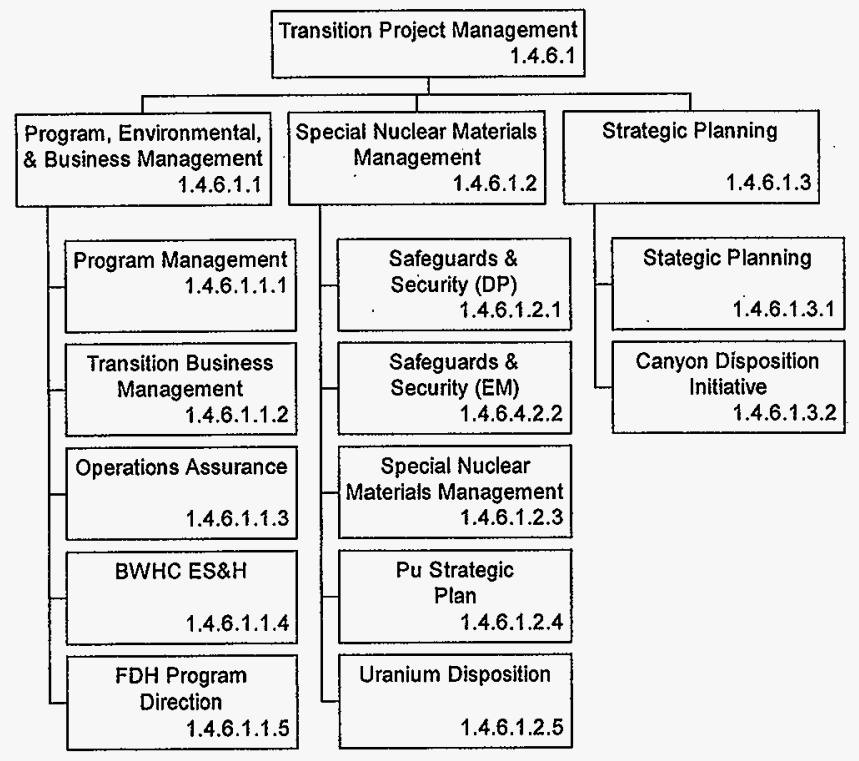


HANFORD SITE WORK BREAKDOWN STRUCTURE DICTIONARY

FACILITY STABILIZATION

WBS: 1.4

\begin{tabular}{|l|l|l|l|l|}
\hline $\begin{array}{l}\text { 1. Activity Title: } \\
\text { PROGRAM, ENVIRONMENTAL, AND BUSINESS MAN }\end{array}$ & $\begin{array}{l}\text { 2. Date } \\
7 / 31 / 1997\end{array}$ & $\begin{array}{l}\text { 3. PBS Number } \\
\text { RL-TP12 }\end{array}$ & $\begin{array}{l}4 . \text { Dict Rev } \\
0\end{array}$ \\
\hline
\end{tabular}

5. Contract WBS No.

1.4.6.1.1

6. Corresponding FDS No. 7. Baseline CR No. K1A

8. Organization Name 11000

10. Scope of Work

The Program, Environmental, and Business Management activity provides management of common resources such as program and environmental management; business management; project control; conduct of operations; financial management and commitment planning; communications support (media response, outreach, public involvement, and employee communication); centralized coordination of environmental, safety, health and quality assurance; operations integration support, and Fluor Daniel Hanford project direction and coordination. Specific tasks include the standardized preparation of Project Baseline Summaries and the Multi-Year Work P1an (MYWP), administration of the Project Status Report; the centralized integration, negotiation, and planning of Facility Stabilization environmental, health, safety, and quality assurance activities; and conduct of performance assessments, publication of lessons learned, and preparation of performance indicators and agreements. 
HANFORD SITE WORK BREAKDOWN STRUCTURE DICTIONARY FACILITY STABILIZATION

WBS: 1.4

\begin{tabular}{|l|l|l|l|l||}
\hline $\begin{array}{l}\text { 1. Activity Title: } \\
\text { SPECIAL NUCLEAR MATERIALS MANAGEMENT }\end{array}$ & $\begin{array}{l}\text { 2. Date } \\
7 / 31 / 1997\end{array}$ & $\begin{array}{l}\text {. PBS Number } \\
\text { RL-TP12 }\end{array}$ & $\begin{array}{l}\text { 4. Dict Rev } \\
0\end{array}$ \\
\hline $\begin{array}{l}\text { 5. Contract WBS No. } \\
1.4 .6 .1 .2\end{array}$ & $\begin{array}{l}\text { 6. Corresponding FDS No. } \\
\text { K1B }\end{array}$ & 7 Basel ine CR No. \\
\hline
\end{tabular}

8. Organization Name 11000

9. $B \& R$ No.

10. Scope of Work

The Special Nuclear Material (SNM) Management activity provides development, maintenance, and implementation of policies and procedures governing the use, control, and overview of transportation and accountability of SNM to ensure compliance with DOE orders; supports development of disposition strategies for uranium and plutonium and other SNM; supports activities to maintain site security requirements; and supports the design and installation of safeguards and security system upgrades for Facility Stabilization Project facilities. 
HANFORD SITE WORK BREAKDOWN STRUCTURE DICTIONARY FACILITY STABILIZATION

WBS: 1.4

\begin{tabular}{|l|l|l}
\hline $\begin{array}{l}\text { 1. Activity Title: } \\
\text { STRATEGIC PLANNING }\end{array}$ & $\begin{array}{c}\text { Date } \\
7 / 31 / 1997\end{array}$ \\
$\begin{array}{l}\text { RL-TP12 } \\
\text { RTAS Number }\end{array}$ & $\begin{array}{l}4 . \text { Dict Rev } \\
0\end{array}$ \\
\hline
\end{tabular}

5. Contract WBS No. 1.4 .6 .1 .3

6. Corresponding FDS No. 7. Baseline CR No. K1C

8. Organization Name 11000

10. Scope of Work

The Strategic Planning activity provides support for further development of the strategy to deactivate facilities and store special nuclear material/nuclear material/spend nuclear fuel. Specific activites include: coordinating and assisting in the development and revision of facilityspecific systems engineering (SE) documentation; supporting the further development of the Hanford Site and Facility Stabilization SE effort; supporting revisions to the Hanford Site-level SE documentation; and supporting the development of the 200 Area Canyon Disposition docurnentation. 
Mission Area Responsibility Assignment Matrix

\begin{tabular}{|c|c|c|c|c|c|}
\hline $\begin{array}{l}\text { Proj Lv] } \\
\text { (PBS \#) }\end{array}$ & $\begin{array}{l}\text { FDS Act } \\
\text { Number }\end{array}$ & Activity Title & Activity Manager & Responsible Organization. & Cost Account \\
\hline \multirow[t]{4}{*}{ RL-TP12 } & & TRANSITION PROJECT MANAGEMENT & & & \\
\hline & KIA & PROGRAM. ENVIRONMENTAL. AND BUSINESS MANAGEMENT & J. 0 . Lundeen & 11000 & $\begin{array}{l}\text { 1K1A01 } \\
\text { 1K1A02 } \\
1 \mathrm{~K} 1 \mathrm{A03} \\
1 \mathrm{~K} 1 \mathrm{~A} 04 \\
\text { 1K1A05 }\end{array}$ \\
\hline & K1B & SPECIAL NUCLEAR MATERIALS MANAGEMENT & R. R. Borisch & 11000 & $\begin{array}{l}\text { 1K1B01 } \\
\text { 1K1B02 } \\
1 \mathrm{~K} 1 \mathrm{~B} 03 \\
1 \mathrm{~K} 1 \mathrm{~B} 04 \\
1 \mathrm{~K} 1 \mathrm{~B} 05\end{array}$ \\
\hline & K1C & STRATEGIC PLANNING & G. L. McCormick & 11000 & $\begin{array}{l}1 \mathrm{~K} 1 \mathrm{CO} 1 \\
1 \mathrm{~K} 1 \mathrm{C} 02\end{array}$ \\
\hline
\end{tabular}




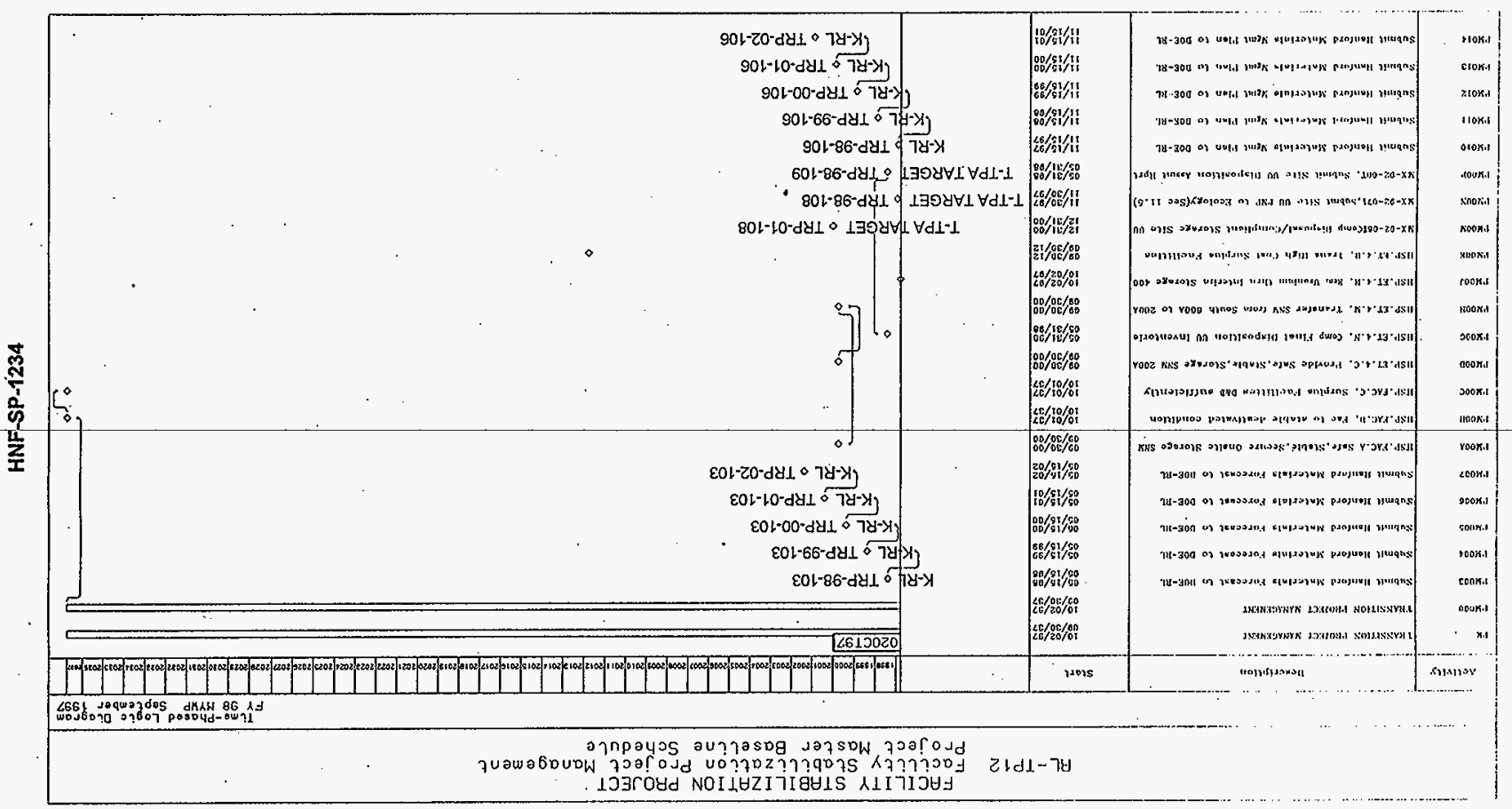


FACILITY STABILIZATION PROJECT

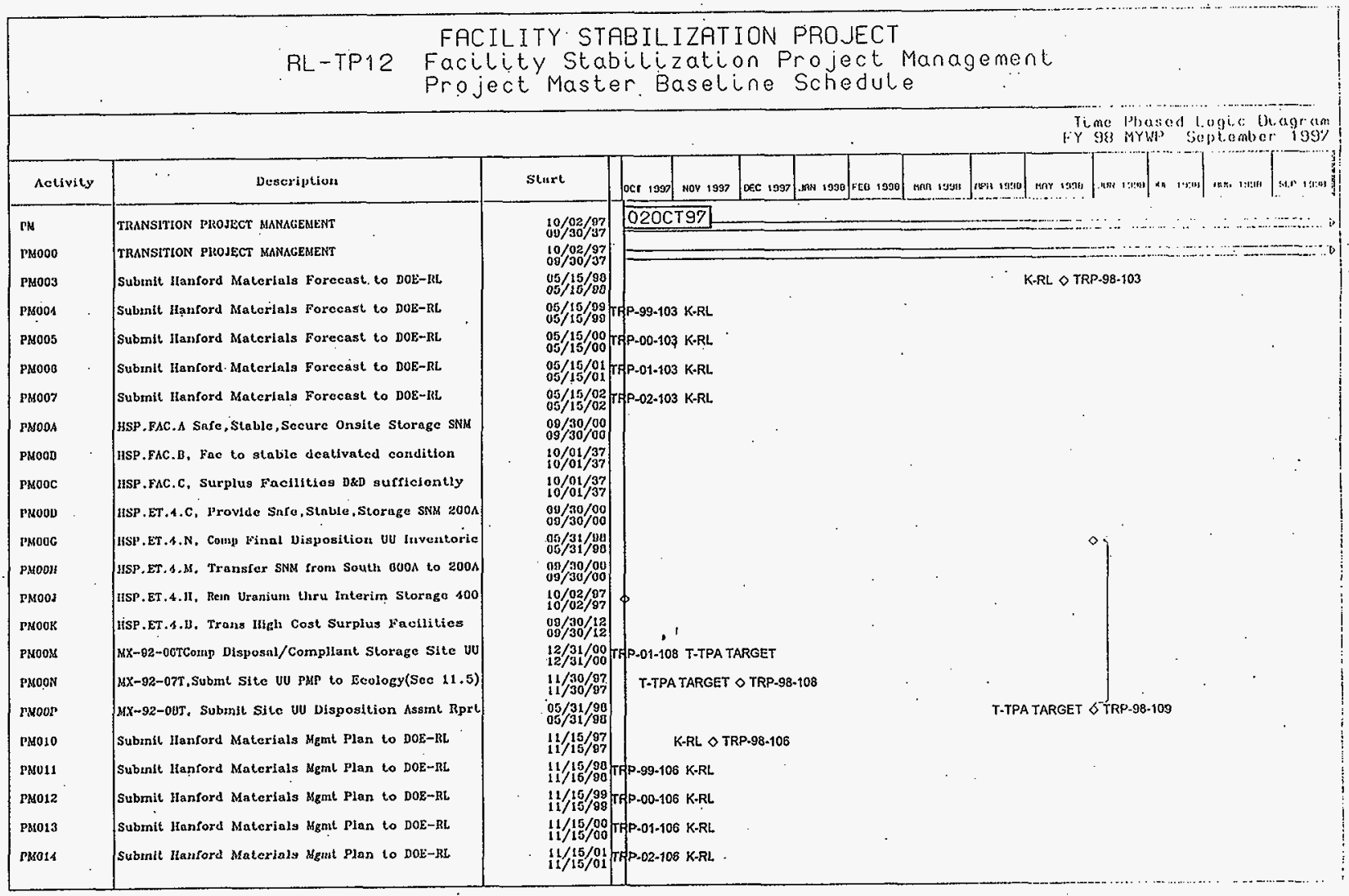




\begin{tabular}{|c|c|c|}
\hline MILESTONE & TPA-MS & TPA \\
\hline CONTROL \# & NUMBER & TYPE \\
\hline & - &.- \\
\hline TRP-98-108 & M-92-07-T01 & $T$ \\
\hline TRP-98-109 & M-92-08-T01 & $T$ \\
\hline TRP-98-103 & & \\
\hline TRP-98-106 & - & \\
\hline TRP-99-103 & & \\
\hline TRP-99-106 & & \\
\hline TRP-00-103 & & \\
\hline TRP $-00-106$ & & \\
\hline TRP-01-103 & & \\
\hline TRP-01-106 & & \\
\hline TRP-02-103 & & \\
\hline TRP-02-106 & & \\
\hline TRP-01-108 & M-92-06-T01 & $\mathrm{T}$ \\
\hline
\end{tabular}

TYPE BASELINE

SUBMIT DRAFT HANFORD SITE UNIRRADIATED URANIUM PROJ, MGMT. PLAN

SUBMIT HANFORD SITE UNIRRADIATED URANIUM DISPOSITION ASSESS. RPT. OTH $5 / 31 / 98$

SUBMIT HANFORD MATERIALS FORECAST TO DOE-RL

SUBMIT HANFORD MATERIALS MANAGEMENT PLAN TO DOE-RL.

SUBMIT HANFORD MATERIALS FORECAST TO DOE-RL

SUBMIT HANFORD MATERIALS MANAGEMENT PLAN TO DOE-RL

SUBMIT HANFORD MATERIALS FORECAST TO DOE-RL.

SUBMIT HANFORD MATERIALS MANAGMENT PLAN TO DOE-RL SUBMIT HANFORD MATERIALS FORECAST TO RL.

SLBBMIT HANFORD MATERIÁLS MANAGEEMENT PLAN TO RL

COMPLETE DISPOSITION/COMPLIANT STORAGE FOR ALL. SITE UU
PLANNED

$5 / 15 / 98$

$11 / 15 / 97$

$5 / 15 / 99$

$11 / 15 / 98$

$5 / 15 / 00$

$11 / 15 / 99$

$5 / 15 / 01$

$11 / 15 / 00$

DATES-

APPROVED

BASELINE

PROJ CIN

PBS \#

RL-TP12

RL-TP12

RL. -TP12

RL-TP12

RL-TP12

RL-TP12

RL-TP12

RL-TP12

RL-TP12

RL-TP12

5/15/02

$12 / 31 / 00$
RL-TP12

RL-TP12 


\section{PHMC}

MILESTONE DESCRIPTION SHEET

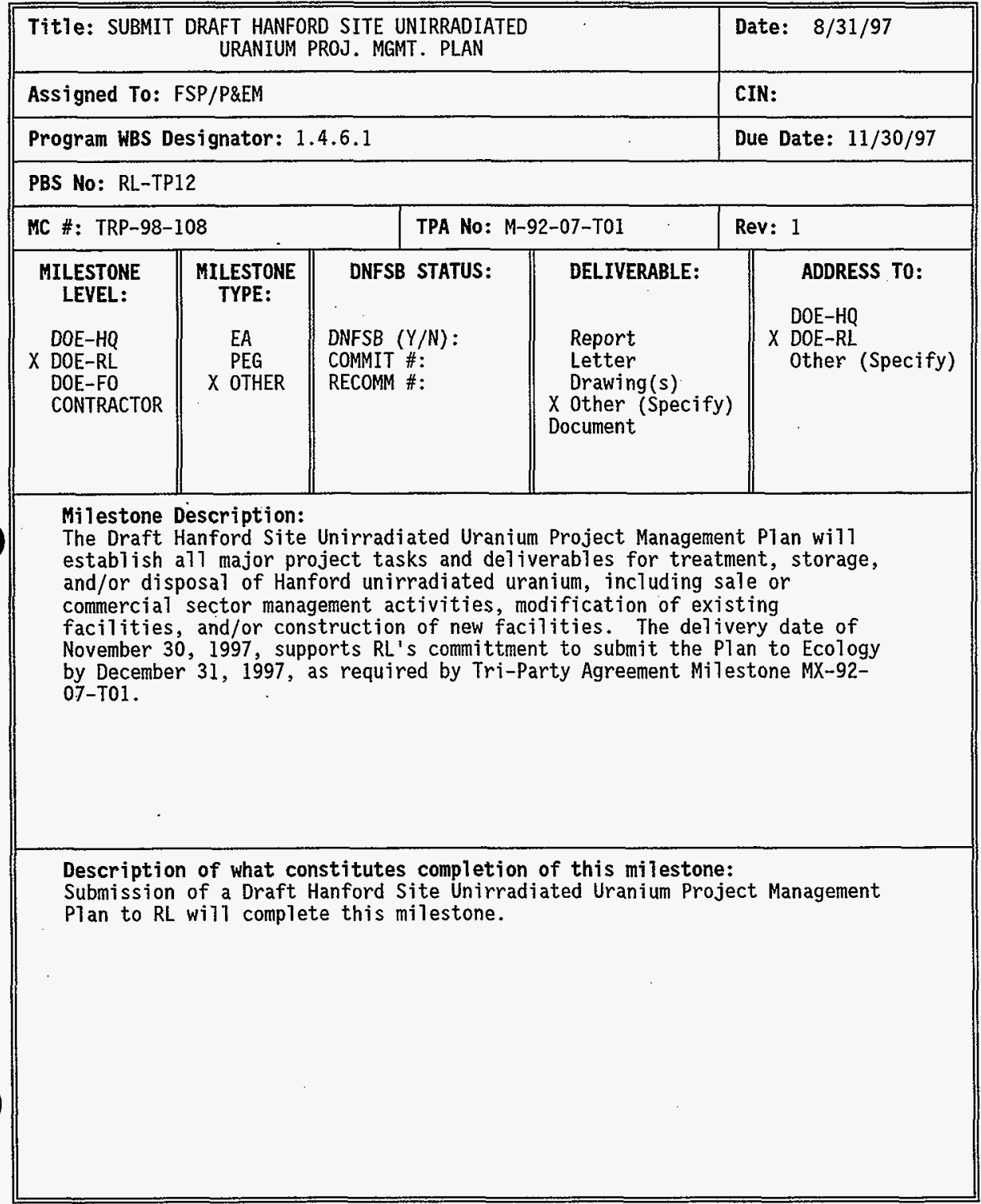




\section{HNF-SP-1234 \\ PHMC \\ MILESTONE DESCRIPTION SHEET}

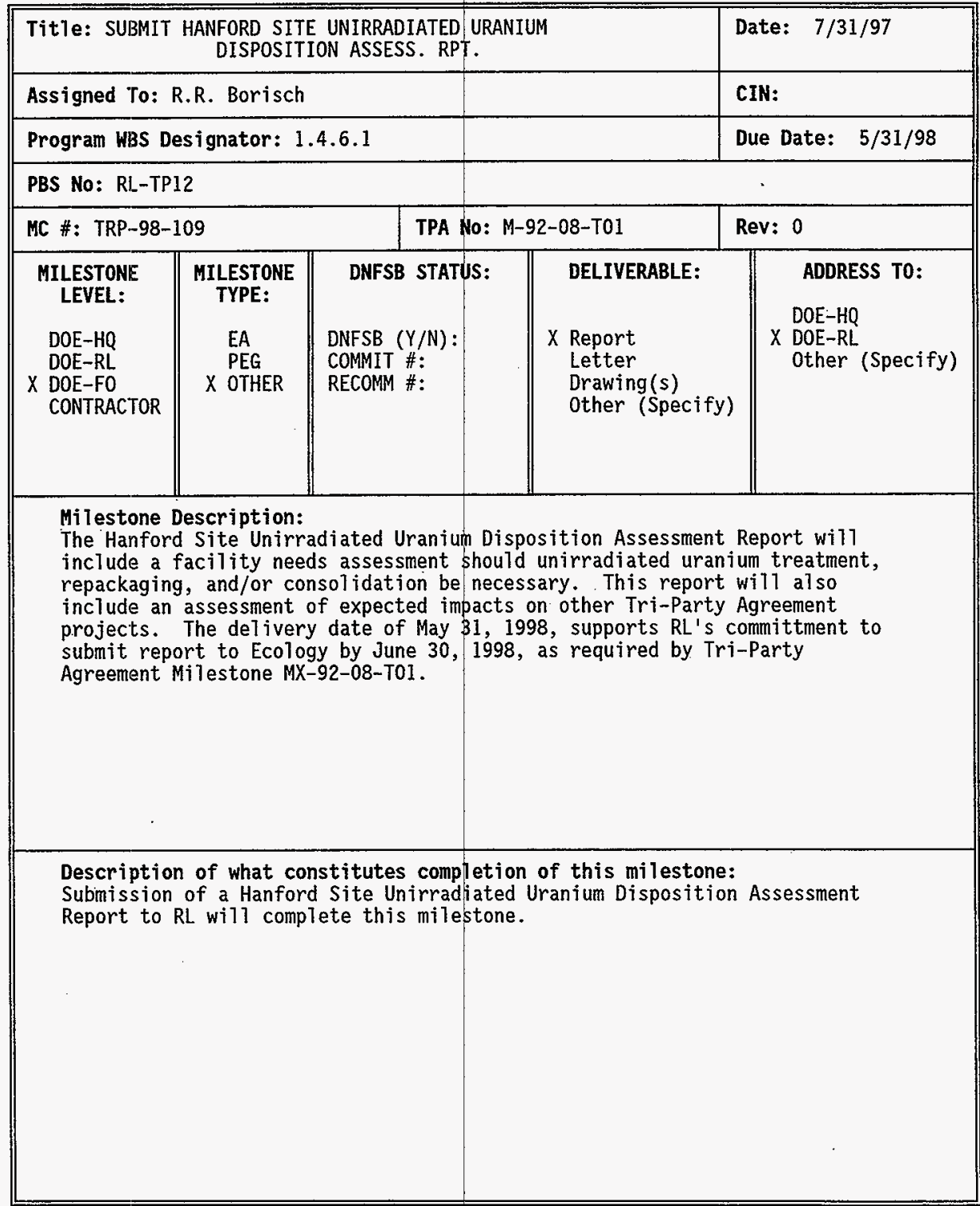


PHMC

MILESTONE DESCRIPTION SHEET

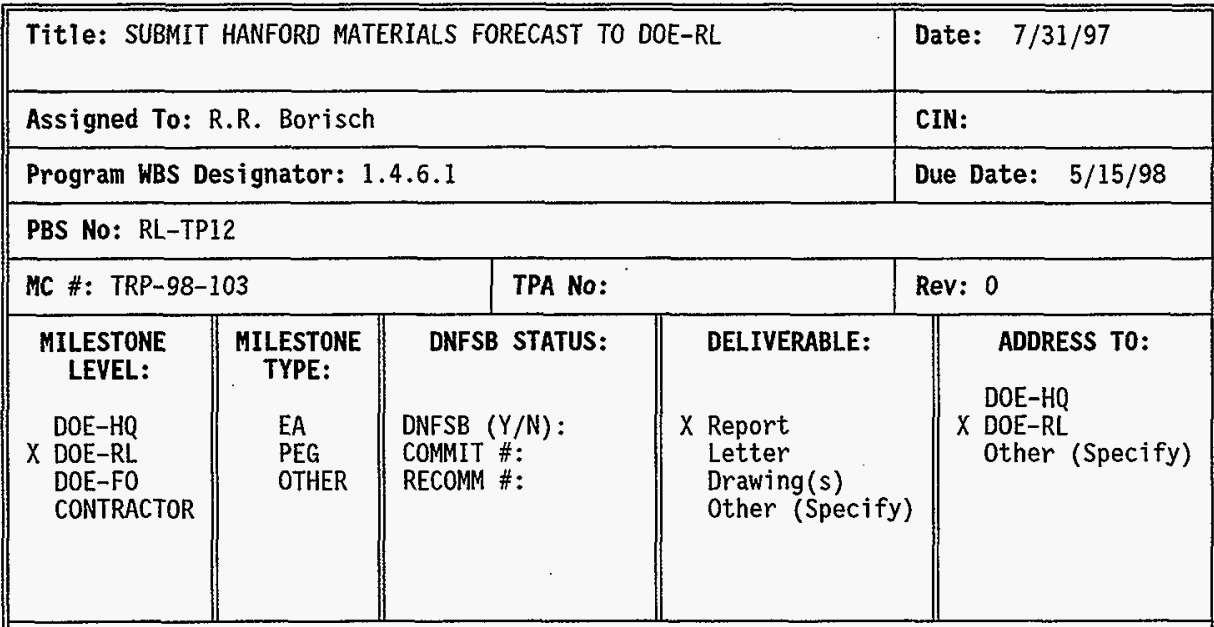

Milestone Description:

The Hanford Nuclear Materials Forecast for the current FY and the next 11 FY is prepared annually per the requirements of DOE Order 5660.1B. The delivery date of May 15, 1998, assumes DOE-HQ provides the guidance for the forecasts by April 1, 1998, and supports RL's committment to submit the Forecast to HQ by June 15, 1998.

Description of what constitutes completion of this milestone:

Submission of the Hanford Nuclear Materials Forecast to RL will complete this milestone. 


\section{PHMC}

MILESTONE DESCRIPTION SHEET

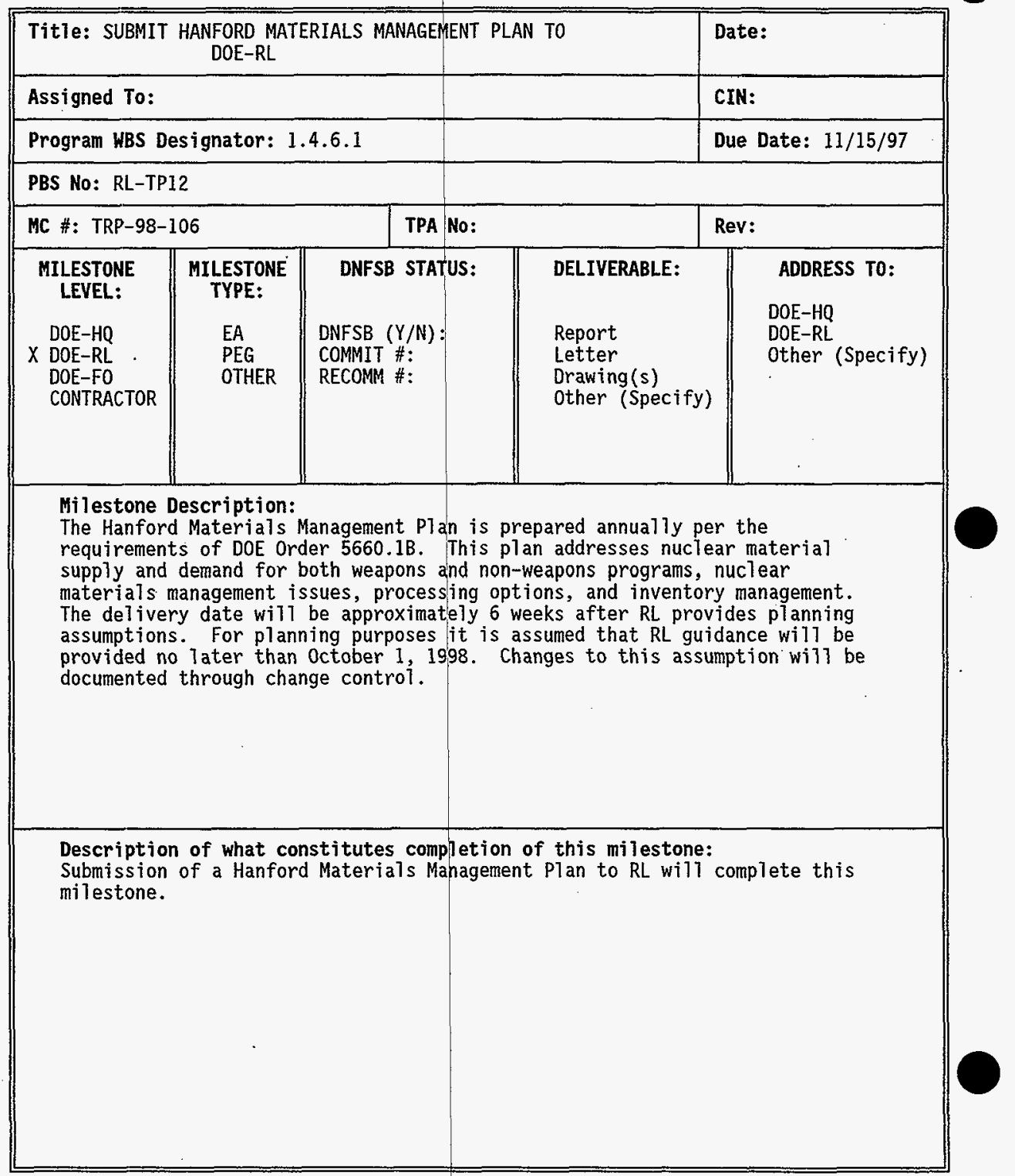




\section{PHMC \\ MILESTONE DESCRIPTION SHEET}

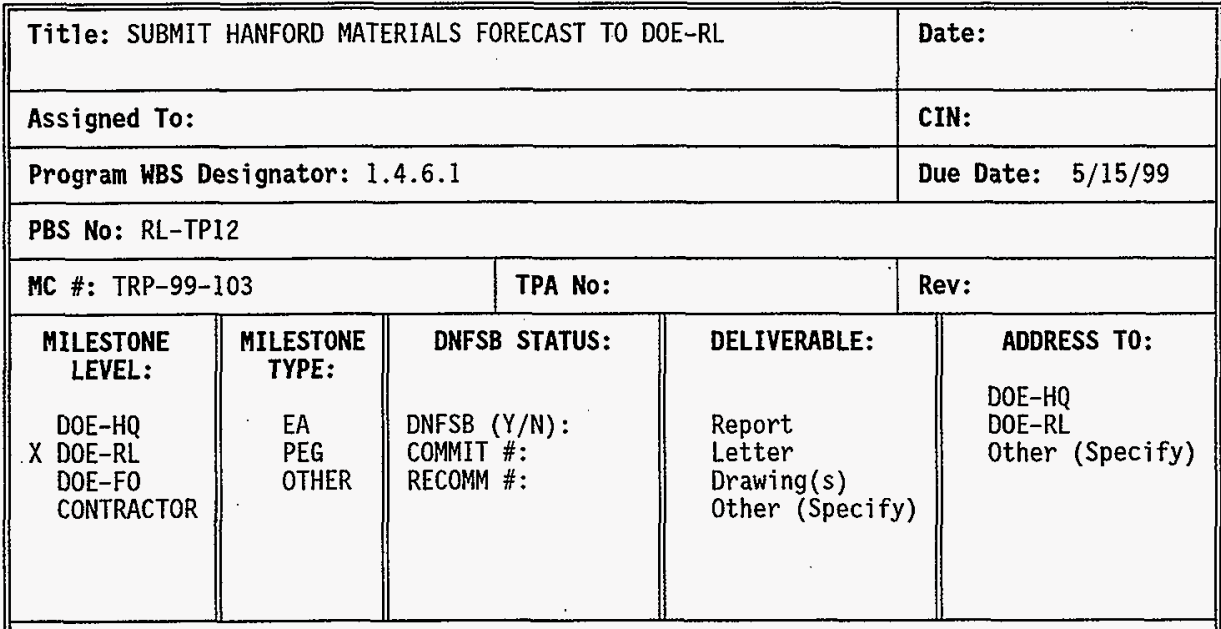

Milestone Description:

The Hanford Nuclear Materials Forecast for the current FY and the next 11 FY is prepared annualiy per the requirements of DOE Order 5660.1B. The delivery date of May 15 assumes DOE-HQ provides the guidance for the forecasts by April 1 and allows RL sufficient time for submission of the Forecast to $\mathrm{HQ}$ by June 15 .

Description of what constitutes completion of this milestone:

Submission of the Hanford Nuclear Materials Forecast to RL will complete this milestone. 
PHMC

MILESTONE DESCRIPTION SHEET

\begin{tabular}{|c|c|c|c|c|c|}
\hline \multicolumn{5}{|c|}{$\begin{array}{c}\text { Title: SUBMIT HANFORD MATERIALS MANAGEMENT PLAN TO } \\
\text { DOE-RL }\end{array}$} & Date: \\
\hline \multicolumn{4}{|l|}{ Assigned To: } & & CIN: \\
\hline \multicolumn{4}{|c|}{ Program WBS Designator: 1.4 .6 .1} & & Due Date: $11 / 15 / 98$ \\
\hline \multicolumn{4}{|c|}{ PBS No: RL-TP12 } & \multicolumn{2}{|c|}{. } \\
\hline \multicolumn{2}{|c|}{ MC \#: TRP-99-106 } & & TPA No: & & Rev: \\
\hline $\begin{array}{l}\text { MILESTONE } \\
\text { LEVEL: } \\
\\
\text { DOE-HQ } \\
\text { X DOE-RL } \\
\text { DOE-FO } \\
\text { CONTRACTOR }\end{array}$ & $\begin{array}{l}\text { MILESTONE } \\
\text { TYPE: } \\
\text { EA } \\
\text { PEG } \\
\text { OTHER }\end{array}$ & $\begin{array}{l}\text { DN } \\
\text { DNFS } \\
\text { COMM } \\
\text { RECO }\end{array}$ & $\begin{array}{l}\text { STATUS: } \\
Y / N): \\
\#: \\
\#:\end{array}$ & $\begin{array}{l}\text { DELIVERABLE: } \\
\text { Report } \\
\text { Letter } \\
\text { Drawing(s) } \\
\text { Other (Specify) }\end{array}$ & $\begin{array}{l}\text { ADDRESS TO: } \\
\text { DOE-HQ } \\
\text { DOE-RL } \\
\text { Other (Specify) }\end{array}$ \\
\hline \multicolumn{6}{|c|}{$\begin{array}{l}\text { Milestone Description: } \\
\text { The Hanford Materials Management Plan is prepared annual1y per the } \\
\text { requirements of DOE Order } 5660.1 \mathrm{~B} \text {. This plan addresses nuclear material } \\
\text { supply and demand for both weapons and non-weapons programs, nuclear } \\
\text { materials management issues, processing opotions, and inventory mangement. } \\
\text { The delivery date will be approximately } 6 \text { weeks after RL provides planning } \\
\text { assumptions. For planning purposes it is assumed that RL guidance will be } \\
\text { provided no later than October I, 1999. Changes to this assumption will be } \\
\text { documented through change control. }\end{array}$} \\
\hline \multicolumn{6}{|c|}{$\begin{array}{l}\text { Description of what constitutes completion of this milestone: } \\
\text { Submission of a Hanford Materials Management Plan to RL will complete this } \\
\text { milestone. }\end{array}$} \\
\hline
\end{tabular}




\section{PHMC \\ MILESTONE DESCRIPTION SHEET}

\begin{tabular}{|c|c|c|c|c|}
\hline \multicolumn{4}{|c|}{ Title: SUBMIT HANFORD MATERIALS FORECAST TO DOE-RL } & Date: \\
\hline \multicolumn{4}{|l|}{ Assigned To: } & CIN: \\
\hline \multicolumn{4}{|c|}{ Program WBS Designator: 1.4 .6 .1} & Due Date: $5 / 15 / 00$ \\
\hline \multicolumn{5}{|c|}{ PBS No: RL-TP12 } \\
\hline \multicolumn{2}{|c|}{ MC \#: TRP-00-103 } & TPA No: & & Rev: \\
\hline $\begin{array}{l}\text { MILESTONE } \\
\text { LEVEL: } \\
\text { DOE-HQ } \\
\text { X DOE-RL } \\
\text { DOE-FO } \\
\text { CONTRACTOR }\end{array}$ & $\begin{array}{l}\text { MILESTONE } \\
\text { TYPE: } \\
\text { EA } \\
\text { PEG } \\
\text { OTHER }\end{array}$ & $\begin{array}{l}\text { DNFSB STATUS: } \\
\text { DNFSB }(Y / N): \\
\text { COMMIT \#: } \\
\text { RECOMM \#: }\end{array}$ & $\begin{array}{l}\text { DELIVERABLE: } \\
\text { Report } \\
\text { Letter } \\
\text { Drawing(s) } \\
\text { Other (Specify) }\end{array}$ & $\begin{array}{l}\text { ADDRESS TO: } \\
\text { DOE-HQ } \\
\text { DOE-RL } \\
\text { Other (Specify) }\end{array}$ \\
\hline \multicolumn{5}{|c|}{$\begin{array}{l}\text { Milestone Description: } \\
\text { The Hanford Nuclear Materials Forecast for the current FY and the next } 11 \\
\text { FY is prepared annually per the requirements of DOE Order } 5660.18 \text {. The } \\
\text { delivery date of May } 15 \text { assumes DOE-HQ provides the guidance for the } \\
\text { forecasts by April } 1 \text { and allows RL sufficient time for submission of the } \\
\text { Forecast to HQ by June } 15 \text {. }\end{array}$} \\
\hline \multicolumn{5}{|c|}{$\begin{array}{l}\text { Description of what constitutes completion of this milestone: } \\
\text { Submission of the Hanford Nuclear Materials Forecast to RL will complete } \\
\text { this milestone. }\end{array}$} \\
\hline
\end{tabular}




\section{PHMC \\ MILESTONE DESCRIPTION SHEET}

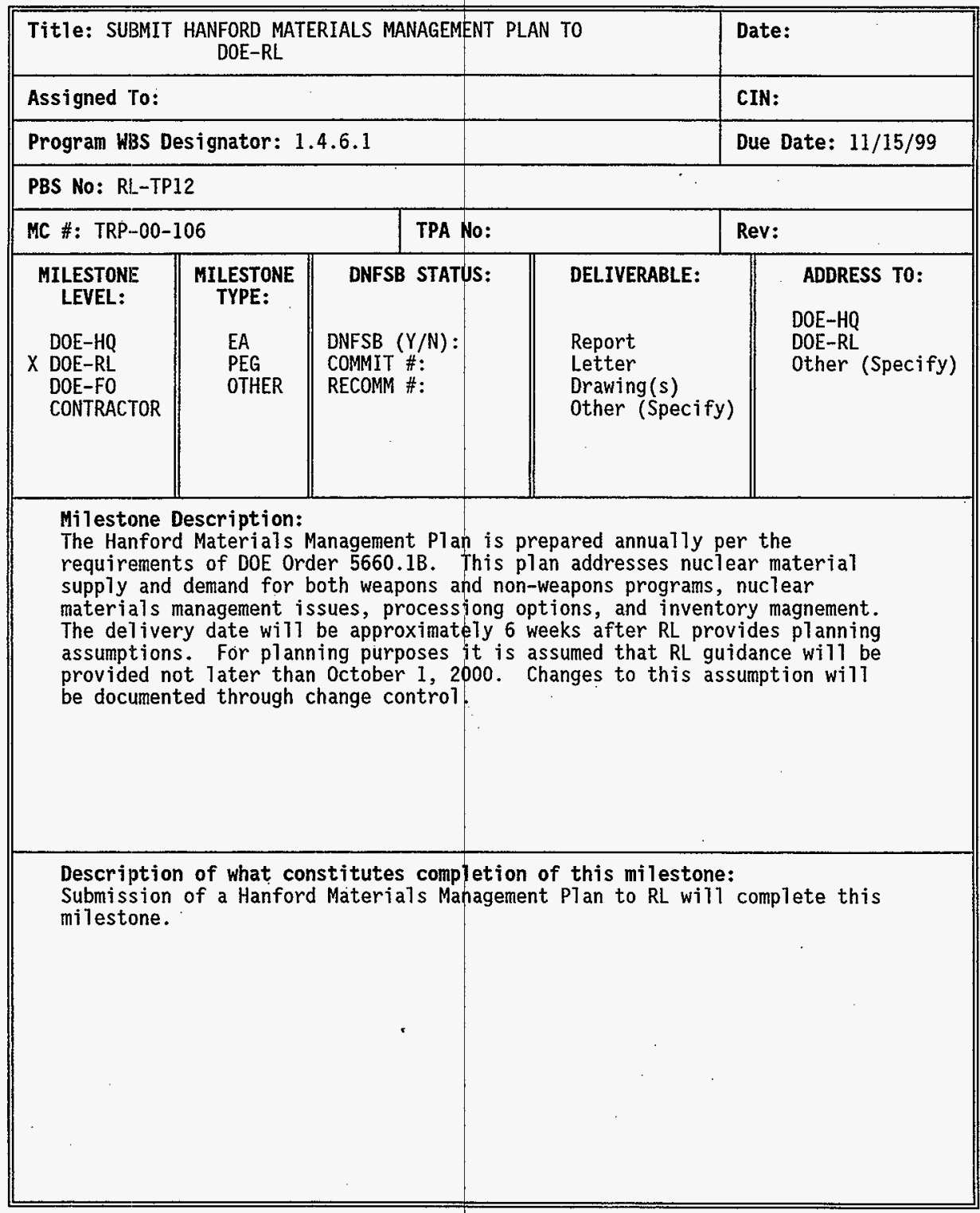




\section{PHMC}

MILESTONE DESCRIPTION SHEET

\begin{tabular}{|c|c|c|c|c|}
\hline \multicolumn{4}{|c|}{ Title: SUBMIT HANFORD MATERIALS FORECAST TO DOE-RL } & Date: \\
\hline \multicolumn{4}{|l|}{ Assigned To: } & CIN: \\
\hline \multicolumn{4}{|c|}{ Program WBS Designator: 1.4 .6 .1} & Due Date: $5 / 15 / 01$ \\
\hline \multicolumn{5}{|c|}{ PBS No: RL-TP12 } \\
\hline \multicolumn{2}{|c|}{ MC \#: TRP-01-103 } & \multicolumn{2}{|l|}{ TPA No: } & Rev: \\
\hline $\begin{array}{l}\text { MILESTONE } \\
\text { LEVEL: } \\
\text { DOE-HQ } \\
\text { X DOE-RL } \\
\text { DOE-FO } \\
\text { CONTRACTOR }\end{array}$ & $\begin{array}{l}\text { MILESTONE } \\
\text { TYPE: } \\
\text { EA } \\
\text { PEG } \\
\text { OTHER }\end{array}$ & $\begin{array}{l}\text { DNFSB STATUS: } \\
\text { DNFSB }(Y / N): \\
\text { COMMIT \#: } \\
\text { RECOMM \#: }\end{array}$ & $\begin{array}{l}\text { DELIVERABLE: } \\
\text { Report } \\
\text { Letter } \\
\text { Drawing(s) } \\
\text { Other (Specify) }\end{array}$ & $\begin{array}{l}\text { ADDRESS T0: } \\
\text { DOE-HQ } \\
\text { DOE-RL } \\
\text { Other (Specify) }\end{array}$ \\
\hline
\end{tabular}

Milestone Description:

The Hanford Nuclear Materials Forecast for the current FY and the next 11 FY is prepared annually per the requirements of DOE Order 5660.1B. The delivery date of May 15 assumes DOE-HQ provides the guidance for the forecasts by Apri] 1 and allows RL sufficient time for submission of the Forecast to HQ by June 15 .

Description of what constitutes completion of this milestone:

Submission of the Hanford Nuclear Materials Forecast to RL will complete this milestone. 


\section{PHMC}

MILESTONE DESCRIPTION SHEET

\begin{tabular}{|c|c|c|c|c|c|}
\hline \multicolumn{5}{|c|}{$\begin{array}{l}\text { Title: SUBMIT HANFORD MATERIALS MANAGMENT PLAN TO } \\
\text { DOE-RL. }\end{array}$} & Date: \\
\hline \multicolumn{4}{|l|}{ Assigned To: } & & CIN: \\
\hline \multicolumn{4}{|c|}{ Program WBS Designator: 1.4.6.1 } & & Due Date: $11 / 15 / 00$ \\
\hline \multicolumn{6}{|c|}{ PBS No: RL-TP12 } \\
\hline \multicolumn{3}{|c|}{ MC \#: TRP-01-106 } & \multicolumn{2}{|c|}{ TPA No: } & Rev: \\
\hline $\begin{array}{l}\text { MILESTONE } \\
\text { LEVEL: } \\
\text { DOE-HQ } \\
\text { X DOE-RL } \\
\text { DOE-FO } \\
\text { CONTRACTOR }\end{array}$ & $\begin{array}{l}\text { MILESTONE } \\
\text { TYPE: } \\
\text { EA } \\
\text { PEG } \\
\text { OTHER }\end{array}$ & $\begin{array}{l}\text { DNI } \\
\text { DNFSE } \\
\text { COMMI } \\
\text { RECOI }\end{array}$ & $\begin{array}{l}\text { STATU } \\
\text { Y/N }): \\
\#: \\
\#:\end{array}$ & $\begin{array}{l}\text { DELIVERABLE: } \\
\text { Report } \\
\text { Letter } \\
\text { Drawing(s) } \\
\text { Other (Specify) }\end{array}$ & $\begin{array}{l}\text { ADDRESS TO: } \\
\text { DOE-HQ } \\
\text { DOE-RL } \\
\text { Other (Specify) }\end{array}$ \\
\hline \multicolumn{6}{|c|}{$\begin{array}{l}\text { Milestone Description: } \\
\text { The Hanford Materials Management PI an is prepared annually per the } \\
\text { requirements of DOE Order } 5660.1 \mathrm{~B} \text {. This plan addresses nuclear material } \\
\text { supply and demand for both weapons and non-weapons programs, nuclear } \\
\text { materials management issues, processing options, and inventory management. } \\
\text { The delivery date will be approximately } 6 \text { weeks after RL provides planning } \\
\text { assumptions. For planning purposes jit is assumed that RL guidance will be } \\
\text { provided no later than October } 1,2001 \text {. Changes to this assumption will be } \\
\text { documented through change control. }\end{array}$} \\
\hline \multicolumn{6}{|c|}{$\begin{array}{l}\text { Description of what constitutes completion of this milestone: } \\
\text { Submission of a Hanford Materials Management Plan to RL will complete this } \\
\text { milestone. }\end{array}$} \\
\hline
\end{tabular}




\section{PHMC \\ MILESTONE DESCRIPTION SHEET}

\begin{tabular}{|c|c|c|c|c|}
\hline \multicolumn{4}{|c|}{ Title: SUBMIT HANFORD MATERIALS FORECAST TO RL } & Date: \\
\hline \multicolumn{4}{|l|}{ Assigned To: } & CIN: \\
\hline \multicolumn{4}{|c|}{ Program WBS Designator: 1.4 .6 .1} & Due Date: $5 / 15 / 02$ \\
\hline \multicolumn{5}{|c|}{ PBS No: RL-TP12 } \\
\hline \multicolumn{2}{|c|}{ MC \#: TRP-02-103 } & \multicolumn{2}{|l|}{ TPA No: } & Rev: \\
\hline $\begin{array}{l}\text { MILESTONE } \\
\text { LEVEL: } \\
\text { DOE-HQ } \\
\text { X DOE-RL } \\
\text { DOE-FO } \\
\text { CONTRACTOR }\end{array}$ & $\begin{array}{l}\text { MILESTONE } \\
\text { TYPE: } \\
\text { EA } \\
\text { PEG } \\
\text { OTHER }\end{array}$ & $\begin{array}{l}\text { DNFSB STATUS: } \\
\text { DNFSB (Y/N): } \\
\text { COMMIT \#: } \\
\text { RECOMM \#: }\end{array}$ & $\begin{array}{l}\text { DELIVERABLE: } \\
\text { Report } \\
\text { Letter } \\
\text { Drawing(s) } \\
\text { Other (Specify) }\end{array}$ & $\begin{array}{l}\text { ADDRESS TO: } \\
\text { DOE-HQ } \\
\text { DOE-RL (Specify) } \\
\text { Other (Specify }\end{array}$ \\
\hline
\end{tabular}

Milestone Description:

The Hanford Nuclear Materials Forecast for the current FY and the next 11

FYs is prepared annually per the requirements of DOE Order 5660.1B. The delivery date of May 15 assumes DOE-HQ provides the guidance for the forecasts by April 1 and allows RL sufficient time for submission of the Forecast to $\mathrm{HQ}$ by June 15 .

Description of what constitutes completion of this milestone:

Submission of the Hanford Nuclear Materials Forecast to RL will complete this milestone. 


\section{PHMC \\ MILESTONE DESCRIPTION SHEET}

\begin{tabular}{|c|c|c|c|c|c|}
\hline \multicolumn{5}{|c|}{$\begin{array}{l}\text { Title: SUBMIT HANFORD MATERIALS MANAGEMENT PLAN TO } \\
\text { RL }\end{array}$} & Date: \\
\hline \multicolumn{4}{|l|}{ Assigned To: } & & CIN: \\
\hline \multicolumn{4}{|c|}{ Program WBS Designator: 1.4 .6 .1} & . & Due Date: $11 / 15 / 01$ \\
\hline \multicolumn{6}{|c|}{ PBS No: RL-TP12 } \\
\hline \multicolumn{3}{|c|}{ MC \#: TRP-02-106 } & TPA No: & . & Rev: \\
\hline $\begin{array}{l}\text { MILESTONE } \\
\text { LEVEL: } \\
\text { DOE-HQ } \\
\text { X DOE-RL } \\
\text { DOE-FO } \\
\text { CONTRACTOR }\end{array}$ & $\begin{array}{l}\text { MILESTONE } \\
\text { TYPE: } \\
\text { EA } \\
\text { PEG } \\
\text { OTHER }\end{array}$ & $\begin{array}{l}\text { DN } \\
\text { DNFS } \\
\text { COMM } \\
\text { RECO }\end{array}$ & $\begin{array}{l}\text { STATUS: } \\
Y / N): \\
\#: \\
\#:\end{array}$ & $\begin{array}{l}\text { DELIVERABLE: } \\
\text { Report } \\
\text { Letter } \\
\text { Drawing(s) } \\
\text { Other (Specify) }\end{array}$ & $\begin{array}{l}\text { ADDRESS TO: } \\
\text { DOE-HQ } \\
\text { DOE-RL } \\
\text { Other (Specify) }\end{array}$ \\
\hline \multicolumn{6}{|c|}{$\begin{array}{l}\text { Milestone Description: } \\
\text { The Hanford Materials Management Plan is prepared annually per the } \\
\text { requirements of DOE Order } 5660.1 \mathrm{~B} \text {. This plan addresses nuclear material } \\
\text { supply and demand for both weapons and non-weapons programs, nuclear } \\
\text { materials management issues, processing options, and inventory management. } \\
\text { The delivery date will be approximately } 6 \text { weeks after RL provides planning } \\
\text { assumptions. For planning purposes it is assumed that RL guidance will be } \\
\text { provided no later than October } 1,2002 \text {. Changes to this assumption will be } \\
\text { documented through change control. }\end{array}$} \\
\hline \multicolumn{6}{|c|}{$\begin{array}{l}\text { Description of what constitutes completion of this milestone: } \\
\text { Submission of a Hanford Materials Management Plan to RL will complete this } \\
\text { milestone. }\end{array}$} \\
\hline
\end{tabular}




\section{PHMC \\ MILESTONE DESCRIPTION SHEET}

Title: COMPLETE DISPOSITION/COMPLIANT STORAGE FOR ALL. SITE UU

Date: $8 / 31 / 97$

\begin{tabular}{l}
\hline Assigned To: FSP/P\&EM \\
\hline Program WBS Designator: 1.4.6.1
\end{tabular}

CIN:

PBS No: RL-TP12

MC \#: TRP-01-108

TPA No: M-92-06-T01

Rev: 0

\begin{tabular}{|c|c|c|c|c|}
\hline $\begin{array}{l}\text { MILESTONE } \\
\text { LEVEL: }\end{array}$ & $\begin{array}{l}\text { MILESTONE } \\
\text { TYPE: }\end{array}$ & DNFSB STATUS: & DELIVERABLE: & \\
\hline $\begin{array}{l}\text { DOE-HQ } \\
X \text { DOE-RL } \\
\text { DOE-FO } \\
\text { CONTRACTOR }\end{array}$ & $\begin{array}{l}\text { EA } \\
\text { PEG } \\
\text { OTHER }\end{array}$ & $\begin{array}{l}\text { DNFSB }(Y / N): \\
\text { COMMIT \#: } \\
\text { RECOMM \#: }\end{array}$ & $\begin{array}{l}\text { Report } \\
\text { Letter } \\
\text { Drawing(s) } \\
\text { Other (Specify) }\end{array}$ & $\begin{array}{l}\text { DOE-RL } \\
\text { Other (Specify) }\end{array}$ \\
\hline
\end{tabular}

Milestone Description:

Description of what constitutes completion of this milestone: 
FACILITY STABILIZATION

LIFE CYCLE COST BASELINE (BCWS) BY YEAR BY FUND TYPE

BY PROJECT BASELINE SUMMARY (PBS)

FY 1998

(\$000s)

\begin{tabular}{|c|c|c|c|c|c|c|c|c|c|c|c|}
\hline $\begin{array}{r}\text { PROJECT WBS: } \\
\text { PBS NO: }\end{array}$ & $\frac{1.4 .6 .1}{\text { RL-TP12 }}$ & & & & & & & & & & \\
\hline PBS TITLE: & Transkition $P$ & roject Man & agement & & & & & & & & SUBTOT \\
\hline $\begin{array}{l}\text { FUND } \\
\text { TYPE }\end{array}$ & FY1997 & 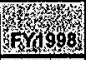 & FY1999 & FY2000 & FY2001 & FY2002 & FY2003 & FY2004 & FY2005 & FY2006 & $\begin{array}{l}\text { FY1997- } \\
\text { FY2006 }\end{array}$ \\
\hline OPERATING EXPENSE & 10,494 & 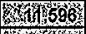 & 12,026 & 11,415 & 13,564 & 13,900 & 14,248 & 15,108 & 15,478 & 13,229 & 131,058 \\
\hline & & 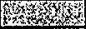 & & & & & & & & & \\
\hline CENRTC & & Wy & & & & & & & & & - \\
\hline & & 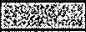 & & & & & & & & & \\
\hline GENERAL PLANT PROJECT & & Wry & & & & & & & & & $\cdot$ \\
\hline & & 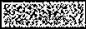 & & & & & & & & & \\
\hline LINE ITEM (LISI Each OnO) & & 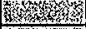 & & & & & & & & & \\
\hline & & 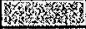 & & & & & & & & & - \\
\hline & & 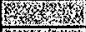 & & & & & & & & & - \\
\hline & & 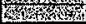 & & & & & & & & & $=$ \\
\hline & & 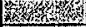 & & & & & & & & & - \\
\hline & & Fin & & & & & & & & & - \\
\hline Subtotal Line lfems & - & 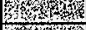 & - & - & - & $=$ & - & - & - & - & $=$ \\
\hline & & 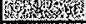 & & & & & & & & & \\
\hline 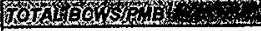 & 40 & H & 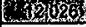 & Sit & 46 & (6) & 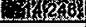 & (1000 & 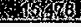 & $4=0(0 ; 4)$ & 134058 \\
\hline & & 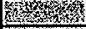 & & & & & & & & & \\
\hline MGMT RESERVE ${ }^{2}$ & & 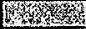 & & & & & & & & & $=$ \\
\hline & & Arr. & & & & & & & & & \\
\hline LINE ITEM CONTINGENGY ${ }^{2}$ & & 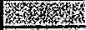 & & & & & & & - & & - \\
\hline & & 20 & & & & & & & & & \\
\hline OFFSITE TRANSFERS ${ }^{3}$ & & 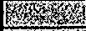 & & & & & & & & & - \\
\hline & & W & & & & & & & & & \\
\hline Subtotal & - & 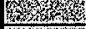 & - & - & $=$ & - & - & $=$ & $=$ & - & - \\
\hline & & MEn & & & & & & & & & \\
\hline TorAL & 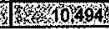 & 7hy & 120263 & 616464 & W(31567) & 40600 & 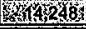 & M610a & 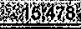 & (x) & 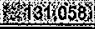 \\
\hline
\end{tabular}

'Budgeted Cost of Work Scheduled (BCWS) Equals Performance Measurement Baseline (PMB);

Expense Caryover NOT Included.

${ }^{2}$ Management Reserve and Line ftem Contingency Held by RL.

sWork Performed at Sites Other Than Hanford. 
FACILITY STABBILIZATION

LIFE CYCLE COST BASELINE (BCWS) BY YEAR BY FUND TYPE

BY PROJECT BASELINE SUMMARY (PBS)

FY 1998

(\$000s)

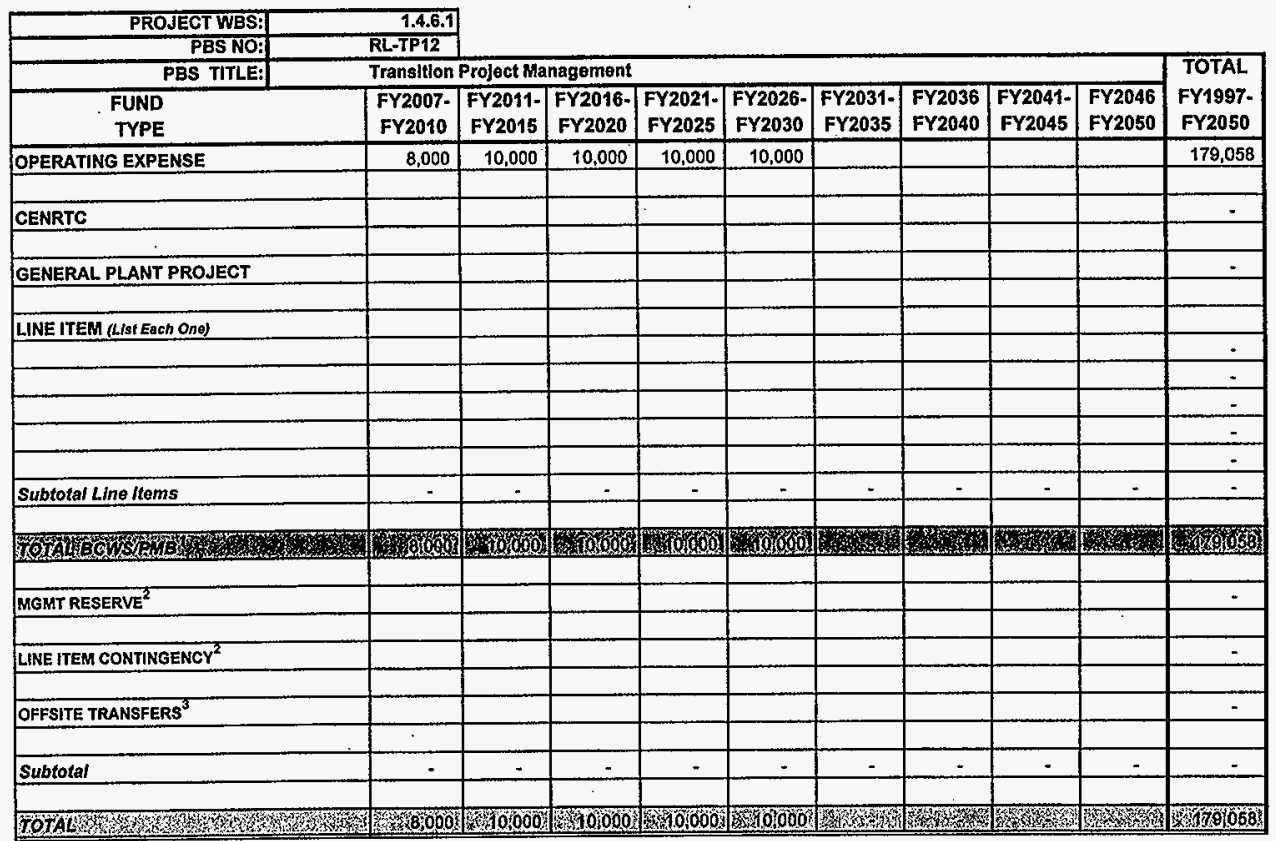

${ }^{1}$ Budgeted Cost of Work Scheduled (BCWS) Equals Performance Measurement Baseline (PMB);

Expense Carryover NOT Included.

${ }^{2}$ Management Reserve and Line Item Contingency Held by RL.

"Work Performed at Sites Other Than Hanford. 
FACILITY STABILIZATION

LIFE CYCLE BUDGET AUTHORITY (B/A) BY YEAR BY FUND TYPE

BY PROJECT BASELINE SUMMARY (PBS)

FY 1998

(\$000s)

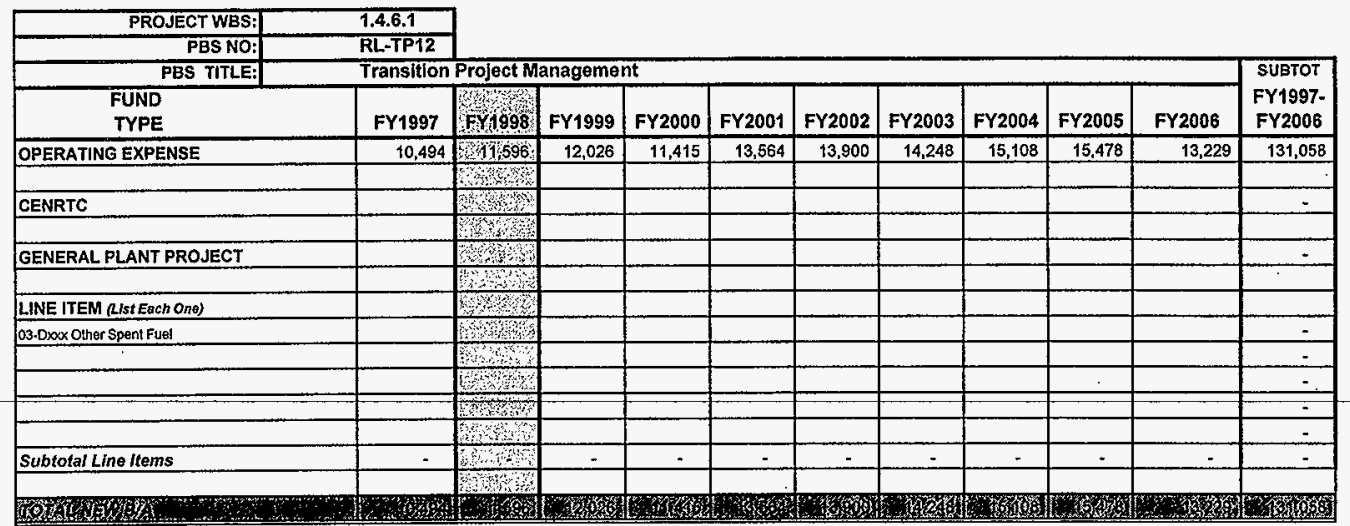


BY PROJECT BASELINE SUMMARY (PBS)

FY 1998

(\$000s)

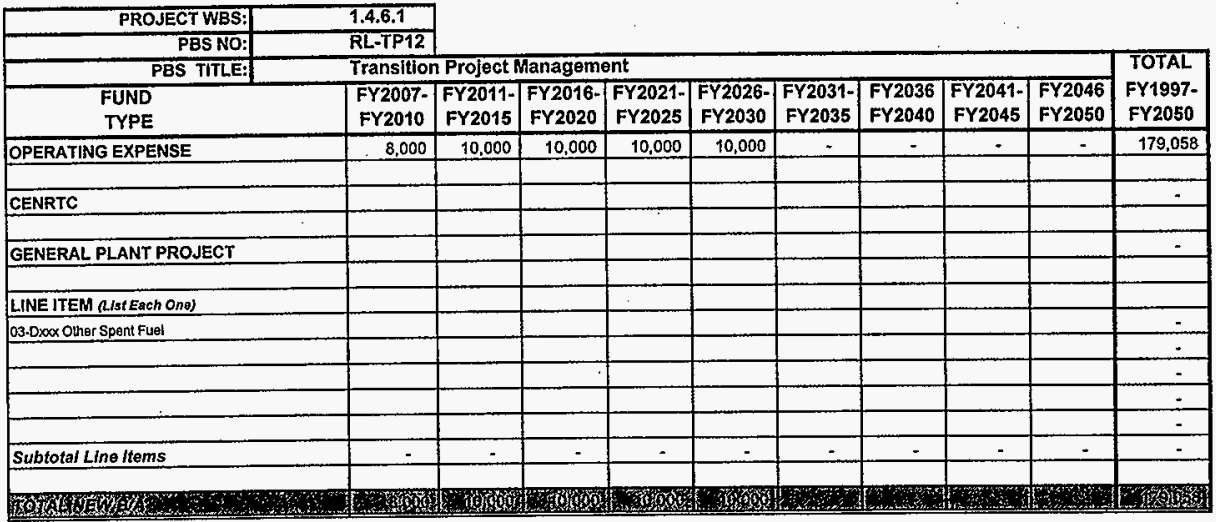




\section{TRANSITION PROJECT MANAGEMENT}

AVERAGE ANNUAL FULL TIME EQUIVALENTS

(includes Major Subcontractors but not Enterprise Companies)

PHBS 1.4.6.1

Submittal Date: 9/10/97

\begin{tabular}{|l|l|}
\hline PBS Number \\
\hline
\end{tabular}

FY 1998

FY 1999

FY 2000

FY 2001

FY 2002

FY 2003

FY 2004

FY 2005

FY 2006

FY 2007

RL-TP12

Trans. Proj. Mgm

61

62

62

81

81

81

81

81

62

62

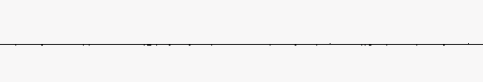


HNF-SP-1234

\section{B.12 Hanford Surplus Facility Program 300 Area Revitalization Project (RL-TP14)}

\section{B.12.1.0 Hanford Surplus Facility Program 300 Area Revitalization Project Technical Baseline (RL-TP14)}

\section{B.12.1.1 Hanford Surplus Facility Program 300 Area Revitalization Project Organization Mission (RL-TP14)}

As a result of Hanford site mission change from defense production to cleanup and downsizing, the 300 area has a number of excess facilities requiring disposition beyond simple removal. These facilities include a reactor building, accelerator building, and numerous buildings used for reactor fuel production and processing activities. Most of the facilities contain significant radiological and chemical contamination, with 8 facilities currently managed under RCRA. The 300 area contains multiple burial grounds and liquid disposal / spill sites, which are managed under CERCLA as 3 separate operable units. There are 156 non-mobile facilities listed in the 300 Area. Of these, 46 facilities are known to contain radioactive and 11 are known to contain hazardous contamination. The remaining 99 buildings are not listed as contaminated but further verification of that condition is warranted on some of them because known historical uses and contamination of nearby grounds make them suspect. Eighteen contaminated buildings are being deactivated ( 300 Fuel Supply Facilities, 308 Building, 309 Building) and five more contaminated facilities are scheduled to begin deactivation in 1997 (324, 324A, 324D, 327, 3723 buildings) and are not included in the scope of this PBS.

Five facilities were assigned to the Faciltiy Stabilization Project this fiscal year and the minimum surveillance and maintenance for them is funded from this PBS. They are 321, 321B, 321D, 3706 and 3706A.

The purpose of this project is to provide a path forward for all 300 Area facilities not currently being managed under another PBS. This path forward includes:

- Monitoring and maintenance of facilities and grounds as required to assure containment of the radioactive and hazardous material.

- Stabilization and deactivation of contaminated facilities.

- Alternative cleanup of facilities, removing the legacy and liabilities of DOE operations ONLY TO THE EXTENT NECESSARY for facility and area alternative use.

- Final disposition of facilities including sale, dismantlement for salvage, demolition, and alternate use of facilities where facility re-use is economically and practically feasible.

These facilities constitute a risk to the public, environment and on-site workers due to contamination with a variety of materials including cesium, strontium, uranium, thorium, mixed fission products, various acids and bases, and a wide variety of cleaning agents and solvents. The facilities covered in this project are in close proximity to the Columbia River and the city of Richland. With the continual reduction in Hanford Site Security taking place, the likelihood of a member of the public entering this area unescorted without the necessary protective clothing and equipment is very high. A fire, containment system failures or structural collapse due to natural causes or facility deterioration could result in a release of contaminants to the environment via air, ground and water pathways. Many of these facilities have exceeded their design life, and will pose an increasing hazard to site workers as the facilities continue to deteriorate.

The activities in this PBS reduces risk to the public, on-site workers and the environment by removing, stabilizing, or isolating contaminants, providing surveillance and maintenance to assure releases do not occur, keeping facilities in an acceptable material condition or sufficiently isolated to avoid worker hazards due to facility deterioration, and providing a mechanism for final disposition of the facilities. Risk is also reduced by assuring that the cleanup follows a priority based path. The planning and scheduling process for the transition of these facilities includes an assessment of each facility's hazards and associated risk, which are then used in determining where the facility 
should be placed on the transition schedule. Another reduction of risk is realized by having the transition activities performed by experienced personnel reducing the risk associated with a lack of experience.

The overall initial cost savings should exceed $\$ 60.00$ per square foot for this phase of the transition effort. Some additional funding will be required for fencing the area restricting public access to specific areas and for monitoring activities, and these costs are reflected in the overall costs shown on the investment sheet.

Land/Facility/Resource availability is greatly enhanced by making the endpoint for transition the lease, sale, or transfer of DOE property to the public whenever possible.

\section{B.12.1.2 Hanford Surplus Facility Program 300 Area Revitalization Project End Point Targets from Hanford Strategic Plan}

- Transition high cost surplus facilities in the central plateau and south 600 areas to a low cost, stable, deactivated condition.

* Remove non-essential, surplus buildings and facilites that don't have identified post-cleanup uses.

* Reuse facilities in the south 600 area for economic diversification where feasible.

\section{B.12.1.3 Hanford Surplus Facility Program 300 Area Revitalization Project Major Facilities}

\section{B.12.1.3.1 South 600 Area Steam System Facility}

\section{B.12.1.3.1.1 South 600 Area Steam System Facility Description}

The South 600 Area steam system includes steam power houses, fuel supply systems, water treatment systems, steam generation systems, steam piping, condensate traps, condensate return systems, exhaust and pollution reduction systems, control systems, and associated office, storage, and shop space in the South 600 Area necessary for operating the system in a safe and compliant manner.

\section{B.12.1.3.1.2 South 600 Area Steam System Facility Technical Logic:}

The Department of Energy (DOE), in partnership with its contractors, shall plan, acquire, operate, maintain, and dispose of physical assets as valuable national resources. Stewardship of these physical assets shall be accomplished in a cost-effective manner to meet the DOE mission. This shall incorporate industry standards, a graded approach, and performance objectives. 


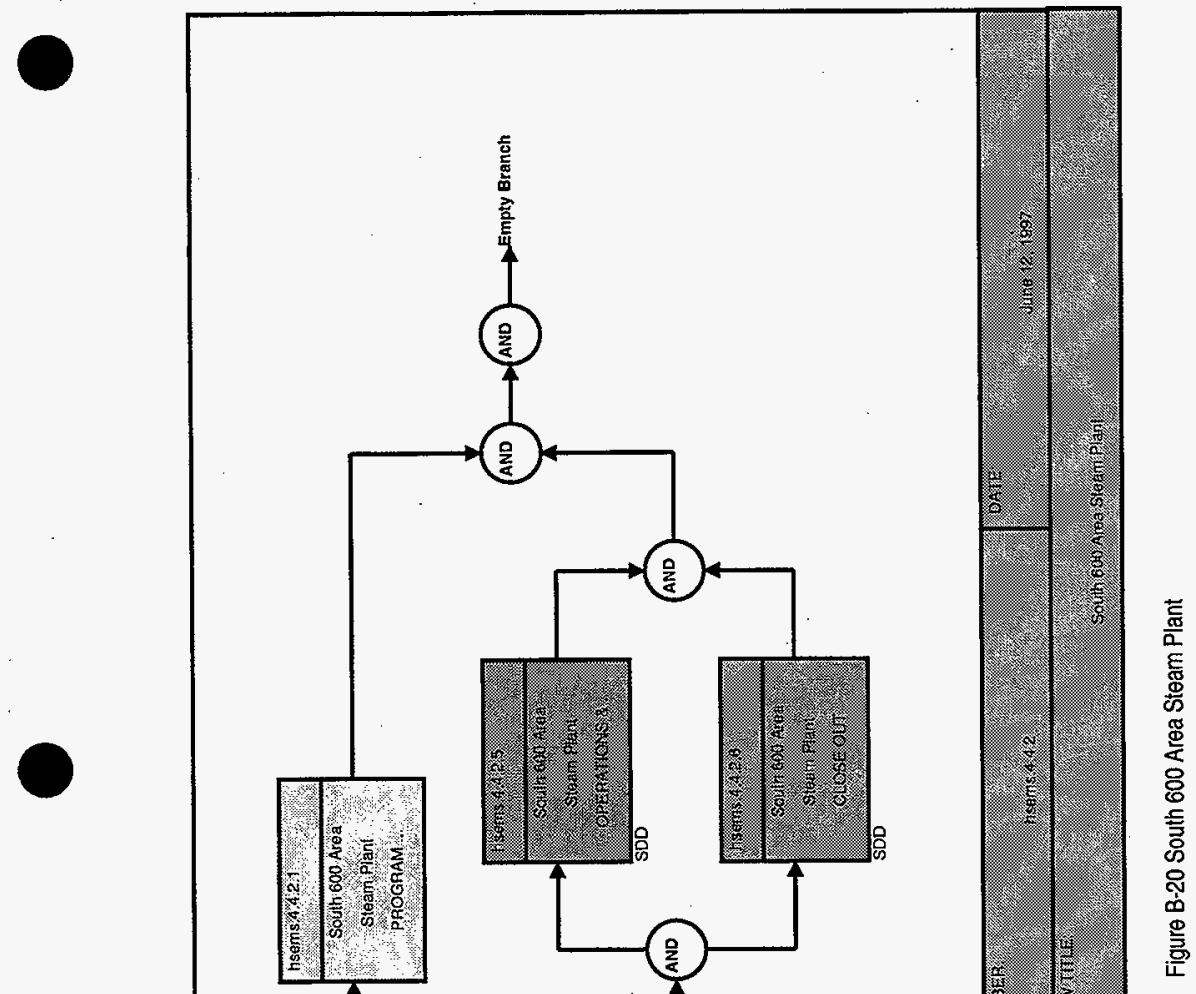




\section{B.12.1.3.1.3 South 600 Area Steam System Requirements and Life Cycle Function Descriptions}

\section{Requirements:}

- South 600 Area high cost surplus facilties shall be transitioned to a low cost, stable, deactivated condition

- South 600 area facilities that can not be used for other purposes, shall be removed

* South 600 area facilities shall be made available for other uses.

* South 600 Area inactive facilities shall be surveillanced and maintained within the approved safety envelope

* South 600 area asbestos abatement shall be performed as necessary

\section{Life Cycle Function Descriptions:}

\section{B.12.1.3.1.3.1 South 600 Area Steam Plant OPERATIONS \& MAINTENANCE WORK SCOPE SUMMARY}

Day-to-day work, including preventive and predictive maintenance, that is required to maintain and preserve plant and capital equipment in a condition suitable for it to be used for its designated purpose.

South 600 Area Steam Plant OPERATIONS \& MAINTENANCE SPECIFIC FUNCTIONS

\section{B.12.1.3.1.3.2 South 600 Area Steam Plant POST OPERATIONS WORK SCOPE SUMMARY}

Day-to-day work, including pre-stabilization surveillance and maintenance, stabilization, post-stabilization surveillance and maintenance, deactivation, and post-deactivation surveillance and maintenance, that is required to allow safe decontamination and decommissioning.

\section{South 600 Area Steam Plant POST OPERATIONS SPECIFIC FUNCTIONS}

\section{B.12.1.3.1.3.3 Maintain Safe \& Compliant South 600 Area Steam Plant}

Maintain the Steam Plant facility structures, operating systems and equipment, and monitoring systems within the approved safety and compliance requirements until the facilities are made available for clean-up.

\section{B.12.1.3.1.3.4 Transition South 600 Area Steam Plant}

Initiate the transition phase of decontamination and decommissioning for the 300 Area Steam Plant

\section{B.12.1.3.1.3.5 South 600 Area Steam Plant D\&D WORK SCOPE SUMMARY}

Day-to-day work, including remediating, stabilizing, controlling, and managing environmental contamination, that is required to allow future land-use objectives. 
B.12.1.3.1.3.6 Decontaminate and Decommission (D\&D) South 600 Area Steam Plant Initiate the final decontamination and decommissioning of the 300 Area Steam Plant

\section{B.12.1.3.1.4 South 600 Area Steam System Boundary Diagram}

Table B.12-1 South 600 Area Steam System Boundary Diagram

\begin{tabular}{|l|l|}
\hline $\begin{array}{l}\text { External Interfaces } \\
\text {-None- } \\
\text { Hanford Site Environmental System Interiaces } \\
\text { None- }\end{array}$ & $\begin{array}{l}\text { External Interfaces } \\
\text {-None- } \\
\text { Hanford Site Environmental System Interfaces } \\
\text { NNene- }\end{array}$ \\
\hline
\end{tabular}


B.12.1.3.1.5 South 600 Area Steam System Interface Description and Forecast EXTERNAL INPUTS -None-

INTERNAL INPUTS -None-

EXTERNAL OUTPUTS -None-

INTERNAL OUTPUTS

-None- 


\section{B.12.1.3.2 South 600 Area Water System Facility}

\section{B.12.1.3.2.1 South 600 Area Water System Facility Description}

The South 600 Area water system includes river intake/outfall structures, wells, pumps, pipes, reservoirs, treatment facilities, and associated office, storage, and shop space in the South 600 Area necessary for operating the system in a safe and compliant manner.

\section{B.12.1.3.2.2 South 600 Area Water System Facility Technical Logic:}

The Department of Energy (DOE), in partnership with its contractors, shall plan, acquire, operate, maintain, and dispose of physical assets as valuable national resources. Stewardship of these physical assets shall be accomplished in a cost-effective manner to meet the DOE mission. This shall incorporate industry standards, a graded approach, and performance objectives. 


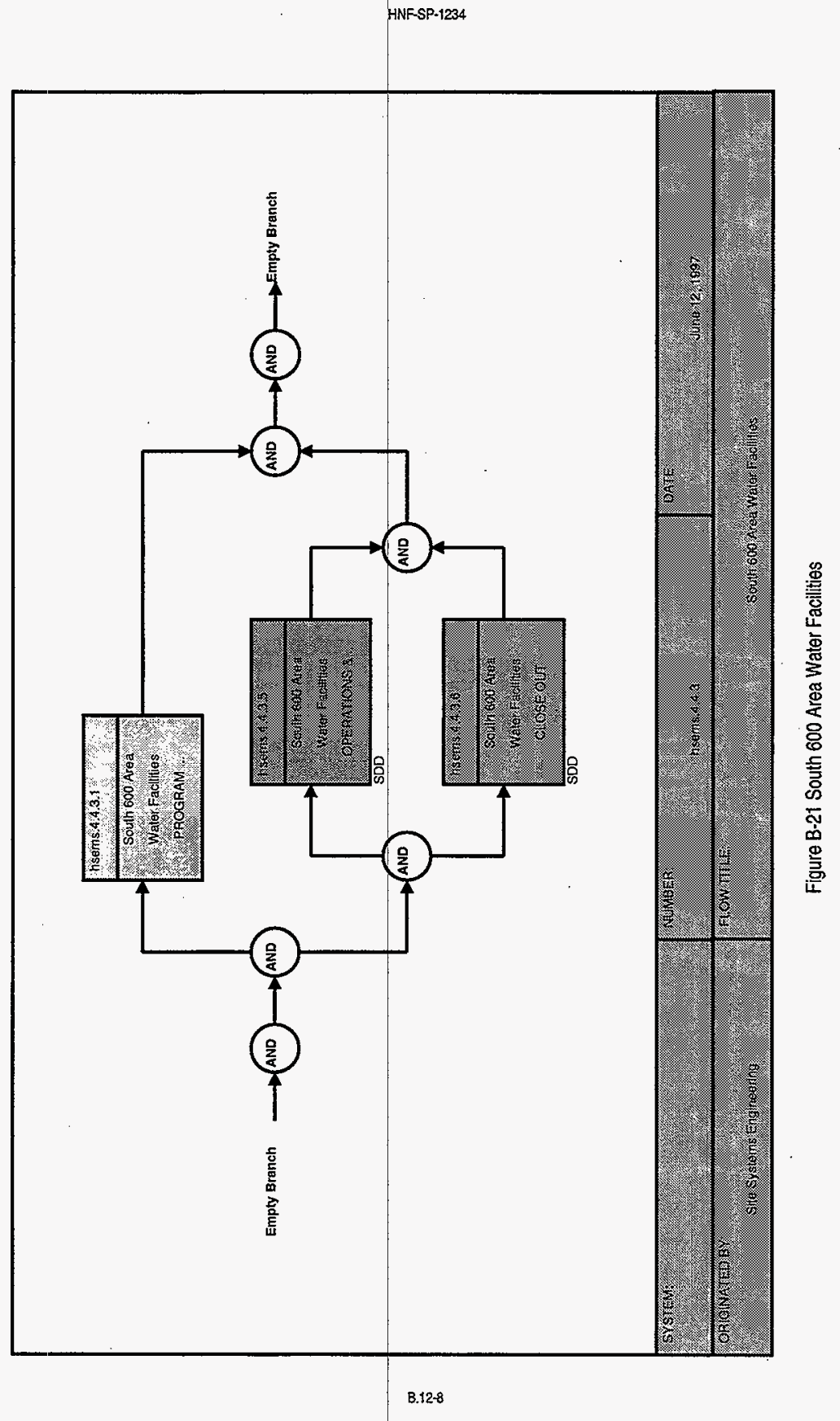




\section{B.12.1.3.2.3 South 600 Area Water System Requirements and Life Cycle Function Descriptions}

Requirements:

* South 600 Area high cost surplus facilties shall be transitioned to a low cost, stable, deactivated condition

* South 600 area facilities that can not be used for other purposes, shall be removed

* South 600 area facilities shall be made available for other uses.

* South 600 Area inactive facilties shall be surveillanced and maintained within the approved safety envelope

* South 600 area asbestos abatement shall be performed as necessary

\section{Life Cycle Function Descriptions:}

\section{B.12.1.3.2.3.1 South 600 Area Water Facilities OPERATIONS \& MAINTENANCE WORK SCOPE SUMMARY}

Day-to-day work, including preventive and predictive maintenance, that is required to maintain and preserve plant and capital equipment in a condition suitable for it to be used for its designated purpose.

South 600 Area Water Facilities OPERATIONS \& MAINTENANCE SPECIFIC FUNCTIONS

\section{B.12.1.3.2.3.2 South 600 Area Water Facilities POST OPERATIONS WORK SCOPE SUMMARY}

Day-to-day work, including pre-stabilization surveillance and maintenance, stabilization, post-stabilization surveillance and maintenance, deactivation, and post-deactivation surveillance and maintenance, that is required to allow safe decontamination and decommissioning.

South 600 Area Water Facilities POST OPERATIONS SPECIFIC FUNCTIONS

\section{B.12.1.3.2.3.3 Maintain Safe \& Compliant South 600 Area Water Facilities}

Maintain the Raw Water Supply facility structures, operating systems and equipment, and monitoring systems within the approved safety and compliance requirements until the facilities are made available for clean-up.

\section{B.12.1.3.2.3.4 Transition South 600 Area Water Facilities}

Initiate the transition phase of decontamination and decommissioning for the 300 Area Raw Water Facilities

\section{B.12.1.3.2.3.5 South 600 Area Water Facilities D\&D WORK SCOPE SUMMARY}

Day-to-day work, including remediating, stabilizing, controlling, and managing environmental contamination, that is required to allow future land-use objectives.

South 600 Area Water Facilities D\&D SPECIFIC FUNCTIONS 
B.12.1.3.2.3.6 Decontaminate and Decommission (D\&D) South 600 Area Water Facilities Initiate the final decontamination and decommissioning of the 300 Area Raw Water Facilities

B.12.1.3.2.4 South 600 Area Water System Boundary Diagram

Table B.12-2 South 600 Area Water System Boundary Diagram

\begin{tabular}{|l|l|l|}
\hline $\begin{array}{l}\text { External Interfaces } \\
\text {-None- } \\
\text { Hanford Site Environmental System Intertaces } \\
\text { None: }\end{array}$ & & $\begin{array}{l}\text { Extemal Interfaces } \\
\text { None- } \\
\text { Hanford Site Environmental System Interfaces } \\
\text { None- }\end{array}$ \\
\hline
\end{tabular}


B.12.1.3.2.5 South 600 Area Water System Interface Description and Forecast

EXTERNAL INPUTS

-None-

INTERNAL INPUTS

-None-

EXTERNAL OUTPUTS

-None-

INTERNAL OUTPUTS

-None- 


\section{B.12.1.3.3 South 600 Area Liquid Sanitary Waste System Facility}

\section{B.12.1.3.3.1 South 600 Area Liquid Sanitary Waste System Facility Description}

The South 600 Area liquid sanitary waste disposal system includes piping, septic tanks, pumps, soil absorption systems, Publicly Operated Treatment Works, lagoons, monitoring systems, and associated office, storage, and shop space in the South 600 Area necessary for operating the system in a saie and compliant manner.

\section{B.12.1.3.3.2 South 600 Area Liquid Sanitary Waste System Facility Technical Logic:}

The Department of Energy (DOE), in partnership with its contractors, shall plan, acquire, operate, maintain, and dispose of physical assets as valuable national resources. Stewardship of these physical assets shall be accomplished in a cost-effective manner to meet the BOE mission. This shall incorporate industry standards, a graded approach, and performance objectives. 
HNF-SP-1234

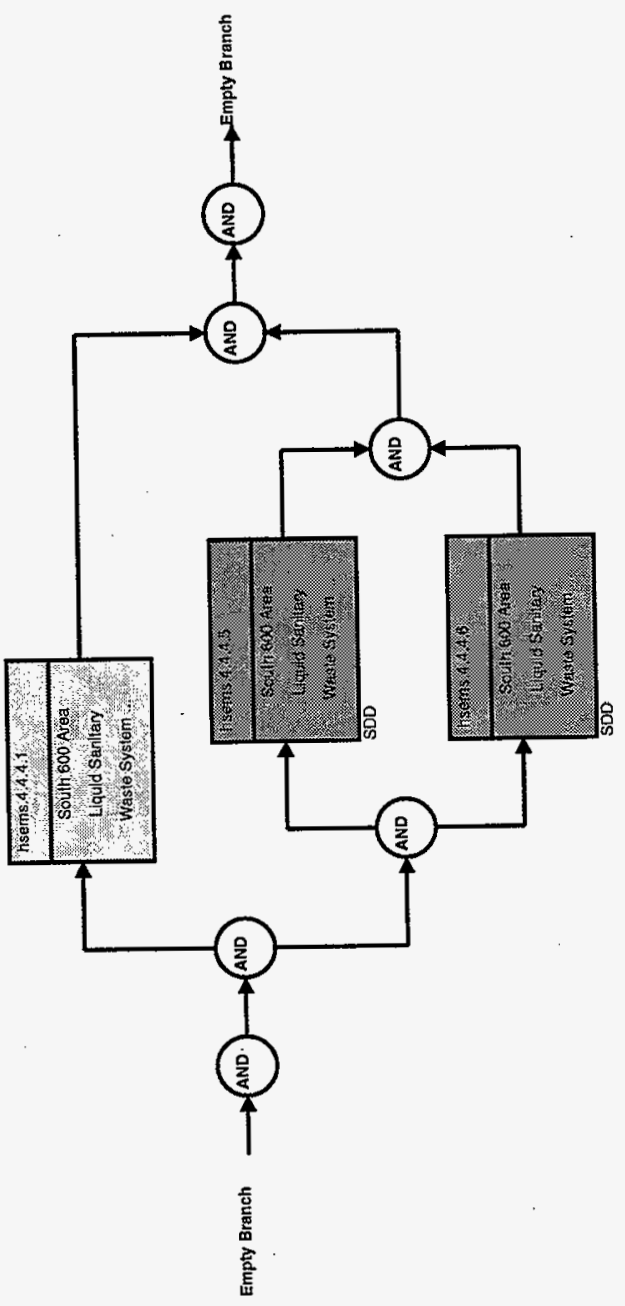

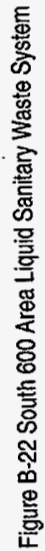




\section{B.12.1.3.3.3 South 600 Area Liquid Sanitary Waste System Requirements and Life Cycle Function} Descriptions

Requirements:

- South 600 Area high cost surplus facilties shall be transitioned to a low cost, stable, deactivated condition

- South 600 area facilities that can not be used for other purposes, shall be removed

* South 600 area facilities shall be made available for other uses.

* South 600 Area inactive facilities shall be surveillanced and maintained within the approved safety envelope

* South 600 area asbestos abatement shall be performed as necessary

\section{Life Cycle Function Descriptions:}

B.12.1.3.3.3.1 South 600 Area Liquid Sanitary Waste System OPERATIONS \& MAINTENANCE WORK SCOPE SUMMARY

Day-to-day work, including preventive and predictive maintenance, that is required to maintain and preserve plant and capital equipment in a condition suitable for it to be used for its designated purpose.

South 600 Area Liquid Sanitary Waste System OPERATIONS \& MAINTENANCE SPECIFIC FUNCTIONS

\section{B.12.1.3.3.3.2 South 600 Area Liquid Sanitary Waste System POST OPERATIONS WORK SCOPE SUMMARY}

Day-to-day work, including pre-stabilization surveillance and maintenance, stabilization, post-stabilization surveillance and maintenance, deactivation, and post-deactivation surveillance and maintenance, that is required to allow safe decontamination and decommissioning.

South 600 Area Liquid Sanitary Waste System POST OPERATIONS SPECIFIC FUNCTIONS

\section{B.12.1.3.3.3.3 Maintain Safe \& Compliant South 600 Area Liquid Sanitary Waste System}

Maintain the South 600 Area Sanitary System facility structures, operating systems and equipment, and monitoring systems within the approved safety and compliance requirements until the facilities are made available for clean-up.

\section{B.12.1.3.3.3.4 Transition South 600 Area Liquid Sanitary Waste System}

Initiate the facility transition phase of decontamination and deactivation for South 600 Area Liquid Sanitary Waste System Facilities.

\section{B.12.1.3.3.3.5 South 600 Area Liquid Sanitary Waste System D\&D WORK SCOPE SUMMARY}

Day-to-day work, including remediating, stabilizing, controlling, and managing environmental contamination, that is required to allow future land-use objectives. 
South 600 Area Liquid Sanitary Waste System D\&D SPECIFIC FUNCTIONS

B.12.1.3.3.3.6 Decontaminate and Decommission (D\&D) South 600 Area Liquid Sanitary Waste System Initiate the final decontamination and decommissioning of the South 600 Area Liquid Sanitary Waste System Facilities

B.12.1.3.3.4 South 600 Area Liquid Sanitary Waste System Boundary Diagram

Table B.12-3 South 600 Area Liquid Sanitary Waste System Boundary Diagram

\begin{tabular}{|l|l|l|}
\hline $\begin{array}{l}\text { External Interfaces } \\
\text { None- } \\
\text { Haniord Site Environmental System Interfaces } \\
\text { None- }\end{array}$ & $\begin{array}{l}\text { Extemal Intertaces } \\
\text {-None- } \\
\text { Hanford Site Environmental System Intertaces } \\
\text {-None- }\end{array}$ \\
\hline
\end{tabular}


B.12.1.3.3.5 South 600 Area Liquid Sanitary Waste System Interface Description and Forecast

\section{EXTERNAL INPUTS \\ -None- \\ INTERNAL INPUTS \\ -None- \\ EXTERNAL OUTPUTS}

-None-

INTERNAL OUTPUTS

-None- 


\section{B.12.1.3.4 South 600 Area Telecommunication System Facility}

\section{B.12.1.3.4.1 South 600 Area Telecommunication System Facility Description}

The South 600 Area telecommunications system includes wire, fiber optic cable, towers and transmission equipment, computers, radios, cameras, switches, and associated office, storage, and shop space in the South 600 Area necessany for operating the system in a safe and compliant manner.

\section{B.12.1.3.4.2 South 600 Area Telecommunication System Facility Technical Logic:}

The Department of Energy (DOE), in partnership with its contractors, shall plan, acquire, operate, maintain, and dispose of physical assets as valuable national resources. Stewardship of these physical assets shall be accomplished in a cost-effective manner to meet the DOE mission. This shall incorporate industry standards, a graded approach, and performance objectives. 


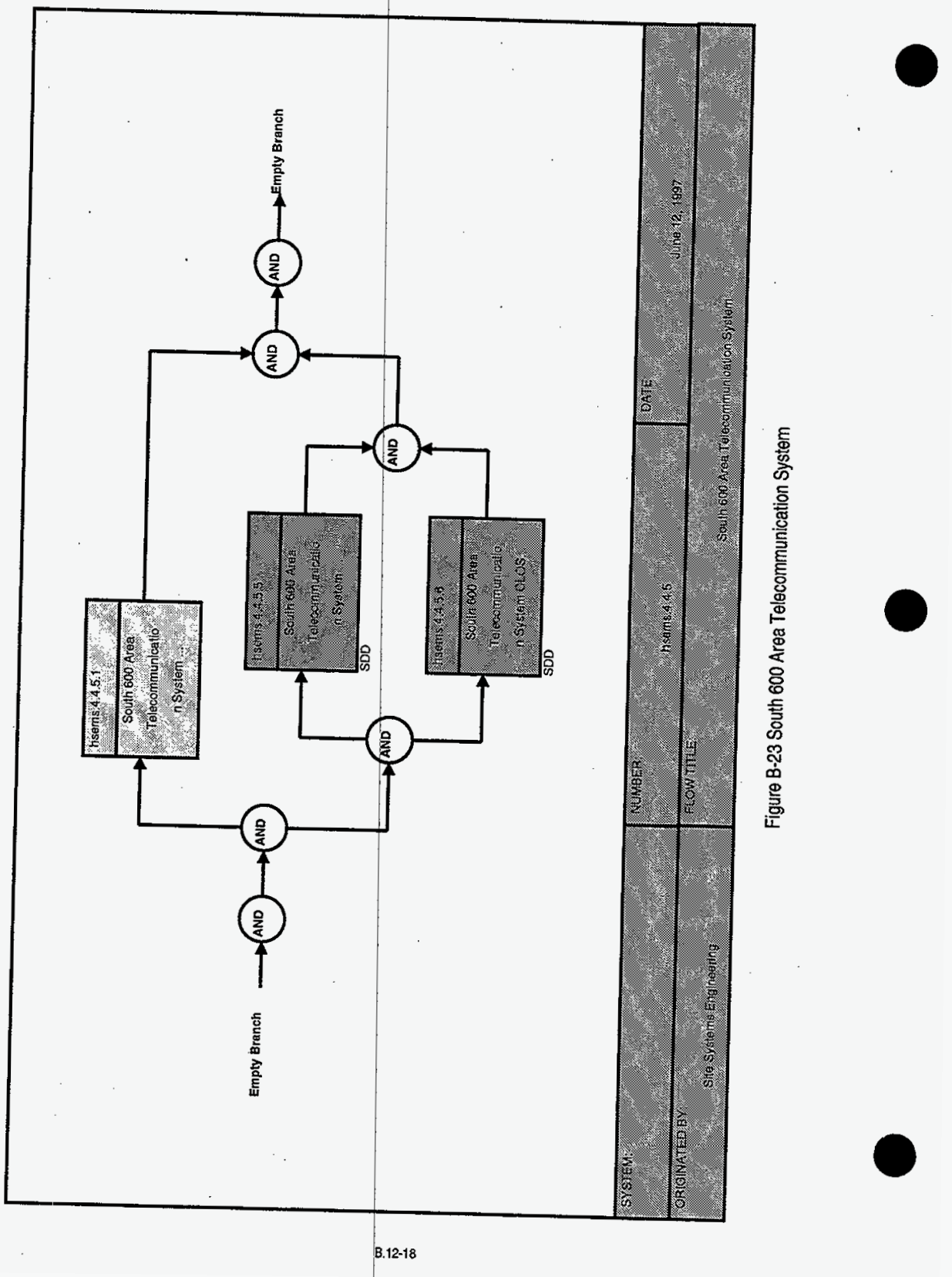


B.12.1.3.4.3 South 600 Area Telecommunication System Requirements and Life Cycle Function Descriptions

Requirements:

* South 600 Area high cost suplus facilties shall be transitioned to a low cost, stable, deactivated condition

* South 600 area facilities that can not be used for other purposes, shall be removed

* South 600 area facilities shall be made available for other uses.

* South 600 Area inactive facilities shall be surveillanced and maintained within the approved safety envelope

* South 600 area asbestos abatement shall be performed as necessary

Life Cycle Function Descriptions:

\section{B.12.1.3.4.3.1 South 600 Area Telecommunication System OPERATIONS \& MAINTENANCE WORK SCOPE SUMMARY}

Day-to-day work, including preventive and predictive maintenance, that is required to maintain and preserve plant and capital equipment in a condition suitable for it to be used for its designated purpose.

South 600 Area Telecommunication System OPERATIONS \& MAINTENANCE SPECIFIC FUNCTIONS

\subsection{2 South 600 Area Telecommunication System POST OPERATIONS WORK SCOPE SUMMARY}

Day-to-day work, including pre-stabilization surveillance and maintenance, stabilization, post-stabilization surveillance and maintenance, deactivation, and post-deactivation surveillance and maintenance, that is required to allow safe decontamination and decommissioning.

South 600 Area Telecommunication System POST OPERATIONS SPECIFIC FUNCTIONS

\section{B.12.1.3.4.3.3 Maintain Safe \& Compliant South 600 Area Telecommunication System}

The telecommunication system that includes facilities, structures, and equipment will be maintained until it is removed for cleanup.

B.12.1.3.4.3.4 Transition South 600 Area Telecommunication System

Initiate the facility transition phase of decontamination and deactivation for South 600 Area Telecommunications System.

\section{B.12.1.3.4.3.5 South 600 Area Telecommunication System D\&D WORK SCOPE SUMMARY}

Day-to-day work, including remediating, stabilizing, controlling, and managing environmental contamination, that is required to allow future land-use objectives.

South 600 Area Telecommunication System D\&D SPECIFIC FUNCTIONS 
B.12.1.3.4.3.6 Decontaminate and Decommission (D\&D) South 600 Area Telecommunication System Initiate the final decontamination and decommissioning of the South 600 Area Telecommunications System Facilities

\section{B.12.1.3.4.4 South 600 Area Telecommunication System Boundary Diagram}

Table B.12-4 South 600 Area Telecommunication System Boundary Diagram

Extemal Interiaces
-None-
Haniord Site Environmental System Interlaces
External Interiaces

None-

Hantord Site Environmental System Interiaces None- 
B.12.1.3.4.5 South 600 Area Telecommunication System Interface Description and Forecast

\section{EXTERNAL INPUTS}

-None-

INTERNAL INPUTS

-None-

\section{EXTERNAL OUTPUTS \\ -None-}

INTERNAL OUTPUTS

-None- 
B.12.1.3.5 South 600 Area Office Facilities

\section{B.12.1.3.5.1 South 600 Area Office Facilities Description}

South 600 Area office facilities include buildings used to house employees involved in administrative, engineering, training, or similar functions.

\section{B.12.1.3.5.2 South 600 Area Office Facilities Facility Technical Logic:}

The Department of Energy (DOE), in partnership with its contractors, shall plan, acquire, operate, maintain, and dispose of physical assets as valuable national resources. Stewardship of these physical assets shall be accomplished in a cost-effective manner to meet the DOE mission. This shall incorporate industry standards, a graded approach, and performance objectives. 
HNF-SP-1234

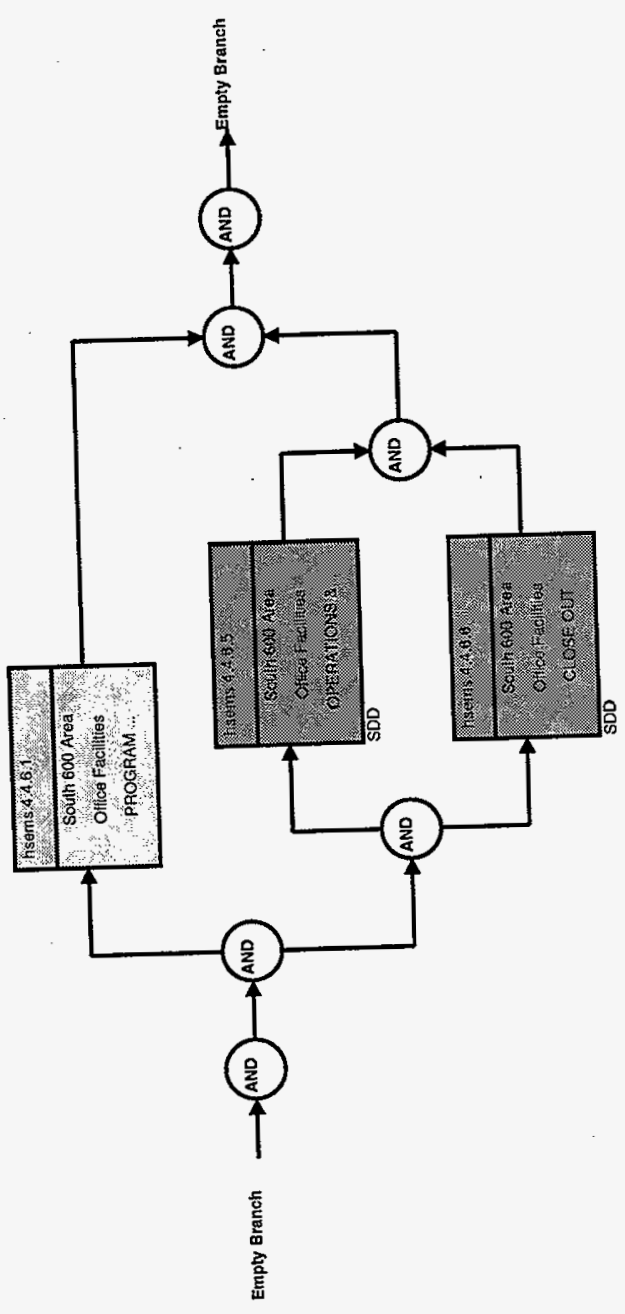

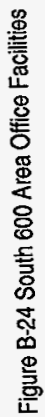




\section{B.12.1.3.5.3 South 600 Area Office Facilities Requirements and Life Cycle Function Descriptions}

\section{Requirements:}

* South 600 Area high cost surplus facilties shall be transitioned to a low cost, stable, deactivated condition

* South 600 area facilities that can not be used for other purposes, shall be removed

* South 600 area facilities shall be made available for other uses.

* South 600 Area inactive facilities shall be surveillanced and maintained within the approved safety envelope

* South 600 area asbestos abatement shall be performed as necessary

\section{Life Cycle Function Descriptions:}

\section{B.12.1.3.5.3.1 South 600 Area Office Facilities OPERATIONS \& MAINTENANCE WORK SCOPE SUMMARY}

Day-to-day work, including preventive and predictive maintenance, that is required to maintain and preserve plant and capital equipment in a condition suitable for it to be used for its designated purpose.

South 600 Area Office Facilities OPERATIONS \& MAINTENANCE SPECIFIC FUNCTIONS

\section{B.12.1.3.5.3.2 South 600 Area Office Facilities POST OPERATIONS WORK SCOPE SUMMARY}

Day-to-day work, including pre-stabilization surveillance and maintenance, stabilization, post-stabilization surveillance and maintenance, deactivation, and post-deactivation surveillance and maintenance, that is required to allow safe decontamination and decommissioning.

\section{South 600 Area Office Facilities POST OPERATIONS SPECIFIC FUNCTIONS}

\section{B.12.1.3.5.3.3 Maintain Safe \& Compliant South 600 Area Office Facilities}

Maintain the South 600 Area Office facility structures, operating systems and equipment, and monitoring systems within the approved safety and compliance requirements until the facilities are made available for clean-up.

\section{B.12.1.3.5.3.4 Transition South 600 Area Office Facilities}

Initiate the transition phase of decontamination and decommissioning for the 300 Area Office Facilities

\section{B.12.1.3.5.3.5 South 600 Area Otfice Facilities D\&D WORK SCOPE SUMMARY}

Day-to-day work, including remediating, stabilizing, controlling, and managing environmental contamination, that is required to allow future land-use objectives. 
South 600 Area Office Facilities D\&D SPECIFIC FUNCTIONS

B.12.1.3.5.3.6 Decontaminate and Decommission (D\&D) South 600 Area Office Facilities Initiate the final decontamination and decommissioning of the 300 Area Office Facilities

\section{B.12.1.3.5.4 South 600 Area Office Facilities Boundary Diagram}

Table B.12-5 South 600 Area Office Facilities Boundary Diagram

\begin{tabular}{|l|l|}
\hline $\begin{array}{l}\text { External Interfaces } \\
\text { None- } \\
\text { Hantord Site Environmental System Interlaces } \\
\text {-None- }\end{array}$ & $\begin{array}{l}\text { External hiterfaces } \\
\text { None- } \\
\text { Haniord Site Environmental System Interfaces } \\
\text {-Nene- }\end{array}$ \\
\hline
\end{tabular}


B.12.1.3.5.5 South 600 Area Office Facilities Interface Description and Forecast EXTERNAL INPUTS -None-

INTERNAL INPUTS -None-

\section{EXTERNAL OUTPUTS} -None-

INTERNAL OUTPUTS -None- 


\section{B.12.1.3.6 South 600 Area Shop Facilities}

\section{B.12.1.3.6.1 South 600 Area Shop Facilities Description}

South 600 Area shop facilities include buildings used to house maintenance, fabrication, modeling, and associated office, storage, and shop space necessary for operating the facilities in a safe and compliant manner.

\section{B.12.1.3.6.2 South 600 Area Shop Facilities Facility Technical Logic:}

The Department of Energy (DOE), in partnership with its contractors, shall plan, acquire, operate, maintain, and dispose of physical assets as valuable national resources. Stewardship of these physical assets shall be accomplished in a cost-effective manner to meet the DOE mission. This shall incorporate industry standards, a graded approach, and performance objectives. 


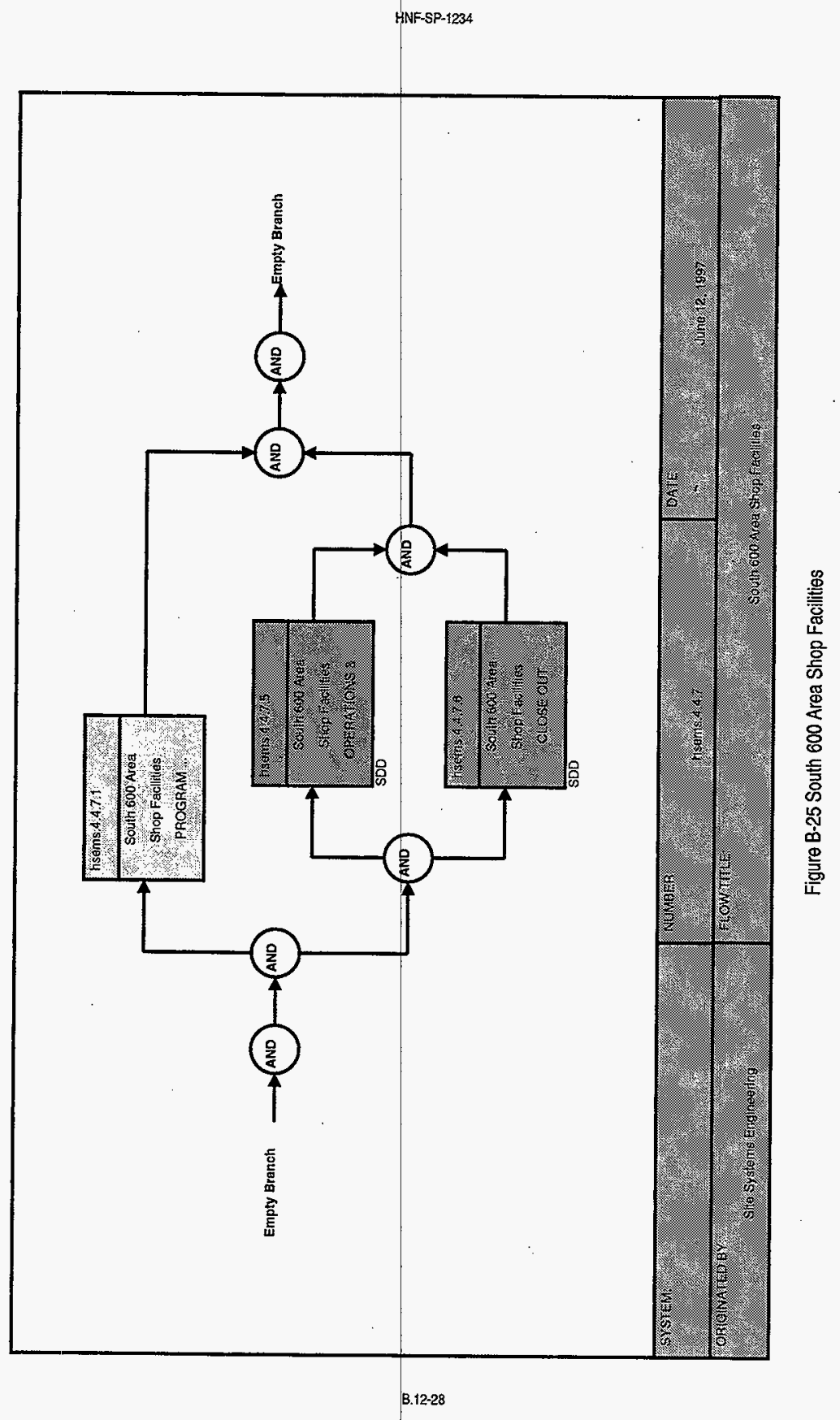




\section{B.12.1.3.6.3 South 600 Area Shop Facilities Requirements and Life Cycle Function Descriptions}

\section{Requirements:}

* South 600 Area high cost surplus facilties shall be transitioned to a low cost, stable, deactivated condition

* South 600 area facilities that can not be used for other purposes, shall be removed

- South 600 area facilities shall be made available for other uses.

- South 600 Area inactive facilities shall be surveillanced and maintained within the approved safety envelope

* South 600 area asbestos abatement shall be performed as necessary

\section{Life Cycle Function Descriptions:}

\section{B.12.1.3.6.3.1 South 600 Area Shop Facilities OPERATIONS \& MAINTENANCE WORK SCOPE SUMMARY}

Day-to-day work, including preventive and predictive maintenance, that is required to maintain and preserve plant and capital equipment in a condition suitable for it to be used for its designated purpose.

\section{South 600 Area Shop Facilities OPERATIONS \& MAINTENANCE SPECIFIC FUNCTIONS}

\section{B.12.1.3.6.3.2 South 600 Area Shop Facilities POST OPERATIONS WORK SCOPE SUMMARY}

Day-to-day work, including pre-stabilization surveillance and maintenance, stabilization, post-stabilization surveillance and maintenance, deactivation, and post-deactivation surveillance and maintenance, that is required to allow saie decontamination and decommissioning.

\section{South 600 Area Shop Facilities POST OPERATIONS SPECIFIC FUNCTIONS}

\section{B.12.1.3.6.3.3 Maintain Safe \& Compliant South 600 Area Shop Facilities}

Maintain the South 600 Area Shop facility structures, operating systems and equipment, and monitoring systems within the approved safety and compliance requirements until the facilities are made available for clean-up.

\section{B.12.1.3.6.3.4 Transition South 600 Area Shop Facilities}

Initiate the transition phase of decontamination and decommissioning for the 300 Area Shop Facilities.

\section{B.12.1.3.6.3.5 South 600 Area Shop Facilities D\&D WORK SCOPE SUMMARY}

Day-to-day work, including remediating, stabilizing, controlling, and managing environmental contamination, that is required to allow future land-use objectives.

South 600 Area Shop Facilities D\&D SPECIFIC FUNCTIONS 
B.12.1.3.6.3.6 Decontaminate and Decommission (D\&D) South 600 Area Shop Facilities Initiate the final decontamination and decommissioning of the South 600 Area Shop Facilities

\section{B.12.1.3.6.4 South 600 Area Shop Facilities Boundary Diagram}

Table B.12-6 South 600 Area Shop Facilities. Boundary Diagram

\begin{tabular}{|l|l|l|}
\hline $\begin{array}{l}\text { Extemal Interfaces } \\
\text { None- } \\
\text { Hantord Site Environmental System Interfaces } \\
\text { None- }\end{array}$ & & $\begin{array}{l}\text { Extemal Interfacas } \\
\text { None- } \\
\text { Hanford Site Environmental System Interfaces } \\
\text {-Nene- }\end{array}$ \\
\hline
\end{tabular}


B.12.1.3.6.5 South 600 Area Shop Facilities Interface Description and Forecast

\section{EXTERNAL INPUTS}

-None-

INTERNAL INPUTS

-None-

EXTERNAL OUTPUTS

-None-

INTERNAL OUTPUTS

-None- 
B.12.1.3.7 South 600 Area Storage Facilities

\section{B.12.1.3.7.1 South 600 Area Storage Facilities Description}

Facilities in the South 600 Area of Hanford used for the storage of waste and materials.

\section{B.12.1.3.7.2 South 600 Area Storage Facilities Facility Technical Logic:}

The Department of Energy (DOE), in partnership with its contractors, shall plan, acquire, operate, maintain, and dispose of physical assets as valuable national resoutces. Stewardship of these physical assets shall be accomplished in a cost-effective manner to meet the DOE mission. This shall incorporate industry standards, a graded approach, and performance objectives. 
HNF-SP-1234

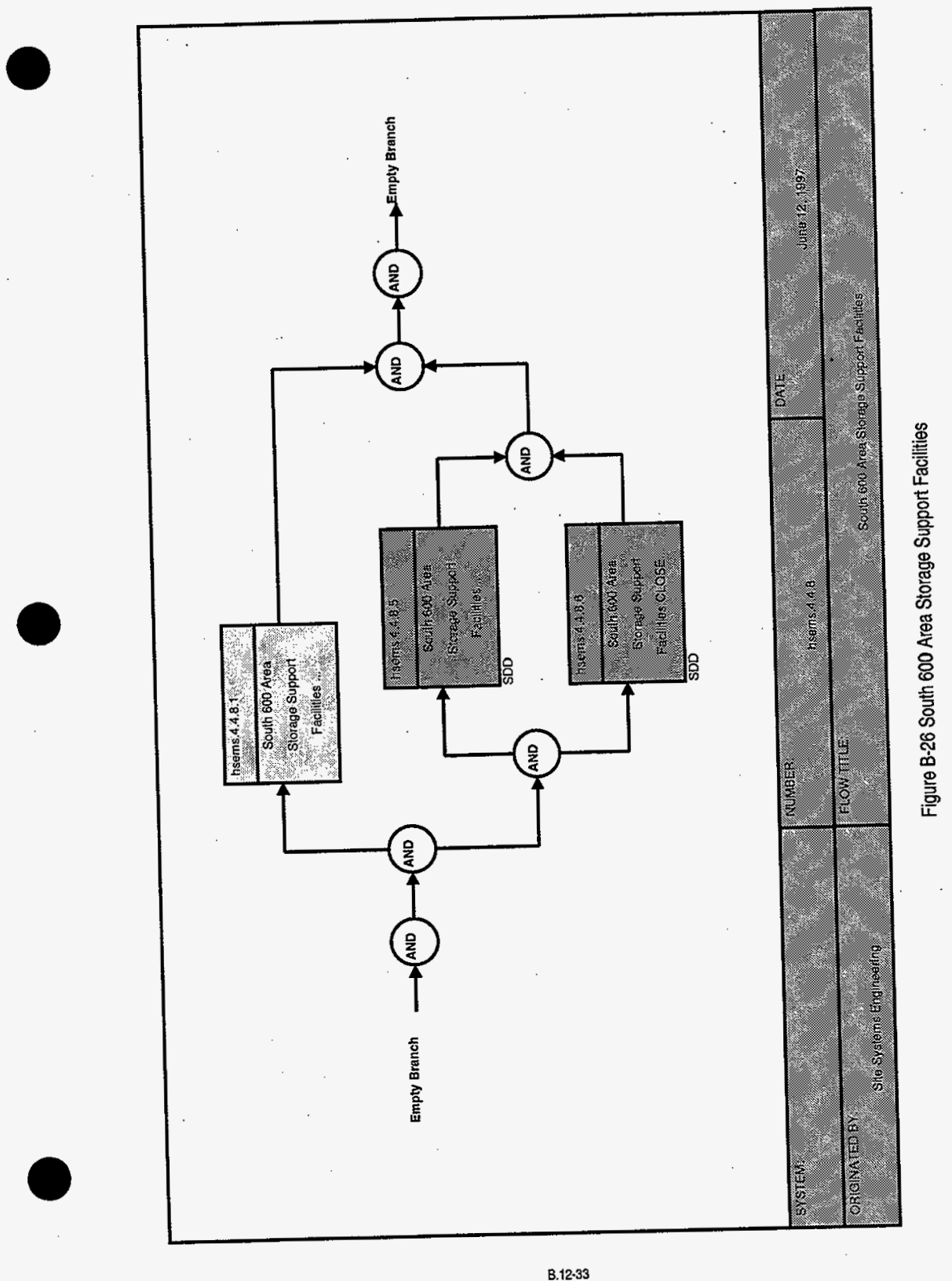




\section{B.12.1.3.7.3 South 600 Area Storage Facilities Requirements and Life Cycle Function Descriptions}

\section{Requirements:}

* South 600 Area high cost surplus facilties shall be transitioned to a low cost, stable, deactivated condition

* South 600 area facilities that can not be used for other purposes, shall be removed

- South 600 area facilities shall be made available for other uses.

* South 600 Area inactive facilities shall be surveillanced and maintained within the approved safety envelope

* South 600 area asbestos abatement shall be performed as necessary

\section{Life Cycle Function Descriptions:}

B.12.1.3.7.3.1 South 600 Area Storage Support Facilities OPERATIONS \& MAINTENANCE WORK SCOPE SUMMARY

Day-to-day work, including preventive and predictive maintenance, that is required to maintain and preserve plant and capital equipment in a condition suitable for it to be used for its designated purpose.

\section{South 600 Area Storage Support Facilities OPERATIONS \& MAINTENANCE SPECIFIC FUNCTIONS}

\section{B.12.1.3.7.3.2 South 600 Area Storage Support Facilities POST OPERATIONS WORK SCOPE SUMMARY}

Day-to-day work, including pre-stabilization surveillance and maintenance, stabilization, post-stabilization surveillance and maintenance, deactivation, and post-deactivation surveillance and maintenance, that is required to allow safe decontamination and decommissioning.

South 600 Area Storage Support Facilities POST OPERATIONS SPECIFIC FUNCTIONS

\section{B.12.1.3.7.3.3 Maintain Safe \& Compliant South 600 Area Storage Facilities}

Maintain the South 600 Area Storage facility structures, operating systems and equipment, and monitoring systems within the approved safety and compliance requirements until the facilities are made available for clean-up.

\section{B.12.1.3.7.3.4 Transition South 600 Area Storage Facilities}

Initiate the transition phase of decontamination and decommissioning for the South 600 Area Storage Facilities

\section{B.12.1.3.7.3.5 South 600 Area Storage Support Facilities D\&D WORK SCOPE SUMMARY}

Day-to-day work, including remediating, stabilizing, controlling, and managing environmental contamination, that is required to allow future land-use objectives. 
South 600 Area Storage Support Facilities D\&D SPECIFIC FUNCTIONS

B. 12.1.3.7.3.6 Decontaminate and Decommission (D\&D) South 600 Area Storage Facilities Initiate the final decontamination and decommissioning of the South 600 Area Storage Facilities

B.12.1.3.7.4 South 600 Area Storage Facilities Boundary Diagram

Table B.12-7 South 600 Area Storage Facilities Boundary Diagram

\begin{tabular}{|l|l|}
\hline $\begin{array}{l}\text { Extemal Interfaces } \\
\text {-Nons- } \\
\text { Hantord Site Environmental System Interfaces } \\
-N o n \theta\end{array}$ & $\begin{array}{l}\text { External Interfaces } \\
\text { None- } \\
\text { Hanford Site Environmentel System Intertaces } \\
\text { None- }\end{array}$ \\
\hline
\end{tabular}


B.12.1.3.7.5 South 600 Area Storage Facilities Interface Description and Forecast

\section{EXTERNAL INPUTS \\ -None- \\ INTERNAL INPUTS \\ -None- \\ EXTERNAL OUTPUTS \\ -None- \\ INTERNAL OUTPUTS \\ -None-}




\section{B.12.1.3.8 South 600 Area Land Facility}

\section{B.12.1.3.8.1 South 600 Area Land Facility Description}

South 600 Area land includes land, including rights-of-way, easements, quit claims, zoning, offsets, culturally sensitive areas, ecologically sensitive areas, and assignment for the use thereof.

\section{B.12.1.3.8.2 South 600 Area Land Facility Technical Logic:}

The Department of Energy (DOE), in partnership with its contractors, shall plan, acquire, operate, maintain, and dispose of physical assets as valuable national resources. Stewardship of these physical assets shall be accomplished in a cost-effective manner to meet the DOE mission. This shall incorporate industry standards, a graded approach, and performance objectives. 


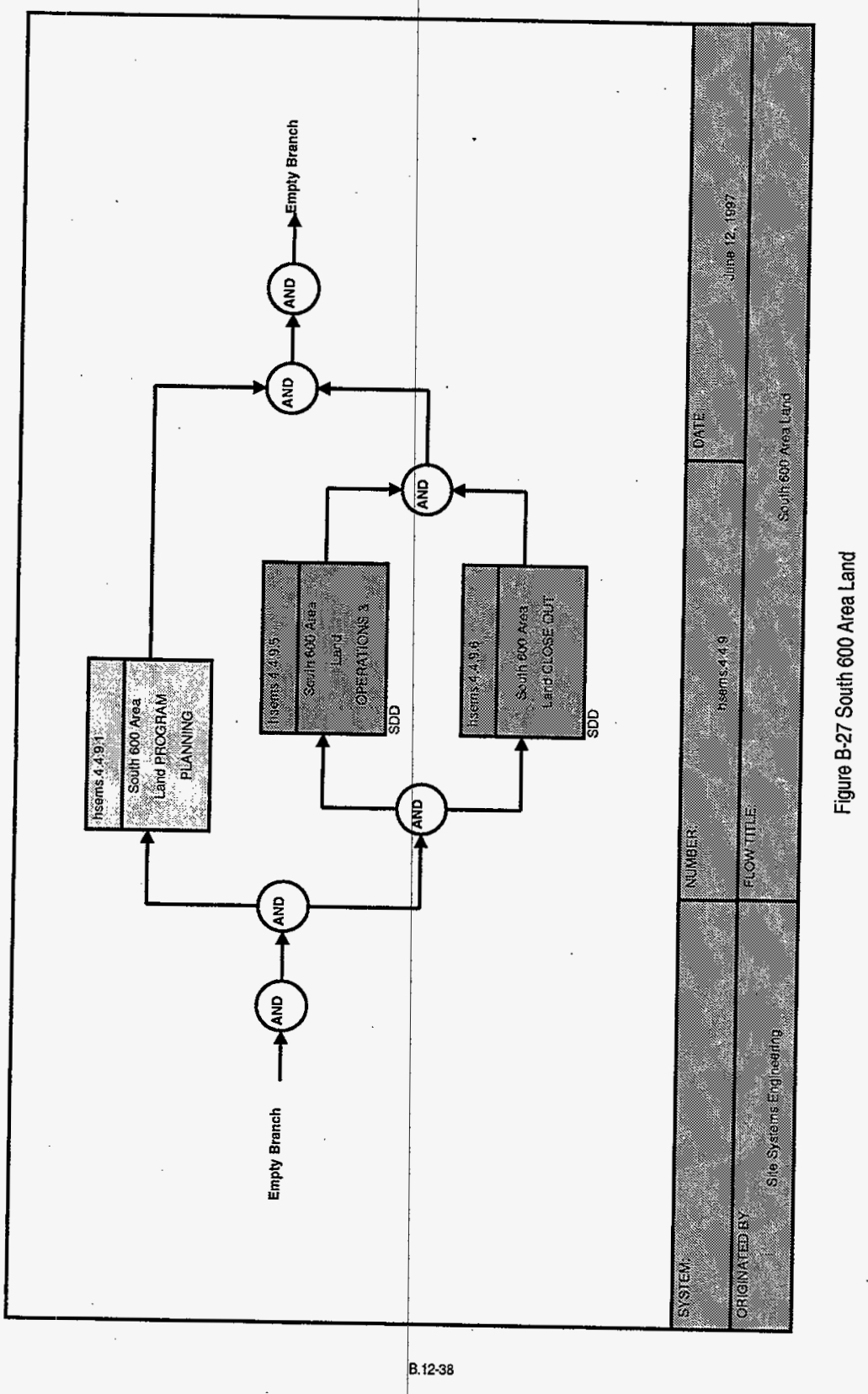




\section{B.12.1.3.8.3 South 600 Area Land Requirements and Life Cycle Function Descriptions}

Requirements:

* 1100 Area excess land shall be transitioned to non-federal ownership

* South 600 area facilities that can not be used for other purposes, shall be removed

* South 600 area facilities shall be made available for other uses.

- Meteorological services shall be provided for the Hanford Site

- Ecosystem management services shall be provided for the Hanford Site

- Arid Lands Ecology Reserve land ownership shall be retained

* North Slope Area land ownership shall be retained

* Arid Lands Ecology Reserve cultural resources shail be protected

* Arid Lands Ecology Reserve ecological resources shall be protected

* Arid Lands Ecology Reserve scientific resources shall be protected

* North Slope scientific resources shall be protected

* North Slope ecological resources shall be protected

- North Siope cultural resources shall be protected

- 300 Area land ownership shall be retained

* 400 Area land ownership shall be retained

* 300 Area land shall be leased for other uses

* 400 Area land shall be leased for other uses

- South 600 Area land ownership shall be retained

* South 600 area asbestos abatement shall be performed as necessary

\section{Life Cycle Function Descriptions:}

\section{B.12.1.3.8.3.1 South 600 Area Land OPERATIONS \& MAINTENANCE WORK SCOPE SUMMARY}

Day-to-day work, including preventive and predictive maintenance, that is required to maintain and preserve plant and capital equipment in a condition suitable for it to be used for its designated purpose.

South 600 Area Land OPERATIONS \& MAINTENANCE SPECIFIC FUNCTIONS 
B.12.1.3.8.3.2 Control Access to the South 600 Areas

Access to the South 600 areas and facilities will be controlled to protect the public and the workers

\section{B.12.1.3.8.3.3 South 600 Area Land POST OPERATIONS WORK SCOPE SUMMARY}

Day-to-day work, including pre-stabilization surveillance and maintenance, stabilization, post-stabilization surveillance and maintenance, deactivation, and post-deactivation surveillance and maintenance, that is required to allow safe decontamination and decommissioning.

\section{South 600 Area Land POST OPERATIONS SPECIFIC FUNCTIONS}

\section{B.12.1.3.8.3.4 Maintain Safe \& Compliant South 600 Area Land}

The Land Access Control System including fences, structures, and equipment will be maintained until it is removed for cleanup.

\section{B.12.1.3.8.3.5 Transition South 600 Area Land}

Initiate the transition phase of decontamination and decommissioning for the South 600 Area Land.

\section{B.12.1.3.8.3.6 South 600 Area Land D\&D WORK SCOPE SUMMARY}

Day-to-day work, including remediating, stabilizing, controlling, and managing environmental contamination, that is required to allow future land-use objectives.

\section{South 600 Area Land D\&D SPECIFIC FUNCTIONS}

B.12.1.3.8.3.7 Decontaminate and Decommission (D\&D) South 600 Area Land

Initiate the final decontamination and decommissioning of the South 600 Area Land.

\section{B.12.1.3.8.4 South 600 Area Land Boundary Diagram}

Table B.12-8 South 600 Area Land Boundary Diagram

\begin{tabular}{|l|l|l|}
\hline $\begin{array}{l}\text { Extenal Interfaces } \\
\text { None } \\
\text { Hanford Site Envizonmental System Interfaces } \\
\text { None: }\end{array}$ & & $\begin{array}{l}\text { External Interfaces } \\
\text {-None- } \\
\text { Hanford Site Environmental System Intertaces } \\
\text { None- }\end{array}$ \\
\hline
\end{tabular}


B.12.1.3.8.5 South 600 Area Land Interface Description and Forecast

\section{EXTERNAL INPUTS}

-None-

INTERNAL INPUTS

-None-

EXTERNAL OUTPUTS

-None-

INTERNAL OUTPUTS

-None- 
B.12.1.3.9 South 600 Area Road System Facility

\section{B.12.1.3.9.1 South 600 Area Road System Facility Description}

The South 600 Area road system includes driving surfaces and associated office, storage, and shop space necessary for operating the system in a safe and compliant manner.

\section{B.12.1.3.9.2 South 600 Area Road System Facility Technical Logic:}

The Department of Energy (DOE), in partnership with its contractors, shall plan, acquire, operate, maintain, and dispose of physical assets as valuable national resources. Stewardship of these physical assets shall be accomplished in a cost-effective manner to meet the DOE mission. This shall incorporate industry standards, a graded approach, and periomance objectives. 


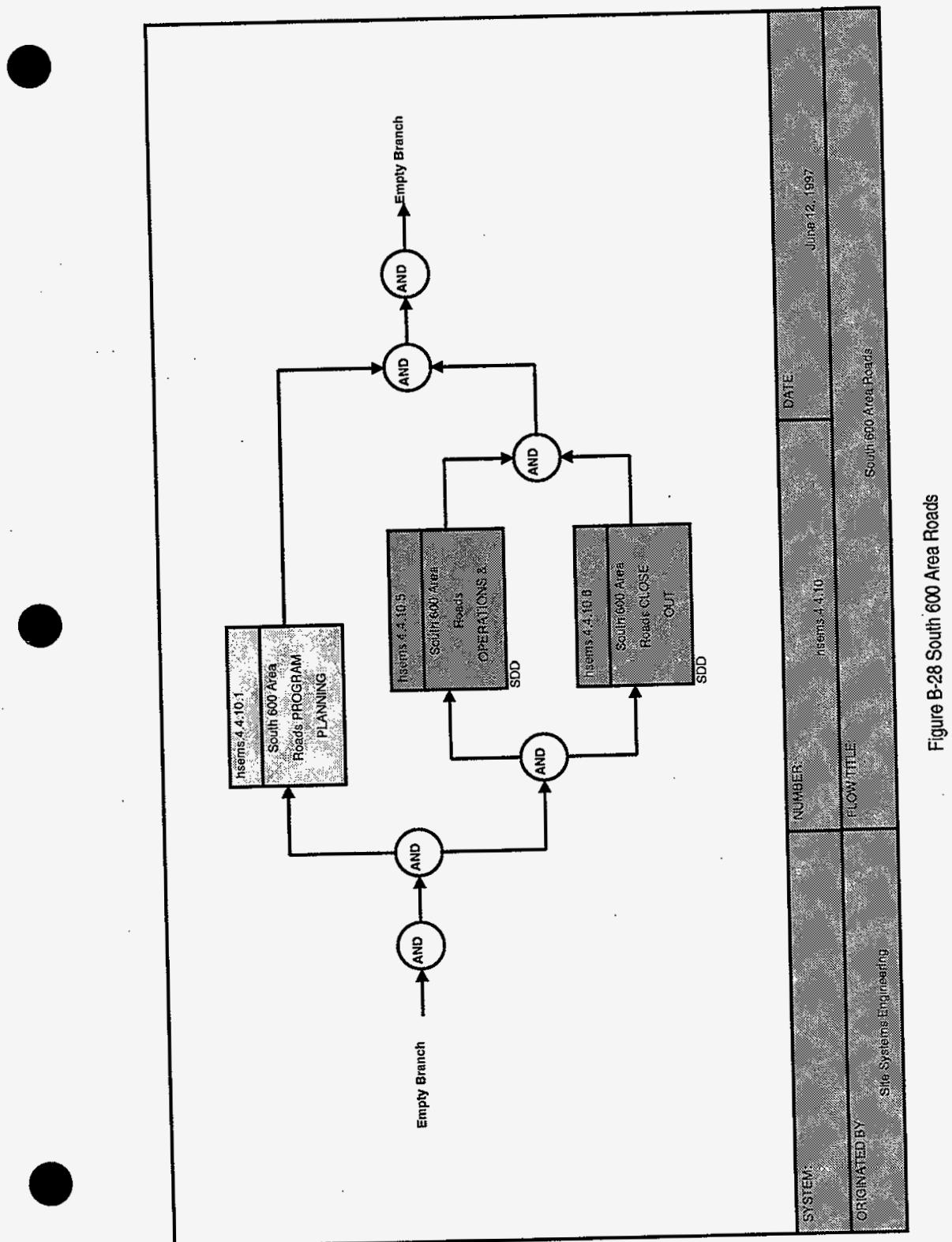




\section{B.12.1.3.9.3 South 600 Area Road System Requirements and Life Cycle Function Descriptions}

\section{Requirements:}

* The Hanford Site Infrastructure shall be optimized.

* South 600 area facilities that can not be used for other purposes, shall be removed

* South 600 area facilities shall be made available for other uses.

* South 600 Area inactive facilities shall be surveillanced and maintained within the approved safety envelope

* South 600 area asbestos abatement shall be performed as necessary

\section{Life Cycle Function Descriptions:}

\section{B.12.1.3.9.3.1 South 600 Area Roads OPERATIONS \& MAINTENANCE WORK SCOPE SUMMARY}

Day-to-day work, including preventive and predictive maintenance, that is required to maintain and preserve plant and capital equipment in a condition suitable for it to be used for its designated purpose.

South 600 Area Roads OPERATIONS \& MAINTENANCE SPECIFIC FUNCTIONS

\section{B.12.1.3.9.3.2 Maintain Road System at South 600 Area}

Maintain primary and secondary roads in the South 600 Area.

\section{B.12.1.3.9.3.3 South 600 Area Roads POST OPERATIONS WORK SCOPE SUMMARY}

Day-to-day work, including pre-stabilization surveillance and maintenance, stabilization, post-stabilization surveillance and maintenance, deactivation, and post-deactivation surveillance and maintenance, that is required to allow safe decontamination and decommissioning.

\section{South 600 Area Roads POST OPERATIONS SPECIFIC FUNCTIONS}

\section{B.12.1.3.9.3.4 Maintain Safe \& Compliant South 600 Area Roads}

The Road System that includes road surface, signs, and equipment will be maintained until it is removed for cleanup.

\section{B.12.1.3.9.3.5 Transition South 600 Area Roads}

Initiate the transition phase of decontamination and decommissioning for the South 600 Area Roads.

\section{B.12.1.3.9.3.6 300 Area Roads D\&D WORK SCOPESUMMARY}

Day-to-day work, including remediating, stabilizing, controlling, and managing environmental contamination, that is required to allow future land-use objectives. 
300 Area Roads D\&D SPECIFIC FUNCTIONS

B.12.1.3.9.3.7 Decontaminate and Decommission (D\&D) South 600 Area Roads

Initiate the final decontamination and decommissioning of the South 600 Area Roads.

\section{B.12.1.3.9.4 South 600 Area Road System Boundary Diagram}

Table B.12-9 South 600 Area Road System Boundary Diagram

\begin{tabular}{|c|c|}
\hline $\begin{array}{l}\text { Extemal Interfaces } \\
\text { Hariord Legacy } \\
\text { Hanford Site Envisonmental System Interiaces } \\
\text {-None- }\end{array}$ & $\begin{array}{l}\text { Extemal Interfaces } \\
\text {-None- } \\
\text { Hantord Site Environmental System Interfaces } \\
\text { hsems.4.2.1 } 300 \text { Area Treated Effluent Disposal Facility } \\
\text { hsems:4.3.2 300 Area Fuel Supply System } \\
\text { hsems.4.13 HAMMER }\end{array}$ \\
\hline
\end{tabular}




\section{B.12.1.3.9.5 South 600 Area Road System Interface Description and Forecast}

\section{EXTERNAL INPUTS}

Table B.12-10 External Inputs for South 600 Area Road System

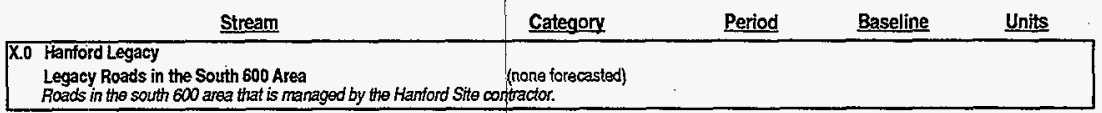

INTERNALINPUTS

-None-

EXTERNAL OUTPUTS

-None-

INTERNAL OUTPUTS

Table B.12-11 Internal Outputs for South 600 Area Road System

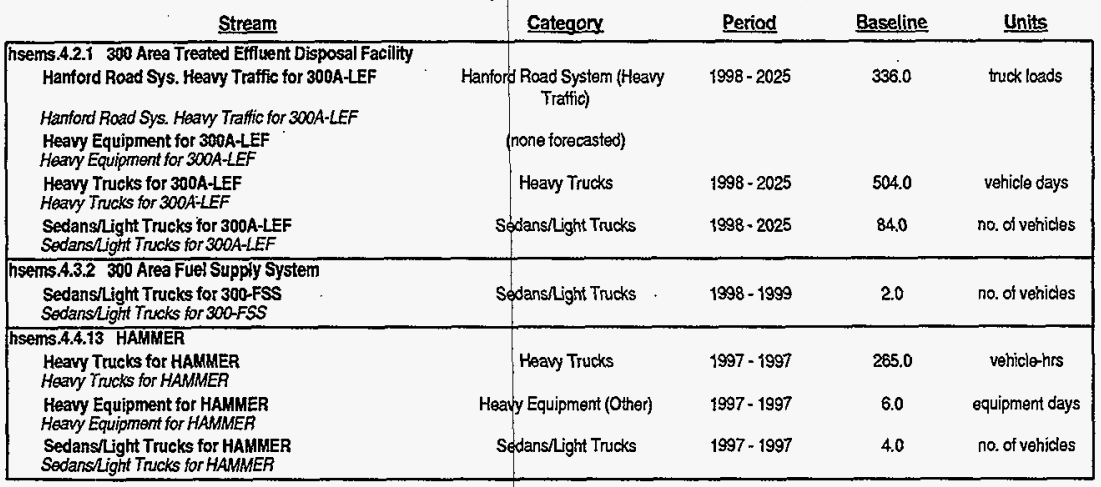




\section{B.12.1.3.10 South 600 Area Rail System Facility}

\section{B.12.1.3.10.1 South 600 Area Rail System Facility Description}

The South 600 Area rail system includes track, bridges, crossings, sidings, locomotives, rolling stock, and associated office, storage, and shop space necessary for operating the system in a safe and compliant manner.

\section{B.12.1.3.10.2 South 600 Area Rail System Facility Technical Logic:}

The Department of Energy (DOE), in partnership with its contractors, shall plan, acquire, operate, maintain, and dispose of physical assets as valuable national resources. Stewardship of these physical assets shall be accomplished in a cost-effective manner to meet the DOE mission. This shall incorporate industry standards, a graded approach, and performance objectives. 


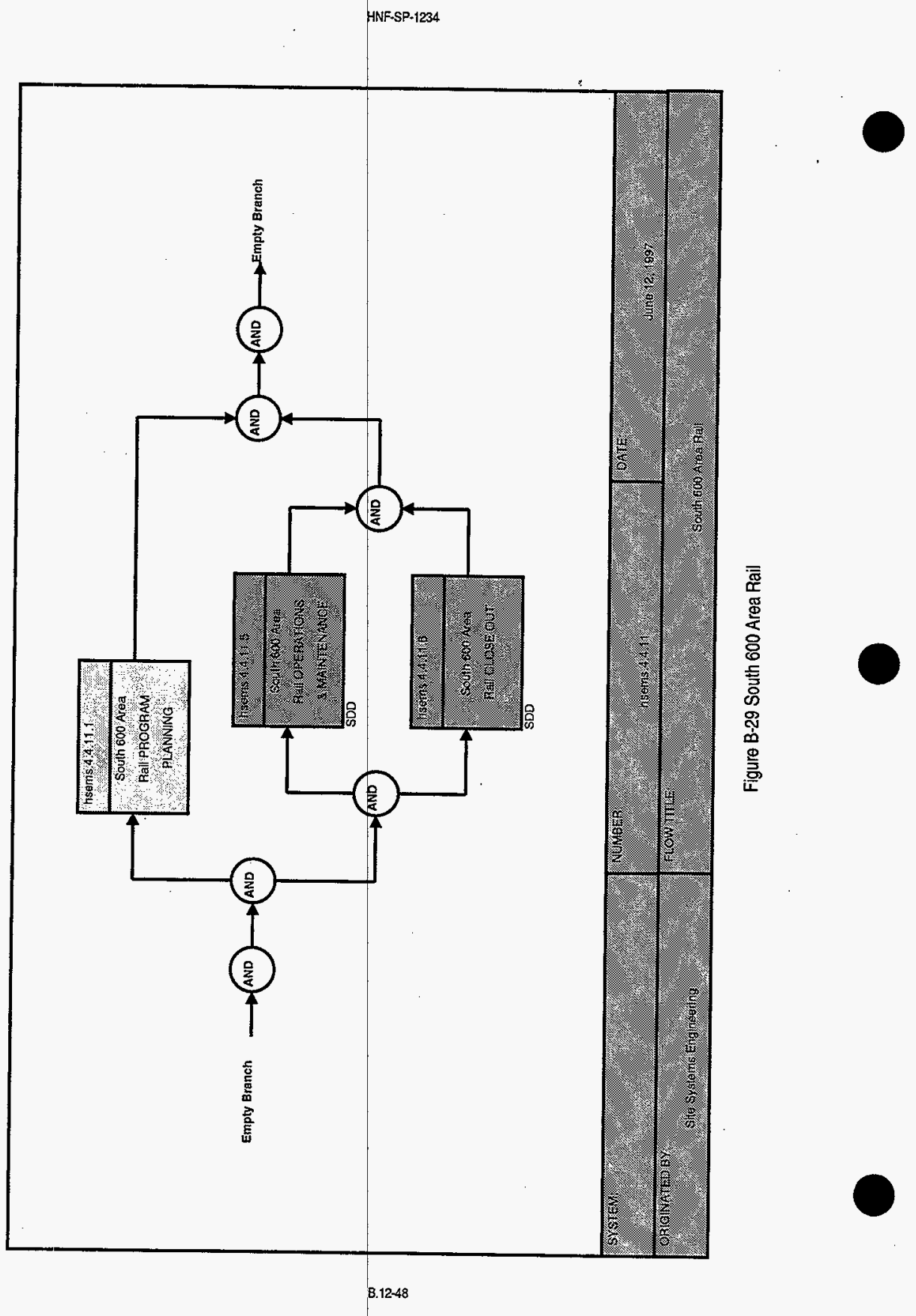




\section{B.12.1.3.10.3 South 600 Area Rail System Requirements and Life Cycle Function Descriptions}

Requirements:

* The Hanford Site infrastructure shall be optimized.

* South 600 area facilities that can not be used for other purposes, shall be removed

* South 600 area facilities shall be made available for other uses.

* South 600 Area inactive facilities shall be surveillanced and maintained within the approved safety envelope

* South 600 area asbestos abatement shall be performed as necessary

\section{Life Cycle Function Descriptions:}

\section{B.12.1.3.10.3.1 South 600 Area Rail OPERATIONS \& MAINTENANCE WORK SCOPE SUMMARY}

Day-to-day work, including preventive and predictive maintenance, that is required to maintain and preserve plant and capital equipment in a condition suitable for it to be used for its designated purpose.

\section{South 600 Area Rail OPERATIONS \& MAINTENANCE SPECIFIC FUNCTIONS}

\section{B.12.1.3.10.3.2 Provide Rail Transportation at South 600 Area}

Operate and maintain the Hanford Rail System in the South 600 Area.

\section{B.12.1.3.10.3.3 South 600 Area Rail POST OPERATIONS WORK SCOPE SUMMARY}

Day-to-day work, including pre-stabilization surveillance and maintenance, stabilization, post-stabilization surveillance and maintenance, deactivation, and post-deactivation surveillance and maintenance, that is required to allow safe decontamination and decommissioning.

\section{South 600 Area Rail POST OPERATIONS SPECIFIC FUNCTIONS}

\section{B.12.1.3.10.3.4 Maintain Safe \& Compliant South 600 Area Rail}

The Rail System that includes tracks, structures, and equipment will be maintained until it is removed for cleanup.

\section{B.12.1.3.10.3.5 Transition South 600 Area Rail}

Initiate the transition phase of decontamination and decommissioning for the South 600 Area Rail.

\section{B.12.1.3.10.3.6 South 600 Area Rail D\&D WORK SCOPE SUMMARY}

Day-to-day work, including remediating, stabilizing, controlling, and managing environmental contamination, that is required to allow future land-use objectives. 
South 600 Area Rail D\&D SPECIFIC FUNCTIONS

B.12.13.10.3.7 Decontaminate and Decommission (D\&D) South 600 Area Rail

Initiate the final decontamination and decommissioning of the South 600 Area Rail.

\section{B.12.13.10.4 South 600 Area Rail System Boundary Diagram}

Table B.12-12 South 600 Area Rail System Boundary Diagram

\begin{tabular}{|l|l|l|}
\hline $\begin{array}{l}\text { External Interfaces } \\
\text { Hantord Legacy } \\
\text { Hanford Site Environmental System Interfaces } \\
\text { None. }\end{array}$ & & $\begin{array}{l}\text { Extemal interlaces } \\
\text {-None- } \\
\text { Hanford Site Envitonmental System Interfaces } \\
\text { hsems.4233,340 Wasto Handling Facility }\end{array}$ \\
\hline
\end{tabular}


B.12.1.3.10.5 South 600 Area Rail System Interface Description and Forecast

\section{EXTERNAL INPUTS}

Table B.12-13 External Inputs for South 600 Area Rail System

Stream
X.0 Hanford Legacy
Legacy Railroads in the South 600 Area
Railroads in the censouth 600 area that is managed by the Hanfond Sito contractor.

\section{INTERNAL INPUTS}

-None-

\section{EXTERNAL OUTPUTS}

-None-

\section{INTERNAL OUTPUTS}

\section{Table B.12-14 Internal Outputs for South 600 Area Rail System}

$$
\text { Stream }
$$

Category

Period

Baseline

Units

hsems.4.2.3 340 Waste Handling Facility

Rail Transportation for $300 \mathrm{~A} 340$

Rail Transportation Services

$1998 \cdot 2001$

24.0

shipments

Rall Transportation for 300A-340 


\section{B.12.1.3.11 325 Building Facility}

\section{B.12.1.3.11.1 325 Building Facility Description}

The Radiochemistry Building provides specially shielded, ventilated, and equipped laboratories for radiochemical experiments. The building consists of a central portion containing general purpose laboratories for low level radiochemical work, a wing containing office space, and two wings containing shielded cells for high level radiochemical work.

\section{B.12.1.3.11.2 325 Building Facility Technical Logic:}

The Department of Energy (DOE), in partnership with its contractors, shall plan, acquire, operate, maintain, and dispose of physical assets as valuable national resources. Stewardship of these physical assets shall be accomplished in a cost-effective manner to meet the DOE mission. This shall incorporate industry standards, a graded approach, and performance objectives. 
HNF-SP-1234

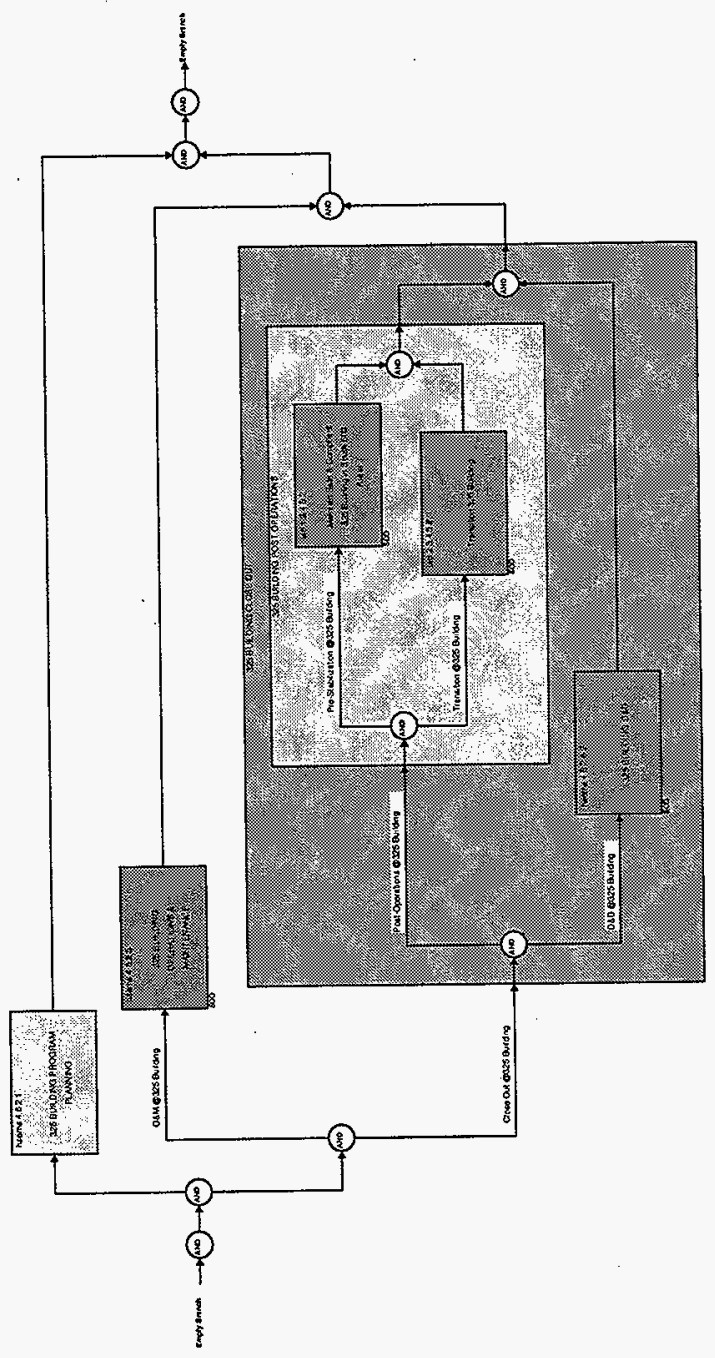

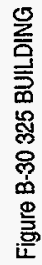




\section{B.12.1.3.11.3 325 Building Requirements and Life Cycle Function Descriptions}

Requirements:

* South 600 Area high cost surplus facitties shall be fransitioned to a low cost, stable, deactivated condition

* South 600 area facilities shall be made available for other uses.

* South 600 Area gaseous effluent releases shall be monitored

* 325 building shall be maintained within the approved safety envelope

* 325 building shall be operated within the approved safety envelope

* 325 inventory system shall be maintained within the approved safety envelope

* 325 building HVAC system shall be maintained within the approved safety envelope

- 325 building radiation monitoring system shall be maintained within the approved safety envelope

- 325 building safeguard system shall be maintained within the approved safety envelope

\section{Life Cycle Function Descriptions:}

\section{B.12.1.3.11.3.1 325 BULLDING POST OPERATIONS WORK SCOPE SUMMARY}

Day-to-day work, including pre-stabilization surveillance and maintenance, stabilization, post-stabilization surveillance and maintenance, deactivation, and post-deactivation surveillance and maintenance, that is required to allow safe decontamination and decommissioning.

325 BUILDING POST OPERATIONS SPECIFIC FUNCTIONS

B.12.1.3.11.3.2 Maintain Saíe \& Compliant 325 Building in South 600 Areas

Maintain the 325 facility structures, operating systems and equipment, and monitoring systems within the approved safety and compliance requirements until the facilities are made available for clean-up.

\section{B.12.1.3.11.3.3 Transition 325 Building}

Initiate the transition phase of decontamination and decommissioning for the 325 Building

\section{B.12.1.3.11.4 325 Building Boundary Diagram}

Table B.12-15 325 Building Boundary Diagram

Extemal Interfaces
-None-
Hantord Site Environmental System Interfaces

None. Extemal Interfaces 


\section{-əLON- \\ SInd IกO TVNYIINI \\ -2UON-

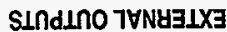 \\ -2UON- \\ SIndNI TVNY $I N I$ \\ -əUON-

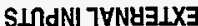

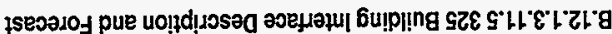


B.12.1.3.12 326 Building Facility

\section{B.12.1.3.12.1 326 Building Facility Description}

The 326 Building was completed in 1953 with major renovations in 1995. The building consists primarily of offices, dry labs, and wet labs with its main occupant the Environmental and Energy Sciences Division of PNNL.

\section{B.12.1.3.12.2 326 Building Facility Technical Logic:}

The Department of Energy (DOE), in partnership with its contractors, shall plan, acquire, operate, maintain, and dispose of physical assets as valuable national resources. Stewardship of these physical assets shall be accomplished in a cost-effective manner to meet the DOE mission. This shall incorporate industry standards, a graded approach, and performance objectives. 
HNF-SP-1234

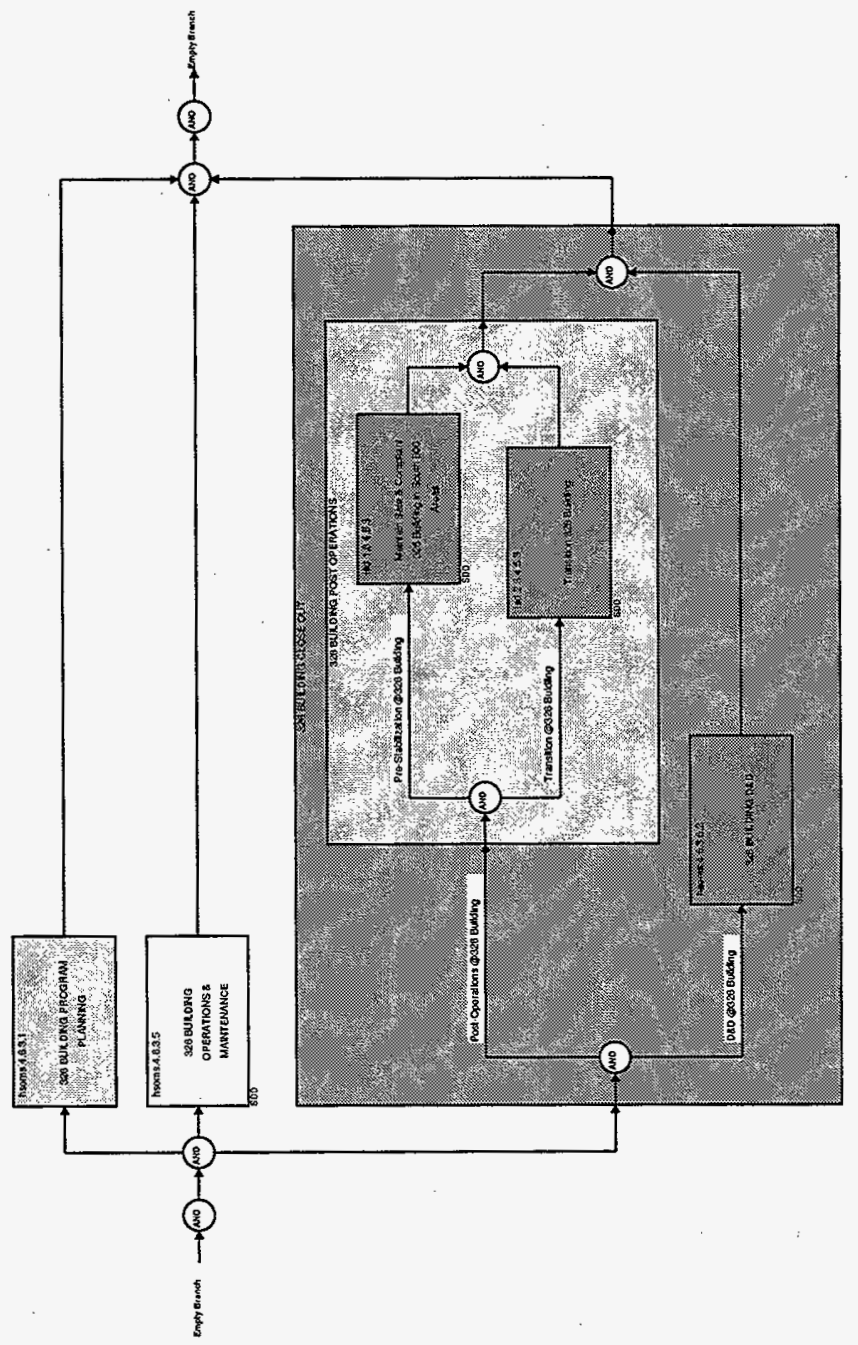

号 


\section{B.12.1.3.12.3 326 Building Requirements and Life Cycle Function Descriptions}

\section{Requirements:}

- South 800 Area high cost surplus facilties shall be transitioned to a low cost, stable, deactivated condition

* South 600 area facilities shall be made available for other uses.

* South 600 Area gaseous effluent releases shall be monitored

* South 600 Area inactive facilities shall be surveillanced and maintained within the approved safety envelope

\section{Life Cycle Function Descriptions:}

\section{B.12.1.3.12.3.1 326 BUILDING POST OPERATIONS WORK SCOPE SUMMARY}

Day-to-day work, including pre-stabilization surveiliance and maintenance, stabilization, post-stabilization surveillance and maintenance, deactivation, and post-deactivation surveillance and maintenance, that is required to allow safe decontamination and decommissioning.

\section{BUILDING POST OPERATIONS SPECIFIC FUNCTIONS}

\section{B.12.1.3.12.3.2 Maintain Safe \& Compliant 326 Building in South 600 Areas}

Maintain the 326 facility structures, operating systems and equipment, and monitoring systems within the approved safety and compliance requirements until the facilities are made available for clean-up.

\section{B.12.1.3.12.3.3 Transition 326 Building}

Initiate the transition phase of decontamination and decommissioning for the 326 Building

\section{B.12.1.3.12.4 326 Building Boundary Diagram}

Table B.12-16 326 Building Boundary Diagram

\begin{tabular}{|c|c|}
\hline $\begin{array}{l}\text { External Interfaces } \\
\text { Hantord Logacy } \\
\text { Hantord Site Environmental System Interfacas } \\
\text { None. }\end{array}$ & $\begin{array}{l}\text { Extertial Interfaces } \\
\text {-None- } \\
\text { Haniord Site Environmental System Interfaces } \\
\text {-None- }\end{array}$ \\
\hline
\end{tabular}


B.12.1.3.12.5 326 Building Interface Description and Forecast EXTERNAL INPUTS

Table B.12-17 External Inputs for 326 Building

\begin{tabular}{|c|c|c|c|c|c|}
\hline & Stream & Category & Period & Baseline & Units \\
\hline $\mathrm{X.0}$ & $\begin{array}{l}\text { Hanford Legacy } \\
\text { Legacy/S5 } 326\end{array}$ & (none forecasted) & & & \\
\hline
\end{tabular}

INTERNAL INPUTS

None-

EXTERNAL OUTPUTS

-None-

INTERNAL OUTPUTS

-None- 


\section{B.12.1.3.13 AEROSOL WIND TUNNEL RESEARCH FACIL Facility}

\section{B.12.1.3.13.1 AEROSOL WIND TUNNEL RESEARCH FACIL Facility Description}

The 329 Building is a chemical sciences facility, occupied by the Nuclear Chemistry Division of PNNL. Two Nuclear Chemistry groups are located in the facility, the Chemical Process and Environmental Technology Group and the Radiation Instrument and Application Group. The activities conducted by these groups involve design and engineering of special purpose radiation detectors and sampling systems, development of electronics to enhance neutron detector performance, and the development of soitware with analyses for the developed detectors. Solid, liquid and gas samples are analyzed in the laboratories and counting room.

\section{B.12.1.3.13.2 329 Building Facility Technical Logic:}

The Department of Energy (DOE), in partnership with its contractors, shall plan, acquire, operate, maintain, and dispose of physical assets as valuable national resources. Stewardship of these physical assets shall be accomplished in a cost-effective manner to meet the DOE mission. This shall incorporate industry standards, a graded approach, and performance objectives. 


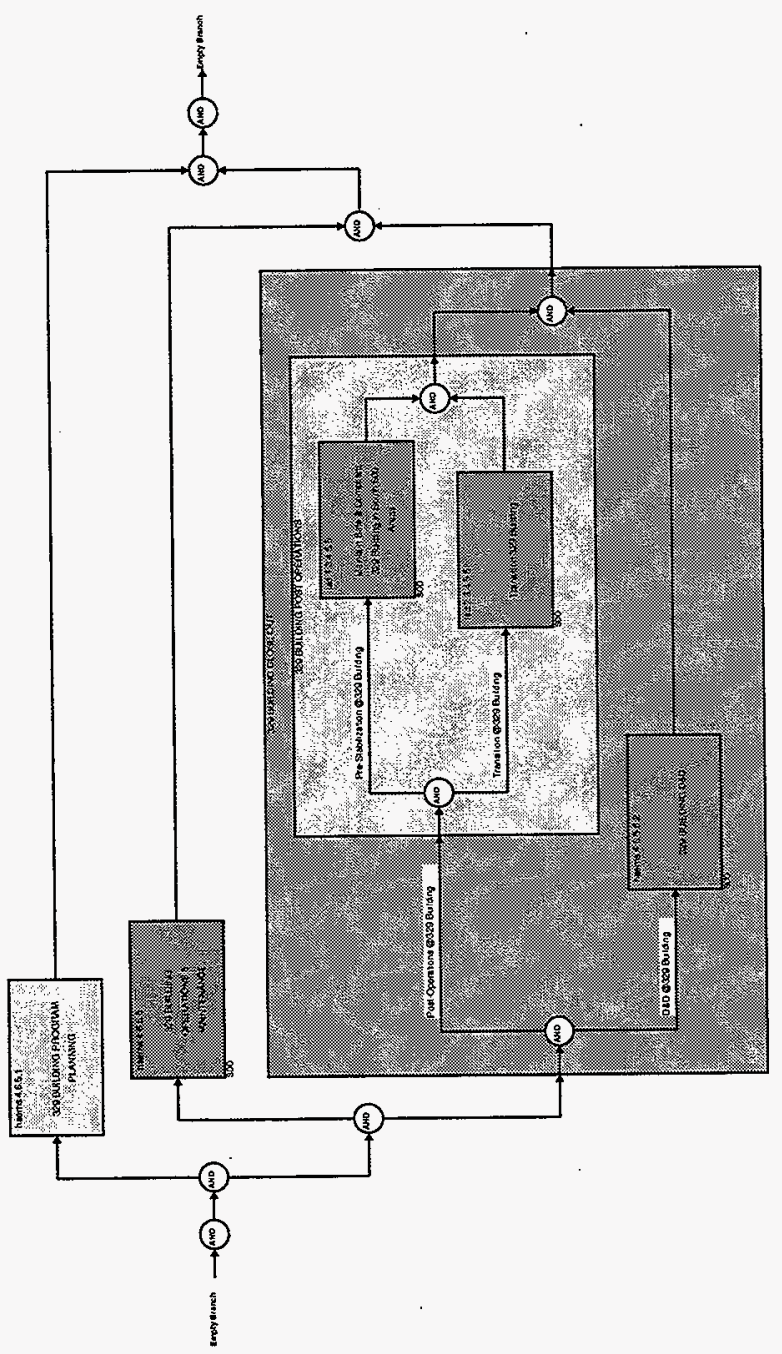

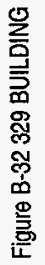




\section{B.12.1.3.13.3 329 Building Requirements and Life Cycle Function Descriptions}

\section{Requirements:}

* South 600 Area high cost surplus facilties shall be transitioned to a low cost, stable, deactivated condition

* South 600 area facilities shall be made available for other uses.

* South 600 Area gaseous effluent releases shall be monitored

* South 600 Area inactive facilities shall be surveillanced and maintained within the approved safety envelope

\section{Life Cycle Function Descriptions:}

\section{B.12.1.3.13.3.1 329 BUILDING POST OPERATIONS WORK SCOPE SUMMARY}

Day-to-day work, inciuding pre-stabilization surveillance and maintenance, stabilization, post-stabilization surveillance and maintenance, deactivation, and post-deactivation surveillance and maintenance, that is required to allow safe decontamination and decommissioning.

\section{BUILDING POST OPERATIONS SPECIFIC FUNCTIONS}

\section{B. 12.1.3.13.3.2 Maintain Safe \& Compliant 329 Building in South 600 Areas}

Maintain the 329 facility structures, operating systems and equipment, and monitoring systems within the approved safety and compliance requirements until the facilities are made available for clean-up.

\section{B.12.1.3.13.3.3 Transition 329 Building}

Initiate the transition phase of decontamination and decommissioning for the 329 Building

\section{B.12.1.3.13.4 329 Building Boundary Diagram}

Table B.12-18 329 Building Boundary Diagram

\begin{tabular}{|l|l|l|}
\hline $\begin{array}{l}\text { Extemal Imeriaces } \\
\text { None- } \\
\text { Hantord Site Environmental System Interfaces } \\
\text { None- }\end{array}$ & $\begin{array}{l}\text { Extemal Intertaces } \\
\text {-None- } \\
\text { Hantord Site Envirenmental System Interfaces } \\
\text {-None- }\end{array}$ \\
\hline
\end{tabular}


-OUON-

SInd LIO TVNYIINI

-จUON-

SIndLnO TVNYIIX]

-OUON-

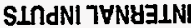

-əUON-

SIIINI T $\forall N Y \exists \perp X I$

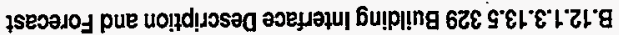




\section{B.12.1.3.14 ANALYTICAL \& NUCLEAR RESEARCH LAB Facility \\ B.12.1.3.14.1 ANALYTICAL \& NUCLEAR RESEARCH LAB Facility Description}

The 320/3720/3745 complex is categorized as a radiological laboratory and is comprised of 320,3720 , and 3745 .

\section{B.12.1.3.14.2 320 / $3720 / 3745$ Facility Technical Logic:}

The Department of Energy (DOE), in partnership with its contractors, shall plan, acquire, operate, maintain, and dispose of physical assets as valuable national resources. Stewardship of these physical assets shall be accomplished in a cost-effective manner to meet the DOE mission. This shall incorporate industry standards; a graded approach, and performance objectives.

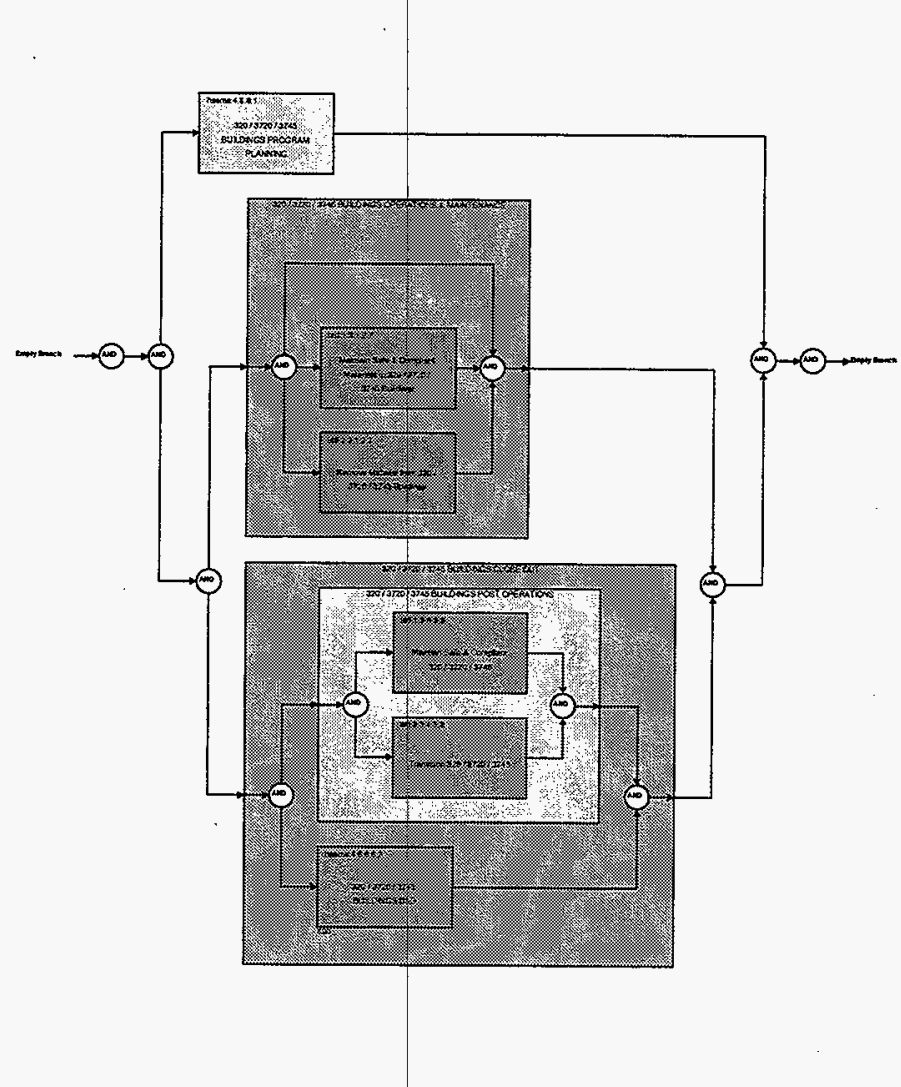

Figure B-33 $320 / 3720 / 3745$ Buildings 


\section{B.12.1.3.14.3 320/3720/3745 Requirements and Life Cycle Function Descriptions}

Requirements:

* South 600 Area high cost surplus facilties shall be transitioned to a low cost, stable, deactivated condition

* South 600 area facilities shall be made available for other uses.

* South 600 Area inactive facilities shall be surveillanced and maintained within the approved safety envelope

\section{Life Cycle Function Descriptions:}

\section{B.12.1.3.14.3.1 $320 / 3720 / 3745$ BUILDINGS POST OPERATIONS WORK SCOPE SUMMARY}

Day-to-day work, including pre-stabilization surveillance and maintenance, stabilization, post-stabilization surveillance and maintenance, deactivation, and post-deactivation surveillance and maintenance, that is required to allow saie decontamination and decommissioning.

\section{$320 / 3720 / 3745$ BUILDINGS POST OPERATIONS SPECIFIC FUNCTIONS}

\section{B.12.1.3.14.3.2 Maintain Safe \& Compliant $320 / 3720 / 3745$}

Maintain the 320 facility structures, operating systems and equipment, and monitoring systems within the approved safety and compliance requirements until the facilities are made available for clean-up.

B.12.1.3.14.3.3 Transition $320 / 3720 / 3745$

Initiate the transition phase of decontamination and decommissioning for the 3708 Building

\section{B.12.1.3.14.4320/3720/3745 Boundary Diagram}

Table B.12-19 320/3720/3745 Boundary Diagram

\begin{tabular}{|c|c|}
\hline $\begin{array}{l}\text { External Interiaces } \\
\text {-None- } \\
\text { Hanford Site Environmental System Interfaces } \\
\text {-None- }\end{array}$ & $\begin{array}{l}\text { External Interiaces } \\
\text {-None. } \\
\text { Hanford Site Environmental System Interiaces } \\
\text { hsems.2.3.5 Central Waste Complex } \\
\text { hsems,4.2.1300Area Treated Eftluent Disposal Facility }\end{array}$ \\
\hline
\end{tabular}


B.12.1.3.14.5 320 / $3720 / 3745$ Interface Description and Forecast

\title{
EXTERNAL INPUTS
}

-None-

\author{
INTERNAL INPUTS \\ -None-
}

EXTERNAL OUTPUTS

-None-

\section{INTERNAL OUTPUTS}

Table B.12-20 internal Outputs for 320/3720/3745

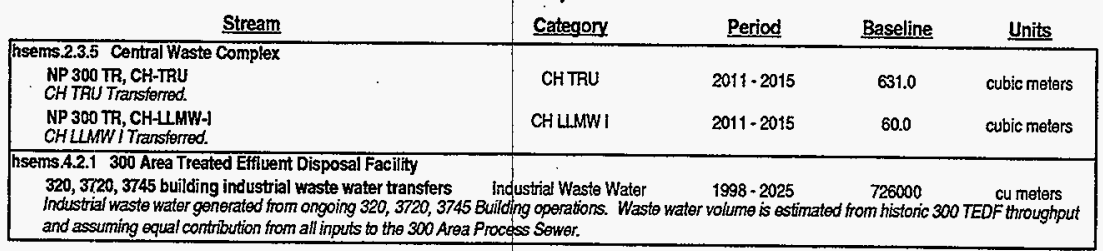




\section{B.12.1.3.15 Misc. Rad Labs Facility}

\section{B.12.1.3.15.1 Misc. Rad Labs Facility Description}

Radiological laboratories that have been used to support the Hanford Site Mission.

\section{B.12.1.3.15.2 Misc. Rad Labs Facility Technical Logic:}

The Department of Energy (DOE), in partnership with its contractors, shall plan, acquire, operate, maintain, and dispose of physical assets as valuable national resources. Stewardship of these physical assets shall be accomplished in a cost-effective manner to meet the DOE mission. This shall incorporate industry standards, a graded approach, and performance objectives. 


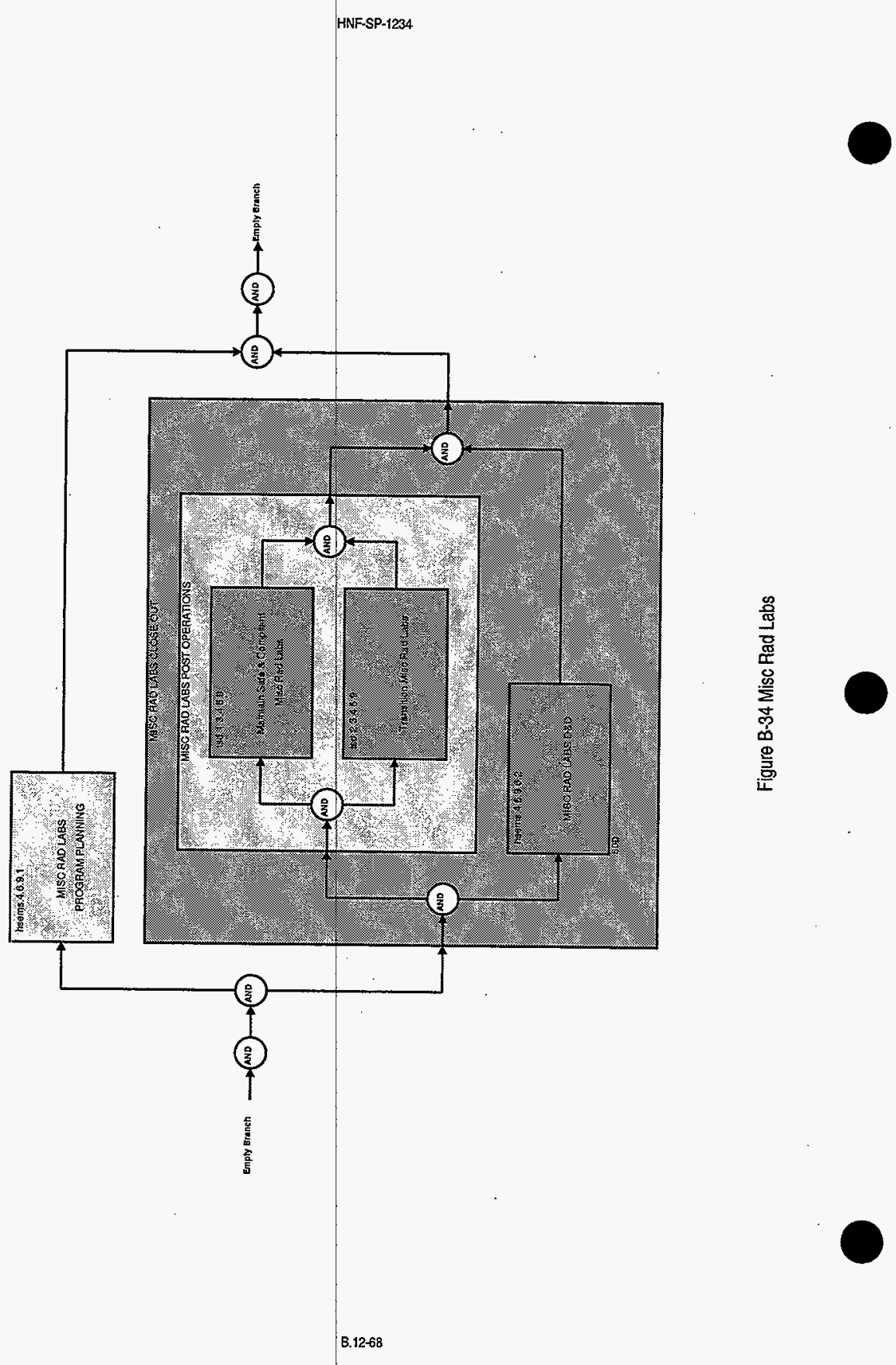




\section{B.12.1.3.15.3 Misc. Rad Labs Requirements and Life Cycle Function Descriptions}

Requirements:

- South 600 Area high cost surplus facilties shall be transitioned to a low cost, stable, deactivated condition

* South 600 area facilities shall be made available for other uses.

* South 600 Area inactive facilities shall be surveillanced and maintained within the approved safety envelope

\section{Life Cycle Function Descriptions:}

\section{B.12.1.3.\$5.3.1 MISC RAD LABS POST OPERATIONS WORK SCOPE SUMMARY}

Day-to-day work, including pre-stabilization surveillance and maintenance, stabilization, post-stabilization surveillance and maintenance, deactivation, and post-deactivation surveillance and maintenance, that is required to allow safe decontamination and decommissioning.

\section{MISC RAD LABS POST OPERATIONS SPECIFIC FUNCTIONS}

\section{B. 12.1.3.15.3.2 Maintain Safe \& Compliant Misc Rad Labs}

Maintain the Miscellaneous Radiological Laboratories within the South 600 Area in a safe and compliant condition in support of the ongoing environmental management mission.

\section{B.12.1.3.15.3.3 Transition Misc Rad Labs}

Initiate the transition phase of decontamination and decommissioning for the 323 Building

\section{B.12.1.3.15.4 Misc. Rad Labs Boundary Diagram}

Table B.12-21 Misc. Rad Labs Boundary Diagram

\begin{tabular}{|c|c|}
\hline $\begin{array}{l}\text { External Intertaces } \\
\text { Hanford Legacy } \\
\text { Hanford Site Environmental System Interlaces } \\
\text {-Nono }\end{array}$ & $\begin{array}{l}\text { Extemal Interfacos } \\
\text {-None- } \\
\text { Hanford Site Environmental System Interfaces } \\
\text { hsems.2.2.5 } 242-A \text { Evaporator } \\
\text { hsems.4.2.1 } 300 \text { Area Treated Efil uent Disposal Facility } \\
\text { hsems.4.2.3 340 Waste.Handline Facility }\end{array}$ \\
\hline
\end{tabular}


B.12.1.3.15.5 Misc. Rad Labs Interface Description and Forecast EXTERNAL INPUTS

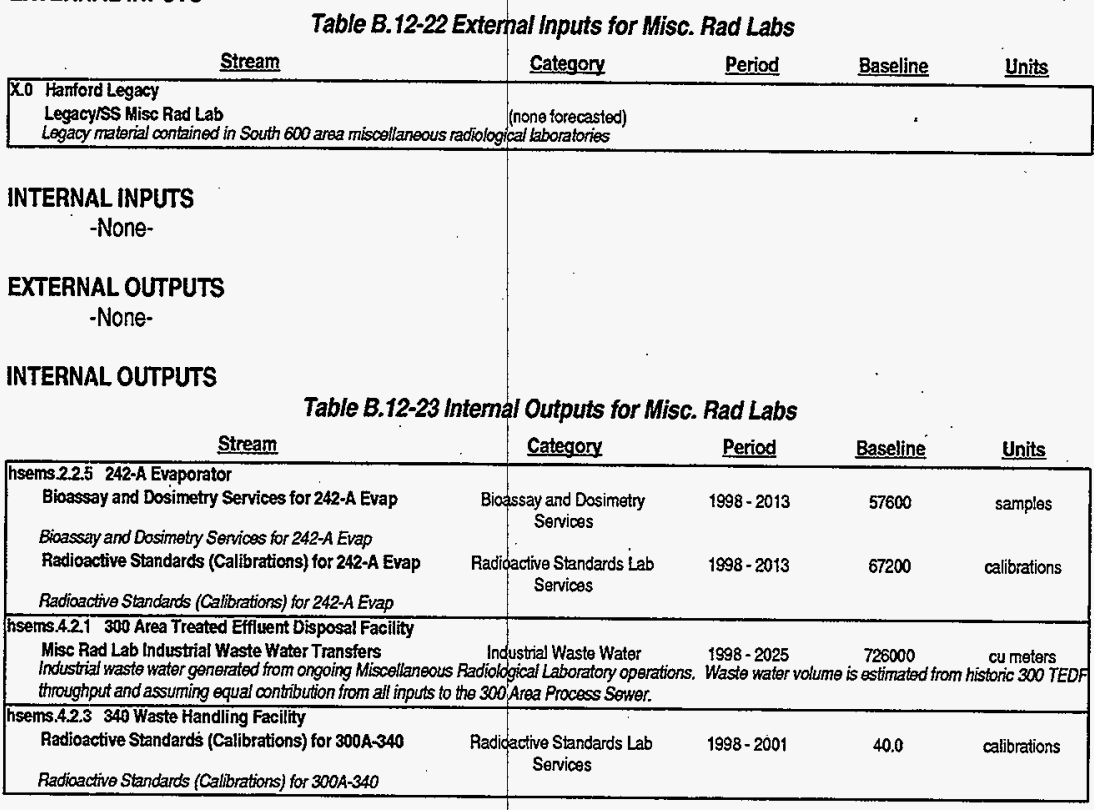




\section{B.12.1.3.16 331 Complex Facility}

\section{B.12.1.3.16.1 331 Complex Facility Description}

The 331 complex is categorized as a non-radiological laboratory and is comprised of $331 \mathrm{~A}, 331 \mathrm{~B}, 331 \mathrm{C}, 331 \mathrm{D}$, $331 \mathrm{G}$, and $331 \mathrm{H}$.

\section{B.12.1.3. 16.2331 Complex Facility Technical Logic:}

The Department of Energy (DOE), in partnership with its contractors, shall plan, acquire, operate, maintain, and dispose of physical assets as valuable national resources. Stewardship of these physical assets shall be accomplished in a cost-effective manner to meet the DOE mission. This shall incorporate industry standards, a graded approach, and performance objectives. 


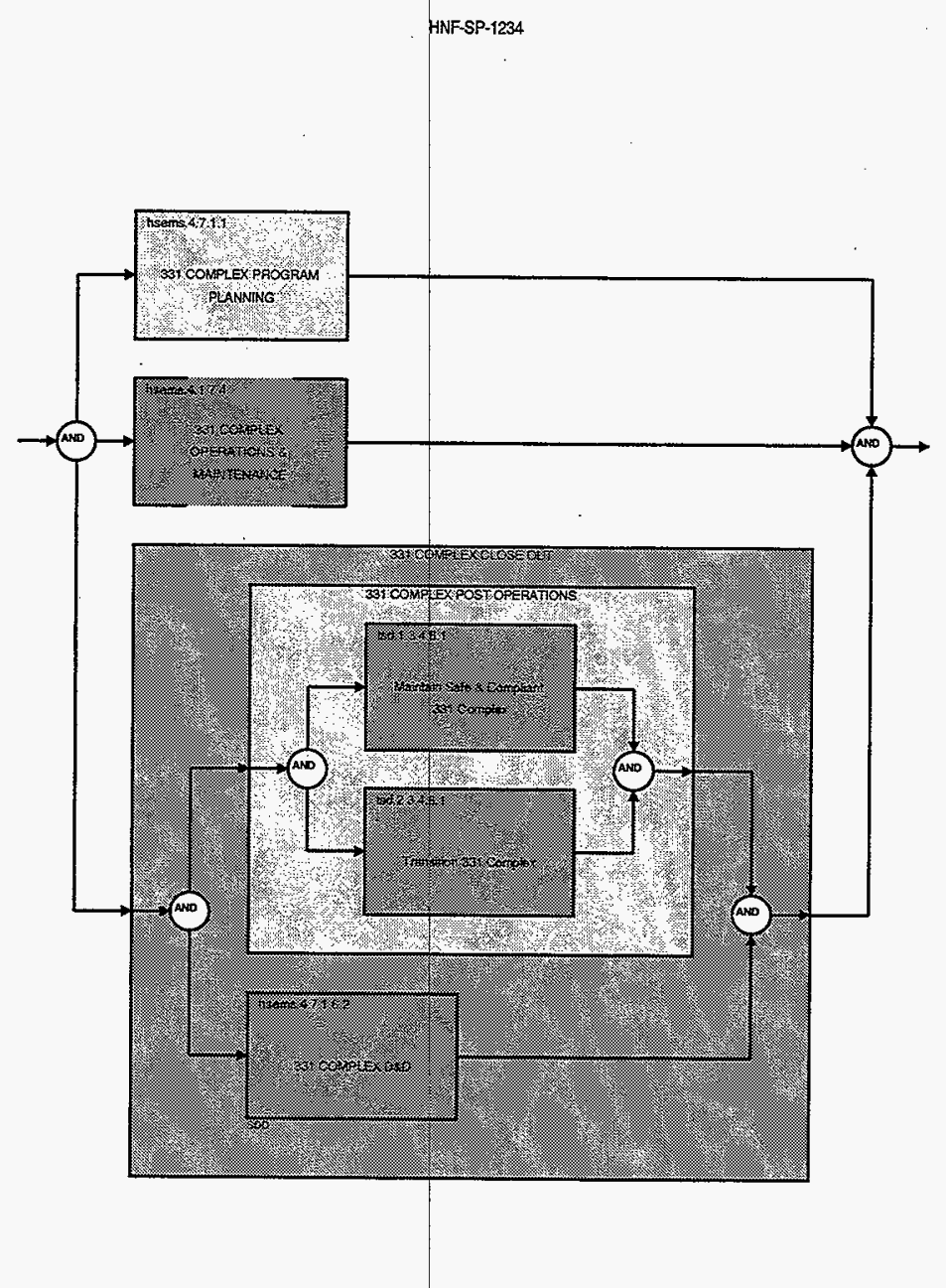

Figure B-35 331 Complex 


\section{B.12.1.3.16.3 331 Complex Requirements and Life Cycle Function Descriptions}

\section{Requirements:}

* South 600 Area high cost surplus facilties shall be transitioned to a low cost, stable, deactivated condition

* South 600 area facilities shall be made available for other uses.

* South 600 Area inactive facilities shall be surveillanced and maintained within the approved safety envelope

\section{Life Cycle Function Descriptions:}

\section{B.12.1.3.16.3.1 331 COMPLEX POST OPERATIONS WORK SCOPE SUMMARY}

Day-to-day work, including pre-stabilization surveillance and maintenance, stabilization, post-stabilization surveillance and maintenance, deactivation, and post-deactivation surveillance and maintenance, that is required to allow safe decontamination and decommissioning.

\section{COMPLEX POST OPERATIONS SPECIFIC FUNCTIONS}

\section{B.12.13.16.3.2 Maintain Sate \& Compliant 331 Complex}

Maintain the 331 Complex in a sate and compliant condition in support of the ongoing environmental management mission.

\section{B.12.1.3.16.3.3 Transition 331 Complex}

Initiate the transition phase of decontamination and decommissioning for the 331A Building.

\section{B.12.1.3.16.4 331 Complex Boundary Diagram}

Table B.12-24 331 Complex Boundary Diagram

\begin{tabular}{|l|l|}
\hline $\begin{array}{c}\text { Extemal Interfaces } \\
\text { Hanford Legacy } \\
\text { Hanford Site Environmental System Interfaces } \\
\text { None- }\end{array}$ & $\begin{array}{l}\text { External Interfaces } \\
\text { None- } \\
\text { Hanford Site Environmental System Interfaces } \\
\text { Nene- }\end{array}$ \\
\hline
\end{tabular}


B.12.1.3.16.5 331 Complex Interface Description and Forecast EXTERNAL INPUTS

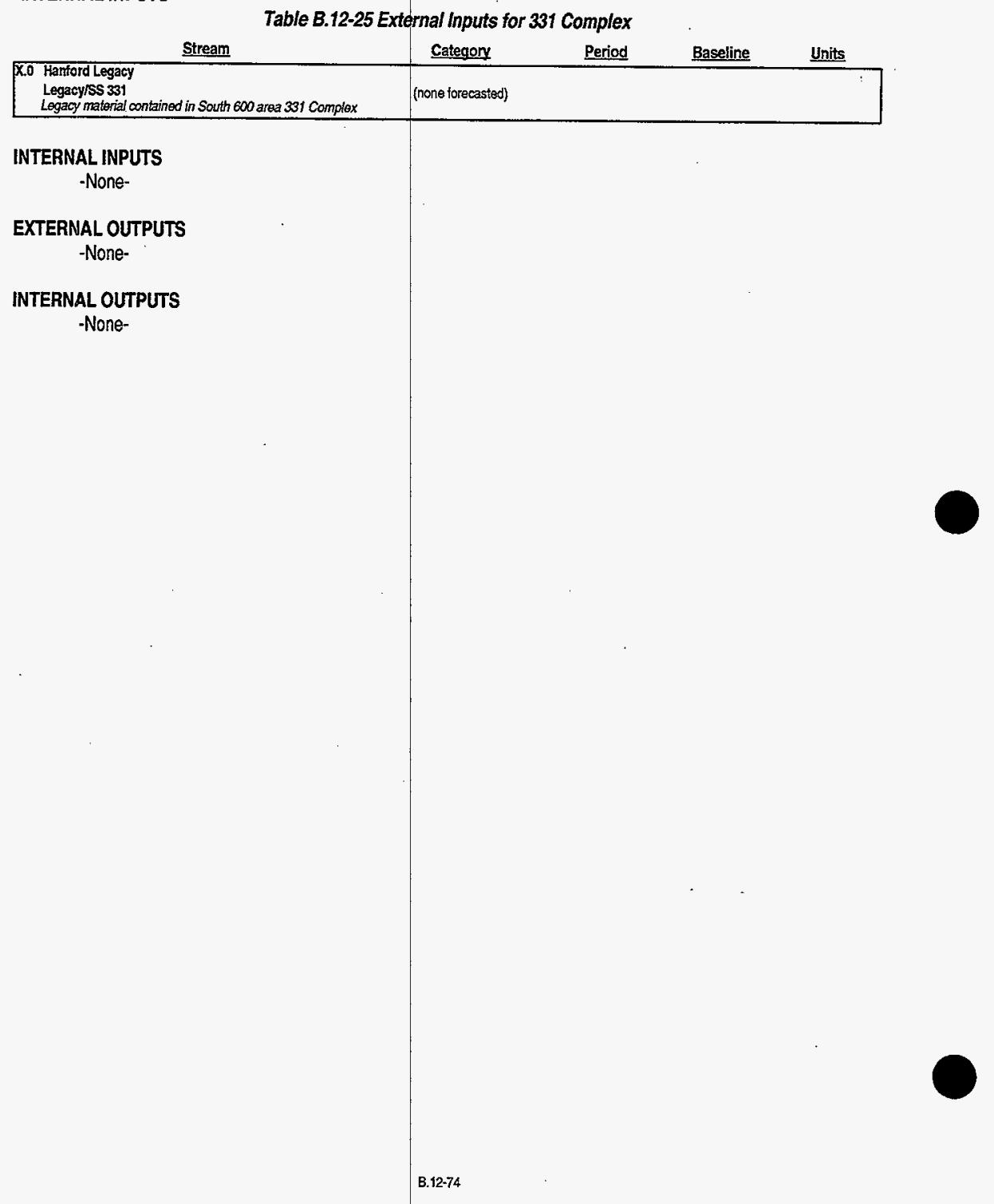




\section{B.12.1.4 Drivers for Hanford Surplus Facility Program 300 Area Revitalization Project}

Table B.12-26 Source Documents for Hanford Surplus Facility Program 300 Area Revitalization Project

\begin{tabular}{ll}
\multicolumn{1}{c}{ Name } & \multicolumn{1}{c}{ Title } \\
DOE/EIS-0222D & Draft Hanford Remedial Action Environmental Impact Statement and \\
& Comprehensive Land Use Plan \\
DOE/RL-96-14 & Updated Draft Mission Direction Document, June 1996 \\
DOE/RL-96-92 & Hanford Strategic Plan
\end{tabular}

\section{B.12.1.5 Hanford Surplus Facility Program 300 Area Revitalization Project Risk Management}

As a result of Hanford site mission change from defense production to cleanup and downsizing, the 300 area has a number of excess facilties requiring disposition beyond simple removal. These facilities include a reactor building, accelerator building, and numerous buildings used for reactor fuel production and processing activities. Most of the facilities contain significant radiological and chemical contamination, with 8 facilities currently managed under RCRA. The 300 area contains multiple burial grounds and liquid disposal/spill sites, which are managed under CERCLA as 3 separate operable units. There are 156 non-mobile buildings listed in the 300 Area. Of these, 57 buildings are known to contain radioactive and/or hazardous contamination. The remaining 99 buildings are not listed as contaminated but further verification of that condition is warranted on some of them because known historical uses and contamination of nearby grounds make them suspect. Eighteen contaminated buildings are being deactivated ( 300 Fuel Supply [16], 308 Building, 309 Building) and four contaminated faciltites are scheduled to begin deactivation in 1997 (324,327, 324A, 324D buildings) and are not included in the scope of this PBS.

These facilities constitute a risk to the public, environment and on-site workers due to contaminination with a variety of materials including cesium, strontium, uranium, throium, mixed fission products, various acids and bases, and a wide variety of cleaning agents and solvents. The facilities covered in this project are in close proximity to the Columbia River and the city of Richland. A fire, containment system failure or structural collapse due to natural causes or facility deterioration could result in a release of contaminants to the environment via air, ground and water pathways. Many of these facilities have exceeded their design life, and will pose an increasing hazard to site workers as the facilities continue to deteriorate. Most areas outside these facilities already contain radiological and hazardous contaminants in the soil and an additional release of contaminants would further complicate and increase the scope of $D \& D$ and future operable unit remediation activities as well as the risk associated with performance of these actions.

Work activities likely to place the workers at risk include: removing inventory materials [Special Nuclear Materials, Nuclear Materials, Nuclear Fuel (SNM/NM/NF)]; flushing, isolating and blanking of process or subprocess systems; removing radioactive and hazardous materials and mixed wastes; deactivating non-essential systems and utilities; reconfiguring systems to facilitate long-tem surveillance and maintenance (LTS\&M) and eventual decontamination and decommissioning (D\&D); "mothballing" of systems necessary for LTS\&M and D\&D; closing facility penetrations to prevent bird, animal and weather intrusion; conversion activities; performing LTS\&M and environmental monitoring; performing remedial investigation and characterization activities; performing radioactive and hazardous waste treatment and disposition activities; performing decontamination of equipment, surfaces and structures; assessing and expediting alternate use; and performing dismantling, segmenting and demolition of facilities and structures. 


\section{Hanford Surplus Facility Program 300 Area}

Revitalization Work Breakdown Structure

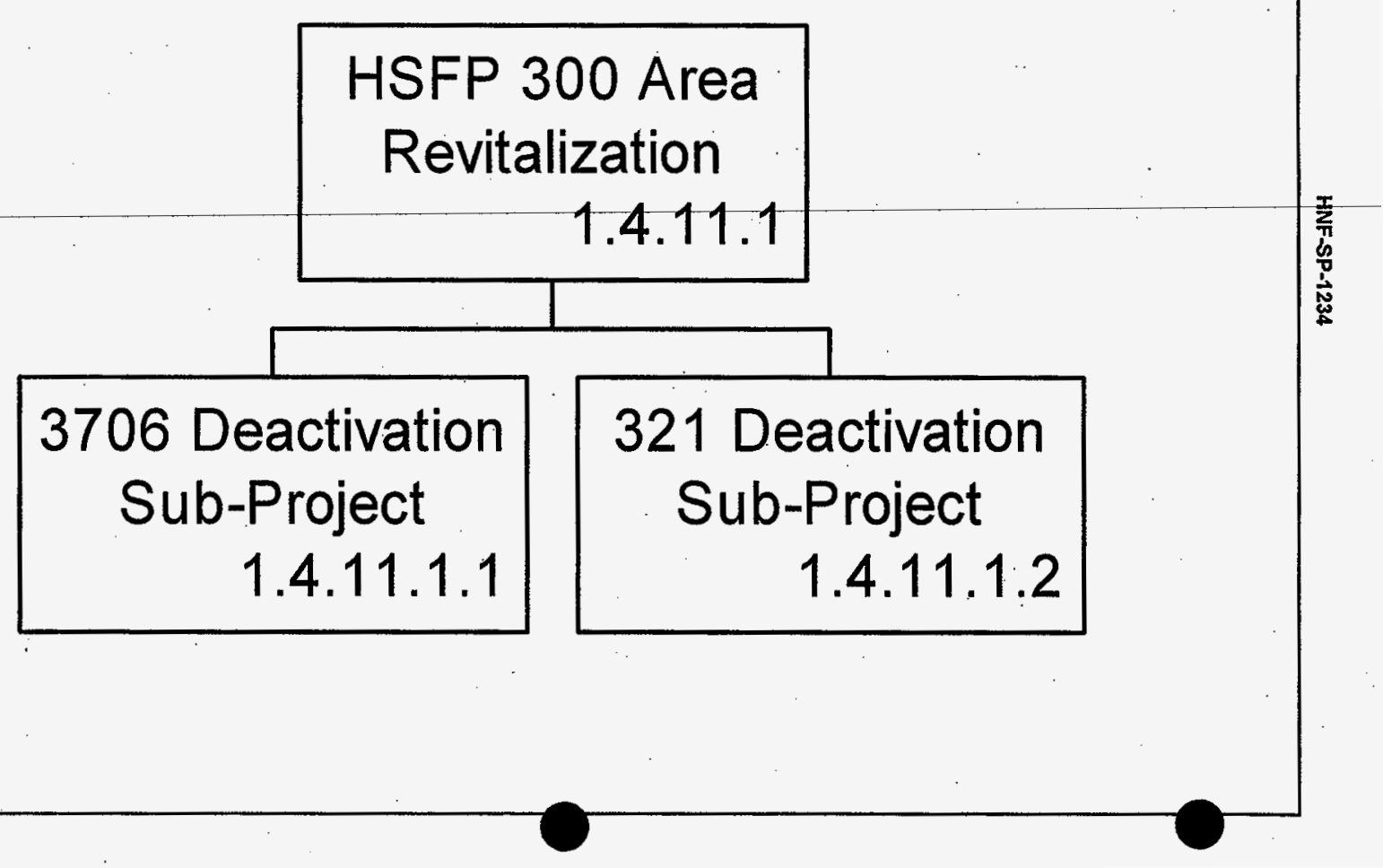


HANFORD SITE WORK BREAKDOWN STRUCTURE DICTIONARY FACILITY STABILIZATION

WBS: 1.4

\begin{tabular}{|l|l|l|l|l|}
\hline $\begin{array}{l}\text { 1. Activity. Tit7e: } \\
\text { 3706 DEACTIVATION SUBPROJECT }\end{array}$ & $\begin{array}{l}\text { 2. Date } \\
7 / 31 / 1997\end{array}$ & $\begin{array}{l}\text { 3. PBS Number } \\
\text { RL-TP14 }\end{array}$ & $\begin{array}{l}\text { 4. Dict Rev } \\
0\end{array}$ \\
\hline $\begin{array}{l}\text { 5. Contract WBS No. } \\
\text { 1.4.11.1.1 }\end{array}$ & $\begin{array}{l}\text { 6. Corresponding FDS No. } \\
\text { KHA }\end{array}$ & 7: BaseTine CR No. \\
\hline
\end{tabular}

8. Organization Name

9. $B$ \& $R$ No. 19000

10. Scope of Work

Minimum safe activities protect the public, workers and environment from exposure posed by loss of containment and control over nuclear material and industrial hazards associated with these facilities. Minimum safe activities will be conducted over the life of the faci]ity, decreasing in scope as risks are removed/reduced within the facilities. This is comprised of the facility surveillance and maintenance required to maintain facility systems and structures. This activity includes required preventative maintenance and calibrations; repair of failed and malfunctioning equipment; walkdown of safety systems, equipment, and facility grounds (operational surveiliances); routine radiological surveys, source checks, and dosimetry; facility utilities and assessments; and waste management assessments. This also includes Management and Assessment activities including the project direction, management and controls, and environmental, quality and safety oversight for the minimum safe condition. 
HANFORD SITE WORK BREAKDOWN STRUCTURE DICTIONARY FACILITY STABILIZATION

WBS: 1.4

\begin{tabular}{|c|c|c|c|}
\hline $\begin{array}{l}\text { 1. Activity Title: } \\
321 \text { ACTIVITIES }\end{array}$ & $\begin{array}{c}2 . \text { Date } \\
7 / 31 / 1997\end{array}$ & $\begin{array}{l}\text { 3. PBS Number } \\
\text { RL-TP14 }\end{array}$ & 4. Dict Rev \\
\hline
\end{tabular}

5. Contract WBS No. 1.4.11.1.2

6. Corresponding FDS No. 7. Baseline CR No. KHB

8. Organization Name 19000

9. $B$ \& $R$ No.

10. Scope of Work

Minimum safe activities protect the public, workers and environment from exposure posed by loss of containment and control over nuclear material and industrial hazards associated with these facilities. Minimum safe activities will be conducted over the 1 ife of the facility, decreasing in scope as risks are removed/reduced within the facilities. This is comprised of the facility surveillance and maintenance required to maintain facility systems and structures. This activity includes required preventative maintenance and calibrations; repair of failed and malfunctioning equipment; walkdown of safety systems, equipment, and facility grounds (operational surveillances); routine radiological surveys, source checks, and dosimetry; facility utilities and assessments; and waste management assessments. This al so includes Management and Assessment activities including the project direction, management and controls, and environmental, quality and safety oversight for the minimum safe condition. The scope of work also includes stabilization of the exterior of the 321 Facility, currently a radiological zone. Paint, primarily applied for contamination fixation, is peeling and requires removal and replacement in order to minimize potential spread of contamination. 


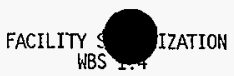

Mission Area Responsibility Assignment Matrix

\begin{tabular}{|c|c|c|c|c|c|}
\hline $\begin{array}{l}\text { Proj Lv } \\
\text { (PBS \#) }\end{array}$ & $\begin{array}{l}\text { FDS Act } \\
\text { Number }\end{array}$ & Activity Title & Activity Manager & Responsible Organization & Cost Account \\
\hline \multirow[t]{3}{*}{ RL-TP14 } & & HANFORD SURPLUS FACILITY PROG 300 AREA REVITALIZA & & & \\
\hline & KHA & 3706 DEACTIVATION SUBPROJECT & E. J. Bitten & 19000 & $\begin{array}{l}\text { 1KHAO1 } \\
\text { 1KHA03 } \\
\text { 1KHA05 }\end{array}$ \\
\hline & KHB & 321 ACTIVITIES & E. J. Bitten & 19000 & $\begin{array}{l}1 \mathrm{KHBO1} \\
1 \mathrm{KHBO3} \\
1 \mathrm{KHBO5}\end{array}$ \\
\hline
\end{tabular}




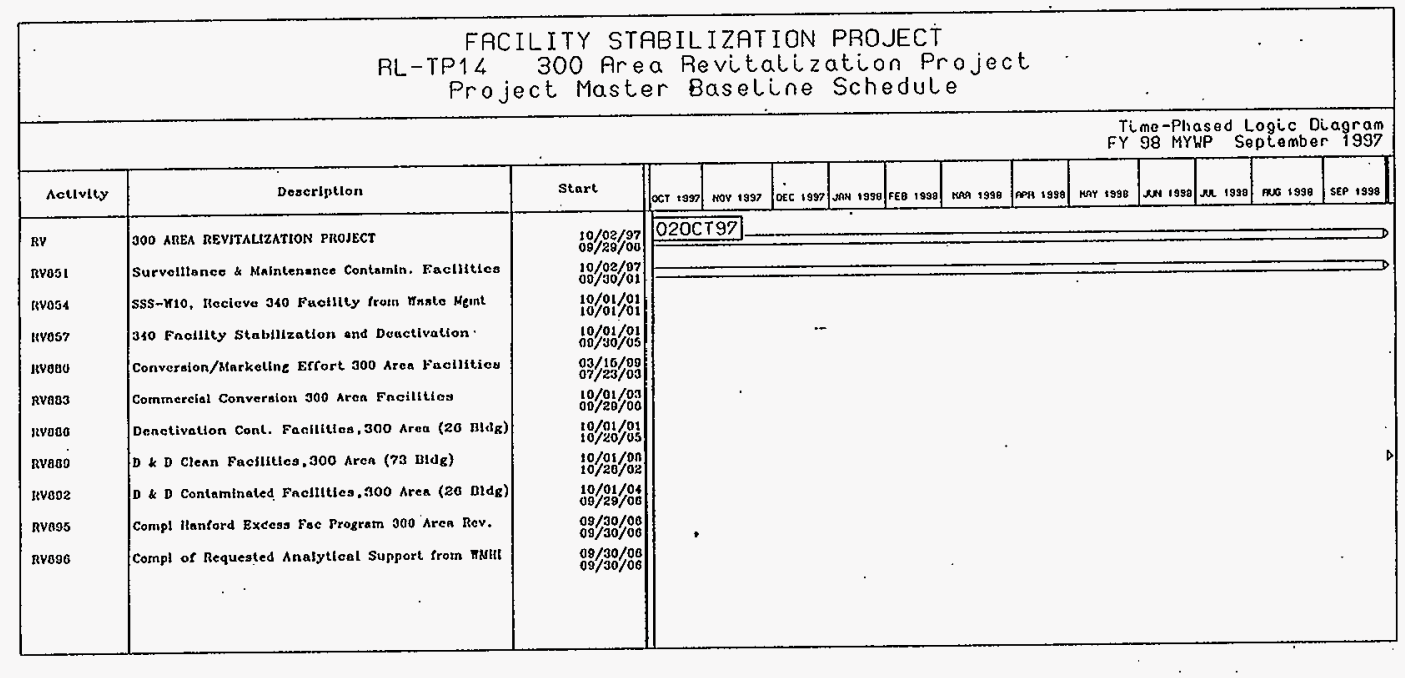


(\$000s)

\begin{tabular}{|c|c|c|c|c|c|c|c|c|c|c|c|}
\hline $\begin{array}{r}\text { PROJECT WES: } \\
\text { PBS NO: }\end{array}$ & $\begin{array}{l}1.4 .11 .1 \\
\mathrm{RL}-\mathrm{TP14}\end{array}$ & & & & & & & & & & \\
\hline PBS TITLE: & HSFP $300 \mathrm{~A}$ & rea Revitali & zation & & & & & & & & SUATOT \\
\hline $\begin{array}{l}\text { FUND } \\
\text { TYPE }\end{array}$ & FY1997 & FY1988 & FY1999 & FY2000 & FY2001 & FY2002 & FY2003 & FY2004 & FY2005 & FY2006 & $\begin{array}{l}\text { FY1997- } \\
\text { FY2006 }\end{array}$ \\
\hline OPERATING EXPENSE & & $8+872$ & 759 & 5,472 & 14,187 & 10,635 & 9,251 & 34,274 & 27,686 & 35.816 & 138,952 \\
\hline & & min & & & & & & & & & \\
\hline CENRTC & & WO & & & & & & & & & - \\
\hline & & थ? & & & & & & & & & \\
\hline GENERAL PLANT PROJECT & & m & & & & & & & & & - \\
\hline & & $5+1$ & & & & & & & & & \\
\hline LINE ITEM (LIst Each Ono) & & Whing & & & & & & & & & \\
\hline & & WW & & & & & & & & & - \\
\hline & & Wh & & & & & & & & & - \\
\hline & & 5 & & & & & & & & & - \\
\hline & & Lit? & & & & & & & & & $=$ \\
\hline & & W6 & & & & & & & & & - \\
\hline Subfotal Line Hems & - & We & - & - & - & - & - & - & - & $=$ & - \\
\hline & & SOth & & & & & & & & & \\
\hline 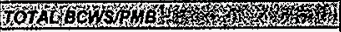 & X & 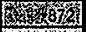 & 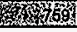 & 5 & 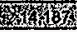 & 60636 & 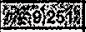 & 3. & 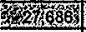 & 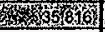 & 4 \\
\hline & & Kivis & & & & & & & & & \\
\hline MGMT RESERVE ${ }^{2}$ & & Why & & & & & & & & & - \\
\hline & & W & & & & & & & & & \\
\hline LINE ITEM CONTINGENCY ${ }^{2}$ & & ysin & & & & & & & & & - \\
\hline & & tring & & & & & & & & & \\
\hline OFFSITE TRANSFERS ${ }^{3}$ & & काin & & & & & & & & & - \\
\hline & & xis & & & & & & & & & \\
\hline Subtotal & - & 8 & - & $\div$ & - & - & - & - & - & - & - \\
\hline & & 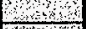 & & & & & & & & & \\
\hline 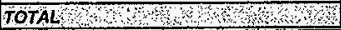 & W & 672 & 3759! & 5472 & 1487 & 60635 & \$2513 & 34,274 & 27.666 & W $3635 ; 16$ & 1361952 \\
\hline
\end{tabular}

'Budgeted Cost of Work Scheduled (BCWS) Equals Performance Measurement Baseline (PMB);

Expense Carryover NOT Included.

${ }^{2}$ Management Reserve and Line ltem Contingency Held by RL.

${ }^{3}$ Work Performed at Sites Other Than Hanford. 
BY PROJECT BASELINE SUMMARY (PBS)

FY 1998

(\$000s)

\begin{tabular}{|c|c|c|c|c|c|c|c|c|c|c|}
\hline $\begin{array}{r}\text { PROJECT WBS: } \\
\text { PBS NO: }\end{array}$ & $\begin{array}{r}1.4 .11 .1 \\
\text { RL-TP14 }\end{array}$ & & & & & & & & & \\
\hline PBS TITLE: & HSFP 300 & Area Rovita & alization & & & & & & & TOTAL \\
\hline $\begin{array}{l}\text { FUND } \\
\text { TYPE }\end{array}$ & $\begin{array}{l}\text { FY2007- } \\
\text { FY2010 }\end{array}$ & $\begin{array}{l}\text { FY2011- } \\
\text { FY2015 }\end{array}$ & $\begin{array}{l}\text { FY2016- } \\
\text { FY2020 }\end{array}$ & \begin{tabular}{|l|} 
FY2021- \\
FY2025
\end{tabular} & $\begin{array}{l}\text { FY2026- } \\
\text { FY2030 }\end{array}$ & $\begin{array}{l}\text { FY2031- } \\
\text { FY2035 }\end{array}$ & \begin{tabular}{|l|}
$F Y 2036$ \\
$F Y 2040$ \\
\end{tabular} & \begin{tabular}{|l|} 
FY2041- \\
FY2045
\end{tabular} & $\begin{array}{l}\text { FY2046 } \\
\text { FY2050 } \\
\end{array}$ & $\begin{array}{l}\text { FY1997- } \\
\text { FY2050 }\end{array}$ \\
\hline OPERATING EXPENSE & 31,200 & & & & & & & & & 170,152 \\
\hline & & & & & & & & & & \\
\hline CENRTC & & & & & & & & & & - \\
\hline & & & & & & & & & & \\
\hline GENERAL PLANT PROJECT & & & & & & & & & & - \\
\hline & & & & & & & & & & \\
\hline LINE ITEM (Lis: Each One) & & & & & & & & & & \\
\hline & & & & & & & & & & . \\
\hline & & & & & & & & & & - \\
\hline & & & & & & & & & & - \\
\hline & & & & & & & & & & 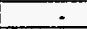 \\
\hline & & & & & & & & & & - \\
\hline Subtotal Line ltems & - & - & - & - & . & - & - & - & - & - \\
\hline & & & & & & & & & & \\
\hline 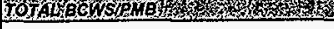 & 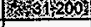 & 3 & 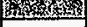 & 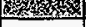 & 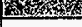 & 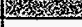 & 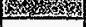 & 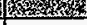 & 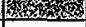 & 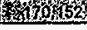 \\
\hline MGMT RESERVE ${ }^{2}$ & & & & & & & & & & - \\
\hline & & & & & & & & & & \\
\hline LINE ITEM CONTINGENCY ${ }^{2}$ & & & & & & & & & & $=$ \\
\hline & & & & & & & & & & \\
\hline OFFSITE TRANSFERS ${ }^{3}$ & & & & & & & & & & 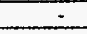 \\
\hline Subtota & & & & & & & & 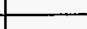 & & 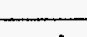 \\
\hline & & - & - & - & - & - & $=$ & - & - & - \\
\hline TOTAL SPY H & 3/3 200 & 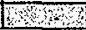 & सिम & Sin & \% & 184592 & mist & (x) & WhP & 170.662 \\
\hline
\end{tabular}

'Budgeted Cost of Work Scheduled (BCWS) Equals Performance Measurement Baseline (PMB);

Expense Carryover NOT Included.

${ }^{2}$ Management Reserve and Line item Contingency Held by RL.

"Work Performed at Sites Other Than Hanford. 
FACILITY STABILIZATION

LIFE CYCLE BUDGET AUTHORITY (B/A) BY YEAR BY FUND TYPE

BY PROJECT BASELINE SUMMARY (PBS)

FY 1998

(\$000s)

\begin{tabular}{|c|c|c|c|c|c|c|c|c|c|c|c|}
\hline PROJECT WBS: & 1.4 .11 .1 & & & & & & & & & & \\
\hline PBSNO: & RL-TP14 & & & & & & & & & & \\
\hline PBS TITLE: & HSFP 300 & Area Revit & alization & & & & & & & & SUBTOT \\
\hline $\begin{array}{l}\text { FUND } \\
\text { TYPE }\end{array}$ & FY1997 & $\begin{array}{l}\text { EY1998 } \\
\text { FYo }\end{array}$ & FY1999 & FY2000 & FY2001 & FY2002 & FY2003 & FY2004 & FY2005 & FY2006 & $\begin{array}{l}\text { FY1997 } \\
\text { FY2006 }\end{array}$ \\
\hline OPERATING EXPENSE & & 8072 & 759 & 5,472 & 14,187 & 10,635 & 9,251 & 34,274 & 27,686 & 35,816 & 138,952 \\
\hline & & onsto & & & & & & & & & \\
\hline CENRTC & & Wh & & & & & & & & & - \\
\hline & & roneng & & & & & & & & & \\
\hline GENERAL PLANT PROJECT & & Whon & & & & & & & & & - \\
\hline & & Why & & & & & & & & & \\
\hline LINE ITEM (RIst Each One) & & ind & & & & & & & & & \\
\hline 03-Dxox Other Spent Fuel & & W & & & & & & & & & - \\
\hline & & ows & & & & & & & & & - \\
\hline . & & Find & & & & & & & & & - \\
\hline & & 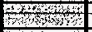 & & & & & & & & & - \\
\hline & & yrasyon & & & & & & & & & - \\
\hline Subtotal Line Items & 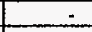 & Why & - & $\therefore$ & $\div$ & - & - & - & - & - & - \\
\hline & & 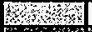 & & & & & & & & & \\
\hline Hownes & & 1" & 61 & 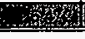 & 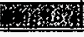 & $70 \%$ & 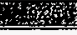 & 聯 & & & 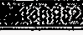 \\
\hline
\end{tabular}


BY PROJECT BASELINE SUMMARY (PBS)

FY 1998

(\$000s)

\begin{tabular}{|c|c|c|c|c|c|c|c|c|c|c|}
\hline PROJECT WES: & 1.4.11.1 & & & & & & & & & \\
\hline PBSNO: & RL-TP14 & & & & & & & & & \\
\hline PBS TITLE: & HSFP 300 & Area ReV & Itallzation & & & & & & & TOTAL \\
\hline $\begin{array}{l}\text { FUND } \\
\text { TYPE }\end{array}$ & $\begin{array}{l}\text { FY2007- } \\
\text { FY2010 } \\
\end{array}$ & $\begin{array}{l}\text { FY2011- } \\
\text { FY2015 }\end{array}$ & $\begin{array}{l}\text { FY2016- } \\
\text { FY2020 } \\
\end{array}$ & \begin{tabular}{|l|} 
FY2021- \\
FY2025
\end{tabular} & $\begin{array}{l}\text { FY2026- } \\
\text { FY2030 }\end{array}$ & $\begin{array}{l}\text { FY2031- } \\
\text { FY2035 } \\
\end{array}$ & \begin{tabular}{|l|} 
FY2036 \\
FY2040 \\
\end{tabular} & \begin{tabular}{|l|} 
FY2041- \\
FY2045 \\
\end{tabular} & $\begin{array}{l}F Y 2046 \\
F Y 2050\end{array}$ & $\begin{array}{l}\text { FY1997- } \\
\text { FY2050 }\end{array}$ \\
\hline OPERATING EXPENSE & 31,200 & & & & & & & & & 170,152 \\
\hline & & & & & & & & & & \\
\hline CENRTC & & & & & & & & & & - \\
\hline & & & & & & & & & & \\
\hline GENERAL PLANT PROJECT & & & & & & & & & & $\therefore$ \\
\hline & & & & & & & & & & \\
\hline LINE ITEM (RIst Each One) & & & & & & & & & & \\
\hline 03.Dxox Other Spent Fuel & & & & & & & & & & - \\
\hline & & & & & & & & & & - \\
\hline & & & & & & & & & & $\therefore$ \\
\hline & & & & & & & & & & - \\
\hline Subtotal Line Hems & - & - & - & - & - & $=$ & - & - & $\therefore$ & $\div$ \\
\hline & & & & & & & & & & \\
\hline
\end{tabular}




\section{HANFORD SURPLUS FACILITIES PROGRAM 300 AREA REVITALIZATION}

\section{AVERAGE ANNUAL FULL TIME EQUIVALENTS}

(includes Major Subcontractors but not Enterprise Companies)

PHBS 1.4.11.1

Submittal Date: 9/10/97

\begin{tabular}{|l|l|l|l|l|l|l|l|l|l|l|l|}
\hline PBS Number & PBS Title & FY 1998 & FY 1999 & FY 2000 & FY 2001 & FY 2002 & FY 2003 & FY 2004 & FY 2005 & FY 2006 & FY 2007 \\
\hline
\end{tabular}

RL-TP14

HSFP 300 Area $R$

2

3

3

1

1

2

a

e

o

e 2


HNF-SP-1234

Appendix A

Comparison of FY 1998 Multi-Year Work Plan vs. April Project Baseline Summary Submittal 
HNF-SP-1234

A-2 
Appendix A

Comparison of FY 1998 Multi-Year Work Plan vs. April Project Baseline Summary Submittal

\begin{tabular}{|c|c|c|c|c|c|c|c|c|c|}
\hline B Plant Sub Project (TP-01) & FY 1998 & FY 1999 & FY 2000 & FY 2001 & FY 2002 & FY 2003 & FY 2004 & FY 2005 & FY 2006 \\
\hline FY 1998 Multi-Year Work Plan & 22,381 & 4,909 & 0 & 0 & 0 & 0 & 0 & 0 & 0 \\
\hline PBS Submittal & 19,719 & 4,824 & 236 & 657 & 0 & 0 & 0 & 0 & 0 \\
\hline Deita & $(2,662)$ & (85) & 236 & 657 & 0 & 0 & 0 & 0 & 0 \\
\hline \multicolumn{10}{|c|}{$\begin{array}{l}\text { Explanation of Changes: The FY98 increase is a result of work scope required that was not recognized when the PBS was prepared. This includes procurement and use of a Gamma } \\
\text { camera to aid in the characterization of the canyon cells, other sampling and analysis needed for facility characterization, and dispositioning five contaminated railroad cars. } \\
\text { The FY99 increase is minor and is related to work scope not completed in FY97 and rate changes. }\end{array}$} \\
\hline \multicolumn{10}{|c|}{$\begin{array}{l}\text { The funding requested in the PBS for FY } 2000 \text { and } 2001 \text { is for work scope planed to follow transfer of the facility to the environmental restoration contractor including demolition of the } \\
\text { 291-B stack. This work scope was requested in the budget submittal but is not part of the B Plant deactivation. Funding would be transterred to the ERC. }\end{array}$} \\
\hline
\end{tabular}

\begin{tabular}{|c|c|c|c|c|c|c|c|c|c|}
\hline WESF Sub Project (TP-02) & FY 1998 & FY 1999 & FY 2000 & FY 2001 & FY 2002 & FY 2003 & FY 2004 & FY 2005 & FY 2006 \\
\hline FY 1998 Multi-Year Work Plan & 13,113 & 10,747 & 16,157 & 12,597 & 12,479 & 12,467 & 12,247 & 13,034 & 13,254 \\
\hline PBS Submittal & 12,879 & 12,962 & 11,857 & 11,643 & 11,543 & 11,534 & 11,713 & 11,870 & 11,808 \\
\hline Delta & (234) & 2,215 & $(4,300)$ & (954) & (936) & (933) & (534) & $(1,164)$ & $(1,446)$ \\
\hline \multicolumn{10}{|c|}{$\begin{array}{l}\text { Explanation of Changes: For FY98, multiple changes took place from the submittal of the PBS to the preparation and submittal of the MYWP for WESF. Completion of clean out of the } \\
\text { WESF hot cells was delayed due to the WESF closed loop cooling piping replacement and K-3 flooding work that was not in the FY97 baseline. Several upgrades, implementalion of the } \\
\text { WESF BlO, and phase } 2 \text { of the design reconsititition were postponed. For FY99, all work scope beyond minimum safe conditions were postponed until FY2000. FY2000 reflects the } \\
\text { FY98 and FY99 work scope that was moved to FY2000. FY2001 and beyond are escalation increases from the prior years. }\end{array}$} \\
\hline
\end{tabular}


Appendix A

Comparison of FY 1998 Multi-Year Work Plan vs. April Project Baseline Summary Submittal

\begin{tabular}{|l|r|r|r|r|r|r|r|r|r|}
\hline 300 Area/SNM Sub Project (TP-04) & FY 1998 & FY 1999 & FY 2000 & FY 2001 & FY 2002 & FY 2003 & FY 2004 & FY 2005 & FY 2006 \\
\hline FY 1998 Multi-Year Work Plan & 4,688 & 4,894 & 8,935 & 0 & 0 & 0 & 0 & 0 & 0 \\
\hline PBS Submittal & 4,341 & 6,491 & 6,314 & 2,261 & 2,295 & 2,326 & 2,362 & 2,393 & 2,463 \\
\hline Delta & $(347)$ & 1,597 & $(2,621)$ & 2,261 & 2,295 & 2,326 & 2,362 & 2,393 & 2,463 \\
\hline
\end{tabular}

Explanation of Changes: Roof repairs added to FY 1998 and 1999. Phase II Shutdown and 313 Bldg. Isolation deferred from FY 1999 to FY 2000 . WATS Phase III accelerated from FY 2000 to FY 1999. In FY 2001 and out, SNM responsibility transferred to RL-TP12 (Transition Project Management).

\begin{tabular}{|c|c|c|c|c|c|c|c|c|c|}
\hline PFP Deactivation (TP-05) & FY 1998 & FY 1999 & FY 2000 & FY 2001 & FY 2002 & FY 2003 & FY 2004 & FY 2005 & FY 2006 \\
\hline PBS Submittal & 0 & 4,035 & 5,494 & 16,344 & 21,778 & 28,258 & 27,279 & 15,950 & 3,320 \\
\hline \multicolumn{10}{|c|}{$\begin{array}{l}\text { Explanation of Changes: Lower than expected funding levels have resulted in a seprioritization and deferral of PFP work scope. A new baseline will be developed later this year } \\
\text { after a thorough analysis of reengineering and funding impacts. }\end{array}$} \\
\hline
\end{tabular}




\section{Appendix A
Comparison of FY 1998 Multi-Year Work Plan vs. April Project Baseline Summary Submittal}

\begin{tabular}{|c|c|c|c|c|c|c|c|c|c|}
\hline PFP Stabilization (TP-06) & FY 1998 & FY 1999 & FY 2000 & FY 2001 & FY 2002 & FY 2003 & FY 2004 & FY 2005 & FY 2006 \\
\hline FY 1998 Multi-Year Work Plan & 11,886 & 30,060 & 18,889 & 13,324 & 8,081 & 0 & 0 & 0 & 0 \\
\hline PBS Submittal & 26,453 & 35,610 & 18,889 & 13,324 & 8,081 & 0 & 0 & 0 & 0 \\
\hline Delta & 14,567 & 5,550 & 0 & 0 & 0 & 0 & 0 & 0 & 0 \\
\hline
\end{tabular}

\begin{tabular}{|c|c|c|c|c|c|c|c|c|c|}
\hline PFP Vault Management (TP-07) & FY 1998 & FY 1999 & FY 2000 & FY 2001 & FY 2002 & FY 2003 & FY 2004 & FY 2005 & FY 2006 \\
\hline FY 1998 Multi-Year Work Plan & 60,975 & 62,687 & 75,140 & 70,120 & 67,068 & 61,532 & 62,406 & 63,535 & 27,329 \\
\hline PBS Submittal & 63,275 & 74,292 & 75,140 & 70,120 & 67,068 & 61,532 & 62,406 & 63,535 & 27,329 \\
\hline Delta & 2,300 & 11,605 & 0 & 0 & 0 & 0 & 0 & 0 & 0 \\
\hline
\end{tabular}


Appendix A

Comparison of FY 1998 Multi-Year Work Plan vs. April Project Baseline Summary Submittal

\begin{tabular}{|c|c|c|c|c|c|c|c|c|c|}
\hline 324/327 Facility Transition (TP-08) & FY 1998 & FY 1999 & FY 2000 & FY 2001 & FY 2002 & FY 2003 & FY 20004 & FY 2005 & FY 2006 \\
\hline FY 1998 Multi-Year Work Plan & 33,481 & 31,042 & 38,661 & 30,329 & 23,021 & 14,132 & 10,188 & 752 & 0 \\
\hline PBS Submittal & 29,627 & 31,651 & 31,588 & 20,224 & 11,890 & 370 & 368 & 364 & 354 \\
\hline Delta & $(3,854)$ & 609 & $(7,073)$ & $(10,105)$ & $(11,131)$ & $(13,762)$ & $(9,820)$ & (388) & 354 \\
\hline \multicolumn{10}{|c|}{$\begin{array}{l}\text { Explanatlon of Changes: The PBS submittal was a rough order of magnitude estimate based on facility size, relative contamination, and other similar deactivation projects at } \\
\text { Hanford. The MYWP was a more detailed analysis which will be refined further. The final estimate will be submilted in March, } 1998 \text {. }\end{array}$} \\
\hline
\end{tabular}

\begin{tabular}{|c|c|c|c|c|c|c|c|c|c|}
\hline K Basin Deactivation (TP-09) & FY 1998 & FY 1999 & FY 2000 & FY2001 & FY2002 & FY 2003 & FY 2004 & FY 2005 & FY 2006 \\
\hline FY 1998 Multi-Year Work Plan & 0 & 0 & 1,196 & 3,284 & 25,189 & 35,341 & 32,895 & 24,589 & 1,158 \\
\hline PBS Submittal & 0 & 487 & 709 & 3,284 & 25,189 & 35,341 & 32,895 & 24,589 & 1,158 \\
\hline Delta & 0 & 487 & (487) & 0 & 0 & 0 & 0 & 0 & 0 \\
\hline
\end{tabular}

Explanation of Changes: The difference is based on a projected delay in a turnover of the facility from the Spent Nuclear Fuel Project. 


\section{Appendix A}

Comparison of FY 1998 Multi-Year Work Plan vs. April Project Baseline Summary Submittal

\begin{tabular}{|l|r|r|r|r|r|r|r|r|r|r|}
\hline Accelerated Deactivation (TP-10) & FY 1998 & FY 1999 & FY 2000 & FY 2001 & FY 2002 & FY 2003 & FY 2004 & FY 2005 & FY 2006 \\
\hline FY 1998 Multi-Year Work Plan & 2,716 & 1,445 & 3,583 & 2,666 & 2,503 & 3,345 & 3,164 & 2,971 & 2,778 \\
\hline PBS Submittal & 0 & 3,736 & 3,388 & 2,502 & 2,335 & 3,095 & 2,907 & 2,706 & 2,475 \\
\hline Delta & $(2,716)$ & 2,291 & $(195)$ & $(164)$ & $(168)$ & $(250)$ & $(257)$ & $(265)$ & $(303)$ & \\
\hline Explanation of Changes: The project was re-evaluated based on the actual facilities that were transferred into this project in FY 1997.
\end{tabular}

\begin{tabular}{|c|c|c|c|c|c|c|c|c|c|}
\hline Transition Project Management (TP-10) & FY 1998 & FY 1999 & FY 2000 & FY 2001 & FY 2002 & FY 2003 & FY 2004 & FY 2005 & FY 2006 \\
\hline FY $\$ 998$ Muiti-Year Work Plan & 11,596 & 12,026 & 11,415 & 13,564 & 13,900 & 14,248 & 15,108 & 15,478 & 13,229 \\
\hline PBS Submittal & 9,905 & 10,854 & 10,894 & 11,016 & 11,085 & 11,436 & 11,649 & 11,844 & 11,831 \\
\hline Delta & $(1,691)$ & $(1,172)$ & $\langle 521\rangle$ & $(2,548)$ & $(2,815)$ & $(2,812)$ & $(3,459)$ & $(3,634)$ & $(1,398)$ \\
\hline \multicolumn{10}{|c|}{$\begin{array}{l}\text { Exptanation of Changes: The FY } 1998 \text { MYWP included new requirements (beginning in FY 98) for FDH project Direction, Rad Con/QA site manuals, Site Systems Engineering, } \\
\text { Site Packaging and Shipping, and project procedure updates. In addition, beginning in FY 2001, SNM management work scope will be transferred from the } 300 \text { Area/SMN Sub- } \\
\text { Project (TPO4). }\end{array}$} \\
\hline
\end{tabular}


Appendix A

Comparison of FY 1998 Multi-Year Work Plan vs. April Project Baseline Summary Submittal

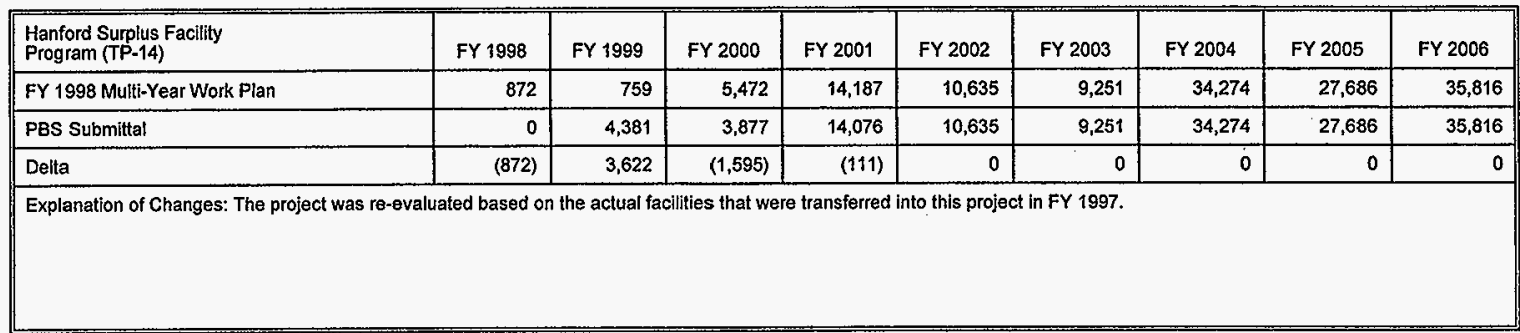




\section{DISTRIBUTION}

Number of Copies

OFFSITE

1 U.S. Department of Energy

Cloverieaf Bldg.

19901 Germantown Rd.

Germantown, MD 20874

1 Washington State Department of

Ecology

P.O. Box 47600

Olympia, WA 98504-7600

1 U.S. Environmental Protection Agency

712 Suite 5, Swift Blvd.

Richland, WA 99352

1 Hanford Advisory Board

Ms. Merilyn Reeves

723 The Parkway, Suite 200

Richland, WA 99352

1 Oregon Department of Energy 625 Marion Street N.E.

Salem, OR 97310

1 Yakima Indian Nation

P.O. Box 151

Toppinish, WA 98948

1 Wanapum Tribe

P.O. Box 878

Ephrata, WA 98823

1 Nez Perce Tribe

P.0. 365

Lapwai, ID 83540

1 Confederated Tribes of the Umatilla Indian Reservation

P.O. Box 638

Pendleton, OR 97801
Number of Copies

ONSITE

13 U.S. Department of EnergyRichland Operations Office

Reading Room H2-53

Hanford Technical Library P8-55

N.D. Moorer, Business

Management Team (11) A5-11

10 Fluor Daniel Hanford Company

Central Files

B1-03

Document Processing

Center

A3-94

E.A. Schultz (3)

B3-53

L.J. Olguin

N1-26

E.L. Reynolds (4)

N1-26

30 B\&W Hanford Company

Stabilization Program

Management (10)

R3-6

E. J. Bitten

L5-65

P. M. Bodmer

T5-45

D. P. Brockman

L6-26

D. B. Cartmell

R3-50

F. R. Crawford

T5-50

J. P. Hayfield

S6-15

G. O. Hayner

15-65

W. F. Heer

P. D. Jensen

H5-31

L. M. Kinsey

T5-51

G. E. Kulynych

R3-61

R. Lehman

H5-31

D. P. Lund

L5-65

J. O. Lundeen

R3-56

G. L. McCormick

R3-51

R. M. Millikin

R3-56

J. R. Montano

L5-65

N2-51

A. E. Schilling

T5-51

D. R. Speer

D. E. Wertz

S4-49

R3-61 


\section{THIS PAGE INTENTIONALLY}

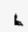
LEFT BLANK 